SZEGEDI TUDOMÁNYEGYETEM

BÖLCSÉSZETTUDOMÁNYI KAR

IRODALOMTUDOMÁNYI DOKTORI ISKOLA

\title{
GRÓF FESTETICS GYÖRGY \\ HELYE A MAGYAR MÜVELŐDÉSTÖRTÉNETBEN, különös tekintettel a Magyar Minerva könyvsorozatra és a Helikoni Ünnepségekre
}

Doktori (Ph. D.) értekezés

Témavezető: Hász-Fehér Katalin

Készitette: Cséby Géza

Szeged 


\section{Tartalomjegyzék}

1.

Bevezető 4

2. Gróf Festetics György 8

2. 1. Az előzmények 8

2. 2. Festetics György ifjúkora és tanulmányai 10

$\begin{array}{lll}\text { 2. 3. A szabadkőmüves Festetics György } & 14\end{array}$

$\begin{array}{lll}\text { 2. } 4 . & 17\end{array}$

2. $5 . \quad$ Festetics György Keszthelyen 40

2. 6. Gróf Festetics György gyermekei 48

3. Gróf Festetics György helye és szerepe a magyar müvelődéstörténetben 58

3. 1. Keszthely városias képének kialakulás 59

$\begin{array}{lll}\text { 3. 1. 1. A kastély } & 60\end{array}$

3. 1. 2. Az első keszthelyi nyomda 64

3. 1.3. A kórház 65

3. 1. 4. A Fenéki Arzenál és a Phoenix 66

3. 1. 5. Hévízfürdő kialakulásának kezdetei 78

3. 2. Gróf Festetics György iskolái 79

3. 2. 1. Keszthelyi elemi- és középiskolák 81

3. 2. 2. A Georgikon 87

3. 2. 3. A csurgói református gimnázium 98

3. 3. Festetics György a sajtó mecénása 101

3. 4. Festetics György kapcsolata az irodalommal és a müvészekkel 107

3. 4. 1. Mikes törökországi leveleinek kiadása 107 
3. 4. 2. Festetics György a magyar színjátszás támogatója 110

3. 4. 3. Festetics György és Csokonai Vitéz Mihály 113

3. 4. 4. Festetics György és Fazekas Lúdas Matyija 128

3. 5. Első hazai könyvsorozatunk a Magyar Minerva 133

3. 5. 1. Az előzmények 133

3. 5. 2. „A` Magyar Országi Írók’ munkájinak Könnyebb ki-nyomtatását tárgyazó Gondolatok” Dokumentumközlés 135

$\begin{array}{lll}\text { 3. 5. 3. A megvalósult sorozat } & 157\end{array}$

3. 6. A keszthelyi Helikoni Ünnepségek 1817-1819 174

$\begin{array}{lll}\text { 3. 6. 1. A kezdetek } & 175\end{array}$

3. 6. 2. Az első Helikoni Ünnep: 1817. február 12. 189

3. 6. 3. A második Helikoni Ünnep: 1817. május 20-21. 209

3. 6. 4. A harmadik Helikoni Ünnep: 1818. február 12. 221

3. 6. 5. A negyedik Helikoni Ünnep: 1818. május 20.

3. 6. 6. Az ötödik Helikoni Ünnep: 1819. február 16. 235

3. 7. Festetics György gróf halála 246

4. Összegzés. Festetics György az utókor tudatában, helye a magyar müvelődéstörténetben 259

$\begin{array}{ll}\text { Rövidítések } & 269\end{array}$

$\begin{array}{ll}\text { Felhasznált irodalom } & 288\end{array}$

$\begin{array}{ll}\text { Mellékletek } & 304\end{array}$ 


\section{BEVEZETÖ}

Ezen dolgozat arra vállalkozik, hogy korabeli és későbbi fellelhető anyagokat összegezve, illetve eddig nem publikált dokumentumok alapján elhelyezze a horvát gyökerü család ${ }^{1}$ legismertebb tagjának, gróf Festetics Györgynek (1755-1819) személyét a magyar művelődéstörténetben. Festetics tevékenységéről több tanulmány született, amelyek adalékul szolgálhatnak a Dunántúl egyik leggazdagabb arisztokratájának megítéléséhez. Összegezni, olykor ütköztetni szeretnénk az eddig több helyütt megjelenő értékes dolgozatok konklúzióit és újabb adalékokkal világítani meg Festetics nagy ívű életútját. A dolgozatban azon fejezeteket bontottuk ki részletesebben, amelyek eddig ismeretlen, vagy csak kevésbé ismert részei művelödés- és irodalomtörténetünknek. Nem kétséges, hogy gróf Festetics György roppant izgalmas egyéniség, rendkívüli elmével megáldott foúr a felvilágosodás és a reformkor határán, aki - Berzsenyi szavaival élve - „oly dicső épületnek rakta le talpköveit, melyet csak a haza omladéka temethet el”. ${ }^{2}$ A kortársak, majd az utókor megítélése felemás volt, amint a kor is, amelyben Festetics gróf élt. A „feudális mecénás”, aki könyörtelenül behajtotta a neki járó adókat, de aki - ha fontosnak tartotta - a magyar oktatásért és művelődésért, a gazdaság modernizálásáért pénzt áldozott. Ebben mindenképpen előfutára unokaöccsének, gróf Széchenyi Istvánnak.

Festetics a felvilágosodás embere volt. Minden tevékenységét, munkáját ez vezérelte. A felvilágosodás második nemzedékéhez tartozott, $\mathrm{s}$ ő érzékenyen reagált a kor ezen kihívásaira.

Festeticsnek, valamint alkotásainak kultusza, iskola- és kultúrateremtő erőfeszítései, mecénási szellemsége elevenen él azokban a városokban, amelyek ma is profitálnak ezekből az értékekből: Keszthely, Hévíz, Csurgó. Ennek a kultusznak eredetét még a gróf életében kell keresnünk. Elsősorban a korabeli dunántúli írók jóvoltából, akik verssel köszöntötték mecénásukat. Kultuszát (és ellenkultuszát) megtaláljuk a nagy levelezők, elsősorban Kazinczy Ferenc barátainak írt soraiban. Érdekes megemlíteni, hogy első, ma is ismert, metszett

\footnotetext{
${ }^{1}$ Črep, 2010. 19-32. ; Josip Črep munkájában a Festetics család magyarországi és horvátországi ágának áttekintését tüzte ki célul.

${ }^{2}$ Berzsenyi Dániel levele gróf Festetics Györgyhöz 1816. november 15-én, amelyben felveti a „keszthelyi Weimar" eszmét. = Berzsenyi, ÖM, 1978. 482.
} 
portréját csak halála után készítették el fia, László megrendelésére. ${ }^{3}$ Halálát követően a XX. században erösödött fel Festetics György szellemiségének tisztelete. Ennek látható és kézzel fogható eredménye, hogy 1902-ben felavatták Keszthely Fő-terén Lukácsy Lajos egész alakos (két mellékalakkal) Festetics szobrát. ${ }^{4}$ 1921-ben és 1932-ben Helikoni Ünnepeket szerveztek. Stróbl Alajos Festeticset ábrázoló fehér carrarai márvány mellszobra a Festetics kastély könyvtárában és a Pannon Egyetem keszthelyi karának aulájában található. 2006-ban újabb egész alakos Festetics szoborral gyarapodott Keszthely, Farkas Ferenc szobrászmüvész alkotásával. 1994-ben Marton László Festetics mellszobrát avatták a hévízi gyógyfürdőkórház parkjában. Számos emléktábla is mecénási tetteit hivatott megőrizni. Képíró Zoltán éremmüvész a Keszthelyi Éremgyüjtő Egyesület megbízásából elkészítette a gróf arcképét ábrázoló érmét (1977). Az Újkori Középiskolás Helikoni Ünnepségek fődíjasainak átadott plaketten három alkalommal is (2000, 2006, 2012) Festetics György portréja látható. Előbbi Molnár Jenő, utóbbiak Orr Lajos, illetve Farkas Ferenc szobrászművészek alkotása. Somogyi Győző festőmüvész megfestette portréját (1989). A keszthelyi zeneiskola 1994-ben felvette nevét. Hévízen felállították mellszobrát (Marton László alkotása, 1994), érmet verettek (Fritz Mihály alkotása, 1994). Nevét felvette a hévízi müvelődési központ (2006), és a 2009-ben átadott új, modern hévízi Wellness és Terápiás Centrum is. Csurgón Farkas Ferenc egész alakos Festetics szobra került a gróf által alapított gimnázium előtti parkba (1999). Az egykori találkozók emlékét ápolandó Keszthelyen 1957-ben létre hívták, majd 1992-ben újjáalakították és kétévente megrendezik a Helikoni Ünnepségeket. A rendezvényre Dunántúl valamennyi középiskolája meghívást kap, hogy tizennyolc müvészeti kategóriában neves zsűri előtt mérettesse meg tudását. ${ }^{5}$ Ide tartoznak a Festetics városok találkozói (Keszthely, Hévíz, Csurgó), kiadványok és a késői utód, Dr. herceg Festetics III. György rendszerese kapcsolata a városokkal. Ez tartja ébren és erősíti a Festetics, de elsősorban a Festetics (I.) György kultuszt.

Ha közelebbről vizsgáljuk, Festetics legnagyobb alkotása minden kétséget kizárva a Georgikon, Európa első felsőfokú mezőgazdasági oktatási intézménye. Ugyanakkor

\footnotetext{
${ }^{3}$ A képet Kinninger rajzolta és Weiss metszette rézre. $=$ Haszn. Mul. 1824./ II. 393

${ }^{4}$ A II. világháborút követően a szobor talapzatát szétverték, a fö- és a két mellékalakot a Balatoni Múzeum raktárába szállították. A szobor helyére a szovjet hősi emlékmü került. Az 1956-os forradalom idején lerombolták a szovjet emlékmüvet és helyére, 1956. október 25-én, visszahelyezték a Festetics szobrot. A forradalom leverését követöen Festetics bronzszobra ismét a múzeum pincéjébe került. A szobrot jelenlegi helyére (keszthelyi Festetics kastély parkja) 1967-ben helyezték el.

5 Szabolcs, 1998. A szerző, mint az Újkori Helikonok egyik alapítója részletesen feldolgozta munkájában az 1958-1996 közötti középiskolás Helikonok történetét. A kötet kiegészül három bevezető dolgozattal: Cséby Géza: A Keszthelyi Helikoni Ünnepsége 1817-1819, Tar Ferenc: Helikon 1921-ben, Cséby Géza: A Balatoni Iróhét és a Helikon.
} 
elévülhetetlen érdemeket szerzett a magyar müvelődésügyben többek közt a Helikoni Ünnepségek megszervezésével, a Magyar Minerva könyvsorozat elindításával valamint számos kezdeményezés anyagi támogatásával. A két név szerint is megemlített vállalkozásával behatóbban kívánunk foglalkozni.

Négyesy László a következőket szögezi le: „Gróf Festetics György alakja a történelemé. Inkább a művelődési, mint a politikai történeté, de egyik sem foglalkozott vele annyit, amennyit megérdemelt volna. Gazdaságtörténet és irodalomtörténet megmegemlékezett róla, de egységes képét még eddig egyetlen életíró sem rajzolta meg igazán. Ezt az életírót várjuk". 6 Négyesy 1921-ben született tanulmánya a mai napig érvényes. Festetics György gróf életútjának, portréjának megrajzolása azért sem könnyü, mert a kortársak sem mindig értette egyet a gróffal és csak élete utolsó éveiben lett sokak számár egyértelmủvé, hogy törekvéseinek indítékait miért palástolta sokszor ellentmondásosnak tünő módon. ${ }^{7}$ Szabó Dezső többször idézett, hatalmas és történelmi vonatkozásaiban korrekt munkája, a „Herceg Festetics család története” (1928), sem könnyíti meg Festetics György megítélését, ugyanis az aulikus herceg Festetics Tasziló pénzén íródott, lehetőleg úgy, hogy a királypárti oligarcha fülét ne sértse semmi. Szabó például Festetics György sorozatosan nyílt szembehelyezkedését az udvarral a következőképpen simítja el: „Gróf Festetics György, aki a maga hibája nélkül járta végig a királysággal való összeütközés kálváriáját, éppen a királyi kegyet legnagyobb mértékben élvező Festetics Pálnak fia volt” (kiemelés tőlem Cs.G.). ${ }^{8}$ Nem segítette érzelemtől és politikától mentes megítélését a második világháborút követő időszak sem, elfogult tanulmányok, dolgozatok láttak napvilágot, amelyek kritikájára jelen dolgozatban kitérünk.

Természetesen születtek részeredmények (Váczy János, Szabó Dezső, Négyesy László, Keresztury Dezső, Sági Károly, Szántó Imre, Cséby Géza). A legutóbbi időben Stohl Róbert és Kurucz György végez figyelemre méltó, mélyreható kutatásokat e témában. Míg Stohl elsősorban György fiának, az ifjú László grófnak nevelésével kapcsolatos kutatásokat végzi, addig Kurucz Festetics György pénzügyeit, birtokviszonyait, a georgikoni oktatás kérdéseit elemzi.

Ebben a dolgozatban arra próbálunk kísérletet tenni, hogy összegezzük mindazokat a tényezőket, emberi és társadalmi körülményeket, amellyel hozzájárulhatunk a mindmáig hiányzó, és a jövőben megírandó Festetics György biográfiához.

\footnotetext{
${ }^{6}$ Négyesy, 1925. 39.

${ }^{7}$ Kurucz, 2006. 1342.

${ }^{8}$ Szabó, 1928. 199
} 
Köszönettel tartozom mindazoknak, akik segítetté munkámat a levéltári, könyvtári és múzeumi munkatársaknak. Külön köszönettel tartozom Hász-Fehér Katalinnak tanácsaiért, Halwax Elisabethnek a kéziratos német levelek tartalmának „megfejtéséért”, Künstlerné Virágh Éva főnyökvtárosnak (Budapest), Dr. Domokos György főtanácsosnak (Bécs) értékes segítségéért, Laczkó Andrásnak és Kardos G. Józsefnek számos javaslatáért. 


\section{GRÓF FESTETICS GYÖRGY}

\section{1. Az előzmények}

Hogy megértsük az indítékokat, amelyek arra predesztinálták gróf Festetics Györgyöt, hogy mindazon intézményeket létrehozza, támogatásokat osszon, segítse a termelékenyebb gazdaság kialakítását, amely méltán emelte őt müvelődésügyünk meghatározó egyéniségei közé, szükségszerü megismerni azt a családi miliőt is, amelyben felnevelkedett. Személyiségének kialakulásában nagy szerepet játszott mindaz, amit gyermekkorában, ifjúkorában megtanult, elsajátított, felnőtt korában pedig átélt, megtapasztalt.

Minden kétséget kizáróan meghatározó volt számára a vagyonszerező nagyapa, Kristóf (1696-1768), aki a soproni gimnáziumot követően a nagyszombati egyetemen tanult, majd a közigazgatásban vállalt szerepet. 1736-ban III. Károly kinevezte a Helytartótanács tanácsosai közé. Mária Terézia aranysarkantyús lovaggá ütötte és a Hétszemélyes tábla bírájává tette. Kristóf tovább növelte Sopron és Somogy megyei birtokait, amikor megvásárolta az 1730-as években, 24000 forintért gersei Pethő Zsigmondtól keszthelyi részbirtokát. Ez a birtok utóbb a család legjelentősebb birtokközpontjává vált. Megkezdte az egykori gersei Pethők várkastélyának helyén egy új, barokk kastély építését. Hasonlóképpen hatással lehetett rá az apa Pál (1722-1782) alispán, megyei követ, udvari kamarai tanácsos, majd titkos tanácsos is, akit 1772. február 24-én Mária Terézia grófi rangra emelt. A nagyapa és az apa kijelölték számára a rangjához és birtokaihoz méltó utat. Főleg az apa sikereiről vehetett példát, aki elsősorban a pénzügyekben elsőrendű bizalmasa volt Mária Teréziának. Korabeli adatok is bizonyítják, hogy Festetics Pál véleményének meghallgatása nélkül, a pénzügyekben és magyar ügyekben, a királynő soha nem döntött végérvényesen. ${ }^{9}$ Festetics mindvégig hủ alattvalója volt az udvarnak, és igyekezett elsimítani az udvar és a rendek közötti nézeteltéréseket, többek közt az adóztatások tekintetében. ${ }^{10}$ Festetics szerint 1765 -ben bebizonyosodott; a törvényeket a király és a rendek közös megegyezése teszi törvénnyé, ennél fogva Mária Terézia országgyülés nélkül is megváltoztathatja azokat. Ugyanakkor leszögezte, az uralkodónak gondoskodnia kell arról, hogy legalább utólag megnyerje a rendeknek akár

\footnotetext{
${ }^{9}$ Szabó, 1928. 176.

${ }^{10} 1765$ februárjában Mária Terézia utasítására Pozsonyban nyilvánosan égették el Richwaldszky György kanonok „Vexatio dat intellectum” címü munkájának elkobzott példányait, melyben szembeszállt az udvar abszolutista törekvéseivel és védelembe vette a nemesi jogokat.
} 
»hallgatólagos consensusát«. Festetics Pált 1765. március 20-án bízza meg Mária Terézia, hogy dolgozza ki az úrbéri tervezetet. Festetics Pál gróf beadványaiban felhívta a figyelmet a hazai törvénykezés átalakításának szükségszerüségére, az ő javaslatára került sor 1774-ben a magyar királyi hitelpénztár felállítására. Mária Terézia felkérésére elméleti közjogi munka összeállítását végezte el. A magyar közjog és a kamarai tudományok hazai egyetemen való bevezetését szorgalmazta. ${ }^{11}$ Festetics Pált hivatala Bécshez kötötte, felesége és gyermekei azonban magyarországi birtokain éltek. Szabó Dezső mutatott rá ennek okára és célszerüségére, ugyanis a család rangjának megfelelő ellátása így is nagy mennyiségü pénzt emésztett fel, a drága császárváros még inkább megterhelte volna a családi jövedelmet. ${ }^{12}$

Festetics Pál felesége gróf bossányi és korlátkeői Bossányi Júlia, gróf Bossányi Imre szeptemvir leánya volt. Eljegyzésük napján, 1751. szeptember 7-én kiállított okirat szerint a leendő férj 3000 körmöci aranyat adott „,móring gyanánt” arájának, amit megtoldott 4000 forinttal, hogy menyegzői ruháját és egyéb tartozékait kifizethesse. Ugyanakkor a sági kastélyt, soproni lakását is reá hagyományozta, 1200 forint évi apanázst biztosított ezek fenntartására nem utolsó sorban azért, hogy megszületendő fia ,jövendőbeli házasságában statusához képest hozzátartozandóival együtt becsületesen subsistálhasson”. Ez részben a menyasszony családjának is kívánalma volt. Erröl Festetics Pál még augusztus 22-én levélben értesítette apját, akinek befolyása egyértelmű volt fia házasságára: „Szükséges, hogy tetőtőltalpig felruházzam a menyasszonyt, még éjszakai ruhát, cipellőt és minden bagatellát hozzáadván; e mellett egy pár csöves gyürüt, ezüst nachzeugot órát és bestecket kell adnom és valamely gyöngyöt, mivel az mátkámnak kövekből való smukja vagyon. Ez kb. 3000 forint.” Eljegyzésükre tehát szeptember 7-én került sor Jabloncán, az esküvőre másnap, ahol a nyitrai püspök, galánthai gróf Esterházy Imre Gábor adta össze az ifjú párt. ${ }^{13}$

Festetics Pál és Bossányi Julianna házasságából hét gyermek, három fiú és négy lány született. Az első Julianna, aki 1753. október 30.-án látta meg a napvilágot, s aki előbb gróf Széchényi József, majd ennek halála után gróf Széchényi Ferenc felesége lett. ${ }^{14}$ Erzsébet leányukat gróf Esterházy Károly vette el. Apjuk halálakor (Pozsony, 1782. április 7.) Julianna (gróf Széchényi Ferencné) és György már nagykorúak, de Anna-Antonina (később gróf Batthyány József felsége), Mária (később gróf Révay Pál felesége), valamint János és Imre kiskorúak voltak.

\footnotetext{
${ }^{11}$ Polgár, 1997. 88.

12 Szabó, 1928. 200.

${ }^{13}$ Festetics Pál Festetics Kristófnak, 1751. augusztus 22. ; MOL Fest. Lvt. P 24519 VI..; Idézi: Szabó, 1928. 190-191. Jablonca (Jablánc, Nyitra vármegye, ma Jabonica - Szlovák Köztársaság)

${ }^{14}$ Koppány-Péczeli-Sági, 1962. 46. ; Széchényi József (1752-1774) és Festetics Julianna (1753-1824) 1772-ben kötöttek házasságot. Ebből a házasságból gyermek nem született.
} 
Festetics Pál nevéhez sok keszthelyi alapítás füződik. Ezeket belsősorban akkor tette meg, amikor grófi rangra emelték. 1772-ben megépíttette a keszthelyi nemzeti (elemi) iskolát, amelynek tanítóit is ő fizette, valamint megfelelő mennyiségü tüzifát is biztosított az iskola számára $^{15}$. Ugyancsak Keszthelyen gimnáziumot alapított (1772), a gimnázium elé még ugyanabban az évben elhelyeztette a ma is álló Szentháromság szobrot. Foglalkozott méhészettel és selyemhernyó tenyésztéssel. Hajómunkásokat hozatott Triesztből és Hollandiából, akik a fenéki hajóépítő mühelyben (arzenál) „sajkákat, vitorlás hajókat építettek" a balatoni só szállítás érdekében. Valószínűleg ő építtette a Balaton első nagy vitorlás hajóját, amit apjáról Kristófról (Christoph gálya) nevezett el. ${ }^{16}$ A kastély építéséhez, bővítéséhez külföldi mesterembereket hozatott. A királynétól hetivásárjogot kért és kapott (1774. április 2.). Az ő ajándéka volt Keszthely első „tűzi fecskendője”. ${ }^{17}$

\section{2. Festetics György ifjúkora és tanulmányai}

Ebbe a családba született gróf Festetics György a Sopron megyei Ságon 1755. december 31-én, hajnali 4 órakor. ${ }^{18}$ A gyermeket elsősorban anyja nevelte, akihez mindvégig nagyobb és bensőségesebb kapcsolat füzte, mint a legtöbbször távol lévő apjához. Az anya befolyása döntő volt fia mentális fejlődésére. Alapvetően meghatározta a magyar nyelvhez való kapcsolatát az a tény, hogy más főúri családokkal ellentétben nem a latin, vagy német nyelv volt az otthoni érintkezés nyelve, hanem a magyar. Erre többször utalhatunk a Helikonok megrendezése, az írókhoz, az irodalomhoz füződő kapcsolatának értékelésekor is. Ugyanakkor társadalmi elvárások, családi tradíciók, illetve a felvilágosodás századának szülötteként, természetes módon a ráció által meghatározott értékrend befolyásolta fiatalkori éveit - jegyzi meg Kurucz György Festeticsről írt munkájában. ${ }^{19}$ Nincs hitelt érdemlő adatunk arra vonatkozóan, hogy elemi iskoláit külön iskolai intézményben végezte-e. A gimnázium alsóbb osztályait sem tudjuk, hol abszolválta. Valószínűsíthetően a többi nemesi családban szokásos módon, ahol a latin, német, történelmi és aritmetikai alapismereteit a gyermek még családi körben szerezte meg. Nevelöje Nagy Jeromos piarista tanár volt, aki egyébként György nővérét is tanította. Festetics Kristóf, aki nemcsak fia, de unokája életére is

\footnotetext{
${ }^{15}$ Szabó, 1928. 192.

${ }^{16}$ A Christoph gálya jelenik meg Keszthely XVIII. századi címerének takaróján.

${ }^{17}$ Szabó, 1928. 193.

${ }^{18}$ Szabó, 1928. 199. ; Festetics György személyével az asztrológia is foglalkozott. Trentai Gábor közli a gróf horoszkópját (www.asztrologbae.hu/6_november/c_4/cikk4.htm) (2007).

${ }^{19}$ Kurucz, 1999. 265.
} 
befolyással bírt, egyik levelében így jellemezte a tanárt: „,...jó szerzetes és emberséges tanult egy ember". ${ }^{20}$ Kézenfekvő lenne azt hinni, hogy György később az apja által alapított keszthelyi gimnáziumban bővítette ismereteit, de erre vonatkozólag sincsenek megfelelő adataink. Szabó Dezső sem tud róla, és a gimnázium mai épületében, a két világháború között elhelyezett márványtáblán, (melyen a gimnáziumba egykor tanult neves emberek kerültek felsorolásra) sem tüntették fel Festetics György nevét. Felsőbb tanulmányait, apja kívánságára, 1768 és 1775 között a bécsi Collegium Theresianumban (Teréz Akadémia) végezte. Ez a jezsuiták által 1746-ban alapított, majd Mária Terézia által anyagilag támogatott intézmény arra volt hivatva, hogy megfelelő jogi, osztrák államigazgatási, nyelvi, bölcsészeti tanulmányok elvégzése után a beiratkozott arisztokrata-ifjú, vagyonosabb nemesifjú „ügyes államférfivá" cseperedjen. ${ }^{21}$ Erre minden eshetőség megvolt. A jezsuiták kiválóan képzett tanárok voltak (Mitterpacher Lajos, Makó Pál, Izzo János, Michael Denis és mások), s a Theresianum pedagógiai színvonalát jelzi, hogy kezdettől törekedtek az - akkor még nagy ritkaságnak számító - szemléltető oktatásra, amihez ásvány-, növény-, állat-, továbbá fizikaimatematikai, eszköz-és gép-, drágakő- és érmegyüjteménnyel és nagyszerü könyvtárral rendelkeztek. ${ }^{22}$ Az első olyan oktatási intézmény volt, amelyben a könyvtártudomány helyet kapott, és a harmadik, ahol a mezőgazdaságtant tanították. ${ }^{23}$ Festetics György már itt megalapozta mindazon ismereteket, amelyeket később könyvtárának gyarapításában, a mezőgazdasági oktatás megszervezésében kamatoztatott. Nem véletlen tehát, hogy az egyetemes könyvtári kultúra kiválósága, Festetics Theresianum-beli tanára Michael Denis, ${ }^{24}$ később büszkén dicsekedett két neves magyar tanítványával, a magyar müvelődésügy kiemelkedő egyéniségeivel, Festetics Györggyel és Széchényi Ferenccel. ${ }^{25}$ Fraknói Vilmos is felhívja a figyelmet arra, hogy a Theresianum kiváló alapokat adott az arra fogékony tanulóinak: „,..az a három foúr, kik a 18. század végén a legjelentékenyebb könyvtárakat gyüjtötték Magyarországban: gróf Apponyi Antal, gróf Batthyány Ignác erdélyi püspök és gróf Széchenyi Ferenc a Theresianum növendékei voltak. Az volt Festetics György is, a

\footnotetext{
${ }^{20}$ Kurucz, 1999. 266.

${ }^{21}$ Századok, 1878. 367-368.

${ }^{22}$ Walleshausen, 2008. 65.

${ }^{23}$ Walleshausen, 2008. 73.

24 Michael Denis (1729-1800) Johann Nepomuk Cosmas Michael Denis osztrák bibliográfus, költő, tanár, entomológus. 1759-ben belépett a jezsuita rendbe. A Theresianum tanára volt, 1784-től a bécsi udvari könyvtár vezetöje. Bárdköltő (Die Lieder Sineds des Barden, 1772). Neves Osszián fordító (Die Gedichte Ossians, eines alten Celtischen Dichters aus dem Englischen übersetz von M. Denis, Bécs, 1796). Klopstock volt rá nagy hatással. 1762-1766 között három kötetben kiadta: Sammlung kürzer Gedichte aus den neuern Dichtern Deutschand címü munkáját. Híres lepkegyüjteményét a Hoffburgban helyezték el, de a gyüjtemény az 1848-es forradalom idején megsemmisült. (Vö.: Pallas Nagy Lexikona V. köt., Budapest, 1893.; Fraknói, 2002,; Kókay, 1983.; Debreczeni, 2009., Walleshauesen, 2008., Hász-Fehér, 2004.)

${ }^{25}$ Fraknói, 2002. 71. ; Walleshausen, 2008. 71.
} 
keszthelyi gazdasági intézet, a Georgikon alapítója. Mind a négyen a császári székvárosban, az előhaladottabb müveltségü országok fiaival érintkezve, azzal az elhatározással tértek vissza hazájukba, hogy nemzetök müveltségi színvonalának emelésére fogják értékesíteni tehetségöket és vagyonukat; aminthogy éppen ebben az időben a bécsi magyar testörség körében az idegen irodalmak tanulmányának talajából a nemzeti irodalom újjászületésének forrása fakadt". 26

Festetics a Theresianum fénykorában végezte tanulmányait. Keményen tanult és eredménnyel. Szorgalmáról négy végbizonyítványa és három nyomtatott tentámene tanúskodik. Egyik fontos tentámenének, Festetics nyilvános vitájának címe: „Materia tentaminis publici quod ex anni hujus scholastici praelectionibus in collegio regio Theresiano subuibit illustrissimus dominus Georgius cimes Festetics de Tolna anno MDCCLXXIII. „27 Festetics a Theresianum falai között megtanult németül, latinul, franciául, olaszul, angolul. (Majd később látni fogjuk, hogy a nyelvek tökéletes elsajátítására mennyi gondot fordított fia neveltetésében.) Ezeken a nyelveken beszélt és levelezett. Kollár Ádám Ferenc, az ifjú Festetics későbbi tanítója ${ }^{28}$ így írt az apának, gróf Festetics Pálnak 1776. június 23-án kelt levelében: „Megvallom ugyanis, hogy nekem életemben még nem volt kellemesebb elfoglaltságom azoknál az óráknál, amelyekben az ő (ti. Festetics György) szellemének és hihetetlen tanulási képességeinek tanúja lehettem". ${ }^{29}$ Természetesen lehet ez a nevelő túlzása is, de nem valószínü. Ugyanis más kortársa is hasonló véleményen volt. Kövér János vörsi plébános a plébánia história domusában azt írta, hogy a gróf „Tanultt majd-majd emberin Föllyül”. ${ }^{30}$ A vörsi plébános, akinek sok gondja, ügyes-bajos dolga akadt Festeticcsel, mert

\footnotetext{
${ }^{26}$ Fraknói, 2002. 71-72.

27 A három tantárgyhoz füződő tentámen 1773-ban Bécsben került kinyomtatásra. A 35 oldalas füzetről részletesen Walleshausen Gyula ír tanulmányában. (Walleshausen, 2008. 72-73.)

${ }^{28}$ Festetics Pál megbízta Ürményi József kancelláriai tanácsost, Majláth József kamarai tanácsost (kinek felesége Bossányi Mária, Festetics György anyjának unokatestvére volt) és Kollár Ádám Ferencet az udvari könyvtár igazgatóját, hogy a theresianumi tanulmányokat követően György fiának magyar jogi ismereteit, latin és német nyelvtudását még inkább elmélyítsék. (Szabó, 1928. 201-202.) Ebben az időben - éppen Kollár jóvoltából olyan francia felvilágosult irodalmat is olvashatott Festetics György, melyet a cenzúra nem engedélyezett széles körben terjeszteni. (Kurucz, 1999. 267.)

${ }^{29}$ Kollár Ádám Festetics Pálnak, 1776. június 23. ; MOL. Fest. Lvt. P245 24 cs. ; Idézi: Szabó, 1928. 202.

${ }^{30}$ Kövér kézirat, 1834.

Kövér János (1789-1873) 1815 és 1842 között volt vörsi (Somogy megye) plébános. Amit látott, hallott, megtapasztalt azt krónikájába lejegyezte. Szuverén egyéniség volt, ez írásából is kitünik. Az új vörsi templom építkezése kapcsán többször „,panaszkodott krónikájának” gróf Festetics György és a grófné Sallér Judit érdektelensége miatt. „Tett az országban sokat (ti.: Festetics György gróf) a hírért a dicsőségért; de de az Istenért ugyan nem ám. Istene igen kitsiny volt. Egy kápolnát nem épített sehol; de az ő rendelésével, vagy tudtával talán egy vakolást nem tettek valami Templomonn.” (Kövér kézirat, 1834. 21) „(1819)...itt volt Vörsönn a Grófné, ennek tiszteletére el jött a fia is, a mastani Gróf feleségestül: mind a hárman eljöttek ezen puszta Templomba a Szent Misére, ebédenn én is velek voltam, kétszer is elő hoztam, mitsoda nyomorultt Templom ez, de a nélkül, hogy vagy jót, vagy rosszat feleltek volna, el fordították a beszédet, és így ekkor sem nyertünk semmit" (Kövér kézirat, 1834,25 .)
} 
nem támogatta templomának felújítását, ilyen szempontból nem volt elkötelezve a gróf irányában. Később, a gróf az 1770-es évek végén báró Pászthory Sándorral levelezett, ahol is a báró magyarul válaszolt mondván, nem tud versenyre kelni Festetics kitűnő franciatudásával. ${ }^{31}$ Ezért csak részben érthetünk egyet Dr. Váczy János Festeticsről és a Helikonról a Vasárnapi Újság 1886-os évfolyamában közölt tanulmánya azon kitételével miszerint: „Maga a gróf, ha bírt is némi klasszikus és nagyvilági müveltséggel, szélesebb irodalmi jártassággal és ismeretekkel nem dicsekedhetett”, majd így folytatja „...élesebb szellem, szilárdabb akaraterő és merészebb tekintet, körültekintőbb s mélyebb fogékonyság és hatalmasabb erély, szélesebb műveltség (...) kívántatott volna meg”. Ezen véleményen Váczy némileg módosított egy tizenöt évvel későbbi, 1905-ben a Budapesti Szemlében megjelent dolgozatában, ahol sokkal árnyaltabban fogalmaz Festetics munkásságáról, elsősorban a Helikonok fontosságát helyezve előtérbe. ${ }^{32}$

A Theresianumban a kor osztrák államigazgatási ismereteit, filozófiai, jogi stúdiumokat hallgatott osztrák és magyar nemesi társával egyetemben. Apja kívánságára azonban további tanulmányokat folytatott, többek közt magyar köz- és államjogi ismereteket. A bécsi évek alatt, éppen Kollár Ádám Ferenc jóvoltából, olyan francia felvilágosult irodalmat is olvashatott, amelyet a cenzúra nem engedett széles körben terjeszteni. ${ }^{33}$

A bécsi Theresianumban ismerkedett meg a mindenre fogékony ifjú Festetics későbbi sógorával gróf Széchényi Ferenccel. Festetics György 1768-tól 1775-ig ${ }^{34}$, Széchényi Ferenc 1772-töl 1774-ig ${ }^{35}$ volt az intézmény növendéke. Ez a kapcsolat az iskola után sem szakadt meg, elsősorban levelezés útján élt. Sajnos leveleiket csak 1781-től ismerjük. ${ }^{36}$ A meglévő levelek tanúbizonyságot adnak arról, hogy a Festetics szinte minden öt érdeklő és tehertételnek számító gondjáról, dolgairól beszámolt Széchényinek. ${ }^{37}$ Elsősorban birtokainak, gazdaságának ügyintézésével kapcsolatosan kért javaslatokat Széchényitől. Kisebb-nagyobb szívességek megtételére is kéri barátját. A levelezés hangneme bensőséges. A levelekre, elsősorban azok tartalmára a későbbiekben még kitérünk.

\footnotetext{
${ }^{31}$ MOL. Fest. Lvt. P 2461 cs. f. 455

${ }^{32}$ Váczy, 1886. ; Váczy, 1905.

${ }^{33}$ Kurucz, 1999. 267.

${ }^{34}$ Szabó, 1928. 200.

${ }^{35}$ Bártfai Szabó, 1912. 272.

${ }^{36}$ Szabó, 1928. 209.

${ }^{37}$ MOL Széchényi Lvt. P 62325 cs. 48
} 


\subsection{A szabadkőműves Festetics György}

Az operatív szabadkőművességből eredeztethető modern, úgynevezett spekulatív szabadkőmüvesség a XVIII. század elején vált ismertté Franciaországban. Bár tagjainak nagy része egyház-és vallásellenes, a páholyokban az ösi tradíciók misztériuma fennmaradt. A gondolkodók nagy része az értelemre, a racionális gondolkodásra alapozza tételeit, szerintük az anyagi és racionális természet uralkodik a természetfelettin és nem fordítva. Magyarországon a francia hatásra létrejött spekulatív szabadkőmüvesség szintén a XVIII. századra tehető. Mivel az ország a Habsburg birodalom része volt, a magyar szabadkőművesek első kapcsolatai a császárvároshoz, Bécshez kötődtek. Ennek folyományaként a magyar páholyok kénytelenek voltak elszenvedni a túlzott idegen befolyást. Nem véletlen, hogy Kazinczy Ferenc éppen a magyar (nyelvü) páholyok létrejöttét sürgetve így fakadt ki: „Gyalázatjára van nyelvünknek, hogy csak németül és deákul dolgozhatunk."

Amint Franciaországban, Magyarországon is megindult a páholyokban egy antiklerikális folyamat. Kazinczy Ferenc a felvilágosodás korának egyik legismertebb szabadkőműves írója, több társával együtt olyan racionalista szabadkőmüves eszméket hirdetett (szintén francia mintára), amelyik egy megújító, filozofikus, deista irányzat volt. ${ }^{38} \mathrm{~A}$ későbbiekben meglátjuk, hogy Festetics György elsősorban ennek az irányzatnak lett a híve. Itt kell megjegyezni, hogy a gróf tetteiben olykor nem nehéz észrevenni az egyházzal szembeni ellenérzést, elsősorban azokban a döntésekben ahol láthatóan birtokainak gazdasági racionalitására fordított nagyobb hangsúlyt.

Festetics Bécsben találkozott a francia felvilágosodás irodalmával, amelynek szelleme végigkísérte életét. Valószínúleg ebben az időben került kapcsolatba a szabadkőműves eszmékkel és Bécsben a Wahrheit im Orient páholy tagja lett, írja híres magyar könyvtárakról szóló munkájában Keresztury Dezső. ${ }^{40}$ Ezen megállapítását azonban nem támasztja alá hivatkozással, így nem áll módunkban annak hitelességét ellenőrizni. Nagyváthy János emlékirataiban megemlíti, hogy 1786-ban a bécsi szabadkőmüves páholyban találkozott Festetics Györggyel és Széchényi Ferenccel. ${ }^{41}$ Keresztury a Helikon Kastélymúzeum (keszthelyi Festetics kastély) rendkívül gazdag szabadkőműves újság és könyvgyűjteményét kutatva talált rá a Journal für Freymaurer bekötetlen 5786 (1786) évi példányára, melynek

\footnotetext{
${ }^{38}$ Pálfy, 2005.

${ }^{40}$ Keresztury, 1982. 70-71.

${ }^{41}$ Czoma, 2003. 23.
} 
borítóján Festetics Györgynek a páholyban viselt sorszáma látható: 488. Az újság címlapjának teljes szövege: Journal für Freymaurer. Als Manuskript gedruckt für Bruder und Meister des Ordens. Herausgegeben von den Brudern der $\square$ zur Wahrheit im Orient von Wien. Dritten Jahrgangs. Zweytes Vierteljahr. 5786. ${ }^{42}$ Az újság melléklet is tartalmaz a következő címmel: „Versammlungs-Rede der R. C. des alten Systems” A meglehetősen homályos R. C. rövidítés feloldásához - írja Tóth István a Helikon Könyvtár egykori vezetője - a füzetke lelőhelye segíthet hozzá, nevezetesen az, hogy a szabadkőművesek újságjából került elő. ${ }^{43}$ Ez a tény, valamint a füzet által tartalmazott beszéd egyértelmủ szabadkőmüves jellege teheti szinte bizonyossá az $\mathrm{R}$. C. = R(osae) $\mathrm{C}$ (rucis) értelmezését. A nyomtatott cím alá kézzel odabiggyesztett szöveg még többet elárul a nyomtatványról: „Gehalten vom $\operatorname{Br}$ (uder) Heliconus. Am 21. 9. 79.” azaz a beszédet Helikon testvér tartotta 1779. szeptember 1-jén. A beszéd választékos németséggel íródott és az emberi nem céljáról, a szabadkőművesség nemes feladatairól, ember és Isten szoros kapcsolatáról elmélkedik. Feltételezhető, hogy abból az alkalomból hangzott el, amikor Helikon testvért egy magasabb rendi fokozatba avatták be. A füzetecske borítójára kézzel rajzolt lefelé fordított félholdon nyugvó világgömb látható, tetején kereszttel, amelyre egy kígyó tekeredik. Az idézett dolgozat erről a következőket írja: „Egy mai szabadkőműves - a Helikon Könyvtár egy külföldi olvasója akit a jelkép értelméről megkérdeztem, annyit mondott, hogy az egy igen magas beavatási fokozat jelölésére szolgált, a további felvilágosítások elől azonban - esküjére hivatkozva elzárkózott. A szóban forgó személy ismereteinek megbízhatóságáról természetesen nem volt módom meggyőződni”. ${ }^{4}$ Ezt a vélekedést támasztja alá Jászberényi József a magyar szabadkőmüvesekröl írt könyvében, miszerint Festetics nemcsak a jánosrendi szabadkőmüvességben (a bécsi Igaz Egyetértéshez páholy tagjaként) vett részt, hanem magasabb fokú rózsakeresztes beavatott is volt. ${ }^{45}$ Munkáját, feladatát és a fontos dolgok átmentését, e téren is komolyan vette. Jászberényi szerint, amikor Ferenc császár 1795 végére betiltotta a szabadkőműves páholyok működését, Festetics György ezt követően dégi levéltárában összegyüjtötte az egyik főmestertől, Aigner Ferenc kapitánytól vásárolt iratokat, okleveleket, mủveket, pecséteket. ${ }^{46}$ A dégi kastély Európa talán legnagyobb szabadkőműves

\footnotetext{
${ }^{42}$ Fest. K. Hel. Knyvt., Folyóiratgyüjtemény 24/8.

${ }^{43}$ Tóth, 1980. 7-8.

${ }^{44}$ Tóth, 1980. 8.

45 Jászberényi, 2005. 73. ; Jászberényi, 2006. 55-63. ; „Rózsakeresztesség és a szabadkőművesség két teljesen más kiindulású és egymástól eltérő hatások alatt fejlődő mozgalom, amelyet egymáshoz közel csupán a XVIII-ik század különös világa hoz. „, (Jancsó, 1936. 63.)

46 Jászberényi, 1996. 90. Jászberényi úgy tudja - helyesen -, hogy a gyüjteményt a II. világháborúban bombatalálat érte és megsemmisült. A Helikon Kastélymúzeum igazgatója, dr. Czoma László szíves szóbeli közlése (2007) szerint a dégi kastélyt nem érte bombatalálat, de a háborút követőn a szabadkőműves anyagot
} 
iratanyagát őrizte, így a rózsakeresztesekre és magára Festetics Györgyre vonatkozó szabadkőműves dokumentumokat is. ${ }^{47}$ Jászberényi következtetése nem pontos, mert a dégi kastély nem a keszthelyi ág tulajdona volt. A Pollack Mihály tervezte dégi kastély nagy építtetője György unokatestvére, Festetics Antal (1764-1853), s ő vásárolta meg Aigner anyagát. Abafi Lajos a maszonériáról írt magyar nyelvü könyve is ezt támasztja alá: „A nagyszámú rózsakeresztesi iratok által, melyeket lassankint Bécsben összegyüjtött (ti: Aigner Ferenc kapitány), nyomára jutott a magyarországi rózsakeresztesek iratainak hollétének is, és csel útján megkapta ezeket is 1797-ben. Anyagi helyzete azonban nem javult ez évek alatt. (...) Rossz viszonyok közé kerülvén, kincseitől t. i. rendi irataitól és nagybecsü csigagyüjteményétől megvált s azokat gróf Festetics Antal barátjának adta el, ki azokért 1805ben 436 frtot, adósságai törlesztésére, és 300 frtnyi évi járadékot fizetett, még özvegye és leányának is. A gyüjteményt a déghi (sic!) kastélyba vitette, a hol az irományok - 104 vaskos kötetben bekötve - az osztrák-magyar szabadkőmüvesség történetére nézve megbecsülhetetlen értéket képviselnek." ${ }^{48}$ A dégi kastély történetéröl és mai állapotáról szóló tanulmányok hasonló végkövetkeztetésre jutnak. ${ }^{49}$ Abafi dolgozatát annyiban kell pontosítanunk, hogy Festetics Antal, a dégi kastély építtetője nem kapott grófi rangot. A dégi ágat 1857-ben emelték grófi rangra. ${ }^{50}$

Abafi gróf Festetics Györgyöt az „Igaz egyetértéshez” (Zur wahren Eintracht) bécsi páholy tagjai közé sorolja, amelynek főmestere Born Ignác udvari tanácsos volt. Abafi által felsorolt páholyok nevei között nem találjuk, a Keresztury által jelzett „Wahrheit im Orient” páholyt. Nem találunk „Az igazság keleten van” elnevezésűt sem. ${ }^{51}$ Felvetődhet a kérdés más páholyról, avagy az elnevezések különbözőségéről van szó. Jászberényi József felhívja a figyelmet arra, hogy a Journal für Freymaurer címü szabadkőműves periodikát a Born Ignác vezette „Igaz egyetértéshez” páholy adta ki, tehát Festetics esetében leszögezhetjük, hogy ennek a páholynak volt a tagja. ${ }^{52}$

\footnotetext{
széthordták, megsemmisítették. Tény viszont, hogy az 1880-as években Abafi-Aigner Lajos kutathatta először a dégi kastély szabadkőmüves iratait, melyekröl másolatokat is készített. Így a II. világháborúban megsemmisült eredeti dokumentumok közel kétharmadának másolata (Abafi jóvoltából) ma is a Magyar Országos Levéltár tulajdona. (Varga, 2010. 52-53.)

${ }^{47}$ Jancsó, 1936. 69.

${ }^{48}$ Abafi, 1993. 425-426.

${ }^{49}$ Sisa, 2005. 30.

50 „Festetics Antal igen jelentős vagyon ura volt, de fönemesi címet nem szerzett; lehet, hogy erre nem is törekedett. Eötvös Károly a „leggazdagabb magyar köznemes”-nek nevezte öt. Megkapta viszont a királyi kamarás címet, ami a maga korában egy köznemes számára szinte példátlan 6kitüntetésnek számított.” (Sisa, 2005. 14.; 110.)

${ }_{51}^{5}$ Abafi, 1993. 140.

52 Jászberényi, 2003. 43. A könyvben Jászberényi megerösíti Abafi adatát Festetics György páholyára vonatkozóan.; Jancsó, 1936. 122.
} 


\section{4. A katona}

Tanulmányai elvégzését követően Festetics György kamarai szolgálatba állt és a pesti pénzügyigazgatóságnál töltötte gyakorló éveit, ahol gyanúval és bizalmatlanul fogadták, elsősorban apja udvarnál viselt magas rangja miatt. Azt hihették, hogy a fiatal gróf protekcióval kerül ebbe az állásba, talán érdemtelenül is. Röviddel ezután Mária Terézia kinevezte a horvát királyi tanácshoz, fizetés nélküli számfeletti tanácsosnak. Zágrábban ismerkedett meg Skerlecz Miklós báróval. ${ }^{53}$ Horvátországi tartózkodása alatt megkereste az ottani Festeticseket, elkérte tőlük a család eredetét igazoló okmányokat, ezeket saját levéltárába helyezte el. Érdeklődni kezdett családja legendáktól mentes történetéröl. Festetics nem sokáig maradt az adminisztráció kötelékében. Apja kérésének ellenére a polgári pálya helyett a katonait választotta. Az apa ezt haláláig nem tudta megbocsátani, hisz végrendeletében is így fakad ki: „Isten és a világ ellen való bomlott szívére szüleinek gyakorta csúfra kitételére nézve" György fia semmit sem érdemel tőle. ${ }^{54}$ Nem egyedüli példa a Festetics család történetében, hogy a szülö és a gyermek közötti összhang nem felhőtlen. Ugyanezt élhette meg Festetics Pál is. Erre enged következtetni apjának Festetics Kristófnak 1761-ben hozzá intézett levele is: „Házasságra való indulatomat ne tulajdonécs jo egésségemnek, mert mastis csak alig vagyok és szüntelen nyomorgattatom az arayn értül és szelektül, ugy hogy egész étzakákon nem alhatom, és regvel jön csak az álom és kevés nyugodalmam, mely miát ritka nap hogy tizenegy orának elöttö, ki kelhessek az ágybül, smég Isten tudgya, nem ezene windt wassersucht belülő, alig várom az tavaszt, föl hogy vitethessem magamat és Consiliumot hogy tartathassak, hanem annál bizonyosabb nincsen, ha csak legh kevesebbet teztek is ellenem, és megh bozontatok, tehát bözüállásül megh házasodom, már vén ember lévén mással nem bűntethetlek benneteket, azért kedvemre járjatok, s az mint irám selem bogárhoz értő embereket, ha nem szereztek, tehát megh házasodom, tőb károtokra lézen, hogy sem selem bogárhoz értő emberekre mely kőltség lenne kihez képest kézzel lábbal azon légy, hogy te küldhez ollyas embert."55 A hatvanöt éves apa

\footnotetext{
${ }^{53}$ Lomniczai báró Skerlecz Miklós (1729-1799) államférfi, politikus, közgazdasági író. Veronából elszármazott horvát család sarja. Középiskoláit és jogi stúdiumait Kőszegen, Bécsben, Bolognában, Egerben végezte. 1756ban Zágráb megye szolgálatába léptett. 1760-tól a horvát báni törvényszék ülnöke, 1763-65 között ítélőmester, majd kormányszéki tanácsos és ügyviteli igazgató, 1776-79-ben helytartótanács tanácsosa. 1782-től Zágráb megye főispánja és a zágrábi tankerület igazgatója, a horvát fókormányzószék tagja. 1785-től a horvátországi báni tábla alelnöke, valóságos belső titkos tanácsos. Az „Első ártatlansághoz” nevü budai szabadkőműves páholy tagja. Munkásságában kiemelkedő szerepet játszottak a hazai kereskedelem fejlesztésére tett erőfeszítései. (Magyar Művelődéstörténeti Lexikon X. Bp., Balassa,2010. 340-341)

${ }^{54}$ MOL. Fest. Lvt. P 235 Major. 181. ; Idézi: Szabó, 1928. 204.

${ }^{55}$ Magyar Levelesk. I. 425. Festetics Kristóf Festetics Pálnak, Keszthely,1761. február 14.
} 
kifakadása arra vezethető vissza, hogy kérését Bécsben tartózkodó fia nem igazán akceptálta és emiatt késett a selyemhernyó tenyésztést értő szakember Keszthelyre érkezése. A házassággal fenyegetés azonban nem vált valóra és Pál megkapta a keszthelyi hitbizományt. Ugyancsak nem lett kitagadva Festetics György sem az apai hagyatékból.

Festetics György valóban öntörvényü fantaszta hírében állhatott, mert korábban nagyapja Kristóf, a bécsi tanulmányait megkezdő unokájáról a következőket írta Pál fiának, azaz György apjának: „...ha Gyuri fog melléd rendöltetni egy nagy hypochondristával és fántástával több lesz Bécsben". ${ }^{56}$ Mindenesetre különös ember lehetett az ifjú György, ami Pászthory 1779. január 15-én kelt, az ifjú grófnak írt leveléből is kitünik: „Akármit is tartottak Nagyságod felől azon emberek, kikkel mindenkor találkoztam, soha az ő ítéletük el nem fojthatta bennem azon szívbéli indulatot, amely azon reménység alatt, hogy Nagyságod hazánknak hajdanta hasznos tagja lesz, szüntelen gerjedezett. Azon ne csodálkozzék Nagyságod, hogy kevés embernek tetszett". 57 Mindebből kitünik, hogy önálló, szuverén egyéniség lehetett, aki nyitott volt a világ dolgaira, de saját elképzeléseinek megvalósításában következetes és megingathatatlan. Ez még akkor is így volt, ha elképzelései sokszor csapongóak, tettei pedig gyakran egymásnak ellentmondóak voltak. Ezért volt ellentét közte és nagyapja, valamint közte és apja között. Nem tagadhatjuk, hogy Festetics Kristóf és Pál szemszögéből valójában renegát, megzabolázhatatlan, álomképeket kergető ifjú volt, legkevésbé olyan egyéniség amit a nagyapa és apa örömmel el tudott volna fogadni. De éppen ez a magatartás, sokszor önfejüség segíthette későbbi elképzeléseinek megvalósításában, amely kiemelte őt a kor arisztokratái közül.

Festetics György minden intés ellenére 1778. július 16-án belépett a Nádasdy huszárezredbe. Gróf Nádasdy Ferenc az ezred tulajdonosa, 1778. július 27-én kelt levelében felhívta Festetics György figyelmét arra, hogy alaposan gondolja át az ezredbe való belépését, és jelenlegi jó állását ne kockáztassa. Mindazonáltal Nádasdy örömét fejezte ki, ha mégis belép az ezred „,illy érdemes taggal szaporittatik”. Tanácsa azonban változatlan, amit megszívlelendőnek ajánl Festetics számára: „...nékem még most is mindenkor az a Tanátsom, hogy ha jó padon ül az Ember, azt egy könnyen el ne hadja". ${ }^{58}$ Érdemes megjegyezni, hogy Festetics korábban maga sem tartotta kívánatosnak a katonai pályát, ami egyik theresianumi évei idején írt verséből ki is tünik:

\footnotetext{
${ }^{56}$ Festetics Kristóf Festetics Pálnak, 1767. október 23. ; MOL. Fest. Lvt. P 24524 d. ; Idézi: Szabó, 1928. 202203.

${ }^{57}$ Pászthory Sándor Festetics Györgynek, 1779. január ; MOL. Fest. Lvt. P 2461 cs. ; Idézi: Szabó, 1928. 206207.

${ }^{58}$ Nádasdy Ferenc Festetics Györgynek, 1778. július 27. ; MOL Fest. Lvt. P 2461 cs. B.IV.2. 420.
} 
Emberség nem festék, ez igaz tudomány

Vitézség e nélkül gyászos és halovány.

Vérben ázott laurust üldözvén keresni

Hóhér-szívet mutat, nem kell azt dicsérni. ${ }^{59}$

Festetics július 29-én már alhadnagyként szerepel, szeptember 1-jétől hadnagyként. A hadsereg kötelékébe lépett ifjú minden bizonnyal gyors elömenetelre számított, amit mindenképpen megerősíthetett az a tény, hogy a királyné háborúban állt II. Frigyes porosz királlyal. Ebben a hadakozásban a Nádasdy huszárezred is részt vett. Nádasdy megelégedéssel nézte az ifjú Festeticset. Fiát dicsérő levelet küldött Festetics Pálnak és Bossányi Juliannának is. 1779 januárjában főhadnagyi kinevezésre terjesztették fel. A háború azonban még ebben az évben befejeződött, így a gyors katonai karrier lehetősége kútba esett. 1779 elején lehetőség nyílott arra, hogy magasabb ranggal átlépjen a Barco regimentbe, ahol másodkapitányi kinevezést kapott (1779. január 16.). Még ezen év június 7-én levélben tájékoztatták, hogy Mária Terézia kamarássá nevezte ki, ezért Bécsbe kell utaznia, letenni a kamarási esküt. ${ }^{60}$

A Barco ezredben ugyan magasabb rangot kínáltak, ám az ezred Galíciában, Zbarazban, az Isten háta mögött állomásozott, és kilátás sem volt arra, hogy máshová helyezzék. Unalmasan és egyhangúan teltek a napok. Az unalom elüzésének szinte egyetlen módja volt, a minél több szabadság igénybevétele. Ezt Festetics meg is cselekedte. Kevés adat közül az egyik arról tájékoztat, miszerint Zbaraz megköszöni Festeticsnek, hogy az éjjelnappal zajongó diákokat lecsillapította, ezzel nyugodalmas éjszakákat biztosítva a település lakosainak. $^{61}$

\footnotetext{
${ }^{59}$ Szabó, 1928. 205. ; A kurzív betűkkel írt szavak gróf Festetics György eredeti kiemelései.

${ }^{60}$ Szabó, 1928. 207.; Szabó jelzete szerint: Hadi Lvt. 1779. F. 93.; „A Habsburg birodalomban is igen elterjedt volt a kamarási méltóság. A kamarási címre pályázónak hiteles dokumentumokkal kellett bizonyítani, hogy régi nemesi családból származik - ez volt az un. kamarási öspróba. - ez ún. kamarási ősfa becsatolásával történt meg. Az öspróbák - „német”, „magyar”, „olasz”, „erdélyi”, „galíciai” - letételét Mária Terézia 1766. május 31-i pátense, illetve I. Ferenc 1824. augusztus 16-i kabinetiratai szabályozták. A kamarási méltóságot elnyertek hivatali jelvényként egy aranyozott kamarási kulcsot viseltek. A kamarásoknak külön kamarási egyenruhájuk is volt - zöld színü, aranyhímzéses frakk, hosszú zöld nadrággal, arany lampaszokkal, ehhez fekete kalap (ún. zweispitz) structoll szegélyzettel és az öltözethez aranyveretes, gyöngyházmarkolatú díszkardot viseltek.” (Pandula, 1986. 224.)

${ }^{61}$ MOL Fest. Lvt. P 235 Memor. 266. ; Idézi: Szabó, 1928. 209. ; Érdemes megjegyezni, hogy Zbaraz lengyel város (ma az Ukrán Köztársaság területén található) központi szerepet játszott 1649. július-augusztus közt, amikor a lengyel csapatok Jeremi Wisniowiecki herceg vezetése alatt igyekeztek megvédeni a zbarazi várat az ukrán Bogdan Hmelnyickijjel szemben, aki káni hadakkal már Krakkót fenyegette. A lengyel seregben lengyeleken kívül, litvánok, rutének, oláhok, németek és magyarok is voltak. Bár a csata elveszett, mégis megkötötték a Lengyelország számára kedvező Zborówi békét. Erről az ostromról ír Henryk Sienkiewicz Nobeldíjas lengyel író regénytrilógiájának Tüzzel-vassal címet viselö kötetében.
} 
Zbarazból írt levelet apjának 1781. december 10-én. Festetics Pál ugyanis visszautasította Graeven tábornok ajánlatát, midőn Festetics Györgynek századot akart adni. György megpróbálta megértetni apjával, hogy az apai döntés tragikus volt számára. „Ez a legjobb eszköz - írja Festetics György - hogy két szék közt a földre essünk”, majd így folytatja: „Könyörgök önnek atyám, hogy ne mulassza el a mostani kedvező alkalmat, amit a körülmények találkozása a Graeven ezredben nyújt. - Ha nem élünk vele, örökre el leszek temetve".62

Úgy tünik, hogy a jajkiáltás sem gyorsította elképzeléseinek valóra válását. 1782. június 22-én Festetics, immár sokadjára, ismét kérelmezte más - nem Galíciában állomásozó ezredbe való áthelyezését. A haditanács a kérelmet irattárba helyezte. ${ }^{63}$ Ebben az időben sokat levelezett Széchényi Ferenccel. Ezekből a levelekből kiolvasható sorsával való elégedetlensége, nyugtalansága és tépelődése. ${ }^{64}$ Ennek egyik oka lehetett döntései helyességébe vetett bizodalmának megingása, valamint az állandó anyagi gondokkal való küszködés. Ez utóbbi nem különösebben költekező életmódjából, hanem sokkal inkább a család öröklött adósságaiból következett. A mintegy százezer holdra tehető családi birtok legnagyobb részét vásárlással, illetve pereskedéssel szerezték az elődök. Egy-egy család férfiágának kihalása után ugyanis a kincstárra visszaszálló birtokot királyi adomány címén meg lehetett szerezni, ha a felbecslést követően a megfelelő összeget az illető nemes családfő befizette a kincstárba. A birtokszerzés ily módja az udvar kegyétől függött, de a vásárlást követően a kamatokkal terhelt összeg évtizedekig megterhelte a birtokosokat. A XVIII. század végére a fö-és köznemesség ilyen módon teljesen eladósodott. Mindenki mindenkinek tartozott. Festetics Györgynek például 1787. június végéig 34000 forintot kellett megadnia, egyik levelének tanúsága szerint. Ez hatalmas összeg volt, ha figyelembe vesszük, hogy a Festetics birtokok évi jövedelme ezekben az években 9300 és 9800 forint körül mozgott. ${ }^{65}$

Ugyanakkor más tartalmú levelek is születtek, amelyek vizsgálódásunk szempontjából fontosabbak. 1781. február 21-én az írja Széchényinek, hogy csupán kezdetei vannak meg egy vegyes irányú könyvtárnak, amely „,arra van szánva, hogy hazafiakat képezzen”, még ezt is kevésbé használhatja, mert „,bolyongó sorsa nem ülő tudóssá, hanem vándorló tatárra” tette. Megírja Széchényinek, hogy két láda kéziratokat, könyveket, a kötetek katalógusaival

\footnotetext{
${ }^{62}$ Magyar Levelesk., I. 428-429. Festetics György Festetics Pálnak, Zbaraz, 1781. december 10. ; A kiadvány több, a Festetics családdal kapcsolatos levelet is közöl.

${ }^{63}$ KA 1782. 59. 152. Sajnos az iratot kiselejtezték, csak az iktatókönyvben szerepel. Idézi: Szabó, 1928. 208. ; Szabó jelzete szerint: Hadi Lvt. 1782. G. 1681.

${ }^{64}$ MOL Széchényi Lvt. P 623.25 cs. 48

${ }^{65}$ Kurucz, 1999. 268.
} 
egyetemben rá fog bízni. ${ }^{66}$ Levelét a következő mondattal zárja: „Te bizonyára jól belátod, hogy én ezeknek nem vehetem hasznát, de téged a természet, a gondviselés és nemes gondolkodásmódod abba a helyzetbe juttatott, hogy egykoron sok szoronghatott emberrel jót tehetsz és szegény elhagyott hazánk mindig őszinte és becsületesen gondolkodó barátot fog benned találni”. ${ }^{67}$ Szabó Dezső immár többször idézett művében arra mutat rá, hogy ezek talán apjának Miscelláneái voltak, amelyek azután a Magyar Nemzeti Múzeumba kerültek a Széchenyi könyvtár többi darabjaival egyetemben. ${ }^{68}$ Kurucz György tanulmányából tudjuk, hogy Festeticset már korában is foglalkoztatta egy könyvtár kialakításának terve, a családi könyvtár meglévő állományán túl. Valószínűleg a fiatal gróf utasítására 1778. május 15-e után két katalógust állítottak össze. Az egyik német nyelvü (Bücher Catalog des Gnädigen Herrn Grafen George v. Festetics 1778), a másik francia (Catalogue des Livres du Comte George Festetics). A katalógus szerint a könyvek egy része a családi könyvtárból, nagyobb részük vásárlás útján került az akkor huszonhárom éves Festetics György bibliotékájába. A katalógus 388 tételt tartalmaz. ${ }^{69}$ Tematikailag Festetics könyveinek leggazdagabb csoportját képezték a történelmi, politikai, továbbá a filozófiai tárgyú művek. Kurucz György elsőként La Bruyére

\footnotetext{
${ }^{66}$ Festetics György Széchényi Ferencnek, 1781. február 21. ; MOL Széchényi Lvt. P 623 I. köt. 48. 409-410. ; Idézi: Szabó, 1928. 209. ; Szabó lábjegyzete szerint: „Talán apja Miscellaneáiról van szó, amely azután a M. N. Múzeumba kerültek. Kollányi: A M. N. Múzeum Széchenyi-könyvtára. 19.

${ }^{67}$ MOL Széchényi Lvt. P 62325 cs. 409-410. Idézi: Szabó, 1928. 209-210.

${ }^{68}$ Nem mehetünk el szó nélkül ezen megjegyzés mellett. Óhatatlanul eszünkbe ötlik a Festetics hagyaték sorsa. A II. világháború vége felé a németek elöl (is) a keszthelyi birtokot elhagyó herceg Festetics Györgyné és fia csupán kézipoggyászokat vitt magával, azzal a meggyőződéssel, hogy a háborút követően visszatérhetnek birtokaikra. A ,gazda” nélkül maradt kastély első kifosztói a Keszthelyen állomásozó német egységek voltak, majd a szovjet hadsereg katonái költöztek a falak közé, őket a helybéliek követték. (Franke Máriának, a Festetics család utolsó kertészének szíves szóbeli közlése, 1965-ben) 1948 nyarán, az elhagyott hitbizományok államosításakor a kastély könyvtára az Országos Széchenyi Könyvtár gondozásába került. Enne következtében olyan kódexek, ősnyomtatványok kerültek el Keszthelyröl, mint Kinizsi Pálné zsoltároskönyve a Festetics-kódex, az un. Keszthelyi-kódex. Ekkor került a keszthelyi kastélyban örzött Festetics és Batthyány levéltár a Magyar Országos Levéltárba. Csupán a levéltári anyag nagyságát jelzendő, ma a Festetics levéltár 1550 csomóból, 1329 kötetből, 153 dobozból, egy tekercsből és egy tékából, összesen 3034 raktári egységből áll. (A Festetics családi levéltár. Repertórium. Összeállította: Kállay István. Kézirat, MOL, Budapest, 1978) Ekkor került számos értékes, még megmaradt berendezési tárgy a budapesti Iparművészeti Múzeumba. (Az Iparmüvészeti Múzeum gyüjteményei. Összeállította: Miklós Pál. Magyar Helikon/Corvina, Budapest, 1979) Az elöször 1974-ben felújított múzeumi részben, eredeti bútorok hiányában olykor nagypolgári bútorokat helyeztek el, ami nem emeli az egységes múzeumi képet. Véleményünk szerint mindenképpen átgondolandó, hogy a Festetics anyagok, megfelelő biztosíték után, visszakerülhessenek eredeti (keszthelyi) helyükre.

${ }^{69}$ Kurucz, Fest. Knyvt, 2006. 95-96. ; A tanulmány többek közt kiemeli, hogy Festetics ezen könyvtárában mennyiségileg messze kitünik a francia nyelvü kötetek száma, majd az után következnek a német, a latin és az angol nyelvü könyvek. A magyar nyelvű munkák kevés darabszámának okára rávilágít, hogy a katalógus 1778ban készült. A fiatal Festetics György könyveinek katalógusa a müvek arányait tekintve, egyértelműen a politikai, történeti, filozófiai tárgyú könyvek dominanciáját mutatja. Vitathatatlan a theresianumi évek meghatározó szerepe, de például a kortárs angol irodalmi müvek iránti érdeklődése már önálló értékítélet kialakulására is következtetni enged. Megállapíthatjuk továbbá azt is, hogy könyvtárában a „ráció századának” valamennyi jelentős szerzőjétől találhatunk müveket, illetve a könyvtár állományának egésze a tulajdonos sokoldalú és rendkívül komoly enciklopédikus műveltségét feltételezi. A katalógus alapján Festetics könyvkultúrája a kortárs európai főnemesség müveltségi szintjéhez mérten sem lebecsülendő. (Kurucz, Fest. Knyvt, 2006. 106-107)
} 
eredetileg 1668-ban megjelent Jellemrajzok címü munkáját említi, de ott húzódott meg a könyvespolcokon Vauban marsall Királyi dézsma címü munkája, Fontenelle Beszélgetések a világ sokaságáról és az apja sági könyvtárából kikölcsönzött Montesquieu A törvények szelleme kötetei, valamint John Locke kormányzati ismeretelméleti könyve német és francia nyelven. ${ }^{70}$ Ugyancsak John Locke könyve a Some Thoughts concerning Education (1693) Borosjenői gróf Székely Ádám magyar fordításában is ott volt Festetics könyvtárában. ${ }^{71} \mathrm{~A}$ szépirodalmi munkák közül Moliére összes müvének 1718-as párizsi kiadása, Marmontel, Tasso, Goldoni Christian Ewald von Kleist, Klopstock, Ramler, Salamon Gessner, Lessing munkáit, Cervantes Don Quijote-ját említhetjük. ${ }^{72}$ Voltaire irodalmi munkáival volt jelen, Rousseau hat kötetével, köztük a Társadalmi szerződés-sel és az Emil-lel. Az ifjú Festetics olvasta Henry Home-nak és David Hume-nak munkáit, járatta a The Spectator-t, amelynek teljes 1767-es évfolyama (1-8 szám) könyvtárában rendelkezésére állt. ${ }^{73} \mathrm{~A}$ magyar nyelvü munkák alulreprezentáltsága, a katalógus összeállításának évét véve figyelembe (1778) talán nem is szorul különösebb magyarázatra. ${ }^{74}$

A család anyagi helyzetének javítása érdekében - mint annyiszor már a család története folyamán - megfelelő házastársat kellett találni. Festetics Pál fia számára ezt meg is találta Jakabházi Sallér Judit személyében, aki Sallér István nádori ítélőmester leánya volt. Elkezdődött a két család közötti levelezés. Sallér István nagy megtiszteltetésnek vette az ifjú gróf leánykérését, és megjegyzi leányáról:”...eő magát ki nyilatkoztatta, hogy mindenek előtt Méltosságos Groff Uramat szereti és ha teczik Nagyságodhoz megy férjhez. (...) Szándékunk nekünk nem volt, oly nagy Méltóságos helyre adni leányunkat, ugy oly nagy házhoz való szükségessekre, és illendökre nem is tanittattuk; De ha Nagyságodnak teczik, nints okunk, hogy ellenezzük, és lányunknak szabadságát gátolluk, mullik, a mi könnyebségünk, mert ugy

\footnotetext{
${ }^{70}$ Kurucz, Fest. Knyvt., 2006. 104.

${ }^{71}$ A mü magyar címe: A gyermekek neveléséről. A fordítás 1769-ben készült, Kolozsváron adták ki 1771-ben.

${ }^{72}$ Kurucz, Fest. Knyvt., 2006. 103

73 Kurucz, Fest. Knyvt., 2006. 105-106 ; Ma is megtalálható a könyvtárban: Fest. K. Hel. Knyvt. Folyóiratgyüjtemény A/8.

74 Magyar nyelven 1 filozófiai, 6 irodalmi, 2 nyelvvel foglalkozó, 1 vallási témáju kötetet találhatunk a katalógusban. A feltüntetett müvek közt megtalálhatjuk Gyöngyösi István Phöenix (1744) és a Murányi Vénusz (1771) címü munkáit, Marmontel Balisarius (1773) és Szomorú játék magyar nyelvü kolozsvári kiadásait, az Újmódi selem ruha (1769) című munkát, valamint Muratori Ájtatosságrul költ munkájá-t (Eger, 1763), A Böltsességnek és jó erköltsnek könyve, a kegyes ifjuságnak a tisztelendö öregségtől nyert ajándéká-t (Pozosny, 1774). Feltünő, hogy Bessenyei egyetlen munkáját sem találjuk az összeírásban. (Kurucz, Fest. Knyvt., 2006. 107.) Ugyanakkor a Festetics Könyvtár mai állományában számos korabeli Bessenyei munka található. Ezek beszerzése a könyvekben meglévő pecsét alapján a XIX. század végére a XX. század elejére valószínűsíthető.
} 
sem sokáig tartando, tsak néki ligyen szive és lelke nyugta". 75 A gazdag Sallér Judit hozománya 400000 forint volt, amely összeg javított volna a Festeticsek szétzilált anyagi helyzetén. Festetics György, akit már ez idáig is nyomasztott apjával a katonai pályára lépés miatti rossz viszony, nem akart ismételten ellenszegülni. Bár fenntartásai voltak, el kellett ismernie, hogy a kiszemelt hölgy szép volt, hozománya is tekintélyes összegre rúgott. 1782. február 10-én Zbarazból írja barátjának és sógorának Széchényi Ferencnek: „,.. ezen alkalmat meg fogom ragadni, hogy mindennek bizton elrendezésével örök békét teremtsek családunkban."76 Azonban az idő gyorsan múlik, Festetics tépelődik és első nekibuzdulása úgy tünik, kezd alábbhagyni. Ugyanezen év szeptember 15-én, Ságon kelt levelében azt írja Széchényinek, hogy semmi sincs még eldöntve: „Ami Sallérékat illeti, remélem, öt nap alatt tudósítlak sorsomról. Köztünk mondva, nem sok reménységem van hozzá."77 Festetics György végül beadta derekát, 1783. február 13-án a 6000 forint kauciót letette és megkapta a házassági engedélyt. ${ }^{78}$

Vajon beszélhetünk-e szerelemröl a két ember között? E rövid kitérőben nem tudunk minden apró részletre rávilágítani, de a rendelkezésre álló és itt idézett dokumentumok arra engednek következtetni, hogy a kezdeti szerelmet később felváltotta az egymástól való elhidegülés. A kutatók ezt a témát különböző módon ítélik meg. Felesége legtöbbször követte Festeticset szolgálati helyére, s csak a terhességek idején tartózkodott Bécsben, vagy valamelyik családi birtokközpontban. Ha úgy adódott leveleiben a gróf tájékoztatta és utasításokkal látta el feleségét. A katonáskodó Festetics György Sallér Juditnak 1790-1798 között küldött leveleiből elsősorban racionálisan gondolkodó, a birtokait és vagyonát féltő, a hitelt időben és pontosan visszafizetni akaró ember képe rajzolódik ki. Nemcsak javaslatokat, utasításokat ad feleségének a gazdaság vezetésére, de saját maga pénzköltéséről (lovakat vesz, stb.) is számot ad feleségének. ${ }^{79}$ Mủvelődéseszményét nem lelhetjük fel a megmaradt levelezésben, de mindegyikben kitér gyermekeire, azok erkölcsi nevelésére: „Az Gyermekeknek Istenes Nevelését ajánlom néked, kérlek az Istenért szemeid előtt tartsad őket, és a mennyire lehet maradj Keszthellyen." ${ }^{80}$ Másutt: „Gyermekeinknek áldásomat adom.."81 A megszólítások és a búcsú szavai ezekben a levelekben talán a korra jellemzően szokványosak, mi mégis hajlamosak vagyunk ennél többet észrevenni. A megszólítások:

\footnotetext{
${ }^{75}$ Magyar Levelesk. I. 432-433 Sallér István Festetics Györgynek, Molnári, 1782. október 21.

${ }^{76}$ Festetics György Széchényi Ferencnek, Zbaraz, 1782. február 10. ; MOL Széchényi Lvt. P 623 25 cs 421-422.

${ }^{77}$ Festetics György Széchényi Ferencnek, Ság, 1782. szeptember 15. ; MOL Széchényi Lvt. P 62325 cs 439 440.

${ }^{78}$ Szabó, 1928. 217.

${ }^{79}$ Festetics György Sallér Juditnak, Trier, 1790. november 8. ; MOL Fest. Lvt. P 2471 cs. B. V. 3. 207.

${ }^{80}$ Festetics György Sallér Juditnak, Lintz, 1790. október 14. ; MOL Fest. Lvt. P 2471 cs. B. V. 3. 206.

${ }^{81}$ Festetics György Sallér Juditnak, Namur, 1790. december 5. ; MOL Fest. Lvt. P 2471 cs. B. V. 3. 208-209.
} 
„Édes Szívem, Kedves Angyalom, Szerelmes Angyalom, Édes Szívem Kintsem Angyalom, Édes Szívem Angyalom, Édes Lelkem Drága Kintsem, stb.”, búcsúzóul pedig ,igaz kis férjed, igaz férjed, örökkön hív igaz szolgád örökön hív férjed, stb.” ${ }^{„ 2}$ A leveleket magyarul írták és legtöbb esetben maga Festetics. Ha a szövegben túlteng is a közölnivalók racionális számbavétele, nem hagyhatjuk figyelmen kívül azokat a mondatokat, amelyek tele vannak aggódással, szeretettel, olykor némi humorral is. Nem mulasztja el, hogy a vele megtörtént eseteket meg ne írja. Brüsszelből 1791. január 7-én írt levelében Festetics várandós asszonyához a következő szavakat intézi: „Reménylem az Úr Isten fog Téged ezen Uj esztendőben különös pártfogásba venni és mivel TE Muraközi Földes Asszony lettél azon fogsz igyekezni, hogy egy egészséges LATOR FITZKÓT a Világra hozol, a ki ma holnap fáradságaidat tiszteletével meghálálja, a midőn a Csáktornyai kastélyban lakni fog." Festetics büszke új „,szerzeményére”, a csáktornyai birtokokra, ez derül ki a levélből és az is, hogy fiút vár. (De nem fiú, hanem Viktória születik meg.) Mindamellett levelét egy kis történettel zárja: „Mi itten nagy csendességben vagyunk, de azért mégis egy napon egy Tracternél levő asztalnál Boros Generális Urra és én reám /:de mégis minden szerencsétlenség nélkül:/ az által ellenben lévő házból szél puskával kétszer lövöldöztek, amidőn ebédnél az Asztalnál voltunk." ${ }^{83}$ Ezen év februárjában, megtudván lánya születését ír a feleségének: „Édes Szivem Angyalom! Kozits Fiscalisnak tudositásábul örvendetessen értettem, hogy szerentsésen egy Leányt az Világra hoztál. Némü némü volt véletlenséggel eseted, azért elegendő hálákat az Úr Istennek nem adhatok hogy, minden kár nélkül egésségben az mind írtam meg tartott. Kérlek tehát vigyázz magadra, és veszedelemben ne ejtsed életedet, hanem kéméllyed ezen drága kintset, az sok számu Leányidnak értelmes, jó tiszta élet-erköltsü tökélletes nevelésére. Vaiha rövid nap alatt bár láthatnálok! - vagyon egy kis reménységnek villogó sugárom, mert ime (titokban irom) Béts felé utban vagyok, azért minden esetre Leveleidet Bétsbe utasitsad, (...) Többet most nem terhellek hanem ezerszer ölelvén maradok Édes Szivem Angyalom örökön hiv férjed

Luxemburg, (?) Febr 791

Festetits György $^{84}$

\footnotetext{
${ }^{82}$ Festetics György levelei Sallér Juditnak ; MOL Fest. Lvt. P 2471 cs. B. V. 3.

${ }^{83}$ Festetics György Sallér Juditnak, Brüsszel, 1791. január 7. ; MOL Fest. Lvt. P 2471 cs. B. V. 3. 199-200.

${ }^{84}$ Festetics György Sallér Juditnak, Luxemburg, 1791. február 2. ; MOL Fest. Lvt. P 2471 cs. B. V. 3. 203.
} 
A következő levelet február 28-án írta Klagenfurtból. Festeticset nem engedték felesége meglátogatására. Terve ugyanis az volt, hogy bécsi útját összekapcsolja egy magyarországi látogatással. A parancsnokság azonban megtiltotta, ezt az utat. A szigor, amely egyben retorzió is volt, elsősorban a „rebellis hírbe” keveredett grófnak szólt nem a katonának. Csalódott és fájdalmasan panaszolja feleségének: „Villogó kis sugára Reménységemnek el enyészett, mert noha Bétsben valék, Magyar Országra nem eresztettek, hanem sietséggel Mailandba, avagy Mediolanumba Olasz Országba az Itabs Dragonyosokhoz kergettek. Okát nem mondották, nem is tudom, azért Bétsbül nem is mertem írni, de most látván, hogy írni nem tilalmas adom tudtodra. Mihelyst Mailandba érek, meg írom ha lehet sorsomat, minden szerencsétlenségben vagyon kis vigasztalás, most az örvendeztet, hogy mégis közelebb vagyunk, mintsem Belgiumban egymáshoz, te úgyis Velentzét mindenkor örömöst láttad volna, most nyáron ezen vagy jövő esztendőben Triestnek vévén utodat Velentzének - közel érsz. Sainálom, hogy Tanátsimmal kezedhez nem járhatok, azért kérlek, hogy minden héten valakivel irass nékem..." ${ }^{85}$ Felmerül a kérdés, vajon tényleg nem volt tisztában a tiltás okával, avagy nem merte nyílt levélben megírni feleségének a tényeket? A második vélekedést tartjuk elfogadhatónak amit alátámaszthat a levél egyik mondatának árulkodó részlete: „Bétsbül nem is mertem írni.” De mintegy túljárva a szigorú parancskiadók eszén azzal vigasztalja feleségét, hogy a Belgiumnál jóval közelebbi Itáliában találkozhatnak végre. Az 1791-es évben Sallér Juditot több alkalommal is férje oldalán találhatjuk, de erről később szólunk.

Nem múlt el másfél évtized, Festetics György és Sallér Judit kapcsolata végképp elromlott olyannyira, hogy a feleség elköltözött a keszthelyi kastélyból. 1805. április 15-én kelt korrekt szerződésben kötötték ki miszerint „mi módon lehessen közöttünk alább irattak között az már meghatározott Elválásunkat tovább is ugy folytattni, hogy ez a Gyermekeinknek legkevesebb kárával, a külső illendőséggel és Tisztességgel megeshessen" ${ }^{86}$ Azt, hogy miként valósuljon meg az elválás és az azt követő időszak, milyen kapcsolat maradjon köztük és gyermekeik között, azt pontokba szedve határozták meg. Az irat szerint a gyermekek érdekeit szem elött tartva arra kell törekedni, hogy elkerüljenek minden alkalmat, amely lehetővé teszi a „háborgás, pörlekedés, vagy szemrehányás” bármilyen lehetőségét. A gyermekek nevelését, későbbi házasságát mindketten szem előtt tartják „státusukhoz alkalmaztatván”. A gazdaságot megfelelő módon kell kezelni. Ügyelni kell, hogy a gyermekek „pazarlással és vesztegető fényeskedésekkel” ne éljenek, hogy „utóbb meg ne

\footnotetext{
${ }^{85}$ Festetics György Sallér Juditnak, Klagenfurt, 1791. február 28. ; MOL Fest. Lvt. P 2471 cs. B. V. 3. $204-205$.

${ }^{86}$ MOL Fest. Lvt. P 2471 cs. B. V. 1. 15-17.
} 
erőtlenedjenek". Mindennek érdekében öt pontban határozták meg a tennivalókat. Érdekes megfigyelni, hogy a két fél mit tartott fontosnak kikötni a szerződésben. Először is „az elválásnak szabadságában” mindkét fél megmaradjon. Együtt élésre egyik fél se kényszerítse a másikat. Másodszor Festetics György kinyilatkoztatja, hogy a grófnét látogatásaival terhelni nem akarja, és nem akar „Jószágainak kormányzássában avatkozni”. Ugyancsak nem foglalkozik tisztjeivel, külső- és belső „Házi Embereivel”. Ezzel egy időben kéri, hogy a grófné hasonlóan cselekedjen. Harmadszorra a gróf kiköti, hogy „Fiamat édes Asszony Anyjához való igaz tiszteletre, és háladatosságra mind magam serkenteni, mind társalkodássai által inditani igyekezni fogok", de ugyanakkor ezt megköveteli saját részére is. Ebben a pontban részletesen kitérnek a gyermekek későbbi házasságára vonatkozó lényeges, elsősorban anyagi kérdésekre. Negyedszerre kikötik, ha valamilyen tragédia, vagy egyéb fontos ügy miatt mégiscsak „,rövid időre öszve jövetelünk szükséges”, akkor sem avatkozik bele egyik fél sem a másik „házi dolgaiba” és mint vendégek fogna egymás iránt viseltetni. Ötödszörre leszögezik, hogy a gazdaság, a vagyon megtartása, gyarapítása érdekében társadalmi rangjuk figyelembevételével fognak eljárni. Megtartják „a’ Gyermekeinknek Javát, az Familiának Díszét, az Király és Hazának hasznát, a' mellett a' Világi és Lelki Üdvösséget”. Festetics György vállalja, hogy gyermekeinek taníttatását saját vagyonából biztosítja. A szerződés utolsó bekezdése szerint az irat két példányban készült, melyet Bécsben Szent György havának 15. napján az 1805-ös esztendőben saját kezüleg aláírta Tolnai Gróff Festetits György és Jakabházi Sallér Judith. ${ }^{87}$

Ezt követően Festetics feleségnek írt levelei kimondottan hivatalosak, érzelemtől mentesek. 1817. május 4-én Keszthelyröl egy eladással foglalkozó levélben megszólítás sincs, csak a levél címzése és búcsúszavai adnak eligazítást arra vonatkozóan kinek íródott. A minden kétséget kizáróan rideg szövegezésű levél végén némi keserűséggel teli fricskát érezhetünk a búcsú szavainál: „Ki többnyire szívességedbe ajánlott vagyok, igaz szívű férjed, Festetics György."

Természetesen nem hagyhatjuk figyelmen kívül a Sallér Judittal kötött házasság anyagi oldalát sem. Házasságuk elején Festetics György így nyilatkozott: „Látván kedves apám nagyszámú családját, úgy tetszik, hogy évente 1000 ducát az az összeg, amelyet az apai jószág a legnagyobb megfeszítéssel tud nekem nyújtani”. Úgy gondolta, hogy felesége legalább ennyit tudna szüleitől a családi költségvetés egyensúlyának fenntartása érdekében kapni. A gazdálkodásban később remek eredményeket elérő gróf már ekkor úgy tartotta, hogy

\footnotetext{
${ }^{87}$ MOL Fest. Lvt. P 2471 cs. B. V. 1. 15-17.

${ }^{88}$ Festetics György Sallér Juditnak, Keszthely, 1817. május 4. ; MOL Fest. Lvt. P 2471 cs. B. V. 3. 212.
} 
az évi 2000 ducátot semmiképpen nem lehet teljes egészében elkölteni, annak egy részét 4 \%-os kamatra Széchényihez „tennék 1e” ${ }^{89}$ Ugyanakkor megjegyzi: „Az adózás fejünk fölött lebeg, a fiatalemberek elhelyezése nem megy többé olyan könnyen, mint azelött s a grófi cím sok hasznos előnyt elvesz tölünk. Ha nem tartunk össze elveszünk". ${ }^{90}$ Talán ez a levél is rávilágít arra, hogy a kezdetben jozefinista elveket valló Festetics, lassan rájött, hogy a nemesség megadóztatása számára is beláthatatlan következményekkel járhat. Ráadásul birtokainak gazdálkodási hatékonysága alacsony volt, érékesítési gondokkal küszködött. Tíz év sem telt bele és Festetics Európára-szóló lépést tett: megalapította a kontinens első felsőfokú mezőgazdasági oktatási intézményét a Georgikont.

Az 1780-as évekhez visszatérve felfigyelhetünk egy rendkívül érdekes esetre, amely bepillantást enged Festetics György gondolkodásába, mentalitásába. Kurucz György hívja fel a figyelmet egy kevésbé ismert, de jellemző történetre. Az 1780-as évek elején az idősebb báró Wesselényi Miklós, egy alkalommal összetüzésbe került a gróf Haller család egyik közismerten aulikus tagjával. Az összetűzés párbajjal végződött. II. József császár elfogatta Wesselényit és súlyos börtönbüntetésre ítélte. A foglyot a magyar határ azon szakaszán átszállították, ahol Festetics katonáival állomásozott. Festetics azonnal felajánlotta Wesselényinek, hogy kiszabadítja fogságából, amit a báró nem fogadott el. Festetics kiválóan tudta, hogy egy ilyen cselekedet súlyos katonai vétségnek, a császárral való szembeszegülésnek számít. Mégis úgy tünik, hogy a fiatal tiszt kész lett volna akár uralkodójával is szembeszállni. ${ }^{91}$

1782 februárjában meghalt Festetics Pál. A halálát követően felbontott végrendelet szerint, a Festetics Kristóf által alapított majorátust az apa a három gyermek között osztotta szét. Nem prosperáló gazdaságról, hanem adósságokban fuldokló nagybirtokról lehetett beszélni. Festetics György azonban szerette volna együtt tartani a birtokot, ezért vállalkozott, hogy öccseit és leánytestvéreit saját vagyonából végkielégíti. Ez hatalmas összegre, 1150000 forintra rúgott. ${ }^{93} \mathrm{Az}$ általa igencsak tisztelt apósához írt levelében, szinte kétségbeesve ecseteli helyzetét: "Néhai édesapám sok ellenségek közt árván hagyott, jószágaim mind a rossz gazdaság miatt, mivel magam elegendőképpen nem értem és odahaza nem lakhatom, mind pedig a török által és az nagy adósságok terhe alatt veszendőbe fognak menni. Én ugyan

\footnotetext{
${ }^{89}$ Szabó, 1928. 212.

${ }^{90}$ Szabó, 1928. 212.

${ }^{91}$ Kurucz, 1999. 268. ; Széchenyi-Wesselényi, 1986. 94

93 Szabó, 1928. 216.
} 
magam bajomat magam viselni igyekeztem és soha édes uramatyámnak terhére esni nem akartam, de mivel most az török háború mintegy bizonyos, olyan inségben vagyok, hogy végső romlásomra sietni fogok, hacsak nem találok olyan igaz barátot, aki biztos tanácsaival igazítson és jószágomban az tolvaj pazarló cselédeimet zabolában vezérelje." ${ }^{94}$ Leveleket ír barátjának, sógorának, Széchényi Ferencnek is, és az iránt érdeklődik mit javasolna arra vonatkozóan, hogyan fizesse ki testvéreit. ${ }^{95}$ Tanácsot kér, nem sajnálatot. Szeptember 15-én a sógorának a következőket veti papírra: „Nyomorúságomat nem azért panaszolom el Neked, hogy segíts rajtam, hanem azért, hogy egy igaz barát előtt kitárhassam szívemet." ${ }^{96}$ Kurucz György Festetics György pénzügyeiről szóló tanulmányában részletesen megmagyarázza a nagy összegü adósság milyen tételekből állt össze. ${ }^{98}$ A gróf kénytelen volt komolyan venni gazdaságának ügyeit. Nem véletlen tehát, hogy a Festetics házaspár közötti levelezésének fő témái a pénzügyek voltak, adósságaik kezelése, az azokra adott megoldási lehetőség. Más témát szinte nem is érintettek a levelek. Sem a társadalmi feladatok területéröl, sem a mecenatúra területéröl nem találunk értékelhető mondatokat. Sem ö, sem a feleség nem említett ilyen témákat. Úgy tünik Sallér Judit számára nem is volt fontos az, amire férje hatalmas energiákat kívánt fordítani. ${ }^{99}$ A keszthelyi gróf a birtokok átvételét követő pénzügyigazdasági lépései átgondoltak, sokszor merészek voltak, ám sohasem felelőtlenek. Nemcsak hitelt vett fel, de adott is, a kor szokásainak megfelelően. Volt aki nem fizetett, mint Vécsey altábornagy és erre a hadbíróság kötelezte, volt, aki megköszönte a hitelt. ${ }^{100}$ Festetics pénzügyi terveiben minden kétséget kizáróan figyelembe vette a háborús konjunktúra pozitív hatását, amely elödjeinek is hasznára vált. Ugyanakkor nem zárkózott el terveinek revideálásától, a mindenkori lehetőségek megragadásától sem.

Festetics György 1786-tól a magyar nemesi testörségnél szolgált - örnagyi rangban -, és ami nem volt utolsó szempont: közelebb lehetett családjához, birtokaihoz. Viszonylag rövid ideig tartózkodott Bécsben, sok befolyásos embert ismerhetett meg, aktívan vehetett részt a szabadkőmüvesek ülésein, találkozóin. 1787. szeptember 20-án saját kérelmére a császár a Graeven huszárezredhez helyezte át. ${ }^{101}$ Ismét a kiújuló török elleni harcban

\footnotetext{
${ }^{94}$ Festetics György Sallér Istvánnak ; MOL által rendezett iratok P 2861 cs. 1782:7. ; Idézi: Szabó, 1928. 218.

${ }^{95}$ MOL Széchényi Lvt. P 62325 cs. 430

${ }^{96}$ Festetics György Széchényi Ferencnek, 1782. szeptember 15. ; MOL Széchényi Lvt. P 62325 cs. 439-440.

${ }^{98}$ Kurucz, Fest. pü., 2006. 546

${ }^{99}$ Kurucz, 1999. 269.

${ }^{100}$ Kurucz, Fest. pü., 2006. 558. Érdekes adalékot közöl Kurucz György tanulmánya, amelyből megtudhatjuk, hogy az 1793. április 13-án a Vécsey-perben a vizsgálóbíró éppen Barco tábornok volt, aki részrehajlás nélkül, a valós tényeket véve figyelembe, marasztalta el Vécseyt.

101 Szabó, 1928. 202. ; A báró Graeven Márton altábornagy nevét viselő, utóbb 4. huszárezredről van szó. (Magyarország hadtört., 1984. I. 427.)
} 
jeleskedett - már alezredesként. A harcok miatt kénytelen volt elhagyni Bécset és 1788. február 18-tól folyamatosan a harctereken tartózkodott. ${ }^{102}$ Ennek - Szabó Dezső szerint legjobban apósa örült, mert roppant költségesnek tartotta Festetics bécsi mindennapjait.

Ebben a háborús vállalkozásban a császárnak nem voltak sikerei. Hogy a továbbiakban elnyerje a magyar nemesek támogatását, engedményeket helyezett kilátásba. Az erőfeszítések azonban későn érkeztek, mert 1790. február 20-án meghalt II. József. Halálakor a birodalom a belső nyugtalanság, zavar jeleit mutatta. A főnemesség visszahúzódott, a köznemesség azonban továbbra is arra törekedett, hogy a császár utódját szinte kész feltételek elé állítsa, visszahozzák a Pragmatica sanctio örökösödési fonalát, az uralkodó kössön új egyességet a nemzettel (értsd: a nemességgel). Ezek a követelések közel jártak a függetlenség kimondásához, amelynek illusztrálására gróf Sztáray Mihály véleménye a legkézenfekvőbb. Ö ugyanis azt hangoztatta 1790 júliusában, hogy az országnak fel kell készülnie egy esetleges Habsburgokkal szembeni lépésre, alkalomadtán a tőlük való elszakadásra. ${ }^{103}$ A köznemesek programját Ócsai Balogh Péter a hétszemélyes tábla bírája fogalmazta meg és a szabadkőmüves páholyokon átterjedt el az egész országban. Ebben a Balogh-féle programban tükröződnek leginkább az egységesen megfogalmazott nemesi törekvések, amelyek közül az egyik legfontosabb, hogy az örökös királyság helyett választói lesz, így a köznemesség kezébe kerülne szinte minden hatalom. ${ }^{104}$ Ugyanakkor ez a program a főnemességet megfosztotta volna eddigi előjogaitól, a jobbágyság és polgárság viszont jogfosztott maradt volna továbbra is. Az óhajtott nemzeti egység a legnagyobb lelkesedés ellenére is töredezett állapotban maradt. A nemesi hatalomátvételhez azonban fegyveres eröre lett volna szükség, nemzeti hadseregre, ami jelenleg nem állt rendelkezésre. A helyzet megértéséhez hozzátartozik, hogy a francia forradalom kezdeti sikereket ért el, a rendek abszolutizmus elleni tiltakozása egyre erősebb lett. A magyar rendi alkotmány és a nemesi közigazgatás tulajdonképpeni megsemmisítése, a német nyelv általános bevezetése kezdete lehetett volna egy nyílt beolvasztásnak, germanizálásnak. A nemesség ellenállása a rendi alkotmány védelme ebben az esetben összefonódott a már csírázó modern nemzeti gondolattal. ${ }^{105}$ II. József alkotmányellenes rendeleteinek visszavonása, az uralkodó halála éppen ezért váltott ki nagy örömöt az országban.

\footnotetext{
102 Szabó, 1928. 220.

${ }^{103}$ Benda, 1957. XIII., 238.

${ }^{104}$ Benda, 1957. XIII-XIV.

105 Benda, 1978. 72.
} 
Ilyen körülmények között érkezett meg Bécsbe az utód, II. József öccse II. Lipót, eddig Toscana, a felvilágosult abszolutisztikus mintaállam uralkodója. ${ }^{106}$

1790-ben, Szent István koronájának Bécsből Budára való visszahozásának ürügyén koronaőrségeket szerveztek, ezzel együtt megindult a megyékben a fegyverkezés. Összeírták mindazon nemeseket, akik fegyverforgatásra alkalmasak voltak és feleskették őket a „megkoronázandó király” iránt. Tehát nem az osztrák császárra, hanem a magyar királyra tettek esküt. Ennek jó oka volt, szerették volna elkerülni II. József, a „kalapos király” által megvalósított alkotmányellenes kormányzás megismétlődését. A nemesi bandériumok megyénként szerveződtek, főparancsnokuk báró Orczy László, a költő Orczy Lőrincnek fia lett. Felhívást intéztek az ország határain túl állomásozó magyar ezredekhez, hogy álljanak a nemzeti ügy mellé. Ezek a nemesi bandériumok egy leendő nemzeti hadsereg csíráit rejthetik magukban. ${ }^{107}$ Ekkor már az udvar előtt is felsejlettek ennek beláthatatlan következményei.

Még II. József halálát (1790. február 20.) megelőzően a koronaőrzők kíséretében Bécsből február 18-án elindult koronát aznap Dévénynél, Pozsony megye ezer fős lovas bandériuma fogadta. Amikor a korona február 19-én Győrbe érkezett nemcsak a nemesség, de a polgárság is kitörő lelkesedéssel üdvözölte. ${ }^{108}$ Nem csoda, hisz maga Kazinczy is így fogalmazott: „József leküldé koronánkat, a jegygyürüt a király és nemzet között, Budára, s akkor lobbanánk örömre."

A nemesi bandériumok tehát megyénként kezdtek megalakulni. Zalában az 1790 márciusában megtartott megyegyülésen gróf Galánthai Fekete Jánost választották vezérnek, Festetics György grófot pedig az egyik prefektusnak. Mályusz Elemér ennek kapcsán az udvar ellenes „,patrióták” közé sorolja Barcsay Ábrahámot, gróf Gyulay Sámuelt Erdélyben, gróf Galánthai Fekete Jánost, ${ }^{110}$ gróf Festetics Györgyöt, Laczkovics Jánost. ${ }^{111}$ Festetics 1500 forintot ajánlott fel a bandérium céljaira. A júniusi országgyülés rendjének fenntartására a Graeven huszárezredet, így Festeticset is Budára rendelték. A déli határszélről Budára masírozó ezred május 18-án a Keszthely határában gyakorlatozó zalai nemesi bandériummal találkozott. Ennek helyét több mint valószínű a Gyenes alatti Falud-i határban állapíthatjuk meg. Novák Ferenc az akkor még Keszthelyhez tartózó Gyenes Hegyközség hites jegyzője ugyanis feljegyzéseiben megörökíti az eseményt, bár konkrét helyet nem említ. Ugyanakkor leírja, hogy ezt megelőzően, 1770-ben József császár vezényletével a Falud-i határban

\footnotetext{
${ }^{106}$ Gonda-Niederhauser, 1997. 145.

${ }^{107}$ Benda, 1978. 83.

${ }^{108}$ Marczali, 1898. 468.

${ }^{109}$ Kazinczy M., 1979., 327.

${ }^{110}$ Részletesebb életrajz: Hirmann, 2004. ; Morvay, 1903.

${ }^{111}$ Sándor Lipót, 1926. 17. A bevezető tanulmányt Mályusz Elemér írta.
} 
gyakorlatozott a darmstadti ezred. ${ }^{112}$ Feltételezhetjük tehát, hogy a már bevált helyen voltak a rendre megtartott katonai gyakorlatok. Ezekből ugyanis nem volt kevés. Erre hívja fel a figyelmet Bontz József is, aki hasonlóképpen pontos helymegjelölés nélkül közli az 1790-es gyakorlatot. ${ }^{113}$ Minden bizonnyal nem véletlen volt az időzítés, sem időben, sem földrajzilag. Az ezredet gróf Festetics János vezette és üdvözölte a „házigazdát”, amire testvére gróf Festetics György válaszolt. Bontz József ugyan romantikusabb ecsettel rajzolja meg a találkozót, miszerint, Festetics György májusban Keszthelyen tartózkodott, amikor „Skaricza őrnagy vezetése alatt a Graeven huszárezred, mely Horvátországból Budára ment, Keszthelyen vonult keresztül. György Kis-Komáromig ezrede elé ment. Vele volt Imre gróf Györgynek testvére, ki, hogy az érkező huszárokat nagyobb fénnyel fogadja, az akkor Keszthelyen lévő Zala megyei bandériumot eléjük vezényelte. György az ezreddel találkozván, ahhoz a hazafias beszédet intézett, azután az ezred a Zala megyei bandériummal együtt Keszthelyre érkezett, hol György gróf őket megvendégelte." ${ }^{114}$ Szabó Dezső szerint a nemesi bandériumot vezető gróf Festetics János üdvözölte a Graeven huszárezredet, erre bátyja Festetics György válaszolt. Az eseményről Pálóczi Horváth Ádám verset is írt, amelyik a Magyar Kurír 1790. évfolyamában ${ }^{115}$ jelent meg:

\section{Midőn Graeven fiait Keszthelyre siettette \\ Festetics György s e zászlóaljat János vezette, \\ És ékes beszéddel mindketten megmutatták, \\ Hogy isteni csodaképpen az egek megadták, \\ Hogy nem lakatul van vetve a hadi nép reájok, \\ Hanem a magyar nemes rend s a katona barátok.}

\footnotetext{
112 „1770-ik Esztendőben Jósef Császár Ő fölsége több Generálisokkal Keszthelyen gvártélyban lévén, a katonaságot pedig int Gyenes alatt a Faludi térein három hétig táborozott, a hol Generál Darmstadnak Német Lovas Regementye naponkint nagy hadi Manuvereket tartott.” (Dornyay, é.n. 5.)

A gyakorlatot részletesen Klempa Károly dolgozta fel. Leírja, hogy az akkor 3500 lelket számláló Keszthelyen II József „Festetics levele szerint a Serházban lakott. Ennek helyét nem ismerjük.” (Klempa, é.n. ) Ma már tudjuk, hogy ez a Sörház az akkori Flöhgassen, azaz Bolha utca (ma Deák Ferenc utca 30.) szám alatt volt. (Lásd: Eszes, 1985. 23. ; Koppány-Péczely-Sági, 1962. 128.) A császár nem azért szállt meg a Sörházban, mert se Festetics Pál, sem felesége akkor nem tartózkodtak Keszthelyen, hanem azért, mert II. József tilalmazott mindennemű szállást a földesuraknál, kastélyokban, ott, ahol egyként az udvar vendégeskedni szokott. Így szálláshelyeken, paplakokban, kamarai épületekben szálltak meg. (Kulcsár, 2004. 114.) II. Józsefet Festetics Pál gróf kérésére Forintos Gábor Zala megyei alispán fogadta. Az alispán Festeticsnek írt levelében idézi a császárt, akinek nagyon megtetszett Keszthely környéke: „Ha Festetics volnék, kastélyomat úgy építettem volna, hogy kertem a Balatonra leszolgált volna.” (Klempa, é.n. 10-11)

${ }^{113}$ Bontz, 1896. 134-135. ; 406.

${ }^{114}$ Bontz, 1896. 406.

${ }^{115}$ Magyar Kurír 1790. 781.
} 
Erröl a nevezetes eseményről részletesen beszámol a „Hadi és Más Nevezetes Történetek" címủ újság 1790. május 28-i száma. Részletesen felsorolja a zalai nemesi bandérium tagjait, némelyiknek beosztását, érdemes szó szerint idézni: „...N. Szalavármegye Zászlóallyának Kormányzója: Mélt. Gróf Galántai Fekete János Úr; Fő Strázsamestere: Mélt. Gróf Tolnai Festetics János Úr; Káplánnya: Főtisztel. Rosty János Apátúr; Kapitánnyai: Gyömörey György, és Kiss Ignátz Urak; Főhadnaggyai: Kiss János, és Nedeczky János Urak; Adjutánsai: Svetits Jakab, és Szalabéri Horváth Imre Urak; Zászlótart(ó): Farkas Lajos Úr; Strázsamesterei: Inkey Menyhárt, és Skublics Imre Urak; Köz Vitézei: Domján József (Hadi Számadó), Deák Péter (Kvártélycsináló), Répás Ferentz, Szigethy Ignátz, Csákány József, Lelovits Ignátz, Thassy Mihály, Diskay Feretz, Győrfy Antal, Vargha Jósef, Marton György, Sidi László, Kerkápoly János, Thury László, Agustits Istv(án), Thassy János, Ibrány János, Farkas Mih(ály), Gerecz Jósef, Domokos Gábor, Horváth Jósef, Salamon László, Zabó Péter, Salamon Ignátz, Rózsás Ferentz, Horváth Antal, Fekete Ignátz, Dely Boldizsár, Takáts Dániel, Fater Pál, Szentgróti Horváth Jósef, Botsárdy Gábor Urak. Seborvosa: Kaposy István Úr. Hat Musikussai, 's két Tárogató-Sipossai vagynak a' Zászlóallynak és 20 Lovásszai, az Inasokon kívül." "116 A cikk továbbiakban leírja a bandérium formaruháját is: világoskék mente és nadrág, fekete dolmány, fekete csótár, fekete tarsoly - mind aranyra. Továbbá kócsagtollal s arany vitézkötéssel ékeskedő kalpag, melynek tetejéből veres posztó csügg ki, valamint fehér köpönyeg. - Minden „vitéznek vagyon szükséges katonai készülete”, úgymint: pár pisztolya, kardja, sátor, stb. ${ }^{117}$

Kurucz György rámutat e találkozó jelentőségére: a bandérium és a huszárok találkozásának fontossága az, hogy választ adott arra a kérdésre; vajon nemzeti hadsereg hiányában a rendi törvényhozó hatalommal szemben, az idegen dinasztia mellett állnak-e ki a magyar sorozású ezredek, vagy pedig számítani lehet támogatásukra, ami komolyan növelhette a nemesség önbizalmát az elkövetkező országgyülés előtt? ${ }^{118}$ Ugyanakkor a találkozó, amely a „testvériség ünnepe” címen vonult be a történelembe, ${ }^{119}$ nem nélkülözi a szabadkőmüves eszmék megjelenését sem. Gondoljunk csak az elnevezésre. Barco tábornok meg is dorgálta Festetics Györgyöt az esemény után. Tetézte a gróf bünét, hogy feleségével együtt kilencven-terítékes lakomát csaptak a nemesi bandérium és a Graeven-huszárok tisztikarának. ${ }^{120} \mathrm{~A}$ bandérium másnap útra kelt és június 8 -án őrt állt a koronánál. ${ }^{121}$

\footnotetext{
${ }^{116}$ Hadi és Más, 1790. május 28. 678.

${ }^{117}$ Hadi és Más, 1790. május 28. 679.

${ }^{118}$ Kurucz, 1999. 271.

${ }^{119}$ Benda, 1957. 210.

${ }^{120}$ Négyesy, 1925. 43. ; Hadi és Más, 1790. május 28. 677.
} 
Festetics pár napig még Keszthelyen tartózkodott, a városban május 21-én megtartott megyegyülésen fel is szólalt. Talán a pár nappal előtti találkozó eufóriájában, vagy nagyon is jól átgondolt és határozott céllal, többek között, a következőket mondta: „Én Festetics György, tagja nemes Zalavármegyének, esküszöm az élő mindenható Istenre, a világ teremtőjére és ezen hitemmel szentül fogadván ígérem, hogy én teljes életemben a szabad magyar nemzet eránt annak eredet szerént való törvényes igazgatásának formája és ezen nemes nemzetet a természetböl és minden jussal illetö törvényt tevő teljes hatalomnak önnön számára örökre leendő megtartása az ország gyökeres és sarkalatos törvényeinek, szabadságainak tökéletes állandóságra és megsérthetetlenségre állétások és végre az országhoz és annak törvényeihez $\mathrm{s}$ szabadságaihoz hathatósan lekötelezendő és megkoronáztatandó király eránt hüséges leszek, az hazafiak között az egyességet minden akármely tekéntetnek félretételével feltartani igyekszem, az beállandó országgyülés ideje alatt vigyázásom alatt (vagy körülöttem lévő vidékbeli) népnek belső csöndességére s bátorságára éjjel-nappal szorgalmatosan vigyázok, azt mindenképpen feltartani igyekszem, ami rosszat pedig, vagy veszedelmet e részben akármi szín és mód alatt tapasztalnék, azt tehetségem szerént orvosolni és megelőzni el nem mulatom és egyszersmind vármegyémnek, hogy onnan az szükség úgy kívánván az ország gyülésének is bejelentethessem, idő haladék nélkül tudtára adom, a nemes magyar nemzet szabadságainak kárára s neminemű elárulására pedig semmi szín és tekéntet alatt semminémü jutalmakat, adományokat, tisztségeket, méltóságokat, jeles rendeket, vagy akárminemủ királyi hivatalokat magam, vagy maradékim számára sem az ország gyülése alatt valósággal, sem annak elmúlása esetére ígéretbe a felső hatalmasságtul el nem veszek s nem keresek, hanem ha az eránt maga az ország, vagy azok, akiknek képét viselem, egyező értelemmel tennének mellettem ajánlást, vagy megegyeznének benne, sőt ha valamely ígéreteket a felső hatalmasságtul vennék is, azt is azonnal a vármegyének kijelenteni el nem mulatom. Isten engem úgy segéljen!" ${ }^{22} \mathrm{Az}$ eskü szövegének első része talán szokványos feladatok felsorolását tartalmazhatja, bár megjegyzi - talán éppen II. Józsefre gondolva -, hogy a „megkoronáztatandó király” iránt lesz hűséges. A második rész azonban nem hagy kétséget afelől, hogy Festetics számára a haza és a nemzet sorsa előbbre való a császári és királyi kérelmeknél, ármánykodásoknál, akármekkora jutalom is járna érte. Egyértelmű és sokat jelentő szöveg. Festetics 35 évesen ugyanazt képviselte szavaival és tetteivel, ami élete végéig jellemző volt rá. Ezért a lépéséért is támadás érte, elsősorban arra

\footnotetext{
${ }^{121}$ Vö.: Morvay, 1903.

${ }^{122}$ MOL Fest. Lvt. P 235 Memor. 266. ; Idézi: Szabó, 1928. 224-225.
} 
szerették volna rábírni, hogy ne vegyen részt az országgyülésen, ne legyen követ. ${ }^{123}$ Azt sem felejtették el, hogy korábban Vinzenz von Barco tábornok kénytelen volt megfedni azért, mert nemzetiszínű kokárdát hordott. ${ }^{124}$ A besúgók 1790. június 15-én névtelen levélben azzal vádolták, hogy két testvérével együtt „,egyenruhában jár és nagy szószólója és védelmezője a honi praerogativáknak”. ${ }^{125}$ Gabelhofer Gyula a pesti egyetemi könyvtár igazgatója, besúgó, július 5-én azt jelenti róla Gotthardi Ferenc (Franz) rendőrfőnöknek, hogy viselkedése igen gyanús, rajongó hazafi, „dummpatriotisch”. ${ }^{126}$ Ekkor azt javasolták az uralkodónak, hogy Magyarországról rendelje vissza délvidéki állomáshelyére, amibe viszont II. Lipót nem egyezett bele. ${ }^{127}$ Van az elmondottaknak egy másik aspektusa is. A Festetics által felolvasott szöveg megegyezik a nemesi bandériumok esküszövegével, amelyben ,a szabad magyar nemzet és annak eredet szerint való jussai, szabadságai és törvényei iránt” továbbá ,a hathatósan lekötelezendő s megkoronáztatandó király iránt” fogadnak hűséget. ${ }^{128}$

Festetics György és katonatársai úgy gondolták, hogy a hadsereget érintő javaslataiknak is az országgyülés elé kell kerülnie. A Rákóczi Szabadságharc óta (1711) ugyanis nem volt magyar nemzeti hadsereg, csak a császári seregbe besorozott, többnyire német főtisztek parancsnoksága alatt álló magyar gyalog-és lovasezredek müködtek. A katonaság sérelmeinek orvoslása 1790-től már minden megyében konkrétan megfogalmazódott. A megyék levélben fordultak a magyar ezredek tisztikarához, hogy álljanak melléjük az alkotmány védelmére. ${ }^{129}$ A magyar tisztikar nagy része lelkes híve volt a függetlenségi mozgalomnak, így csatlakoztak a megyei felhívásokhoz. Ezzel viszont megindult a hadsereg fegyelmének bomlása; a legénység szökdösni kezdett, a Gyulai ezred 400 katonája például átszökött a lengyel hadseregbe, hogy a császár ellen harcolhasson jegyzi meg Marczali Henrik, valamint erre következtethetünk Sándor Lipót nádor irataiból is. ${ }^{130}$ Festetics és tiszttársai is megkapták a megye felszólító levelét. A hirtelen és

\footnotetext{
${ }^{123}$ Kurucz, 1999. 271.

${ }^{124}$ Morvay Győző gróf Fekete Jánosról írt dolgozatában jegyzi meg: „A katonai hatóság előtt még föltűnőbbé vált Fekete azzal, hogy Festetich gróffal és Dániel báróval együtt nyilvánosan is kifejezik német ellen táplált megvetésüket és gyülöletüket, »sőt katonai állásuk ellenére nemzeti kokárdát viselnek «" (ItK., 1901. 11 évfolyam 2. szám 177.)

${ }^{125}$ Szabó, 1928. 230.

${ }^{126}$ Benda, 1957. 210.

127 Szabó, 1928. 230.

${ }^{128}$ Benda, 1957. XIV.

${ }^{129}$ Benda, 1957. 207.

${ }^{130}$ Marczali, 1884. 271. ; Sándor Lipót, 1926. 17

Sándor Lipót többször foglalkozik emlékirataiban Festeticcsel. Többek között azt írja, hogy Lipót császár véleménye szerint a II. József ellen Berlinben segítséget kereső magyarok ügyeibe Festetics is belebonyolódott. Bár a mozgalom megindítóinak névsora ismert, Lipót a következő személyeket tartotta ez ügyben besározottaknak: Dr. Orczy László, Vay József, Balogh Péter, gr. Sztáray Mihály, gr. Forgách Miklós, báró Podmaniczky József, gr. Esterházy Ferenc, gr. Teleki József, a négy Festetics gróf, gr. Széchényi Ferenc, a
} 
hevenyészve összeállított folyamodvány nem nyerte meg a tisztikar, de elsősorban Festetics gróf tetszését, ezért egyik tiszttársával, Laczkovics Jánossal együtt újrafogalmazták azt. Ebben szerepet játszott az is, hogy Skaricza őrnagy az első fogalmazványt elküldte a Haditanácshoz Bécsbe, ami nagy megrökönyödést keltett. A tisztek, menteni, ami menthető új levelet írtak, ami lényegében megegyezett az elsővel. A felterjesztést még aznap (1790. július 5.) elküldték az országgyülés elnökének. A feliratot teljes egészében közli Benda Kálmán már idézett háromkötetes mủvében. ${ }^{131}$ Ebből világosan kiderül mi az, amit a magyar tisztek sérelmeznek és milyen javaslatokat terjesztettek az országgyülés elé. A felirat a bécsújhelyi (németújhelyi) német katonai akadémia mellett magyar katonai akadémia felállítását javasolta, továbbá azt, hogy békeidőben a magyar egységek Magyarország területén tartózkodjon, a vezényleti nyelv legyen ezeknél az ezredeknél magyar és magyar nemzetiségü legyen a tisztikar is. A levél hangneméböl, egészéből kiolvasható még, hogy törekedni kell a legénységgel való emberibb bánásmódra is. A levelet a következő sorrendben írták alá: „gróf Festetits György m. p. obers-laidinand, Laczkovits János m. p. svadronyos kapitány, Archi Pál m. p. svadronyos kapitány, Vincze János m. p. fö-hadnagy, Tstitsmán István m. p. föhadnagy". 132

A Graeven huszárezred felirata komoly felháborodást keltett a birodalom katonai vezetésében. Megütközést váltott ki az is, hogy Festeticsék nem a szolgálati utat tartották be, hanem egyenesen az országgyüléshez fordultak. Nem csoda a felháborodás a magyar nyelv vonatkozásában sem, hisz az uralkodó, II József, a német nyelvrendeletről szóló királyi leiratot 1784. április 26-án bocsátotta ki, illetve küldte meg a magyar kancellárnak, Esterházy Ferenc grófnak. Ebben a latint holt nyelvnek nyilvánította, a magyart a soknemzetiségü ország miatt alkalmatlannak. Az új hivatalos nyelv így csakis a német lehetett, amely egyben a hivatalos katonai és politikai igazgatásnak nyelve is. ${ }^{133}$

A katonai főparancsnok Barco tábornok azonnal jelentést kért Festeticstől és maga is jelentést tett a Haditanácsnak. 1790. július 15-én Barco tábornok kihallgatta Festeticset. ${ }^{134}$ Ezzel elkezdődött Festetics Györgynek a felirattal kapcsolatos kálváriája. Szabó Dezső szerint

\footnotetext{
három Batthyány gróf. (Sándor Lipót, 1926. 5.) Lipót császár megírja fiának a nádornak, utalva az előbb említett föurakra, hogy „Ezek mindig veszélyesek lesznek.” (Sándor Lipót, 1926. 443.) ; A négy Festetics gróf valószínüleg: György, János, Ferenc és Ignác voltak. (Sándor Lipót, 1926. 443.) ; Festetics János (1763-1844), György testvére volt. Ferenc (1763-?) és Ignác (1761-1826) szintén testvérek voltak, János és György másodfokú unokatestvérei. A közös ös, dédapjuk, Pál ( 1639/40?-1720), dédanyjuk Fitter Erzsébet (?-1711) ${ }_{131}^{131}$ Benda, 1957. 211-213.

${ }^{132}$ Festeticsék feliratát megelőzte egy katonai folyamodvány, amelyet június 18-án olvastak fel a rendeknek. Ennek 12 pontja sokban megegyezik Festeticsék felterjesztésével, mégsem okozott akkora feltűnést. (Marczali, 1898. 496.)

${ }^{133}$ Soós, 2005. 266.

${ }^{134}$ Szabó, 1928. 232.
} 
a Haditanács július 18-án Bécsbe rendelte Festeticset, 20-án pedig báró Gemmingen táborszernagynál kellett jelentkeznie kihallgatásra. Festetics azonban kifogásokat emelve csak július 25-én indult el Bécsbe, ahová 27-én meg is érkezett és másnap jelentkezett a Haditanácsnál. A Haditanács elnöke gróf Tige ekkor már utasítást adott Festetics szigorú megfigyelésére. Festetics a Wieden szállodában lakott és meglátogatta régi ismerősét, a híres jogtudóst, a szabadkőműves Born Ignácot is. A Haditanács kihallgatását július 28-án kezdte meg és július 30-én már be is fejezte. ${ }^{135}$ Eközben Festetics György a királyhoz fordult, amiben kifogásolta az eljárást, mondva, hogy neki, mint magyar mágnásnak a budai országgyülésen lenne a helye. Az uralkodó rövid és hideg levélben tudatta vele, nem mint mágnást, hanem mint alezredest idézték Bécsbe. ${ }^{136}$ Augusztus 6-án az uralkodó már meghozta Festeticsre vonatkozó döntését: „Az itt Bécsben tartózkodó Graeven-ezredbeli Festetics alezredest 14 napi fogsággal kell büntetni és ennek kitöltése után erőteljes és határozott rosszallást kell neki kapnia szolgálat- és rendellenes viselkedéséért, a parancsnokság alól pedig fel kell menteni. Azután a nélkül, hogy Budára mehetne, alezredesi minőségben a Németalföldön állomásozó La Tour ezredhez kell áthelyezni. Ha ez ellen kifogást emelne, elbocsátással kell fenyegetni”. ${ }^{137}$ Festetics a büntetést Gemmingen táborszernagy útján szó nélkül tudomásul vette. Komolyabb retorziót nem alkalmaztak, mert országos botránnyal számoltak. Így is megbolydult a budai országgyülés alsó háza, magyarázatot kérve a történtekről. A felsőház ugyan nem küldte el az alsóház által írt folyamodványt az uralkodóhoz, de felvilágosítást kért Barco tábornoktól, aki a következőket nyilatkozta: „gróf Festetics alezredes és Laczkovics kapitány dolgát illeti, azok eránt jelenthetné, hogy nem az országhoz tett folyamodása a regementnek, hanem valami más dolog forogna fönt irántok". Barco válasza természetesen csak részben fedte az igazságot. ${ }^{138}$

Festetics kétheti fogsága augusztus 20-án lejárt. De már ennek előtte Reuter nyugalmazott századost rendelték ki melléje, hogy vigyázzon rá, figyelje minden megnyilatkozását, ügyeljen magaviseletére, ne engedje beszélni a Magyarországról jövő követekkel. A Haditanács parancsa úgy szólt, hogy mindezt „további rendelkezésig” köteles Reuter e feladatát ellátni. A megbízásba e két szót („,további rendelkezésig”) azért szúrták be, mert a Haditanács szükségesnek tartotta Festetics fogságának meghosszabbítását. Augusztus 20-val meg is érkezett a császári parancs a fogság meghosszabbításának tárgyában. Festetics ekkor két kéréssel fordult az uralkodóhoz. Az egyikben azt kérte engedjék szabadon, mert

\footnotetext{
135 Szabó, 1928. 234-237.

136 Szabó, 1928. 239.

${ }^{137}$ KA 1790. 44. 343. 1872. sz. doboz ; Idézi: Szabó, 1928. 239.

138 Szabó, 1928. 244.
} 
lejárt a kirótt büntetése, a másikban azt kérte engedjék Firenzébe, vagy Pisába, mert megrendült egészségi állapotát ott tudná gyógykezelni. Lipót egyik kérést sem akceptálta. Enne oka az volt, hogy Barco tábornok szerint Festetics betegsége csak színlelés, másrészt Wallis gróf azzal vádolta meg a Haditanács előtt Festeticset, hogy Laczkovics tulajdonképpen nem is akarta aláírni a folyamodványt, csak Festetics rábeszélésére tette azt meg. Ennek kivizsgálására Lipót augusztus 17-én újabb meghallgatást rendelt el, amelynek a következö kérdésekre kellett választ adnia Festeticcsel kapcsolatban:

1. Igaz-e, hogy június végén, vagy július elején felkereste és rávette Laczkovicsot arra, hogy az ezred nevében folyamodványt nyújtson be a rendekhez, sőt arra is rábírta, hogy ő maga fogalmazza meg e folyamodványt?

2. Mondotta-e Laczkovicsnak, hogy a folyamodást megmutatta a parancsnokló tábornoknak, aki azt helyeselte is?

3. Látott-e nála Laczkovics más folyamodványokat is, mégpedig olyanokat, amelyeket öt más ezred írt alá?

4. Ezredének Magyarországba jövetele előtt kérte-e Laczkovicsot, hogy fogalmazzon ilyen folyamodványt az ő részére is?

5. Milyen volt a budai országgyülésre való utazás idején, Keszthelyen tanúsított magaviselete? ${ }^{139}$

Az ötödik kérdés egy névtelen feljelentés alapján született meg. Ebben arról tájékoztat az iromány szerzője, hogy akkor amikor a Graeven huszárezred Keszthelyen találkozott a Zala megyei nemesi bandériummal, gróf Festetics János üdvözletére testvére György válaszolt a „Graeven-ezred nevében emelt hangon igen hosszú és bő beszédű szónoklattal (...) amely a jelenlévők tanúsága szerint ilyen hazafias kifejezéseket tartalmazott, mint pl. kardjaink még nem rozsdásak, ha a hazáról van szó, a szívünk helyén van, stb.”. ${ }^{140}$ Az újabb vádakról augusztus 24-én hallgatták ki Festeticset. Vallomásában kereken tagadta az ellene felhozott vádakat és nem látott kivetnivalót keszthelyi dolgaira vonatkozóan sem. A Haditanács azonban újabb és újabb vádpontokat keresett. Eközben Festetics szeptember 7-én kelt levelében arról biztosította Lipót császárt, hogy cselekedetei sohasem irányultak az uralkodó személye ellen, elismeri a királyt törvényes urának és arra kéri őt, hogy azok ellen a tisztek ellen szüntessék meg a kereseteket, akik ez ügyben vele kapcsolatban álltak. ${ }^{141} \mathrm{~A}$

\footnotetext{
${ }^{139}$ KA 1790. 62. 1666. 1887. sz. doboz ; Idézi: Szabó, 1928. 247-248.

${ }^{140}$ KA 1790. 62. 1666. 1887. sz. doboz ; Idézi: Szabó, 1928. 248.

${ }^{141}$ Szabó, 1928. 249.
} 
Haditanács végül nem osztotta az augusztus 24-i meghallgatás bírájának súlyos megállapításait Festeticcsel szemben. Úgy döntött, hogy a két hét után elszenvedett további három heti fogságot nem kell meghosszabbítani, hanem azonnal át kell helyezni más alakulathoz (jelen esetben - az uralkodó döntésének megfelelően - a La Tour dragonyos ezredhez) és megfizettetni vele az összes felmerülő bírósági költséget. ${ }^{142} \mathrm{Az}$ uralkodó természetesen egyetértett a Belgiumba való áthelyezéssel, de a perköltségeket a kincstárral fizettette meg. A császár azonban nem enyhült meg sem Festetics György, sem fiútestvéreinek irányában. ${ }^{143}$

Festetics szeptember második felében indult útnak új ezredéhez. Október 13-án érkezett Linzbe, november 8-án volt Trierben, december 5-én Namurban, karácsonytól fogva pedig állandóan Brüsszelben tartózkodott. ${ }^{144}$ Feleségének Linzből küldött rövid levele instrukciókat és kívánságokat tartalmaz, ${ }^{145}$ a Namurból ${ }^{146}$ küldött sanyarú sorsát ecseteli: „Nem gondolhatod meg, hogy mennyit itten szenvedek. Luxemburgban érvén a Lengyel Ulánusokhoz tettek, kelletet tehát Limburgi Tartományban ${ }^{147}$ tsunya hegyes utakon indulni, Vervier ${ }^{148}$ nevü Városban egy hegyrül le ereszkedvén, az Lovak el ragadtak, az Bastárdot sok darabra öszve törték, az kotsison és az szakátson az kerék által mennt, az Dienes lábát ki fitzamitotta, de még-is annyira ugyan semmi bajok nem lett, immár paraszt két kerekü taligára szorulván alig értem Statiomra éjtszakának idején, mindjárt azon szempillantásban kellett az katonaságban indulni, Lüttichi Városon ${ }^{149}$ által menvén ellenség földére jöttünk, szabad ég alatt kellett táborozni sátor nélkül az hidegben, az Bagagia hátra maradván, és igy nagy nehezen Namur nevü erös Városban értünk az mellyett az Pártosok kevés villongás után

\footnotetext{
142 Szabó, 1928. 249.

${ }^{143}$ Sándor Lipót, 1926. 443. ; II. József halálát követően megindultak a Habsburg-ellenes nemzeti mozgalmak. A Habsburg-birodalom külpolitikai helyzete az 1790. július 27-i reichenbachi megállapodással (a birodalom háború nélkül visszakapja Belgiumot, s ennek fejében - szerény ellenértékül - lemond balkáni hódításairól) mégiscsak megszilárdult. Festetics így került Belgiumba.

144 Szabó, 1928. 250.

145 Édes Szivem! Tizen harmadik Octoberben érkeztünk Lintz nevü Várossában, ma tovább Bavária felé vévén utunkat. - Mi eddigg szerentséssen utaztunk. Az Gyermekeknek Istenes Nevelését ajánlom néked, kérlek az Istenért szemeid előtt tartsad öket, és a’ mennyire lehet maradj Keszthellyen. Evvel ölellek igaz hiv férjed Festetits György Oberst 14 Oct 790 Lintz. (MOL Fest. Lvt. P 2471 cs. B.V.3. 206)

${ }^{146}$ Namur. Város Belgiumban, a Sambre folyó partján. 1713-tól osztrák Habsburg kézen. 1794-től a francia forradalmat követően ismét Franciaország része lett. 1830-tól Belgiumé.

${ }^{147}$ Lengyel ulánusok: valószínűleg az 1. Galíciai Ulánus Ezredről (1 Galycyjski Pułk Ułanów ; Galizisches Ulanen-Regiment „Ritter von Brudermann” Nr. 1) van szó. II. József 1784. október 21 -én rendelkezett egy lengyel ulánus hadtest felállításáról, melynek parancsnoka von Hotce alezredes lett, s kinek segítségére herceg Józef Poniatowski örnagyot rendelték ki. II. Lipót 1790. július 15-én döntött az ulánus ezred felállításáról. ; Limburg. Tartomány Belgiumban. Belgium függetlenségének kiáltását követően (1830) Belgium része.

${ }^{148}$ Vervier (helyesen: Verviers). Város Belgiumban a Vesdre folyó partján.

${ }^{149}$ Lüttich. Liège német neve. Város Belgiumban a Meuse folyó partján.
} 
nékünk fel adtak. Most Brüszel felé indulok. Azért Leveleidet kérlek p. Luxemburg a Namur utasítsad". 150

Bécs azonban hamar rájött, hogy Belgium nagyon közel van Párizshoz. Ráadásul Johann Bender tábornok azt jelentette Bécsnek 1791. január 23-án, hogy Festetics szerint a magyarok csak egyelöre dugták vissza hüvelyükbe a kardjukat. Mercy-Argentau miniszter is azt a véleményét juttatta el az udvarhoz, hogy Festetics számára nem megfelelö hely Brüsszel. ${ }^{151}$ Festetics György számára ez az időszak különösen nehéz lehetett, mert családi gondokkal is küszködött. Öccse arról tájékoztatta, hogy lejártak váltói. ${ }^{152}$ Felesége, aki negyedik gyermekükkel volt áldott állapotban azt írta férjének, hogy barátja és sógora Széchényi Ferenc megneheztelt rá, amikor megtudta, hogy a csáktornyai uradalmat meg akarja vásárolni. Festetics válaszában sajnálkozását fejezte ki, hogy ezt a Széchenyiek rossz néven veszik, de amikor Széchényi alkudott a csáktornyai birtokra, igen alacsony árat ígért, így az Althanok neki adták azt el. ${ }^{154} \mathrm{Az}$ uradalmat Festetics 1791-ben tehát megvette az Althan grófi családtól, de ezzel még több adósságot vállalt, melyet hosszú éveken át fizetett az eladóknak.

Festetics György méltán érezhette azt, hogy katonai előmenetele ismét megakadt, ugyanakkor birtokai nélkülözték az eröskezü vezetést. Festetics szívesen hazalátogatott volna, de amint azt már írtuk, erre nem volt lehetősége. Ugyanis 1791. február elején a király úgy döntött, hogy Milánóba helyezi az ott állomásozó milánói dragonyos hadosztályhoz. Ezt a döntést Terzy altábornagy közölte Festeticcsel, aki felháborodva azt válaszolta, hogy kérni fogja nyugdíjaztatását. Ezt írásban másnap meg is tette. Festetics nyugdíjazási kérelmét gróf Joseph Kinszky lovassági tábornok, Ausztria katonai parancsnoka továbbította a Haditanácshoz. A király a befutott jelentések hatására úgy döntött, hogy a rendkívül veszélyes Festeticset nem bocsáthatja el a szolgálatból. Február 20-án azt az utasítást adta, hogy Festetics azonnal induljon Milánóba, ott szigorú felügyelet alatt legyen és figyeljék minden lépését, Milánó elhagyására pedig csak a Haditanács adhat engedélyt. ${ }^{157}$

Az uralkodó nem saját tapasztalata, hanem tanácsadóinak jelentése alapján alkotott képet Festeticsről. Természetesen mindenki tisztában volt azzal, hogy a gróf lojalitása uralkodója iránt ugyan töretlen - mást nem is tehetett volna anélkül, hogy hurokba ne dugta volna a nyakát - de azt is látták, elkötelezettsége elsősorban Magyarország iránti. Ez a

\footnotetext{
${ }^{150}$ Festetics György Sallér Juditnak, Namur, 1790. december 5. ; MOL Fest. Lvt. P 2471 cs. B.V.3. 208-209.

${ }^{151}$ Szabó, 1928. p. 251

${ }^{152}$ MOL. Fest. Lvt. P 2461 cs. 218

${ }^{154}$ MOL Fest. Lvt. P 2471 cs. B.V.3. 201-202

${ }^{157}$ Szabó, 1928. 252.
} 
nemzeti érzés részben érthetetlen, másrészt roppant gyanús volt a katonai vezetés, az udvari bürokrácia számára is, akik csak a dinasztia iránt éreztek feltétlen lojalitást. Festetics tiszttársa Laczkovics János Trenck Frigyeshez intézett levelében némi önigazolás miatt is, azt írja, hogy az császárt „csirkefogók veszik körül”, akik akarattal rosszul informálják az uralkodót. ${ }^{160}$ Ha egyetértünk Laczkovics kifejezésével, akkor nem sok reményt füzhettünk Festetics tevékenységének ,igazságos” elbírálásához.

Festetics milánói parancsnoka Stein táborszernagy a grófot megérkezése után (1791. február 26.) a cremonai escadronba osztotta be, közölte vele, hogy állomáshelye Lodi lesz. A táborszernagy havonta küldött jelentést új beosztottjának viselkedéséről. ${ }^{161}$ Festetics kényszerüen volt távol családjától, birtokaitól, ami minden kétséget kizáróan rányomták bélyegét hangulatára. Aggódó levelek érkeztek hazulról. János öccse 1791. április 13-án a következőket írta neki: „Vigyázz magadra édes bátyám, magad nyájától jobban óvakodj, mint idegentől; szörnyü az ellenséged az nagyok közt. Arra céloztak itt, hogy tébolyodott eszünek deklaráljanak és már a lyukas és rongyos része nemzetségünknek két kézzel kapott hozzá". ${ }^{162}$

\section{5. Festetics György Keszthelyen}

Sallér Judit - talán éppen családja javaslatára, de mindenképpen férje beleegyezésével - kihallgatást kért Lipóttól. Erre 1791. március 10-én került sor Bécsben. Nem tudni mivel vette rá a grófné a császárt arra, hogy elbocsássa férjét a katonaságtól. Az uralkodó ugyanis a kihallgatás végén közölte vele, hogy két-három hónap múlva nem lesz akadálya férje katonai kötelékből történő távozásának. ${ }^{163}$ Bár szóba került annak eshetősége, hogy a grófné személyes varázsának köszönhető a királyi kegy, erre azonban semmi bizonyíték nincs, inkább Lipót jól felfogott politikai érdeke játszott az ügyben meghatározó szerepet. ${ }^{164}$ Április végén Festeticsné felkereste férjét Milánóban, aki ezt követően levelet küldött az uralkodónak, megismételve kérését a katonai szolgálatból történő elbocsátásáról. Négy kiskorú gyermek nevelése, sok pörös ügyeinek és nagy adósságainak rendezése sürgősen szükségesé teszik otthoni jelenlétét - indokolta kérelmét. Szinte ezzel egy időben április 30-

\footnotetext{
${ }^{160}$ Benda, 1957. 509.

161 Szabó, 1928. 252. ; Lodi (Lod): város az olaszországi Lombardiában. 1158-ban alapította I. Barbarossza Frigyes.

162 Festetics János Festetics Györgynek, 1791. április 13. ; MOL Fest. Lvt. P 2461 cs. 2. ; Idézi: Szabó, 1928. 252-253.

${ }^{163}$ KA 1791. 44. 231. 1959 sz. doboz ; Szabó, 1928. 253.

${ }^{164}$ Kurucz, 1999. 265.
} 
án Stein táborszernagy a következő jelentést küldte az udvarnak: „Festetics György viselkedése, beszédei és magaviselete ellen semmi kifogása, sem pedig arra vonatkozólag valami megjegyezni valója nincsen". Stein ugyanakkor közölte azt is, hogy javasolja Festetics katonai szolgálat alóli felmentését. ${ }^{165} \mathrm{Az}$ uralkodói döntést, miszerint leszerelhet és Magyarországra utazhat, május 30-án közölték vele. Harminchat évesen tehát végleg hazatérhetett birtokaira, ahol elmaradott gazdaság, hatalmas adósság várta, de várta családja is.

A Festetics birtokok központja Keszthelyen került kialakításra. ${ }^{166}$ Festetics hazaköltözött és nekilátott birtokai rendbetételének. Belekezdett abba a meghatározó kulturális fejlesztésbe, amely méltán helyezi őt nemzetünk legnagyobbjai közé. Egész életében fennmaradtak ifjúkori ideáljai. Ezeket próbálta megvalósítani a közjó érdekében sajátos módon, sajátos megoldásokkal. Hogy az adósságokkal terhelt hitbizomány csak nagyon szívós, kitartós és kemény munka eredményeként válhat ismét prosperáló birtokká, Festetics külföldi tapasztalatai alapján ezt kiválóan értette és tudta. 1793-ban megszervezte a kormányszéket (directiót), azt a központi hivatalt, „amelynek parancsai és intézkedései feltétlen érvénnyel bírnak". A directio nemcsak tanácsadó, de végrehajtó szerv is volt. ${ }^{167}$ Festetics feszített munkatempót diktált önmagának és minden munkatársának. Többbek közt a Batthyány és Festetics levéltárak neves kutatója Iványi Béla mutat rá a gróf sikeres erőfeszítéseire: „Midőn ugyanis 1791 tavaszán Festetics György a katonai szolgálatból kilépett és Keszthelyre hazatért, nyomban kezébe vette nagy vagyonának kormányzását."168 A bírtok megfelelő kormányzása erős és következetes vezetést igényelt. Festetics figyelme mindenre kiterjedt és lehetőleg mindent önmaga intézett, legtöbbször a legapróbb részletekbe menően. ${ }^{169}$

Festetics alig érkezett vissza Keszthelyre, 1792. március 1-jén meghalta II. Lipót. A trónon II. Ferenc császár ${ }^{170}$ követte.

A magyar jakobinus mozgalom, amely egy maroknyi radikális értelmiségi próbálkozása volt a független polgári Magyarország megvalósítására ${ }^{171}$ 1795. május 20-án a

\footnotetext{
165 Szabó, 1928. 253.

${ }^{166}$ A Festetics-birtokok igazgatásáról lásd: Kállay, 1980.

167 Szántó, 1984. 39.

${ }^{168}$ Iványi, 1947. 17. ; A továbbiakban Iványi leírja a Festetics levéltárra vonatkozóan: „Az eredményesség érdekében 1792. július 1-én Keszthelyen Oeconomica Directio-t állított föl és ő maga dolgozta ki: $A$ gazdaságnak közönséges igazgatására Keszthelyen felállittatott Oeconimica Directionak rajzolatjá-t”, valamint a Directionak szolgáló Instructio-t is.

${ }^{169}$ Iványi, 1947. 20

${ }^{170}$ I. Ferenc néven magyar király

${ }^{171}$ Magyarország tört., 1980. 211
} 
budai Vérmezőn fejeződött be. Festetics tiszttársát Laczkovics Jánost lefejezték. Festetics gróf maga is belekeveredett az ügybe, a gróf elleni vádaknak természetesen némi alapja volt, de maga Laczkovics és Martinovics is többször ellene vallottak. ${ }^{172}$ Ugyanis Martinovics, aki mindent elkövetett, hogy az új császár II. Ferenc kegyeibe férkőzzön, már 1791-től kapcsolatban állt Gotthardi Ferenccel ${ }^{173}$ a titkosrendőrség egyik fönökével. Martinovics rendszeresen küldött neki jelentéseket. 1793. május 18-án kelt levelében arról tájékoztatja Gotthardit, hogy Magyarországon nagy az elkeseredés, az Ausztriától való elszakadást fontolgatják, és javaslatot tesz a leggyanúsabb nemesek megfigyelésére. Zala megyében Festetics Györgyöt és Spissich János alispánt jelölte meg, mint megfigyelésre javasolt személyeket. Martinovics és társainak perében is felvetödött Festetics neve. Martinovics ugyanis azt vallotta, hogy többször találkozott Festeticcsel, egy alkalommal magánál a grófnál volt a találkozó, ahol mások is megjelentek. Martinovics 1794-es emlékiratában az antimonarchisták nevét sorolta fel. A névsorban megtaláljuk a Festetics nevet - keresztnév nélkül ugyan, de nem hagy kétséget afelöl, hogy Györgyröl van szó. ${ }^{174}$ Az udvarnál Festetics gyanúba keveredett, de mégsem indítottak ellene eljárást.

$\mathrm{Az}$ 1794-ben fellobbant láng úgy tünt örökre elaludt. Az országban csend honolt. A nemesség hallgatott, a szabadkőmüves páholyokat bezárták. A patrióta reformerek és a radikális demokraták egyaránt elhallgattak. A látszólagos keszthelyi magányban élő gróf azonban kiválóan értesült mindenről. Ismerte a magyarországi, az európai és természetesen a franciaországi fejleményeket. Amikor az 1796-os országgyülésen elfogadták a birodalmat fenyegető Napóleonnal szemben a nemesi felkelést, az insurrectiót minden megyegyülésen felolvasták.

Festetics utolsó szembehelyezkedése az udvarral éppen ezzel a leirattal kapcsolatos. Az 1797. áprilisi 18-i Zala megyei gyülésen felolvasott insurrectió kiállását elrendelő királyi parancs elhangzása után gróf Szápáry Péter a nemesi felkelés ellen szólt. Festetics pedig nem tartotta célszerünek megvalósítását. Skublics János hirtelenjében még azt is mondta: „Ha béüt az ellenség, fogjunk vele kezet". ${ }^{175}$ Festetics ugyan nem helyeselte Skublics szavait ám ő is

\footnotetext{
172 Erre utalást és adatokat találhatunk Benda Kálmán idézett müvében (Benda, 1957), Sági Károly dolgozatában (Sági, 1967), valamint A magyar jakobinusok elleni felségsértési és hütlenségi per irataiban (Benda, 1952)

${ }^{173}$ Gotthardi kiemelt feladata volt, hogy a magyar nemesi mozgalom vezetőiről tájékoztassa az uralkodót.

${ }^{174}$ Sági, 1967. 331.

${ }^{175}$ A történetet színes tollával Darnay Kálmán dolgozta fel. Az ő regényes változatában a következők történtek: „...a simogató királyi szó ezúttal olyan felháborodást váltott ki a nemes urak között, hogy a közbekiáltások szavától visszhangzott a terem. A fülsiketítő zaj tetőpontját akkor érte el, amikor Spissich János első alispán érces hangon olvasva - a királyi leirat azon pontjához ért: $<<$ Ha a Grácig hatolt franciák Magyarországba betörnének, a megye Sümegnél a Rába hídját azonnal romboltassa le. >> Még az elnöklő császárhü Althan gróf is elpirult szégyenletében, Spissich alispán pedig a tanácskozó asztalra csapta a leiratot. Festetics György és
} 
megerősítette: „Szükség törvényt bont”. E felszólalások után a megyegyülés úgy határozott, hogy a kért katonaság helyett, csak jóval kevesebbet, 200 gyalogost és 200 lovas felkelö katonát ugyan kiállít, de egyúttal reguláris hadsereget kér a megyébe. ${ }^{176}$ Természetesen a megyegyülésen elhangzottak nem maradtak az épület falai között. A határozat nagy megrökönyödést keltett az udvarban és azonnali vizsgálatot rendelt el. Megütköztek azon is, amit besúgóiktól hallottak, miszerint Festetics még azt is mondta volna, hogy „az ellenség igen közel van, a megyében pedig nincsen katonaság és ennek a bécsi miniszterek az okai, akik azért hanyagolták el a megyét, hogy bajba vigyék a készületlen nemességet”. ${ }^{177}$ Ezekkel a szavakkal egyetértett gróf Szápáry és Spissich János alispán is. Vádként fogalmazódott meg, hogy javaslataikat latinul adták elő, amit a megyegyűlés jó része nem értett. Így ennek következménye volt a megyegyülés határozata. A vádat alátámasztottnak vélték azzal, hogy az egy hét után ismételten megtartott megyegyülés már a kért katonaságot szavazta meg. A vizsgálatot Somogyi János udvari kancelláriai tanácsos végezte. Megállapította a megyegyülés jegyzőkönyvéből, hogy semmi felségsértő nincs, viszont tényként fogalmazta meg azt is, hogy gróf Althan János föispán, gróf Festetics György, gróf Szápáry Péter, Tuboly László és Spissich alispán arról beszélgettek, hogy az insurrectio elkésett, a katonai összevonás csak ingerelné az ellenséget. Végső következtetésként megállapította a vizsgálat, hogy az insurrectio elleni szavazás nem a megye müve, csak néhány nemesé s ebben leginkább vétkes Festetics és Spissich, másodsorban a főispán, Szapáry és Tuboly. Ebben volt némi igazság, mert Festetics mondta tollba a királyi leiratra adott megyei választ. ${ }^{178}$ Bár József nádor, aki végül kézbe kapta a vizsgálat eredményét, úgy nyilatkozott, hogy felségsértés tény nem áll fenn, Festetics elvesztette kamarási kulcsát és a császár megtiltotta az udvarban való megjelenését. A bécsi udvarból való kitiltás közel két évig tartott, mígnem 1800. február 2-án Ferenc, Festetics ,jó magaviseletére” hivatkozva, ezt a büntetést eltörölte. A császári lépéshez minden kétséget kizáróan hozzájárult az is, hogy a gróf adományként 31 959 forintot fizetett be, hadi segély gyanánt, a királyi kincstárba. ${ }^{179}$

Szapáry Péter grófokkal együtt éljenezte meg Káldy Ferenc föbíró uram harsogó közbekiáltását: $<<$ Inkább kezet fogunk az ellenséggel, semhogy olyan kormány alatt éljünk, amelyik a Rába hídját Sümegnél keresi >>. Ilyen értelemben hozták meg a megyei Karok és Rendek határozatukat. Althan gróf föispán hirtelen rosszullétet színlelve, az ülésteremből távozott, átadva az elnöklést Spissich első alispánnak. Hogy se látója, se hallója nem legyen a nemes vármegye Bécsbe küldendő válaszfeliratának, nyomban fel is ugrott csézájára s eltűnt a megye területéről (Darnay, é. n. II. 46.)

Ugyancsak regényes formában írta meg a történetet és a kamarási kulcs elvesztését Vas Gereben, aki a Festetics legendák első összegyüjtője volt.. (Vas, é. n., 172-179)

${ }^{176}$ MOL Kancelláriai Lvt. Acta gen. A 39. 1797:6074. ; Idézi: Szabó, 1928. 254.

${ }^{177}$ MOL Kancelláriai Lvt. Acta gen. A 39. 1797:6074. ; Idézi: Szabó, 1928. 254.

${ }^{178}$ Sági, 1972. 27.

${ }^{179}$ Szabó, 1928. 257. 
Festetics a francia háború elhúzódása miatt megterhelt kincstár segítségére sietett, amikor 1800 szeptemberében a Zala megyei közgyülésen rövid beszédet mondott az insurrectio érdekében, a szegényebb nemesek segélyezésére pedig 4000 forintot fizetett be. Még ezen év decemberében a maga költségén tíz katonát fogadott és a vasmegyei insurrectiohoz öt, a sopronihoz pedig egy felfegyverzett katonával járult hozzá. ${ }^{180}$ Azonban a hadi események felettébb foglalkoztatták. Éppen ezért kérte meg Berke József soproni számtartót, hogy közvetlenül értesítse a franciák lépéseiről. Berke ezt leveleiben meg is tette. ${ }^{181} \mathrm{Az}$ ismert és idézett levelek, a hadi események végéről, abból az időből valók, amikor I. Ferenc már fegyverszünetet kért Napóleontól. ${ }^{182}$

Festetics és az udvar közti viszony javulásának döntő pillanata volt József nádor keszthelyi látogatása. Szapáry János gróf 1801. július 8-i levelében arról tájékoztatta Festeticset, hogy a nádor Velencéből jövet, meg kívánja tekinteni Festetics új mezőgazdasági iskoláját, a Georgikont. Megírta, hogy a nádor augusztus 18-án érkezik Keszthelyre, onnét hajón kíván továbbmenni Balatonfüredre. Szapáry kérte Festeticset, hogy gondoskodjon a nádor fogadásáról, valamint egy hajóról, ami tovább vinné Balatonfüredre. Festetics augusztus 1-jén válaszolt Szapárynak és javaslatot tett a nádori programra, ugyanakkor megpendítette egy esetleges szántásnak lehetőségét: „Mivel ilyen magas személyiségnek leereszkedése valóságos korszak volna a magyar ipar és mezőgazdaság fellendítésében, ez alkalommal nem tudom magamat visszatartani a József császárral való összehasonlítástól, aki Csehországban egy ilyen alkalommal maga is szántott és így emléket állított a szántásnak az utódoknál. E nagy uralkodónak ez a jellemvonása okozza azt, hogy ez a most kifejlődésnek induló gazdasági iskola Ő királyi fensége magas támogatását kérni merészeli, hogy Ö fensége örökös emlékünnepképpen jelenlétével a Georgikon mezőit hasonlóképen felszentelni kegyeskedjék, amennyiben egy ekét kegyesen megfogni, és a szántást színlelni méltóztatnék."183 Megmosolyogni való, ám a korabeli szokásoknak teljes mértékben megfelelt Festetics azon kérése, miszerint a nádor feladata csupán annyi, hogy „a szántást színlelni méltóztassék”. A szándék kinyilvánításának egyértelműsége a fontos, nem a valós szántás mennyisége, vagy minősége. A gróf bizonyos volt abban, ha ez a protokolláris szántás

\footnotetext{
${ }^{180}$ Szabó, 1928. 257.

${ }^{181}$ MOL Fest. Lvt. P. 2461 cs. B. IV. 2. 76-82 Berke három levelét örzi a levéltár. Keltezésük: 1805. december 3., december 8., december 9.

${ }_{182} 1805$. december 4. December 15-én a király utasítást adott József nádornak, hogy a magyar nemesi fölkelést oszlassa szét. December 26-án kerül sor Pozsonyban a békeszerződés aláírására, ahol I. Ferenc lemondott Velencéről, Isztriáról, Dalmáciáról, Tirolról és Vorarlbergről, elismerte az itáliai, a bajor és a würtembergi királyságokat. (Vö.: Benda, 1982. 622.)

${ }^{183}$ Festetics György Szapáry Jánosnak, 1801. augusztus 1. ; MOL. Fest. Lvt. P 235. Memor. 418. (eredeti helyén nem található) ; Idézi: Szabó, 1928. 282.
} 
megvalósul, helyzete könnyebbé válik, elgondolásait nyugodt szívvel megvalósíthatja. Festetics ugyanebben a levélben megígérte, hogy az ünnepség nem lesz több egynegyed óránál. A nádor a javaslatot elfogadta. Így a látogatás fénypontja minden kétséget kizáróan a gróf által alapított intézményben megtörtént georgikoni szántás volt. József főherceg római felső palástban jelent meg a Georgikon szántóföldjén, megfogta az eke szarvát és néhány barázdát szántott. A nádor udvarmestere Szapáry János vitte az ostort, Festetics pedig az ökröket vezette. Az ünnepélyen a keszthelyi Zeneiskola növendékei Stärk Péter vezetésével tíz versszakos énekkel is készültek, amit később nyomtatásban is megjelentettek, kottával együtt, valószínűleg a gróf költségén. ${ }^{184}$ A művet az iskola tanítója Stärk Péter írta és adatta elő nagy lelkesedéssel, ami arra enged következtetni, hogy az egész ünnepség minden bizonnyal tovább tartott, mint egynegyed óra. Az énekkel kísért szántás sikeresen fejeződött be. Az eke, amelyik kimondottan erre az ünnepségre készült úgynevezett "talyigás eke" volt, melynek fáját nemzeti színüre festették, vas részeit később Festetics ezüsttel vonatta be és elhelyezte a családi levéltárban. ${ }^{185}$ Az ekét Richard Bright angol orvos-utazó is látta 1815ben, Festetics vendégeként. Könyvében a következőképpen írja le: „A könyvtár egy fényes terem, köröskörül erkéllyel és roskadásig rakva minden nyelven írt könyvekkel. A főhelyen egy ekét őriznek itt: avval az ekével szántott egy barázdát János főherceg (sic!) és ugyanazt a szertartást végezte a nádor is, amikor meglátogatta az intézetet". ${ }^{186}$ Az esemény Festetics György számára az udvarhoz való „visszatalálást” jelentette, ami rendkívül fontos volt ahhoz, hogy további elképzeléseit, nagyobb ellenállás nélkül valóra válthassa. A látogatás emlékére cseresznye és diófából fiókos szekrényt készíttetett oldalt két hermával, s négy fiókjának bronz vereteit magyar koronás drapéria alatt ovális medalionban József nádor dombormüvü mellképe díszítette. ${ }^{187}$ Volt a nádori látogatásnak egy kimondottan személyes része, amelyre Vay Sarolta mutat rá regényes, de a tényekhez ragaszkodó müvében. József nádor ugyanis ezen év tavaszán vesztette el szeretett feleségét Alekszandra Pavlovna orosz nagyhercegnőt. A nádor meglátogatta Festetics rajziskoláját is, ahol - ahol Vay szerint - meghatotta Kóber

\footnotetext{
${ }^{184}$ Búza-kalász koszorú, mellyel Jósef Ö királyi fö-hertzegségének, Magyar ország nádor-ispánnyának, midön Töle felséges kegyességgel látogattatnék, tisztelkedik a keszthelyi Georgikon. 1801. Eszt. Kis-asszony Hav. 23dikán. Következendő Muzsikákra alkalmaztatva: canto I., canto II., oboe I., oboe II., clarinetto I., clarinetto II., corno I., corno II., fagotto, basso. Stärk Péter, Keszthely Muzsika-Oskola tanítója által. Bétsben, Täubel Christián Gottl. betüivel, 1802. Esztendőben. (Másolat: Balatoni Múzeum, 2178.2006/204-2006) A barokkosan áradó versezet és ének természetesen a nádort dicsöíti, utolsó versszaka: 'S míg élünk, / Örökre Néked szentelve lesz szívünk, / Lesz mindenünk, / Nevedet fákra felvéssük, / S képeddel felékesítjük / Kis tanyánkat, / Kalibánkat.

${ }^{185}$ Szabó, 1928. 282. Az eke végül is a grófi könyvtárba került. Itt jegyezzük meg, hogy a nádori szántást regényes formában Vas Gereben dolgozta fel. (Vas, é. n. 275-284) Péczely Piroska szerint az ekét nemcsak beezüstözték, hanem némelyeik részét be is aranyozták. (Péczely, 1958. 47.)

${ }^{186}$ Bright, 1935. 31.

${ }^{187}$ Péczely, 1958. 47.
} 
Kristóf balatonedericsi születésű asztaloslegény rajza. „A palatinus eő fensége gyásza” címet viselő szerény rajz egy mauzóleumot ábrázolt, elötte Magyarország géniuszát, aki sírva takarja el arcát. Fölötte fátyollal borított koszorúban a következő írás volt olvasható: Eő fensége Alekszandra Pavlovna, tsászári orosz herczegnő. Vay Sarolta visszaemlékezések alapján született írása szerint: „A nádor nagyon elszomorodott, és öt aranyat ajándékozva a fiúnak, elhagyta a rajztermet". ${ }^{188}$

Festetics maga is kitűnően tudta, mit jelentett számára a nádori szántás, tehát támogatott mindent, ami e jeles napra emlékeztetett. A Stärk Péter által megzenésített verset ugyan 1802-ben adták ki, egy évvel a látogatás után, de maga a vers nyomtatásban már a nádor látogatásakor elkészült magyar és német nyelven egyaránt. Mindkét aprónyomtatvány megtalálható a Helikon Könyvtár miscelláneái között. ${ }^{189}$ Másfél évtizeddel később, 1816-ban, Festetics a nádori szántást megörökítő érmet veretett Würth János rézmetszővel. ${ }^{190}$ A harmadfél hüvelyknyi átméröjü érme később a jó tanulók jutalmazására is szolgált. Egyik oldalán a nádor az eke szarvát fogja, „,s nagy Rómának halhatatlan férfiaira emlékeztet. - Az ekét két lengyel fajta szarvú bika vonja, melyek közül egyiken trombitát fúvó Genius ül. Ezen figurák jelennek meg a sík mezőn". ${ }^{191}$ Az érem másik oldalán Ceres látható, jobb kezében virágkoszorú, bal hóna alatt kéve, bal lábánál bőségszaru, szőlővessző. Jobbról kopár fa és a Festeticsek címere. ${ }^{192}$ Ezt az érmet kiválóan tanuló diákok kapták, mentekötős változatát neves gazdász vendégek. A dicséretes tanulmányi eredményt elért jogászok a Numisma Iuridicum érmet vehették át. ${ }^{193}$

A nádori szántást a Georgikon egyik történetírója Süle Sándor véleménye alapján csupán „csinnadrattás hangú” sokak által túlméretezett, tulajdonképpen jelentéktelen

\footnotetext{
${ }^{188}$ Vay, 1986. 170-171.

189 BÚZA-KALÁSZ-KOSZORÚ, MELLYEL JÓ'SEF Ö KIRÁLYI FÖ-HERTZEGSÉGÉNEK, MAGYAR ORSZTÁG' NÁDOR-ÍSPÁNNYÁNAK, Midön TÖLE Felséges kegyességgel látogattatnék, tisztelkedik A' KESZTHELYI GEORGIKON. 1801. Eszt. Kis-Aszszony Hav. 23dikán (Helikon Könyvtár Miscellanea 80. 4.) (a nap helyét a nyomdász kihagyta, a 23 kézzel lett beírva, a vers utolsó sora ezen kiadás szerint Katzagánkat. Ezt a szót áthúzták és helyébe kézzel beírták Kalibánkat. Már a Kalibánkat szóval adták ki 1802-ben a versezetet) ; FREUDENSCHALL AN SEINE KÖNIGLICHE HOHEIT, DEN ERZHERZOG JOSEPH, PALATIN VON UNGARN; ALS GNAEDIGSTER HERABLASSUNG, die Musikschule in Keszthely am 23ten August, 1801. befichtigte. A kiadványban nincs kotta. (Helikon Könyvtár Miscellanea 11. 11.)

190 Süle, 1967. 202. ; Péczely Piroska úgy tudja, hogy az érmet Karl Henrik Ernő körmöcbányai vésnök készítette. (Péczely, 1958. 47.) Péczely azonban nem hivatkozik adatának lelőhelyére. Lehetséges, hogy az eltérés a Numisma Oeconomicum illetve a Numisma Iuridicum alkotóinak nevével hozható összefüggésbe.

${ }^{191}$ HKT. 1817/I. 259-260

192 Az érem nádori szántást idéző oldalán a körirat: SER. ARCHID. C. R. IOSEPHO PAL. R. H. SULCUM DUCENTE. DIES NOBIS MELIORES NITENT. Lent: AUSPICATA DIES XXIII AUGUSTI MDCCCI. A Cerest ábrázoló oldal körirata: VIVE MEMOR NOSTRI RIGIDI SERVATOR HONESTI. Lent: ADJUD. C. G. F.

193 A Numisma Iuridicum ezüstérem volt, előlapján Verbőczy arcképével, a hátoldalon Astrea képével. (Bontz, 1896. 327.)
} 
rendezvény volt. ${ }^{194}$ Süle, mint annyiszor munkája során, elfogult Festeticcsel kapcsolatban és nem veszi észre, hogy az esemény több irányban is alapvetően hatott, amint arra Sági Károly is rámutatott dolgozatában. ${ }^{195}$

A magyar katonaság létrehozásának kérdése mindvégig ott lebegett Festetics szeme lebegett, ám tanult mindabból, ami vele történt, és más stratégiát választott. 1802. június 25én a következő elöterjesztés került a felsőtábla elé: „Gróf Festetics György addig is, míg a hadi tudományoknak a tanítása Magyarországon felállítattatik, olyan ifjaknak felsegítésére, kik a hadi tudományokban kívánják magukat gyakorolni, a következő ülésben beadandó feltételek s mód szerint 40000 forintot ajánlott legyen". A felajánlás lényeget tehát az volt, hogy Festetics pénzt ajánlott fel annak érdekében, hogy a nemes ifjak katonai pályára léphessenek. E tőkének évi 2000 forintot kitevő kamatját évente három nemesi származású ifjú nyerhette el, akik „vagy Magyarország jelenlegi területéről, vagy a Részekből és Erdélyből, vagy az ország visszacsatolandó területeiről származnak". ${ }^{196}$ Festetics realitásérzékére jellemző - amit később is tapasztalhatunk majd a keszthelyi udvar vitelében -, hogy differenciált ösztöndíjakban gondolkodott. A mágnások fia 700, a nemesé 600, a katonatisztté 550 forintot kaptak évente. Mivel az ösztöndíj nem teszi ki a 2000 forintot, a maradék kamatot a tőkéhez csatolandónak rendelte. Ugyanakkor az alapítvány megtételekor azt is leszögezte Festetics György, hogy addig ameddig nincs Magyarországon megfelelő katonai iskola, a bécsi mérnöki akadémiába járó magyarok kapják. Abban az esetben, ha Magyarországon megnyílna a katonai iskolának kapuja, automatikusan ebbe az intézménybe járók részesülhetnének az ösztöndíjban. A királyhoz ez a felterjesztés már úgy jutott el, s ebben az esetben ez a kegyes csalás nagyon is szerencsés volt, hogy Festetics a pesti egyetemen felállítandó katonai tanszék alapításához adta a 40000 forintot. A király, I. Ferenc az ajánlatot elfogadta, és arra utasította az országgyülést, hogy az eseményt vegyék jegyzőkönyvbe: „Ezt a felajánlást pedig vegyék be az országgyülés Naplójába, hogy ezen nemeslelkű bőkezüség emlékezete az utókorra is megmaradjon." ${ }^{198}$ Nemcsak az uralkodó, de Csokonai Vitéz Mihály is megemlékezett az eseményről. Valószínűleg Festetics László gróf házitanítójának Kultsár Istvánnak javaslatára írta meg a „Mélt. Gróf Festetics György ő Nagyságára. A’ hadi oskoláról” címü ódáját. Ebben felmagasztalja Festeticset, leírván azt, hogy miért fontos egy „hadi oskola”, miért nem elég csupán a virtus. A katonai technikák

\footnotetext{
194 Süle, 1967. 201.

195 Vö.: Sági, 1972. 35.

${ }^{196}$ Szabó, 1928. 258-259. ; Szabó jelzete szerint: Házi, udvari és állami Lvt., Staatsrat 1802. 2438. (Bécs)

198 Szabó, 1928. 260. ; Szabó jelzete szerit: Az 1802-iki Országgyülés naplója, 185.
} 
előre haladtával ugyan okulni kell a régiek dicsőségén, de ismerni kell a legújabb hadi vívmányokat, eredményeket is, ha a katona sikeres akar lenni.

\section{$(\ldots)$}

Azon igyekszik FESTETITSÜNK, hogy e’

Kartáts-világban hív unokáitok

Ésszel 's okossággal tanúlják

Örzeni érdemitek’ jutalmát,

$$
\text { (...) }
$$

Hijjába vinnéd rettenetes Botond

Mennykőtsapású bárdodat a' mai

Bizántzium' várához, annak

Rézbeborúltt kapuját bevágni:

Egy messzelátó cső kitekintené

Szándékod', egy más cső az egész kaput,

A' bárdot, a' vitéz Botondot

Egyszeri pertzbe' darabra törné. ${ }^{199}$

Festetics felajánlását követően az uralkodó úgy döntött, hogy ismét megajándékozza Festeticset a kamarai kulccsal, amely aktusra 1802. november 15-én került sor. Festetics számára azonban ennél több is megvalósult; a magyar hadsereg tiszti állománya képzési rendszerének konzekvens képviselete végül is eredményt hozott. 1808-ban az országgyülés törvénybe iktatta a Ludovika Akadémia felállítását.

Festetics ezt követően fokozatosan visszavonult a közszerepléstől és erejének nagy részét a magyar müvelődés, oktatás ügyének szentelte.

\section{6. Gróf Festetics György gyermekei}

Festetics György első gyermeke László 1785-ben született, majd őt követték: Szidónia (1787. férje: gróf Almássy Illés), Julianna (1789. férje: gróf Zichy Károly) és Viktória (1790,

${ }^{199}$ Csokonai ÖM., 2002. 172-177. 
aki kevéssel születése után meghalt). Gyermekei nevelésére rendkívül nagy hangsúlyt fektetett. Amíg katonáskodott, feleségére hárultak a gyermeknevelés gondjai. Keszthelyre való visszatérését követően nevelőt fogadott gyermekei mellé.

Fiának neveltetése volt a legfontosabb, mert benne látta Festetics György annak a munkának továbbvitelét, amit ő kívánt elindítani és megvalósítani. Fontos volt tehát számára, hogy birtokainak utódja milyen szellemben nevelkedik. A leánygyermekekkel kapcsolatban az volt a legfontosabb, hogy ,jól” menjenek férjhez, azaz megfelelő birtokkal és ranggal rendelkező arisztokratákat tudhassanak az egyre bővülő rokoni körben.

Gróf Festetics György 1791-ben László fia nevelését egy igen kiváló ifjúra, könyvtárosára, Péteri Takáts Józsefre bízta. ${ }^{200}$ A nevelői állást 1799-ig állott fenn, amikor is Péteri Takáts lemondott. ${ }^{201} \mathrm{Az}$ eltelt idő legnagyobb részét az ifjú gróffal Bécsben töltötték, ugyanis Festetics László ott folytatta tanulmányait. Péteri Takáts rendszeresen számolt be Festetics Györgynek fia tanulmányi sikereiről, sikertelenségeiről, betegségeiröl. De tulajdonképpen a titkári funkciókat is ellátó nevelőnek más feladatok is osztályrészül jutottak: a keszthelyi könyvtár részére beszerzendő könyvek felkutatása, megvétele és a grófi bibliotékába való elszállítatása, az épülő keszthelyi kastély számára Bécsben készülő kályhák felügyelete, a Festetics által támogatott Görög-féle térképek sorsának figyelemmel kísérése, a bécsi politikai hírek továbbítása Keszthelyre. De rendkívül fontos volt a kapott pénzekről törtnő elszámolás, Festetics György utasításainak szigorú betartása, amellyel kapcsolatban Festetics sokszor fejtette ki rosszallását. Mindazonáltal Takáts Sándor olykor elfogult művében $^{202}$ így jellemzi Péteri Takáts nevelői munkáját: „A ki végig lapozza egykorú költőink verseit, s olvassa azokat a magasztalásokat, melyekkel Virág, Berzsenyi, Szabó Dávid, Kis János stb. elhalmozták Festetits Lászlót, az kénytelen bevallani, hogy Takáts jelesen nevelte tanítványát. Igaz, hogy a költők által reá halmozott sok dicséretet nem lehet

\footnotetext{
${ }^{200}$ Péteri és téti Takáts József 1767. március 18-án született Keszthelyen elszegényedett (valószínüleg) nemesi családból. Elemi iskoláit szülővárosában, gimnáziumi tanulmányait Győrött végezte. Ott vették fel a győri papnövendékek közé, de a theológia utolsó négy évét már Pozsonyban végezte. Pozsonyban akkor mozgalmas irodalmi és hazafias nevelés folyt, és magas színvonalra emelték az önképzést is. A növendékek között sok zalai ifjú is tanult: Fejér György, Juranits László és Péteri Takáts. Tanulmányaik vége felé ők hárman „,̈nnepélyes fogadalmat tettek egymásnak, hogy életüket és tehetségüket a nemzeti nyelv és a hazai tudományosság felvirágoztatására fogják fordítani”. 1789 nyarán Péteri Takáts hosszas tusakodás után otthagyta a papi pályát és - Festetics meghívására - a keszthelyi kastély könyvtárnoka lett Bolla Ferenc levéltárnok mellett. Ő volt a Magyar Minerva könyvsorozat elindítója. Meghalt 1821. május 3-án. (Szabó, 1983. 184-185. ; Szinnyei XII., 1909. 1237-1239.) ; Részletes életrajz: Takáts, 1890.

${ }^{201}$ Péteri Takáts József és Festetics György gróf kapcsolatairól Stohl Róbert írt elemző doktori értekezést. (Stohl, 2009.)

${ }^{202}$ Erre már a könyv megjelenését követően rámutatott kritikájában Ballagi Aladár: „Irányzatosság mindenkor csökkenti történelmi müvek értékét; Takátsnál kész veszedelem: szeretete nagy voltában elhomályosulnak előtte a kritikai aranyszabályai. (...) Takáts igazán szereti Péter Takátsot, s innen ered tárgyának érzelgős exaltátiója.” (ItK., 1891. 1. évfolyam 4. füzet. 390-391.)
} 
mind kész valóságnak vennünk; de az is igaz, hogy a kis Lászlót már ekkor igen kedvelték, s úgy Bécsben mint itthon ismeretes volt neve." ${ }^{203}$ A Takáts által említett túlzások elsősorban abból adódhattak, hogy költőink Festetics Lászlótól György mecénási munkásságának továbbvitelét várták. Sok esetben hiába.

Az új nevelő, Péteri Takáts jó ismerőse a hasonlóan kiváló Kultsár István lett. ${ }^{204}$ Valószínűleg Péteri Takáts javasolta Kultsárt, aki hat éven át töltötte be e tisztséget. ${ }^{205}$ Kultsár jellemrajzához Kazinczy Ferenc szolgál adalékkal, amikor a következőket írja róla Kis Jánosnak: „Az egy különös ember. Jó ember és buzog, de még soha sem juthattam-el arra a’ pontra, hogy őtet ismerjem, sőt csak meg is foghassam. hogy Festetics reá bízta a' fija nevelését, azt nem csudálom. Két originális, két megfoghatatlan ember akadt eggyüvé". 206 Festetics mindkét nevelőnek részletes utasításokat adott fia neveltetésével kapcsolatban. ${ }^{207}$ Péteri Takáts Józsefnek lelkére kötötte, hogy az ifjú László grófba „, csepegtesse bele az európai műveltséget és a grófi rang megkívánta finomságot úgy, hogy azért a hazai erények becsülése és a hazaszeretet tiszta világa maradjon az ifjú keblének egyedüli vezére". ${ }^{208} \mathrm{~A}$ neveléssel kapcsolatban kontraktus is született a gróf és Péteri Takáts között. ${ }^{209}$ Péteri Takáts kéthetente levélben tájékoztatta Festetics Györgyöt az ifjú gróf előmenetelével, magaviseletével kapcsolatban. Megírta, hogy örömmel vette a gróf elöírásait, azonban azokat túlzónak tartja, mert az iskolai elfoglaltságok nem teszik lehetővé, hogy mindennel olyan alaposan foglalkozzanak, amint azt elöírta: „ha tsak a pihenésre szükséges időtől meg nem

\footnotetext{
203 Takáts, 1890. 49.

${ }^{204}$ Kultsár István 1760. szeptember 16-án született Komáromban, nemesi származású iparos családban. Kilenc évesen a helybéli jezsuita gimnáziumba íratják be szülei. 1776-ban járta a költészeti osztályt, ahol tanára Baróti Szabó Dávid volt. 1778-ban a bencés rend kötelékébe lépett. A próbaévet Pannonhalmán töltötte, majd a pozsonyi szemináriumba iratkozott be. II. József 1786. november 14-én kelt rendeletével a bencés rendet is feloszlatta, így Kultsárnak más pályát kellett választania. Előbb Komáromban, majd Szombathelyen és Esztergomban tanított. A Hazai Tudósítások és a Hazai és Külföldi Tudósítások lap elindítója. Kiadta Mikes Kelemen törökországi leveleit. Meghalt 1828. március 28-án. (Bausz, 2001. 12-14.)

${ }^{205}$ Kultsár Esztergomban együtt tanított Révai Miklóssal. Komoly ellentét alakult ki közöttük pedagógiai elveik különbözősége miatt. Kultsár szelíd, békés kedélyes ember volt, Révai konok, komor, rideg, epés. Kultsár nevelési rendszere a szelíd bánásmódban testesült meg, éppen ezért szerették diákjai. Révai kemény, a büntetésben is sokszor szélsőséges megnyilvánulásokra ragadtatta magát. Kettejük összeütközése kikerülhetetlen volt. A hírek - Péteri Takáts révén - Keszthelyre is eljutottak. Éppen ezért írhatta Festetics György Kultsárnak, 1798. november 13-án, a következőket: „Takáts Uramnak levelébül értettem: mi módon Révay Miklós az Úrnak izetlenségeket szerezni igyekezik. Erre való nézve nem tudván ha vallyon azon levelem, a melyet az Úrhoz írtam Esztergomban fogja-e találni az Urat, akartam ezen levéllel is az Urat, Professzor Uramat Budán fel-keresni, és ujjonan ajánlásomat meg-bizonyítani.” (tudniillik Festetics László nevelésére vonatkozóan) (MOL Fest. Lvt. P. 246 5. cs. B. IV. 8. 37.)

${ }^{206}$ Kazinczy Ferenc Kis Jánosnak, Széphalom, 1810. október 15. ; KazLev. VIII. 128-129.

${ }^{207}$ Péteri Takáts Józseffel kötött Contractus: MOL Fest. Lvt. P 246 5. cs. 9.; Kultsár Istvánnal kötött Contractus: MOL. Fest. Lvt. P 2465 cs. B. IV. 9.

208 Szabó, 1983. 185.

${ }^{209}$ MOL Fest. Lvt. P 246 5. cs. 9. ; Contractus. Péteri Takáts József szerződése. Keszthely, 1791. június 24.
} 
akarom fosztani a' minek több rossz következései lehetnének". ${ }^{210}$ Ugyanakkor leveleiben szelíden, de a gondokat el nem hallgató módon, a nevelt iránti szeretettel jellemzi is Festetics Lászlót: „, Mindenek előtt, a’ mi az Ifjú Gróf’ Caracteristicáját illeti, irhatom: hogy tsak egy szembe tünö hiba se gyökerezik szivében. Meg botlik ugyan néha a’ szóban ollykor; meg lehet a tselekedetben is: de ennek nem a' rögzeni kezdő hajlandóság, hanem a' gyermek kornak természete: az elevenség, a’ kivántsi szemfülesség, a’ még neki nem törődött gyenge test az oka. A' melly hibák idővel a' gyakori intés, 's a' vele járó oktatás által mind el mulnak. Ellenben ditséretére lehet mondani: hogy természete szelid, erköltse ártatlan, engedelmes, a' ditsőséget szerető, sokat tudni vágyakodó, a' munkában türő 's szorgalmatos”. ${ }^{211}$ László gróf, szülei megelégedésére az elemi iskolát két év alatt elvégezte, majd elsősorban anyja kívánságára, aki ekkor már Bécsben élt, ${ }^{212} 1793$ és 1799 közt Bécsben járt gimnáziumba. A bécsi úttal Péteri Takáts is egyetértett, mert úgy gondolta, hogy az apa túlzottan türelmes volt fiával szemben. Péteri Takáts József vele ment a császárvárosba, és odaérkezésükkor levélben azonnal tájékoztatta a grófot, hogy Festetics Lászlónak megvan már a korrepetitora, hogy a fiatal grófnak külön padja lesz, amelyben a korrepetitor mellette fog ülni addig, ameddig a professzor az órára be nem jön. ${ }^{213}$ A huszonhárom éves korrepetitort Tessényinek hívták. ${ }^{214}$ Megnyugtatta az apát, hogy minden a legnagyobb rendben fog zajlani, de írásbeli instrukciót kér a továbbiakra. ${ }^{215}$ Ezeket meg is kaphatta, mert ennek alapján határozta meg a tanulandó tárgyakat. ${ }^{216}$ Bécsben is jó mentek a dolgok, a grófné 1795. április 1-jén azt írhatta férjének Keszthelyre, hogy „Laci fia jól végezte exameneit s az elöljárói meg voltak vele elégedve". ${ }^{217}$ Péteri Takáts és az ifjú gróf évente tanulmányutakat tettek Magyarországon és külföldön, amelyröl a nevelő részletes jelentést

\footnotetext{
${ }^{210}$ Péteri Takáts József Festetics Györgynek, Bécs, 1794. június 14. ; MOL Fest. Levt. P 2795 cs. 511.

${ }^{211}$ Péteri Takáts József Festetics Györgynek, Bécs, 1794. június 11. ; MOL Fest. Lvt. P 2795 cs. 511.

212 Szilágyi, 1993. 398.

213 „A Principiorum Professzort fel kerestem. Jó üdős Pap Úr, ha nem hibázok, Wellnek neveztetik. Bően értekeződtem véle mindenekröl, mellyeket a Gróf javára szükségeseknek lenni itéltem. Hogy a Correpetitor jelen legyen egész prolectio alatt. Szokatlan dolognak állította. Hanem minden veszedelemnek el távoztatására azt tanátslotta, hogy valamint másokkal is már történt, egy különös padotska készítetsék a Gróf számára; de azért még is itéletem szerint a hely mellyet érdemelni fog a Gróf, mindenkor üres lészen a többi Tanulók között. Ez a nemes szívnek elegendö ösztön gyanánt szolgálhat. Így tehát a Correpetitor mind addig az iskolában marad a gróffal, míg a Professor meg nem jelenik; azutánn ennek gondviselésére fog bizattatni. Melly szolgálatra önként ajánlotta magát. Az iskolák végezete előtt már helyben várni fogja a Correpetitor s haza késéri.” (MOL Fest. Lvt. P 2461 cs.) ; Péteri Takáts József kéthetente küldött jelentéseket Festetics Györgynek fia előmeneteléröl, a kiadásokról. Péteri Takáts 1794. január 12-én kelt levelét, létrejöttének körülményeit Stohl Róbert dolgozta fel Adatok Péteri Takáts József nevelöi tevékenységéhez című munkájában. (Könyv és Nevelés, 2005/4. 88-90.)

${ }^{214}$ MOL. Fest. Lvt. P 2461 cs. „,...ezen Tessényi nevű 23dik esztendőben lévő Ifjú, a ki külső maga viselésével is minden jót igér; s ugyantsak az a Mélt. Grófné helybe-hagyásával meg is fogadtatott.”

${ }^{215}$ MOL. Fest. Lvt. P. 246 1. cs.

${ }^{216}$ Fehér, 1999. 49.

${ }^{217}$ Sallér Judit Festetics Györgynek, Bécs, 1795. április 1. ; MOL Fest. Lvt. P 2461 cs. ; Idézi: Szabó, 1928. 318-319.
} 
tett az apának. Az uti jelentések mellett olykor üdvözlő verseket is tartalmaztak levelei. ${ }^{218} \mathrm{Az}$ egyiket idézett müvében Takáts Sándor is közli. Ennek címe: „Mohács vidékjén írt levél, Augusztus fogytán, 1797”. ${ }^{219}$ Péteri Takáts ebben a viszonylag hosszabb versében, melyet Mészáros ${ }^{220}$ nevü barátjának írt, megidézi a mohácsi tragédiát, békességért áhítozik. A vers mély, belső érzésekkel fütött, több erő van benne, mint egy alkalmi költeményben. Érdemes idézni Péteri Takáts által kiemelt soraiból:

$(\ldots)$

Méltó tárgy! sírjunk! van elég ok sírni, Barátom

Nem titok: elpártolt tőlünk a csalfa szerencse

$(\ldots)$

Árva hazám temetője, Mohács! környékedet értem

$(\ldots)$

A föld megrendül és a széjjel heverő holt

Testek alatt nyög; s nem győzvén már színi magába

A sok vért: ez partot mos, s mindaddig igyekszik,

Míg, te szerencsétlen Cselye! barna vizedhez elérvén,

Drága királya hideg tetemeit megölte utólján. -

Itt, itt húnyt el örökre talán szeretett Magyarország!

$(\ldots)$

A békességet! - Mert nincsen igaz gyönyörüség,

Nincs haszon e nélkül; bármyel jó légyen egyébként

A polgári kötés. - Szent béke! az Égbe kiáltunki

Hozzád: Szállj le megint nyomorult földünkre, s maradj itt! ${ }^{221}$

Egyik évben a Dunántúlt, máskor Eger környékét, a Jászságot, az Alföldet járták be, 1796-ban pedig a felvidékre látogattak, majd Szegedre, Nagyváradra. Később Grácba, Marburgba, Görzbe, Udinébe, Velencébe, Triesztbe, Fiuméba utaztak. ${ }^{222}$ Péteri Takáts részletes útirajzot írt vándorlásaikról és az ifjú gróf neve alatt szerette volna kiadni. Erre

\footnotetext{
${ }^{218}$ Takáts, 1890. 65.

${ }^{219}$ Takáts, 1890. 63-65.

${ }^{220}$ Valószínűleg Mészáros Józsefröl van szó, akinek prédikációját Péteri Takáts segítette kinyomtatni (,,Egyházi beszéd a papi rendröl. Mondotta Rédén pünkösd utánn X. vasárnap eggy új misének szolgáltatásakor" Veszprém, Szammer Mihály, 1801. ; Mészáros József (1764-1839) székesfehérvári kanonok, 1794-töl váli plébános, majd esperes.

${ }_{221}$ A versrészleteket Takáts Sándor átiratában közöljük.

${ }^{222}$ Szabó, 1928. 319.
} 
azonban nem került sor. ${ }^{223}$ A még meglévő kéziratból végül is a győri Szabad Polgár címü lap közölt részleteket. ${ }^{224} \mathrm{Az}$ 1799-es esztendő közepéig állt Péteri Takáts nevelése alatt László gróf. Ezt követően Kultsár Istvánt bízta meg Festetics György, akivel szintén megfelelő kontraktust kötött fiának nevelésére vonatkozóan. ${ }^{225}$ Az 1799. június 15-én Festetics György által megfogalmazott utasítás minden részletre kitért. A tíz pontban megfogalmazott plánum legfontosabb leszögezi, hogy a nevelés három részből áll úgy mint „a szívbéli gondolkodásnak jóindulatra való hajtása, az elmének hasznos és a környülállásokhoz alkalmaztatott tudományokkal való megékesítése és az egészségnek rendes életmódjával való megtartása”. Ennek érdekében a nevelö köteles „practica moralis philoshophiá”-t megtaníttatni, megszerettetni a nevelttel és ugyancsak köteles minden nap az ifjú gróffal fél órát „philosophal”-ni. Jócselekedetek véghezvitelére, állhatatosságra, jó erkölcsre, megbocsátásra, takarékosságra, a király, a haza iránti tiszteletre köteles tanítani. Köteles megismertetni neveltjével a tudományokat: a geometriát, az architektúrát, a matematikát, fizikát, statisztikát, politikát, stb. Mértékletes ételfogyasztásra, sok mozgásra kell az ifjú grófot nevelni, és ,amennyire lehet, bor és hevesítő italokhoz nem kelletik szoktatni”. 226

Az új nevelő az ifjú gróffal többnyire Pesten töltötte a téli hónapokat. Szorgalmatosan látogatják az egyetemi előadásokat. Mindketten Festeticsék Cukor utcai ${ }^{227}$ házában laktak. ${ }^{228}$ Nem maradtak el az utazások sem, főleg külföldre: Teplitz, Drezda, Meissen, Lipcse, Halle, Jena, Weimar, Erfurt, Gotha, Coburg, Bamberg, Erlangen, Nürnberg, Regensburg, Linz voltak útjuk fontosabb állomásai. Ezekről jelentéseket írt Festetics György grófnak. ${ }^{229} \mathrm{Az}$ út során az ifjú gróf magokat gyüjtött a Georgikon részére, amit az intézményben később szaporítottak. ${ }^{230}$ Amikor László 19 éves lett az apa új írásos utasításokat adott Kultsárnak. Ennek lényege szinte kizárólagosan az ifjú megfelelő viselkedéséről szólt. Bécsben és Pesten is csak Kultsár tudtával mehetett el az ismerősöket, rokonokat meglátogatni, ami kívánatos dolog volt, de a rövid látogatásról be kell számolnia nevelőjének. Érdemes megjegyezni, hogy

\footnotetext{
${ }^{223}$ A kézirat elkészülte után Péteri Takáts újabb köteten dolgozott, amit ki is adott gróf Festetics György pénzén. Ez a könyv László grófnak szóló „Erkölcsi oktatások” voltak. Péteri Takáts halála után, 1873-ban minden kéziratban maradt munkája szatócsboltba került, ahol nagy részét csomagolópapírként használták fel. A maradékot véletlen folytán Brocskó Lajos, később a budapesti protestáns árvaház igazgatója, mentette meg. (Takáts, 1890. 57.)

${ }^{224}$ Szabad Polgár. Szerkeszti Kiss Sándor. 1873-as évfolyama.

${ }^{225}$ MOL. Fest. Lvt. P. 2465 cs. B.IV.9. 5 Lásd még: Fiam Nevelését tárgyazó Plánum, 1799. június 5. MOL. Fest. Lvt. P 279 1799:688 ; Kornis I., é. n. 491-498.

${ }^{226}$ Szabó, 1928. 320-323. Szabó Dezső idézett müvében teljes egészében közli a „Fiam Nevelését tárgyazó Plánum"-ot.

${ }^{227} \mathrm{Az}$ V. kerületben található utcát ma is Cukor utcának hívják. Festeticsék házának helye azonban nincs jelölve.

${ }^{228}$ Alapi, 2001. 26.

229 Szabó, 1928. 323.

${ }^{230}$ Bright, 1935. 45.
} 
Festetics György még a neveket is felsorolta, akiket az ifjú gróf látogatásai során ki nem hagyhat. Szabadon látogathatta a következő személyeket: Kolonics kalocsai érsek, gróf Brunszvik, Almássy Pál, báró Orczy László, Széchenyi, Semsei, Sauer püspök. A professzorait, a rektort, Revitzki, Markovits, Kelemen, Schwartner, Schedius consiliariusokat csak havonta egyszer. Hat hetente kell meglátogatnia gróf Barkótzy administratort, Laczkovics ordinarius viceispánt, Ónodi főnótáriust. Az is kiköti, hogy ne az „asszonyságokat, vagy gyermekeiket” látogassa meg, hanem az urakat. Egyéb látogatási javaslatokat Széchenyi gróf segítségével kell megválasztani. Pesten megengedi, hogy színházba járjon az ifjú gróf, de a kávéházat, az ifjak összejövetelein való részvételt tiltja. Festetics György utasításában rögzíti: ha fia jól tanul, megkapja a balatonkeresztúri uradalmat, ha nem tanul és megbukik „a balatonkeresztúri jószág nem fogna általadódni”, lovait, díszesebb ruhát pedig eladatja és a szegényebb diákok közt a pénzt szétosztja. ${ }^{231}$

Festetics elveire és mindenre kiterjedő figyelmére következtethetünk abból is, hogy a két Festetics árva Ernő és Leó ${ }^{232}$ neveltetésére vonatkozóan is pontokba szedve utasította a nevelöt. Az árváknál is meghatározta kiket látogathatnak Almássy Pált, báró Malonyait, azután az „attya-fiakat” Festetics Antalt, Festetics Jánost, Almásy Jánost, tudósabb társalkodás végett menjenek el „Schediushoz, Schwartnerhez, Vasshoz, a Tudományos Gyűjtemény redaktorához Rőtthöz, Stettnerhez, Vutsetitshez”. Bálokra, vadászatokra külön engedéllyel járhattak, de azt is meghatározta, hogy „főlöstökömre” mennyi kávé, cukor és csokoládé jár. Ami ennél is sokkal fontosabb és Festetics György mủvelődéstörténeti nagyságára is rámutat, hogy Festetics Ernő nevelési utasításában leszögezi; havonta egy levelet írjon neki, „egyik honapban deákul, masikban Frantziául, hogy mitsoda könyveket olvas, mellyeket fordít? Mennyire ment tanulásban, nem szükség pedig, hogy német fordításokat is tegyen, hanem tsak Deák, Frantzia és Magyart". ${ }^{233}$ Az is kikötötte, hogy Ernő és Leó apanázsuk negyedét könyvvásárlásra fordítsák. (Festetics György halálát követően fia László vállalta magára a két árva nevelését.) $)^{234}$

\footnotetext{
${ }^{231}$ MOL Fest. Lvt. P 235 Memor. 447. ; Gróf Festetics György az utasításban leszögezi, hogy a rokon Széchenyiéknél hetente kétszer is ebédelhet, de más uraságoknál csak legfeljebb havonta kétszer. Lovagolni csak lovásszal szabad. Ha távolabb megy a „háztól” inast vigyen magával. Az ifjú gróf szobája legyen „,csinos”, de ne hivalkodó, ám az egyik szobában könyvtárat alakítsanak ki ,amint egy eszes, tanult és nagyra menendő mágnást illet”. Az utasítás teljes szövegét közli Szabó Dezső. (Szabó, 1928. 323-327.)

${ }^{232}$ Festetics Ernő (1800-1859) és Leo (1800-1884) unokatestvérek voltak. Festetics György nagyapja Kristóf és Festetics Ernő, valami Leó nagyapja Pál, édestestvérek voltak. Festetics Leó volt később a pesti nemzeti színház igazgatója. Árvaságra jutásukat követően Festetics György gondoskodott róluk. Érdekes, hogy a Festetics Directio valamennyi iratában a „két Árvának”, vagy „Árva Grófoknak” titulálják őket.

${ }^{233}$ MOL réthei Rötth Lvt. P 589. 7 cs. 9-10

234 1819. május 9-én már Festetics László utasítja Rőtth fiskálist, hogy Ernő és Leó grófok számára szobákat béreljen, valamint azokat rendezze be. MOL réthei Rötth Lvt. P 589. 7 cs. 18.
} 
Visszatérve László gróf szigorú feddésére úgy tűnik javult a helyzet, mert az apai rendelkezést követően Festetics László mindent megígért apjának, amit időlegesen be is tartott. Erre - többek között - abból is lehet következtetni, hogy a balatonkeresztúri birtokot rövidesen megkapta. A Kultsárnak adott utasítás további részéből világosan kitünik, hogy fiát (mint egykor öt is apja) a jogi pályára szánta. Ugyanakkor a nevelés végső konklúzióját is megfogalmazza a tizenhárom pontos utasítás tizedik fejezetében: „...azért Kultsár urat megkérem, 1. hogy fiamnak szíve igazgatására szolgálható és jövendő életére kiterjesztett józan intéseit bizonyos renddel adja elejébe, 2. hogy a háznak és jószágoknak administratiójára megkívántatott útmutatót neki megmagyarázza, hogy így tudniillik az fiam jó ember, jó gazda, jó polgártárs, jó hazafi, hív jobbágy legyen”. 235

A kitűnő nevelés és apai szigor sem volt ahhoz elég, hogy László gróf - Szabó Dezső megfogalmazása szerint - „munkához való szoktatását ${ }^{\text {"236 }}$ sikeresen megvalósítsa. Állandó pénzügyi zavarban volt, hatalmas kölcsönöket vett fel sokszor uzsorásoktól. Amikor László gróf az 1809-diki insurrectio alkalmával táborba szállt, költekezésének megakadályozására, az apa titkárát, Török Jánost küldte vele, hogy vigyázzon fiára. ${ }^{237}$ Még inkább csődbe került, amikor hercegi asszonyt, Hohenzollern-Hechingen Josefint elvette feleségül. Bár az apa áldását adta a frigyre, a Hechingenben 1811. augusztus 31-én megtartott esküvőre nem ment el. ${ }^{238}$ Az esküvőről a korabeli újság a következő hírt közölte: „Hazánknak díszére, Nemzetünk ditsőségére, 's önnön Familiájának jeles fényességére a' régi nagy példákat megújította Mélt. Gróf Tolnai Festetits László Úr, Ts. Kir. Kamarás és a’ Nemes Felkelő Seregnél Fő Fő (sic!) Hadnagy Ö Nga, midőn ezen nyáron a’ Hohenzollern Hechingen Uralkodó Háznak Josefina nevü Herczeg Asszonyát magának eljegyezte. A’ házassági összekelés ugyan Hechingenben Stuttgard (sic!) mellett September elején ment végbe. A’ honnan ezen szép ifjú pár már haza érkezett”. ${ }^{239}$ A cikk talán akaratlanul is ,a régi nagy példákat” emlegetve arra mutat rá, hogy a Festeticsek rangbéli emelkedése és vagyonuk gyarapodása nagyon sok estben jó házasságkötésüknek volt köszönhető.

Apja halála után László gróf az ország egyik legnagyobb vagyonának birtokosa lett, költekezéseiről azonban nem mondott le. ${ }^{240}$ Unokatestvére gróf Széchenyi István így írt róla

\footnotetext{
${ }^{235}$ Festetics György utasítása 1804. április 15-én. ; MOL Fest. Lvt. P 235 Memor, 447. ; Idézi: Szabó, 1928. 326.

${ }^{236}$ Szabó, 1928. 331.

${ }^{237}$ Szabó, 1928. 301.

${ }^{238}$ Szabó, 1928. 331.

${ }^{239}$ HKT. 29 sz. 1811 . október 9.

${ }^{240}$ Gróf Festetics László életrajzának hiteles és részletes változata sem készült el. A „,költekező fiú” jelző csak egyoldalú beállítása életének. Nem szabad elfelejteni, hogy Péteri Takáts, Kultsár tanítása és gróf Széchenyi István is hatással voltak rá. Itt csupán rendkívüli mecénási bőkezüségét emelnénk ki: Magyar Nemzeti Tudós
} 
Naplójában: „Laci azt ajánlotta, töltsek nála néhány hónapot. Inkább cukrot finomítanék a gyarmatokon. - Egy másik ilyen bolond nincsen a földön. Egészen bizonyos, hogy eltángálnám, ha egy hétig szorosan vele kellene élnem. Felesége, Istenemre, rászolgált a mennyországra". ${ }^{241}$ De Festetics László volt az, aki a Magyar Tudós Társaság javára 10000 forintos alapítványt tett, országos könyvtárszervező mozgalmat indított ${ }^{242}$ és ehhez Zala megyének 2 000, Somogy, Sopron és Vas megyéknek pedig $1000-1000$ forintot ajánlott fel. $^{243}$ Jelentős pénzek voltak ezek, föleg az az összeg, amelynek adománylevele 1826. június 27-én kelt, s amelyet a szeptember 22-i országos ülésen jelentettek be. A mai szemmel terjengős, sok magyarázattal és kikötéssel tarkított okmányban Festetics a hadtudományok fejlesztésére 10000 pft-os alapítványt tett 6\%-os kamattal, „melly kamatok a’ Magyar Nemzeti Tudós Társaság olly rendes Tagjának fizetésére fordíttassanak, kinek kötelessége legyen a' Tudós Társaság felvigyázása alatt az Angol, Francia, Muszka, Német, 's a' t, Európai Nemzeteknek a' hadi Tudományokról szólló érdemes munkáikat magyarra fordítani, de az e'féle munkák közzé a' katonai Regulamentumokat, vagy azok kivonatját nem értvén..." A kinevezés befolyást kért - magának és örököseinek. Ez volt az első - és a reformkorban az utolsó - alkalom, hogy valaki egy rendes tag fizetésére, mégpedig meghatározott tudományágban ajánlott fel alapítványt. ${ }^{244}$ Alapítványok létrehozásával, nemes célokra felajánlott támogatásaival, birtokgyarapításokkal megpróbált apja nyomdokaiba lépni, de ahhoz nem volt elég ereje, hogy a kiadások gazdasági, pénzügyi hátterére is nagyobb gondot fordítson. Pedig mindenki a neves apa utódját látta László grófban, még édesanyja is erre ösztökélte fiát, Berzsenyi, Virág ${ }^{245}$ intézett hozzá verset. Mindez, kétséget kizáróan, súlyként nehezedett Festetics Lászlóra, amit haláláig le nem vethető koloncként hordozott.

Nem szabad azonban elfelejtenünk, hogy László gróf idejében tértek át az apja által alapított Georgikonban a magyar nyelvü tanításra. Festetics László 1828-ban olyan határozatot hozott, hogy a Directio jegyzőkönyveinek vezetése és a Georgikon ügyintézése magyar nyelven történjék. 1837-ben a keszthelyi születésű Lehrman József tanár a szőlészetet,

\footnotetext{
Társaság, Ludovika Akadémia, megyei könyvtárak, balatonfüredi magyar nyelvü kőszínház, Balaton-parti lecsapolások, a Georgikonban magyar nyelven folyó oktatás, stb. Adományait törvénykönyve is iktatták: 1827. évi XIX. törvénycikk. „Gróf Festetits Lászlónak két rendbeli ajánlatai beczikkelyeztetnek” = Netjogtár. A CompLex Kiadó Kfrt. CompLex jogi adatbázisa (2009)

${ }^{241}$ Széchenyi, 1978. 243.

${ }^{242}$ 1826-ban került sor az első országos könyvtárszervező akcióra, amikor is Festetics László gróf „,a közösség feladatának tekinti (...) a megyei és városi könyvtárak létesítését és fenntartását”, s ,nemzeti”, azaz magyar könyvekből álló könyvtár felállítására szólítja fel a vármegyéket. (Fülöp, 2010. 40.)

${ }^{243}$ Részleteiben lásd: Fülöp, 1978. ; Fülöp, 2010.

${ }^{244}$ Bényei, 1998. 57.

245 Berzsenyi Dániel: Gróf Festetics Lászlóhoz ; Virág Benedek: Festetics László ifjú grófnak, Tolnai Festetics László ifjú grófhoz 1798.
} 
a kertészetet és a növénytant már magyarul adta elö. A gazdasági, jogi és matematikai ismereteket továbbra is latinul tanították. 1839-ben Festetics László újabb utasítást ad: „az a kívánságom, hogy a tanulmányok, nevezetesen az oeconomia és technologia a Georgiconban idővel magyar nyelven előadassanak.” Ennek az utasításnak megvalósítására három évet kellett még várni. ${ }^{246}$

Festetics László erőteljesen érdeklődött családja története iránt. Maretich Ernő nyugalmazott ezredest, amatőr-történészt bízta meg családja történetének megírásával. Maretich elkészült mủve, amelyben levezeti Festetics László "illyr" származását, boszniai eredetét, a legendáriumok világába való. ${ }^{247}$ Gróf Festetics László 1846. május 22-én halt meg. Négy gyermeke volt: Ilona (1812), Tasziló (1813), György (1815), Lajos (1823). 


\section{GRÓF FESTETICS GYÖRGY HELYE ÉS SZEREPE A MAGYAR MÜVELŐDÉS- TÖRTÉNETBEN}

Festetics György gróf mủvelödéstörténetünk szempontjából meghatározó alkotásait leginkább keszthelyi évei alatt (1791-1819) valósultak meg, főleg az iskolaalapítás, a könyvkiadás, az irodalom, a sajtó, együttesen a mecenatúra területén. De számos egyéb intézménynek rakta le alapjait és segítette tevékenységét a közjó, a város fejlődésének érdekében úgy, mint nyomda, kórházügy, hajóépítő műhely, posta.

Erre az időre vonatkozóan Keszthely társadalmi helyzetét, a keszthelyi uradalom hagyatéki és vagyoni összeírásai alapján vették górcső alá Benda Gyula és társai, aki kutatatásaik eredményét többször publikálták is. ${ }^{248}$

„A XVIII. század 70-es 80-as éveiben felnőtt és tevékenykedni kezdett az árutermelő nemességnek egy, sajátos gazdasági tényezőktől indított élcsapata, amelyet a reformkor előnemzedékének tekinthetünk.” - idézi Kosáry Domokos Tompa József Müvészi archaizálás és nyelvemlék-hamisitás 1772 és 1873 között címü munkáját, rámutatva, hogy a nemesség bizonyos középső és felső rétegei váltak fogékonnyá a felvilágosodás iránt. Ide sorolja az Orczy, Podmaniczky, Ráday, stb. családokat. Emellett arra is emlékeztet, hogy előzőleg a Festeticsek, Niczkyek közül került ki a felvilágosult abszolutizmus első garnitúrája. ${ }^{249}$

Festetics szerepét vizsgálva nem érthetjük meg annak lényegét, ha nem vesszük figyelembe: a fogékony Festetics abban a korszakban élt, amelyben Bessenyei egy stagnáló „nemzetietlen” korral szemben egy fejlődő „nemzeti” kor időszakát nyitotta meg, amelynek kezdetei nem köthetők évszámokhoz. Azért - írja Bíró Ferenc - mert a felvilágosodás-kori magyar irodalom redukált szemléletéhez jutunk, ha csak a hetvenes évek (1770-es Cs. G.) fejleményeiben látjuk meg az alapjait, de a hetvenes éveket is redukáltan szemléljük akkor, ha

\footnotetext{
${ }^{248}$ A keszthelyi uradalom 1850 elötti hagyatéki és vagyoni összeírásai I. Keszthely 1711-1820. Közreadja: Benda Gyula. Fontes Musei Ethnographiea 1., Budapest, 1988. ; A keszthelyi uradalom 1850 előtti hagyatéki és vagyoni összeírásai II. Keszthely 1821-1849. Közreadja: Benda Gyula. Fontes Musei Ethnographiea 2., Budapest, 1995. ; Benda Gyula: A keszthelyi uradalom 1850 elötti hagyatéki és vagyoni összeirásai III. Szölőhegyek, falvak. Fontes Musei Ethnographiea 7., Budapest, 2005. ; Benda Gyula: Zsellérből polgár - társadalmi változás egy dunántúli kisvárosban. Keszthely társadalma, 1740-1849. Mikrotörténelem 3. L’Harmattan, 2008. ; Benda Gyula: Kisvárosi társadalom és gimnáziuma. = Korall/3-4. Társadalomtörténeti folyóirat, 2001. Tavasz-Nyár. 104-127. (A kutatások további irodalomjegyzékét lásd. = Korall, 2001/3-4. 126-127.)

${ }^{249}$ Kosáry, 1983. 321-322.
} 
a későbbi fejlődés alapjait látjuk meg benne. ${ }^{250} \mathrm{Az}$ 1770-es kulturális teljesítményeket mindenképpen egy szélesebb folyamat részeként kell figyelembe vennünk.

\section{1. Keszthely városias képének kialakítása}

Keszthely a neolitikumtól folyamatosan lakott település. A mai Dunántúlt Kr. e. 13. és 8. között hódította meg Tiberius császár és Pannónia tartományként a Római Birodalomhoz csatolta. A mai Keszthely területén haladt át az a provinciát diagonálisan átszelö fontos kereskedelmi és hadiút, amely Aquincumot és Aquileát kötötte össze. Az út védelmének érdekében, a ma közigazgatásilag Keszthelyhez tartozó Fenékpusztán, római erődöt építettek, de római villa maradványait találták meg Keszthely belvárosában is a legutóbbi feltárások eredményeként (2010). A település későbbi meglévő szerepére olyan régészeti leletek is bizonyítékot adnak, mint például a Népvándorlás-kori un. „Keszthely-kultúra”.

Keszthelyt nem véletlenül nevezik a Balaton-part egyetlen városias jellegü településének. Már a kora középkorban kialakult észak-déli és kelet-nyugati kereskedő utak találkozásánál felépült település mai arculatát a Festeticseknek, elsősorban Festetics Györgynek köszönheti. Ugyanis az 1715-ben Keszthelyen járt angol utazó Clements, könyvében arról írt, hogy a városban mindössze két-háromszáz ház található, ebből mindössze három épült köböl. A többi nagyrészt sövényfalú, zsúp-, vagy nádfedeles, földszintes épület. ${ }^{252}$ Festetics Kristóf is ilyennek láthatta Keszthelyt, amikor 1738-1739-ben nekiállt itteni birtokai megvásárlásának. Csak rontott a város helyzetén, amikor 1745-ben, földesúri jogaival élve és visszaélve - bekérette Keszthely szabad polgáraitól az ingatlanaik birtoklásra vonatkozó iratokat, inskripciós leveleket. Tisztje Szaurer József hajtotta végre a rendelkezést. A felülvizsgálatot „Purizációnak” nevezte Festetics Kristóf, aminek az volt a célja, hogy a Keszthely határában lévő földeket urasági földdé változtassa, amellyel azután tetszése szerint rendelkezhet. ${ }^{253}$ Festetics ezen lépése hosszú évtizedekre meghatározta a város és a Festeticsek kapcsolatát, a két fél végeláthatatlan pereskedését, amely csak a XIX. század közepére oldódott meg megnyugtatóan.

Keszthelynek lakossága 1773-ban még teljes egészében magyar. Jobbára kézműves, iparos. A XVIII. század eleji némi fogyatkozást Festetics Kristóf németek betelepítésével

\footnotetext{
${ }^{250}$ Bíró, 1994. 9-12.

${ }^{252}$ Koppány-Péczeli-Sági, 1962. 34.

${ }^{253}$ Kovacsics, 1991. 72.
} 
pótolta, úgy, hogy 1775-ben már 220 német telepes lakott a városban. Ök azonban nem befolyásolták a lakosság magyar etnikumát, mert gyorsan elmagyarosodtak. Keszthelynek a XVIII. és XIX. század fordulóján 19 utcája volt. ${ }^{254}$ Ezt a várost választotta ki Festetics Kristóf, hogy birtokainak központjává tegye.

\section{1. 1. A kastély}

Festetics Kristóf 1745-ben birtokaihoz méltó kastély építésébe kezdett, ehhez azonban nem talált megfelelő szakembereket Keszthelyen, így a fentebb említettek szerint, Ausztriából és Morvaországból telepített iparosokat a városba. Ez először felháborodást keltett a helybéliek között, de idővel a várt eredmény bekövetkezett és a század második felében a város kisipara, kézmüipara, különösen a takácsok, asztalosok, kőfaragók, fazekasok vonatkozásában hírnevet szerzett magának. ${ }^{255}$ Ebben az időben érkezett Keszthelyre Hofstädter Kristóf, aki számos megvalósult épületnek terveit készítette el, ezzel alakítva ki a mai Kossuth Lajos utca északi részének, valamint a mai Kastély utcának képét. ${ }^{256}$

Festetics György Keszthelyre költözését követően, figyelme mindenre kiterjedt, főleg a kereskedelemre, hisz birtokainak bevétele elsősorban ebből adódott. Ezért 1780-as években tervezetet dolgozott ki a kereskedelmi úthálózatra. Javasolta, hogy a (Nagy)Kanizsa környéki és más mocsarakat a Zala folyótól a Muráig húzódó, Zalaistvándnál kezdődő csatornával le kell csapolni és ez a megépítendő csatorna egybe kereskedelmi útvonal is lenne. A Dráva és a Száva összekötésével Károlyváros felé kellene biztosítani a gabona közvetlen szállítását, amivel meg lehetne akadályozni a konkurenciát, jelentős szlavóniai gabona közvetlen felhozatalát. ${ }^{257}$

Festetics György bővítette kastélyát. Nem a legdrágább, de mindenképpen jó szakembereket szerzett meg kastélya bővítéséhez, a belső berendezések elkészítéséhez. Ezeket az éveket a kastély harmadik nagy átépítési időszakának nevezzük, idejét pedig 1792 és 1801 közé tesszük. Andreas Fischer bécsi akadémiai építész terveinek elvetése után Hofstädter utódja Rantz János György kapott megbízást a tervek elkészítésére. Rantz 1799-

\footnotetext{
${ }^{254}$ Kovacsics, 1991. 73.

${ }^{255}$ Festetics György kastélyának copf könyvtártermét Kerbl János keszthelyi asztalossal készíttette 1800-1801ben, Festetics László Kugler keszthelyi kőfaragóval készíttette a Kisfaludy Sándor által szorgalmazott balatonfüredi magyar színház oszlopait és a zalaszentgróti híd kőpilléreit. A keszthelyi kőfaragó mühelyről többet: Eszes, 1980. 84-107.

${ }^{256}$ Keszthelyen az Amazon Szálló (Kastély u. 11.), az első keszthelyi zsinagóga - ma átalakítva - (Kossuth u. 22.), régi városháza - ma átalakítva - (Kossuth u. 28.), Városháza (Fő tér 1.) és a már lebontott, vagy megmaradt parasztbarokk földszintes lakóházak, mint például a Kastély u. 16. számú.

${ }^{257}$ Kovacsics, 1991. 70. ; Károlyváros = Karlovac (ma Horvátország)
} 
ből származó rajzain klasszicizáló késő-barokk, gazdag architektúrájú, kétemeletes formában jelenik meg a kastély. Azonban ez a terv sem nyerte meg a gróf tetszését, így ebben a formában nem készült el az átalakítás. Megépült viszont a könyvtár, a kápolna, később a levéltár, a barokk kertet angolparkká alakították, megépítették a gloriettet és az úgynevezett Mulató Házat. ${ }^{258}$

A kastély könyvtári gyüjteményének alapját Festetics Kristóf rakta le. Megbízottai bejárták az egész országot, hogy a bibliotékát értékes újdonságokkal gyarapíthassák. Festetics Kristóf nemcsak gyüjtötte, de óvta is könyvtárát. Ennek jó példája az az eset, amikor 1745ben József bátyja gyermekeivel együtt megérkezett a kastélyba és igénybe szerették volna venni a könyvtárat. Kristóf azzal a kikötéssel egyezett bele, ha lajstromba veszik a kikölcsönzött könyveket, s az átvételi elismervény a könyvtárban marad, így nyomon követhető a könyv sorsa, azaz „hogy tudassa az ember, hová lett”. ${ }^{259}$ A Festetics Kristóf által alapított könyvtár állománya Festetics Pál és Festetics György jóvoltából megszaporodott. Amikor Festetics György a kastélyt kibővítette, külön könyvtártermet építtetett, belső berendezésével Kerbl János keszthelyi asztalosmestert bízta meg. Ez a könyvtári berendezés található meg mind a mai napig. A falakat tölgyfából készített négy méter magas nyitott könyvszekrények borítják, amelyeket egyszerü félpillérek, pilaszterek választanak el. A pillérek feje egy kecsesen faragott volutás oszlopfö, ezeken nyugszik az emeleti karzat. Itt három méter magas könyvpolcok futnak körül a falak mentén. A karzatot faragott korlát szegélyezi. Az épületrészt 1810-ben alakították ki, belső berendezése 1812-ben készült el. Miután elkészült a pompás könyvtárterem, Festetics már bátrabban vásárolhatott könyveket. Gyarapodott a barokkos-enciklopédikus állomány, bővült a világi tárgyú, a modern irodalmi gyüjtemény. ${ }^{260}$ Annak érdekében, hogy könyveit rendszerezni lehessen saját elképzelése szerint osztályozta könyvtárát, amelynek kivitelezését Péteri Takáts József könyvtárosára (fia későbbi nevelőjére) bízta. 1810-ig jobbára gazdasági könyvek beszerzése iránt intézkedett, 1817-et követően a történelmi tárgyúak aránya emelkedett. A polcok felett a jobb tájékozódás érdekében táblácskákat helyeztetett el: Philologia, Literatura Hungarica, Theologia, Jurisprudentia, Acta Diaetalia, Medicina, Philosophia, Pedagogia, Militaria, Scientiae Naturales, Oeconomia, Mathematica, Historia Universalis, Historia Hungarica, Genealogia et Heraldica, Aesthetica, Mappa Geographia, Musica, Literatura Germanica, Literatura

\footnotetext{
${ }^{258}$ Koppány, 1993. 167-170.

${ }^{259}$ Klempa KFK, é. n., 5.

${ }^{260}$ Fülöp, 2010. 42.
} 
Britannica, Literatura Romana, Geographia. ${ }^{261}$ Korabeli feljegyzések szerint Festetics György idejében nem múlott el hét, hogy külföldről, vagy belföldről ne érkezett volna könyvküldemény, amelynek tételeit maga a gróf válogatott ki és rendelte meg. Ezek könyvek, illetve folyóiratok voltak. Ö rakta le alapjait Magyarország egyik tekintélyes szabadkőmüves gyűjteményének. Ebben az időben a könyvtár állománya 8000 kötet lehetett. ${ }^{262}$ Richardt

Bright angol orvos-utazó 1815-ben már 15000 kötetre becsüli a könyvtár állományát. ${ }^{263} \mathrm{~A}$ sok könyv a pocok folyamatos bővítését kényszerítették ki. Erre példa a Directio Protokollumának egyik bejegyzése 1815. január 14-ről: „Holtzhammer Imre üveges a bibliotékába üveges almárium iránt kötött Contractus 72 f 24 xral kifizetés által assignáltatik.”264 A Bécsben tartózkodó „Festetics-ágens”, Keresztury István „főfoglalkozása” az volt, hogy a grófi könyvtár számára beszerezze és Keszthelyre szállíttassa a megjelenő könyveket és folyóiratokat. ${ }^{265}$ Ezek bekötésére nagy gondot fordított, külön könyvkötőt alkalmazott Földesi István személyében. A könyvtár Festetics féltett kincse volt. Klempa idézett müve szerint családtagjait sem szívesen engedte be a könyvtárterembe, de a tudósok előtt mindig nyitva állt a bibliotéka.

Érdemes nagyobb figyelmet fordítani a keszthelyi Festetics kastély a kápolnájára is. Az empire stílusban készült kápolna falmezőit erezett szürke alapon tizenkét vörös márvány falpillér tagolja, ezeken aranyozott korinthusi fejezetek tartják a vörös márvány profilált, aranyozott fogsoros párkányt. A boltozatos mennyezet halványrózsaszín, szürke, fehér, zöldes árnyalatú márványozása felhős eget utánoz, legmagasabb pontján aranyozott, sugaras Istenszem. A koporsó alakú oltár sötétvörös fehérrel pettyezett márványból készült, homloklapján három fából faragott, aranyozott dombormü van. Rajta mahagóni tabernákulum és két oldalszekrényke, ezeken a Hite, a Reményt és a Szeretetet jelképező három alabástrom szobor. ${ }^{266}$ Mögötte félköríves, vörös márvány fülkében Szent Zsófia majdnem életnagyságú

\footnotetext{
${ }^{261}$ A könyvek elrendezése a nagykönyvtár szabad polcain mind a mai napig ezen könyvtári beosztást szerint történik.

${ }^{262}$ Klempa KFK, é. n. 8. ; A könyvtár ősnyomtatványainak száma viszonylag kevés volt. A legrégebbi nyomtatványok Velencéből származtak és 1471-böl valók voltak. Részletesen lásd: Klempa Károly: A keszthelyi Festetics-könyvtár 1500-ig terjedö ösnyomtatványai. Sujánszky, Keszthely, é. n.

${ }^{263}$ Bright, 1935. 11.

${ }^{264}$ MOL Fest. Lvt. P 279 Directio Protokollum anni 1815. 281-282.

${ }^{265}$ Iványi, 1947. 19.

${ }^{266}$ A három szobor elveszett, csupán a Szent Zsófia szobor került vissza az 1990-es években eredeti helyére, amit a Veszprémi Egyházmegye Múzeuma őrzött meg. A Festetics kastély könyvtárában őrzött, az 1930-as években készített fényképen még jól láthatóak a Hit, a Remény és a Szeretet szobrai. Kettő az oltár pilasztere előtt, míg a harmadik Szent Zsófia előtt került elhelyezésre. Nagyságuk kisebb volt, mint Zsófia szobrának fele, ma már nehéz pontos méretet adni. (Keszthelyi Festetics Kastély Helikon Könyvtára 7. boríték Családtagokról, kastélyról készült fekete-fehér fotók + negatívok. 78.79.)
} 
alabástrom szobra került elhelyezésre. Az oltár fölött a Példabeszédek könyve II. részének 3. és 5. verséből vett, a bölcsességre utaló sorok állnak:

\section{SI SAPIENTIAM INVOCAVERISET INCLINAVERIS COR TUUM PRUDENTIAE TUNC INTELLIGENS TIMOREM DOMINI ET SCIENTIAM DEI INVENIES ${ }^{267}$}

Nagyváthy Kálmán Döbrentei Gáborra hivatkozva megemlíti, hogy ő a bölcsesség, az ész istennőjét látta Festetics kápolnájában. ${ }^{268}$ Nagyváthy Kálmán adatait tehát Döbrenteitől vette át, aki személyes élményeit a következőképpen jegyezte le: „1814-ben meg valék lepve Keszthelyen, házi kápolnájában. (ti. Festeticsnek Cs. G.) Oltár helyett a’ „bölcsesség istennéje" alabastromból e' felirással: keressétek a' bölcsességet." ${ }^{269}$ Valószínüleg Döbrentei emlékezete itt nem pontos, hisz a sorokat a látogatás után huszonnyolc évvel vetette papírra. A lényeget azonban emlékezetébe véste, mégha a felírásnak csak egyszerüsített változatát jegyezte is meg.

A kápolna padlójának márványburkolatát Cristoffoli Giovanni Battista Forliból való olasz mester készítette. A falak márványozását Gigl Márton zágrábi mesterre bízták. A szobrok Robatz Augustin bécsi szobrász müterméből kerültek ki. ${ }^{270}$ Ami külön érdekessége, hogy a kápolnában nem nehéz felfedezni a szabadkőmüves jegyeket. Az oltár feletti szöveg a célnak kitünően kiválasztott bibliai sorok, a racionalizmust, az ész-kultuszt igenlik. Szent Zsófia alakja is kétséges, ha az egyház szentjei között keressük. A középkori folklór talajából serkent ki, történelmi hitele nincs, - jegyzi meg Bálint Sándor. ${ }^{271}$ Zsófiának a Bölcsesség anyjának három leánya volt: Fides (Hit), Spes (Remény), Charitas (Szeretet), alakjukat a hittudomány pártfogójaként tisztelik. A alakjaik veszik körül anyjukat a Bölcsességet. A legenda szerint Zsófia építette Konstantinápolyban a Bölcsesség templomát (Hagia Sophia), Rómában pedig tizennégy szentélyt emelt. Itt kell megemlítenünk azt a levelet, amelyet a szabadkőműves, vagy a szabadkőműves eszméket jól ismerő Csokonai küldött 1800. december 19-én, Debrecenből, Festeticsnek. Ennek utolsó bekezdésében olvasható: „Nem nem e' Világból való NAGYSÁGOD', nem e' puhalelkü 's alatsony módú emberek közül. -

\footnotetext{
${ }^{267}$ Ha bölcsességért esedezel, / és szívedet az okosságra hajtod, / akkor megérted az Úrnak félelmét / és az Istennek ismeretére jutsz.

${ }^{268}$ Nagyváthy K., é. n. 28.

${ }^{269}$ Berzsenyi ÖM, 1842. 92.

${ }^{270}$ Péczely, 1958. 33-35.8

${ }^{271}$ Vö: Bálint, 1977.
} 
A Sz: SOPHIA' Templomában látom én felszentelve NAGYSÁDAT; az Értelem' Mysteriumiba van béavatva; 's a' Köz-jó' oltárára halmazza a' tömjéneket, mellyeknek füstje az égig emelkedik 's az egész hazát elborítja illatjával..."272 Itt Csokonai egy hagyományos szabadkőműves szimbólumot említ, a Sophia, a „bölcsesség” kifejezést. ${ }^{273}$ Tehát a kor ismert szabadkőműves szimbóluma, a mozgalom nyelvi világában a beavatások során elnyert titkot jelöli, maga a név pedig a bölcsességet. ${ }^{274} \mathrm{~A}$ templom kifejezése pedig a maszonista páholyt jelenti. Talán nem rugaszkodunk el messze a valóságtól, ha azt feltételezzük, hogy a szabadkőmüves Festetics a Bölcsesség Istennőjét, Zsófiát helyezte el házi kápolnájának oltárán.

A kastélykertben elhelyezkedő Mulató Ház belső freskóit a Szent Domonkos rendi fráter Seraphinus „Pictor” 1793-ban készítette. Ugyancsak az ő munkája volt az akkori vendégfogadó (ma Amazon) biliárdszobájának freskója. Az angolparkot romantikus ízü gloriettel díszítették, a Georgikon kertjében (georgikoni fás kert) úgynevezett Békás tavat építettek, ebben tenyésztették a grófi konyhában elkészített teknősbékákat. A gróf 1798-ban elrendeli, hogy a tó közepébe „homokbul halmot, mint az illyes Békás Tavakban szokás készíttessen az Udvari Kasznár". ${ }^{275}$ Ugyancsak a georgikoni fás kertben készíttette el Festetics Keszthely eddig ismert legrégebbi szabadtéri színpadát, amelyen nemcsak vendégeit szórakoztatták pásztortánccal a Georgikon hallgatói, de a Helikoni ünnepségre érkező költők is minden bizonnyal itt szavalhatták el müveiket. ${ }^{276}$

\section{1. 2. Az első keszthelyi nyomda}

Keszthely fejlődését azonban az iskolák biztosították. A grófi Directio és az iskolák nyomdai igényét ki kellett elégíteni, de Keszthelyen ebben az időben erre nem volt lehetőség. A magyar könyvnyomtatás a XIX. század elején a múlt hagyományaihoz viszonyítva gyenge lábakon állt. Dunántúlon három nyomdász család dolgozott: Veszprémben Számmerék, Sopronban illetve Győrött a Streibig család, Szombathelyen a Siess család. Siess József 1776ban Szombathelyen telepedett le a szeminárium egyik földszinti helyiségében Szily János püspök jóvoltából. Sopronban fióknyomdát nyitott. Siess József halála után az örökösön a szombathelyi nyomdát átadták a soproni fiók vezetőjének Perger Ferencnek. Perger jó, ám

\footnotetext{
${ }^{272}$ Csokonai Lev, 1999. 108-109.

${ }^{273}$ Minden kétséget kizáró bizonyíték nincs Csokonai szabadkőműves voltáról, de az bizonyos, hogy nagyon jártas volt a szabadkőmüvességben. Vö: Jászberényi, 2000. 201-209.

${ }_{274}^{275}$ Ladó, 1982. 121.

275 Péczely, 1958. 38.

${ }^{276}$ Cséby, 2004. 137-147.
} 
olykor gyanús üzletekbe keveredő vállalkozó volt, aki szerette volna „,nyomdabirodalmát” bővíteni. Erre a legalkalmasabbnak Keszthely bizonyult, hiszen Festetics György neve és tevékenysége már az egész birodalomban ismert volt. Perger 1816. november 14-én megírta Festeticsnek, hogy szívesen nyitana nyomdát Keszthelyen és ehhez kéri a gróf támogatását, elsősorban egy házat, ahol a mühelyét berendezhetné. Festetics válasza pozitív volt és e célra felajánlotta, hogy „Keszthely fő utcájának nyugati oldalán fekvő nagy kertes uradalomi házat három évi használatra, évi nyolc forint bérért" Pergernek biztosítja. ${ }^{277}$ A költözésre 1817 tavaszán került volna sor, de a szombathelyi tüzvész miatt a nyomdász kocsit nem kapván a költözéssel késlekedett. A nyomda végül 1817. augusztus 7-én nyílt meg. Nemcsak Keszthely, de Zala megye első nyomdászaként tartjuk számon. Keszthelyi tartózkodása alatt olyan nyomdatermékeket állított elő, mint az 1817-es Helikonon elhangzott magyar nyelvü szépirodalmi munkák antológiája a Helikon I. (1818), Csondor János Gazdaságbéli számadó és számvevő tiszti utasitások... (1819) vagy Phaler Károly Jus Georgicum regni Hungariae et partium eidem adnexarum commentatus est (1820) címü munka két kötete. Sajnos azonban Perger kiadványai nem voltak igényesek, ami a sajtóhibákat illeti. Számos helyesírási hiba, betücsere jellemző nyomtatványaira. Festetics György halála után megritkultak Perger megbízatásai. Előbb Zalaegerszegre költözött, 1824-től visszaköltözött Szombathelyre, ahol az 1840-es évek végén halt meg. ${ }^{278}$ Keszthelyről való elutazását nem csak a mecénás gróf halála, de Perger összeférhetetlen, durva természete is minden bizonnyal elősegítette.

\section{1. 3. A kórház}

Keszthely első uradalmi kórházát Festetics Kristóf alapította 1759-ben. ${ }^{279}$ Minden bizonnyal saját „nyavajáinak” gyógyítását is célul tűzve ki. Erre enged következtetni fiának Pálnak 1751-ben Pozsonyból írt levele: „Hogy Uram Attyámrul az Nyavalának sullya el tért, minden lehető vigasztalásomnál legh nagyobb: hogy mindazonáltal az Nyavala gyökerébül curáltassék, méltóztassék Uram Attyám magát ide hozatni, az hol több és tudósabb orvosok vannak."280 A kórház 200 éves történetét feldolgozó munka helyét tévesen jelöli meg a mai Kastély utca keleti oldalának végén található 2 számú házban. A város új vízvezeték hálózatának kiépítésekor ugyanis feltárták az egykori kórház alapfalait, amelyek a kastélypark 1885-ös átalakításakor kerültek a parkot elkerülő országút burkolata alá. Ez az épület a

\footnotetext{
277 Az első keszthelyi typogrfiai mühelyröl lásd: Klempa, 1943. 3-6.

${ }^{278}$ Perger nyomdáját 1846-ban Bertalanffy Imre soproni nyomdász vásárolta meg. (Fülöp, 2010. 158.)

${ }^{279}$ Keszthelyi kórház történetét lásd: Péczely-Sági-Szutrély, é. n.

${ }^{280}$ Magyar Levelesk. I., 423. Festetics Pál Festetics Kristófnak, Pozsony, 1751. április 24.
} 
Kastély utca 2 számú ház északi szomszédépülete volt. Az első keszthelyi kórház kezdetleges volt, jobbára szegényházi funkciókat látott el, és orvos sem mindig állt rendelkezésre. Ennek a rossz orvosi ellátásnak esett áldozatul Festetics György testvérének Júliának első férje gróf Széchényi József, aki 1774-ben oly szerencsétlenül esett le lováról, hogy eltörte lábát és gyors orvosi beavatkozás hiányában meghalt. ${ }^{281}$ Gróf Széchényi Ferenc (Festetics Júlia második férje), József testvére, 20000 forintos alapítványt tett egy Keszthelyen felépítendő és az irgalmas rend vezetése alatt álló kórház céljaira. „Ez az alapítás tehát ezen eset helyéhez legyen kötve, hogy ama környék lakosságával a betegek ápolása tekintetében jobb gondoskodás történjék." - szögezi le a hospitály 1778. évi alapító tervében, utalva testvére balesetére is. ${ }^{282}$ Festetics Pál a maga részéről 19000 forintot ajánlott fel az építkezéshez. Elkészültek a tervrajzok, két változatban is. Az egyiket Franciscus Carl Rőmisch kamarai építész készítette, a másikat Rantz János György keszthelyi uradalmi építész. ${ }^{283}$ A kórház felállításához, mivel szerzetesrend vezette volna, pápai engedély kellett, amit a pápa Bajzáth József veszprémi püspökön keresztül meg is adott. Az úgynevezett misericordianus kórház építkezése el is kezdődött, de röviddel ezután, 1782. április 7-én meghalt Festetics Pál. Festetics György magára vállalta a kórház építésének folytatását, de azzal a kikötéssel, hogy az világi kezelés alatt álljon. A szerzetesrend szabályai ugyanis nem tették lehetővé női betegek, elmebajosok, fertőző nemi betegek felvételét. A tárgyalások nem vezettek eredményre és 1784-ben a Helytartótanács úgy döntött, hogy az alapítványt ugyanilyen célra, a Pápán lévő irgalmas rend kapja meg. ${ }^{284}$

\section{1. 4. A Fenéki Arzenál és a Phoenix}

A Festeticsek Keszthely melletti birtokukon, a Fenékpusztai majorátusukban (ma közigazgatásilag Keszthelyhez tartozik), az egykori római erőd területén megépítették a Balaton első hajóépítő mühelyét a Fenéki Arzenált. ${ }^{285}$ Fenék a magyar középkorban még lakott volt, az 1571-73-as összeírásban Keszthely mellett sorolják fel, mint önálló falut, melynek dűlőnevei: fenékwar, fenékben az war alatt, fenéki mező. A XVII. századtól

\footnotetext{
281 Halálának okát, körülményeit testvére Széchényi Ferenc 1778. évi keszthelyi kórházlapítási tervének dokumentációjából tudjuk meg. (Cséby-Sági, Kézirat)

${ }^{282}$ Czoma, 2003. 19.

${ }^{283}$ A kórház tervrajzát, kertjének tervét lásd: Koppány-Péczely-Sági, 1962. 47. ; 49.

${ }^{284}$ Koppány-Péczely-Sági, 1962. 48. ; A kórház utódja és épületének mai (2012) használója a Gróf Esterházy Kórház és Szakambulancia, Pápa, Jókai u. 5-9.

${ }^{285}$ A témával részletesen foglalkozik: Tóth, 1965. ; Sági, 1987. ; Cséby, 1996. ; Müller, 1996.
} 
puszta. $^{286}$ A hajóépítő műhely első nagy vitorlása a Christoph (Kristóf) gálya. ${ }^{287} \mathrm{Nem}$ tisztázott, hogy Festetics Kristóf, avagy fia Pál építette, arra viszont vannak adataink, hogy vízrebocsátása 1753. július 26-án történt. Elsősorban só szállítására használták. A Balatonvidék a sót Erdélyből, Máramarosból kapta. Átvételi helye Dunaföldvár volt, onnét szállították szekereken rendeltetési helyére. A só szállítása a kátyús, bakhátas, gödrös utakon hosszadalmas, vesződséges és költséges volt. A szállítás megkönnyítésére készült a Festeticsek első sószállítója a Kristóf. A hajót Kenesén rakták be és Keszthelyen pakolták ki. Ez egy darabig jó üzletnek bizonyult, ám 1792-ben a keszthelyi uradalmi igazgatóság azt javasolta Festetics Györgynek, hogy a hasznot nem igen hozó sószállítást adják bérbe. Erre az időre a gálya is olyannyira elöregedett, hogy ki kellett vonni a forgalomból. ${ }^{288}$

Festetics György 1792-ben úgy döntött, hogy új hajót építtet és erre megfelelő szakembert keresett. Az első eredménytelen keresés után az 1790-es évek közepén, sikerült megnyernie egy trieszti fiatal hajóácsot, az 1764-ban született Antonio Borrit, aki hajlandó volt Keszthelyre jönni és a gróf szolgálatába állni. 1796-ban a Kristóf gálya néhány megmaradt eleméből elkezdte az új hajó, a Phoenix megépítését, előtte azonban elkészítette annak tervrajzát. ${ }^{289}$ A hajó több mint egy esztendeig készült, amikor vízre bocsátották „számos Uraságok jelenlétében” 1797. július 16-án, ${ }^{290}$ hatalmas érdeklődés kísérte üzembe helyezését, annál is inkább, mert ugyanebben az évben nyitotta meg kapuit Keszthelyen a kontinens első agrár felsőoktatási intézménye a Georgikon is. Festetics annyira büszke volt hajójára, hogy névkártyáján is megjelenítette. A hajó később protokolláris célokat is szolgált, így Festetics György, majd később Festetics László is „meghajókáztatta” nevesebb vendégeit a Phoenixen. Mindezeken felül Festetics György a Phoenixszel „tengeri módú csatát” is eljátszatott. A „,csatában”, melynek ő maga is részese volt, jobbágyai katonának és matróznak öltözve vettek részt. ${ }^{291}$

A Phoenixnek irodalmi vonatkozása is van. A gálya oldalára Festetics verset kívánt vésetni. Ez alkalomból a grófot tisztelő költők több verset írtak, amelyeket Festetics elküldött az akkor Bécsben, Festetics László gróf nevelőjeként tevékenykedő Péteri Takáts Józsefnek, hogy mondjon róla véleményt. Péteri Takáts nem vállalta a minden kétséget kizáróan kényes feladatot, hanem a meglévőkhöz csatolta sajátját és recenzióra elküldte Batsányi Jánosnak, valamint Kultsár Istvánnak. Batsányi elolvasván a költeményeket, azokat megtoldotta

\footnotetext{
${ }^{286}$ Tóth, 1965. 15.

${ }^{287}$ Keszthely 1781-ben készített, és ma is használt címerének takaróján a Christoph gálya látható.

${ }^{288}$ Tóth, 1965. 27-28.

${ }^{289}$ A színezett tervrajz ma a Helikon Kastélymúzeum kiállításán, a nagy könyvtárteremben átható.

${ }^{290}$ Magyar Hírmondó, 1797. augusztus 1.

${ }^{291}$ Cséby, 1996. 50.
} 
sajátjával és visszaküldte Péteri Takátsnak. Nos a megküldött Batsányi vers Péteri Takáts versének átdolgozása volt. ${ }^{292}$

A Péteri Takáts vers a következőképpen hangzott, amelyet Bécsböl el is küldött Festeticsnek:

\author{
Az Idő nagy hatalmának \\ E' gálya is engedett; \\ De, mint Féniksz, az Urának \\ Szavára feléledett: \\ Magyar Földnek ditső Népe! \\ Serkenny, ébreszt a’ Köz-jó; \\ 'S boldog újúlásod' képe \\ Lészen, hidd el, e' Hajó;
}

(Péteri Takáts József: Azidő nagy hatalmának...)

Ehhez a vershez még három másik variációt is csatolt. Valószínűleg valamennyi Péteri Takáts munkája, erre engednek következtetni a konzekvensen ismétlődő szavak, valamint a grófnak írt sorok: „a’ Só Hajóra készült versek szerint némelly változtatásokkal készítettem egy két példát.”

1.

Fel-éledt e’ Hajó, mint Fémiksz hamvából:

Bízz Magyar! Hazánk is ki kél homályából,

'S hajdani szép Neved tisztább fényben ragyog,

Ha az ész, jó szándék, szorgalom kezet fog.

2.

Nézd Magyar e' gállyát! Mint Féniksz' hamva fel éledt:

A' Tudomány, 's egy Szív Téged is újra teremt.

\footnotetext{
${ }^{292}$ Cséby, 1992. 94. Péteri Takáts és Batsányi rossz viszonyát is minden bizonnyal erre a történetre tudjuk
} visszavezetni. 
3.

Ím e’ gállya ki kélt, mint Féniksz régi porából:

Hidd Magyar! A’ Tudomány hajdani fényre vezet. ${ }^{293}$

Péteri Takátsot úgy tünik nagyon foglalkoztatta a hajó oldalára vésendő vers. Ugyanis a fenti levél megírását követő harmadik napon ismét írt a grófnak, figyelmébe ajánlva újabb vers-variációját:

Ezen Hajót a' nagy Idő el rontotta,

De a' jámbor szándék ím fel támasztotta:

Vajha! Kár', szorgalom', új élet' példáját

Látván itt a’ Magyar, visgálná Hazáját! ${ }^{294}$

Tóth Lajos szerint a következő vers is Péteri Takáts munkája. ${ }^{295}$ Keresztury és Tarnai viszont rámutat Batsányi kritikai kiadásában, hogy az alábbi vers Péteri Takács versének Batsányi általi átigazítása. Ezt a tényt támasztja alá Péteri Takáts József gróf Festetics Györgynek írt levelében. ${ }^{296}$

A’ mindent elrontó Idő hatalmának

Már egyszer én is engedek.

De Hazája’ hasznát kereső Urának

Szavára megint fel-éledek:

Serkenny te is, Magyar Földnek ditső Népe!

Légyen ez éltednek példát-adó képe! ${ }^{297}$

Batsányi, miután megküldte változatát Péteri Takátsnak még tovább dolgozott a versen. Elkészítette annak saját változatát. Egy levél kíséretében - kihagyva Péteri Takátsot -

\footnotetext{
293 Péteri Takáts József levele Festetics Györgynek. Bécs, 1797. március 4. MOL. Fest. Lvt. P 27911 cs. 1797:324. Közli: Stohl, 2009. 219-220.

${ }^{294}$ Péteri Takáts József levele Festetics Györgynek. Bécs, 1797. március 7. MOL Fest. Lvt. P 279 11. cs. 1797:279. Közli: Stohl, 2009. 220-221.

${ }^{295}$ Tóth, 1965. 36.

296 Péteri Takáts József levele Festetics Györgyhöz. Bécs, 1797. március 13. MOL Fest. Lvt. P 27911 cs. 1797:313. Közli: Stohl, 2009. 221-222.

${ }^{297}$ Tóth, 1965. 36. ; Batsányi ÖM. I., 1953. 397-398. ; Stohl, 2009. 221-222.
} 
közvetlenül a grófnak küldte meg, a Batsányi kritikai kiadás szerint talán azért, mert már nem volt lehetősége Péteri Takátscsal találkoznia: ${ }^{299}$

„Méltóságos Gróf Úr! A’ magyar tengeri hajóra írandó versnek thémáját közölvén velem Takáts Úr, által- adtam néki a’ minap hat sort, mellyet akkori első ideám szerént tsináltam volt. Azutánn változtatást tettem rajta és íme, most magam udvarlok vele Nagyságodnak: - hozzá adván még egy mást - ugyan-annyi sorból álló inseriptiót is mellyet talán a’ hajónak másik felére lehetne vágattani, Horatius' annak isméretes mondásának mint egygy ellenére: - Nequidquam Deus abscidit prudens Oceano dissociabili terras, si tamen impia non tangenda rates transiliunt vada! - Azonban: akár találtassanak méltóknak ezen két féle versetskék a' ki-vágatásra, akár nem: legalább könnyebb lészen választani eggyet kettőt a’ sok közül. Méltóztassék úgy fogadni tsekély rendetskéimet úgy fogadni Nagyságod, mint némünémü kis jeleit azon mélly tiszteletnek, a' mellyel vagyok Méltóságos Gróf Úr Nagyságodnak alázatos szolgája: Batsányi Bécs 10-dik Mart. 797.

\section{Féniksz}

A’ mindent elrontó Idő hatalmának

Már egyszer e’ Hajó-is engedett.

De, szeretett Hazánk’ egygyik hív Fijának

Szavára, most megint feléledett.

Nézz e’ kis példára, Magyar Föld' nagy Népe!

Ez lehet (tsak akard!) új életed' képe.

Igaz, hogy ezer veszély köztt fordúl-meg életünk,

Szerentsét keresvén, vizenn és szárazonn;

Azonba', fáradság nélkül nem élhetünk!

S' tsak-ugyan el-ér a Halál, vagy ezenn, vagy azonn. -

Munkával kelnek-fel Emberek, Országok;

E’ nélkül nints nevek, nints állandóságok. ${ }^{300}$

E vers második versszakának van egy másik változata, amelyet Batsányi hagyatékában, valószínűleg egy 1790-es évek végéről származó papírdarabkán találtak:

\footnotetext{
${ }^{299}$ Batsányi ÖM. I. 398.

${ }^{300}$ MOL Fest. Lvt. P 279 1797:314 ; A Batsányi, 1980. kiadásban ez a vers nem szerepel.
} 
Ezer veszélyek közt fordul meg életünk

Szerencsét keresvén vizen és szárazon.

De gond és baj nélkül nem élhetünk;

S csakugyan feltalál

És elér a Halál

Egykor mindnyájunkat vagy ezen vagy azon.

Munkával kelnek fel emberek országok;

Enélkül nincs nevek, nincs állandóságok. ${ }^{301}$

Ne tudható, hogy Batsányi írt-e bírálatot a versekről, elképzelhető, hogy véleményét csupán szóban mondta el Péteri Takátsnak, aki a kritikákat továbbította Festeticsnek. ${ }^{302}$

Batsányi János ezeket az első variációkat alakította verssé, amelyet kéziratos versgyüjteményébe is beemelt. Az átalakítás folyamán a tömör, epigrammatikus inscriptioszöveg tágasabb üdvözlő költemény kerekedett ${ }^{303}$ :

\section{A keszthelyi hajóra}

A’ mindent elrontó Idő' hatalmának

Már eggyszer e’ Hajó-is engedett...

De köz jóra termett jeles nagy urának

Szavára még eggyszer feléledett;

'S bár néha e' gyakran háborgó tengernek

Hullámi majd eget, majd poklot vernek, -

Megvetvén a' szelek' mérges ostromait,

Bátorsággal járja kiszabott úttyait.

Áldgyák Somogy’s Szala’ megörültt vidéki,

'S állandóbb szerentsét óhajtanak néki.

\footnotetext{
${ }^{301}$ Batsányi ÖM.I., 1953. 398 ; A Batsányi 1980. kiadásban ez a vers sem szerepel. A kritikai kiadás szerint a feltalálás helye: MTA. - M. Irod. R. u. i. $2^{\circ} 18.8$.

302 Batsányi ÖM.I., 1953. 397.

${ }^{303}$ Batsányi ÖM. I., 1953. 398.
} 
Áldom, 's dicsőíttem én is! ’s örömemet

Zengvén, homlokára függesztem versemet:

„Nézz e’ kis példára, Magyar Föld’ nagy Népe!

Ez lehet még a' Te újúlásod' képe.

Két Leopold után a' mi még elhaladt,

Végbe megy nem soká' Ferentz 's József alatt.

Bízván kormányzójid' bölts intézetében,

Remélly! ’s erőlködgyél e' szélvész' dühében,

Hogy, el nem tsüggedvén bajod' tengerében,

A’ köz boldogságnak kiköthess révében! ${ }^{304}$

Kultsár kétoldalas recenzióját küldte vissza, amelyben valamennyi kételyét célirányosan, minden kertelés nélkül tíz pontban sorolta fel. ${ }^{305}$

„I. Fénix madár története Mese. Nem illik a valóság példázattyára. Régi setétséget jelentene illy világos században. De helytelenül is van alkalmaztatva; nem tsak a Fenix, hanem a Cornix is elvénhedik.

II. Nem a vénhedésből: hanem a porból elevenedik fel, a monda szerént, a fenix madár. Különben is élö dolognak kell lenni, melly meghallyon; megholtnak, melly megelevenedjék. Már pedig a Töredék se élt, se halt.

III. Annyi költségbe került e gállya, hogy ujj tsinálmánynak mondathatik: de talán igen kevés része is az, melly a töredékből vétetik. Mi szükség tehát a töredékek emlegetésével ezt a Nagy tehetségü Méltóság munkáját kissebbíteni?

IV. Szeretném tudni,mért bús a Magyar. Semmi sints ok nélkül. Talán ugyan valami halottat néz, vagy a maga sirját?

V. Tsúfos vigasztalás, mellyet a lehetség nyújt. Tehát felkelhetünk hamvainkból? de mikor? ha a Sas tüzet gyújt? vagy mivel már gyújt? Adja Isten! hogy el se égjünk, hogysem a lehetséges felkelhetés által vigasztalódjunk meg.

VI. A Sas gyújt? honnét veszi? Fenixnek a Febus szokott gyújtani. Hogy repül oda, hogyan lop a Febustól a Sas tüzet? Nem kívánom, hogy illyen tủznél melegedhessem. Talán úgy is nagyot gyújtott. Bár fel ne persellyen. - - - már a Szomszéd ég ${ }^{306}$.

\footnotetext{
${ }^{304}$ Batsányi, 1980. 99-100.

${ }^{305}$ MOL Fest. Lvt. P 279. 11 cs. 70. Közli: Stohl, 2009. 222-223 (MOL Fest. Lvt. P 279. 11 cs. 1797:315)
} 
VII. Üszke nem Magyar szó. Ha üszögét vészi az oltárról, vigyázzon, hogy szentség törést ne kövessen el. De ha szerentséssen gyujtana is tüzet, és hamvainkból felkeltetne, az egész ditsöség, melly onnét következik, a Sasra, és Febusra térül. Mi módon illik ez a gállyára? Inkább illenék a Bétsi Züwigra. Hová marad a Hajó Alkotójának érdeme?

VIII. A Fészek, egy Ország helyett, igen tsekély, 's alávaló szó.

IX. Mi köze a hajóhoz a hármas halomnak? Nem illenék é inkább a 4. vizektől venni hasonlatosságot. Ezen Allegoria homályos, és idegen.

X. Halomja tsigázott szószármaztatás,vagy hajlatás. Kelendőbb, ’s törvényessebb halma: hatsak a maga álomját nem akarja nekünk valóságúl fitogtatni a Szerző.

Mivel pedig az Ur olly hizelkedve reám bitangolta a Poeta nevet, egy két példát ide irok, mellyből kitessék melly keveset tehetek. Az első vers, a ketteje tsak azok számára való, kiknek a Jómód sem akadnak torkokon:

I.

Álmélkodsz Vendég? Ne tsudáld tág Öblömet égig

Felnyúlt árbotzomat, sürü kötelekre akasztott

Gyenge vitorlámat: de tsudáld, hogy szíve Uramnak

Akkor örül, hasznát 's díszét ha segíti Hazádnak.

II.

Balaton vizének e gállya hírére,

Terhe van gállyának megkedvellésére:

Ha vizre ditsőség, áldás a gállyára;

Mi fér ez alkotmány’ Nagy lelkü Urára?

III.

E Tóban úszkálván tengert mutogatok.

Magyar szájba jó ízt terhemmel hozhatok.

Ritka tekéntetem méltó ditséretre.

Hasznom a Nemzetnél örök köszönetre.

Kultsár"

Averset követően Kultsár még három sort írt, azonban ezeket oly vastagon húzta át tintával, hogy teljes mértékben olvashatatlanok.

\footnotetext{
${ }^{306}$ Az eredeti kéziratban maga Kultsár írt három vonalat - - -, minden egyéb magyarázat nélkül. Szerintünk gondolatjelként értelmezendő.
} 
Nem tudható, hogy a kritika tulajdonképpen melyik versekre, kinek a verseire vonatkozik, elképzelhető, hogy egy versről van csupán szó. Azt tudjuk, hogy a Phoenix nevet, amit Kultsár erőteljesen kritika alá vont, némely források szerint Péteri Takáts József találta ki. $^{307}$ A névhez viszont Festetics ragaszkodott, talán két okból is. Ugyanis a gróf lánya, Szidónia (később Almássy Illés gróf felesége), a gályára indulót szerzett, és ennek a következö címet adta: „,March für den Phönix auf dem Balaton verfast für das Clavier und gewidmet Ihrem verehrungswürdigen Vater Grafen Georg Festetits von Tolna von Seiner

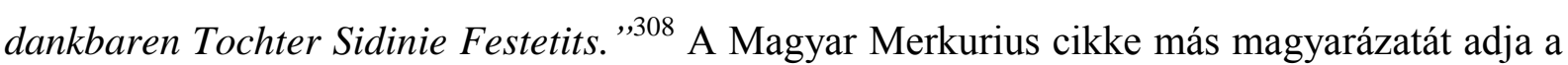
Phoenix névnek. Szerinte Festetics a nála vendégként megforduló nádor iránti udvariasságból - a föherceg testvérének tüzhalállal történő pusztulása emlékére - keresztelte el a tüzböl, a hamvából megelevenedő madárról. ${ }^{309}$ Itt kell megemlítenünk, hogy a hajó Phoenixként sohasem szerepelt a jószágkormányzóság hivatalos protokollumaiban csupán „sóhajó”-ként említették. Még a hajó keresztelése alkalmából is csak ennyit jegyeztek be: „A keszthelyi sós Hajónak lett megszenteltetése". 310

Baróti Szabó Dávid is elküldte versét Péteri Takáts Józsefnek „A vitorlás hajójú Balaton"-ról. A vers szerint, amikor Neptun meglátja a Phoenixet örvendezve csapja össze kezét,” így a tó híre megnő. A Balaton már akkor is létezett, amikor „még nem volt magyar”, ám Festeticset várta az idő...

Látván a gállyát a Balatonra felülni

Neptún, örvendő két kezeit öszvecsapá.

Már, úgy mond, felvészi magát neve, híre vizemnek;

Már Magyarországnak tengere fényre kelend.

Már az hamis panaszok megszünnek: hogy olly sok üdőkig

Mértföldekre terül, mégpedig hasztalanul...

Úgy van, hamis panaszok: mert jók a tengerek, ámbár

Nem tud az agg restség élni haszonra velek.

Szoktál-e járni kaszák, sarlók a víznek alatta?

S ez meg nem lévén, a vizek hasztalanok?...

Nézd most a Balatont: melly szörnyü terheket hordoz!

Sík hátára miként illik az újdon hajó!...

\footnotetext{
${ }^{307}$ Tóth, 1965. 36.

${ }^{308}$ Cséby, 1996. 250

${ }^{309}$ Magyar Merkurius, 1797. július 17.

${ }^{310}$ Tóth, 1965. 37.
} 
Már ökröd, szekered, lovad, el nem vesznek az útban:

E tenger s ez hajó terheid elviseli...

Még nem vólt magyar, és e víz már itt vala: nem vólt

Haszna, mivel nem vólt, akivel ossza javát...

Festetitset várták az üdők. Ez végire hajtá,

Amivel eddigelé más nem is álmodozott.

Nyújtsd hátad Balaton, s úgy vedd mindenkor hajóját,

Mintha hajójával Festetics ülne reád. ${ }^{311}$

Vajon Virág Benedek az „Egy hajóhoz” című költeményét a Phoenix költői versenyre írta? A már előbb többször említett Batsányi kritikai kiadásban nem szerepel Virág neve, őt Sági Károly hozza össze a Phoenix gályával egyik, a Balaton irodalmáról szóló dolgozatában. $^{312}$ A költő lelki szemei elött már látja a szélnek feszülő vitorlákat, de megborzong a vihartól, amelynek háborgásától óvja a nagyszerü alkotmányt. Ami feltünő a versben, hogy nem említi Festeticset, ez okoz némi fejtörést a vers születésére vonatkozóan:

Sok szélvészid után tégedet, oh Hajó!

A tenger közepén járni fel és alá

Látlak: büszke vitorlád

Bátran nézi dagályait,

S nem tart kárhozatos háborodásitól.

Mert csendes Zefired szárnyai közt forogsz,

Napról napra reményed

Édessége nevelkedik.

Erdők ritka, magas szála, visellyenek

Gondot szüntelenül rád az Egek! S veled

Járván régi szerencséd,

Kívánt révedet el ne vétsd.

Mégis rettegek én. Nincsen az ég alatt

\footnotetext{
311 Baróti Szabó, 1802. II. 41.

312 Sági, 1974. 417.
} 
Állandó dolog: a Nap hamar elborúl:

Jö egy fergeteg, amelly

Ránk bút mennydörög és halált.

A tündér szigetek szirteid ismered;

Parthoz tartsd magadat, mint lehet. Életed

Táplál engem is; élek

Míg élsz; hogyha nem: elhalok. ${ }^{313}$

Süle Sándor hívja fel a figyelmet, hogy kisszántói Pethe Ferenc is írt a Phoenix oldalára szánt verset. Öt epigramma-szerü versében, saját életének gondolatait pendíti meg, amelyek utalnak a „porából megelevenedett” hajóra is.

Engem az ész fel-szült: így jársz Magyar! akiben a nem hült

Vér pezseg. - Egy akarat széltire gyöngyöt arat.

Ész, gond, szív, kedv, adták vissza életemet;

Reménylhetsz Hazafi! tsak nézd a nevemet.

A szorgalmatosság, jó szív eggyetértés,

Nagyra törekedés nem Isten-kísértés.

A szorgalmatos ész adott új életet

Belém...

A szorgalmatos ész, jó szív, ujj életem

Eszköze, nézd Magyar!... ${ }^{314}$

A többi költő is sietett elküldeni versét, de a kutatások még nem találtak arra vonatkozó adatot, hogy a hajóra oldalára véstek-e verset, s ha igen, melyiket. Sajnos a Phoenix versíró versenyre beküldött versek elvesztek, így hitelt érdemlően a versengő költők névsorát nincs lehetőségünk megismerni. Müller Róbert szerint az 1950-es évek elején még

\footnotetext{
${ }^{313}$ Virág, 1980. 37-38.

${ }^{314}$ Süle, 1964. 81-82.
} 
megvoltak a Batsányi hagyatékban, a MTA Kézirattárában, Kultsár bírálatával együtt. Valószínüleg Tóth Lajos még ismerhette azokat. ${ }^{315}$ Batsányi János összes műveinek kritikai kiadása kapcsán - esetleg később - emelték ki a csomagot, ami azóta elveszett, vagy lappang. ${ }^{316}$

A Phoenixre Csokonai Vitéz Mihály is utal a „Mélt. Gróf Festetics György Ngyságára. A’Hadi Oskoláról” címü versében. Festetics Györgyröl szólva írja:

\section{Ö, a’ ki földünk’ Pontusa' habjait}

Törvényre húzá, száz lehetetlenen

Tett, ’s tesz csudát: ő mér fuvallni

Lélekerőt az inas Magyarba. $^{317}$

Csokonai mint annyi versében ebben az ódában is tesz lábjegyzeteket. A Pontusa magyarázatát így adja meg: „Ama’ tengeri módú Gályával, melly a’ Balatonon zajjait neveti”. Nem érthetünk teljesen egyet Vargha Balázs „Miért remekmü és miért nem az?” címü tanulmányában foglaltakkal, ahol azt állítja, hogy kínosak az ódába foglalt információk, s itt kitér az egyikre, miszerint „Festetics tengeri módú gályát építtetett Keszthelyen”. ${ }^{318}$ Ha kissé túloz is Csokonai, azért a Phoenix, Festetics gályája tekintélyes hajó volt a korabeli Balatonon. (Mind a mai napig a legnagyobb balatoni vitorlásként tartjuk számon.) Richard Bright, a Festeticset meglátogató angol orvos-utazó, aki szintén megcsodálta, könyvében így írt: „A hajót a gróf az ő fregattjának nevezi, mert a legnagyobb és alighanem az egyetlen vitorláshajó ezen az édesvizü tavon. Nagy, egyárbócos és hol kirándulásra, hol meg teherszállításra használják...”. 319

\footnotetext{
${ }^{315}$ Müller, 1996. VII ; Ugyanakkor meg kell jegyezni, hogy a Kultsár recenziónak, több mint valószínű Kultsár saját kezével írt piszkozata, megtalálható a Magyar Országos Levéltárban.

${ }^{316}$ Müller Róbert szíves szóbeli közlése. Ezt feltevést erösíti meg, hogy a kritikai kiadásban a következő mondat került: „A MTA kézirattárában megtaláltuk a keszthelyi hajóra szánt feliratok egész gyüjteményét (M. Irod. Lev. $4^{\circ}$ 127.) köztük Takátsnak azt a versét is, amelyet B(atsányi) átírt.” (Batsányi ÖM. I., 1953. 398.) A MTA Kézirattárában érdeklődésemre Tóth Gábor a következő levelet küldte: 1.) Batsányi kritikai kiadás 398. oldalán közölt hivatkozások pontatlanok: a M. Irod Lev. 4r 127-es doboz Kisfaludy Sándorral kapcsolatos anyagot tartalmaz. Ennek D, jelzetủ palliumában (M. Irod. Lev. 4r 127/D) volt Takáts József verse, amit Batsányi átírt. Adataink szerint a Takáts-verset (tehát nem Batsányi verset) tartalmazó D. pallium 1976 óta lappang. 2.) A kritikai kiadásban hivatkozott másik jelzet (RUI 2r 18/8) minden bizonnyal téves hivatkozás: Ezen a számon Podhradszky József történeti jellegü és vegyes jelzetei találhatók, Batsányi kézirat soha nem volt köztük, így a Phoenix-vers sem. 3.) A kritikai kiadás 399. oldalán közöltek szerint a kiadás alapjául szolgáló kézirat a Keszthelyi Helikon Könyvtárban van. (Ezúton köszönöm Tóth Gábor szíves segítségét.)

${ }^{317}$ Csokonai ÖM, 2002. 175.

${ }^{318}$ Vargha, 1984. 310.

${ }^{319}$ Bright, 1935. 55.
} 


\section{1. 5. Hévízfürdő kialakulásának kezdetei}

Festetics György rakta le a hévízi gyógyfürdőkultúra alapjait. ${ }^{320}$ A hévízi tó neve a XVIII. században Keszthelyi Bozót, a gondozatlan, elmocsarasodott területen a víztükör szinte megközelíthetetlen volt. Bél Mátyás, aki Festetics Kristóf vendégeként tartózkodott Somogyban és Zalában, volt a hévízi forrás első részletes leírója. 1734-ben a következőket jegyzi fel: „Vize pedig savas és gyógyító hatású, éppen ezért régebben fürdőházat is építettek melléje, amelyben vizét tüzzel is melegítették és így sok embernek adott módot fürdésre. De miután az épület összeomlott már többé nem használják". 321

Az első tudományos leírást Zala vármegye orvosa dr. Szláby Ferenc tette 1769. június 24-én. ${ }^{322}$ 1790-től Festetics folyamatosan foglalkozik azzal, hogy a hévízi tó fürödhetővé tétele érdekében mit kell tenni. A Directio számos javaslattal él. Elöször is a területet kell megtisztítani, utakat építeni, majd ezt követheti fürdőházak állítása. ${ }^{323}$ Szaller György földmérő és vízépítő mester a helyszíni szemlét követően írja: „Itt a Hévíz pataknak kénkő szaga érzik, orvosságul szolgál sok nyavalyában”. ${ }^{324}$ Fontossá vált majdani fürdő propagálása. Erre dr. Babocsay (Babochay) József vállalkozott, amikor megírta „Boldog Zala vármegye! Keszthelyi Hév-vizedröl méltán neveztetel így attól a' ki ezen rendeket írta ditséretedre" címü, huszonnyolc oldalas munkáját, amit Sopronban Siess (Sziesz) Klára betűivel adtak ki 1795-ben. A direktóriumi jegyzőkönyv 1795. október 7-ei bejegyzése tartalmazza, hogy Festetics György levélben tudatta Hertelendy főbíróval; „az ő hathatós gyámolyítása által annyira jött a Keszthelyi Hév-vízi feredőnek állapotja, hogy Baboltsai (sic!) József Kanisai Doctornak Dissertatioja szerént is reménység van a további jó successushoz". ${ }^{325} \mathrm{Az}$ sem véletlen, hogy ez idő tájt új fürdőház épült. 1795 körül Rantz János György keszthelyi uradalmi építész terve, amit Szláby megyei főorvos is láttamozott, a fürdő egy kupola boltozattal fedett középtár körül négy-négy csehsüveg boltozatos szobácskát tüntet fel. A szobákat cserépkályha fütené, az előtérbe kerek fürdőmedencét tervezett Rantz, amelyet lépcsőzetesen alakított ki. Ez az időjárástól függetlenített fürdőház ${ }^{326}$ úttörő jellegű lehetett a maga korában, de természetesen a magas díjakat csakis a jómódúak tudták megfizetni ${ }^{327}$ Két év múlva lacikonyhát építettek a fürdöházhoz. 1797. október 13-án Festetics György a

\footnotetext{
${ }^{320}$ Erről részletesen: Zákonyi, 1974. ; Szántó, 1977-1980. ; újabban Szántó Endre és Szarka Lajos.

${ }^{321}$ Bél, 1943. 270. Idézi: Görgényi-Péczely-Sági, 1957. 216.

322 Zákonyi, 1974. 23-24.

${ }^{323}$ Zákonyi, 1974. 40-77.

${ }^{324}$ Eredeti közlés: Bal. Sz., 1943. 329. Idézi: Görgényi-Péczely-Sági, 1957. 217.

${ }^{325}$ MOL. Fest. Lvt. P 279. 7. 983. Idézi: Szántó, 1977. 159

${ }^{326}$ A ma rendkívül divatos ,élményfürdő” őse.

${ }^{327}$ Görgényi-Péczely-Sági, 1957. 217-219
} 
következőket rendelte el: „A fürdőháznál az kiadott Abrisz szerint közönséges emberek számára Latzi konyhája elkészítteteik, hogy tisztességesebb embereknek ne alkalmatlankodjanak". ${ }^{328}$

Hévíz gyógyhatású fürdőjét újságban először Gutten József keszthelyi orvosdoktor hirdette meg. ${ }^{329}$

Hévíz minden fejlesztés ellenére még a XIX. század elején is jobbára parasztfürdőhely volt, de Festetics György halálával minden fejlesztés leállt és hosszú évtizedekre megakadt a ma már neves fürdőhely fejlödése.

\section{2. Gróf Festetics György iskolái}

Az 1781-ben kibocsátott Edictum tolerantiae lehetővé tette, hogy protestáns és görögkeleti iskolák is alapíthatók legyenek a birodalomban. 1785-töl bárhol állíthattak iskolát, és az alsó-és középfokú oktatás megváltoztatása az egyetem átalakítását is szükségessé tette. Az 1777-ben Nagyszombatról Budára helyezett Egyetem új karokkal bővült, 1782-ben a mérnöki, 1784-ben az állatorvosi képzés is beindult. Az oktatás fejlődésének is szerepe volt abban, hogy II. József uralkodásának végére már mintegy húszezerre lehetett becsülni az értelmiségiek számát. Az értelmiség kialakulásához döntően járult hozzá a szabadkőművesség is. Csökkent a tiltott nyomdatermékek listája, nőtt a nyomdák száma. Számos fönemes, köznemes ajánlotta fel gyüjteményét a közönségnek (Teleki, Széchényi, a zalai Skublics Károly). ${ }^{330}$ Kezdett kialakulni egy jól körvonalazódó új réteg, a honorácior értelmiség. Mindezek ismeretében értékelhetjük a Festetics családnak és elsősorban Festetics Györgynek az iskolateremtés és iskolafenntartás területén tett erőfeszítéseit. Ennek számbavétele, megismerése újabb adalékkal szolgálhat gróf Festetics György müvelődésünk történetében elfoglalt helyére. ${ }^{331}$ Festetics iskoláinak vizsgálatakor azonban nem téveszthetjük szem elől Mária Terézia Ratio Educationisát, amelyik rendelet minden iskolát, elemit és magasabb szintűt is, akár egyházi, akár magánszemély tulajdonában müködött, állami felügyelet alá helyeztetett. Az iskolák müködéséről félévenként jelentést adtak a föigazgatók a

\footnotetext{
${ }^{328}$ MOL. Fest. Lvt. P 279. 1124. Idézi: Görgényi-Péczely-Sági, 1957. 217.

${ }^{329}$ Cséby, 1993. 43-48.

${ }^{330}$ Kósa, 1998. 334-336.

331 Festetics oktatással kapcsolatos tevékenységét a korabeli sajtó is elismerte. Erről részletesebben: Fehér Katalin: Festetics György oktatásügyi tevékenysége a korabeli sajtó tükrében. (Magyar Pedagógia 97. évf. 1. sz. 61-77) Másodközlés: Festetics emlékkötet. Georgikon kiskönyvtár 5. Keszthely, 1997. 7-38.
} 
Helytartótanácsnak. $^{332}$ Festetics valamennyi iskolája természetszerüleg igazodott a rendelethez s ennek tudatában kell vizsgálnunk az iskolák (elsősorban a keszthelyi gimnázium) érdekében váltott számos levelet, amelyre az iskola tárgyalásánál térünk ki.

Festetics fáradhatatlanul foglalkozott és törődött az ifjúság nevelésével. A felvilágosodás „hasznossági elve” figyelhető meg Festetics György iskolapolitikájának hátterében. Erre következtethetünk akkor is, amikor soproni alapítását vesszük figyelembe. Festetics több házzal rendelkezett Sopronban. Az egyikben internátust alapított. De másképpen is támogatta a soproni ifjúságot - hívja fel figyelmünket Péczely Piroska. ${ }^{333}$ Ugyanis, amikor 1790-ben a soproni líceum a költészet iránt érdeklődő fiataljai önképzőkört alapítottak Magyar Társaság néven, Festetics 180 forintos alapítványt tett célkitüzéseik megvalósítása érdekében. Nem véletlen tehát, hogy midőn az 1803-as májusi országos vásáron megpillantották a grófot, Döbrentei Gábor tagtársuk (a későbbi akadémiai titkár, író) javaslatára örömöünnepet rögtönöztek mecénásuk tiszteletére. Festetics meghatódott és még 60 forinttal megtoldotta alapítványát. ${ }^{334}$ A Magyar Társaság költőinek több versét megőrizte a Festeticsek könyvtára, ezek ma is megtalálhatóak. ${ }^{335}$ Jobbára gyengécske munkáról van szó, de tagadhatatlan az is, hogy a társaságból több neves írónk is kikerült. Az említett Döbrentein kívül Kis János, Bárány Boldizsár, Pákh Albert és mások. ${ }^{336}$

Festetics idejében már annyi diák gyült össze Keszthelyen, hogy elhelyezésük gondot okozott, ezért csak olyanoknak adott el a városban házhelyet, akik kötelezték magukat, hogy diákok számára szobát építenek. A szegény sorsú, kiváló előmenetelü tanulóknak saját kastélyában adott szállást és a lehető legteljesebben el is látta őket. Birtokain kötelezővé tette, hogy mindenki tudjon írni és olvasni. Ez az alapja annak az egykori szállóigének, amely szerint Festeticsnél a mezőkön a pásztor könyvvel a kezében őrzi a nyájat. ${ }^{337}$

Keszthelyen 1800-ban Festetics György jóvoltából, segítségével, hét iskola müködött:

3 osztályú elemi iskola,

polgári iskola,

zeneiskola,

rajziskola,

tanítóképző,

\footnotetext{
332 Sági, 1967. 333.

${ }^{333}$ Péczely, 1963. 278

334 Péczely, 1963. 278 ; Részletesen lásd: Kovács Sándor: A soproni ev. lyceumi Magyar Társaság Története 1790-1890. (reprint) Bp. Históriaantik Könyvkiadó, 2012 (eredeti megjelenés dátuma: 1890)

${ }^{335}$ HK Lit. hung. 607 ; HK Lit. hung. 608 ; HK Lit. hung. 361

${ }^{336}$ Péczely, 1963. 278

${ }^{337}$ Koppány-Péczeli-Sági, 1962. 57.
} 
gimnázium a nemesi konviktussal,

Georgikon.

Keszthely szempontjából rendkívül fontos és meghatározó a szerepük, hisz a város fejlődését, a városias környezet kialakítását, nagymértékben ennek köszönheti.

\section{2. 1. Keszthelyi elemi- és középiskolák}

Az elemi iskola eredete legalább 1247-re vezethető vissza. Az iskola épülete a Szent Márton templom közelében állott és benne helyezkedett el a kántortanító lakása is. Az iskola körzetéhez tartoztak a Polgárváros, ${ }^{338}$ valamint Györök ${ }^{339}$ kivételével a környező hegyközségek. A Ratio Educationis kapcsán új, nemzeti iskolát kellett felépíteni, amelyik legalább 3 teremből állt és 60-60 gyerek befogadására volt alkalmas. Festetics Pál gróf a nemzeti iskola szükséges tantermeiről, felszerelésükről, a tanító lakásáról, tüzelőjéről. ${ }^{340}$ az iskola müködéséről az 1780. szeptember 1-jén kelt alapító oklevélben intézkedett. ${ }^{341}$ Festetics György 150 forinttal emelte meg a kántortanító fizetését. 1799-ben Festetics 400 forintos alapítványt tett arra a célra, hogy a keszthelyi nemzeti iskolában egy tanítót tartsanak a rajz tanítására, kettőt pedig a tanítók képzésére, akiknek lakásáról az alapító maga gondoskodott. $^{342}$

1790 után Festetics falusi iskolákat létesített birtokain. Ezek az iskolák jobbágyai szellemi szintjét emelték, az értelmesebb munkásra azonban a francia háborúk konjunktúráját élvező nagybirtoknak is szüksége volt. Tulajdonképpen ebből a meggondolásból alapította

\footnotetext{
${ }^{338}$ Polgárváros, később Kiskeszthely, 1929-től Keszthely közigazgatási területe.

${ }^{339}$ Balatongyörök

340 A tanító fizetését és egyéb járandóságát a nemeseknek, nem nemeseknek, polgároknak, egyszóval mindenkinek állnia kellett, felekezetre való tekintet nélkül. A későbbiekben úgy tűnik, hogy a nemesek vonakodtak a rájuk eső részt kifizetni, ezért a Pécsett székelő ivánkai Vitéz Imre a nemzeti iskolák főigazgatója dörgedelmes levélben fordult hozzájuk 1798. október 19-én: „Nemes és vitézlő urak! (...) A közjó iránt való buzgóságunkat, hazaszeretetünket drága magzatjaik földi és örök boldogságáról való gondoskodásukat kétségbe vonni nem akarom. Vakmerő megbántása lenne ez, az urakkal vele született nemességnek. Amiért nem is bizonyítgatom, hogy az illendőség és igazságosság hozza magával, miszerint az urak is fölös jövedelmeikből, nem mint a nemesi szabadsággal ellenkező adóval, hanem olyan jótéteménnyel, melyről eleink határt nem ismerő jótevő szíve megfeledkezett, járuljanak annak az iskolának fenntartási költségeihez, mely a felső iskolának talpköve, s melyböl nemcsak az adózó nép, mely e végre tetemes áldozatot hozott, hanem kiváltképpen a nemzetes és vitézlö urak vesznek legtöbb hasznot. Méltóztassék az uraknak bölcsen belátni, hogy a nemzeti iskola a méltóságos uraságtó kezdve egészen az utolsó házaló zsidóig minden keszthelyi lakosban jótevőjét áldja: egyedül az urakban, igen egyedül az urakban, a kik a terhek alól magukat kivonni akarják, nem talál jóakarókat.” (Bontz, 1896. 273-2749.) A levélnek meg lett a hatása, a nemesség is hozzájárult az iskola fenntartásához.

${ }^{341}$ Bontz, 1896. 272.

342 Szabó, 1928. 273.
} 
meg Festetics György a polgári iskolát. Már 1802-ben müködött. Ez olyan iskolatípus volt, amely az uradalmi gazdák, iparosok, kereskedők gyakorlati irányú általános müveltségét biztosította. Ilyen jellegü iskolák Németországban már müködtek és XVIII. század végén nálunk is létjogosultságot nyertek. Az első polgári iskolák a népiskolák felsőbb osztályai voltak csupán. Magyarországon legelőször Pozsonyban állítottak fel polgári iskolát (1785), majd Sopronban (1798), Lőcsén (1801). A keszthelyi polgári iskola a negyedik ilyen típusú volt az országban. $^{343}$

A zeneiskola 1800 novemberében nyitotta meg kapuit. Alapításában valószínüleg Stadler Antal (1753-1812) bécsi zenész segédkezett, aki az iskola felállítására tervet dolgozott ki a grófnak. A tervezet tulajdonképpen tizenkét pontban összefoglalt válasz volt Festetics javaslattevő levelére. A gróf levele elveszett, de a válaszokból mód nyílik a kérdések rekonstruálására.

Az iskola a kezdetekben megfelelő kottatárral sem rendelkezett, éppen ezért kérte a gróf 1809. október 19-én Szegedy Rózának írt levelében, hogy a „távoli rokon”344 lemásolás céljára bocsássa rendelkezésre saját kottatárát. Kérte, hogy „némelly Hazai darabokat” adjon át, kiváltképp Kisfaludy Sándor insurrectióra írt Nemzeti Marsát, ha meg van zenésítve. A kottákért személyesen a zeneiskola tanára Stärk Péter utazott el Sümegre. ${ }^{345}$

Az iskola tanára Stärk Péter, kiváló pedagógus volt, jeles szervező, zeneszerző. 1800tól körülbelül 1810-ig majdnem minden ünnepséget ő rendezett, amelyekre a zeneszámokat, énekszámokat is ő írta. Erre számos alkalom kínálkozott. ${ }^{346}$ Stärk rendszeresen tartott

\footnotetext{
343 Sági, 1972. 29.

344 Kisfaludi Kisfaludy Sándor feleségének mezőszegedi Szegedy Rózának nagyapja Szegedy Ferenc volt. Szegedy Ferenc testvére Szegedy Judit, Festetics György nagyanyja. Szegedy Juditot Festetics Kristóf vette el feleségül. Tehát mindkettőjük esetében a dédszülök, Szegedy Ferenc és felesége Török Kata jelentették a közös őst. (Lásd: Nagy I., 1858. 161-166. ; Nagy I., 1863. 547-550.)

${ }^{345}$ Festetics György Szegedy Rózának, Keszthely, 1809. okt. 19. ; MTA Kézirattár K 376/71;

346 A már említett müvön kívül, amellyel József nádort fogadták, ez az iskola mutatta be többek közt: „A keszthelyi Népnek Öröméneke, mellyel Első Ferentz Ő császári, s királyi Apostoli Felségét utazásban készült üdvözleni. Szent Iván havának negyedikén 1807.”; Festetics Sidonia grófnő, György leánya ünnepi menyegzője alkalmával 1806-ban bemuatták ,Lobgesang mit zwi Singstimmen und einer Harminie Begleitunk” címü dalt; , Cantate an die durchlauchtigste Prinzessin Josephine von Hohenzollern-Hechingen bey Ihrer Ankunft in Keszthely, den 10-ten November 1811. Geordnet von Georgikon. Gesungen von der Musikschule daselbst. Verasst von John. v. Asbóth, Güter-Präfekt und Direktor des Georgikons.” Ennek az utóbbi münek magyar kiadása így hangzik: Örvendezö vers, A melly Keszthelyen énekeltetett midön A Méltóságos Tolnai gróf Festetics László Az ausztriai ts. k. A kamarássa A hazánkat védelmezö nemes seregnek Egy osztályában Ezredes föhadnagy helytartója, A föhatalmú Hechingen Hohenzollern uralkodó hercegnek vérébül eredett Jozefinával Az ö hitves társával Keszthely városába érkezett. Szerzette kőszegi Rainiss József A keszthelyi Georgikonban scholarcha (Veszprémben Szammer Klára betüivel. 1881.) A Zeneiskola mintegy 2000 darabos kottatára a Festetics levéltárba került az iskola megszünését követően. A zeneiskola müködéséröl részletesen ír Klempa Károly Győrben megjelent dolgozatában. (Klempa, 1938.)
} 
növendékhangversenyeket, amelyekről országos lapok is beszámoltak. ${ }^{347}$ Festetics a Georgikon kiegészítő ágának szánta a zeneiskolát. A tanulók és tanáraik rendszeresen szerepeltek Festetics és a Georgikon rendezvényein. Természetesen Festetics György születésnapján szintúgy, amelyre alkalmi verseket, zenemüveket írtak. Ilyen születésnapi ajándék készült 1805-ben is: „Örvendezés mellyet Méltóságos Gróf Tolnai Festetits György Úr Ö Nagyságának a' Szép Mesterségek hathatós Pártfogójának Új esztendői, 's Születése' ditső Innepére mélj tiszteletének 's örökös hálaadatosságának bizonyságául zengedezett: a' Keszthelyi Musika Iskola 1805” A gyengécske mü tipikus példája a kor, számtalan amatőr, alkalmi szövegének (versezetének):

Vígabban szólljatok kis Sípjaink

Édessebb hangokat zengjetek hurjaink!

Egünkre kellemetes, be gyönyörü nap derült,

Az a’ szép nap, melly Hunniának Mecenást

szült. Ki Músa Szüzeket édesgetett partjainkra

Bővséget, 's kellemeket hintett ugarjainkra;

Minket úgy ápol hü kebleben,

Mint Atya, szeretett magzatját (!) őlében

Éjen, ó! éljen boldog napokat,

Éljen a’ Nagy Ferfiú századokat

Legyen halhatatlan:

Kiben a' virtus, és érdem szamlalhatat-

lan. De Ti énekeljétek ditsosségét

Koszorús Lantosok!

Mi Gyáva Dallosok

Inkább Kezeit tsókolva háláljuk Kegyességét ${ }^{348}$

Nem tudni meddig állhatott fenn az intézmény. ${ }^{349}$ Annyit tudhatunk azonban, hogy Thiele, Das Königreich Ungarn (1833) címü műve II. kötetének 128-129-dik oldalán

\footnotetext{
${ }^{347}$ A Pester Zeitung a követezőket írja 1802 februári számában: „Der Graf, der sich immer mit der Jugend beschäftigt lies am 4-ten Februar in der Musik eine Prüfung veranstalten, bei welcher Gelegenheit die Konvikt Jünglinge, sowohl auch die übrigen, wegen ihrer grossen Fertigkeit in allerley Instrumenten, wegen der Genauigkeit und Richtigkeit, womit sie die vorgeschriebenen Stücke exequirten, allegmeine Bewunderung und das aussprechendste Lob des Grafen und Zuhörer sich erwarben." (Klempa, 1938. 11.)

${ }^{348}$ MOL Fest. Lvt. P 2461 cs. B.IV.2. 684-685
} 
Keszthelyről többek közt azt írja: „gróf Festetics-féle nemesi konviktus, zene és rajziskola”. Így arra következtethetünk, hogy a Zeneiskola 1833 körül még állt. ${ }^{350}$

A Festetics által alapított rajziskola 1799-ben fogadott először tanulókat. A kisipar fejlesztését volt hivatva szolgálni. Az iskola tanterve szerint ugyanis az alábbi iparágakban szükségeltetik a rajztudás: kőmüves, kőfaragó, stukkátor, asztalos, kerékgyártó, ács, lakatos, ötvös, nyerges, aranyöntő, harangöntő, üvegcsiszoló, rézmüves, paszományos, gombkötő, takács, szerszámkovács, gerencsér, kályhás. Úgy tűnt, Festetics megelőzte korát és törekvése elöremutató volt, ám az akkori iparosok és ipari tanulók nem értették meg az iskola fontosságát. Így csakis szigorú rendszabályokkal lehetett őket tanulásra bírni. Ennek ellenére 1816-ban mindössze tíz tanulót jegyzett fel Budinszky Lajos rajztanár az osztályozási naplóba. ${ }^{351}$

A keszthelyi három osztályos gimnáziumot Festetics Pál gróf alapította 1772-ben. A tanítás feladatát Festetics a ferencrendiekre bízta, akiket Lackfi István nádor telepített le Keszthelyen nekik adományozva az általa 1386-ban épített templomot és kolostort. ${ }^{353} 1789$ ben ötosztályúvá emelték a gimnáziumot, megtoldva a három grammatikai osztállyal, a humanitás, a költészet és szónoklattan két osztályával. ${ }^{354}$ Ugyanakkor a tanerők pályázat útján kerültek az intézménybe. 1790-ben Roth Erhard ferencrendi tanárt azért mentették fel állásából, mert nem tudott magyarul. Ez mindenképpen következménye volt az 1790/91-es országgyülésben elfogadottaknak, ugyanis ekkor iktatták először törvénybe a magyar nyelv tanítását. ${ }^{355}$ A Hadi és Más Nevezetes Történetek című lap 1791-ben a következő szavakkal lelkendezik: „Amiről élesztő reménységet nyújtottunk volt, hogy t. i. a Magyar Nyelvnek és Stílusnak közönséges taníttatása minden órán el fog kezdődni a Pesti Universitásban, immár bé tellyesedett". Más volt ekkor már a magyar nyelvhez való viszony, mint másfél évtizeddel korábban. Bár voltak ellenzői is a magyar államnyelvnek, többek közt gróf Cziráky Antal, aki az 1791-ben megalakult Pesti Magyar Társaságnak elnöke is volt. De Kölcsey is bevallotta, hogy ifjúkorában jobban beszélt latinul, mint magyarul. Révai Miklósnak még 1807-ben is csak összesen nyolca diákja volt, aki magyar nyelven tanult, s magának Révainak is több

\footnotetext{
${ }^{349}$ Thiele Das Königreich Ungarn című Kassán megjelent munkája II. kötete még megemlíti az iskolát. (Thiele, 1833. 128-129.)

${ }^{350}$ Klempa, 1938. 16.

${ }^{351}$ Koppány-Péczely-Sági, 1962. 56.

${ }^{353}$ A keszthelyi gimnázium történetét a kezdetektöl 1896-ig részletes, elemző munkával Györffi Endre dolgozta fel. (Györffi, 1896. 8-9.)

${ }^{354}$ 1789. június 24-én kelt császári rendelet alapján. (Györffi, 1896. 13.)

${ }^{355}$ Nagy képes világtörténet XI. köt. Szerk: Marczali Henrik. Franklin, Budapest, é.n. 364; Elsősorban a közoktatásügyröl lásd még: Kornis Gyula: A magyar müvelödés eszményei 1777-1848 I. - II. köt. Magyar Királyi Egyetemi Nyomda, é.n. ill. 1927.
} 
verse maradt fenn latinul, mint magyar nyelven. ${ }^{356}$ A felvilágosodás kori magyar irodalom egyik sajátossága, hogy szorosan össze van kötve a nemzeti nyelv ügyével. - írja Bíró Ferenc egyik tanulmányában. ${ }^{357}$ Szerinte Bessenyei a felvilágosult rendiség első nemzedékének tagja az 1770-es években nem tartotta a nemzeti lét ismérvének a nyelvet, mivel szerinte a nemzeti fennmaradáshoz a hatalom és erő szükséges. A hatalom a XVIII. században viszont abban mutatkozik meg, hogy a nemzet milyen mértékben és milyen színvonalon birtokolja a tudományokat, méghozzá saját nyelvén. ${ }^{358}$ Bessenyei röpirataiból világosan kiderül álláspontja, miszerint ő is a nemzeti lét ismérvének tartotta a nyelvet. Nem véletlenül írta le, a Magyarság címü röpiratában a ma már szélesebb körben is ismert gondolatát: „Minden nemzet a maga nyelvén lett tudós, de idegenen sohasem”. A keszthelyi születésü Fejér György szülővárosa gimnáziumának volt tanulója. Önéletírásában megemlíti az 1775/76-os tanév egyik, számára örökké sérelmezett, történetét: „Az iskolaév kezdetétől fogva anyanyelvünkön beszélni tiltva volt; a kik e tilalmat áthágták, egy nálamnál hosszabb tuskó hazavitelére ítéltettek..."359 Természetesen az eminens, de magyarul megszólaló Fejért is ilyen büntetéssel sújtották. Klempa Károly szerint, aki megtiltotta a magyar beszédet a keszthelyi gimnáziumban, hogy jobban megtanulják a latint, Bárány Lajos ferences tanár volt. ${ }^{360}$ II. József a szerzetesrendek feloszlatásáról szóló pátensével ugyanis a ferenceseket nem oszlatta fel, csak zárdáik számát csökkentette.

Nagy megpróbáltatás elé állította a gimnáziumot és Festeticset helytartótanács, mert fölöslegesnek ítélte a keszthelyi gimnázium fenntartását. Ugyanis a megyében, Nagykanizsán, már müködött egy, Somogy megyében viszont egy sem. Megszületett a helytartótanácsi elhatározás: Somogyba kell a gimnáziumot áthelyezni. ${ }^{361}$ A keszthelyi gimnáziumnak azonban befolyásos mecénása volt, nem szünt meg, tovább taníthattak a ferencrendi tanárok. Idővel világi tanárokat is alkalmaztak a szerzetesek mellett.

1796-ban végképp kivonultak a ferences rendi szerzetesek a keszthelyi gimnáziumból, s ekkor ismét felvetődött a gimnázium Somogy vármegyébe való költöztetése. Nagy szószólói volta az ügynek: Esterházy Miklós, Czinderi Pál. Festetics György átérezve mindazt, amit Keszthelynek a gimnázium jelent, levelet intézett Zala vármegyéhez, ebben vállalta, hogy a

\footnotetext{
356 Margócsy, 2005. 71-73. Margócsy tanulmányában részletesen kitér a magyar nyelv ügyére, bevezetésének nehézségeire. Dolgozatának végén az iskolai nyelvoktatás történetét feldolgozó kronológia könnyebb áttekinthetőséget biztosít.

${ }^{357}$ Bíró, 2005. 7.

${ }^{358}$ Bíró, 2005. 18.

${ }^{359}$ Sági, 1983. 237. ; Sági Bátorfi Lajos Adatok Zala megye történetéhez I. Nagykanizsa, 1876 alapján közli a történetet.

${ }^{360}$ Klempa, F.Gy., é.n. 4.

${ }^{361}$ Ilyen értelmü irat keletkezett 1788. augusztus 27-én, 29002/2450. szám alatt. (Győrffi, 1896. 13.)
} 
gimnázium további támogatása mellett, a megüresedett ferences rendházban, nemes ifjak részére konviktust biztosít, amit 1798-ban meg is alapított. ${ }^{362}$ A Magyar Hírmondó a következőképpen adta hírül az esetet: „Meg vagyon vetve a fundamentoma egy Convictusnak, a keszthelyi Gymnasium mellett öt nemes ifjak számára. A most folyó oskolai esztendőben egy tanuló Iffjú nyer stipendiumot, a jövő esztendőben pedig egygyel egygyel nevekedik a stipendisták száma, míg t. i. ötre fog telni."363 Festetics továbbá leszögezi a vármegyének írt levelében: „Tudva vagyon az is, hogy Tannétó Professoroknak fizetésében én mostan tsak ollyan fel tétel alatt, a' melly írásban is költt, hozzája járulok, hogy én tsak addig fogom azon Summa pénzt fizetni, míglen Keszthelyen marad a Gymnasium. Azért ha Somogy Vrgyében akar készülni egy Gymnasium, azt Tettes Nemes Zala Vrmegyei Gymnasiumainak tsorbitása nélkül készüllyön”. ${ }^{364}$ A gróf végül is megkapta a ferencesek egykori épületeit, ahová áthelyezte a gimnáziumot, ezen felül ide volt köteles helyezni a latin iskolát a múzeummal és a könyvtárral együtt. Kikötés volt az is, hogy ebben az épületben a diákok szállást is nyerjenek. ${ }^{365}$ A gimnázium 1802-ben hat évfolyamú lett és a premontrei rend felügyelete alá helyezték. ${ }^{366}$ Két évvel a konviktus megnyitását követően a Magyar Hírmondóban megjelent, cikk felfedi, hogy Festetics mennyire fontosnak tartotta az iskolázottság, a müveltség kérdését; „a gróf a konviktorokat asztalához rendében ülteti, ajándékozza, ösztönzi a

\footnotetext{
${ }^{362}$ Szabó, 1928. 270. ; Bontz tévesen adja meg az alapítás évét, szerinte a nemesi konviktus alapítási éve 1782. A konviktorok létszáma 12-20 között változott. Többen is jelentkeztek a Zala és Somogy megyei nemesifjak közül, de a rendelkezésre álló hely behatárolta a létszámot. A nemes ifjak fele a gróf költségén, másik fele 150 forint lefizetése mellett vehette igénybe a konviktust, azaz a szállást, étkezést és ruházatot. Ruházatuk vörös színủ egyenruha volt. Az intézetben a felügyeletet a gimnázium igazgatója gyakorolta. (Bontz, 1896. p. 262) A konviktus tíz évig maradt Keszthelyen. Festetics ekkor úgy döntött, hogy a nemesi konviktust egy nagyobb városba, Sopronba helyezi át. (M. K., 1811. augusztus 17. 264-265)

${ }^{363}$ M. H., 1798. I. 13-14

364 Balatoni Múzeum 2178.2006/99 (Az eredeti fénymásolata található a múzeum könyvtárában) Zala vármegyéhez intézett levelet teljes terjedelemben Győrffi Endre is közli idézett müvében. (Györffi, 1896. 18-20.) ${ }^{365}$ Györffi, 1896. 21-22.

${ }^{366}$ A Ratio educationis által a hat osztályú nagygimnáziumok osztályai számára előírt tantárgyak a következök voltak: I. osztály: hittan és bibliai történetek, latin nyelv gyakorlati elemei, számtan négy alapművelete, olvasás elsajátítása, helyesírás, szépírás. II.. osztály: hittan és bibliai történetek, latin nyelvben szófejtési gyakorlatok és minél több szó és mondat megtanulása,, számtanban a közönséges törtek, Magyarország földrajza. III. osztály: vallástan, bibliai történetek, a latin nyelvben a syntaxis, a latin irodalmi mủvek olvasása, nyelvtan, Magyarország története a mohácsi vészig, Erdély, Gács, Lodomeria, Bukovina és a Balkán félsziget azon országai amelyek Magyarországhoz tartoztak, a számtanban a viszonyok, arányok, a hármas szabály. IV. osztály: vallástan, hitágazatok, a latin nyelvben a sintaxis ornata és a prosodia szabályai, irodalmi müvek olvasása, nyelvtan, Magyarország története a Habsburg házból származott királyok alatt, az örökös tartományok földrajza és mennyiségi földrajz, a számtanban az arányok. V. osztály: vallástan hitágazatok, szónoklattan, különösen a gondolkodástan alapszabályai, szemelvények beható elemzése, fejtegetése, iskolai és házi dolgozatok, Európa és Ázsia egyetemes és részletes földrajza, görög régiségek és regék, természetrajz, állattan, társaságszabály. VI. osztály: vallástan, erkölcstan, költészettan, szemelvények fejtegetése, megtanulása, iskolai és házi dolgozatok készítése a tanultak nyomán és szabadon, Magyarország részletes történelme, Afrika és Amerika földrajza, római régiségek és regetan, számtanban az eddigi szabályok alkalmazása a gazdaságban. (Győrffi, 1896. 144-145.) Amikor a föigazgató a Ratio educacionis egy példányát a gimnázium igazgatóságának megküldte, csatolta a használandó tankönyvek jegyzékét is.
} 
tudományokra.”367 Festetics György grófot a gimnázium alapítása körüli „dicséretes buzgalmáért”, a tudományos intézetek pártolásáért az uralkodó a valóságos belső titkos tanácsosok sorába emelte. ${ }^{368}$

Festetics 1808/1809-es tanévkezdettel, tulajdonképpen a gimnázium teljessé tétele érdekében, filozófiai magánlíceumot állított fel. Ennek célja volt, hogy a Georgikon hallgatói a gazdasági szakismeretet minél könnyebben elsajátítsák. Mintegy előkészítője volt a Georgikonnak, de felvételt nyerhettek azok is, akik más felsőfokú tanintézetben akartak tanulni. Festetics a tanárok kinevezési jogát magának tartotta fenn azzal a kikötéssel, hogy lehetőleg katolikus tanárt fog alkalmazni, de protestáns tanár kinevezését sem zárta ki. ${ }^{369} \mathrm{~A}$ tanárok fizetését is ő biztosította. A helytartótanács azonban kikötéssel élt és leiratában tudatta, hogy csakis egyetemet végzett és római katolikus vallású egyén lehet tanár a líceumban. A líceum tanárai között két rendi (szerzetes) volt, akik a logikát és metafizikát, valamint a történelmet oktatták. Az egyéb tantárgyakat a Georgikon tanárai adták elő. ${ }^{370}$

\section{2. 2. A Georgikon}

Festetics György intézményei közül legnagyobb alkotásának, minden kétséget kizáróan, a Georgikont tekintjük. Erre már Szabó Dezső is felhívta a figyelmet. ${ }^{371}$ Célja az elmaradt mezőgazdaság helyzetének javítása volt, amit Festetics saját birtokain is tapasztalhatott és a látottak alapján rendkívül sürgősnek ítélt. Ami tovább növelte a tanintézet és alapítójának hírét minden kétség kívül az volt, hogy nemcsak a saját birtokainak, de később más birtokok számára is képzett agrárszakembereket. Nem járunk messze az igazságtól, ha feltételezzük, hogy Festetics tisztában volt azzal a ténnyel, miszerint a felemelkedés, a haladás alapvető záloga, ha az ország legjelentősebb termelő-szférájának az agráriumnak megfelelő

\footnotetext{
${ }^{367}$ M. H. 1800. I. 19. Idézi: Szabó, 1928. 271

${ }^{368}$ Győrffi, 1896. 41.; Szabó, 1928. 274.

${ }^{369}$ Szabó, 1928. 274.

${ }^{370}$ A líceumnak két osztálya volt, az 1811/1812-es tanévben 44 hallgatóval. Tíz évig állt fenn, olyan tanárok müködtek falain belül, mint Lipp Bonaventura, Schindler Bernard, Münich Ferdinánd, Drinóczy György, Lents Ambró és Rajniss József. 1818-ban megszüntetésre kerültek a magán líceumok, tanáraik kinevezését kivették az alapítók kezéből. Gróf Festetics György, később László fia sem akarta a továbbiakban anyagilag támogatni azt az iskolát, amelyhez tulajdonképpen már nem lett volna semmi köze. (Győrffi, 1896. 35-36.; Szabó, 1928. 275.)

371 A Georgikon részletes történetét többen dolgozták fel: Süle Sándor: A keszthelyi Georgikon 1797-1848. Mezőgazdasági, Budapest, 1967; Georgikon 175. Szerk.: Sági Károly. Mezőgazdasági, Budapest, 1972; Csiki László: A keszthelyi agrár-felsőoktatás története. Georgikon kiskönyvtár I. Keszthely, 1993; Georgikon 200 I. Emlékkönyv a Georgikon alapitásának 200. évfordulójára. Szerk.: Fülöp Éva Mária. Keszthely, 1996; Georgikon 200 II. Adattár 1797-2000. Emlékkönyv a Georgikon alapitásának 200. évfordulójára. Keszthely, 2001; Csoma Zsigmond: Kertészet és polgárosodás. (Az európai szőlészeti-borászati-kertészeti ismeretek oktatása, szaktanácsadása a Georgikonban és a Keszthelyi Uradalomban, a 18. sz. végétöl a 19. sz. közepéig) Centrál Európa Alapítvány, Budapest, 1997. Lásd még: Pőr Csilla, Egyházy Tiborné, Dömötör Lajosné: Veszprémi Egyetemi Levéltár Repertórium 1861-1995. Georgikon kiskönyvtár 10. Veszprém, 2001.
} 
képzettséggel rendelkező szakembereket biztosít. A Georgikon megelőzte Philipp Emanuel von Fellenberg 1804-ben és Albrecht Thaer 1807-ben mezőgazdasági iskoláinak létrejöttét. A Georgikon kapuinak megnyitása az akadékoskodók számára említésre sem méltó dolog volt, míg a fejlődést az iskoláztatásban és a szakma elsajátításában bízók számára példaképként jelent meg. A fanyalgók persze a bécsi udvar gyanakvását is beleszámították véleményük kialakításába. A cseh Chotek gróf ${ }^{372}$ „sarlatánnak” tartotta Festeticset, ugyanakkor Kretsmann szász miniszterelnök a Georgikon példájára kívánt hasonló intézményt létrehozni hazájában. A lengyel Seweryn Potocky gróf ${ }^{373}$ a cárnak javasolta, egy hasonló iskola felállítását. ${ }^{374} \mathrm{Ez}$ annál inkább fontos volt a lengyelek számára, mert agrár ország révén náluk is lényeges kérdés volt a megfelelő szakemberek nevelése. Lengyelországban ebben az időben már komolyan foglalkoztak bizonyos agrárreformokkal, így például Andrzej Zamoyski gróf ${ }^{375}$ mazóviai birtokain. ${ }^{376}$ Chotek viszonylag hamar száznyolcvan fokos fordulatot tett. 1803. augusztus 1-jén levelet írt Festetics sógorának Széchényi Ferencnek azzal, hogy Csehországban egy a Georgikonhoz hasonlatos iskolát kívánnak létrehozni és ehhez alapszabályra lenne szükség. Arra kérte Széchényit segítse megszerezni Festetics intézményének ez irányú iratait. A Georgikon alapszabálya végül eljutott Chotek gróf kezéhez. ${ }^{377}$ Mindezeken túl érdekes adalék az intézmény vonatkozásában, hogy az 1800-1805 között megjelenő „Patriotisches Tageblatt”, mely II. József és Lipót reformtörekvéseinek volt szószólója, többször is példaként hivatkozott a Georgikonra. ${ }^{378}$

Újabban került csak az érdeklődés fókuszába az a tény, hogy Festetics a keszthelyi Georgikonnal egy időben Csurgón is mezőgazdasági iskola felállítását tervezte. Tessedik Sámuelhez intézett levelében „tudtára adja a M. Gróf azon plánumát is, mely szerént jószágaiban Csurgón és Keszthelyen két institutumot akar fel-állítani. (...) Csurgón már introducál az árvák institutuma, mellybe paraszt gyermekek fognak fel vétetni s a föld mívelés jó módjának tanulása mellett a fabrica mesterségre is taníttatnak, főképpen pedig minden dolgokat magok kézi munkájok által fognak véghez vinni. Ezekhez képest kéri ő Nagysága Teschedik (!) urat, hogy az előadott institutumoknak eránt közöllye bölts tanátsát." 379 A

\footnotetext{
${ }^{372}$ Jan Rudolf Chotek (1748-1824) cseh birodalmi gróf, udvari kancellár, pénzügyminiszter, a cseh tartományok királyi helytartója, a Királyi Cseh Tudós Társaság titkára.

373 Seweryn Potocki gróf (1762-1829) szenátor, Lengyelország feldarabolását követően az orosz államtanács tagja, Katalin cárnő titkos tanácsosa.

${ }^{374}$ Kurucz, 1999. 277. (MOL Széchényi Lvt. P 62325 cs. f. 457.)

375 Andrzej Hieronim Franciszek Zamoyski gróf (1716-1792) lengyel kancellár.

${ }^{376}$ Kociszewski, 1982. 63.

377 Széchényi és Cseho., 2003. 43.

${ }^{378}$ Széchényi és Cseho., 2003. 49.

${ }^{379}$ Horváth, 2009. 89.
} 
csurgói mezőgazdasági iskola ugyan nem valósult meg, helyette gimnázium épült. Tessedik viszont hathatós segítséget nyújtott a Georgikon létrejöttében. Festetics tisztelte és tudós szakembernek tartotta Tessediket. A szarvasi iskolában diákok oktatását támogatta. Erre enged következtetni a zalai megyegyüléshez intézett egyik levelének részlete: „...ama híres Tessedik úrnak szarvasi industriális iskolájában ifjakat neveltettem...”380

Az uradalmakat vezető gazdatisztek képzettsége a XVIII. században - de még a következő század elején is - nem annyira az iskolázottságon, mint inkább a gyakorlaton, a föld népének évszázados tapasztalatain alapult. A birtokkormányzatokban éppen ezért nem annyira az elmélet, mint inkább a gyakorlat érvényesült. Az uradalomba felvett gyakornoknak végig kellett járnia a szamárlétra fokait és munkája során kellett elsajátítania a szükséges ismereteket. Jogi ismereteket nem is követeltek meg tőlük. 1798-ban például a dombóvári Esterházy hercegi uradalom tizenhárom tisztviselője közül egyedül a számtartó írnok volt jártas a magyar és német jogban. A birtokkormányzatok kiépülése azonban megkövetelte, hogy a tisztek képzettsége és képessége közötti különbség csökkenjen. ${ }^{381}$ Ez volt Festetics elgondolásának mozgatórugója is: tanult gazdák, bővebb termés, nagyobb hozamok, több bevétel. A későbbiekben a végzettség kizárólagos volt, e nélkül nem alkalmazhattak senkit magasabb beosztásban. Erre mutat rá az a történet is, amikor 1841-ben Balogh János káplár felsőbb ajánlással a keszthelyi igazgatósághoz fordult gazdatiszti állásért. Festetics László grófnak az üggyel kapcsolatos állásfoglalása egyértelmű volt. Baloghot - mivel Georgikont nem végzett - nem javasolta gazdatisztnek. ${ }^{382}$

Így az igények figyelembevételével a Georgikon a mezőgazdaság különböző irányú szakember-szükségletét kívánta kielégíteni. A Georgikonban éppen ezért nemcsak felsőfokú, de középfokú és alsó fokú képzés is folyt. A kontinens első ilyen jellegü iskolája Tessedik Sámuellel $^{383}$ történt előzetes tárgyalásokat követően 1797. július 1-jén nyitotta meg kapuit. ${ }^{384}$ A kapcsolat ezután sem szakadt meg a szarvasi iskolaalapító Tessedik és Festetics között. Levelezésük baráti viszonyra enged következtetni, hisz Tessedik 1800. február 15-én, többek között arra kéri Festeticset, hogy a jakobinus, börtönviselt, kettétört pályájú ifjút Pruzsinszky

\footnotetext{
${ }^{380}$ Süle, 1967. 20.

${ }^{381}$ Kállay, 1980. 99.

${ }^{382}$ Kállay, 1980. 100.

383 Tessedik Sámuel (1742-1820) Ev. lelkész, író, pedagógus, mezőgazda. Szarvason 1780-ban gyakorlati gazdasági intézetet állított fel (Gyakorlati-gazdasági-szorgalmatosság iskolája). Az intézmény országos hírnévre tett szert, ez győzte meg Festeticset, hogy kikérje javaslatát a keszthelyi gazdasági iskola felállítása kapcsán. A Georgikon megnyitását megelőzően Festetics György elsősorban gyakorlati és szakmai kérdésekben tárgyalt Tessedikkel. A szarvasi iskolát anyagi nehézségek miatt 1802-ben be kellett zárni.

${ }^{384}$ Helyét ma emléktábla jelöli a keszthelyi Járásbíróság épületének kerítésében, amely valaha a Georgikon első épületének része volt.
} 
Józsefet $^{385}$ alkalmazza. Festetics aggályos, kicsit bizonytalan, nem a legjobb ómen az udvar szemében, ha jakobinusokat foglalkoztat, de a legvégén elfogadja Tessedik ajánlatát és hetvenöt forintot küld Pruzsinszkynek Szarvasra, hogy biztosítsa a Keszthelyre való utazás költségeit. Pruzsinszky 1800. május közepétől már Keszthelyen munkálkodik. ${ }^{386}$ Ez a tény is rávilágít Festetics óvatosságára, de a körülményekhez igazodni próbáló lépéseire. Tessediken kívül nem felejthetjük el a georgikoni ügyek többi tanácsadóját sem: Peter Jordant ${ }^{387}$ a nagyhatású osztrák agrárszakembert, Schönfeldet ${ }^{388}$ és Nagyváthyt sem. ${ }^{389}$ Nagyváthy János a Georgikon elökészítésében vett részt, az oktatásban már nem. A tanintézet megnyitásának évében, negyvenkét évesen ugyanis nyugdíjba vonult. ${ }^{390}$ Csurgóra költözött, ahol Festeticstől végkielégítésként megfelelő házhelyet, kertet kapott, amelyen mintagazdaságot alakított ki. Kapcsolata sohasem szünt meg Festeticcsel. A Georgikont Nagyváthy is páratlan intézménynek tartotta. Nem csoda hát, hogy a halála után kiadott müvének előszavában ezt olvashatjuk: „A Keszthelyi Georgikon pedig példátlan bőkezüséggel és szorgalommal a szomszéd Nemzetek gazdasági Fogásait, talált szerszámjait, ditsért Magjait, stb. amellyeket sok Majorokba az ujságokon való kapás és személyes ajánlás szekerekkel behordott, próbára vonta és amellyek a sárt kiállották, azoknak egész kiterjedést adni igyekezett, azok pedig amellyek a mi Erőnkkel és mindenképpen terhes kivitelükkel öszve nem férnek, erőltető Patikaszerekkel való Nemzésnél egyebet nem szereztek, hazafiságot nála éppen nem nyertek". 391

A bécsi Magyar Hírmondó a megalakult intézményről a következőképpen számolt be: "A magyar Földközi tenger (Balaton!) meljékérõl. Sep. 7-dikénn:-- Minden pallérozott

\footnotetext{
385 Pruzsinszky József (1767-1830 után) egyetemi hallgatóként került a magyar jakobinus mozgalomba. A jakobinusok perében 3 év börtöne ítélték. 1798 májusában szabadult.

${ }^{386}$ Mészáros, 1980. 96-97. ;Tóth, 1980. 96-97.

387 Peter Jordan Tirolban, Sellrainban született 1751. február 2-án. Családja szegény volt. Kezdetben állatőrző fiúként dolgozott, mígnem a helybéli falusi lelkész fel nem figyelt képességeire és egyetemi tanulmányokra elő nem készítette. Orvosi és természettudományi tanulmányokat folytatott előbb Göttingenben, majd Bécsben. 1783-tól Bécsben tanszékvezető. 1827-ben halt meg. (Csoma, 1997. 75-77.)

$388 \mathrm{Az}$ első magyar gazdasági folyóirat megindításának kísérlete az egyik legjelentősebb, szerteágazó nyomdászati tevékenységet folytató bécsi udvari nyomdász, mükereskedő és kiadó, Johann Nepomuk Ferdinand von Schönfeld (1750-1821) nevéhez füződik. A Magyar Újságot 1796-ban ő kezdte kiadni Bécsben, majd fél év múlva Pethe Ferenc mezőgazda, szakíró lett a szerkesztője. (Magyar Könyvszemle - 125. évf. 2009/2.)

389 Csoma, 1997. 72.

390 A szorgalmatos mezei gazda (Pest, 1791) nagyon megtetszett a grófnak és elsősorban ezért kérte fel szaktanácsadónak. A Nagyszívűség páholy 1790-ben kiadta Nagyváthy három szabadkőműves munkáját: $A$ veres barát-ot, a Vallástserélés-t és a L' horoscope de Pologne. A Veres Barát, fő mondanivalója:

„...És a méltóságos

Gróf örül a szürös embert, barátságos

Karjai láncával melléhez kulcsolni

S mint testvér testvérét nyájasan csókolni;"
}

Vö.: Vörös, 1961. 17-19. ; Nagyváthy K., é.n. 11. ; Sági, 1967. 330.

${ }^{391}$ Nagyváthy, 1821. Elöbeszéd. 
nemzetek által látták azt eleitől fogva, hogy valamint kívülröl fegyverrel védelmezi a Tartományokat: úgy belőről a Tudományok ékesítik, s a Mesterségek gazdagítják. Egy kiváltképpen ezen Mesterségek közül, s lehet mondani, hogy első a Mezei Gazdaság fő Mestersége. (...) Ritka boldogságára iparkodik szives igyekezettel juttatni vidékeinket Hazánk méltó Fija, M. Gróf Festetits György Ur Ö Nga. (...) Kész mindent el követni a Georgikon nevezet alatt Keszthelyen fel állított Gazdasági Oskolának virágoztatására...Az említett Georgikon, különössen s főképpenn a Gróf Ur tulajdon Tisztjeinek formáltatásokra állíttatott ugyan fel, mindazonáltal Hazánknak akármelly részéből való más Ifjak is, kiknek a Gazdaság fundamentomos megtanulásához kedvel s hajlandósággal vagynak, ingyen hallgathatják abban a Gazdasági tanításokat folyvást, s egyéb tudományokban való magok tökélletesítése rövidsége nélkül, mert a Georgikon Oskolai esztendeje is éppen akkor kezdődik s végződik, mikor a Kir. Oskoláké, és a Kir. Gymnásiumbéli letzkék órái nem esnek öszsze a Georgikonéival." 392

A Georgikon valóban Európa első ilyen jellegü felsőoktatási intézménye volt, megelőzte a Thaer által Cellében, majd Möglinben 1806-ban, a Fellenberg által Hofwylben 1804-ben felállított tanintézetet. ${ }^{393} \mathrm{Az}$ iskola tanára és egyben igazgatója, Bulla Károly javaslatára Vergilius híres tankölteményéröl és Festetics György keresztnevéről nevezték el Georgikonnak. ${ }^{394}$ Ugyanezen év októberében kezdte meg munkáját az intézményben Pethe Ferenc is. ${ }^{395} \mathrm{Az}$ 1797-ben kezdődő tanévben még nem voltak teljesen készek az iskolaépületek, tangazdasági épületek. Az építkezések állandóan folytak, s ez zavarta az oktatás menetét. Az építkezésekkel kapcsolatos szervezetlenségeket, még 1799-ben is kénytelen volt kifogásolni Pethe Ferenc. ${ }^{396}$ Az első tantervet 1797/98-as tanévre Pethe Ferenc és a prágai születésű Bulla Károly dolgozta ki. ${ }^{397}$

A Georgikon szervezetét az alapító 1798. január 15-én kelt rendelkezése határozta meg. E szerint a Georgikon a hozzá csatlakozó gazdasággal önálló uradalomnak tekintendő, mely - úgy, mint a gróf többi uradalmai - a jószágkormány (Directio) alá tartozik, és ezen ikersztül van kapcsolata a gróffal. Ugyanakkor a Georgikon számára külön referenst neveztek ki, aki tagja volt a jószágkormányzatnak, s aki a tanárok ülésein is részt vett. A fógazda a

\footnotetext{
${ }^{392}$ MH., 1798. II. 337-339.

${ }^{393}$ Csiki, 1993. 9.

${ }^{394}$ Csiki, 1972. 43.

395 Pethe Ferenc fő műve a Pallérozott mezei gazdaság mellyet a magyar mezei gazdaság tökélletesebbítésére a haza természetéhez s a nemzet állapotjához szabva theoretice és practice kidolgozott kisszántói Pethe Ferenc. Sopronban, Szísz Antal Jósef nyomtatószereivel 1805-ödik esztendőben. Ebben a könyvben megemlékezik arról is, hogy négy és fél évet a Georgikonban töltött. Részletes életrajz: Süle, 1964.

${ }^{396}$ Kurucz, 1996. 87.

${ }^{397}$ Kurucz, 1996. 89.
} 
tiszttartó szerepével bírt, a hallgatók a tiszteket képviseltékk, és fizetésképpen ösztöndíjat kaptak. ${ }^{398}$ Ez a rendelkezés szabályozta az intézmény tanárainak munkáját is. A Georgikonba vallásra, származásra, nemzetiségre való tekintet nélkül vették fel a hallgatókat, de szigorúan megkívánták a jó előmenetelt, a jó magaviseletet, a latin, magyar és német nyelv tudását. ${ }^{399}$ A felvételről, annak megkívánt feltételeiről országos lapokban olvashattak az érdekeltek.

Festetics szigorúan és legtöbbször személyesen felügyelte intézményeit. A diákokat jó tanulásra és jó magaviseletre ösztönözte, és büntette, ha nem elképzeléseinek megfelelően tevékenykedtek. Az 1815-ös Protokollum érdekes adattal szolgál: „Hogy az Ifjúság az tanulásra jobban serkentessen, méltóztatott a Mtgos Uraság mindegyik Lyceumbéli Deáknak mulatságára $2 \mathrm{ft}$ hegyesen applacidálni, melly ajándék pénz ezennel az Oskolai Cassára assignáltatik, és Archon Urnak hozzájárulásával egy Consignatio mellett kifizettessen mindegyik Ifjunak. (...) Minekutánna Kováts Gyuri Al-practicans tőbb rendbéli verekedésekben avatkozott, egy recroutát az őtet kísérő Jobbágyok kezeiből erőszakossan ki vett azon fellül a marhákkal is gorombávúl bánik, és buja élettel vádoltatik, el eresztetik, és helyébe azon Supernumerarius Al-practicans tétetik, aki már ugyis a Georgiconban vagyon." 400

Festetics és a Georgikon vezetése folyamatosan fáradozott az intézmény hírnevének gyarapítására, ösztöndíjakat tűztek ki, a lehető legjobb képességü diákok felvételét szorgalmazták. 1800 szeptemberében a bécsi Magyar Hírmondóban a következő hirdetés jelent meg, amely szintén alátámasztja vélekedésünket: "Keszthelyen, Ns. Szala Vármegyében helyeztetett Mezõ-Városban, Georgicon nevezet alatt, fel-állíttatott gazdasági foglalatosságot tárgyazó Majorban, ollyas Iffjaknak, a kiknek a Gazdaság meg tanúlására, és abban szerzett Tudományok után gazdasági Tisztségre kedvek vólna, mostanság két üressen álló Stipendiumnak elnyerésére alkalmatosság lévén, a nevezett Georgicon részéről ezennel jelentetik mind azoknak, a kik magokat a Gazdasági tárgyakban gyakorolni kívánnyák, hogy ollyanok magokat, ezen most folyó September, ugy következő Octóber Hónapokban a Georgiconbéli Elöljáróknak személlyesen bé jelentsék. A Gazdaságot tanúló Iffjúban, akármelly vallású, születésü, és nemzetbéli légyen is az, a meg kivánandó Tulajdonságok ezek: hogy õ a Filosófiát, vagy leg-alább az alsóbb deák Oskolákat jól elvégezte, Deák, Magyar, Német nyelveken írjon, és beszéllyen, az elvégzett Tanúlásról, s maga viseletéröl hiteles bizonyság, vagy Ajánló-Levelet mutasson, végre ép és egésséges testü legyen,

\footnotetext{
${ }^{398}$ Csiki, 1993. 9.

${ }^{399}$ HT, 1806. július 19.

${ }^{400}$ MOL Fest. Lvt. P 279. 281. Protokollum 1815. II. (1815. március 29.)
} 
ellenben pedig néki az õ élelmére, és ruházattyára (szabad szálláson, füttésen, és gyertyán kívül) első esztendőre 100, 2-dikra 120, 3-dikra 150 forint adattatik, s egyszersmind arról, ha a három esztendőt dicséretes előmenetellel el végzendő, hogy gazdasági Tisztségre emeltetik, bizonyossá tétetik. "401 Ami figyelemre méltó, és ismét alátámasztja Festetics felvilágosult gondolkodását a hirdetésnek azon passzusa, hogy vallásra, születésre és nemzetiségre való tekintet nélkül várja a leendö ösztöndíjasok jelentkezését. A „szüröt” ebben az esetben is amint azt már írtuk -, a jó képességek jelentették: jó előmenetel a korábbi iskolákban, a latin, magyar és német nyelv ismerete, jó magaviselet.

A Ratio Educationis arra is felhívta a figyelmet, hogy az egyes oktatási intézmények számára milyen fontosak a könyvtárak. A Georgikon kezdetben külön könyvtárral nem bírt, de a grófi család könyvtára rendelkezésre állt. Figyelemmel a tanárok tudományos működésére az egykorú német és francia nyelvű gazdasági irodalom minden valamire való művét megszerezte és a gazdasági folyóiratokra is előfizetett. ${ }^{402}$

A kezdetben kizárólagosan saját birtokaira képzett ki szakembereket, de később az egész ország területéről várta a hallgatókat. Így a századfordulón hírtelen megnő a diákok száma.

Tanév

Fö

1797/98

2

1798/99

4

1799/800

1800/01

1801/02

1802/03

1803/04

1804/05

$1817 / 18$

\footnotetext{
${ }^{401}$ MH., 1800. II. 374.

${ }^{402}$ Klempa KFK, é. n. 9. ; Klempa leírja, hogy Asbóth János a Georgikon igazgatója, az intézmény feljegyzése szerint, kosárszámra hordta ki a könyveket a grófi könyvtárból, amelyek nem mindig kerültek vissza. Festetics László gróf már külön könyvtárat építtetett a Georgikonnak, ezzel tulajdonképpen megszüntetve a grófi könyvtár kölcsönkönyvtár jellegét.
} 
$1819 / 20$

$39^{403}$

Süle Sándor idézett művében megjegyzi, hogy magánintézmény volt ugyan a Georgikon, de a század elején mégis többen látogatták, mint a pesti egyetemet. Igaz - írja, hogy Pest ekkor még nem töltötte be a főváros szerepét, és a gazdatiszti pálya is népszerübb volt, mint a mérnöki. ${ }^{404}$ A Georgikonban több iskolatípust magába foglaló tanintézet volt, amely a következő iskolákból állt:

Tudományos Gazdasági Iskola,

Parasztiskola,

Pristaldeum,

Erdésziskola,

Kertésziskola,

Ménesmester- és lovásziskola,

Mérnökiskola,

Gazdasszonyképző Iskola.

A Tudományos Gazdasági Iskola 1797-ben nyitotta meg kapuit. Ez a három éves iskola jelentette a Georgikon gerincét. Az iskola első tárgyát még Nagyváthy János állította össze a következő címmel: „Utasítás a gróf Festetics György jószágai igazgatásában követendő eljáráshoz". 405 A cím minden kétséget kizáróan igazolja, amit eddig is tudtunk, hogy a Georgikon kezdetben kizárólagosan a Festetics birtokok számára képzett mezőgazdákat. Müködésének elején néhány ösztöndíjas hallgatót vettek fel, de 1798-tól már külső (köztük külföldi) hallgatói is voltak. A felvételt 18 életév betöltéséhez és középfokú végzettséghez kötötték. Hallgatóit (fö)praktikánsoknak nevezték. ${ }^{406}$ Az iskola három fö szakmára, szakra tagozódott:

- két tanárral a tulajdonképpeni mezőgazdasági szakra,

- két tanárral az alkalmazott mennyiségtani szakra,

- három tanárral a gazdának szükséges fizika-veterinaria szakra. ${ }^{407}$

\footnotetext{
403 Süle, 1967. 55.

${ }^{404}$ Süle, 1967. 56.

405 Kállay, 1980. 99. ; Szabó szerint az 1799. október 1-jén keltezett nyomtatvány a Magyar Nemzeti Múzeum Könyvtárában található. (Szabó, 1928. 280)

406 A keszthelyi Szent Miklós temetőben állították fel azt a síroszlopot, amelyik egy tragikusan meghalt praktikáns hamvait takarta. A sír felirata: EGY ROSNYOI 18 ESZT. REMEK IFJAT MAJOR SÁMUELT KIT ÁRTATLAN BARÁTJA TRÉFA KÖZÖTT FÖBE LÖVÖTT ITT SIRATJÁK ITT FÁJLALJÁK ÉDES ANNYA JÓ BARÁTI A KESZTHELYI MEZEI PRACTICANSOK ÉS AZ IDE VALÓ ÉRZÉKENY SZÜZEK DIE 31 DECEMB. MDCCC VIII. A sírkő jelenleg a Balatoni Múzeum Kötárában van.

${ }^{407}$ Csiki, 1993. 9.
} 
A Parasztiskola 1798-ban indult. ${ }^{408}$ Célja a képzett uradalmi cselédek nevelése, hogy az uradalomban ,jó béresek, béresgazdák, pallérok" legyenek. A Parasztiskola tanulóit alpraktikánsoknak nevezték. Ide kizárólag a Festetics hitbizomány ösztöndíjasait vették fel, „külső” diákok nem jöhettek. A tanulmányi időt nem határozták meg, az a tanuló szellemi képességeitöl függött. Tantárgya: vallástan, olvasás, írás, számolás, földművelés, gyümölcstermesztés, állattenyésztés, méhészet, selyemhernyó-tenyésztés, erdészet. A legjobb tanulókból uradalmi gazdák lettek, a középszerüekből vincellérek, kertészek, erdőpásztorok, méhészek, csikósok, tehenészek, birkások, a leggyengébbeket kézi munkára irányították. Az alpraktikánsok ruházatát ismerjük. Borza Miksa Georgikon-béli alpraktikáns ünnepi ruházatát Festetics a következőképpen határozta meg, ami azt is jelentette, hogy ez, valamennyi parasztiskolai tanulóra vonatkozott: „....setétkék posztóbul mente, fekete Birka prémre, világoskék szőr sinórra, s fejér ón gombokra tsináltasson, ha pedig a szőr gombok oltsóbba kerülnének azok is világos kék szőrbül készéttessenek valamint a Tisztség által projectált dolmány is, ugy szintén az ezekhez készéttendő két nadrágra is világos kék szőr sinor tetessen. Mely ruházatját mind az által tsak Innepen viselje, és más napokon mint paraszt gyermek, közönséges munkás Embernek illő ruhába és szürbe járjon."409

Süle müvében idézi Csanády Gusztávot, aki maga is leírja a Georgikon alapításának 100. évfordulójára Keszthelyen, 1897-ben kiadott emlékkönyvében, hogy a Parasztiskola diákjai „...igen szigorúan és minden elkényeztetés nélkül tartattak, azért nem volt ritka közöttük a szökés, de a jóravalókat gyakran megajándékozta a gróf". ${ }^{410}$ Csanády nem hagy kétséget a felől, hogy Festetics vasszigorral felügyelte az iskolát. Ráadásul az alpraktikánsok a tanulás mellett fizikai munkára is kötelezve voltak, s kötelesek voltak kiszolgálni a föpraktikánsokat.

Richard Bright keszthelyi látogatása (1815) során az iskolát gazdasági népiskolának nevezte és leírta, hogy a tanítást két ösztöndíjas hallgató végzi. ${ }^{411}$

A Pristaldeum ${ }^{412}$ az 1804/1805-ös tanévben nyílt meg. Az uradalmak jogi igazgatására készítették fel a hallgatókat. A különböző jogi és mezőgazdasági tantárgyak mellett nagy súlyt fektettek az instrukciók, urbárium és számvitel tantárgyakra. A gyakorlatot az uradalmi ügyész mellett szerezték meg. A Pristaldeum tanulóit pristaldusoknak, vagy jurátusoknak ${ }^{413}$

\footnotetext{
408 Sági, 1972. 50.

409 Péczely, 1958. 48.

${ }^{410}$ Csanády, 1897. 21. ; Idézi: Süle, 1967. 60.

${ }^{411}$ Bright, 1935. 14.

412 Sági, 1972. 51.

413 A jurátusoknak mind a mai napig álló emléke Keszthelyen, az úgynevezett ,jurátusok kőkeresztje”. Első ábrázolása Rochbock metszetén 1859-ből való. A kereszt ma Keszthelyen, a Karmelita bazilika előtt található.
} 
nevezték. A Tudományos Gazdasági Iskola tanárain kívül egy jogtanár is adott elö a Pristaldeumban.

Az 1806. július 30-án kiadott grófi utasítás szerint az Erdésziskolában ${ }^{414}$ minden olyan tárgyat tanítani kell, melyre az uradalmi erdészeti tisztviselőknek, erdészeknek, vadászoknak szükségük van. Festetics ezen modern szemléletű erdészeti instrukciója - II. József erdőfenntartási nyomdokait követve - visszajelzést kért az elvégzett erdészeti munkákról. Erre mindenképpen szükség is volt. A nagy uradalmi építkezések miatt megritkult faállományt pótolni kellett. Festetics ezt annyira fontosnak tartotta, hogy már az iskola megnyitása elött az egyik vadásznak a fiát, Lakos(z)il Antalt öt évig külföldön taníttatta különböző erdészeti magán tanintézetekben és fơuri (Schwarzenberg) erdőuradalmi központokban. ${ }^{415}$ Hasonló feladattal küldte Bécsbe a fiatal Herenkovitsot is. Mindkettőjüknek felügyeletét a császárvárosban ekkor tevékenykedő nevelő Péteri Takáts József gondjaira bízta, aki a „vállusi jäger fiát”, Lakos(z)ilt kosztra, kvártélyra „Hertey magyar szappanyosnál” helyezte el, aki „Mindgyárt a' Duna mellett lakik a' Leopold várasában". ${ }^{416}$ Festetics későbbi leveleiben sem felejt el érdeklődni Péteri Takáts Józsefnél Lakosil és Herenkovits tanulmányi előmenetele iránt, ugyanakkor meghatározza a tanulók lakásának, élelmezésének, iskolai szünet-béli munkájának módozatait, formáit. Péteri Takáts részletesen beszámol leveleiben Festeticsnek az alumnusok eredményeiről. Herenkovits később a Georgikon hallgatója lett. ${ }^{417}$

1810-ben a direktoriátusi fővadász és két vadásztanító irányította az oktatást. A négy éves oktatás keretén belül a tantárgyak írás, olvasás (magyar és német nyelven), számtan, mértan, természetrajz, erdőgazdálkodás, rajz, fizika, kémia, számvitel, elméleti és gyakorlati vadászati ismeretek voltak.

\footnotetext{
Rajta a felírás: EX VOTO JURATORUM 1813" Ennek ellenére a veszprémi püspökségen megtalált feljegyzés (Canonica visitatio, 1816) szerint e keresztet mégsem a Georgikon jurátusai, hanem Keszthely város tanácsa állíttatta. (Sági, 1972. 51.)

${ }^{414}$ Sági, 1972. 52.

${ }^{415}$ Magyar, 2006. 18.

${ }^{416}$ Péteri Takáts József Festetics Györgynek. Bécs, 1796. augusztus 23. ; MOL. Fest. Lvt. P 2799 cs. 1796:1186. Közli: Stohl, 2009. 203.

${ }^{417}$ Stohl, 2009. 44. ; Stohl szerint Herenkovits a Geoorgikon első tanulója lett. A Georgikon fennállásának 200. évfordulójára készített emlékkötet viszont a Georgikonba való belépésének idejét 1807-re datálja. (Georgikon, 200. II. 20.) Az 1807-es dátum azért megkérdőjelezendö, mivel Festetics a következö szünidőre ígéri az ösztöndíjas Keszthelyre való érkezését: „Herenkovits ifjú örömest Magyar Országra viszsza vágyodván, mondja meg-néki azon ideáját Ő Nagyságának, mivel ő ezen esztendőben a’ német nyelv tanulásába jó progressust tészen a' következö vacatiokra midőn a' Cursussának ugy-is vége léend Keszthelyre le-hozattatik, és Bulla Uram mellé praxisba adatik.” (Festetics György Péteri Takáts Józsefnek. Keszthely, 1797. február. ; MOL Fest Lvt. P 279. Directoriatus regestruma 258. köt. 1797:219. Közli: Stohl, 2009. 217-218.)
} 
A Kertésziskola ${ }^{418}$ ugyancsak 1806-ban létesült. A két éves tanulmányokra először az alpraktikánsok közül válogatták ki a diákokat. Az oktatásukat egy tanító és a grófi kertész látta el. Tantárgyaik a számtan, magyar és német írás, olvasás, kerti kalendárium (a kerti munkák hónap szerinti bontásban), tollbamondás, faiskolák, fáskertek, üvegházat berendezése, kezelése, kertészeti növénytan, díszkertek kialakítása.

1807-től működött a Ménesmester- és lovásziskola. Az iskola célja az uradalmi ménesszemélyzet képzése. Az iskola előbb két éves volt, majd Festetics László gróf 1819-ben négy évre emelte a tanévek számát. Tantárgyaik voltak a ló természetrajza, küllemtana, bonctana és élettana, zablázás, nyergelés, befogás, lovaglási ismeretek, állatorvostani ismeretek, lóegészségügy, lóidomítás. Az iskola tanulói az alpraktikánsok szintjén álltak. Richard Bright szerint ,,a lovagló iskolában nemcsak hivatásos lovászokat képeznek, hanem uri emberek is vehetnek mindennemü elméleti és gyakorlati leckét. (...) Külön engedéllyel a Georgikon gazdasági hallgatói is beiratkozhatnak ide és használhatják a gróf lovagló termét" ${ }^{419}$

A Mérnök-iskolát ${ }^{420}$ 1808-ban alapították háromszintű oktatással. Felsőfokon mérnököket, középszinten földméröket, alsó fokon leendő uradalmi mesterembereket képeztek. A mérnökhallgatók a georgikoni föpraktikánsokkal együtt több tantárgyat is hallgattak. A Georgikon fő́pületében oktatták őket matematikai, geometriai és mechanikai ismeretekre. A földmérők (geodéták) négy gimnázium elvégzése után kérhették felvételüket. A mesterembereket a helyi polgári iskolában oktatták eleinte, majd „,normális iskolabéli tanító” irányította tanulásukat. ${ }^{421}$ A mérnökhallgatók tanulmányi ideje két elméleti és egy gyakorlati év volt. Ök is tanultak növénytermelést és állattenyésztést, de talán a legfontosabbak voltak a statikai, mechanikai, hidrostatikai, optikai, trigonometriai, geometriai, aerostatikai, pneumatikai, hidraulikai, hidrotechnikai stúdiumok, az építéstan, térkép és építési rajz készítése. A sikeres három év után Pestre küldték a diákokat vizsgázni. A földmérők már két év után megkapták földmérői bizonyítványukat. ${ }^{422}$

Szintén 1808-ban nyílt meg a Gazdasszonyképzö Iskola, amely három éves volt. Az iskola célja a takarékos és művelt háziasszonyok nevelése. Két tanítótól általános ismereteket, a női munkákról egy tanítónőtől kaptak oktatást. ${ }^{423}$ A férfi tanerő rendszeresen a főpraktikánsok soraiból került ki, a női oktató, valószínűleg valamelyik georgikoni tanár

\footnotetext{
${ }^{418}$ Sági, 1972. 53. ; Részletesen lásd: Csoma, 1997.

${ }^{419}$ Bright, 1935. 14-15.

${ }^{420}$ Sági, 1972. 56.

${ }^{421}$ Süle, 1967. 66.

422 Süle, 1967. 66-67.

${ }^{423}$ Bright, 1935. 15.
} 
felesége volt, 1808-ban például Liebbald professzoré. ${ }^{424} \mathrm{Az}$ iskolában, írást, olvasást, földrajzot, számtant, illemtant, történelmet, vallástant, fogalmazást, selyemhernyótenyésztést, kézimunkázás különféle formáit, sütést, főzést, fonást, csipkeverést, varrást, vasalást, rajzot, zenét tanultak. Az iskola 1820-ig állt fenn.

A Georgikont az 1848/49-es szabadságharcot követően bezáratták, mivel a diákok és a tanárok seregestül vonultak a szabadságharc zászlai alá. Csupán 1865-ben nyithatta meg kapuit, mint Országos Gazdászati és Erdészeti Tanintézet. 1905-től akadémiai, 1962-ben főiskolai, majd 1970-ben egyetemi rangot kapott. Ma többszöri átszervezés és névváltoztatás után a Pannon Egyetem Georgikon Karaként müködik. Ezen intézmények mindegyike a Georgikont tartotta elődjének, és hitet tett a történelmi kontinuitás mellett.

\section{2. 3. A csurgói református gimnázium}

Festetics György szándékában állt nagyobb iskolák alapítása Csáktornyán és Perlakon, de ezek nem valósultak meg. Csurgón azonban a gróf által alapított református gimnázium megnyithatta kapuit.

Ismeretes, hogy 1788-ban felvetődött a keszthelyi gimnázium Somogy vármegyébe történő áthelyezése, mivel Zalában már két gimnázium müködött, Somogyban egy sem. Festetics Györgynek köszönhetően a gimnázium Keszthelyen maradt, sőt kibővült.

1799-ben Csokonai Vitéz Mihály megírta „Jövendölés az első Oskoláról a Somogyban" címü versét, amelynek hátteréül a korabeli somogyi müvelődési viszonyok szolgáltak. Az alkalmi költemény bizonyos fokig számonkérés, az elmaradottság fájdalmas felpanaszolása, ám az utolsó versszak mégis bizakodó:

$$
\begin{aligned}
& \text { De tán jő } \\
& \text { Olly idő, } \\
& \text { Mellyben nékünk } \\
& \text { A' vidékünk } \\
& \text { Új Hélikon lesz- }
\end{aligned}
$$

A vers valószínüleg 1799 májusában született, amikor Csokonai elfoglalta Csurgón a helyettes tanári állást. ${ }^{426}$ Úgy tünik, alkalmi költeményről van szó, de mindenképpen a

\footnotetext{
${ }^{424}$ Süle, 1967. 67.

${ }^{426}$ Csokonai ÖM., 1994. 815.
} 
gimnázium, az oktatás, a müvelődés fontosságát jelzi a vers. A racionális gondolkodású Festetics hasonló elveket vallott, hisz iskolaalapítási terveit tulajdonképpen, ezen gondolat mentén valósította meg. Juhász Géza hívja fel a figyelmet arra, hogy „a müvelt nagybirtokos, a katolikus Festetics György már be is látta, mennyivel értékesebb a tanult ember munkája; ajánlott hát kálvinista jobbágyai oktatására pénzt is, telket is, építőanyagot is". ${ }^{27}$

Horváth József Csurgó monográfiájá-ban idézi, hogy az általános hiedelemmel ellentétben nem Csokonai verse tette közismertté az iskola küldetés-szerepét, hanem az 1771 és 1868 között 71 kiadást megért Hármas Kis-Tükör címü munka. Losonczi István ezen könyvének korai kiadásaiban fellelhető, Somogyra vonatkozó, négy sor:

\footnotetext{
Somogy- vármegyében Tolnáról elérhetsz

Koppánra, Szigetre, Babotsára mehetsz,

Somot, almát, körtvélyt itt eleget ehetsz,

De a tudományban részt keveset vehetsz. ${ }^{428}$
}

1822-ben a vers utolsó sora azonban megváltozott, büszkén vallva a korábban hiányolt gimnázium müködésének hathatós munkáját:

Tudományban is már Részt benne jól vehetsz. ${ }^{429}$

1794 januárjában elkészül a gimnázium alapító-levelének tervezete, amely nem nélkülözte a felvilágosodás eszméinek gyakorlati megvalósítását. Festetics ebben azt írta, hogy ,a birtokaimon lakó protestánsok pedig efféle tanintézetnek mindezideig nagy híjával vannak: hogy protestáns jobbágyaim gyermekeiknek a haza távol vidékein fekvő iskolákba való taníttatása költségeitől megkíméltessenek, sőt a környékbeli nemes ifjúság oktatására is kész alkalom nyújtassék, Somogy vármegyébe kebelezett Csurgó mezővárosomban, a közjó előmozdítása és jobbágyaim könnyebbsége céljából, önként (..) megmásíthatatlan, örökérvényü alapítványt teszek". ${ }^{430}$ A végleges változatot ugyanezen év áprilisában írta alá a

\footnotetext{
427 Juhász, 1997. 297.

${ }^{428}$ Horváth, 2009. 85.. 55.

${ }^{429}$ Hármas Kis-Tükör melly elöször: A' Szent Históriát, másodszor: Magyar Országot, harmadszor: Erdély Országot azoknak Földével, Polgári Állapotjával, és Históriájával gyenge Elmékhez meg-bövítve alkalmazott módon a’ Nemes Tanulóknak summásan, de világosan elö-adja és ki-mutatja. Buda, 1822. 55. ; Vö.: Sági, 1967. ${ }^{430}$ Horváth, 1992. 10.
} 
gróf. A csurgói iskola alapkövét 1795. április 30-án tették le. ${ }^{431}$ Az építési anyagra Festetics 6000 forintot kötött le, évi 200 forintot pedig a professzor fizetésére. A bécsi kancellária 1794 júliusában megadta az iskola müködési engedélyét. A szervezésben hatalmas munkát végzett az egykori georgikoni tanár, Nagyváthy János, aki 1797-ben nyugdíjaztatását követően végleg Csurgóra költözött. ${ }^{432}$ Itt kapott házat, földet Festeticstől, aki a továbbiakban sem feledkezett meg egykori tanácsadójáról, szabadkőműves társáról.

A gimnázium két tanulócsoportos volt. A kisdiákok a latin nyelvtan elemeivel, a nagyobb tanulók - a grammatisták, szintaxisták - a latin nyelvtan részletes alapos elsajátításával foglalkoztak. A csurgói gimnáziumhoz népiskola is tartozott, ahová fiuk, lányok egyaránt jártak. A Helytartótanácsnál 1797-ben kérték, hogy a gimnázium tantárgyait a bölcsészetannal és hittannal bővíthessék, valamint ezek oktatására egy rendes és egy segédtanárt meghívhassanak. Az engedély kiadása előtt a helyszínen tájékozódott a Helytartótanács megbízásából Somogy vármegye „közönsége”. Az 1797. november 9-én felvett jegyzőkönyv az ott látottakról a következőket rögzítette: „Mindenekelőtt megtekintettük a nagyszerü iskolaépületet, mely a külső vakoláson kívül egészen készen van. Az épület földszinti részén a jelenlegi rektor, a grammatisták tanítója és ezeknek szolgái és a felsőbb tudományokat hallgató alumnusok számára külön-külön elégséges lakóhelyek vannak. A nemzeti iskolában 40, a felsőbb osztályokban pedig 20 tanulót találunk, de még egyszer annyinak befogadására is elég tágas helyiségek lesznek. Az emeleten hasonlóan, minta a földszinten a leendő professor, subrector és azok tanítványai részére szánt lakószobák, tantermek és más alkalmatosságok készen állnak; megnéztük az épület északi részén azzal szélességben, magasságban egyméretű s az iskolákkal egy fedél alatt álló imaházat is". ${ }^{433} \mathrm{~A}$ pápai és csurgói református gimnázium hosszú ideig versengett azért, hogy melyik intézmény legyen az egyházkerület anyaiskolája. Végül az egyházkerület Pápa mellett döntött. A gimnázium megszilárdulását 1803 és 1849 közé tehetjük. Ebben az időben, 1818-ban készítette el Nagyváthy János „, A csurgói Gymnasiumbeli Rectori és Professori rendtartás”-t. Ebből azt is megtudhatjuk, hogy a gimnáziumnak 1819-ben 8486 forint alapítványösszeg volt a birtokában. A patrónus Festetics György 2 000, gróf Festetics János 1000 , gróf Vay Ábrahám 600, Csépán István 550, Sternberg Löbl csurgói izraelita vallású polgár 250 forintos

\footnotetext{
${ }^{431}$ MOL Fest. Lvt. P 274. 245 cs. fol. 13. ; Merész Gyula (1888-1949) festőművész 1939-ben megfestette az alapítást ábrázoló olajfestményét, amely jelenleg is a csurgói református gimnázium dísztermében található. A mủvész kissé eltért a valóságtól, mert az alapkő letételekor ott nem lévő Festeticset is ráfestette a képre.

${ }^{432}$ Horváth, 1992. 10-13. ; Horváth, 2009. 86.

${ }^{433}$ Horváth, 1992. 19-20.
} 
alapítványának évi $6 \%$-os kamata 364 forint. ${ }^{434}$ Ezek az összegek azonban nem voltak oly nagyok, hogy az iskola folyamatosan meglévő anyagi gondjait enyhíteni tudták volna. ${ }^{435}$ Mai szemmel nézve az iskola, minden kétséget kizáróan legismertebb tanára Csokonai Vitéz Mihály volt, aki Csurgón csupán helyettes tanárként működött alig hosszabb ideig, mint fél esztendő. ${ }^{436}$

\section{3. Festetics György a sajtó mecénása}

A magyar szellemi és azon belül az irodalmi életnek sokszínü kibontakozása, amelyet a XVIII. század végén figyelhetünk meg, szoros összefüggésben, kapcsolatban állt az irodalmi élet aktív és passzív tényezői körében bekövetkezett változásokkal. Különösen fontos volt abban az időben azon különböző intézmények létrehozása, ahol az író és az olvasó egymásra találhatott. A század végén a polgárság a társadalom mintegy másfél-két százalékát tette ki és nagy részében nem is volt magyar anyanyelvü. Éppen ezért ellentétben Angliával, vagy Franciaországgal a magyar felvilágosodás élén elsősorban nem a polgárságot, hanem a nemességet találhatjuk.

Magyarország különleges helyzetben volt. 1798-ban Schwartner Márton statisztikus feljegyzése szerint „,nehéz Magyarországon azt a határvonalat meghúzni, amely a várost a falutól megkülönbözteti. Az ország minden városa (még Pest és Pozsony sem kivétel) a városi iparon kívül többé-kevésbé mezőgazdaságból és állattenyésztésből él”. Az iparosok csak úgy tudnak megélni, ha földet is müvelnek. Ezeket a félparaszti elemeket nyilván még nem nevezhetjük polgárnak. De nem nevezhetjük polgárnak, a polgárjoggal sem rendelkező nagyszámú szolgát, napszámost sem, akik a polgári öntudattól messze járnak, akik egyes városokban a többséget alkotják, - fogalmazza meg Benda Kálmán. ${ }^{437}$

A század 80-as éveiben megindult egy rövid, de viszonylagosan gyors polgárosodási szakasz és torkollt bele a magyar jakobinus mozgalomba. A korábbi évtizedekkel szemben, ahol a kizárólagos nemesi többség volt jellemző, egész sor olyan író, kötő került a szellemi élet élére, mint Batsányi János, Révai Miklós, Ráth Mátyás, Dugonics András. Sok jobbágy,

\footnotetext{
${ }^{434}$ Gróf Festetics János (?-1844) gróf Festetics György testvére. Gróf Vay Ábrahám (1789-1855) földbirtokos, az MTA egyik alapító és igazgatósági tagja, alispán. Csépán István ügyvéd, vicekurátor, gondnok.

435 Horváth, 1992. 43-44.

${ }^{436}$ Szentgyörgyi esperes 1799. június 13-án írja a grófnak, hogy Csokonai „örömmel tanittya a Csurgói Ifjakat”. (Horváth, 1992. 28-29.) ; A csurgói gimnázium falán elhelyezett márvány emléktábla szerint a költő 1800. február 17-ig tartózkodott Csurgón.

${ }^{437}$ Benda, 1978. 22-23.
} 
illetve elszegényedett kisnemesi eredetű író is felbukkant a nyolcvanas években, így Baróti Szabó Dávid, Szentjóbi Szabó László, Virág Benedek. Ugyanakkor jelentős a honorácior értelmiség száma, akik közül sok a tanár, lelkész, nevelö, titkár. ${ }^{438}$ A megújuló szellemi életnek egyik legnagyobb feladata volt az irodalmi, szellemi központ létrehozása. Bécs nem volt igazán erre alkalmas, Buda inkább, főleg a nagyszombati egyetem áttelepítését követően. Ilyen szellemi központokkal, újságokkal állt kapcsolatban néhány felvilágosult főnemes is, bár óvatosságból csak laza kapcsolatot engedhettek meg maguknak. Kapcsolattartójuk jobbára titkáruk, könyvtárosuk, nevelőjük, orvosuk volt. ${ }^{439}$

1780-ban Pozsonyban beindult Ráth Mátyás szerkesztésében az első magyar újság a Magyar Hírmondó. ${ }^{440}$ A lap megindítása rendkívül fontos volt, kiemelkedő eseménynek számított. Maga Kazinczy Ferenc is meleg hangon üdvözölte az „újszülöttet”: „Ráth Mátyás, győri evangélikus prédikátor 1780 január első napján kezdé el a magyar újságlevelek kiadását, s hálátlan volna a maradék, ha feledhetné, hogy nemzetünknek nem más vala, mint ö, igazi Prometheusa". ${ }^{441}$ Már első évfolyamai eljutottak az ország szinte egész területére, elsősorban a nagyvárosokba: Pestre, Győrbe Kolozsvárra, Nagyszebenbe, Nagyváradra, Pápára, Debrecenbe, Komáromba, Pécsre, Sopronba, Nagyszombatra, Nyitrára, Budára, Egerbe, Eperjesre, Gyulára, Máramarosszigetre, Marosvásárhelyre, Ónodra, Pozsonyba, Székesfehérvárba és Veszprémbe. Ezeken a városokon kívül 184 kisebb helységbe járt már az újság első évfolyama. ${ }^{442}$ Egy példány eljutott Keszthelyre is. Festetics György ugyanis hü olvasója volt a lapnak, amelyből magyar nyelven volt képes tájékozódni honi állapotainkról. ${ }^{433}$ A Magyar Hírmondó politikai lap volt, így csak alkalmanként hozott irodalmi anyagot, irodalmi vonatkozású cikkeket. Időrendben a Magyar Hírmondó után következő, Szacsvay Sándor által szerkesztett bécsi Magyar Kurír-jának már irodalmi mellélete is volt, Magyar Musa néven. ${ }^{444}$ Ebben Batsányi, Baróti Szabó, Kazinczy is publikáltak. Az első magyar nyelvü irodalmi folyóiratunk a Magyar Museum (1788). A lapalapítók Batsányi János (aki egyben szerkesztette is az újságot), Kazinczy Ferenc és Baróti Szabó Dávid. Szinte ezzel egy időben Kazinczy önálló folyóirat megteremtésén fáradozott, s

\footnotetext{
${ }^{438}$ Kókay, 2000. 114.

${ }^{439}$ Kókay, 1979. 128.

${ }^{440}$ A témával részletesen foglalkoznak: A magyar sajtó története I.-II. Szerk.: Kókay György, Kosáry Domokos, Németh G. Béla. Akadémiai, Budapest, 1979-1985. ; Kókay György: Könyv, sajtó és irodalom a felvilágosodás korában. Akadémiai, Budapest, 1983. ; Kókay György: Felvilágosodás, kereszténység, nemzeti kultúra. Historia Litteraria 8. Universitas, Budapest, 200

0 .

${ }^{441}$ Kazinczy, 1979. 252.

${ }^{442}$ Kókay, 2000. 117.

${ }^{443}$ Cséby, 1992. 92.

${ }^{444}$ Kókay, 1983. 117.
} 
ennek eredményeként 1790-ben Kassán meg is jelent saját lapja az Orpheus. ${ }^{445}$ 1789-ben pedig megjelent Komáromban, a Péczeli József által jegyzett Mindenes Gyüjtemény.

1789 júliusában Bécsben Görög Demeter és Kerekes Sámuel szerkesztésében megindult Hadi és Más Nevezetes Történetek címü lap (amely 1792-től felvette az első magyar újság nevét: ez is Magyar Hírmondó lett) élénken bekapcsolódott a nemesi ellenzéki mozgalomba és nagy érdemeket szerzett a nemzeti nyelv és irodalmi fejlesztés terén. Ennek a lapnak szerkesztőségében ott találhatjuk Hajnóczy Józsefet is, a Martinovics-féle összeesküvés később kivégzett alakját. Görög és Kerekes Bécsben kis társaságot hoztak létre az újságot kedvelők köréből. Bár elsősorban politikai hírekről tudósítottak, gyakran közöltek irodalmi jellegü cikkeket. A korszak valamennyi jelentékeny írójával (így Kazinczyval is) kapcsolatot tartottak. ${ }^{446}$ A lap mögött ellenzéki főnemesek: gróf Széchenyi Ferenc, gróf Festetics György, gróf Teleki Sámuel álltak. Ez az újság volt a II. József uralma alatt kifejlődő patrióta nemesek mozgalmának szócsöve. Bár maguk a főurak a szerkesztőkhöz füződő kapcsolataikat leplezendő, nem jelentek meg a bécsi szerkesztőségi üléseken, megbízottjaikat küldték (Festetics Péteri Takáts Józsefet ${ }^{447}$ ), valamint anyagilag is támogatták a lapot. ${ }^{448}$ Nevük titokban maradt, mecénási tevékenységük azonban hozzájárult a lap létezéséhez. Kókay György rámutat: „Görögéknek a demokratikus értelmiség tagjaihoz és vezetőihez - Batsányihoz, Kazinczyhoz, Verseghyhez, Révaihoz és másokhoz - füződő kapcsolatai, másrészt pedig a nemesi ellenzék vezéreivel - Festeticcsel, Széchényivel, Ráday Gedeonnal, Orczy Lászlóval - való összeköttetései arra engednek következtetni, hogy újságjuk e két csoport egymásra találását és együttműködését is szolgálni óhajtotta". ${ }^{449}$

Kókay kitünően látja, hisz Festetics további kapcsolatai e feltevést igenlik. Azt sem szabad elfelejtenünk, hogy az anyagilag bizonytalan helyzetben lévő Festetics által nyújtott támogatásról van szó. Görögék lapjának hírszolgálata, publicisztikája azt bizonyította, hogy a reformizmus, a felvilágosodás eszméi társadalmi, politikai és világnézeti téren egyaránt átjárták gondolkodásukat. A már említett megváltozott néven 1803-ig élt a lap.

\footnotetext{
${ }^{445}$ Kókay, 2000. 142.

${ }^{446}$ Kókay, 1983. 119.

${ }^{447}$ Kókay, 1979. 127. ; Cséby, 1992. 92-93.

${ }^{448}$ Festetics György nemcsak az újság révén állt kapcsolatban Göröggel. Térképeket is nyomtatott a grófnak. Erre enged következtetni Péteri Takáts Festeticsnek 1794. június 14-én írt levele: „Görög Urral közlöttem Nagyságod' gondolatait a' mappák iránt. Azt felelé, hogy meg fogja jól vizsgálni a' már ki jött mappákon maradt üres helyeket, és a' mint tsak lehetséges lesz, leg jobb móddal reájok alkalmaztatja a' dedicatiót. Én ugy tartom, hogy az illyen értelmű kifejezés: >Munificentia Comitis Georgii Festetits de Tolna< kevéssel mindent magába foglalna". (MOL. Fest. Lvt. P 2795 cs. 511.) ; Debreczeni, 2009. 43.

${ }^{449}$ Kókay, 1979. 128.
} 
Az időszaki sajtó fejlődése számára kedvezö rövid másfél évtized utolsó magyar folyóirata, Kármán Urániája. E lap nemcsak időrendben, volt utolsó képviselője egy nagy korszaknak, hanem tartalmilag is összefoglalója az elődök irányainak, eredményeinek és összekötő kapocs a XVIII. és XIX. század között. 1794 elején kezdett hozzá Kármán József, szerzőtársával, Pajor Gáspár orvostanhallgatóval az indítandó folyóirat hírveréséhez. ${ }^{450}$ Kármán, aki a kor hazai lapszerkesztői közül a legfiatalabb volt, sikerrel használta fel az elödök: Ráth, Batsányi, Péczeli és Kazinczy publicisztikai tapasztalatait. A tervezett folyóirat erkölcsi, történelmi, természettudományi, esztétikai és gazdasági vonatkozású cikkeivel a nök erkölcsi nevelését és müveltségük fejlesztését kívánták elérni. A negyedévenként megjelenő folyóirat kiállítását is igyekeztek a női ízléshez szabni. ${ }^{451}$ A lap bevezető írásában felhívta a figyelmet a magyar nyelv fontosságára: „Jó Királyunk’ Akarattya, Mindnyájunknak Kívánsága Nemzeti-Nyelvünk’ Virágzása... ${ }^{452}$ Ugyanakkor a londoni Spectator, valamint a francia enciklopédisták példáját felhasználva igyekezett a hazai szellemi élet fellendítése érdekében munkálkodni. ${ }^{453}$ A folyóirat első száma 1794 májusában már sajtó alatt volt, novemberben pedig a második szám is napvilágot látott. A lap nem jelenhetett meg támogatók nélkül. Ma már megerősíthetjük, hogy Festetics György gróf volt az az ismeretlen „Hazafi”, akit Kármánék az első számban hálával emlegettek, mert „titkosan”, anyagilag - mint később kiderült Nagyváthy János útján - támogatta a folyóirat kiadását. ${ }^{454}$ Úgy is fogalmazhatunk: Festetics anyagi segítsége nélkül az Uránia nem jelenhetett volna meg. Festetics érdeklődő levelet ír a Bécsben Festetics László nevelésével foglalatoskodó Péteri Takáts Józsefnek, ha megjelenik az Uránia, vegye meg és küldje el neki. Péteri Takáts tájékoztatja, hogy a lapot nem lehet megvenni, csak az előfizetők kaphatják meg. ${ }^{455}$ Festetics mecénási szerepére enged következtetni a rövid életű (1794-1795) lap két szerkesztöjének Festetics Györgyhöz írt

\footnotetext{
${ }^{450}$ Az Uránia folyóirat történetéröl az utóbbi évtizedben megjelent legjelentősebb kötet: Szilágyi Márton: Kármán József és Pajor Gáspár Urániája. Csokonai Könyvtár 16. Debrecen, 1998. ; Ezt követően jelent meg Szilágyi Márton szerkesztésében Első folyóirataink: Uránia című forráskiadvány (Csokonai Könyvtár, Források 6. Debrecen, 1999.).

${ }^{451}$ Kókay, 1979. 223.

452 Uránia I. Első Esztendő (1794) Be-vezetés.

453 Kurucz, 1999. 273.

454 „Egy édes Kötelesség fekszik rajtunk, mellyet itt közönségesen tellyesítünk. Egy Hazafi a’ ki titkosan és Rejtekbe summás Adakozásával Lételét Tsetsemö Urániánknak fel-tartotta, el-vonta magát Háladatosságunk elöl, és rajtunk az édes terhet hagyta, hogy egyenessen néki véle nem adózhatunk: Nem halgathatyuk-el azt mindazáltal egésszen, és itt a’ Közönség elött azt háládóan emlittyük. Az a' Gondolat: hogy egy jó Intézet' Fennállása az ő Kezei’ Munkája, - és a' maga nagy Szívének Meg-elégedése, éppen Szívéhez illő Jutalom... Azon Kezet, melly által hozzánk jutott Jó-tétele őleljük, nem ezért tsupán, de leg-inkább hogy bőlts Vezetésével, Támogatásával ugyan az vólt Fö-meg-tartója Igyekezetünknek. Kívánnánk mind Kettőt az egész Világnak nevezni - Szívünk’ háládatos Tisztelettel nevezi mindég!” (Uránia I.); Lásd még: Kókay, 1979. 224. ; Vermes, 2011. 141. ; Debreczeni, 2009. 443-444.

${ }^{455}$ Péteri Takáts József levele Festetics Györgynek. Bécs, 1794. június 7. MOL Fest. Lvt. P 2795 cs. 1794:526. Közli: Stohl, 2009. 162.
} 
levele: „...Gyönyörüséggel adunk számot Nagyságodnak, mert érezzük rólunk való gondoskodásának becsét és eredetét. miolta szerencsénk volt személyesen udvarolni Nagyságodnak, kijött harmadik kötetje Urániá-nknak. Eztet magánosan, és ezenkívül parancsolatja szerint Nagyságodnak mind a három kötetet küldjük. Fogadja kegyesen Nagyságod igyekezetünknek csekély gyümölcsét. Még egy kötet vagyon hátra; azzal nem háládatlan hazánknak, hanem tulajdon szavunknak tartozunk. (...) Nagyságos Uram, nem marad eltitkolva Nagyságodnak kegyessége erántunk, anélkül hogy az a nagy ember árulta volna el Nagyságodat, akinek kezéből vettük a Nagyságod hozzánk való hajlandóságának bizonyságát. Tudjuk mi, hogy sokkal tartozunk Nagyságodnak, és boldogoknak tartjuk magunkat, ha azt mondhatja felölünk Nagyságod: nem érdemtelenekkel tettem jót" ${ }^{456}$ A levél azonban felvet egy érdekes kérdést, amit viszonylag könnyen megoldhatunk. Ki lehetett hát „a nagy ember”, aki elárulta volna Festetics nevét? Festetics György, ahogyan Széchényi Ferenc is, a magyar irodalom, és elsősorban a folyóiratok támogatását titokban kívánta tartani, hogy semmiképpen gyanúba ne keveredhessenek. A közvetítő Nagyváthy János azonban úgy tünik, elkottyanthatta magát, ami zavarhatta Festeticset, s Nagyváthy mentegetése ezért történt meg.

Sajtótörténetünkben a Hazai Tudósítások megindulásának évét jelentős korszakhatárként szokták emlegetni, mindenekelőtt azért, mert az első, folyamatosan megjelenő pesti magyar újság a fővárosi hírlapirodalom valódi meghonosítójának tekinthető. E lap a magyar sajtó fejlődésében új korszakot nyitott, és egyszersmind lezárta a XVIII. századi hírlapirodalmunk történetét. ${ }^{457}$ A lapot Festetics László egyik nevelője, Kultsár István alapította és első száma 1806. július 2-án kerülhetett az olvasók kezébe. Döbrentei Gábor és Kazinczy Ferenc is üdvözölte az új sajtóorgánumot: „Íme, amit mindig óhajtottam, megvagyon! Van tehát egy folyó munkánk, amelyben a hazai literatúra productumai a publicumnak tudtára adatnak és talán recenseáltatnak is. Jól, rosszul, az csaknem egyenlő, mert ez által az írók felriasztatnának álmosságokból s inkább fognak igyekezni a publicum javallásának megnyerésére". ${ }^{458}$

A Hazai Tudósítások állandó munkatársai közé Horváth István és Beregszászi Nagy Pál tartozott. Segédszerkesztőként Kultsár fiatal írókat alkalmazott: Légrády Imrét, később Ungvárnémeti Tóth Lászlót és rövid ideig Kölcsey Ferencet. A lap megindításához szükséges

\footnotetext{
${ }^{456}$ A levelet teljes terjedelemben közli: „,Tekintetes Szerkesztő úr!” Levelek a magyar sajtóról 1790-1848” címü kötet. (Fehér-Kókay, 1990. 87-91. ); Sajnos Kálmán és Pajor levelében közölt negyedik kötet már nem látott napvilágot anyagi nehézségek miatt.

${ }^{457}$ Kókay, 1979. 247.

${ }^{458}$ Kókay, 1979. 249.
} 
tőkét maga Kultsár gyüjtötte össze, de kapott támogatást Széchenyi Ferenctől és Festetics Györgytől is. ${ }^{459}$ Tehát ugyanazok a fönemesek álltak vállalkozása mögött, akik annakidején Görög Demeter és Kerekes Sámuel lapját is szponzorálták. Amikor az Uránia és a bécsi Magyar Hírmondó közötti hasonlóságra hívjuk fel a figyelmet, mindenekelőtt magyarázatul szolgálhatnak az előbb említett személyi kapcsolatok és megfelelések. Később Kultsár magyarországi hírek mellett külföldieket is megjelentetett, éppen ezért 1808 májusától megváltoztatta az újság címét Hazai 's Külföldi Tudósításokra. A lap szerzői gárdájához tartozott többek közt Horváth István, Fejér György, Vitkovics Mihály, Szemere Pál, Kisfaludy Károly, Virág Benedek, Ungvárnémeti Tóth László, Berzsenyi Dániel, Kazinczy Ferenc, Dukai Takács Judit, Édes Gergely, Guzmics Izidor. Ugyanakkor a helyzetnek és az érdekeknek megfelelően sok kevésbé színvonalas írásmü is napvilágot látott a lap hasábjain. Erre jó példa, amikor Vitkovics Kazinczynak elpanaszolja a szerkesztőbizottsági ülésen történteket: „Csak azt hallhattad összegyüttünkkor: ennek munkáját be kell venni, mert pap, mert báró, mert pápista, mert protestáns, mert professzor, mert ifjú, mert tehetős, mert annyi prenumeránst szerzett... ${ }^{460}$ Vitkovics bár éles, minden kétséget kizáróan találó bírálatot írt a lapról, annak honi tudósításai messzemenően kielégítették az olvasókat. 1817-től Kultsár a Hazai 's Külföldi Tudósítások melléklapjaként megindította a Hasznos Mulatságok címü lapot is, ahová az irodalmi munkák kerültek.

Árulkodó bejegyzésre találtunk a Festetics Directio Protokollumaiban 1815-ben: „Trattner János Pesti Könyvnyomtató Eő Exját valamelly tudományos gyüitemény nevü társaságba hívja". ${ }^{461}$ A jegyzőkönyvvezető valószínűsíthetően semmit nem tudott az alakuló Tudományos Gyüjteményröl. Festeticset minden bizonnyal a Kultsár István által 1815. április 19-én, Pesten Kazinczy tiszteletére adott vacsorára volt hivatalos. A vacsorán ugyanis Fejér György javaslatára olyan lap megindítását határozta el, amelyben „,nem bántják egymást” a szerzők. Itt természetesen a nyelvújítási harcok miatt kirobbant vitáról volt szó. Olyan lap megalapítására szánták el magukat, amely a szépliteratúra mellett a tudományos igényü és értékü dolgozatoknak is teret adna. Trattner János Tamás vállalta az újság kiadását, amely aztán több szerkesztőváltással 1817 és 1841 között meg is jelent. ${ }^{462}$ Nincs arról tudomásunk, hogy Festetics eleget tett volna a meghívásnak. Két okból is: viszonya Kazinczyval közelről

\footnotetext{
${ }^{459}$ Markos, 2001. 49.

${ }^{460}$ Kókay, 1979. 250.

${ }^{461}$ MOL Fest. Lvt. P 279 Szakmutató, 1815

${ }^{462}$ Cséby, 2001. 51.
} 
sem volt felhőtlen, s a sajtót mindig titkárain keresztül támogatta. ${ }^{463}$ Exponálni semmiképpen nem akarta magát.

\section{4. Festetics György kapcsolatai az irodalommal és müvészetekkel}

E témában mind a mai napig legátfogóbb munkát Négyesy László írta. ${ }^{464}$ Négyesy dolgozatában részletesen foglalkozik Festetics írókhoz, költőkhöz füződő szinte valamennyi kapcsolatával. Az irodalmárok és Festetics közötti viszony erjesztői elsősorban Péteri Takáts József és Kultsár István voltak.

\section{4. 1. Mikes törökországi leveleinek kiadása}

Kultsár István még az 1790-es évek elején kereste fel Festetics Györgyöt Mikes Kelemen leveleinek kiadása érdekében. Az irodalomtörténet mind a mai napig csupán feltevésekkel szolgál arra vonatkozóan, hogy Mikes kézirata hogyan kerülhetett a szombathelyi tanárhoz Kultsárhoz. Először Toldy Ferenc tett kísérletet a kérdés megoldására. Szerinte báró Tóth Ferenc, aki 1762-ben mint francia tüzértiszt Konstantinápolyban járt megmentette a kéziratot. A francia forradalom elől Vas megyébe menekülve a kéziratot is magával hozta. Később átadta Kultsárnak, aki azonnal nekilátott a mű kiadásának megszervezéséhez. Pintér Jenő magyar irodalomtörténetében is közli Toldy feltevését, de valószínübbnek tartja, hogy a kéziratot egy Mészáros nevü ember hozta Magyarországra és Görög Demeter közvetítésével került Kultsárhoz. ${ }^{465}$ Később Thaly Kálmán arra hívta fel a figyelmet, hogy a kéziratot Mikes a bizalmát élvező Horvát Istvánra bízta. A kézirat Görög

\footnotetext{
${ }^{463}$ Kazinczy és Festetics ellentétének oka a következő: Kazinczy 1802. november 30-án kelt levélben fordul Festeticshez: „Nagyságodat jövök megkoldulni...” - írja. Leírja pénzügyi nehézségeit, fizetési kötelezettségeit és pénzt kér Gessner újabb fordításának kiadására. Nem alamizsnát kér, hanem „hazafiui áldozatot”.A kiadás vonatkozásában megírja Festeticsnek: „Ötszáz forintot kérek érette, azzal a’ szabadsággal, hogy Gessnert nem Nagyságod, hanem én magam adhassam ki.” A könyv elé természetesen odakerülne a köny kiadását támogató mecénás, Festetics neve. (MOL Fest. Lvt. P 279. 1802 : 1244. 672-674) ; Festetics titkára útján röviden elutasítja a kérést. Elsősorban azért, mert Kazinczy az udvar előtt több mint gyanús. Maga a király hívja fel egy beszélgetés kapcsán Festetics figyelmét: ,avval a bizonyos Kazinczyval kerüljön minden érintkezést.” Festetics az elutasítást bizonyosan nem fukarságból teszi. Ehhez hozzá kell tenni, hogy Kazinczy előbb Széchényi Ferencet kereste fel, aki valószínűleg hasonló okból, szintén elutasította. Mert, „aki az udvar előtt a gyanú hínárjába sülyedni nem akar, csak okkal-móddal érintkezhet Kazinczyval”. (Váczy, 1905. 321-353.)

${ }^{464}$ Négyesy, 1925. 37-233. Négyesy László pályadíjnyertes munkáját a Keszthelyi Helikon 100. évfordulójának tiszteletére meghirdetett pályázatra készítette. (Az ünnepségre az I. világháború miatt nem 1917-ben, hanem 1921-ben került sor. A dolgozat címe: Gróf Festetics György a magyar irodalomban )

${ }^{465}$ Pintér, 1942. 423.
} 
Demeter birtokába került, de - Hopp Lajos vélekedése szerint - sem ő, sem Kerekes Sámuel politikai okokból nem merte kiadni. Így kerülhetett Kultsár Istvánhoz. ${ }^{466}$

A 445 lapos, negyedrétü kézirat eredeti címe: Constantinapolyban Groff P... E... irott leveli M... K.... Kultsár István adta a kötet címeként: „Török Országi Levelek, mellyekben a II ${ }^{\text {dik }}$ Rákótzi Ferentz Fejedelemmel Bujdosó Magyarok Történetei más egyébb emlékezetes dolgokkal együtt barátságossan eléadatnak. Irta: Mikes Kelemen az emlétett Fejedelemnek néhai Kamarássa. Most pedig az eredetképpen való Magyar Kézírásokból kiadta Kultsár István Az Ékesszóllásnak Tanitója. Szombathelyen, Nyomtatta Siess Antal Jósef. 1794”. 467 Riethaler Mátyás kanonok a budai cenzor 1792. július 10-én adta ki a nyomtatásra szóló engedélyt. $^{468}$

A kiadás bevezető szövegében Kultsár nem tesz említést a kiadás mecénásáról. Kultsár Festeticshez írt levele rávilágít ennek okára, és ugyanakkor bizonyítja a kiadást finanszírozó személyét. A Festeticsek 1794. évi protocollumában, március 17-ei keltezéssel ezt olvashatjuk: „Professor Kultsár István Úr egész köszönettel megküldi azon Török Országi Leveleket, mellyek Ö Nagyága adakozásából, napfényre segítettek. Nevezeteken egy exemplart frantzia compacturában, $12^{\text {töt }}$ pedig kötetlenül”. A küldemény a következőlevél kíséretében érkezett:

\section{Méltóságos Gróf!}

Ime megjelennek Méltóságod előtt azon levelek, mellyeket a setétségből napfényre segitett kegyelmével. Méltóztassék őket olly kegyességgel fogadni, melly buzgó hálaadással nyújtom bé Méltóságodnak. Óhajtom ugyan, hogy nagy érdemeinek megismertetésére ezen bőkezüségét a könyvben hirdethettem volna, de az mostani változásokra nézve a gyanúságtól féltettem igaz Hazafiúságát. Miglen tehát nyilvábban kijelenthetem azt az elfelejthetetlen példákban tündöklő Hazai szeretetét, addig is azon örvendek Méltóságodnak, hogy szivében érezheti azt a gyönyörüséget, mellyet a jótétemények, 's a valóságos érdemek szoktak okozni még akkor is, ha titokban maradnak. De sokkal többek, 's nagyobban Méltóságod' érdemei, hogysem azokat vagy a Haza most nem tudná, vagy a maradékunk valahára elfelejthetné. Sött nagy híre napról napra inkább fog virágozni, és mennél későbbre terjed, annál felségesebben magasztaltatik ditsősége. Én szerentsésnek tartanám magamat, ha ezen érdemlett ditsőségnek

\footnotetext{
${ }^{466}$ Hopp, 2001. 106-107. ; Lásd még: Mikes Kelemen: Törökországi levelek és misszilis levelek. Sajtó alá rendezte: Hopp Lajos. Budapest, 1966.

${ }^{467}$ Arról a Siess Józsefről van szó kinek nyomdáját később Perger Ferenc nyomdász vásárolta meg. (Fülöp, 2010. 158.) ; Lásd még: A levelek eredetiségét és a levelek körül kibontakozott vitát boncolgató tanulmányt: Huttkay Lipót dr.: Mikes Kelemen törökországi levelei. Eger, 1905.

${ }^{468}$ Pintér, 1942. 423.
} 
bár leg kisebb részben is lehetnék nevelője. Azon való igyekezetemet ugyan elmúlaszthatatlan kötelességemmé teszem, és azon kérem Méltóságodat, hogy ezt az alázatos hálaadásképp bémutatott kész akaratomat méltóztassék kegyessen elfogadni, és engem kegyelmében megtartani, aki mély tisztelettel vagyok Méltóságos Grófnak

leg kisebb szolgája

Kultsár István

Szombathely

$17^{\text {dik }}$ Mart. $1794^{469}$

Az előbb említett protokollumból azt is megtudjuk, hogy a gróf pár kötetet beköttetett és azokat a könyvtárába helyeztette el, a többit szétosztotta a Directio tagjai között. ${ }^{470}$

Mikes leveleinek kiadás körüli bonyodalom kiválóan mutat rá arra a légkörre, amely akkor nemcsak Festetics Györgyöt vette körül, de amelyik jellemzően hatott az egész országra. Festetics maga kérhette, ebben az esetben is, hogy neve ne szerepeljen támogatóként. A politikai légkör óvatosságra intette, tartózkodóvá tette. Ebben az időben jelentette Martinovics Gotthardi rendőrfönöknek, hogy a Zala megyei szervezkedés élén Festetics és Spissich állnak. De pár hónappal később már megkezdődött Martinovics és társainak letartóztatása is. Mindazonáltal - írja Kurucz György - a fentiek rámutatnak arra is, hogy volt egy olyan közege a korabeli hazai belpolitikai életnek, melyet ténylegesen soha nem tudott ellenőrzése alá vonni a központi kormányzat. A vármegyék nemesi önkormányzati függetlensége ugyanis sok tekintetben lehetőséget adott az országos szintü politikai megnyilvánulások elökészítésére, hiszen senki sem tilthatta meg, hogy a megyék ne tájékoztassák egymást Közgyüléseik határozatairól. A példaadás hatásának fokozása érdekében azután e nyilvánosság erejét használta ki Festetics György, hogy látszólag egyéni indíttatású, de valójában országos jelentőségü kultúrpolitikai törekvéseit szélesebb körben is megismertesse. $^{471}$

\footnotetext{
${ }^{469}$ MOL Fest. Lvt. 391 cs. 227. ; Idézi: Kostyál, 1960. 475.

${ }^{470}$ Kostyál, 1960. 475-476.

${ }^{471}$ Kurucz, 2006. 1367.
} 


\section{4. 2. Festetics György a magyar színjátszás támogatója}

Festetics György a magyar nyelv és irodalom pártolás érdekében támogatta a magyar színjátszást is. Keszthely első ismert színháza Festetics György nevéhez füződik. A Georgikoni Fás Kertben felállított szabadtéri fő́ri színpad szolgált számos rendezvény helyéül. A Kerényi Ferenc által szerkesztett Magyar színháztörténetet feldolgozó kötet adatait Sági János cikkéből vette, amely a Vasárnapi Újságban ${ }^{472}$ jelent meg 1909 télutóján: „A negyvenhárom méter széles terepet négy méter magas gyertyánfák vették körül. A hét méter széles és két méter magas földszínpadhoz több út vezetett föl, hogy a szereplök könnyen megközelíthessék. Hat méterrel a „színpad” előtt sövény választotta el a zenekart a nézőtértől, melynek oldalbokraiban „páholyok” voltak”. ${ }^{473}$ 1909-ben már nem voltak meg a páholyok, csupán következtetni lehetett egykori létükre. A nézőtér 60-70 négyzetméter területü volt, a takarásokat különféle méretre nyírt, átláthatatlan bokrok voltak hivatva ellátni. ${ }^{474}$

Véleményünk szerint ez lehetett az első keszthelyi szabadtéri színpad, amelyről Richard Bright és Kisfaludy Sándor is írt. Kisfaludy az 1817. februári Helikonon látott egy színpadot, amely szerinte egy „amphiteatrum-forma” domb a zöld növényzet között, ahol tizenkét ifjú dudaszóra pásztortáncot járt. ${ }^{475}$ Hasonlóan írja le a színpadot 1815-ben Richard Bright is: „Aztán megint a Georgiconba mentünk. (...) Itt beszélgetés közben megálltunk egy fákkal körülvett gyepszínpad előtt, amely a gróf felvilágosítása szerint pásztorjátékok előadására van szánva. De abban a pillanatban dudaszót hallván a gróf felkiáltott: - Itt is vannak; most megláthatja, milyen előadást gondolok! Csakugyan vagy tizenkét fiatalember, magyaros bőrdolmányban és nadrágban, csizmában és nagy prémsapkában, minden oldalról a színpadra vonult. A grófi erdészeti iskola (Georgikon Cs.G.) növendékei voltak, s egy dudás jött velük. Mindegyikük nagy botot szorongatott. Azonnal nemzeti táncba kezdtek. Tánc közben hol körben mozogtak, hol diadalmasan rázták botjukat a levegőben, majd földhöz vágták, majd újra felvették. Tenyerükkel csizmájukat verdesték és hangos csattanással összeütötték bokájukat. Azután keresztben tartott vagy más-más irányba szegzett botjaikkal középre jöttek és élénken hadonásztak. A hellyel-közzel tombolóvá vált játék egyszer csak

\footnotetext{
472 Sági J., 1909.; Keszthely színházi életéröl többet: Szarka, 1990. 303-328..

${ }^{473}$ Kerényi, 1990. 33. ; Ugyancsak itt jegyzi meg Kerényi, hogy ez volt az egyetlen szabadtéri főúri színpad.

${ }^{474}$ Sági, 1909. 111.

${ }^{475}$ Kisfaludy, 1817.
} 
véget ért és a színészek elvonultak, ahogy jöttek, a falusi duda hangjainál”. ${ }^{476}$ Bright pontosan, szinte koreográfusi hüséggel írta le a fellépést. Ez az első tudósítás - legalább is Keszthely vonatkozásában - egy néptánccsoport fellépéséről. Később több bemutatóra is sor került a színpadon, amit a keszthelyiek mindig Arénának hívtak. 1862-ig müködött, amikor is megépítették az első keszthelyi kőszínházat. ${ }^{477}$

Sági azt vélelmezi, hogy a színház „ültetésére” az 1817-19-es Helikonok adták meg az ötletet. Ez téves következtetésnek tudhatjuk be, ugyanis a keszthelyi Georgikon Majormúzeum tulajdonában lévő, 1807-ben Szajdensvartz János által rajzolt tervrajzon ${ }^{478}$ már megtalálható a színház alaprajza. Ez az alaprajz hasonlatos a Sági féle cikket illusztráló alaprajzhoz. ${ }^{479}$ Ugyanis keszthelyi szabadtéri színpad, azaz „Theatromos kert”-et, amely szemben helyezkedett el a „Grottás kerttel”, 1804-és 1806 között ültették be növényzettel és 1807-ben készült el végleg. ${ }^{480}$ A színház a mai Georgikon (Alsópáhokra vezető út) utcától északra esett, tájolása kelet-nyugati volt. A színpad mögött, akár Hippokréné víze, folydogált a Szent Imre árok akkor még jóval bővebb patakja. Ez az árok volt tulajdonképpen a Georgikoni Fás Kert természetes nyugati határa.

A színházi sövényeket folyamatosan gondozták, pótolták a kiszáradt növényzetet. Ezt támasztja alá a Festetics Directió egyik jegyzőkönyve, ahol 1815. augusztus 31-ei bejegyzéssel a következőket olvashatjuk: „A' fejér égerfa sövények a' Theatrumnak déli oldalán való ki potlása rész szerint ugy is történnyen meg, hogy a’ bokrosabb tsemeték ki vétetvén, és gyökereivel együtt szellyel bontatván másunnan hozott jó földre ültettessenek mellynek November Hónapban mihelyest leveleiket vesztik kell történnie."481 Az eddigi dokumentumok alapján joggal vélelmezhetjük tehát, hogy Bright és Kisfaludy ugyanazt a színpadot írta le a XIX. század első negyedében, amelyet később a XX. század elején, Sági János is feltérképezett. ${ }^{482}$

Ha országos viszonylatban vizsgálódunk, akkor a Kelemen László által 1790-ben PestBudán életre hívott első magyar színtársulatot tekinthetjük a magyar nyelvü színjátszás első

\footnotetext{
${ }^{476}$ Bright, 1935. 32 ; A Georgikon erdészeti hallgatóinak mai utódja a több évtizedes múltra visszatekintő keszthelyi Georgikon Néptáncegyüttes, illetve a Tátorján Népzenei Együttes.

${ }^{477}$ VU., 1862. július 13. 28. ; Sági ugyan 1864-et ír cikkében, de az első keszthelyi kőszínházat (Keszthelyi Nemzeti Színház) egy Horváth István nevü épitőmester készítette el 1862-ben a mai (2012) Deák Ferenc és Sörház utca sarkán található telekre.

478 „A Georgiconi Majorral által ellenbe fekvő Teleken meg határozott es projectált Erdei Fás Kertnek Planuma. Az egész ABCD Teleknek lapja 5 Hold $520^{\square}$ 'd. A $A^{o}$ 1807. Szajdensvartz János által.”; Szajdensvartz János Alajos 1805-1807 között a Georgikon mennyiségtan tanára, 1806-1807 között archon, később uradalmi föépítész volt.

${ }^{479}$ Sági, 1909. 111. A keszthelyi kerti színház alaprajza Sági János fölmérése alapján.

${ }^{480}$ Németh, 1804.

${ }^{481}$ MOL Fest. Lvt. P 279 Protokollum anni 1815. augusztus 31. Rendelések.

${ }^{482}$ Lásd még: 838. lábjegyzet
} 
próbálkozásának. A színtársulat azonban csak 5 évig állt fenn. 1790-ben alapították Szatmárban az első ilyen jellegü vidéki színház is. ${ }^{483}$ Budán a német színház mellett létrejött magyar színházi társulat azonban állandó adósságokkal küszködött és téli játszóhelye sem volt. A vármegye anyagi és eszmei segítsége is jobbára elmaradt. A színtársulat segítségére siető pénzadományok is csupán a hiányok foltozására voltak alkalmasak, pedig 1792 végén a nádor 225, Festetics György 400, a rendek több mint 737 forinttal támogatták e nemzeti érdeket képviselő színjátszás fennmaradását, további müködését. Ezek a folyamatosan újratermelődő problémák előrevetítették az első magyar hivatásos színtársulat szükségszerü jövőjét. ${ }^{484}$

Festetics véleményét ezzel kapcsolatban Zala megye 1793. február 18-i jegyzőkönyvéből tudhatjuk meg, ugyanis a magyar nyelv, illetve a hazai színjátszás elősegítése érdekében a Magyar Játék Színi Társaság részére felajánlással élt, remélve azt is, hogy más föurak követik majd példáját: „Vice Ispány Úr jelentette, hogy Nemes Vármegye Rendelése szerént általa tett Jelentésekre némelly Földes Urak, és nevezetessen Gróff Szécheny(!) Ferencz és Festetics György Urak Eő Excellentiája, és Nagysága a Magyar Játék Szin Társaság részére Szép ajánlásokat tettek”. A felajánlási ív nem került elő - írja Sági Károly - így a felajánlások összege nem ismert. ${ }^{485}$

Szathmáry Király József Szabolcs vármegyei alispánnak a vármegyéhez Nagykállóból, 1794. szeptember 5-én címzett leveléből megtudjuk, hogy a vármegye gróf Nagykárolyi Károlyi József főispáni beiktatásakor felvetette „a magyar játékszínnek előmozdítását”. A levélben tett jelentés tulajdonképpen ennek megvalósulásáról szól. A levél szerint egy megfelelő játékszín építésére 400000 rhénes forint tőkepénz szükségeltetik, amelynek összegyüjtésében már jó néhány magyar förang példát mutatott. Így Festetics György 1000 rhénes forintot adományozott e célra. ${ }^{486}$ A játékszín azonban nem épült fel.

Festetics a kolozsvári színház építésére is adományozott. A színház telkét 1803. július 13-án vette meg öt arisztokrata: gróf Teleki Ferenc, gróf Teleki Lajos, báró Wesselényi

\footnotetext{
${ }^{483}$ Benda, 1978. 49-50.

${ }^{484}$ Kerényi, 1990. 65.

${ }^{485}$ Sági, 1972. 25. Lelöhely: Zala megyei Levéltár Protokollum de anno 1793. 152-153.

${ }^{486}$ A megajánlók listája Bayer József alapján: „A magyar játszószínnek megörökítésére szolgáló tőkepénzek kipótolására egyenlően 1000 - 1000 rftnak összetételével egybenállott hazafiaknak lajstroma 5 cento pro interesre: Czindery, Péczhy Imre, Szathmáry József, br. Vay Miklós, Kazinczy Ferenc, Jósa Gábor, br. Wesselényi Miklós, Hodosy Sámuel, Kazinczy András, Gróf Gyulai Sámuel Gömör vármegyéből, Fráter István, Rhédey Lajos, br. Podmaniczky József, Szirmay Ádám, Berzeviczy Gergely, Vay László, br. Palocsay, ottományi Komáromi György, gr. Barkóczy János, Fáy Ágoston konziliárius, Ibrányi, Szirmay Pál, Szerdahelyi László, Horváth Antal, Almásy József, Tisza László, gr. Keglevich György, gr. Berényi, gr. Festetics, Somogyi Ferenc, Kölcsey István szolgabíró, Lónyai László, Márjássy István, Rettegi Zsigmond, ifj. Patay József, id. Patay József”. Bár Festetics György csupán vezetéknevén szerepel, de nem lehet kétségünk afelől, hogy róla van szó. (Kerényi, 1987. 38. ; 284.)
} 
Miklós, báró Thoroczkai József és báró Bánffy József a református kollégiumtól 5000 rhénes forintért. Még ebben az évben megindult az építkezés, azonban gyorsasága a begyüjtött pénzek nagyságrendjétől függött. Az Országos Levéltárban, valamint fénymásolatban a Festetics Kastély Helikon Könyvtárában is megtalálható az a Festetics Györgynek címzett levélé, amelyet báró Wesselényi Miklós, gróf Teleki Ferenc, gróf Teleki Lajos és báró Bánffy József írtak alá. Azért ők, mert „....minket, kikre az Erdély Országi nemes Rendek az 1794 és 95 ${ }^{\text {dik }}$ Esztendőben tartott Országh Gyülésében egy Nemzeti Játszo Magyar Társaságnak fel állitását bízták vala". ${ }^{487}$ A levélben Festetics támogatását kérik a Kolozsváron létesítendő magyar színház felépítéséhez. Az országgyülés számára kinyomtatott jelentés szerint 1802 és 1808 között 14072 forint és 68 krajcár gyült össze. Az adakozók Erdélyből és Magyarországról is jobbára arisztokraták voltak. Magyarországon a kormányszéki tisztviselőkön túl elsősorban gróf Festetics György és herceg Esterházy Miklós támogatta a kolozsvári színház felépítését. ${ }^{488}$

Pesten 1815 és 1833 között csak alkalmilag fordultak meg társulatok, a színházépítés azonban folyamatosan napirenden volt. Mindazonáltal nagyon kevés, szinte semmilyen eredményt nem tudtak felmutatni. Pest vármegye kéréssel fordult Borsod vármegyéhez, hogy fogadja be a társulatot. 1815. július havának 1-jén a következőket írta: „A Magyar Játszó Társaság Hazánk főbb Várossát Pestet azon okból, hogy azon épület, mellyben mutatványait elöadta, a Város építésére Ügyelö Bizottságnak rendeléséből el adattatott, el hagyni kéntelenéttetvén, Nagyságotok, Kegyelmetek Megyejékben keresett menedék helyet, a holis Miskólcz várossában leg közelébb letelepedett”. Ugyanis 1815. augusztus 31-én Borsod vármegye közgyülése akceptálta a kérést és nemcsak befogadta, de a kérésnek megfelelően a közgyülés három színházi biztost is kinevezett Miskolczy György főadószedő, Szrogh Sámuel táblabíró és Eröss József szolgabíró személyében. Ök hárman 1820. január 2-án kértek levélben támogatást a nemes ügynek, de már az új gróftól, Festetics Lászlótól. ${ }^{489}$

\section{4. 3. Festetics György és Csokonai Vitéz Mihály}

Csokonai Festeticshez füződő kapcsolatát sokan, sokféle módon értelmezték. Bár Csokonai munkásságát szinte teljes egészében feldolgozták, itt elsősorban Vargha Balázsra, Szilágyi Ferencre és Debreczeni Attilára gondolunk, számos Keszthellyel, Festeticcsel

\footnotetext{
${ }^{487}$ MOL Fest. Lvt. P. 248 ; Fest. K. Hel. Knyvt. 1976/79. (Másolat) ; Benda, 1978. 50.

${ }^{488}$ Kerényi, 1990. 158.

${ }^{489}$ MOL Fest. Lvt. P. 248. ; Fest. K. Hel. Knyvt. 1976/79.
} 
kapcsolatos válasz végére nem került pont. Nem volt tisztázott hányszor járt Keszthelyen, miért feddte meg a gróf a csurgói záróvizsgán, tartozott-e Festetics Csokonainak, szándékáéban volt-e támogatni a költő munkájának kiadását? Számtalan kérdés, amelyekre e fejezetben próbálunk meg választ adni.

Csokonai Festetics mecénási kegyeit keresve látogatott el a Balaton-parti városba, Keszthelyre. Vas Gereben kedves anekdotával emlékezik meg az eseményről: „Midőn Csurgón tanítóskodott, akkor voltak a keszthelyi Helikoni ünnepélyek melyeken az irodalom emberei tömegesen sereglettek össze. Az egyszerü poéta megelégedett azzal, hogy szerény bámulója legyen az ünnepségnek, tehát ahogy tellett, azaz gyalog ment Keszthelyre, ahol odaérkeztekor minden zúg tömve volt, s így Csokonay (sic!), minthogy a kastélyba a világért sem mert volna menni, a vendéglőben nem kapott egyéb helyet, mint a bormérőrekeszben". 490 Majd leírja Vas Gereben, hogy reggel a kastély parkjában sétálgatva az egyik asztalra ráírta:

Festetics! itt voltam, mint árva poéta gyalog csak;

Ám de mezítláb is szívesen itt vagyok én.

\section{Csokonai Vitéz Mihály}

Az anekdota szerint később a gróf ezt elolvasván felkereste Csokonait a fogadóban és sok huzavona után bevitte a kastélyába. A történet írója így zárja: „A gróf szobáját osztá meg a költővel, ki aztán csurgói székébe azon hittel ment, hogy kevesen bár, de néhányan mégis vannak, akik a szegény magyar költőt becsülni tudják".

Bisztray Gyula a Jókedvü magyar irodalom ${ }^{491}$ című összeállításában közli Vas Gereben eme írását, de már korrigálja; miszerint nem a Helikoni ünnepség, de a georgikoni vizsgák idejére datálja az eseményt. A történetet Laczkó András szintén átveszi a Keserédes történetek ${ }^{492}$ címü kötetébe, de jelzi annak lehetetlenségét is.

Az anekdota egyetlen valós momentuma Csokonai keszthelyi tartózkodása. Szállása a mai Amazonban, a város akkori egyetlen tekintélyes, egyemeletes, copf stílusú vendégfogadójában volt. Ennek emlékét örökíti meg az épület falán elhelyezett márványtábla is. ${ }^{493}$ Simon István 1954-ben írt, „Csokonai a vendégfogadóban "494 című versével állít emléket neves elődjének. A történet többi része kitalált. A Helikoni ünnepeket 1817-1819

\footnotetext{
${ }^{490}$ Vas, 1856. 43-49.

${ }^{491}$ Bisztray, 1986. 60-62.

492 Laczkó, 1991. 8-10

493 A tábla szövege: Itt szállt meg Csokonai Vitéz Mihály a nagy magyar költő 1798-ban. 1954. Keszthely városa

494 Simon, 1982. 110-112.
} 
között rendezték meg, Csokonai halála után 12 évvel. A vers is - mutat rá Vargha Balázs csupán ,,a korai anekdota-tradícióhoz tartozik”. 495

Csokonai keszthelyi, így Festeticshez füződő kapcsolatait kis erőltetéssel 1797 és 1803 közé tehetjük.

A költő 1797. júliusában Komáromban megismerkedett Vajda Juliannával. Az akkor 24 éves Csokonai szerelmes lett a fiatal lányba, ám Vajda Julianna apja leszögezte; a házasság feltétele, hogy Csokonainak megfelelö állása és jövedelme legyen. Csokonai úgy döntött, hogy a „keszthelyi gróf” iskolájába vállal tanári állást. Tervét annál is inkább reálisnak érzete hisz müködött a csurgói gimnázium és megnyitotta kapuit a Georgikon is. Csokonai személyesen látogatott el Keszthelyre. Ferenczy Miklós Csokonai Lillája címü könyvében ezt írta: „1797 decemberében ismét Keszthelyre utazott”. ${ }^{496}$ Az „ismét” szó itt valószínűleg sajtóhiba, vagy elírás.

Kisszántói Pethe Ferenc, aki tizenegy évvel volt idősebb Csokonainál és akit még Debrecenből ismert, ekkor már a Georgikon tanára volt. ${ }^{497}$ Csokonai bízott Pethe pártfogásában. A költő 1797 év végén Keszthelyen volt és több, mint valószínű a karácsonyt és az újesztendőt is ott töltötte. Minden bizonnyal Keszthelyen írta meg a campoformioi béke megkötésének emlékére szánt „A békekötésre” című versét. Ezzel ért egyet Szilágyi Ferenc is Csokonai kritikai kiadásában. ${ }^{498}$ A keltezés segítségére volt a vers kéziratán eltérő árnyalatú tintával, de a költő kézírásával csatolt függeléket:

E’ szívből eredett Újesztendői Ajándék

Záloga szívemnek légyen örökre Juli!

Éljetek, óh szeretett Lelkek! kiket édes örömmel

Gyakran emlegetek hegy közi lakhelyemen.

Most Levelem tisztel; hanem a' Fársángi napokban,

A’ mint már írám, Városotokba megyek.

Mert akkor Juliána' Nevét, a' mellyet imádok,

A’ maga képében fogja köszöntni VITÉZ. mk.

\footnotetext{
${ }^{495}$ CsEml, 1960. 624.

${ }^{496}$ Ferenczy, 1984. 22.

${ }^{497}$ Cséby, 2000. 69. A dolgozat Csokonai Keszthelyhez és Festetics György grófhoz füződő kapcsolatáról közöl adalékokat.

${ }^{498}$ Csokonai ÖM.. 1994. 391.
} 
A vers felett Csokonai keze írásával ez a keltezés olvasható: Keszthely, 24. Dec. $1797 .{ }^{499}$

Nem tisztünk itt a vers keletkezésének körülményeit részletesen taglalni, azt viszont leszögezhetjük, hogy a „hegy közi lakhely” azonos Keszthellyel. Csokonai a függelék versben azt ígérte, februárban Lilla névnapján már együtt ünnepelnek Komáromban. A lényeg: Csokonai több napot töltött el Keszthelyen, amelyröl azonban ez idáig konkrét életrajzi adatokkal nem rendelkezünk. ${ }^{500}$ A viszonylag rövid tartózkodás oka lehetett, hogy nem tudott Festeticcsel beszélni. Talán Pethe sem volt Keszthelyen, vagy legalább is, mint másodtanár kevés információval rendelkezett az intézmény személyi dolgait illetően. Remélhetjük, ha Pethe tudja a valót, Csokonait megkímélte volna az 1798-as tavaszi úttól.

Csányi László írja, hogy Csokonai 1798 tavaszán pár hetet töltött a gróf kastélyában Keszthelyen, ahol átdolgozta Bürger elégiáját (Als Molly sich losreissen wollte), itt keletkezett a Bácsmegyei leveleire, Az estvéhez. ${ }^{501}$ Mindamellett, hogy e versek keletkezése az átírások miatt bizonytalan - ahogy erre Szilágyi Ferenc is felhívja a figyelmet ${ }^{502}$ - nem datálhatjuk a több hetes tartózkodást 1798 tavaszára, legfeljebb csak 1797 és 1798 évek fordulójára. ${ }^{503}$ Egy bizonyos, 1798. január 22-én már Komáromból írt Festeticsnek. „A’ ki hívatalt kér, arról sokan sokképpen - 's többnyire balúl ítélnek. Ki azt mondja, hogy szemtelen, ki azt, hogy azért tolja magát elő, mert érdemtelen voltában mások reá nem akadtak volna. Kiről ki hogyan ítél, ítéljen: én legalább érzem, hogy nemesebb Rúgó ösztönözi Intézeteimet. Nagyságodnak Nagylelkéhez, 's magam középszerü tehetségemhez való bízakodásom az, a' melly engemet felbátorított arra, hogy Nagyságodnál magamat, érdemlett tisztelettel, 's alázatossággal Professzori hívatalra béajánljam". A levél további részében megismétli kérését: „méltóztasson engemet valamellyik Oskolájában Professzorságra kegyelmesen felvenni; hogy így mikor pénz nélkül visszatérek, légyen magamnak és gyámoltalan özvegységre jutott Édes Anyámnak hol találni menedéket a' Nagyságod' szárnyai alatt". 504 Csokonai Festeticset érzelmi oldalról szerette volna megnyerni magának. Ezért írt édesanyjáról és ezért nem szólt Vajda Juliannáról, aki miatt tulajdonképpen a munkát vállalni akarta. Tehát nem egyértelműen a Georgikont említi. Mivel ebben az időben csak Keszthelyen több iskola is müködött, meg merjük kockáztatni azt a feltevést, hogy Csokonai

\footnotetext{
499 Szilágyi, 1981. 334-335.

500 Sem Szilágyi, sem Vargha Balázs nem foglalkozik Csokonai 1797-es keszthelyi útjával, bár elismeri annak megtörténtét. (Szilágyi, 1981. 335.)

501 Csányi, 1962. 55.

502 Szilágyi, 1981. 286-343.

${ }^{503}$ Cséby, 2000. 69-70.

${ }^{504}$ Csokonai Lev., 1999. 76-77. Csokonai Vitéz Mihály Festetics Györgynek, Komárom, 1798. január 22. MOL Fest. Lvt. P 279. 1798:148
} 
kérelmét ne csupán a Georgikonra és esetleg Csurgóra szűkítsük. Az előbb említett iskolák jó néhányát persze eleve kizárhatjuk, de a többit számba kell vennünk, annál is inkább, mivel jó részük ez idő tájt indult, s Csokonainak a keszthelyi tartózkodása alatt fülébe juthatott az iskolanyitások terve. A legnagyobb megtiszteltetés természetesen egy georgikoni professzori állás lett volna és a költő dédelgetett álma is ez volt, hisz a levél további részében megemlíti Festeticsnek, hogy kis vagyonkáját eladva Svájcba utazna mezőgazdasági jellegü tanulmányútra. Csokonai tudhatta, hogy a gróf iskoláiban elsősorban a világjárt tanárokat alkalmazza - és a korabeli adatok alapján leszögezhetjük: volt kiböl válogatni. A külföldi út azonban csak pillanatnyi fellángolás, nagyzoló ötlet - figyelmeztet Debreczeni Attila -, ugyanis Széchényi Ferencnek másnap megírt levelében teljesen más célokról ír. ${ }^{505}$

Festetics február 19-én válaszolt a kérelemre. Az eredeti levél nem maradt fenn, csak az iktatókönyvben található kivonat ismert, ahol a gróf közli, hogy a Georgikonban állást nem tud biztosítani, mivel a jelenlegi tanárt elbocsátani nem akarja, több pedig nem kell. ${ }^{506}$ Erre persze minden alapja megvolt Festeticsnek, hisz akkor csupán két fő tanult az intézményben. Itt azonban meg kell jegyezni: úgy tünik, hogy Festetics is elsősorban a Georgikonra gondolt.

Csokonai mintha nem kapta volna meg a levelet, mindenkinek a biztos válasz megérkezését sugalmazta. Magát is áltatta? Közben egyre komolyabb kérővé lépett elő Lilla apjáéknál Lévai István dunaalmási kereskedő. Csokonainak sietnie kellett, így újból tervbe vette keszthelyi útját. De a dolog tragikus fordulatot vettek Csokonai és talán Lilla számára is. A költő megírta a sok irodalomtörténeti és filológiai fejtörést okozó két levelét: egyet Komáromból, egyet Mocsáról. ${ }^{508}$ A komáromi levél kétségbeesett búcsú a kedvestől: „Lili többé nem az enyém. Lilinek vége van, vége minden én reménységemnek, az én szivem, az én lelkem, az én életem, ismét a holtig-való magányosságra, az emésztő bura és a titkos nyögésre van kárhoztatva. (...) Mert az én szivem ugy van alkotva, hogy az kettőé sohasem lehet, Te birtad azt, és te kivüled senki meg nem nyerhette volna. Csudálkozom, hogy a tied ugy megváltozott, ugy elpártolhatott attól a kinek már ajánlva látszott”. Majd később, mintha nem kapott volna Festeticstől elutasító levelet a következőket írta: „, Még most sem lett volna késő, még meg lehetett volna mindent orvosolni, és József-napra a grof hintaján láttál volna bé menni udvarotokra. Két hét alatt minden köny öröm-könyekre változtak volna! (...) Két hét múlva egy városbeli Professzorné lettél volna, én pedig legboldogabb teremtés te általad.” Majd végső búcsúként, így folytatta levelét: „Elmegyek Keszthelyre és csak édes emlékezeted

\footnotetext{
505 Csokonai Lev., 1999. 528.

${ }^{506}$ Csokonai Lev., 1999. 529.

${ }^{508}$ A keltezéssel kapcsolatos problémákat lásd: Csokonai Lev., 1999. 533-548.
} 
viszem el magammal. Üres lesz az én szobám te töled: de szivemben mindenkor jelen leszel. Elmegyek Keszthelyre te pedig Almásra s két egymásért teremtett sziv ily messze fog egymástól esni mind örökké. (...) Isten hozzád! - Csokollak - még egyszer - a legutolszor csokollak - - Ah elveszett kedves Lillám Istenhozzád'."509 A levél kelte: 1798. március 12., az aláírás pedig Profeszor Csokonai. Vajon csak Lillának szólt a megelölegezett titulus, vagy a leány apjának is? Talán mindkettőjüknek.

E búcsúlevél után valóban furcsának tünik az 1798. március 18-án keltezett mocsai levél: „Óhajtott Szép Kintsetském! Ime midőn te Éretted ki indúlok az én Balatoni útamra, sírni láttatik az Ég, és szomorú felhőknek fátyolával borította el kedveltető homlokát. (...) És azonn az első Napon, a' mellyen lehet tőlem, azonn az első Napon indúlok fel a' te szép Kebelednek megölelésére. Most se lett volna ennyi baj, ha a' télen jobban siettem volna. (...) Légy, Kintsetském! mindvégig állhatatos, én szavamnak ura leszek. - Köszönt téged ezer tsókkal a' Te hív V(itéze)d”. ${ }^{510}$ Talán az előző levél után a költő biztatást kapott, Lillától, esetleg Lilla apjától: ha megfelelö állást kap, feleségül veheti Vajda Juliannát. Nem szabad azonban megfeledkezni a mocsai levél következő mondatairól: „De van Levelem az én Lillámtól, van az én Lillámtól Levelem. - - Áldalak oh jóltévő szerentse! 's kezdem érzeni, hogy te vélem nem ellenségeskedel. Tsókolom ezerszer azokaz a' betütskéket, a' mellyek Kedvesemnek ujjaitól származtak. Megvan legfőbb örömöm: ki érzi azt most, a’ mit én? Mellyik halandónak szíve repes úgy, mint az enyém? Köszönöm, édes Juliánnám! ezt a’ vigasztaló Levélkédet, köszönöm szívednek igaz hűségét, - százszor köszönöm”. Lillának melyik leveléről van szó? Azt is feltételezhetjük, hogy március 12 és 18 között bátorító, vagy bátorítónak vélt levelet kapott Vajda Juliannától, ezért a változás. Mindenesetre elindult Keszthelyre.

Amint a költő kitette lábát Komáromból, Lilla apja ostromolni kezdte lányát és olyan cselekvéshez folyamodott, amit a legjobb indulattal sem lehet tisztességesnek nevezni. Gaál László emlékezése szerint a kétségek közt hányódó leány ezt követőn Komáromból levelet küld Csokonainak, valószínűleg Keszthelyre: „Kedves Drága Lélek! Én élek és vigan, - azt hallom az úr is vigan mulat Keszthelyen. Én az urat óhajtom, várom is, mindazonáltal mikor leg jobbnak véli és itéli az Úr akkor jöjjön, Ha soká késik, addig a Lidi is férjhez megy. Ezzel maradok az Urnak hüséges Juliannája". ${ }^{11}$ Lilla nem kapta meg Csokonai leveleit, mivel

\footnotetext{
${ }^{509}$ Csokonai Lev., 1999. 81-84. Csokonai Vitéz Mihály Vajda Juliannának, Komárom, 1798. március 12. MTA K 668. 23a 24b; K 672/I. 22b.

${ }^{510}$ Csokonai Lev., 1999. 85-86. Csokonai Vitéz Mihály Vajda Juliannának, Mocsa, 1798. március 18. MTA M.Irod.Lev. 138/I.4.

${ }^{511}$ CsEml., 1960. 421.
} 
azokat apja eldugdosta. A leány végül 1798. március 30-án kezét nyújtotta Lévai Istvánnak. Csokonai Nagyvázsonyban, Édes Gergelynél értesült Lilla házasságáról, mégis elindult Festetics meglátogatására. Szinte a résztvevő pontosságával megírt Gaál-féle visszaemlékezés megírja, hogy Pethe Ferenc semmiképpen sem bíztatta, mert a gróf a fizika és a filozófia tanítására már megegyezett a premontrei renddel és azon változtatást nem tehet. ${ }^{512}$ Bár Pethe barátságos volt, még Festeticsnek is bemutatta, s a költő a grófot - Gaál szerint - egyik kötetével meg is ajándékozta. Csokonai pár napot töltött Keszthelyen, ahonnét továbbindult Festetics három aranyával Somogy vármegye irányába. A továbbiakban már csak levelezés útján volt kapcsolata Keszthellyel, Festeticcsel még többször találkozott. ${ }^{513}$

1799 áprilisában Csokonait váratlanul éri a csurgói tanítói állás. Nem állandó, csak helyettesítő tanárnak veszik fel a külföldön tanulmányúton lévő Császári Lósi Pál helyett. Az állás tehát átmeneti, Csokonai mégis teljes szívvel áll neki a tanításnak. Horváth József tanulmányában összefoglalja a Festeticsnek írt, Csokonai első tanítóskodása eredményét bemutató leveleket. Csépán István fiskális szerint: „már május 24-től ott van mint időközi professzor Csokonai Úr és a tanulók nagy tetszésére tanít”. Szentgyörgyi esperes 1799. június 13-án írja: „Méltóságos Gróff, Nagyságosa Uram! örömmel tanittya Csokonyai Mihály úr interimaliter a Csurgói Ifjakat, azok nagy kedvvel tanulnak”. Sárközi István nagybajomi földbirtokos, megyei tisztviselő június 17-i leveléből. „Hivatalombul annyi időcskét szakíttatván, hogy itt való Oskola mostani állapottyát megtekintsem, nagy örömmel tapasztaltam hogy interimaliter substitutus Csokonyai Úr a Tanulóknak helyes contentumokra és nem kevés épülettel jár el kötelességében. A methodus docenti, modus agendi, melyet mint publice mint sétálási közben Tanítványaival elkövetni szokott igen magához édesítette őket $\mathrm{s}$ minden jó reménységet nyújt Császári Úr eljöveteléig maga felöl”. ${ }^{514}$ A levelekben külön kiemelték, hogy Csokonai helyettesítő tanár, amivel Festeticset akarták megnyugtatni, hogy a világlátott Császári Lósi Pál helye biztosított.

\footnotetext{
${ }^{512}$ „A fogadóba háltak, s innen mentek látogatására a Georgikon akkori igazgatójának, Kis Szántói Pete Ferentznek, kinek is mint földijének Csokonai elöterjesztette idé jövetele okát, s nézeteit s kívánságát. Keszthelyen a derék [magyar szívü] Professor Kis Szántói Pete Ferentz nem tsak barátságos szívességgel fogadta, hanem a tiszteletre méltó Grof Festetits Györgynek be is mutatta - a ki is öket - s különössen Csokonait - minekutánna ez a Grofot, akkoriban már nyomtatott munkájával megtisztelte - egész betsülettel látta. Jóllehet Csokonai a Grofnak eránta hajlandóságát tapasztalta - de mivel Pete Ferentz úrtól elöre megértette, hogy az intézetnek nagyobbra kiterjesztését tsak a következendő évekre határozta, azonban a Philosophiai és Physicai Cathedrák eránt a Praemonstartensis Tisztelendő atyákkal tractusba bocsátkozott, - Csokonai kívánságát a Grofnak nem is jelentette.” (Cs.Eml., 1960. 424 ; Cséby, 2000. 72.)

513 Cséby, 2000. 73.

514 Horváth, 1992. 29.
} 
Csokonai és Festetics György személyes találkozását Csurgón kellemetlen incidens zavarta meg. Festetics György az 1799. július 10-én, vagy 12-én ${ }^{515}$ megtartott csurgói záróvizsgára érkezett, ahol a diákok Csokonai vezetésével betanulták és bemutatták a Cultura avagy Pofók címü színmüvét. Ma már nem vitatható, hogy darabjában helyi személyiségeket formázott meg. Tisztesben egyértelműen Nagyváthyra lehetett ismerni, Petronellában Nagyváthy házvezetőnőjére, Szakay Katalinra, a hencegő Szászlakyban Császári Lósi Pálra. ${ }^{516}$ Az előadás alatt nem is volt semmi baj, míg az egyik szereplő el nem énekelte a „Hej Rákóczi, Bercsényi..” kezdetű nótát. ${ }^{517}$ Festetics már az előadás alatt felháborodva fordult a mellette ülő Csépánhoz, vagy Csokonaihoz: „Uram illyenekért Oskolánkat is széllyel hányhatják - vigyáznunk kell!",518 A gróf mellett Sárközy István is megszidta barátját emlékezik vissza Gaál -, mondván, „távoztatnunk kell az ollyast mikben valaki megbotránkozhatna”. Csépán Istvánhoz írt levelében Festetics szigorú ítéletet mond: „...mert annak a parasztfiúnak Rákóczi és Bercsényiről elénekelt dala, jóllehet tréfálkozva és némi gúnnyal lett előhozva, sem a hallgatósághoz, sem a helyhez, sem a mostani időhöz nem illett, sőt egyáltalán menthetetlen hiba volt. Részemről ugyan határozottan kijelentem, hogy ha még ezentúl is meghívatnám, soha addig meg nem jelenek, míg kellő bizonyítékot nem nyerek arról, hogy a közvizsgán vagy efféle látványosságon semmi olyan elő nem hozatik, ami gyanúra vagy kétértelmü magyarázatokra szolgálna alkalmul. Sokkal helyesebb volna és arra is kell törekedni, hogy az ilyes ünnepélyeken uralkodó felséges urunkat, vagy a felséges nádort dicsénekekkel magasztalnók szívünk teljességéből. Ezt kívánja tőlünk a csak közelebb megnyert kegyelmes királyi engedélyért való hála is, hogy egyéb ebből ránk háramló hasznokat elhallgassak." ${ }^{519}$ Festetics feddése érthető és politikus. A vizsga 1799-ben volt, amikor Festetics az 1797-es zala megyei felszólalása miatt már elvesztette kamarási kulcsát, megtiltották az udvarnál való megjelenését és minden lépését besúgók figyelték. Ugyanakkor az uralkodó mégiscsak engedélyezte az iskola müködését. Festetics nem tett mást, mint aggódott valamennyi iskolájáért, amit már eddig megvalósított. A levél azonban érdekes kitételt tesz, nem a hasonló darabok színre vitelét tiltja meg határozottan, hanem azt; ha ő ott van, ilyeneket nem játszhatnak. A szóbeli feddést követő levél nemcsak Csépánnak és

\footnotetext{
${ }^{515}$ CsEml., 1960. 437-438. Gaál visszaemlékezése

${ }^{516}$ Horváth, 1992. 30 ; Lásd még: Laczkó, 1981. 20.

${ }^{517}$ A Rákóczi Szabadságharc utáni időkből, a XVIII. század végéről származó, fél népi eredetü, folklorizálódott dalról lehet szó, amely több változatban ismert: „Hej Rákóczi! Hej Bercsényi! / Dicső magyarok vitézi! / Sebeink csak nem szünnek, / Fájdalmaink nem enyhülnek.” Vagy „Hej Rákóczi, Bercsényi,/ Magyar vitézek nemes vezéri! / Hová lettek, hová mentek / Válogatott vitézi?”, de az egyik variációban Bezerédi (Bezerédj) is megjelenik.

${ }_{518}$ CsEml., 1960. 437. Gaál visszaemékezése.

${ }^{519}$ Laczkó, 1981. 23. ; Horvát, 1992. 31.
} 
Csokonainak szólt, hanem Festetics megnyilvánulásait, tetteit számba vevő és jelentő titkosrendöröknek is.

Császári Lósi Pál 1800 februárjában érkezett Csurgóra és március 19-én iktatták be. ${ }^{520}$ Ezért kerülhetett a csurgói gimnázium falán elhelyezett emléktáblára az 1800. február 17-es dátum, miszerint Csokonai akkor fejezte be tanári tevékenységét. Nem állítunk mi sem mást, csak azt, hogy Csokonai még legalább március 19-ig Csurgón maradt, hisz ebben az időben búcsúzott el tanítványaitól is. ${ }^{521}$ Csurgót elhagyva Szigetvárt érintette, ahol két napot töltött gróf Festetics Lajos ${ }^{522}$ vendégeként, megbámulta a várat $\mathrm{s}$ az élmények hatása alatt megerősödött benne a közel öt éve dédelgetett nagyobb mű megírása. Az Árpádhoz hasonló epopeián ${ }^{523}$ kezdett el gondolkodni, melynek hőse Zrínyi Miklós lenne. Festetics György aki értesült Csokonai tervéről megígérte, hogy a csáktornyai várában lévő két Zrínyi, a szigetvári hős és a költő arcképét elkészítteti számára. ${ }^{524}$ Erről Csokonai nagy örömmel számolt be Kazinczynak 1804. június 14-én írt levelében: „El is mentem a’ Várhoz, a’ tábor' helyéhez, a' tábori Rezidentiájához az Uraság' kotsiján, a’ ki azt is megígérte, hogy a’ Szigeti Parochiale Templomnak (Török Moschée volt) hemisphaerica Cuppoláján lévő pompás festést, melly a' Zrinias foglalatját adja elö, a’ könyv eleibe lerajzoltatja. Ennél még többet ajánlott Gróf Festetits György Ő Nga, a' ki a' Hérós Zrininek, 's a' Poéta Zrininek valóságos képeket, mellyek a Csáktornyai Várban in Origináli megvannak, a számomra megígérte". 525 A tervezett kötetből azonban nem lett semmi.

1800. december 19-én Debrecenből Csokonai levelet intézett Festetics Györgyhöz, amely levélben két dolog érdekel bennünket. Munkájának kiadása és az a panasz, miszerint két forinttal hagyta ott Csurgót: „....még a’ fizetésemet sem vettem el, tudván a’ Tractusnak tagadhatatlan szegénységét". ${ }^{526}$ Festetics megkapta a levelet és 1801. január 9-én kelt válaszában megírta: „Az Úr nemesi felszánásának, mellytől indíttatván Csurgón a’ fizetését ki nem vette, igaz betsüllöje lévén, ezen Nagy Szívüségnek jutalmáúl ezennel 25 ftokat küldök

\footnotetext{
${ }^{520}$ Bertók, 1973. 157-158.

${ }^{521}$ CsEml., 1960. 439 ; Horváth, 1992. 33. ; Bertók, 1973. 158.

522 Tolnai gróf Festetics Lajos (1772-1840) Festetics I. György elsőfokú unokatestvére. Édesanyja nagy-jókai hügyei Farkas Krisztina (1743-?), édesapja Festetics Lajos (1732-1797) Festetics Pál (1722-1782) testvére.

${ }^{523}$ Festeticsnek írt leveleiben többször tesz említést az Árpád-ról, gyakorlatilag a tervezett müből csak az elöhang és egy szükszavú vázlat maradt fenn. (Juhász, 1977. 28.)

${ }^{524}$ Cséby, 2000. 73. ; Minden bizonnyal a keszthelyi Festetics kastély kiállításán ma is szereplő két Zrinyi képröl van szó (2009).

${ }^{525}$ Csokonai Lev., 1999. 300. Csokonai Vitéz Mihály Kazinczy Ferencnek, Debrecen, 1804. június 14. MTA M.Irod.Lev. 4-r 37/9

${ }^{526}$ Csokonai Lev., 1999. 108.Csokonai Vitéz Mihály Festetics Györgynek, Debrecen, 1800. december 19. MOL Fest. Lvt. P 279. 1800:1423
} 
az Úrnak; kinekis Barátságába magamat ajánlván minden tisztelettel vagyok". ${ }^{527}$ Festetics tértivevénnyel, recepissével adta fel a levelet a pénz miatt ám a pénzt a költő nem kapta meg, mivel elveszett, vagy ellopták a postán. A tértivevény is csak késve, érdeklődést követően érkezett vissza a grófhoz. Csokonai megírja Festeticsnek, hogy hiába szaladt azonnal a postára „felőle semmit sem akartak tudni, mondván, hogy a’ Postán úgysem szabad pénzt küldeni". ${ }^{528}$ Festetics elhatározta, hogy ismét elküldi Csokonainak a 25 forintot, de igazolásokat kért a költőtől arra vonatkozólag, hogy valóban nem volt pénz a levélben. ${ }^{529} \mathrm{~A}$ magyarázó levél két formában került megfogalmazásra, de csak a másodikat küldte el Csokonai. ${ }^{530}$ Csokonai 1801. május 16-án megírt, de a posta késlekedése miatt csak 1801, július 7-én (újrafogalmazva) a grófnak megküldött levelében részletesen leírja, hogyan vette kézbe a pénz nélküli levelet. ${ }^{531}$ Festetics augusztus 21 -én kelt válaszában zárja le a konfliktust azzal, hogy megírja Csokonainak: pénze már Pesten van Pintér György ügyvédnél, akitől a költő Pesten lévő és Debrecenbe utazó barátja bármikor felveheti. Úgy tünik Csokonainak Pesten nem volt Debrecenbe utazó barátja, önmaga pedig nem vállalkozhatott az utazásra. Éppen ezért szeptember 2-án Pintér György ügyvéd sürgeti a költőt a pénz felvételére. ${ }^{532}$

Csokonai 1799-ben Hedrehelyen és Csökölyben megírta vígeposzát, a Dorottyát, vagyis a' dámák’ diadalmát a' Fársángon. Festetics értesülhetett a vígeposzról és felajánlotta Csokonainak a mü kiadását. Szilágyi Ferenc szerint Csokonai szerette volna megnyerni a grófot, hogy a Dorottya megjelenhessen, 1800. december 19-én kelt levelében azonban meghátrált és másik művét ajánlotta: „...hogyan nyerhetett az én egyűgyü Múzsám annyi Pártfogást NAGYSÁGODTÓL? - Nagyságodtól, a’ Kivel az Ángliai Zsenik barátkoznak, 's a’ Frantzia Szép-lelkek megtestvéresedtek. - Eleven hála pesdült meg bennem, a’ midőn NAGYSÁGODNAK azt a’ Kegyes Ajánlását, hogy a’ Farsangról írott Heroicocomicumomat kinyomtattatni méltóztatik, hallani szerentsém volt; de midőn ennek belső mivoltát elgondolám, meghúnyászkodtam, és sajnáltam hogy illy tsekély tárgyú 's készűletű munkámnak lehetett éppen szerentséje a’ NAGYSÁGOD Grátziájához. Illy szándékból

\footnotetext{
${ }^{527}$ Csokonai Lev., 1999. 113. Festetics György Csokonai Vitéz Mihálynak, Keszthely, 1801. január 9. MTA K $3 / 39(\mathrm{~K})$

${ }^{528}$ Csokonai Lev., 1999. 121. Csokonai Vitéz Mihály Festetics Györgynek, Debrecen, 1801. ápr. 10. k. MTA K $3 / 14(\mathrm{~K})$

${ }^{529}$ Csokonai Lev., 1999. 125. Festetics György Csokonai Vitéz Mihálynak, Keszthely, 1801. április 21. MTA K $3 / 40(\mathrm{~K})$

${ }^{530}$ Erről részletesen lásd: Csokonai Lev., 1999. 625-626. és Csokonai, 1844.

${ }^{531}$ Csokonai Lev., 1999. 131-135. Csokonai Vitéz Mihály Festetics Györgynek. Miskolc, 1801. július 7. és Debrecen, 1801. május 16. MOL Fest. Lvt. P 279 1801:812

${ }^{532}$ Csokonai Lev., 1999. 145-146. Pintér György Csokonai Vitéz Mihálynak, Pest, 1801. szeptember 2. MTA K 4/32 (K)
} 
fordítottam tehát a' Virgilius Georgiconját..." 533 Úgy tünik Csokonai nem szeretett volna ismét negatív színben feltünni az esetlegesen kétes sikerü Dorottyával, ezért ajánlotta fel Vergilius fordítását, már csak a keszthelyi Georgikon miatt is. Ebből a levélből más is kiderül, nevezetesen az, hogy Csokonai ismerte a szabadkőművesek világát, de elképzelhető - amire nincs adatunk -, hogy maga is maszonista volt. Levelének utolsó bekezdésében a már korábban is említetteket írja: „Nem - nem e' Világból való NAGYSÁGOD, nem e’ puhalelkü 's alatsony módú emberek közül. - A' Sz: SOPHIA' Templomában látom én felszentelve NAGYSÁDAT, ; az Értelem' Mysteriumiban van béavatva; 's a' Köz-jó' oltárára halmazza a' tömjéneket, melylyeknek füste az égig emelkedik 's az egész Hazát elborítja illatjával; a’ Músák, ki lanton, ki trombitán, zengik tiszteleti Adóként a' magok Panegyrisseit; az én Lelkem elragadtatva repül ki belőlem 's hálá-sohajtásokká válván, e' füstök, e' hangok', ez Érdemek felhőjiben elenyészik és én... mit tudjak tenni? elhallgatok". 534

A Dorottyának keszthelyi vonatkozása is van. Figyeljük meg az Első könyv alábbi két sorát:

\section{Ím a’ Toponári Zsidók békerülének, És muzsikájokkal hellyekre leülnek,}

Majd a lábjegyzet: „A’ TOPONÁRI ZSIDÓK nevezetes Muzsikusok Toponár nevü mezővárosban Somogy Vármegyének, melly a' Tek. Festetits familiának uradalma, 's Kaposvártól nem messze esik". ${ }^{535}$ S. Mohos Márta egyik, a Festetics kastélyban elhangzott előadása szerint a Dorottyában Csokonai által megénekelt toponári zsidók nagyrészt a Festetics-féle keszthelyi zeneiskolában tanultak. Ezt csak abban az esetben fogadhatjuk el, ha a „nevezetes muzsikusok” későbbi tanulmányairól, vagy utódjairól beszélünk. A Dorottya ugyanis 1799-ben íródott, a keszthelyi Zeneiskola viszont 1800 novemberében nyitotta meg kapuit. Meg kell jegyeznünk, hogy a Dorottya Negyedik könyvének jegyzeteiben találunk

\footnotetext{
${ }^{533}$ Csokonai Lev., 1999. 107. Csokonai Vitéz Mihály Festetics Györgynek, Debrecen, 1800. december 19. MOL Fest. Lvt. P 279 1800:1423

${ }^{534}$ Csokonai Lev., 1999. 108-109. Csokonai Vitéz Mihály Festetics Györgynek, Debrecen, 1800. december 19. MOL Fest. Lvt. P 279 1800:1423

${ }^{535}$ Csokonai ÖM. 1994. 146. ; A toponári muzsikusokkal kapcsolatban Kostyál István Kultsár István levele Festetics Györgyhöz címü tanulmányában megjegyzi: „...a Riedl-féle kézirat szerint 'Toponáron laknak a legjobb muzsikus zsidók egész Somogy vármegyében’. Még érdekesbb, hogy a toponáriakon kívül megemlítik a keszthelyi zsidó muzsikusokat is, akik Ábrahám szerint még azoknál is különb muzsikusok, legalább is szebben fogja a hegedüt: 'nó így fogja a hegedüt (mutatja neki a zsidó), a Thópönári zsidók is így fogjá, a kesztheliek mígh szebben.” ItK, 1960. 475
} 
még Festeticcsel kapcsolatos adatot, ahol is Csokonai felsorolja a gróftól kapott pénzeket: 100 Rf. + 25 Rf. + 30 Rf. + 40 Rf. $^{536}$

Festetics bár úgy érezhette, hogy mecénási választását felülbírálták, nem zárkózott el Vergilius kiadásától, de több mindenre felhívta a kötő figyelmét 1801. január 9-én kelt levelében: „Megszóllamlatta az Úr deák Virgiliust hazai nyelven? és Magyar köntösbe felékesítve a’ Magyar Tudományoskodásnak díszesíttésére a' Világgal láttatni akarja? szép ösztön, kies tárgy és gondos fáradság ez valóban - mégis mivel Erdélyben Kováts József az Aeneist már kiadta, Tiszt. Rajnis József pedig a Bucolicát lefordította, reménylhetni, hogy ez a' Georgicát is kiadgya; és így tartani lehet attól ne, hogy a' külömbféle Kiadásokból valamelly Confusio eredgyen - én úgy gondolnám, jó volna ezen dítséretes Szándékot késöbbre hallasztani - Mindazonáltal ha az Úr azt ítéli hogy az Úr munkája amazokét fellülhalladgya, tessék azt Pestre Pintér György Szalkszentmártonyi Fiscálisomhoz leküldeni; én azt, minthogy magam több foglalatosságoktól elfoglaltatom, a’ Minerva Költeménnyei megvizsgálóinak általadván ki fogom nyomattatni”. ${ }^{537}$ Festetics nem vállalta magára az ítész szerepét, ezért ajánlotta a Minerva szerkesztőit, Batsányi Jánost, Péteri Takáts Józsefet, Báróczy Sándort. ${ }^{538}$ A fordítás azonban nem érkezett meg. Festetics Csokonai leveléből azt vette ki, hogy az kész - pedig nem volt az! 1801. április 21-én sürgeti a költőt: „Ugyan az említett Fiscálisom kezéhez, úgy gondolnám, vásári alkalmatosságok által, elküldhetné az Úr Virgiliusnak az Úr által Magyarra fordított, 's kéz írásban lévő Georgicon-ját, mellyet én kezemhez vévén, megolvasván, és jónak találván ki nyomattatnék, és az Úrnak fáradságát, 's Barátságát megjutalmaznám". ${ }^{539}$ Csokonai július 7-i nagyon határozott levelében még inkább megnyugtatja Festeticset arról, hogy a fordítással jól áll, s akis késedelem oka hosszas gyengélkedése: „...lehet, hogy Tiszt. Rájnis Úr ki fogja adni: de a’ mi még Ö nála a’ Lehetőség' világában gombolyog, az nálam a' Valóságban kifejtődve van”. A levél befejező részében megszólal Csokonai önérzete is: „Az olly Fő Literatorok, mint Rajnis Úr, a’ kik már országos Irókká lettek, irjanak az Országnak Georgicát: én a' magamét Nagyságod' udvarlására készítettem. És ezzel a Kinyilatkoztatással ajánlom azt és magamat Méltóságos Gróf, Nagyságodnak". ${ }^{540}$ Csokonai a levelet későn vehette csak kézbe, minden bizonnyal

\footnotetext{
${ }^{536}$ Csokonai ÖM. 1994. 188.

${ }^{537}$ Csokonai Lev., 1999. 113. Festetics György Csokonai Vitéz Mihálynak, Keszthely, 1801. január 9. MTA K $3 / 39(\mathrm{~K})$

${ }^{538}$ A Festetics által megjelölt három szerkesztő tevékenysége a Magyar Minerva könyvsorozat vonatkozásában erősen eltérő. (Lásd: Első hazai könyvsorozatunk a Magyar Minerva címü fejezetet)

${ }^{539}$ Csokonai Lev., 1999. 126. Festetics György Csokonai Vitéz Mihálynak, Keszthely, 1801. április 21. MTA K $3 / 40(\mathrm{~K})$

${ }^{540}$ Csokonai Lev., 1999. 134-135. Csokonai Vitéz Mihály Festetics Györgynek, Miskolc, 1801. július 7. és Debrecen, 1801. május 16. MOL Fest. Lvt. P 279 1801:812. ; Rájnis valóban elkészült a fordítással, de nem
} 
Komáromba kellett utána küldeni - véli Vargha Balázs. ${ }^{541}$ Festetics augusztus 21-én röviden, de mégis barátságosan ismét ír. „Bizodamas Nagy jó akaró Uram!” a megszólítás és újból a kérés: küldje meg fiscálisának a „Magyar Virgiliust, kinek nékem leendő ajánlását elfogadom, megnevezett fiscalisomhoz elküldeni méltóztassék”. ${ }^{542}$ Festetics György tehát ismét sürget, Csokonai pedig hallgat.

Az ügy kínosságát Csokonai is érezhette és gyorsan postára adta Komáromban, 1802. január 10-én (egy évvel Festetics első bátorító levele után), a fordításokat. De csak a Második könyvet. Vargha Balázs szerint az Első könyv is készen volt, de valószínüleg nem vitte magával Komáromba, így azt a grófnak megküldeni nem tudta. ${ }^{543}$ Csokonai mentegetőzik, hogy csupán mostanság tudta beszerezni Vergiliust Heine fordításában, amelynél soha jobb még nem született, ezért a késés. Kérte viszont, hogy Festetics a könyv kinyomtatásának költségét tegye le a nyomdásznál, Weinmüllernénél. A levélhez csatolt fordítás elött az ajánlást is megfogalmazta Csokonai: „Mélt: Tólnai Gróf FESTETITS GYÖRGY” Ö Nagyságának, 's a' Keszthelyi GEORGICONNAK adja, ajánlja, áldozza a' Fordító".544 Csokonai meg is magyarázza, hogy a leendő dedikációt előre szerette volna már Festeticsnek megküldeni, amely szerinte rövid és a gróf „,nemes szemérmetességéhez van” igazítva. Festetics 1802. február 17-én válaszolt ugyancsak rövid, hidegebb, de nem elutasító levélben. Kifejti „,igen tsudálkozását”, hogy az előbbi levélben ígért fordításnak csak töredékét kapta meg. Nem ígérhet most már semmit, amíg ,,azon $1^{\text {sỏ }} 3^{\text {dik }}$ és $4^{\text {dik }}$ részt is el nem küldi az Úr. Mellyeket én annak utána, mivel magam nem értek hozzá, más ahoz értő Vers irokkal meg

Festetics adta ki, hanem 1814-ben Pesten, Kondé József Benedek, amikor a költő, pap-tanár már a keszthelyi gótikus templom kriptájában nyugodott. A klasszikus triász tagjai, Rájnis József, Baróti Szabó Dávid és Révai Miklós kapcsolatban álltak a keszthelyi gróffal.

${ }^{541}$ CsEml., 1960. 562. Erre a levélre Csokonai csak 1802. január 10-én válaszolt, Komáromból.

542 Csokonai Lev., 1999. 145 ; A CsEml., 1960. 96. oldalán a „leendő ajánlását” helyett „teendő ajánlását” olvashatjuk.

${ }^{543}$ CsEml., 1960. 564.

${ }^{544}$ Az ajánlás után a további szöveg: MÉLTÓSÁGOS GRÓF! Soha az Elő-jel, az Omen, szerentsésebben a' Valóságot egszer-egyszer el nem találta, mint a' NAGYSÁGOD’ Keresztnevében GEORGIUS Főldmívelőt, vagy a' földmívelés' kedvellőjét tészi a' Görög Szók' ereje szerént. és ki az, a' ki nagyobb buzgósággal, fáradsággal, és költséggel igyekeznék ennek a', valamint legrégibb, úgy leghasznosabb emberi foglalatosságnak gyarapításán? Legközelébbi, 's legpompásabb bizonysága ennek a' GEORGICON; mellynek, a' maga nevében, mind felállása' tzélját, mind Alkotója' nevét viseli, szerentséje vagyon. - Kevélykedve hordozza ez a' Deákból fordított GEORGICON is a' maga nevezetét; melly is, mind a' benne lévő matériára, mind Nagyságos Pártfogójára mind a' Keszthelyi hasonlíthatatlan Fundatióra, a' jó Magyart reá emlékezteti. - Én pedig szerentsésnek vallom magamat, hogy a' VIRGIL remekjét pannoni polgárrá tehettem; hogy NAGYSÁGOD' Grátiájával élhettem; hogy a' Gazdasági Oskolát valaha láthattam. A'Hazafiúság, a' Literatúra, a' Földmívelés, adják hozzá ehez a' követhetetlen Poémához azt, a' mit ennek betséből az én érdemetlen voltom lekoptatott; talentomom' tsekélységét pedig pótolja ki az a' Szív, a’ mellyel változhatatlanúl maradok NAGYSÁGODNAK alázatos szolgája Cs. V. M.

( Csokonai Lev., 1999. 159-161 ; Csokonai Vitéz Mihály Festetics Györgynek, Komárom, 1802. január 10. MOL. Fest. Lvt. P 279 / 1802:105) 
visgáltatván, ha valyon méltó dolog lészen é azoknak ki nyomtatására kőltséget adni vagy nem? az eránt az Urat bővebben tudositani kivánom". ${ }^{545}$

A Vergilius fordítás ügye Festetics leveleiben már soha többé nem fordul elő. Előfordul viszont kétszer is Kultsár István Csokonainak küldött levelében. Kultsár, az ifjú Festetics László gróf nevelője, 1802. február 20-án írja Csokonainak, hogy leveléből - amit a grófnak írt és felbontásakor ő éppen Keszthelyen volt - értesült arról „hogy Virgilius Georgiconi Könyveit a’ mi Grófunknak méltóztatott ajánlani. Minthogy mi az ifjú Gróffal itt az Universitásnál vagyunk, talán későn juthatnánk olvasásához, azért bátorkodom az Urat barátságossan kérni, hogy leg alább kóstolóra egynehány versekkel ismertessen meg bennünket”. ${ }^{546}$ Úgy tünik, hogy Kultsár megkapta a „kóstolóra” küldött verseket, sőt sor került személyes beszélgetésükre is. Ez világosan kitünik a második levélből, amelyben továbbra is bátorítja a költőt és Széchényi Ferenc száz forintos támogatását is át kívánja neki adni. Kultsár bízik a fordítás elkészültében: „Midőn nyáron kérdéseire felelnék, egyszersmind Virgiliussal buzdítám: Tu ne cede malis". 547

Tulajdonképpen a Vergilius ügy itt véget is ért, mivel az Első és Második könyvön kívül csak a Harmadik töredéke készült el bizonyíthatóan. ${ }^{548}$ Úgy gondoljuk Festeticset nem marasztalhatjuk el ez ügyben, Gaál szerint „,a grófnak Csokonai tetszett”, s nem befolyásolták a költőről terjedő mendemondák. ${ }^{549}$ Julow Viktor Csokonai Vitéz Mihály című könyvében egy rendkívül lényeges dologra hívja fel a figyelmet, ami meghatározta Csokonai egész életét: „Debrecenből magával hurcolt rossz híre, kiátkozottsága is (a magyar reformátusság hírcsatornái az egész országot behálózták) szerepet játszhatott” kudarcaiban. ${ }^{550} \mathrm{Nem}$ szabad elfelejtenünk, hogy 1794 decemberében már azért vonták felelősségre, mert rossza hatással volt tanítványaira, állítólag italozásra, táncra és pipázásra buzdította őket. Ismerve Csokonai mentalitását, ha nem is javasolta mindezeket, bizonyára a nagyerdei órák alatt nem is tiltotta. Martinovicsék lefejezését követően a kollégium vezetése megtiltotta, hogy betegye lábát a debreceni kollégiumba, ami több a diákok nem állhattak vele szóba. Természetesen ezt

\footnotetext{
${ }^{545}$ Csokonai Lev., 1999. 171. Festetics György Csokonai Vitéz Mihálynak, Keszthely, 1802. február 17. MTA K. 3/42. (K)

${ }^{546}$ Csokonai Lev., 1999. 173. Kultsár István Csokonai Vitéz Mihálynak, Pest, 1802. február 20. MTA K. 4/1 (K)

${ }^{547}$ Csokonai Lev., 1999. 217. Kultsár István Csokonai Vitéz Mihálynak, 1802. december 8. MTA K. 4/3 (K)

${ }^{548}$ Szilágyi Ferenc szerint Csokonai állítólag lefordította Vergilius Georgicájának mind a négy könyvét. Erre enged következtetni az 1802-ből származó Csokonai műveinek részben autográf kéziratos katalógusa, amely a 6. helyen így lajstromozta: „A’ Vergilius Georgicon-ja négy könyvben.” MTA Könyvtárának Kézirattára K 679/II, 41a-44a. A négy könyv hiányzó részeit Csokonai - Kazinczy szerint - elégette. (Csokonai ÖM., 2002. 606 ; CsEml., 1960. 472.)

${ }^{549}$ Cséby, 2000. 76.

${ }^{550}$ Julow, 1975. 160. Julow Viktor szerint Festetics a georgikoni katedrák egynémelyikét a piarista atyáknak ígérte.
} 
követően ajánlást sem kaphatott az intézménytől. ${ }^{551}$ Biztosak vagyunk abban, hogy Festetics ismerte ezeket a híreket, mégsem volt ellenséges a költővel szemben.

A gróf és a költő levelezése továbbra is fennállt. 1803. július 17-én azt írta Festeticsnek, „mikor Poétai Launé”-ja nincsen, akkor Linné Systema Vegetabilium-ját magyarítja. Ugyanebben a levélben tájékoztatta Festeticset, hogy a Hadi Oskoláról írt ódáját elküldte Kultsár Istvánnak, ahogy azt a gróf kérte és örömmel tájékoztatja, hogy Amaryllis címü kötete nyomdában van. Megköszöni Festetics minden támogatását és „Ez okon Magát, Lantját, Trombitáját és pásztori Sípját a' Nagyságod' örök Nevének zengésére ajánlja fel a' Keszthelyi erdők' árnyékiban”. 552

Festetics és Csokonai kapcsolata feltételezhetővé teszi, hogy a Helikon Könyvtárban több dedikált Csokonai kötet is található. Sajnos nincs így. A könyvtár első katalógusát Festetics György instrukciói alapján csak 1810-ben készítették el, de nem szerepelnek benne a beszerzések időpontjai. ${ }^{553}$ Mindeddig csupán a katalógus részleges feldolgozására került sor. Csokonai kézírásával nem találkoztunk és ez értendő a dedikációkra is. Nem találtuk a Diétai Magyar Múzsa 1796-os kiadását sem dedikálva, sem a nélkül. Ha Csokonai keszthelyi látogatásakor, 1798-ban átadta Festeticsnek e munkáját, minden bizonnyal ajánlással tette. Amennyiben ezt elfogadjuk, azt kel feltételeznünk, hogy a sok viszontagságot megért könyvtár e kötete elveszett, vagy lappang.

Izgalmas felfedezést az egyik, eddig feldolgozatlan, Miscellanea kötet adott. ${ }^{554}$ Három Csokonai műről van szó. Egy fordításról, két saját versről. A Miscellanea borítása korabeli és valószínüleg a gróf könyvkötője Földesi István készítette a könyvtár számára, tehát nem később került a gyüjteménybe. Odakerülésükről azonban semmiféle feljegyzés nincs. A müvek a következők:

- MÉltÓSÁGOS KIRÁlyI TANÁTSOS SOMSSICH LÁZÁR ÚR' ÓDÁJA MÉLTÓSÁGOS RHÉDEY LAJOS TS. IR. KAMARÁS Ö NAGYSÁGÁHOZ. Fordította

Csokonai Vitéz Mihály Impresszum nincs. A nyomtatvány két lapos, azaz négy oldalas.

\footnotetext{
551 Juhász, 1963. 78-79.

${ }^{552}$ Csokonai Lev., 1999. 276-277. Csokonai Vitéz Mihály Festetics Györgynek, Debrecen, 1803. július 17. MOL Fest. Kvt. P 279 1803:773

${ }^{553}$ Csokonai következő korabeli könyvei találhatók a Helikon Könyvtárban: A Tavasz Írta Kleist. Fordította. Csokonay Vitéz Mihály Komáromban, özv. Weinmüllerné betüivel, 1802. (Lit. hung. 717) ; Amaryllis. Csokonai Mihály által. Pesten, Trattner Mátyás Bötüivel, 1803. (Lit. hung. 334). Megtalálható még a Bécsben Pichler Antalnál 1813-ban kinyomtatott Márton József-féle Csokonai Vitéz Mihály poétai munkái címü sorozat négy kötete. Az első kötetben a Békaegérharc és a Dorottya, a másodikban az Anakreoni dalok és a Tavasz, a harmadikban a Lilla és az Ódák, a negyedikben a Diétai Magyar Múzsa és az Alkalmatosságra írt versek találhatók. (Lit. hung. 378) A könyvtárban újabb-kori Csokonai kötetek is találhatók.

${ }^{554}$ HK. Misc. 80. kötet 10. tétel
} 
- CSOKONAI VITÉz MIHÁly ÓDÁJA M. G. FESTETICS GYÖRGY Ö NAGYSÁGÁHOZ AZON TÁRGY FELŐL. Impresszum nincs. A nyomtatvány három lapos, azaz hat oldalas. (Az „azon tárgy felöl” a hadi oskolát jelenti.)

- A' SZÉLHEZ. ÓDA CSOKONAI VITÉZ MIHÁLY ÁLTAL. Impresszum nincs. A nyomtatvány három lapos, azaz hat oldalas.

Sajnos ezeken az aprónyomtatványokon sem fedeztük fel Csokonai keze írását.

Tehát 1988-ban a keszthelyi Festetics kastély Helikon Könyvtárában sikerült megtalálnunk annak az 1803-ban kiadott három nyomtatványnak eg-egy ép példányát, amelynek - Vargha Balázs szerint - csak töredékesen ismertük eddig létezését. ${ }^{555}$ Azonban Szilágyi Ferenc a Csokonai kritikai kiadás 5. kötetében rámutat, hogy az OSZK. Aprónyomtatvány Tárában finom papírosra nyomtatva megtalálható egy ívnyi terjedelemben a három Csokonai-óda, amelyről Vargha Balázs sem tudott. ${ }^{55}$

\section{4. 4. Festetics György és Fazekas Lúdas Matyija}

Fazekas Mihály 1804-ben írta a „Lúdas Matyi” művét, amely kéziratos másolatokban terjedt. ${ }^{557}$ Így jutott el Kerekes Ferenchez a debreceni Kollégium későbbi jeles természettudós polihisztor professzorához, a Magyar Tudományos Akadémia levelező tagjához, aki akkor volt egyetemi hallgató Bécsben. ${ }^{558}$ Kerekes Ferenc Erdöhegyen született 1784-ben, szegényparaszti családból és mind ingyenes szolgadiák végezte el a debreceni kollégiumot. ${ }^{559}$ Erre későbbi írásaiban is visszaemlékezett, s e meghatározó élménye inspirálta arra, hogy tanárként behatóan foglalkozzon nevelésüggyel is. Kerekes a kezdeti „szolgadiákság” után, jó előmenetele következtében 1809-ben köztanító lett. 1811-től Kisújszálláson s debreceni Kollégium partikulájában segédrektor. Ezt követően iratkozott be a keszthelyi Georgikonba, de 1815-től már Bécsben találjuk. Bejárta Európát, az egyetemi városokat, hogy megismerhesse a kor új irányzatait, szélesítse látókörét. Maga, szinte mindenre érzékeny volt: fiatalabb korában az irodalom terén ért el sikereket, később a matematika, a kémia, a

\footnotetext{
555 Vargha Balázs szerint ez a három nyomtatvány csak egy példánya található meg, az is töredékesen ( $A$, szélhez óda nélkül). Ezt a példányt Vargha Balázs könyvtára örzi. (Vargha, 1984. 315. )

${ }_{557}^{557}$ Csokonai ÖM.2002. 667.

${ }^{557}$ A Lúdas Matyi elterjedéséről és kiadásáról részletesen lásd: Szilágyi M., 2002. 41-57.

${ }^{558}$ Kerekes Ferenc életéről és munkásságáról részletesen: Fehér, 2001.

${ }^{559}$ Született Erdőhegyen (ma: Padureni - Románia-), 1784. június 22-én, meghalt Balatonfüreden 1850. július 29-én.
} 
botanika, a nyelvészet és neveléstan területén alkotott figyelemre méltót. Jelen dolgozat kizárólagosan a Lúdas Matyi kiadása körüli tevékenységét boncolgatjuk.

Kerekes, anélkül, hogy tudta volna ki a mű szerzője ellátta bevezetővel és névtelenül kinyomatta Bécsben, vélhetően 1815 kora telén, október végén, vagy november első negyedében. A mű már 1816 elején kapható volt Bécsen kívül Pesten, Debrecenben és Kolozsvárott is. ${ }^{560}$ Kerekes a kiadás elöljáró beszédében szólítja meg a „Jámbor Olvasót”-t és elismeri, hogy „E’ munkátskának ki legyen Szerzője, ha kérded, / Nem tudom: a’ bizonyos, hogy az én kezeimbe tsak így jött / Név nélkül; nekem egy Szomszédom hozta az Erdő- / Hátról, vagy honnan, hogy jó lesz rajta nevetni / Majd botozás közben..."561 Fazekashoz viszonylag gyorsan eljutott a kiadott kötet, mert már 1815. november 24-én dorgáló, az ügyet tisztázni kívánó levelet intézett Kerekeshez: „Matyi az én szülöttem. Született $1804^{\text {ben }}$, betsülettel tanúlni ment Kazintzi Ferentz Urhoz (...) onnan jó tanátsokkal és intésekkel jött vissza $1805^{\text {ben }}$ de amellynek Matyira nézve még akkor semmi sikerek nem lehetett, mivel már akkor minden figyelmemet a fák füvek és virágok vonták magokra. Egy különös környülállás $1814^{\text {ben }}$ eszembe juttatta, hogy még egy neveletlen fijam van, a Matyi. Ötet tehát akkor, tsak azért, hogy ha életben talál maradni, holtom után betstelenségemre ne legyen, amint tudtam, körül nyalogattam. Már most képzelheti az Úr, mint hülhettem el belé, midőn őtet Bécsből, a hová tudja a kurvannya hogy barangolt, egy néhány bába kéz szennyével hozzám, mint nyeletlen furkot bevetődni látnom kellett, még pedig azon lutskoson, mint $1804^{\text {ben }}$ a világra ki pottyant. (...) Ha tudta az Úr, hogy ő az én Szülöttem, meg botsáthatatlanúl bántott meg, ha szándékát velem nem közlötte, de ha nem tudta, még úgy jó Komáji lehetünk egymásnak e feltételek alatt: 1-ör fel küldöm őtet a mint újjá Szültem a ránk jövő Vízkereszti Vásárkor, ha addig válaszát nyerhetem az Úrnak, és botsássa ki őtet másodszor, s aha hasznát látja, többször is, de nagyobb betükkel. 2-or A nevemröl semmi emlékezetet benne ne tegyen, mivel nemzetünknek erántunk való érzéketlensége engem is azzá tett minden betsüllet eránt, melly a nyomtatás útján nyerhetődne. De az Úr engemet azért ne szánjon, mert Hypocondriacus nem vagyok, hanem tsak Magyar." ${ }^{562}$ Kerekes a levélre 1815. december 7-én válaszolt, azonban a levél nem maradt fenn. A két férfi kapcsolata nem mérgesedett el, hisz Fazekas, mint a debreceni kollégium pénztárnoka, 1816. augusztus 18-án írt levelében arról

\footnotetext{
${ }^{560}$ A Magyar Kurír 1816 január 12-i száma a következőképpen számol be a mủ megjelenéséről: „A múlt 1815. esztendő vége felé jött ki itt Bécsbe egy furcsa kis magyar versezet hexameterekben, illyen titulus alatt: Lúdas Matyi, Egy Eredeti magyar rege Négy Levonásban. Az ára csinos borítékba kötve 17 kr. Találtatik Bécsben a Dominicanus Piaczon Gerold, Pesten Eggenberger és Kilián könyváros uraknál, Debrecenben a Reformatum, és Kolozsváron az Unitárium Colegiomban.” (Fehér, 2001. 25-26.)

${ }^{561}$ Lúdas Matyi egy Eredeti Magyar Rege Négy Levonásban Bétsben 1815. 3.

${ }^{562}$ Fehér, 2001. 21-22. Fazekas Mihály Kerekes Ferencnek, 1815. november 24. Közli: Delejtü, 1859. 286
} 
tájékoztatja Kerekest, hogy további pénzt kapott külföldi tanulmányútjaira, s a megszólítás is barátságos: „Kedves Komám Uram! A Venerabilis Superintendentia azt rendelte, hogy Komám Uramnak fél esztendei tanulására 500 pengő forintot küldjön. Mennyi az a pengő pénz mi azt könyv nélkül nem tudhatjuk, de én nyilvánsággal tudván, hogy se több sem kevesebb nincs kezem alatt 1400 Wft azaz Egyezer Négyszáz váltó forintnál, íme azt kedves Komám Uramnak küldöm, ha abból ki nem telik, írjon Komám Uram és valahogy majd ki pótolja a Consistorium". ${ }^{563}$

Nem tudni, hogy Kerekesnek volt-e lehetősége segíteni a Lúdas Matyi javított kiadását, annyi azonban bizonyos, hogy Fazekas javításai után a mü, 1817-ben Bécsben, megjelent. A papírkötéses könyvecske 18,5 x 12,5 cm. nagyságú, 16 oldal + 4 képmelléklettel díszített, borítóján a következő szöveg szerepel: Lúdas Matyi egy Eredeti Magyar Rege. Négy Levonásban. Bétsben Pichler Antal betüivel. 1817. A borító közepén rajz, amint Döbrögi éppen alkuszik a ludakra, alatta az idézet: „Id’ adod fele árrán? / nem alább párját egy kurta forintnál”. A belső címlapon a szöveg, részben megegyezik a borító szövegével: Lúdas Matyi egy Eredeti Magyar Rege. Négy Levonásban. Irta F. M. Második megjobbított Kiadás. Négy tábla rajzolattal együtt. Az ára tsinos borítékban harmintzhat krajtzár. Bécsben 1817. A külső borító hátsó utolsó oldalán a következő szöveg olvasható: „Minden ebből bejövendő pénz, a’ tüz által még károsodott Szombathelyi és Körmöndi szegényebb sorsú lakosok felsegéllésére fordíttatik, a’ benn lévő Híradás szerént". ${ }^{564}$ A kötet utolsó lapján szerepel a Híradás, amelyben a támogatás módjairól és szükségszerüségéröl tájékoztatják az olvasót. ${ }^{565} \mathrm{~A}$ kötetben Kerekes és Fazekas bevezetője is megtalálható, jelezve, hogy az előbbi az első

${ }^{563}$ Fehér, 2001. 8-9. Fazekas Mihály Kerekes Ferencnek, 1816. augusztus 18. Közli: Kiss Sándor. ItK., 1954. 337-338.

${ }_{564}$ A kötet megtalálható a Helikon Könyvtárban Nc 3674 szám alatt. Sérült és restaurált példány. A Helikon Könyvtárba a keszthelyi premontrei gimnázium könyvtárából került át. Azt láthatjuk, hogy a szerző itt se írta ki nevét, csupán a monogramja jelent meg a borítólapon. A névtelenség tehát továbbra is fennmaradt. Ennek anomáliáira és a szerző kilétének meghatározása iránti kutakodás eseményeit dolgozza fel Szilágyi Márton dolgozatában. (Szilágyi M., 2002)

565 „Híradás. Szombathely Püsp. várost, Vass Vármegyében, a’ mult hónap 27dikére éjjel, egy szélvészes időben támadt szerentsétlen tüz nagy részént elpusztította, 's lakosainak egy részét szánakozásra méltó állapotra juttatta, úgymint a' kik, hirtelen elborítván éjjel a' tüz lakhelyeiket, alighogy életeket is megmenthették. Hasonló szomorú sorsra jutottak kevéssel az előtt Körmönd lakosai is, azon mezőváros nagyobb részének elégése által, úgy hogy azok a' szíves szánakozás mellett, a' munkás emberszeretet hathatós segedelmét mind azoktól reménylhetik, kiknek a' segedelemnyújtásra módjok vagyon. A' jelenvaló Munkátska kiadója is kívánván a’ két városbeli szerentsétlenül járt szegényebb lakosoknak segíttséget nyújtani; Minden ebböl bejövendö pénzt arra szán, hogy az, a két Város Magistrátusa által azoknak némü némü felsegéllésekre fordíttassék. Kéretnek tehát ezennel a’ Magyar Hazabéli érdemes és jószívü Könyváros és Könyvkötö Urak, hogy ezt minden haszonkeresés nélkül, legjobb móddal terjeszteni, és abból a' szokott Rabatot is illy szent végre elengedni ne terheltessenek. Az ebből begyülő pénzt vagy Bétsbe kell felküldeni az itt lévő Nemes Pázmaneum Collégiumba Tisztelendő Kaprossy János Spiritualis, vagy Tek Márton Jó’sef Professor Urakhoz, vagy pedig két részre osztva mindenkor, egyenesen a' fenn nevezett két város Magistratusaihoz." 
kiadás bevezetőjét írta. Ezt a kis kötetet tekinthetjük tehát az első, Fazekas Mihály által is jónak tartott, hiteles kiadásnak.

Fehér Katalin dolgozata szerint Kerekes az első kiadás két példányát is elküldte Keszthelyre, Rumy Károly Györgynek a Georgikon tanárának, akit jól ismert keszthelyi tanulmányai idejéből, a következő humoros sorok kíséretében: „Hát ez a bohó Lúdas Matyi esmeretes-é már Keszthelyen? Ha még nem esméretes, hadd esmerkedjen ott is meg. Ime ide teszek egy párt. A kék fedelüt tartsa meg K. Professor Úr magának, a verset pedig ne sajnálja alázatos tiszteletem mellett Ő Excellentiájának általadni." "566 A keszthelyi Helikon Könyvtárban megtalálható a Kerekes által kiadott és Festeticsnek elküldött mü, igaz az egyik Miscelaniae kötetbe kötve: Lúdas Matyi egy Eredeti Magyar Rege Négy Levonásban. ${ }^{567}$ Ami a kötet értékét adja az Kerekes Sámuel Festetics Györgynek (aki nem Döbrögi) ajánlott dedikációja, amelyet külön levélben írt meg és amely levél a kötet elejére van bekötve ( a dedikáció tehát nem a könyvbe került beírásra):

\section{NAGY MÉLTÓSÁGÚ TÓLNAI GRÓF.}

Festetics György.

Ö Excellentiájának.

alázatos tisztelettel ajánlja.

a’ Kiadó

$-\mathrm{O}-$

Menj Matyi a’ Balaton' bóldog partjára hol a' bőlts

Fabricius Rómát ide hagyván, abba találja

Fő gyönyörüségét, hogy bő termésre tanítja

A’ sivatag földet. Gyakrann a' nyári havakban

A’ vén Istenség, Balaton, szigonyára botsátván

Teste nehéz terhét, partját bámulva tsudálja

Keszthely környékén, hogy a' hol tsupa tiszta kopár vólt

Hajdan, vagy pedig a' fák 's füvek tsak tsenevésztek,

\footnotetext{
${ }^{566}$ Fehér, 2001. 23. Fehér jegyzetei szerint a levél megtalálható: MTA. Lev. 4023

${ }^{567}$ HK. Misc. 78. köt. 20. A kötet formátuma 18,5 x $11 \mathrm{~cm}$., 16 oldalas $8^{\circ}$ alakú, utólag bekötött, körbevágott példány. ; Fehér Katalin idézett müvében a Kerekes-féle Lúdas Matyit könyvészeti ritkaságnak mondja. „A kutatóknak mindössze néhány példányt sikerült fellelnie. Egy-egy példány található Budapesten, a Magyart Tudományos Akadémia Könyvtárában, a Fővárosi Szabó Ervin Könyvtár Szüry-gyüjteményében, Debrecenben, a Tiszántúli Református Egyházkerület Nagykönyvtárában és a KLTE Magyar Intézetének Könyvtárában”. (Fehér, 2001. 7.) Fehér, bár tudja, hogy Keszthelyre is került könyv, nem biztos a kötet fellelhetöségében, minden bizonnyal ezért nem jelöli meg a keszthelyi Helikon Könyvtárat.
} 
Most a' borvesszö, és mindenféle gyümöltság

Nyög gazdag termése alatt, 's a' lóhere reng a'

Görbe kaszák élén. Hát még mikor a’ maga duzzadt

Habjainak tetején a’ gályát látja repülni

Vászonszárnyakkal, örömében tapsol, üvöltöz,

'S a' festett deszkát játszodván verdesi nyájas

Hullámmal, hogy már ő tengeri Isten ezentül,

Mert hátán gályákat emel. 'S Ki tsinállja ezen sok

Példás jobbitást? Keszthelynek bőlts Ura, a’ ki

Ott a' legnemesebb mesterségekre tanítja

A’ Magyarok Fiait. Ö hozzá menj Matyi mondom,

Ö nem Döbrögi Úr; igazán kegyes Attya azoknak

A’ kik alatta-valók; jó-szívvel lát bizonyossan.

Ért Ő tégedet, és tréfádat fogja szeretni.

Béts. 28. Dec. 1815

Kerekes Ferentz mk. s.

Kerekes nagyon meghitt szavakkal ajánlja Festeticsnek a kötetet. Minden bizonnyal személyesen is ismerte, ugyanis Kerekes 1813-ban a keszthelyi Georgikont látogatta. Mintegy fél évig volt a városban, ahol a georgikoni tanárokkal nagyon jó és bensőséges viszonyba került. Keszthelyröl ment azután tovább Bécsbe, ott Pethe Ferencnek, a Nemzeti Gazda szerkesztőjének segédszerkesztője lett. Mindezeken túl volt abban némi pikantéria, hogy Kerekes minden skrupulus nélkül Festeticsnek ajánlotta az uraságot háromszor is megverő legény történetét. Ez még akkor is így van, ha egyetértünk Négyesy László és Szerb Antal majd azon vélekedésével, hogy Fazekas szándéka az igazságtalanság elleni fellépés volt csupán, nem pedig valamiféle demokratikus elkötelezettségü mű megírása. ${ }^{568}$

Az általunk megtekintett későbbi kiadásokban, azt tapasztaltuk, hogy valamennyiben megjelenik Kerekes 1815-ös és Fazekas 1816-os bevezetöje is.

Fazekas Mihály és Festetics György személyesebb kapcsolatáról nem találtunk hitelt érdemlő adatokat. Azonban elképzelhető, hogy Kerekes Ferenc felajánlotta Fazekasnak: összeismerteti a gróffal, akinek nem ismeretlen már a Lúdas Matyi. Fazekas valószínűleg

${ }^{568}$ Vermes, 2011. 141. 
megírta Kazinczy Ferencnek Kerekes javaslatát, mert a széphalmi mester 1812. január 7-i levelében óvja Fazekast: „Festetics szolgálatjától ójja magát. Az a’ phantasta ember a' Sopronyi Institútum praefectusát most azért eresztette el (az az kivetette) szolgálatjából, mert az egész tisztelettel 's modestiával egy előterjesztést tett nála, hogy $400 \mathrm{ft}$. bankoczedula fizetéséből el nem élhet, 's kéri hogy adjon neki más szolgálatot. - Mentsen meg az Isten mindent az illy Musagetáktól”. ${ }^{569}$ A megbántódott Kazinczy hasonló lekicsinylő levelekkel bombázta valamennyi barátját, bár kéziratgyüjteménye számára szerette volna megszerezni Festetics írását és ennek megszerzésére kérte Dessewffy József grófot: „Te is küldj nekem ismét értte valamit, az az valamely írását Ipadnak, Napadnak, vagy Illésházynak, Festetics Györgynek, vagy akárkinek a’ nevezetesbbek közzül, akár meghaltak, akár élnek". 570

\section{5. Első hazai könyvsorozatunk a Magyar Minerva}

E dolgozatban külön és behatóan foglalkozunk Festetics György gróf két „szülöttjével” a Magyar Minerva könyvsorozattal és a Helikoni Ünnepségekkel.

A Magyar Minerva könyvsorozat az első ilyen jellegü hazai vállalkozás, melynek feladata volt, hogy a magyar költők és írók munkáinak kiadását megkönnyítse. ${ }^{571}$

\section{5. 1. Az előzmények}

II. József rendeleteivel igyekezett elérni, hogy legalábbis Ausztriában - az ország történelmében elöször - ne kizárólagosan a rang, a gazdagság, a származás, hanem a szellem kölcsönözzön valakinek hírnevet, tiszteletet és olykor hatalmat. Kiváló írók, költők, pedagógusok és zeneszerzők tüntek fel és dolgoztak, olykor tündököltek a császárváros egén (Haydn, Gluck, Mozart). Ők voltak a felvilágosult eszmék terjesztői. Maga Kazinczy

\footnotetext{
${ }^{569}$ Kazinczy Ferenc Fazekas Mihálynak, 1812. január 7. ; KazLev. IX. 2123. 213.

${ }^{570}$ Kazinczy Ferenc Dessewffy Józsefnek, 1809 (?) ; KazLev. VII. 1569. 25.; Kazinczynak rendelkezésére kellett állnia annak az 1802. november 30-i levélnek, amelyben Festetics elutasítja támogatási kérelmét. Igaz, Festetics titkárával íratta meg az elutasítást.

571 A Magyar Minerva történetét feldolgozó nevezetesebb munkák: Takáts Sándor: Péteri Takáts József. Hunyadi Mátyás Intézet, Budapest, 1890 ; Csányi László: Első könyvkiadói vállalkozásunk a Magyar Minerva. = Új Helikon. Tudományos kulturális kiadvány, Veszprém, 1962. 51-56 ; Harmath István: A Magyar Minerva könyvsorozat és társadalmi inditékai. = A Veszprém megyei Múzeumok Közleményei 17. 1984. Szerk.: Töröcsik Zoltán-Uzsoki András. Veszprém, 1985. 453-460. ; Stohl Róbet: Péteri Takáts József irodalmi kapcsolathálója a Magyar Minerva körül. = Kutatások az Eötvös József Főiskolán. Szerk.: Steinerné Molnár Judit. Budapest, 2005. 229-236. ; Stohl Róbert: Fragmenta Takatsiana. Források és kiegészítések péteri és téti Takáts József (1767-1821) életrajzához. Doktori Ph.D. értekezés. Szeged, 2009.
} 
hasonlóképpen vélekedett, s ezt papírra is vetette 1780-ban: „Mely jól mennek a dolgok, ahol az első tudja és akarja, amit kell, s mint szereti ott minden az elsőt, mint az első az utolsót". Az észrevétel - írja Harmath István - föképp akkor meghökkentő, ha tudjuk, hogy Bécsben 1784-ben négyszázharmincöt író élt, és Blumauer az 1782. áprilisától 1783. szeptemberéig megjelenő röpiratok számát 1 142-re, az értük kifizetett összeget 39066 forintra becsüli. Magyarországon pedig az írók és költők néhány felvilágosult főúr támogatásával folytatták harcukat nyelvünk pallérozása érdekében, a tudatlanság és a közömbösség ellen. ${ }^{572}$ Hazánkban a felvilágosodás eszméi legelébb a testőrifjakat érintette meg. Gondoljunk csak Bessenyeire, a magyar felvilágosodás irodalmának első elismert nagy alakjára, akire elsősorban Voltaire hatott. 1772 évi berobbanása a magyar irodalomba korszakhatárként volt értékelendő. Bíró Ferenc azonban rávilágít ennek árnyaltabb megközelítésére: „a felvilágosodás-kori magyar irodalom redukált szemléletéhez jutunk, ha csak a hetvenes évek fejleményeiben látjuk meg az alapjait, de a hetvenes éveket is redukáltan szemléljük akkor, ha csak a későbbi fejlődés alapjait látjuk meg benne. (...) Úgy véljük tehát, hogy az 1770-es évek kulturális teljesítményeit mindenképpen egy szélesebb, az előzményeket is magába foglaló folyamat keretei között célszerű szemügyre venni."

E korhoz köthetően jelent meg az irodalomban többek közt Orczy, Báróczi, Barcsay, Faludy, Amade, Szentjóbi, később Batsányi is. Megerősödni látszott egy olyan írói csoport, amelyik hangot akart magáról adni. S már nem csak a nemesi költők jutnak szóhoz. A dunántúliak közül mindenképpen jelentős szerepet kaptak: Ányos Pál, Berzsenyi Dániel, Kisfaludy Sándor, Kis János, Pápay Sámuel, (Pálóczi) Horváth Ádám, Édes Gergely, Révai Miklós, Péteri Takáts József, Rájnis József, Ruszek József és az ide kötődő Verseghy Ferenc, Virág Benedek. Élő kapcsolat alakult ki a Dunántúl és Debrecen (Weszprémi István, Fazekas Mihály, Földi János, Csokonai Vitéz Mihály) között.

Festetics György szívesen áldozott az irodalom oltárán, de mecénási tevékenységének elismerését jó néven vette. A hazai irodalmi és kulturális események, hírek neves külföldi szószólója Rumy Károly György - a Georgikon későbbi tanára - „kijárta” Göttingában, hogy Festetics György grófot vegyék fel a göttingai tudományos társulatba és elnyerje a Societas tiszteletbeli tagságát. Az oklevelet 1802. augusztus 9-én állították ki és professor Henricus Augustus Wrisberg látta el kézjegyével. ${ }^{574}$ Festetics jó néven vette mindezt és megerősítette abban, hogy a továbbiakban is segítse a magyar müvelödés ügyét. Rumy különben azt is

\footnotetext{
${ }^{572}$ Harmath, 1984. 455.

${ }^{573}$ Bíró, 1994. 12.

${ }^{574}$ MOL Fest. Lvt. P 2461 cs. 3
} 
elintézte németországi, illetve göttingai jó kapcsolatai révén, hogy Asbóth János, aki 1801-től a Georgikon igazgatója, majd Festetics uradalmi inspektora volt, szintén a tagok közé kerüljön.

Rumy amikor Göttingában a gróf ügyében eljárt a Georgikonra hivatkozott, mint olyan intézményre, amelyik egész Európa számára mintául szolgálhat. Ám a magas kitüntetést Festetics a Magyar Minerva könnysorozat elindításával is kiérdemelte volna. Igaz, „csak” pénzét adta hozzá, és nem is olyan mértékkel amint azt az elején megígérte, kezdeményező szerepét nincs joga senkinek elvitatni. A könyvsorozat fáradhatatlan kivitelezője, fenntartója, továbbvivője Péteri Takáts József volt. Péteri Takáts, mint a fiatal Festetics László nevelője Bécsben nemcsak írókkal, költőkkel ismerkedett meg, hanem irodalomszervezőkkel is kapcsolatot tartott; Görög Demeterrel és Kerekes Sámuellel. Talán éppen az 1795-ben kiadott debreceni grammatikájuk bátorította fel Péteri Takátsot, hogy előadja a Magyar Minerva eszméjét Festeticsnek. A grófnak az elképzelés tetszett és évente 1000 forint támogatást ígért, ${ }^{575}$ de kikötötte, hogy a megjelenések sorrendjét ő akarja meghatározni.

\section{5. 2. „A’ Magyar Országi Írók’ munkájiknak Könnyebb ki-nyomtatását tárgyazó Gondolatok” Dokumentumközlés}

A Magyar Minerva az első pillanattól kezdődően országos vállalkozás volt. A Magyar Tudományos Akadémia Kézirattárában, a Kisfaludy Társaság iratai között őrzik „A’ Magyar Országi Írók’ munkájiknak Könnyebb kinyomtatását tárgyazó Gondolatok” című kiadói tervezetet, amely kézirat több mint valószínü, Péteri Takáts József munkája. Annak ellenére, hogy Péteri Takáts kézírásával maradt fenn az okirat, mind a mai napig kétséges, ki volt a szöveg megalkotója. ${ }^{576}$ A dokumentumot több Batsányi-életrajz Batsányi szellemi termékének tulajdonítja, de Festetics neve éppúgy felmerül, mint Péteri Takátsé. Takáts Sándor, Péteri Takáts életrajzírója is rámutat erre az irodalomtörténeti anomáliára többek közt Toldy Ferencet és Bayer Ferencet okolva a téves adatért: „Virág Benedek életírója, Toldy állítását tartván szem elött, még tovább megy s azt is leírja, »mint vitte Virág költeményeit Bacsányihoz Bécsbe, hogy a Magyar Minerva védelme alatt megjelenhessenek! Pedig egy kis

\footnotetext{
${ }^{575}$ Fülöp, 2010. 91.

${ }^{576}$ Főleg az internetes portálokon található írások Batsányinak tulajdonítják éppúgy, mint a Magyar Minerva könyvsorozat elindítását, létrejöttét. A teljesség igényét meg sem közelítve, csupán jelzem az internetes portálokat: http://enciklopedia.fazekas.hu/palyakep/magyar/Batsanyi.htm (2012) ; http://www.vajda-khely.sulinet.hu/bemutat/hirhd/1.htm (2012) ; http://www.literatura.hu/irok/felvil/bacsanyi.htm (2012)
} 
után-nézéssel milyen könnyen ki lehet mutatni Toldy és Bayer tévedéseit; milyen szépen be lehet bizonyítani, hogy Virág költeményeit póstaszekéren küldötte fel Takátsnak, s eszébe sem jutott, hogy maga vigye azokat Bécsbe Bacsányinak «"577 A tévedés minden bizonnyal abból adódhatott, hogy a Magyar Minerva első köteteként megjelenő Ányos munkáit valóban Batsányi rendezte sajtó alá.

Stohl Róbert hívja fel a figyelmet ${ }^{578}$ arra a, regestrumra, amely a tervezethez csatolva adalékkal szolgál a kiadói vállalkozás sorsát illetően.

A regestrumot napló-szerüen vezette Péteri Takáts 1797 és 1802 között, de találhatunk benne későbbi, 1805-ös beszúrást is. Ebből részletesen kitünik Péteri Takáts levelezése, főleg a Magyar Minerva ügyében kapott levelek tartalma. A Magyar Országos Levéltár is őriz a kiadás szerzői munkájára vonatozó leveleket. ${ }^{579}$ A Magyar Minerva történetében, ha úgy gondoljuk, hogy mégsem Péteri Takáts volt a javaslattevő, a könnyebb nyomtatást „tárgyazó Gondolatok" megfogalmazója, érdeme az elindításban és a fenntartásban elévülhetetlen.

Amit mindenképpen meg kell állapítani az az, hogy precízen, körültekintően fogalmazták meg az okiratot. A légyeget teljes-körüen sikerült papírra vetni. A szerzök müveinek könnyebb kiadása érdekében Festetics vállalta, hogy minden évben egy bizonyos összeget, amit később az utolsó pontban nevesített is 1000 forintot, szán a könyvek kiadására. Ha ez nem lenne elég, más támogatókat is lehet és kell szerezni. Bármilyen témával lehet pályázni, s nem kell feltétlenül magyar munkának lennie a beküldött münek, de semmiképp sem lehet erkölcsöt sértő irodalom. A sorozat egyöntetüsége érdekében meg kell határozni az egységes „orthographiát” és arra is ügyelni kell, hogy a müvek a cenzúra által jóvá legyenek hagyva. A dokumentum tartalmazza, hogy a könyvárusoknál el kell érni, ne dolgozzanak nagyon nagy árréssel.

Bár a tervezet az irodalomtörténészek előtt nem teljesen ismeretlen, Takáts Sándor is közli művében, ${ }^{580}$ fontosnak tartjuk, hogy Tudományok’ Tárháza, azaz a Magyar Minerva tervezetének tizennyolc pontját szó szerint közöljük:

„A' Magyar Országi Írók' munkájiknak

Könnyebb Ki-nyomtatását tárgyazó

\section{Gondolatok}

\footnotetext{
577 Takáts, 1890. 100-101. ; Takáts Sándor állítását támasztja alá a regestrum 1799. január 16-i bejegyzése, ahol

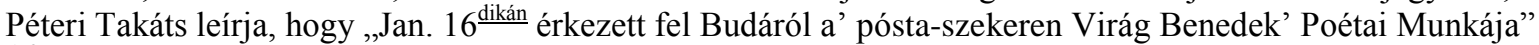
${ }^{578}$ Stohl, 2005. 230.

${ }^{579}$ MOL Fest. Lvt. P 279.

${ }^{580}$ Takáts, 1890. 101-103.
} 
$1^{\text {ször }}$ Bizonyos somma pénz fog meg határoztatni, hogy abból esztendőnként némelly könyvek, a’ Magyar Litterátorok' szüleménnyei könnyebben jöhessenek a' világ’ elejbe; olly fel-tétel mindazonáltal

$2^{\text {szor }}$ Hogy a' ki-adandó munkák a’ Censura által helybe-hagyattassanak.

$3^{\text {szor }}$ Hogy előbb némelly tudós Uraknak vélekedéseik irántak kérettessenek. A' végre: vagy el küldetnek a' visgáló Uraknak biztos alkalmatossággal a’ munkák, és elejénten tsak ez fog meg esni; vagy utóbb a' ki rendelendő helyre a' közel-levő Urak közzül, a’ kiknek kedve fogja tartani, öszve-jöhetnek, és ollyankor az útiköltség is meg-térittetik.

$4^{\text {szer }}$ De hogy a' be küldött munkáról annál egyenesebb ítélet hozattassék, a' Visgálónak ne légyen tudtára, ki az Író. Sőt még az egész Társaság előtt is titokban maradhat, ha akarja a' Szerző, és ollyankor tsak egy választott mondás által jegyezze meg neve helyett maga munkáját.

$5^{\text {ször }}$ A' könyvek' tárgyai a' Litteraturának minden ága. Ki-vévén, a' mellyek vagy személyes sértéseket, vagy tzivódásra szolgáltató alkalmatosságot foglalnának magokba.

$6^{\text {szor }}$ Hasznos lenne, ha az Academiakban és Gymnasiumokban, akár melly Religiobéliek legyenek is azok, a’ nevezetesebb Tanítók számba vevődnének, és azokból a' Jó-tévő 's Munkás Urak' ki-keresésekre némellyek ki-választatnának.

$7^{\text {szer }}$ Ezen ki-választott Urak' segétségével egy ollyan lajstrom készíttessék, a' mellyből ki lehessen venni, kik és miben dogoznak most a' litteraturában, vagy millyen munkáik vagynak már készen kéz-irásokban. Jó lészen annak is végére járni, kiknél találtatnak régtől fogva nyomtatást érdemlő kész munkák.

$8^{\text {szor }}$ Bizonyos Idő-tájban, p. o. October' elején meg lehetne későbben a’ bé küldött munkákat részint olvasgatni, részint a' már által olvasott kész írásokról hozott itéleteket elöadni 's okokkal támagatni; a' ki-adandókat meg határozni; a' többieket pedig, ha a' Szerző Kívánnya, vissza küldeni.

$9^{\text {szer }}$ A' helybe-hagyott munkáért az Író jutalom nélkül nem fog maradni. A' leg nagyobb jutalom 500. exemplárban, a' leg kisebb 150. állhat. Ha pedig talán inkább kész pénzt kívánna a' Szerző, jókor jelentse meg szándékját, és ugy fog azutánn Köz-megeggyezéssel a' jutalom meg határoztatni. Tudni való, hogy az eredeti munkák mindenkor nagyobb betsben tartatnak, mint a' fordítások: mindazonáltal a' jelesebb könyvek’ fordítóira is illendő tekéntet fog lenni. 
$10^{\text {szer }}$ A' nyomtatott Könyvek' el-adásából be-jött pénz több és több munkák’ kiadására, a’ szükségesebb tárgyak' ki-dolgoztatására, a’ szükölködőbb Tudósok’ elősegéllésére fog fordíttatni.

$11^{\text {szer }}$ A' ki-jött munkák’ el-adásokra a' $6^{\text {dik }}$ Tzikkelyben meg nevezett Férfiak közzül egynéhány levelező Barátok Kérettessenek meg, hogy a' Könyvtárosok' mértékletlen nyerekedésnek gát vettessék, és a’ bé-vett pénz annál bizonyosabban Kézhez Kerüllyön.

$12^{\text {szer }}$ Miképpen Kellessék a' Szám-vételt rendbe hozni, jó lészen arról egy projectumot ki-dolgozni.

$13^{\text {szor }}$ Egy állandó Levelezőnek kell lenni, a’ kinél minden Barátok írásai egybegyüllyenek, és a' tárgyat illető tudósítások fel-jegyeztessenek.

$14^{\text {szer }}$ Egy ollyan Férfiat is Kelletik választani, a' ki a' helyben hagyott munkák' tsinos, 's a' nyomtatásbéli hibáktól ment Közre botsátására figyelmezzen; a' nélkül, hogy a' Szerző' megy-egyezése ellen valamit meg változtatni mérészellyen.

$15^{\text {ször }}$ Hasznos volna, ha a' Gyülekezetnek meg-eggyezéséből az orthographia megállapittatnék; ez által a’ nagy külömbbség a’ Magyar írásra nézve, leg alább jövendőre, alkalmasint meg szünnék.

$16^{\text {szor }}$ Nem ártana talántán a' jobb el-kelés, 's a' Gyüjteménynek egysége 's öszvekaptsolása végett egy közönséges nevet ragaszztani mindenik munkának elejbe, a’ melly, mivel semmi hasznos tudomány nem lenne ki-rekesztve, ez lehetne: Tudományok’ Tárháza.

$17^{\text {szer }}$ Azonban nem tsupán a’ Magyar nyelven íratott munkák fogadtatnának el a’ kiadás végett.

$18^{\text {szor }}$ Mind ezeknek el-kezdésekre ezer forint ajánltatik esztendőnként. De mivel sok mellékes költségek, és ne talán több elöadandó tárgyak miatt, ez nem lenne elegendő: ezen jámbor Szándéknak állandóságára nézve' is, köz-tanátskozással olly módok találtassanak ki, hogy minden eröltetés nélkül más Jó tévők is szereztessenek." ${ }^{581}$

A tervezet mind a mai napig tökéletes példája egy felvilágosult mecénási magatartásformának és annak is, hogy Festetics figyelmét az apróbb dolgok sem kerülték el. Ismerve a gróf mentalitását, miszerint a legkisebb dolgok tervezésébe és megvalósításába is beleszólt, így a tervezet mindenképpen tükrözi az ő akaratát (is). A tervezetből kitünik, nem akar egyedül dönteni a kiadást illetően, lektorokat kíván alkalmazni, kiknek - ha e témában összejönnek - útiköltséget fizet. Később megerősítette eme vélekedését, amikor világossá vált

${ }^{581}$ MTA Kézirattár, MS 5086/47.; A kiemelések a kézirat kiemeléseivel azonosak.) 
a beérkezett munkák nagy száma és sokszor nagyon alacsony színvonala. Erről több levelet is váltott a sorozat szerkesztőjével, az akkor Bécsben gróf Festetics László nevelőjeként tevékenykedő Péteri Takátscsal. Ilyen beérkezett anyag volt Szaller Györgygyé, akiről Péteri Takáts azt írta: „...olvastam már némelly munkájit. Igen közönségeseknek, sőt néhol heányosoknak találtam." 582 Hasonló vélemény alakult ki Káts István nagyváradi pap munkájával kapcsolatban. Festetics is érezte azt a felelősséget, amely reá hárult a könyvsorozat belbecsét illetően. 1798. március 8-án töprengő hangú levelet írt Péteri Takátsnak, hogy Káts István munkáját, és a többit is most még nem lehet kiadni, s javaslattal élt, miszerint „,..el-kell osztani több részekre a’ revisiot, hogy ez illyen Munkák megnézettessenek értelmes Emberekkel: ha vallyon meg-érdemli-é a' Sajtot? - De vallyon kik lehetnének a' Materiak szerint a' Recensensek, a’ kiknek itéletében meg-nyugodhatnánk?” Ugyanakkor arra is ráirányítja Péteri Takáts figyelmét, hogy a szűk szakmai érdeklődésre számot tartható könyveket csak népszerü kötetek kibocsátása után ajánlatos kiadni. Éppen ezért Földi János jeles könyvét csak később lehet a sorozat kötetei közé iktatni, ugyanis „,...az ilyen Könyvek nyomtatása nem igen kelendő; azért mindenkor elöbb 3 popularis Könyvet adjunk-ki, annak utána egy Seriosust."

A munkákat azért kellett névtelenül leadni, nehogy az ismertség befolyásolja az ítészeket. Ne legyen sértő a munka, de vallásra való tekintet nélkül minden értéket be kell fogadni. Meghatározza az írók javadalmazását is, vagy tiszteletpéldányokat kapnak, ami tekintélyes példányszámot jelentett, ha azonban a szerző kéri, a pénzt honoráriumként is megkaphatja. Javaslatot tesz a magas közvetítői százalékkal dolgozó könyvkereskedők vonatkozásában is: meg kell őket az ügynek nyerni, vagy ki kell iktatni őket a terjesztéséből. A könyvek árából befolyt pénztöbbletet a szegényegg sorsú tudósok, író között tervezték kiosztani. A tervezet a sorozatnak nevet is adott: Tudományok Tárháza, ám a kinyomtatott könyvek elejére mégis a Magyar Minerva név került. Felveti a tervezet annak szükségességét is, hogy több szponzor is kell, hisz a költségek tetemesek, ráadásul állandó adminisztrátorra és korrektorra is szükség lenne. Itt főleg a sajtóhibákra gondol és a nyelvtani egységességre, de kiköti: a szerző tudta nélkül változtatást a szövegen nem eszközölhet a korrektor.

A tizennyolc pontot követően Péteri Takáts leírja, hogy kiket tartottak érdemesnek arra, hogy értesítsék a tervről: „Hogy ezen köz hasznú Szándék a’ nevezetesebb Írók’ tudtára

\footnotetext{
582 Péteri Takáts József levele Festetics Györgyhöz. Bécs, 1798. január 23. MOL Fest. Lvt. P 27912 cs. 1798:121. Közli: Stohl, 2009. 243-244.

${ }^{583}$ Festetics György levele Péteri Takáts Józsefnek. Keszthely, 1798. március 8. MOL. Fest. Lvt. P 279 Directoriatus regestruma 259. köt. 1798:121. MOL Fest.Lvt. P 279 Directoriatus regestruma 259. köt. 1798:250. MOL Fest. Lvt. P 279 Directoriatus regestruma 259. köt. 1798:265. ; Közli: Stohl, 2009. 248-249.
} 
essék, különös levelekben meg írattatott: Szabó Dávid, Gróf Gvadányi, Molnár Borbála, Kultsár István, Virág Benedek, Révai Miklós, Weszprémi István, Keszthelyi László, Dugonics András, Szathmári Pap Mihály Uraknak: hogy ha vagy magoknak ki-adandó kész munkáik volnának, vagy másoknál nyomtatást érdemlő kéz-írásokat tudnának heverni, adgyák Takáts Józsefnek értésére, a’ ki mind a’ revisionak, mind a’ közre-botsátásnak előmozdításában egész hívséggel el fog járni, és bizonyosá teszi őket a' $9^{\text {dik }}$ szám alatt meg igért jutalomnak meg-nyeréséröl." ${ }^{254}$

Péteri Takáts József a felszólításokra százkét levelet kapott. Ugyanakkor Festetics Györgyöt is személyesen keresték meg levélben az írók. Így például Kis János, aki Nagy Barátiból, előbb 1798. március 15-én megköszönte Festetics pénzbeli jutalmát, ${ }^{585}$ majd 1799. január 15-én arra kérte a grófot, hogy munkáját a Magyar Minervába „béiktatni szíveskedjék”: „A’ Magyar Minerva, ha Barátaim által jól vagyok tudósítva, egy ollyan bölts Institutuma Nagyságodnak, melly minden hazai irót méltán pályafutásra ösztönözhet, a’ kiben a nemesebb ditsőség szeretete lakik." ${ }^{586}$ Majd mikor pozitív válasz kap, örömmel köszöni azt meg „hozzám való kegyességének újabb bizonyosságát." 587

Szerkezetét tekintve, a „könnyebb nyomtatást tárgyazó Gondolatok” 1797-ben írt tizennyolc pontból álló vázlata adja az első elemet - hívja fel a figyelmet Stohl Róbert is ehhez kapcsolja időrendben a „Gondolatok” megvalósításával kapcsolatos történéseket. Az első három év (1797-1799) bejegyzései terjedelmükben is elkülönülnek a következő évekétől. Minőségét tekintve ezen évek bejegyzései bővebbek, magyarázó elemekkel, idézetekkel tarkítottak. Az 1800-as évtől azonban lecsökken a bejegyzések terjedelme, akár egy-egy sorra. A bejegyzések a terjedelem változásával együtt fontos, tartalmi változáson is átesnek. Az első két évben írott bejegyzések leginkább az újonnan szerveződő társaság müködésére, a korabeli irodalmi termés felmérésére vonatkoznak, az 1799 év utániak azonban egyre erősebben munkanapló, végül pénzügyi elszámolás jellegét öltik. ${ }^{58}$ 1799-ig Péteri Takáts a Festetics család alkalmazásában volt, majd a veszprémi káptalan ügyésze lett. Nem csodálkozhatunk a bejegyzések egyszerüsödésén, a kezdeti lelkesedés megszűnésén, mert Péteri Takátsnak ekkorra már rá kellett jönnie, hogy a gróf be fogja szüntetni a Magyar Minerva támogatását.

\footnotetext{
${ }^{584}$ MTA Kézirattár, MS 5086/47 ; Stohl a dokumentum ezen bekezdésével igazolja dolgozatában, hogy a szöveg készítője és a leíró nem azonos: ”....adgyák Takáts Józsefnek értésére...stb.” (Stohl, 2005. 230.) ; Véleményünk szerint ez lehet a tájékoztató levél szövegének idézése is, miszerint a megkeresettekkel közölték, kinek kell a müveket megküldeni s ő milyen feladatokat fog ezzel kapcsolatban ellátni.

${ }^{585}$ Kis János Festetics Györgynek, Nagy-Baráti, 1798. március 15. ; MOL Fest. Lvt. P 279/1798:323.

${ }^{586}$ Kis János Festetics Györgynek, Nagy-Baráti, 1799. január 15. ; MOL Fest. Lvt. P 279/1799:118.

${ }^{587}$ Kis János Festetics Györgynek, Nagy-Baráti, 1799. február 8. ; MOL Fest. Lvt. P 279/1799:194.

${ }^{588}$ Stohl, 2005. 230.
} 
A dokumentum eddig közölt szövegének folytatása, az autográf regestrum, számba veszi a tájékozató levélre küldött válaszokat és lejegyzi azoknak rezüméjét, szó szerint idézve a levelek legfontosabb részeit és a levelek keltezését. A válaszlevelek azonban nemcsak a kiadandó kötetekről szóltak, hanem javaslatokat tettek a sorozat egészére. (Később más kiadványokról is szó esik.) Kultsár István olyan sorozatcímet ajánlott, amit nem kell majd később magyarázni és lándzsát tört a kötetek egységes grammatikája mellett, bár ezt kritikusnak tartja a versek esetében. A regestrumból az is kiderül, hogy Festetics végül dönt, a sorozat nevére vonatkozóan. Péteri Takáts hatalmas munkájának megértéséhez és Festetics maradandó művelődéstörténeti lépésének megítéléséhez, a korabeli gondolkodást, véleményeket is magába ölelő levélrészletek fontos adalékul szolgálhatnak. Éppen ezért a regestrumot is, amely eddig közlésre nem került, teljes egészében közöljük: ${ }^{589}$

„1ํㅡㄹ Szabó Dávid' feleletjének sommája:

Én hát jó biztatásod mellett, a' mint gyenge tehetségem meg engedi, hozzá látok Költeményes munkáimnak ki sikogatásához. Már második ízben rostálgatom. Hátra vagyon még valami 4. s. árkos. A' jobbítgatás száma 2 ezer 's edgynéhány százra fel-telik. Ezen dolgon túl esvén, a’ még edgy testben ki nem adott költeményeimre fordittom magamat. Ezeket rész szerént az $\mathrm{I}^{\underline{0}}$ rész szerént $\mathrm{a}^{\prime} \mathrm{II}^{\underline{\mathrm{dik}}}$ kötetbe akarom bé tenni. - Hát a' Paraszti Majorságról, mellyet $8^{\mathrm{ad}}$ részben adtam-ki másodszor, minémü ítélettel vagy? itt egyedül a' mivoltáról szóllok; mert a' nyomtatás nékem is igen viszsza tetszik. - Mind a’ Magyar Orthographiat, mind a' Prosodiát örömest fel-vállalva, tsak egészségem legyen ki dolgozásokhoz. De ezzel vallyon nyakát szakasztom e a' fenn forgó pernek? - Kassán. Sz.

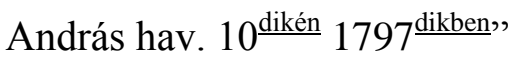

$2^{-}$Kultsár István ezeket írja:

„Varga Márton Komáromi Tanító tökélletes Arithmetikát és a’ Természet Közönséges Historiáját készítette el magyarúl. Piber Benedek Úr Seneca Philosophiai Munkáit fordíttya. Barkótzi Rosti Antal Úr nem tsak énekeit szedi öszve, hanem fontossabb dolgokról való elmélkedéseit is, mellyekből, merem mondani, sokat lehet tanulni: - Az én Szándékom:

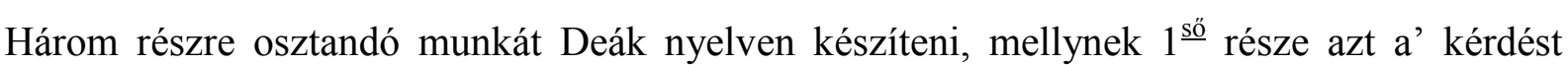
vizsgállya: Quis gaudet Jure Curandi aducationem. $2^{\frac{\text { dik }}{2}}$ Per quos hoc Jus exercendum sit? $3 \frac{\text { dik }}{}$ Quomodo administrandum sit? - Ugy reménylem, hogy sem a' Nemességnél, sem a' Városi

\footnotetext{
${ }^{589}$ MTA Kézirattár, MS 5086/47 (A kiemelések a kézirat kiemeléseivel azonosak.)
} 
Lakosoknál nem lesznek azok az ídeák kedvetlenek, mellyeket én ide már el intéztem. Esztergomban, 6 ${ }^{\mathrm{dik}}$ Dec. 1797”

$3^{\text {o }}$ Gróf Gvadányi József Generális Úr Detzember $15^{\frac{\text { dikén }}{n}}$ kezemhez küldötte Molnár Borbálának Szerentsétlen Szerelem nevü munkáját, és mivel abban némelly veszedelmes kiejtéseket talált a’ leányzókra nézve, meg rostálás végett T. Báróczi Sándor Urnak adta által; hogy ugy azután a’ kényesebb helyek meg változtatására kérhesse meg az Irónét.

$4^{\mathrm{O}}$ Molnár Borbálától is érkezett Detzember $23^{\text {dikán }}$ Kolosvárról levelem, a’ mellyben jelenti, hogy Gróf Gvadányi Genereális Urnak küldött Munkáján kívül, vagynak még némelly kész munkáji; ezeknek tiszta le-írásokra fogja tehát már örömest azon kevés idejét fordítani, mellyet néha el lophat foglalatosságaitól, de nem jövendőben, úgy mond, másnak kötelese lévén ujjaknak készítésébe soha sem lesz módja. - 10 dik Detzembr. 1797.

$5^{\text {o }}$ Révai Miklós a' Tsászári Könyv-tárban talált Magyar Kéz-írást, melly a’ Szent Irásnak egy részét foglalja magába, tisztára irja és deák nótákat készít alája, a' régi magyarság' érdemeit és gántsait akarván fel fedni. - Én ugy mond, a' Grammaticámat is már deákul írom Pereszlényi példája után, hogy a' deák Oskolákban is hasznát vehessék. Esztergom, Dec. 20 dikán 1797.

$6^{0}$ Kultsár István. Esztergomból Januariusnak $3^{\text {dikán }} 1798$.

Virág Benedek nékem olly formán beszélt, mintha kész munkája nem volna: de azt tsak láttam, hogy ott könnyen lehetne egy tsomót készíteni.

Dugonits András mutatta kész munkáját ezen név alatt: A’ Szeretsenek, kiket újj életre hozott D. A. Ezen munka, melly Kariklia' történetet foglallya magában, két részből fog állani - mintegy 60 árkus. Minden árkusért egy aranyat ád néki Landerer, és azon fellyül 50 darabot. - Ha ezen könyv el készül, a’ Köz-mondások’ ki-adásáról gondoskodik, mellyek is már nagy számmal öszve vannak gyüjtve. Bár eredetjeiknek fel keresésében jobban törné fejét. A' Szók' hangzattyokban is különös kezd lenni. p. o. röggel, högy, teremtött írja, reggel, hegy, teremtett helyett.

Vályi András a’ Diétára készít egy munkát. Neve: Az árva Magyar Nyelv.

Kéts István Nagyváradi Pap egy ollyan munkát készített, mint Révai, de a' kézi mesterségekre alkalmaztatta. Ezen kívül de Caculo hexapedali - ez is igen nagy applicatióval. Végre egy munkát a' Palatinusról, mellyben az egész Magyar Constitutiót fejtegeti.

A' Bétsi Német Ujsághoz: Der neue Merkur von Ungarn - literaria recensio fog

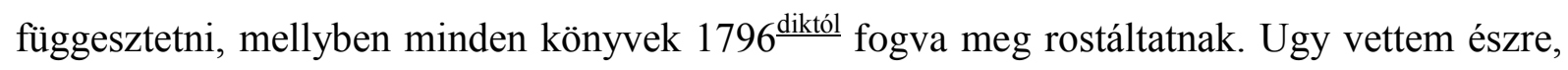
hogy Schedius fö mestere. 
Én (Kultsár) szolgálhatnék egy kellemes történettel illy név alatt: Zoroaster. Eben mind a' Mágusok' Szokásairól, mind pedig az emberi szivre ható érzékeny történetekből ollyan példák vannak, hogy az egész historia tsupa kellemetesség. A’ nyelv éppen nem lesz fel tsigázva. Az egész munkát nem vinné a’ nyomtatás 12 árkusnál többre.

Az egész gyüjteménynek talán leg jobb volna Könyvtár vagy Bibliotheca nevet adni; mert attól félek, hogy ha igen különös nevet nyerne ezen Szent Szándék, még a' nevének is magyarázat kellene.

Az is méltó kérdés: ha a' kiadandó munkák meg maradhatnak e azon orthograpiaval és grammaticával, mellyel a Szerzők éltek? A' versekre nézve ez igen terhes kérdés: de pedig igen nemesítené a' munkát nem tsak az egy név hanem az egyenlő nyelv is.

$7^{\underline{0}}$ Nagy János Szanyból Január 9 $\stackrel{\text { dikén }}{ } 1798$

Én másoknak kész, vagy készülő munkáiról semmit se tudok; hanem magam a’ Bétsi Richter nevezetü, Satyricus Poetának némelly tsipősebb Satirait magyarra fordítottam. Ha ezek tetszenének, örömmel le irnám és által küldeném. A’ melly Satiraihoz ha más különbféle gondolataim is, a' mellyeket magyar versbe szedtem, kiadattatnának, ezekből is majd ollyan Könyvetske nevekednék, mint a' mellyet a’ Nyájas Múzsának neve alatt adtam ki. A' Richter Satiraiban nem hagyom a' Magyarokat is marás nélkül, a' kik a' Bétsiekkel holmiben véttenek. Minden nyájas verseimet tehát a' télen öszve szedem, és egyéb hasznot nem várok, hanem tsak azt kérem, hogy valami 50 nyomtatványban részesülhessek.

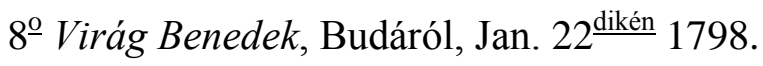

Jó volna egy Énekes Könyvet készítteni, de kótákkal. Lehetnének benne imitt amott elmés mesék, vagy rövid narratiók is. Először tsinállyunk Magyarokat, azután írjunk nekik. Az én Munkám még sok hejjával van.

9ํㅡㄴ Mór Borbála, Kolosvárról Jan. 14 $\stackrel{\text { dikén }}{ } 1798$.

A'Szerentsétlen Szerelemben valami az Urnak nem tetszik, bátran haggya ki belőle, vagy tetszése szerint változtassa meg. De azt még egyszer jelentem, hogy akár mennyire látszatik is a' természetet meg eröltetni, még is nem Román, hanem valóságos történet. A' ki a' Kis Asszony mellett volt halálos betegségében, és a' kinek mindent meg mondott, az beszéltt-meg nékem mindent. - A’ M. Grófnak azt bátorkodom jelenteni, hogy ezen tsekély munkám után, az Ő Nagysága érdemeihez méltóbbakat kívánok udvarolni.

$10^{\circ}$ Kósa György, Petendi Plébános, Jan. $25^{\text {dikén }} 1798$.

Azon Költeménynek, mellyet 1788 esztendőben irogattam, tárgya: Az igaz szeretetnek példákban való meg mutatása. Más is keveredik bele, hol szomorú hol víg eset. Tészen 24 árkust, a' lapokat tele írva. Ha tetszik, fel-küldhetem. - Irogatok fontosabb dolgokról is. 
$11^{\mathrm{O}}$ Weszprémi István M Dr. Debretzenböl Jan. $29^{\text {dikén }} 1798$.

A’ Ki nyomtatásban két hasznos munkákat tudnék ajánlani. Az első, Historia Naturalis, Lineus utmutatása szerint irott könyv magyar nyelven. A’ Szerzője Földi János, a' Hajdú Városokk Ord. Fisicussa, a’ Jenai tudós Társaságnak Tagja. Az állatok’ Országát már el végezte, 30 arkusra terjed, tisztán le írva. A' Regnum Vegetabilium is vége felé jár. A' Botanicában már valamelly munkátskát is botsátott ki elő-járóúl. - $2^{\frac{\text { szor }}{2}}$ a' Gyulai Ref. Prédikátor amaz híres, természet-visgáló Bonnetnak Könyvét: Contemplation de la Nature már szinte el-végzette magyarra lett fordítását. Szikszai a’ Fordítónak neve a’ ki Genuaban létekor Bonnet' jószágan sokáig lakott, 's vele társalkodott. -

$12^{\circ}$ M. Aranka György M. Vásárhelyről Febr. 24 $\frac{\text { dikén }}{2798 . ~}$

Az Erdélyi M. Nyelv mivelő Társaság ${ }^{590}$ nevében kivánnya, „hogy arról a’ nemes Igyekezetről, mellyek a’ könyvek’ ki nyomtatásában M. Gr. Festetits György Úr Hazánkat boldogítani igyekszik, és annak egész állapottyáról, egy rendes tudósítás küldessék meg, a' M. Gróf’ engedelméből a’ Társaságnak.”

Egyszersmind tudósít arról is, hogy több szép munkátskák jöttek bé a’ Társasághoz, a' mellyeket, mivel a' Tarsaság maga munkáji között nagyságok miatt ki nem adhattya; kérdi, ha szabad leszsz e a' Társaságnak, vagy magának a’ Személlynek a’ M. Grófot meg-találni, és ki adásokat kérni?

$13^{\mathrm{o}} A$ ' M. Grófnak Martius $8^{\text {dikán }}$ költt levele szerint az idén a' következendő három munkák jönnek-ki a’ ki szabott 5 000. forintból. t. i. $1^{\circ}$ Ányos Pálnak versei. 2º $\mathrm{Gr}$. Teleki Domokosnak deák munkája de Administratione legali Comitatum. 3ํำ Molnár Borbálának Költeményes Munkája. - Batsányi Urnak 500. forint rendeltetett elöre jutalom gyanánt Ányos’ Munkájáért; Molnár Borbálának pedig tizenkét arany. De úgy, hogy a’ nyereségből deductis deducendis, és az előre letett Summának bele-számlálásával, utóbb a’ haszonfélt meg nyerjék.

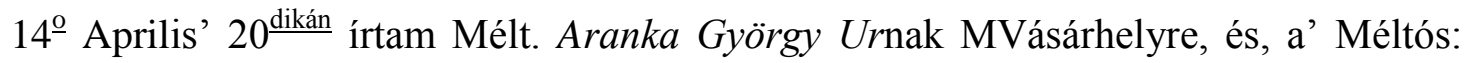
Grófnak Aprilis $6{ }^{\text {dikán }}$ költt levele szerínt, a’ fellyebb-említett kérdésre ezeket feleltem: „Hogy ha a’ M. Nyelvmüvelő Társasághoz bé küldött munka előfordúlt a’ Tarsaság' Ülésében, és méltónak iéltetett a' ki-nyomtatásra: tehát, ha mí-nálunk leszsz annyi Költség, igen is ki fog nyomtattatni, ollyan megjegyzéssel; hogy, ha eredeti a' munka, egy fele haszon rész - ha fordíttás, egy harmad rész adatik jutalom gyanánt (le számlálván a’ költségeket) de ugy, hogy

\footnotetext{
${ }^{590}$ Az Erdélyi Magyar Nyelvmívelő Társaságot Aranka György kezdeményezésére alakították meg 1793 öszén Marosvásárhelyen. A társaság elnöke Bánffy György, titkára Aranka György lett. Tagjai közt nemcsak erdélyi, de magyarországi írókat, tudósokat is találunk, például Péteri Takáts Józsefet is.
} 
ezen adománynak fele a’ Szerzője, fele pedig az Erdélyi Nyelvmívelő Társaságé légyen. - De ha az Author maga különösen kívánnya munkájának kinyomtatását, a' nélkül hogy a' Társaság ajánllya, akkor az October hónapban tartandó Revisiótól fog függni, ha vallyon reá jöhet e az illyen munkára a' sor a' könyvek ki-adásiban.

15ํ) Molnár Borbála Aprilis $15^{\text {dikén }}$ Kolosvárt költ levelében megköszöni a’ számára kirendeltt 12 aranyokat. A' mellett írja, hogy a' Mélt. Grófnak eránta való kegyességét versekben akarja, ha egészsége helyre-áll, megköszönni. Kikéri egyszersmind, hogy Ö Nagysága méltóztassék elfogadni munkájának ajánlását.

16º ) A'Méltóságos Gróf helyben-hagygya, hogy az Alberti' mühelyében nyomtatandó könyveknek árkusáért (ha 5000 példák adódnak a' prés alá; azon kivűl 12 exemplár velin ${ }^{591}$ 12 pedig író papirosra készülnek) 14 forint fizettessék. A’ nehezebben kelő könyvekből pedig tsak 500 exemplár nyomtatassék, 8 forintot számlálván árkusáért. - Az-is meghatároztatott, hogy a' Magyar Könyvek külön adódjanak-ki Magyar Minerva név alatt; a' deák 's német munkák - is hasonló formatumban nyomtattassanak alkalmatos nevezet alatt, melly utóbb fog a' projectum szerint helyben-hagyódni.

17º) Aranka György’ Marosvásárhelyröl, Junius $2^{\text {dikán }}$ írott levelében többek között

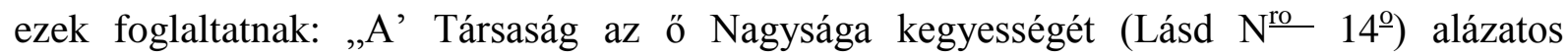
köszönettel vette, és gratiáját ki fogja kérni." - Azólta (Lásd $\mathrm{N}^{\text {ro }} 16^{\underline{0}}$ ) méltóztatott igérni Ö Nagysága, hogy az Erdélyi tudós Társaságnak még másként - is fog szolgálni, ha Ányos', Molnár Borbála’ munkájinak kelését fogja látni.

18º̄) A' Méltóságos Gróf Molnár Borbála' munkájának neve alatt való kiadását elfogadgya, 's fáradságáért különös jutalmat-is ́gér. - Ha Gróf Teleki Domokos Úr' deák munkája ki fog nyomtatódni, 30 exemplárok adatnak Ö Nagyságának.

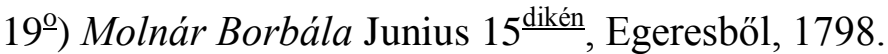

„Ha a’ Mélt. Grófné gyönyörködik a’ Magyar Könyvek’ olvasásában, nem sokára udvarolhatnék Ö Nagyságának-is egy munkátsával, mellyen most dolgozom Nemünk' tudatlanabb részének számára. Folyó beszédben leszsz, Épületes Barátság név alatt, egygyütt való beszéllgetések formájában: de úgy reménlem, hogy a’ szorgalmatos olvasónak nem fogna haszontalan lenni."

20.) Hegyi József Pesti Professor Junius' 11 dikén írtt levelében kéri a' Méltóságos Grófot, hogy Gebhardi Lajosnak M. Országi Historiáját, mellynek általa lett fordíttása kéziratban mintegy harmad fél száz arkust tészen, Neve alatt engedgye közre-botsáttatni.

\footnotetext{
${ }^{591}$ Erre figyelemmel vélelmezhetjük, hogy a kiadó a drága papír felhasználásával a könyvgyüjtőknek akart kedveskedni.
} 
21.) Csizi István, Fő-Strása-mester, Tokajból Julius’ $29 \stackrel{\text { dikén }}{\text {. }}$

„Tessék a’ M. Grófnak béjelenteni, hogy én Fábián Julianna nevezetü Komáromi Vers-szerzővel levelezvén, azon verseket a’ Mgos Gróf nevével kívánnám kevélykedtetni.

A’ Miltonnak fordíttója, Kapitány Bessenyei Úr - is frantziából magyar köntösbe öltöztetvén Marcus Aurelius Julianus Apostata, Stanislaus Lengyel Király és $2^{\frac{\mathrm{dik}}{}}$ Fridrichnek jeles mondásaikat kívánná a' Gróf’ kegyessége által kinyomtatni.”

22.) Weszprémi István Debretzenből Aug. $4 \stackrel{\text { dikén }}{\text {. }}$

T. Professor Sárvári Uram ajánllya magát, hogy Ányos munkájinak eladásában hűségesen elfog járni. Ő Kegyelme - is mostan Tanítványainak számokra Theologia moralist írogat; közel jár a' vége felé: jól indúlt a’ munka. Ha az argumentum megengedi, reménylem, hogy ama' jó 's hasznos tzélra törekedő Mecenássa Hazánknak a' kidolgozására nézve helyben fogja hagyni.

A’ Vőm, Dr Földi János, Naturalis historiáját tisztán maga kezdette leírni. Rövid időn készen fog lenni vele.

23.) Nagy János, Szanyból Aug. 10 $\underline{\text { dikén }}$

Imhol két könyvetske verses költeményem. Az elsőnek tzíme: Józan érzések 's. a' t. A’ másiknak: Nyájas kötet. Az elsőben nincs semmi, a’ mi vagy Bétsben, vagy másutt ki nem nyomtatta volna; mert mindeneket a’ Censurán által-esett könyvetskéből szedegettem; ugyan azért mások nem-is hátráltathattyák. A’ másikat Richter Bétsi Vers szerzőnek Bétsben nyomtatott könyvetskéjéből fordítottam, a’ ki Béts Városát ütögeti ugyan, de én nagy részét a' Magyarokhoz - is alkalmaztattam.

24.) Káts István némelly kéz-írásnak lajstromát adta-által.

25.) Kósa György Petendi Plébános, két rendbéli munkáját küldötte kezemhez, mellyek Kultsár Professor’ Úrnak adattak-által megvisgálás végett.

26.) Szabó Dávid - megjobbított 's bővített költeményeihez járandó Ajánló-levelet,

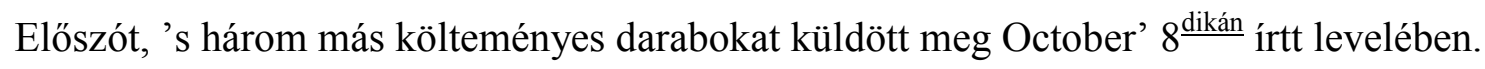

27.) Jordánszky Elek, Szölgyéni Plébános, azon kérésemre, hogy Szentiványi Püspök’ Magyar Virgyiliussát keresné-ki Primás Ö Eminentiája’ Könyvtárjában, ezeket felelve: „Hogy azon Bibliothecában tsak két nyomtatlan fordíttása találtatik Virgyil' Munkájinak. Egygyiknek Gyárfás a’ Szerzője a’ másiknak pedig egy Nevezetlen. - Szentiványi Püspök iránt azt mondotta néki Szabó Püspök Úr, hogy igen - is fáradozott Ö - is Virgyilius' munkájinak fordíttásában; hanem hová lett kéz-írása, azt nem tudgya: azonban iparkodni fog a’ dolog' kitanúlásában. - Bölöni Agens Úrtól hallám, hogy Ovidius’ Metamorphozissa Viski Pál Úr által volna szépen magyarra fordíttva. 
28ํㅜ) Nagy János, Szanyból a’ $23^{\text {dik }}$ szám alatt említett munkájához tartozandó Toldalékot küldött kezemhez, kikérvén egyszersmind, hogy a’ verseihez semmi anecdotakat

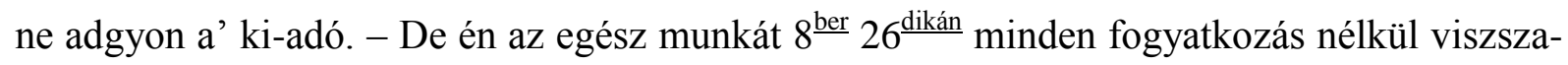
küldöttem a' Plébános Úrnak, minthogy a' kiadást sürgette; pedig a’ jövő esztendőbéli nyomtatásra már más kéz-írások vagynak meghatározva.

29ํㅜ) Sárvári Pál Debretzeni Professor Úr tudósít, hogy Ányos’ munkáji, mellyket az eladás végett küldöttem hozzá, kezéhez jutottak. Azt kárnak állíttya hogy a’ Kiadó semmi rendett nem tartott a' darabok' felosztásában.

30) Virág Benedek szándékozik nem sokára felküldeni Munkáit, mellyek Ódákból, Hexameterekből, különbféle versezetekből, ’s Horatiusnak némelly fordított Ódájiból álanak.

November $2^{\text {dikán }}$ írtam Aranka Györgynek MVásárhelyre, 's reá emlékeztettem azon munkák’ megküldésére, mellyket az Erdélyi Társaság maga rendes darabjaiban ki nem

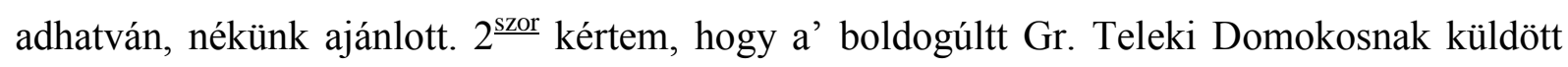
500 nyomtatványokról az Ányos' munkájiból tudósíttson.

Írtam ugyan az nap' Csizi István Főstrása-mesternek - is Tokajba, 's tudtára adtam, hogy a' $21^{\text {dik }}$ szám alatt ajánlott munkákat elfogadgya a' $M$. Gróf a' kiadás végett, ha a' Szerző Urnak a’ M. Minervába akarják azokat bé iktattatni de úgy, hogy a' nyomtatás' idejét nem lehet mindgyárt meghatározni; 's ha a' munkák nem tennének külön külön 18 arkust egy kötetbe szoríttathassanak.

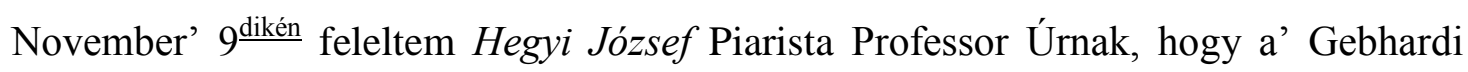
Lajosnak Magyarra fordított historiáját, ha felküldené - is, mindgyárt Sajtó alá nem lehetne adni, mivel több részekből fog állani, és igy mind a' költségből mind az időből sokat fogna-el, holott már több Tudósok küldötték-be munkájikat, mellyek meg sértés nélkül hátra nem verődhetnek. - Írtam egy uttal Kis István Pesti Könyv-árosnak - is, hogy Schedius Professor Úrnak a’ M. Minerva I. Kötettyéből egy exemplárt adgyon-által ajándékba, a' mint a' $M$. Gróf méltóztatott $9^{\text {ber, }} 2^{\text {dikán }}$ küldött levelében parantsolni.

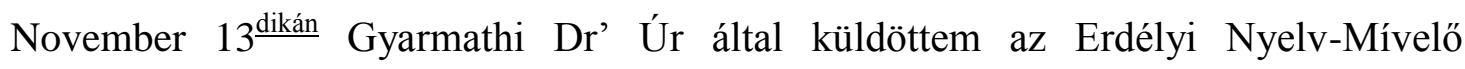
Társaságnak egy nyomtatványt, a’ M. Minerva I. Kötettyéből velin papiroson.

Ugyan azon Úr vitt-el magával két levelet Debretzenbe, Dr Weszprémi István Úrnak, mellyben Földi János Úr' Magyar Hist. Natur. miben-létéről tudakozódom; és Sárvári Prof Úrnak, a' kit újra kérek, hogy Ányos’ munkájiból be vett pénz iránt tudósíttson az esztendő' végével 's a' pénzt (le huzván a' posta költségeket) adgya által vagy Nagy József Bétsi Kalmárnak, vagy Kis István Pesti könyv-árosnak (...) 
$\left.31^{\circ}\right)$ Csizi Fő Strásamester Úr azt írja Detzember' $5 \frac{\text { dikén }}{}$ vett levelében, hogy Kapitány Bessenyei Úr az új esztendő elején kívánnya elkészítteni munkáját; a’ melly, mivel fordíttás, 's tellyes a' felséges gondolatokkal: Csizi Úré pedig eredeti, 's tárgyára nézve nyájaskodó egy kötetbe nem lehetne azokat szoríttani; annyival - is ritkább, hogy ez a' második munka maga - is fog egy 20 arkusnyi darabot adni; a’ mellyet a' Mélt. Grófnénak akarna szívesen ajánlani.

$\left.32^{\underline{\mathrm{o}}}\right) 13^{\mathrm{dik}} 10^{\text {berben }}$ küldött-fel Pozsonyból T. Döme Károly Úr 21 f. 40 xrt. az eladott 22 nyomtatványokért Ányos' Munkájiból. A' hátramaradott 4 exemplárok Weber könyvnyomtatóhoz fognak küldettetni, a' kinél 50 exepl. vannak letéve.

$33^{\circ}$ ) M. Aranka Úr tudósítt $1^{\circ}$ hogy az Erdélybe küldött exemplárok a’ M. Minervának I Kötettyéből kezéhez mentek ugyan Gr. Teleki Domokosnak; de hamar halála történvén, a' többi portékájival ezek - is mind ez ideig zár alatt tartatnak. - $2^{\circ}$ Az Erdélyi Társaságnak ezen munkák vagynak béküldve: Salzmann az Emberi Nyomorúságokról, Archenholtz Angliája, ’s mások. $3^{\text {o }}$ Maga Aranka Úr - is megküldi munkájinak lajstromát, míg azokat tisztára írattathatná.

34ํㅜ) Czinke Ferenc Prof. Úr’ Köszöntő Versei.

1799

$-\mathrm{O}-$

Januarius.

№ ) Januarius' 2 $2^{\text {dikán }}$ Kis István Pesti Könyvtárostól vettem az Ányosból eladott 78 Exemplárokért 65 f. 10 xkt . - 11 f. 51 xrt tartott - meg magának jutalmúl, (15 procentot kérvén fáradságáét) 2 f. 41 xrt fizetett harmitzadúl.

$\left.1^{\underline{0}}\right)$ Jan. $9^{\text {dikén }}$ megküldötte a' Mélt. Gróf Bessenyei Kapitány Úr levelét, mellyben némelly már kész munkáiról emlékezik: u. m. L’Esprit des Monarques Philosophes és Essay sur l’homme par Pope, mellyeket Magyarra fordított, Tovább igéri szolgálattyát akármelly megnevezendő német vagy frantzia könyvnek fordíttásában.

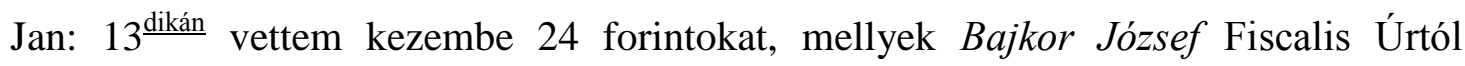
küldettek fel Ányos' verseiből eladott 24 exemplárokért.

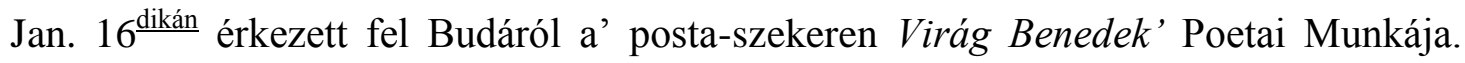
Fizettem érette 1 f. 5 xrt. 
Ugyan az nap írtam újjolag Kis István Pesti könyv-árosnak, hogy Ányos' verseiből egy exemplárt adgyon által Schedius Professornak, a’ M. Gróf' nevében. Irtam a’ Pesti Harmitzadhoz - is, az ott letartóztatott nyomtatványok végett.

$\left.2^{\underline{Q}}\right)$ Febr. $3 \frac{\text { dikán }}{}$ vettem Kolosvárról Szathmári Pap Mihály Professor Úrnak levelét, mellyben Tiszteletes Predikátor Viski Pál Uramnak magyarra fordíttatott Ovidius' Metamorphosissát ajánllya a' kinyomtatásra. - Ezen kívül ígéri, hogy a’ M. Athenás' kinyomtatásáról ez utánn fog tudósíttani.

$\left.3^{\underline{0}}\right)$ Földi János Úr, a' Hajdú Városok’ Orvos Doctora Febr. 11 $\frac{\text { dikén }}{}$ vett levelében, tudósítt akarattyáról, melly szerint kívánnya Ö M. Természeti Historiájának kiadását.

$\left.4^{\underline{o}}\right)$ Febr. 23 $\frac{\text { dikán }}{}$ küldött Zsoldos István Szombathelyi könyvkötő a’ M. Minerva’ I Kötettyéből eladott 15 exemplárokért 13 f. 30 xrt; tizet számlálván százért. Marad még 10 Exempl. Comissióban nála.

$5^{\circ}$ ) Martius 24 $\frac{\text { dikén }}{2 . ~ D o ̈ m e ~ K a ́ r o l y ~ U ́ r ~} 10$ f. 10 xrt küldött-fel Pozsonyból a' Minerva' II Kötettyéből eladott exemplárokért. Levelébe rekesztette Weber könyvnyomtató' tudósíttását is, melly szerint Ányos' munkájiból tsak egy exemplárt sem adhatott el. Én tehát írtam Schwaiger Pozsonyi Könyvárosnak, hogy Webernél lévő 53. nyomtatványokat vegye által, és hírdesse - ki tudósíttásában.

$\left.6^{\underline{0}}\right)$ Aprilis $19^{\frac{\text { dikén }}{2}}$ tudósított Kiss István Úr Pestről, hogy a’ hozzá utasított 300 exempl. a' Minerva' $2^{\frac{\text { dik }}{2}}$ részéböl kezéhez vette; de a' mellyek közzül 8 borítékok, és 4 darabban az utólsó arkus el rongyollottak. - Írja egyszersmind, hogy ezen $2^{\underline{\mathrm{dik}}}$ kötetből 25 exempl. T. Sárvári Professor Úrnak Debretzenbe, és még más 25. exempl. T. Benke Prof. Urnak Enyedre el fog küldeni.

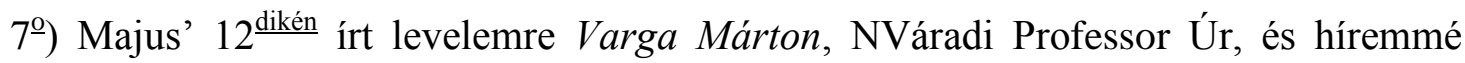
adgya, hogy Káts Istvántól kezéhez vett 15. nyomtatvánnyait Ányos' Verseinek (én 30 exempl. adtam által T. Káts István Urnak) eladta. A’ $2^{\text {dik }}$ kötetből - is 15 nyomtatványokat kíván. A’ bévett pénzt vagy Kis Istvánnak teszi-le, vagy maga fogja kezembe leolvasni.

$8^{\circ}$ ) Majus $14^{\text {dikén }}$ T. Kis Ferentz Úr 25. forintokat küldött-fel, a' Minerva $2^{\text {dik }}$ kötettyéből eladott exemplárokért. Erről quietantziát küldöttem néki. Még 26 nyomtatványok vagynak nála az eladás végett. - Az Ányos Verseiből ujra 50 exepl. küldöttem kezéhez. Egynéhány napok múlva ismét $13 \mathrm{f}$. küldött. - Ismét $13 \mathrm{f}$.

9ํㅜ) Schwaiger Pozsonyi Könyváros quietantziát küldött azon 53 exemplárokról, mellyeket Weber könyvnyomtatótól által vett Anyos verseiből, és a' Minervának $2^{\text {dik }}$ kötettyéből hozzá leküldött 35. exemplárokról. 
$\left.10^{\mathrm{O}}\right)$ Kultsár Úr tudósítt, hogy Ányosból elkeltek már nála 30. darabok és hogy a’ $2^{\text {dik }}$ kötetből hozzá küldött 28 exempl. vette, mellyekért 1 f. 48 xrt kellett a’ kotsisnak fizetnie. Kér, hogy ezen részből még 10. nyomtatványt küldgyek néki.

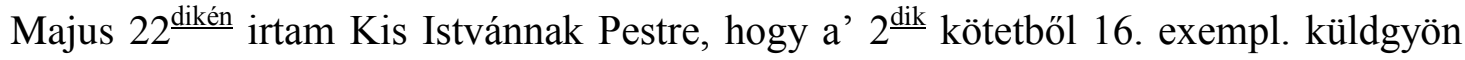
NagyVáradra Varga Márton Professor Urnak (a’ kinek Nagy József kereskedő Úr által mindgyárt írtam - is) és 10. exempl. Kultsár Prof. Úrnak Esztergomba.

Julius $3^{\text {dikán }}$ T. Juranits László a’ Minerva $2^{\text {dik }}$ kötettyéből eladott 24 exeplárokért kezemhez küldött 24. forintokat.

$11^{\mathrm{o}}$ ) Julius' $15^{\text {dikén }}$ a' Méltóságos Grófnak parantsolattya szerint fel kerestem Dr Nagy Samuel Urat, és bizonyossá tettem Ö Nagysága nevében, hogy Huffeland' Guter Rath an Mütter etc. nevü munkájának magyar fordíttását ki fogja a’ M. Gróf nyomtattatni, hogy ha Ö Nagysága' Neve alatt a' M. Minervába akarja azt iktattatni. A' mellyre Nagy Samuel Úr örömmel 's köszönettel reá állott és meg - is ígérte fordíttásának kezemhez adását, mihelyest azt tökélletesen el fogja végezni.

12º̣) Földi János Dr Úr tudósítt, hogy a’ M. Naturalis Historiáját Weber könyvnyomtatónak adta által, a’ ki 300. exemplárokat ígért néki jutalom’ fejében. Kész volna azonban még velünk végezni, kivált a’ képek’ kedvéért. - Irja egyszersmind, hogy Scheller Német Lexiconjának meg magyarosíttását magára vállalva, és már nagy részínt által-esett rajta.

13ํำ Kis István, Pesti Könyváros, felküldött Aug. $5^{\text {dikén }}$ a' második szám-adásával 102 f. 37 xr. a’ Minerva' árrából.

14º̣) Zsoldos István, Szombathelyi könyvárostól fel vettem a’ M. Minervából elkeltt exemplárokért, Septembernek $4 \stackrel{\text { dikén }}{2} 22$ f. 30 xrokat. Az első kötetért esik 7 f. 12 xr; a' másodikért $15 \mathrm{f} .18 \mathrm{xr}$.

Schwaiger, Pozsonyi könyváros, lefizettetett Doll Aloys által a' Minerva I et II Kötettyéből 20. forintokat. $=$ Ismét $9 \stackrel{\text { ber }}{2} 2^{\text {dikán }} 20$. forintokat.

Földesi, Keszthelyi könyvkötő, adós maradt 11 forinttal a’ Minerva árából.

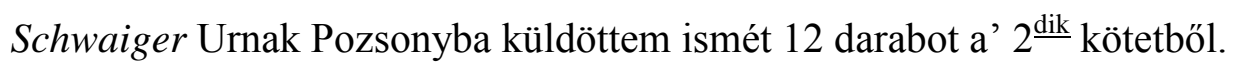

Kis István $\mathrm{X}^{\underline{\mathrm{br}}} 19^{\underline{\text { dikén }}}$ letett a' nála levő Minerva árrából $71 \mathrm{f}$. 15 xrt. - Számat vetvén vele az eddig elkelt exemplárok iránt, a' fenn-maradtak’ számos illy renddel írtuk-fel Jegyző könyvébe: A’ Minerva' $1^{\underline{o}}$ kötettyéböl békötve 109. exempl. - kötetlenül 32. ex. - A' $2^{\text {dik }}$ kötetből békötve: 57. exemp. - kötetlenül: 82 exempl.

Varga Márton Professor Úr lefizetett a’ Minerva $1^{\underline{0}}$ kötettyéért Kis István Uram által $15 \mathrm{f}$. 


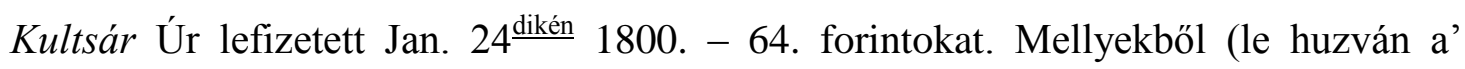
költségeket) az első kötetre esnek 42 f. 30 xr. A’ másodikra: 22 f. 3 xr.

1800.

$-\mathrm{O}-$

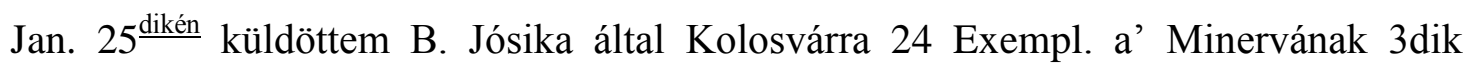
kötettyéből T. Rosenbacher Professor Urnak; a’ kinek számára két héttel ezelőtt el vitt magával Debretzenbe Kis István Uram 20 Exemp a’ Minerva I. köt. és ugyan annyit a' $2^{\frac{\text { dik }}{}}$ kötetből. Azon kívül mindegyikből egygyet egygyet a’ fáradság’ jutalmául.

$1^{\underline{0}}$ ) Hogy ezen 42. nyomtatványok kézhez jutottak, T. Rosenbecher Úr tudósított Feb. $23^{\text {dikán }}$ irtt levelében; megírván egyszersmind, hogy az alkalmatosságért 2 f. 42 xrt kelle fizetnie, 's hogy a' $2^{\text {dik }}$ kötetből három arkus megrongyollott. Ezeket utóbb kipótoltam.

$\left.2^{\underline{o}}\right)$ Schwaiger pozsonyi könyváros kér 36 Exepl. a' Minerva' $3 \frac{\text { dik }}{}$ kötettyéből, mellyeket fel - is küldöttem hozzája a' József vásárosok által. Azon alkalmatossággal útnak eresztettem még 20. Nyomt. T. Döme Károly Úrhoz.

$\left.3^{\text {o }}\right)$ Németh László Győri Professor tudósítt, hogy a’ Minerva $3^{\text {dik }}$ kötet általadott néki Müller könyvtáros 7. Exempl. - A’ két első köteteladott négy négy darabokat. - A' M. Tudós Ujságot szándékozik juliusban, vagy az új esztendővel megindíttani.

$\left.4^{\underline{0}}\right)$ T. Keszthelyi László Rector Úr tudósítt, hogy a’ Minerva' $3^{\text {dik }}$ kötettyéből kezéhez vett 23 Exempl. (Én 24 ${ }^{\text {et }}$ küldöttem). T. Sárvári Pál Professor Úr által adott néki 12 Ex. mind az első mind a’ második kötetből.

5o) Ossovszki Pál Úr közli Antal Prof. Úrnak levelét, mellyben tudtára adgya, hogy néhai Gr. Teleki Domokos 35 Ex. adott légyen néki által Ányos' Verseiből. Ezekből 12.

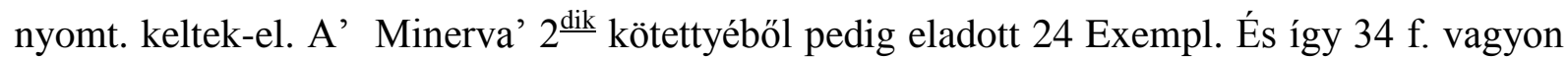
nála bészedve; a' Kotsisnak fizetett $2 \mathrm{f}^{\text {ton }}$ kivül. - Nemes György Urnál pedig 25 Exempl. voltak letéve Ányos' munkájiból; és eddig tsak 5 u 6 exempl. keltek-el belőlek.

$\left.6^{\circ}\right)$ Schwaiger Pozsonyi könyváros megküdötte Számadását, 20 forinttal egygyütt; és így már mindenestől $60 \mathrm{f}$. tett - lesz. - Azon észre-vételem vagyon, hogy a’ $3^{\text {dik }}$ kötetből tsak 30 Exemplárral számol; holott én $36^{\text {ot }}$ küldöttem.

7º̣) Molnár Borbála viszsza-küldötte a’ Szerentsétlen Szerelem nevü munkáját, némelly megjobbításokkal. Két egyszersmind, hogy előbbeni munkájiból a' $3 \frac{\text { dik }}{\text { 's }} 4^{\text {dik }}$ Darabnak uj kiadására beszéllem reá Landerert. 
$8^{\mathrm{O}}$ ) T. Rájnis Úr tudósítt hogy a’ M. Helikonra vezérlő Kalauzzát az új kiadás végett bővítti 's tsinosgattya; 's ugy reményli, hogy a' jövő Junius' közepe' táján elkészül vele. Biographiáját - is megküldi.

9ํㅜ) Junius $8^{\text {dikán }}$ kezembe vettem Nagy József Úr által 20 f. mellyeket Szoboszlai Úr küdött Bétsből az eladott Minerva’ árrából.

$\left.10^{\circ}\right)$ Junius $9^{\text {dikén }}$ küldött T. Kis Ferenc Úr a' M. Minerva' árrában 30 f.

$11^{\mathrm{O}}$ ) Junius $19^{\frac{\text { dikén }}{{ }^{2}}}$ vettem fel Schedius Prof. Urtól 9 f. 20 xrt, mellyek T. Németh

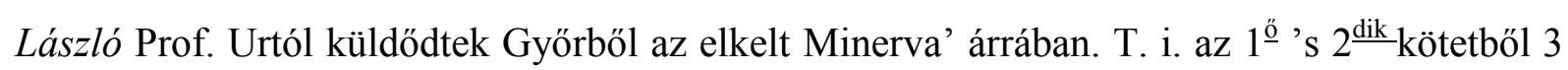
Exempl. a' $3 \frac{\text { dikból }}{}$ pedig 5 . nyomt.

Ugyan mai nap küldöttem Ossovszki Úr által leveleket: $1^{\text {ször }}$ N.Váradra Varga Márton Prof. Urnak; Kolosvárra T. Rosenbacher Urnak 's Molnár Borbála Aszszonynak; MVásárhelyre Aranka Consiliarius Urnak. Az írás' tárgya a' Minerváról való értekezések voltak.

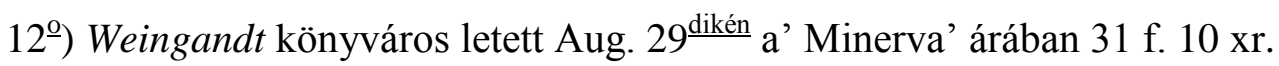

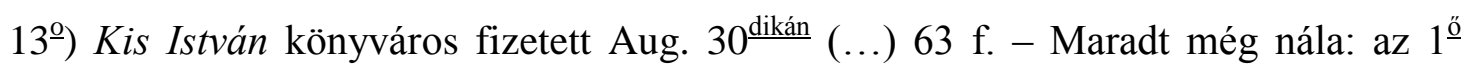
kötetböl békötve: 84 Exempl. Köttetlen 22 Ex. - A' 2 ${ }^{\text {dikból. }}$ : köttetlen: 75 Exempl. A' $3 \frac{\text { dikból. }}{\text { : }}$ kötve 21; köttetlen 25 Exempl. - Költeményes munkáimból 10 Ex.

Nov. $1^{\underline{0}}$ Napj. Zsoldos István, Szombathelyi könyváros letett a’ Minerva' exeplárjiért 21. f. 50. xrt. - Az $1^{\text {ö }}$ kötetböl maradt még nála 2. Ex. a’ $2^{\text {dikból }} 5$; a’ $3 \stackrel{\text { dikból }}{15} 15$.

A' verseimből 6. Exemplár. - A' 3dik kötetből hozzá küldött exemplárokért a’ kotsisnak fizetett 1. f. - Ezen Exempl árrát 20. 20 xrt 23 ${ }^{\frac{\mathrm{dik}}{\mathrm{k}}}$ Apr. 1805 magamnak kifizette.

14º ) Ossovszki Úr, Nov. 6 ${ }^{\underline{\text { dikán }}} 82$ f. 40 xrt tett-le nálam. Az $1^{\underline{0}}$ 's $2^{\underline{\text { dik }}}$ kötetért 47 f. küldött T. Antal Prof. Úr MVásárhelyről; a' $3^{\text {dik }}$ kötetböl el kelt exempl. 14 f. 40 xrt. T. Benke

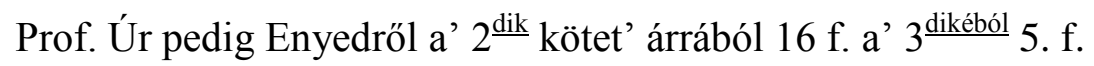

15) Schwaiger Könyváros megküldi szám-adását a’ M. Minerváról 25. forintokkal egygyütt.

16º ) Weingandt Pestről küld 25. ftokat az eladott Himfy árrából.

Kis István Pesti Könyvkötő lefizetett Kolosváry Miklós Urnak 12. f. a’ Himfy’ árrából, mellyeket fogyatkozás nélkül kezemhez - is vettem.

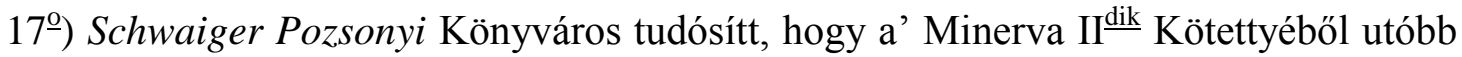
küldött 10. Exempl vette; hogy a’ III ${ }^{\text {dikból }}$ nem vett mindenestől többet 49. Exemplároknál; végre hogy a’ Himfyből - is 50 . Nyomt. mentek kezéhez. Junius $5^{\text {dikén }} 1802$. letett 25 . f. Pozsonyban. 
18º̄) Kultsár Úr Himfynek széllyel küldött Nyomtatványiról tudósítt; ugy nem különben arról - is, hogy Varga Márton Prof. Úr 7. forintokat tett-le számomra Weingandt könyvárosnál.

19º) Légrádi Imre Úr a Himfyhez járuló Képre tett költségeket számba veszi, és a' Bétsben felküldött 66. Exemplárok’ állapottyáról tudósitt.

$\left.20^{\circ}\right)$ Schedius Lajos Pesti Professor Úr megkér, hogy Zeitschrift von und für Ungern nevü munkájára szedgyem-be az Előfizetőktől a' pénzt; és küldgyek én - is néha a' munkájába iktattandó darabokat.

$\left.21^{\underline{0}}\right)$ Juranits László Értényi Plébános irja, hogy a’ Himfy’ exemplárjait kezéhez vette; kér, hogy prenumerallyok az ő részére Schedius Úr' munkájára; tudosítt egyszersmind, hogy Vitéz Imre Urnak írt; a’ M. Minerva' exemplárjai iránt.

$\left.22^{\circ}\right)$ Tomentsek János, Landerer Typograhus' Factorja tudósítt, hogy a’ Keszthelyi Könyvkötő Földesi István kezéhez vett a’ M. Minerva I kötettyéből 10. Ex; a’ II kötet. ismét

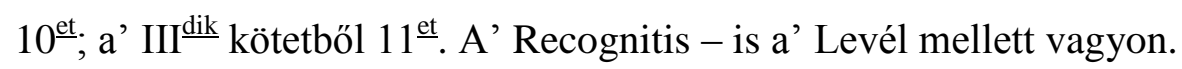

23ํำ Bétsben a' M. Hirmondó 'Irójinál a’ M. Minervából letett Exemplároknak specificatiója és az Elkölttekről Szoboszlai Uramnak számadása.

24ํㅜ) Fő T. Nagy József számos Exemplárokat kíván a’ Himfyből. Küldöttem - is. ét ízben 125. Nyomtatványokat. - Egyszer kérésemre 30 f. fizetett-le belőle a’ Bátyámnak; másodszor ismét ennyi summat aszignáltam számára.

25ํㅜ) T. Szent Györgyi Gellért Úr levele a' Fő T. Hertelendi Gáspár Kánonok Úr' számára küldött Portzellánról.

26ํㅜ) Sándor István Úr némelly M. Tudósokról értekeződik, hogy M. Könyves-Ház nevü munkáját annál tökélletesebbé tegye.

27º) Mészáros József Barátom Rhédén mondott Prédikátziójának kinyomtattatását bizza reám.

28ํㅜ) T. Szabó Dávid Úrnak egynéhány levelei, mellyekből a’ Minerva állapottya alkalmasint kitetszik.

29ํㅜ) Kultsár István Úr tudósítt, hogy T. Virág Benedek Urral számot vetvén a' Minerva' 3dik kötettye iránt (mellyből a' Pesten lévő Exemplárokat mind által vette) 135. ftokkal maradt még nékem adós. Ezekből 25. ftokat mindgyárt lefizetett, 's nékem megküldött. - Kevés idő mulva ismét 33 ftokat és 40 xrokat vettem kezemhez mellyekből 26. f. 40 xrokat T. Konde Ur küldött Himfynek 20. Exemplarjaiért; 7. forintot pedig Varga Prof. Úr, de nem tudatik, melly munkákért. 
30) Kultsár Úr ismét 112. ftot küldött kezemhez, mellyekből 50. ftot Kis István, 50. ftot Weingand Könyváros, és 12. ftot Bernáth László Úr tett-le.

$\left.31^{\circ}\right)$ Kis István Ur számot ád Himfynek 100 Exemplárjáról. - Az egész summa tenne 133. f. 20 xrokat. Magának 20. ftot rabat képpen lehuzván, 113. f. 20 xr járt nékem.

Ugyan Kis István Úr adott az Assignatiómra T. Révai Miklós Urnak 25. ftokat.

32ํ) Kultsár Úr megküldi Eggenberger Könyvárosnak Számadását Himfynek 120. Exemplárjairól; 's Minervának egynéhány darabjairól. Az egész summa, lehuzván a' 25. ft. 26 xr. Rabattot, tett 143. ft. 54. xrt. - Ezekből Kultsár Úr felvett 45. ft. 54 xr.

33ํํ) Kultsár Úr tudósítt, hogy 67 ftokat kifizetett Eggenbergernek némelly könyvekért, mellyeket ez Weszprémbe küldött kérésemre.

34ํํ) Kultsár Úr küldött 65. ftokat, mellyek 75. Exempl. a’ Himfy’ Szerelmeiért Kis

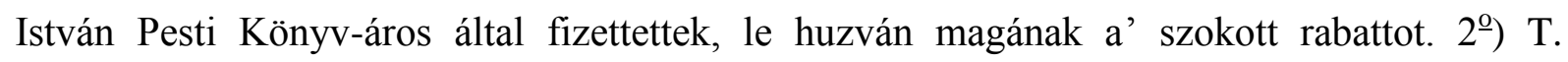
Rosenbacher Prof. Úr - is küldött 20. ftokat a’ M. Minerva' Exemplárjai’ árrából.

35ํ) Eggenberger Könyvárosnak le fizetett Kultsár Úr $47 \mathrm{ft}$.

36º ) Kultsár Úr felvett Gebhárdi 20. Exemplárjáert 100. ftokat.

37ํㅜ) Kis István Himfy 16 Exemplárjaiért fizetett 18. f. 14 xrt.

$38^{\circ}$ ) Légrádi Imre Himfynek veszendő Exemplárjaiból 12 f. 11 xrt liquidál számomra.

39º) Schwaiger Pozsonyi Könyváros a' Himfyből 36. a’ M. Minerva $1^{\underline{0}}$ és $2^{\text {dik }}$ Kötettyéből 8, és 8. Exemplárokat kíván az eladásra. Ígéri egyszersmind, hogy a’ mivel még adós maradott, első alkalmatosságal megküldi.

40ํ) Virág Benedek 24 Exempl. küld Telegdi négy Prédikátziójiból, és Miklósi Püspökre készült verseiből. Ugy nem különben tudosítt arról - is, hogy Kátót de Senectute most (...) - Ismét (...) 10 Ex. Horatiusból 5. - Mindeniéből egyet egyet Rájnis Józsefnek küldöttem.

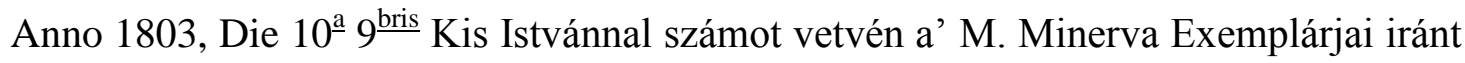
(mellyeknek száma állott az $1^{\underline{0}}$ Kötetből kötve 64 Darab, kottetl 18. A' 2 ${ }^{\text {dik }}$ kötetböl köttetlen 38 Darab. A' $3^{\text {dikból }}$ 9, Darab) az eladott Exeplárokért járt volna 72. ft, de le huzván a 15 per centumot, kezemhez tsak 61. ftot, 12 xrt vettem. Maradt eladandó Exemplár: az 1 $1^{\text {sỏ }}$ Kötetből

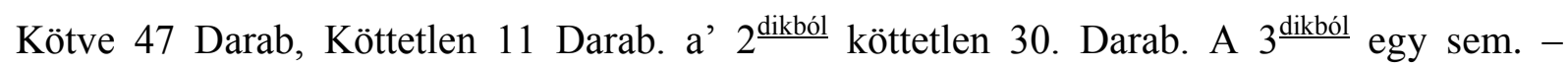
Magammal elhoztam az $1^{\underline{o}}$ kötetből 4. Exemplárt, a’ $2^{\underline{\text { dikból }}} 31$ Darb. - Pozsonyba Schwaigernek küdöttem Eggenberg által az $1^{\underline{0}}$ és $2^{\text {dik }}$ kötetböl 8 és 8 Exemplárokat. - Kultsár István Úr' feljegyzése szerint maradott nála az $1^{\underline{o}}$ kötetből 51. Darab; a’ $2^{\frac{\text { dikból }}{1}}$ 169. Darab. Le huzván ezekből az onnét általam elvitt exemplárokat, maradtak még az 1̋ㅡ kötetből: 39. Darab;

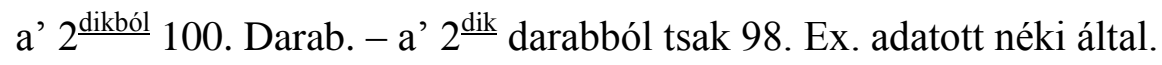


41ํํㄱ) Révai Miklós Úr 30. nyomtatványt küld M. Régiségeinek ${ }^{592}$ első Darabjából, és segedelmet kér M. Gramaticájának könnyebb kiadathatására, mellyet meg - is nyert 800 . ftokban Mélt. Zsolnai NPrépost, Fő Tiszt. Hertelendy, Nedeczky és Hornyik Kánonok Uraktól.

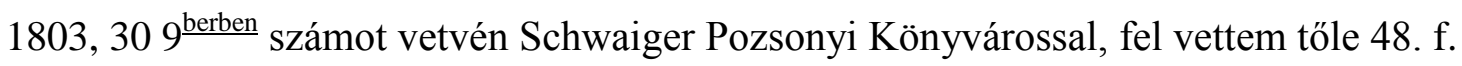
25. xrt. 25 Ex. Himfyért, 10. Exempl. M. Minerváért, és 6. Ex. Költ. Munkáimért. Még maradt nála 8. Ex a' M. Minerva 1 és $2^{\frac{\text { dik }}{2}}$ Kötet és 12 Ex. a' $3^{\text {dik }}$ Kötetböl.

42ํㅜ) T. Rájnis József szívesen veszi a’ számára megküldött Himfy' Szerelmeit viszontag Apátzai Tsere János' M. Encyclopediajával kedveskedik. - A' Magyar Parnaszszussa' Kinyomtattatásáról tett ígéretemet elfogadgya, és a’ Kéz-irásának megküldését ígéri.

43ํ) Georch Illés a’ Honnyi Törvény’ Irója, ${ }^{593}$ küldött hozzám munkájának első Darabjából Iró papirosra 18. Ex. - Nyomtatásra 107 Ex.

44ํㅜ) T. Révai Miklós az Elaboratior M. Gramaticajának két első szakaszszából 30 Ex. a’ Magyarság’ Régiségiből pedig ujra 10 Exempl küld hozzám eladás végett.

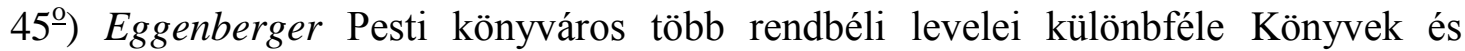
azoknak fel vett árrok iránt.

46º) Kis István tudósitt, hány Exemplárokat adott néki által Kultsár Úr a’ M. Minerva I, és II. Kötettyéből.

47º) Ugyan az megirja, hogy Himfy’ Szerelmeiböl 20 Exempl vett kezéhez, á 2. ft. $\left.48^{\circ}\right)$ Kultsár Úr Kisfaudy Bódi által küldött a’ Himfy árrában 50. ft. --

Az eredeti kézirat megtekintését követően leszögezhetjük, hogy Péteri Takáts a beérkezett leveleket nem egyenként a beérkezést követően írta be a regestrumba, hanem párat összevárva időközönként jegyezte be azokat. Ezt az eltérően megfaragott tollhegyek bizonyítják (hol vékonyabb, hol vastagabb az írás). Vannak időszakok, amikor Péteri Takáts kapkod, kevesebb információt közöl, lehagyja a levelek keltezésének dátumát, siet. Ilyenkor az írásban nem konzekvens, egy-egy szót másképpen vet papírra: Ur - Úr, Weigend Weigandt, rabatt - rabat, Eggenber - Eggenberger, grammatika - gramatika, rövidítéseket alkalmaz, ékezeteket hagy el. A levelekben érdekes javaslatokat vetnek fel az írók. Kultsár István olyan sorozatcímet javasol, amit nem kell magyarázni a nagyközönségnek - javaslata

\footnotetext{
${ }^{592}$ Minden bizonnyal Révai Miklós: Antiquitates literaturae Hungaricae (Pest, 1803) kötetről van szó.

${ }^{593}$ A kötet végül négy évvel később jelent meg: Honnyi Törvény. Öszve-szedegette Ettre-Karchai Georch Illés, tekintetes Zágráb Vár'megyének, és nemes Vajka Széknek tábla-bírája, fel-esküdt ügyész és királlyi oktató. Első könyv. Po'sonyban, Belnay György Aloys' betűivel, 1804.
} 
szerint legyen Könyvtár vagy Bibliotheca -, és lándzsát tör „az egyenlő nyelv”, azaz az azonos szavak azonos írása mellett. Van, aki azzal ajánlja mủvét, hogy a cenzúra már látta és nem volt kivetnivalója (Nagy János), Molnár Borbála a grófnak ajánlja múvét, egy másikat pedig a grófnénak, van, aki vidámabb alkotását ajánlja, de megjegyzi, hogy ,,irogat fontosabb dolgokról is" (Kósa György). Nagy János szanyi plébános nemcsak sürgette művének kiadását, de leszögezte, hogy a kiadó ne füzzön munkájához semmiféle kommentárt (anecdotát). Péteri Takáts megjegyzi, hogy a kéziratot maradéktalanul visszaküldte a feladónak, Nagy Jánosnak. A levelek az első évben (1798) szinte kizárólag a Minerva szervezésével, az anyagok begyüjtésével kapcsolatos témákat sorjáznak. 1799-ben már a terjesztés és a pénz útja a nagy kérdés, mígnem 1800-ban szinte kizárólag erről folyik a levélváltás. Péteri Takátsnak hatalmas szervezőmunkát kellett kifejtenie a terjesztés érdekében is. Teleki Domokosnak elküldött könyveket zárolták, mert a gróf meghalt. Több esetben a kötetek a szállítás során megsérültek. A regestrumból megtudhatjuk, hogy olykor a darabszámmal is gondok voltak. 1799. május 12-én Varga Márton nagyváradi professzor azt írja, hogy Káts Istvántól átvett tizenöt Ányos kötetet. Péteri Takáts megjegyzi a regestrumban, hogy ő harmincat küldött. Az 1800-as esztendő negyedik bejegyzéséből megtudhatjuk, hogy Keszthelyi László rektor huszonnégy példányát igazolta vissza a Magyar Minerva harmadik kötetének, ám Péteri Takáts megjegyzi, hogy ő huszonötöt küldött. Hasonló az eset ugyanezen év hatodik bejegyzésénél is, ahol Schwajda pozsonyi könyvkereskedő harminc példányról ír Péteri Takátsnak, holott ő harminchatot küldött. 1800-ban a levelek már nem kizárólagosan a Magyar Minerváról szólnak, hanem arra is rávilágítanak, hogy Péteri Takáts valójában irodalomszervezöként müködött. Többen kérik könyveiknek nemcsak kiadását, hanem a meglévő köteteik terjesztését (Révai Miklós). Legtöbbször Kisfaludy Sándor Himfyje kerül szóba. Tudjuk, hogy kiadásának évében „A kesergő szerelem” hatalmas sikernek bizonyult. Ezt támasztják alá a Péteri Takátsnak írt levelek is. Tudjuk, hogy „A kesergő szerelem” 1796-1798 között keletkezett, az első kiadásnál kétszáz dalt és húsz éneket tartalmazott, mely dalok Kazinczy elnevezése szerint szerelmi epigrammok. Péteri Takátsnak köze volt a kiadáshoz, ő bíztatta Kisfaludyt, ő vitte el a cenzorhoz, Engelhez a müvet, engedélyeztetésre. 1801 júliusában Péteri Takáts előszavával megjelent Budán a „Himfy szerelmei". 594 Így érthető a könyv többszöri megjelenése a regestrumban.

\footnotetext{
${ }^{594}$ Császár, 1910. 88-89.
} 


\section{5. 3. A megvalósult sorozat}

A kiadói tervezet (A’ Magyar Országi Írók’ munkájiknak Könnyebb ki-nyomtatását tárgyazó Gondolatok) részletesen foglalkozik a társaság szervezetével, is. Elöször is helyzetfelmérést terveztek, amelyben megtudhatták az irodalom helyzetét: írók, kiadatlan művek, készülő és elkészült írások számbavétele. Erre elismert, neves tanárokat kértek fel: Keszthelyi László (Nyitra), Szatmári Pap Mihály (Kolozsvár), Révai Mikós (Győr), Szabó Dávid (Kassa), Dugonics András (Szeged), Virág Benedek (Buda), Kultsár István (Esztergom). A szerkesztést „némelly tudós urak”-ra bízták volna: Batsányi, Báróczy. A cenzori engedélyt követően kerülne sor, a könyvek kinyomtatására. Ugyanakkor azt tervezték, hogy a nyomdai tipográfiáról, a korrektúrákról egy személy gondoskodik majd. A tervezet a terjesztésre vonatkozóan is tartalmaz elgondolásokat miszerint törekedni kell arra, hogy a „könyvárosok mértéktelen nyerészkedésének gát vettessék, és a’ bé-vett pénz annál bizonyosabb kézhez kerüljön". 595

Baróti Szabó Dávid, Révai Miklós, Kultsár István, Dugonics András, Molnár Borbála, Aranka György, Weszprémi István neve szerepel azok között, akiktől Péteri Takáts közvetlenül kért kéziratot, gondolván, hogy rendelkeznek kiadatlan írásokkal. Dugonics nem jelentkezett - hívja fel figyelmünket Harmath -, éspedig azért, mert a jól fizető Landerer volt állandó kiadója. Gvadányi József Molnár Borbála verseit ajánlotta, Weszprémi Földi János munkáit, míg Révai a Bécsi Kódex sajtó alá rendezését szorgalmazta. ${ }^{596}$ Összességében megállapíthatjuk, hogy a legtöbb megkeresettnek volt javaslata, de azt is láthatjuk, hogy páran saját müvel nem tudtak (vagy nem akartak) megjelenni a Magyar Minerva könyvsorozatban. Ez adódhat abból, amire Harmath István hívta fel figyelmünket, hogy a szerzők szoros kapcsolatban voltak eddigi kiadóikkal, de elképzelhető, hogy nem volt publikálatlan írásuk. Stohl részletesen feldolgozta az „irodalmi termés számbavételét”. Fontos és a Magyar Minerva tárgyalásánál lényeges adatok ezek, így fontos azok ide emelése.

Szerzők, akik a felhívásra maguk jelentkeztek munkáikkal:

1. Baróti Szabó Dávid ajánlja Költeményes munkáinak második kötetét,

2. Bessenyei György ajánlja nyomtatásra L'Esprit des Monarques Philosophes és Pope: Essay sur l’homme címü munkák fordítását, és vállalja a Társaság által később megnevezett német vagy francia munkákét is,

\footnotetext{
${ }^{595}$ Stohl, 2005. 231.

${ }^{596}$ Harmath, 1985. 457.
} 
3. Csizi István ajánlja a maga Fábián Juliannával váltott verses leveleit.

4. Czinke Ferenc Köszöntő versek,

5. Földi János Magyar természeti história első kötete; Scheller Lexikonjának fordítása,

6. Hegyi József Gebhardi: Magyar Országi Historiájának fordítása,

7. Káts István A kézi mesterségekröl; De calendo hexapedali; A palatinusról,

8. Kósa György Költemények,

9. Kultsár István Quis gaudet Jure Curandi educationem?; Per quos hoc Jus exercendum sit?; Quomodo administrandum sit?; Zoroaster,

10. Mészáros József Rédén tartott prédikációja,

11. Molnár Borbála Szerentsétlen szerelem; Épületes barátság,

12. Nagy János Nyájas kötet (Richter szatíráinak fordítása); Józan érzések (antológia),

13. Nagy Sámuel Huffeland fordítás,

14. Németh László Magyar Tudós Újság megindítását tervezi,

15. Rájnis József Magyar Helikonra vezérlő Kalauz (új kiadás),

16. Révai Miklós Bécsben talált magyar nyelvü Biblia fordításról,

17. Sárvári Pál Theologia moralis (gimnáziumi tankönyv),

18. Vályi András Az árva magyar nyelv

19. Virág Benedek Énekeskönyv; Horatius fordítás; Cato: De senectute. ${ }^{597}$

Látható a felsorolásból, hogy a kiadásra javasolt müvek müfajilag, tartalmilag eléggé eltérnek egymástól. Megtalálhatóak benne saját költemények, fordítások, theológiai munkák, tankönyv, jogi könyvek, újság megindításának terve, történelmi tárgyú munkák. Ugyanakkor a felajánlott anyagok sem lehettek hasonló színvonalúak, hacsak az írók neveit vizsgáljuk is.

\footnotetext{
${ }^{597}$ Stohl, 2005. 231-232. ; Baróti Szabó Dávid (1739-1819), jezsuita, majd világi pap, tanár, Nagyszombatban, Kassán tanult, Székesfehérváron, Kolozsvárott, Egerben, Nagyváradon, Besztercebányán tanított. Bessenyei György (1747-1811) testőríró, a magyar felvilágosodás első szakaszának vezető alakja. Ekkor már Pusztakovácsiban visszavonultan élt. Csizi István (1728-1805) katonatiszt, nyugalmazása után haláláig Tokajban élt. Fábián Julianna (1765?-1810) költőnő, Komáromban élt. Levelezett Gvadányival, Széchényi Ferenccel, Csizi Istvánnal. Czinke Ferenc (1761-1835) egyetemi tanár. Sopronban, majd Budán élt. Földi János (17551801) orvos, természettudós, író. Csokonai barátja és mestere. A debreceni füvészkör munkáinak elindítója. Hegyi József (1756-1827) piarista pap. Elöbb Vácott, majd Pesten, Kalocsán, végül Szegeden élt. Káts (Bukovecz) István (+1812) nagyváradi plébános. Kósa György pettendi plébános. Kultsár István (1760-1828) író, szerkesztő, Festetics László gróf nevelője. Mészáros József (1764-1839) székesfehérvári kanonok. Molnár Borbála (1760-1825) költőnő. Rádai Gedeon buzdította versírásra. Nagy János (+1808k.) szolgabíró Győr vármegyében. Nagy Sámuel (+1810) orvos. 1799-töl Komáromban lakott. Németh László (1770-1806) 1796-tól győri rektor. Rajnis József (1741-1812) volt jezsuita, győri tanár, költő, müfordító. Sírja a keszthelyi Fö téri plébániatemplom kriptájában található. Sárvári Pál (1765-1846) debreceni tanár. Vályi András (1764-1801) 1792-től a pesti egyetem tanára. Virág Benedek (1754-1830) költő, müfordító, történetíró. A magyar ódaköltészetnek Berzsenyi megjelenéséig legnagyobb mestere.
} 
Amint azt már említettük, voltak írók, akik mások - szintén változó színvonalú - munkáját (is) ajánlották:

1. Aranka György - Az Erdélyi Magyar Nyelvmívelő Társasághoz beküldött nagyobb terjedelmü munkákat ajánlotta (Salzmann: Emberi nyomorúságokról, Archenholtz: Anglia),

2. Bölöni Sámuel - Viski Pálnak Ovidius: Methamorphosis fordítását ajánlja,

3. Csizi István - Bessenyei György: Marcus Aurelius; Julianus Apostata,; Stanislaus király; II. Frigyes mondásait,

4. Festetics György - Teleki Domokos: De administratione legali comitatum címü munkáját kérte a Magyar Minerva második köteteként megjelentetni,

5. Gvadányi József - Molnár Borbála munkáit ajánlja,

6. Jordánszky Elek - Szentiványi püspök Vergilius fordítását nem találta ugyan a bíboros könyvtárában, de helyette tudósít két másikról, egyikük egy Gyárfás nevezetü munkája, másik szerzője anonim,

7. Kutsár István - Varga Mártontól Arithmetica; A természet közönséges históriája; Pyber Benedektől Seneca filozófiai munkái; Barkótzi Rosti Antaltól éneke és elmélkedések; Virág Benedek versei; Dugonics András A Szeretsenek; Közmondások; Schedius Pesti Német Újság,

8. Szatmári Pap Mihály - Földi János Természethistóriáját ajánlja; egy Szikszai nevezetű fordítását Bonnet: Contemplation de nature címü munkájáról; Sárvári Pál Theologia moralis címü munkáját. ${ }^{598}$

A javasolt kötetekből is kiderült, hogy nem elsősorban szépirodalmi munkákat ajánlanak kiadásra, hanem a kornak megfelelően szép a természettudománnyal, joggal, történelemmel foglalkozók aránya. Az elkészült könyvek terjesztése a könyvkereskedői hálózaton keresztül, illetve személyes egyedi körben történt. Az ország középső és nyugati részén jobbára a könyvkereskedői hálózatban, a Tiszántúlon és Erdélyben a személyes terjesztéssel oldották meg. Stohl szerint a sorozat valamennyi kötete eljutott Bécsbe is, az

\footnotetext{
${ }^{598}$ Stohl. 2005. 233. ; Aranka György (1737-1817) költő, nyelvművelö. Elsősorban, mint irodalomszervező vált ismertté. Bölöni Sámuel jogtudós, író, az erdélyi udvari kancellária ágense, késöbb a Theresianum tanár. Gvadányi József gróf (1725-1801) író, a nemesi-nemzeti ellenállási mozgalom eszméinek hatásos hírdetője. Jordánszky Elek (1765-1840) szentszéki jegyző, a prímási levéltár őre, bíborosi titkár, plébános, majd 1830-tól püspök. Szatmári Pap Mihály (1737-1812) 1767-töl a kolozsvári teolgia tanára. Weszprémi (Csanády) István (1723-1799) író, orvos, a XVIII. század kiemelkedő polihisztora
} 
első kettő természetszerüleg, mivel azokat a császárvárosban nyomtatták. ${ }^{599}$ Érdemes a könyvterjesztők névsorát és székhelyét is megismerni, valamint azt, hogy a Magyar Minerva melyik kötetének terjesztését vállalták:

1. Antal János - Marosvásárhely - 1-2. kötet, ${ }^{600}$

2. Bajkor József - (?) - 1. kötet,

3. Benke Mihály - Nagyenyed - 2. kötet,

4. Döme Károly - Pozsony - 1. és 3. kötet,

5. Juranits László - Értény - 2. kötet,

6. Káts István - Nagyvárad - 1. kötet,

7. Keszthelyi László - Nyitra - 1-3. kötet,

8. Kis Ferenc $-(?)-1-2 . k o ̈ t e t$,

9. Kondé - (?) - Himfy,

10. Kultsár István - Keszthely - 1-2. kötet, Gebhardi fordítás,

11. Nemes György - Bécs - 1. kötet,

12. Németh László - Győr - 1-3. kötet,

13. Rosenbacher Ferenc - Kolozsvár - 1-3 kötet,

14. Sárvári Pál - Debrecen - 1-2. kötet,

15. Szoboszlai József - Bécs - (?),

16. Teleki Domokos - Marosvásárhely - 1. kötet,

17. Varga Márton - Györ - 1-2. kötet. ${ }^{601}$

Látható, hogy egy városban esetleg többen is vállalkoztak a sorozat terjesztésére (és terjesztettek más Péteri Takáts által propagált müveket), azonban kevesen voltak azok, akik folyamatosan vállalták a kötetek árusítását. Többen csupán egy-egy kötet terjesztésének nyügét vették magukra s csak kevesen mind a háromét. A tizenhét személy közül csak

\footnotetext{
${ }^{599}$ A kötetek a Magyar Hírmondónak, valamint Légrády Sándornak köszönhetően juthattak el Bécsbe. (Stohl, 2005. 234.)

${ }^{600}$ Ahol nincs külön cím, ott a Magyar Minerva értendő.

${ }^{601}$ Antal János (1767-1854) erdélyi református püspök. Bajkor József ügyvéd. Benke Mihály (1757-1817) Teleki Lajos nevelöje, 1791-töl nagyenyedi tanár. Döme Károly (1768-1845) pap, költő. Tanfelügyelö Pozsonyban, majd izsai és erdélyi tartózkodása után pozsonyi kanonok, iskolaigazgató. Juranits László (1765-1850) nagyprépost, apátkanonok, az írók művei kiadásának mecénása. Keszthelyen járt gimnáziumba, ott barátságot kötött iskolatársával, Batsányi Jánossal, akivel hatvan éven át levelezett. Keszthelyi László (1732-1803) piarista pap, 1776-tól a nyitrai iskola igazgatója. Nemes Görgy, erdélyi udvari ágens Bécsben. Rosenbacher Ferenc (1758-1822) piarista pap és tanár, 1799 és 1803 között Kolozsvárott tanított. Szoboszlai József, erdélyi származású bécsi orvos. Teleki Domokos gróf (1773-1798) költő, író, természettudós, Teleki Sámuel gróf fia, az Erdélyi Magyar Népmívelő Társaság tagja.
} 
hárman. A hivatásos könyvterjesztők között találhatjuk: a pesti Eggenberger Józsefet, a pozsonyi Schwaiger Andrást és a szintén pozsonyi Simon Pétert, valamint Kis Istvánt, a győri Müller Ferencet (?), a szombathelyi Zsoldos Istvánt, a budai Weingandt János Mihályt és a keszthelyi könyvkötőt Földesi Istvánt. ${ }^{602}$

A Magyar Minerva sorozatban öt kötet jelent meg, amely közül az első kettőt Festetics sponzorálta a maradék háromnak nyomtatási költségeit Péteri Takáts szedte, koldulta össze. ${ }^{603}$ A Minerva valamennyi kötetének borítóját, amelynek elejére ovális keretben Minerva arcképét, a hátsó borítóra a müvészetek attribútumait vésték, Czetter Sámuel készítette. A kiadási terv tulajdonképpen felborult, csak Ányos Pál munkáinak kiadása valósult meg a terveknek megfelelően. Ez is elhúzódott, mert Batsányi hosszú ideig csak ígérgette a nála lévő kéziratok átadását Péteri Takátsnak. Péteri Takáts eszményképének tartotta a már elhunyt költőt és választása - amellyel egyetértett Festetics György is - szerencsés volt. Ányos magasan kiemelkedett a kor költészetéböl és bizonyos lokális színt is tudott adni, mert sok szál füzte a Balaton környékéhez: Veszprémhez, Pápához. Utolsó évet Veszprémben töltötte, ott is temették el. ${ }^{604}$ A sorozat első kötetének címe:,

\section{ÁNYOS PÁL' \\ MUNKÁJI. \\ BÉTSBEN, ÖVEGY ALBERTI IGNÁTZNÉ’ BETÜJIVEL. 1798.605}

A 260 oldalas kötetet Batsányi János szerkesztette és rendezte sajtó alá. Bár neve sehol sem jelenik meg tudjuk, hogy „A kiadónak előbeszédgye” az ő munkája. Ebben előrevetíti irodalmi programját is a nyelvújítás egyes tartalmi elvárásainak felvázolásával. Batsányi azonban a sajtó alá rendezésnél túlzott buzgalommal járt el, javítgatta, átírta a verseket: „,A’ közép útonn jártam tehát; az az: helyre hoztam a' valóságos és tetemesebb fogyatkozásokat; megegyengettem a' hibás verseket; és azt, a’ mi azonban nyelvünknek kényes természetét,

\footnotetext{
${ }^{602}$ Stohl, 2005. 234.

${ }^{603}$ Stohl Róbert idézett művében nem tér ki arra, hogy melyik kötetet sponzorálta Festetics és mikor szüntette be a támogatást. Harmath István idézett müvében a harmadik kötetet tartja az utolsó Festetics által támogatottnak. ; Harmath István és Katsányi Sándor munkájukban hasonlóképpen az első három kötet kiadását tulajdonítja a grófnak (Harmath-Katsányi, 1984. 239.), akárcsak Csányi László is idézett művében. Takáts Sándor, szintén idézett munkájában, arra hívja fel a figyelmet, hogy a támogatás megvonása a második kötet után következett be. ${ }^{604}$ Csányi, 1962. 54.

${ }^{605}$ Fest. K. Hel. Knyvt. Lit. hung. 127/1.
} 
vagy a' poézisnak megszeghetetlen regulájit sértette, - a’ mennyire az értelem csonkitása vagy egész rendek felbontása nélkül lehetséges vala, - szabadon 's könnyü kézzel megváltoztattam”. ${ }^{608}$ Festetics 100 forintot adott a kötet gondozójának, Batsányinak, aki az április megjelenést követően Péteri Takátstól még tiszteletpéldányokat is kért. Péteri Takáts Festetics véleményét kérte, aki nem akarván a költőt megsérteni Takátsra bízta az ügy elrendezését. Batsányi újabb goromba levelére végül Takáts hat példányt küldött a Magyar Minerva első kötetéből. ${ }^{609}$ Péteri Takáts és Batsányi között ekkor már végképp elmérgesedhetett a kapcsolat, ami az emlékezetes Phoenix hajó oldalára írandó versek kapcsán keletkezett. Batsányi úgy érezte, hogy joga és kötelessége a Magyar Minerva munkálataiban részt venni. Takátsot azonban bosszantotta a költő erőszakos beavatkozása. Éppen ezért fordult levélben Festeticshez: „Nagyságod' bölts meghatározásától függ, ha a’ M. Minerva kiadásába legyen-e jövendőben-is béfolyása Batsányi Úrnak”. ${ }^{610}$ Festetics válasza ugyan nem ismert, de feltételezhetjük, hogy nemleges volt, mert a könyvsorozat további köteteinél már nem találkozunk Batsányi nevével. ${ }^{611}$

A kezdeti lendület nagy volt, azután alábbhagyott. Hiába várták Baróti Szabó Dávid és Virág Benedek munkáit. Ekkor került látókörbe a már kész mű, Péteri Takáts munkája. A müvet Péteri Takáts először Festetics Györgynek adta át recenzálásra, aki nem rejtette véka alá véleményét. Nyolc pontba szedte össze észrevételeit, a művel kapcsolatban és olyan dolgokra hívta fel a szerző figyelmét, ami Festetics számára lényegesnek bizonyult: kifogásolta, hogy az erkölcsi oktatásokban nem szerepel a király s a haza iránti szeretet. S Festetics, aki a család jelszavát, „Deum time, regem honora!” összességében megtartotta, mindjárt meg is toldotta mondandóját, miszerint „az én Házamnak helyheztetésében, és az Urnak magának reputatiójára igen hasznos volna.” Ugyancsak felhívta a figyelmet, hogy a müben talált olyan kitételt, amely „fel-gyullasztja a Papi Rendet” és olyat is amely a gyerekek számára „megutáltatja a Szülőknek ítéleteit”. A végén megköszöni, hogy Péteri Takáts megdicséri „,némely institutioját”, de ezeket „talám jó volna ki-hagyni”, mert nem akar hiúnak mutatkozni. ${ }^{612}$

A következő évben, 1799-ben tehát kiadták a sorozat második kötetét:

\footnotetext{
${ }^{608}$ Ányos Pál’ Munkáji. Bécs, 1798. IX-X. ; A Magyar Minerva I. és II. kötetétének a Helikon Könyvtárban őrzött példányait Festetics György könyvkötője (valószínűleg Földesi István) kötötte be, nagyon szépen díszített bőrkötésbe, aranymetszéssel. Az eredeti papírborító a könyvbe bekötésre került.

${ }^{609}$ Stohl, 2009. 104.

${ }^{610}$ Péteri Takáts József Festetics Györgynek, Bécs, 1798. augusztus 7. , MOL Fest. Lvt. P 27913 cs. 1798:826. Közli: Stohl, 2009. 277-278.

${ }^{611}$ Stohl, 2009. 105.

${ }^{612}$ Festetics György Péteri Takáts Józsefnek. Keszthely, 1798. december 27. ; MOL Fest. Lvt. P 27914 cs. 1798:1291. ; Közli: Stohl, 2009. 295-296.
} 


\author{
ERKÖLTSI \\ OKTATÁSOK, \\ MELLYEKET \\ TOLNAI \\ GRÓF FESTETICS LÁSZLÓ' \\ KEDVES TANÍTVÁNYÁNAK, \\ SZÍVÉRE KÖTÖTT \\ PÉTERI TAKÁTS JÓZSEF \\ BÉTSBEN, \\ ÖZVEGY ALBERTI IGNÁTZNÉ BETÜJIVEL, \\ $1799 .{ }^{613}$
}

A 394 oldalas mü igényes pedagógiai munka tulajdonképpen a kor illemtankönyve. Péteri Takáts az ifjú gróf szívére akarván hatni, személyes, szinte lírai visszaemlékezéssel indítja a könyvet: „, Emlékezel-e, kedves Ifjú, midőn öt esztendős korodban a’ dajka-kézből gondviselésem alá vettelek? Nékem legalább igen elevenen jutnak mindenek eszembe. Vonakodtál te akkor az első pillanatban, hallván, hogy Nevelőd fogok lenni: de én azonn meg nem ütköztem; mert jókor értésemre esett, hogy a' Praefectus nevet mindenkor fenegetődzés között rebesgette előtted az oktalan tseléd, mely továbbra-is szükségessé akarta magát tétetni körületted." ${ }^{614}$ Péteri Takáts mindent beleírt, amire úgy gondolta, hogy az ifjú grófnak szüksége lesz élete során, de ennél többre vágyott sokaknak szóló könyvet akart megjelentetni. Az első részben a boldogságról és az emberségről szól. Történetileg visszanyúl a sztoikusokhoz és epikureusokhoz. A második részben a becsületes magaviseletről hetven oldalt írt és a harmadik cikkelyben tulajdonképpen ugyanezt folytatja, amikor a kellemetlen magaviseletről értekezik. A második rész föcíme: „Az erköltsi jóságról”, amelyben az erkölcsi törvényekről, az erkölcsiség eredetéről ír, olyan elödöket sorakoztatva fel, mint Montaigne, Helvetius, Epicur, Hume, Wolf, Crusius és Kant. A harmadik rész címe: Az ember tisztéről. Ezen belül szól a hitről, a reményröl és a szeretetről, a vallásról, az imádságról, az isteni szolgálatról, az esküről, majd folytatásként az emberről, az önismeretről, a helyes életvitelről, az evésről, a művelődésről, a helyes időtöltésről és a lelki jegyek gazdagításáról

\footnotetext{
${ }^{613}$ Fest. K. Hel. Knyvt. Lit. hung. 127/2.

${ }^{614}$ Péteri Takáts, 1799. 5.
} 
szól. A negyedik cikkelyben az egyes társaságok kötelességeiről, a fiúi kötelességről, az úri hatalomról, a polgári kötelességekről találhatunk gondolatokat.

Meglepő helyen, egy erkölcstanban bukkannak fel - írja tanulmányában Szajbély Mihály - Péteri Takács által kifejtett vélemény a régiek és újak munkáiról. Bár ezek a gondolatok már Magyarországon sem számítottak újdonságnak, de Péteri Takáts frappáns megfogalmazása mindenképpen az újszerüség erejével hatott. Péter Takáts szerint a régiek teljes elismerése, ismerete mellett nagyon fontos - talán fontosabb is - az újabb könyvek olvasása, megismerése: „Ki nem láttya? hogy inkább kell tudni: millyen az állapottya mostanság Európának, mint ezer esztendők elött, akár a' külömbféle Nemzetekre, kormányzásokra nézve; akár a' mesterségeket, tudományokat, 's terméseket ' a' t. vegyük tekéntetbe". 615

Ballagi Aladár az Irodalomtörténeti Közleményekben „Elfelejtett írók. Péczeli és Péteri Takáts” címmel írt kritikát. ${ }^{616}$ Ebben leszögezi, hogy az „Erköltsi oktatások...” Péteri Takáts legjobb műve. Jobb, megjelent verseinél. ${ }^{617}$ Mindazonáltal Toldy Ferenc ítéletével ért egyet, aki szerint „tisztán gyakorlati modorú” írásról van szó. Ballagi hasznos olvasmányként aposztrofálja és megállapítja: „Nagy olvasottságot látunk benne: idézetek rengetegét, még pedig mindent a maga helyén. Szorgalmas, becsületes munka, mely Faludi moralitásaival nem ér ugyan föl, mégis kár, hogy a maga korában több olvasóra nem talált.",618

A nyomtatás körül is akadtak gondok. Takáts szerint, Batsányi sugallatára a cenzor ellenségesen viseltetett „Az erköltsi oktatások...” beadott szövegével olyannyira, hogy másik cenzort kellett keresni. ${ }^{619}$

Még ugyanabban az évben Pesten került ki a nyomdából a sorozat következő kötete. S talán nem véletlen, hogy éppen Virág munkáiról van szó. Amint arra Bíró Ferenc is rámutat, „a tekintélynek, amelyet Virág Benedek a XIX. század elejétől élvezett a magyar írók körében, e költői szerep kialakítása s költőileg hiteles megszólaltatása"620 bizonyosan közrejátszott Festetics és Péteri Takáts döntésében. A kötet címe:

\footnotetext{
${ }^{615}$ Péteri Takáts, 1799. 136-139. Idézi: Szajbély, 2001. 193.

${ }^{616}$ Takáts Sándor: „Péteri Takáts József” Bp., Hunyadi Mátyás Intézet, 1890. könyvének kritikájáról van szó.

${ }^{617}$ Péteri Takáts József: „Költeményes munkái” Bécs, 1796.

${ }^{618}$ ItK., 1891. 1. évfolyam. 4. füzet 399. Ballagi kritikája Péteri Takáts jelentőségét elsősorban nem írói, vagy költői tevékenységében látja, hanem irodalomszervezői és mecénási szerepkörében.

${ }^{619}$ Stohl, 2009. 107.

${ }^{620}$ Bíró, 1994. 393-394.
} 


\section{VIRÁG BENEDEK' \\ POÉTAI \\ MUNKÁJI. \\ PESTEN, \\ TRATTNER MÁTYÁS’ BETÜIVEL \\ $1799 .{ }^{621}$}

A 174 oldalas kötetnek nincs előszava, csak dedikációja: „Méltóságos Tolnai Gróf Festetits György Ő Nagyságának hálaadó tiszteletül ajánlya a' Szerző”. A kötet első verse $A$ ' Múzsákhoz címet viseli és programadó versnek is vehetjük:

Itt é magános szent helyeken fogom

Magyar Minervát zengeni lantomon.

A' halhatatlanság' fijának

Érdemit itt fogom énekelni.

A vers fölött ovális keretben metszett kép. A képen bal oldalt a Pegazust ábrázoló oszloptöredéken bagoly ül. Az ülő, pihenő és az oszlopnak dőlő Minervát sisakkal a fején és lándzsával ábrázolta a müvész. Az idilli tájban két aprócska hegy, kis ház, fa, virág, nádas tó és mező látható, amelyek részben a kép hátterét, másrészt a képi szerkesztés egyensúlyát adják. Az ovális keret bal alsó részén a felirat: „delin Anton Flor”. Jobb oldalán: „sc. Fr: Karacs Pestini 1799.

A kötet második verse „Gróf Festetits György Ö Nagyságának”. Ebben Virág még „Minerva' példás gyámolá”-nak nevezi Festeticset, s amint azt már korábban idéztük a vers végén megjelenik a Phoenix gálya képe is kijelentvén "Festetitsed Balatonnya tenger."

A kötet olyan kitágult horizontú képet ad egyrészt saját klasszikus müveltségigényéről, másrészt a kortársi világról, hogy szinte teljes kitekintést kapunk a századforduló Magyarországának jelentős személyeiről, eseményeiről, a hazai tennivalókról. A pálos rend tagja, így jó barátja Ányosnak is, s egész életét irodalmi küldetésnek szenteli vállalván a budai szegényes életvitelt és kiérdemelvén a legjelentősebb kortársak tiszteletét és barátságát. $^{622}$

\footnotetext{
${ }^{621}$ Fest. K. Hel. Knyvt., Lit. hung. 127/3

${ }^{622}$ Harmath, 1985. 458.
} 
Festetics György gróf végül megvonta Péteri Takátstól a kiadásra szánt pénzeket. Erröl külön levélben értesítette, de megírta azt is, hogy az „,Erköltsi oktatások...” valamennyi, még meglévő példánya, a szerzőt illeti. ${ }^{623}$ Később gyenge célzást tett a Magyar Minerva esetleges további támogatására, de csak akkor, ha „valamelly takarékos potoló Fundust talál”. ${ }^{624}$ Ma már nehéz megállapítani mi volt az, ami Festetics Györgyöt arra ösztönözte, hogy beszüntesse a Minerva támogatását. Nincs kizárva, hogy megijedt a nagyszámú beérkezett, vagy megígért kézirattól, esetleg a terjesztés és a megvásárolt példányszámok alacsony aránya tette kétségessé számára a kiadványok megjelentetésének fontosságát. Döntése visszavonhatatlan volt és elhibázott, hisz a szárnyait bontogató magyar irodalom egyik fontos támaszától lett megosztva. Ugyanakkor nem tekinthetünk el a mecénás-kiadó és a sorozat-szerkesztő közötti viszonytól sem. Festetics és Takáts levelezéséből sokkal világosabban láthatjuk a két férfi egymáshoz való viszonyát, a világ dolgai, a nevelés területén vallott elvek különbözőségét. ${ }^{625}$ Talán nem tévedünk, ha az évek alatt felgyülemlett gondok a kapcsolat - így a Magyar Minerva sorozat támogatása is - megszünésének erjesztői voltak. Festetics többször dorgálta meg Takátsot fia László nevelése ügyében. Takáts folyamatosan magyarázta maga mentségét, egyik későbbi levelében mindvégig tisztelettel, de meg nem alkuvóan válaszolt. 1799. január 11-i hosszú levele egy öntudatos férfi végső elhatározását tükrözi: „Miként érdemlettem-meg azon szemrehányást, hogy kis Pap létemre ki nem tisztúltam a’ Theologiának rosdájából, fel nem érhetem. Ha az okos religyiozitást érti Nagyságod, szívesen magamra válalom a’ feddést. Más tekéntetben nem férhet reám. Valamint azon vádalás sem, hogy Tanítványom' eszét versekkel, metaphysicaval, Görög nyelvel vesztegetem. Kisebb gondom-is nagyobb ezeknél. - Hogy az ifjú Gróf' írása az előkkel jobb volt, tagadhatatlan Én tehát jól tanítottam: bátor különös író-mesternek nem tartom magamat. Későbben az iskolában való sebes írás miatt romlott az meg valamennyire;

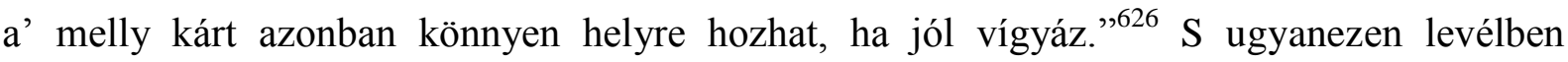
megelégelve az állandó feddést döntésre jut: „Szívem olly érzékeny, hogy az ollyan hangú buzdíttásokat, mellyek már többször érdeklettek, de a’ jobbra-fordúlásnak örvével mindenkor nagy erőszakkal elnyögtem azokat, meg nem emészthetvén többé, egészszen elkeseredem,

\footnotetext{
${ }^{623}$ Festetics György Péteri Takáts Józsefnek. Keszthely, 1799. április 12. ; MOL Fest. Lvt. P 279 Directoriatus regestruma 260. köt. 1799:300. ; MOL Fest. Lvt. P 279 Directoriatus regestruma 260. köt. 1799:411. ; Közli: Stohl, 2009. 316.

${ }^{624}$ Festetics György Péteri Takáts Józsefnek. Keszthely, 1799. április 23. ; MOL Fest. Lvt. P 279 Directoriatus regestruma 260. köt. 1799:4.; Közli: Stohl, 2009. 317-318.

${ }^{625}$ Közli: Stohl, 2009. 153-332.

${ }^{626}$ Péteri Takáts József Festetics Györgynek. Bécs, 1799. január 11.. ; MOL Fest. Lvt. P 279 15. cs. 1799:122. ; Közli: Stohl, 2009. 298-302.
} 
magam előtt elszégyenlem magamat, siratom kárvallásomat. Tsúszni mászni rabszolgaként nem tanúltam, nem tudok, nem-is akarok. Méltatlan lettem volna egy Magyar Magnásnak nevelésére, ha színeskedni, vagy igát hordozni tudnék; ha nemes érzésü szív nem verne mellyemben. - Mi van tehát mit tennem? Nem találok más módot, mint (keserves kínomba kerül ezen kifakasztás!) Nagyságod elejbe terjeszteni kérésemet, hogy az ifjú Grófnak, az én jó 's kedves Tanítványom' kormányozásától szabadíttson fel mennél előbb Nagyságod; mivel úgy-is (a’ mint a’ levél mondgya) továbbra-is el nézhetvén tsúf, fertelmes hibájit, annyival inkább, hogy szinte már erőt vett rajtam! - Kiki tartozik a' természet’ ösztönéből bátorságos 's nyúgodalmas kilátást keresni magának. Íme nyoltz esztendőnél többet, életemnek legjobb idejét, mellyben jó karba helyheztethettem volna jövendőmet, mostani hivatalomban elvesztettem már!” Úgy tünik Festetics is megérezte feddésének súlyát, erre választ is adott, mert 1799. január 14-én kelt levelében Péteri Takáts már megenyhülve ír: „Nagyon örvendek, hogy az ifjú Gróftól 's irántam kinyilatkoztatott kemény itélete Nagyságodnak engesztelődik; vajha egészszen jóra fordúlna! Ugy reménylhetném, hogy tovább-is örömmel dolgozhatok Nagyságod' pártfogása alatt; és se Nagyságodnak nem leszsz oka a' panaszolkodásra, se nékem a’ keserüségre. Méltóztassék Nagyságod azon egyenességgel tudtomra adni szándékát, a' millyen nyíltt szívvel ki öntöttem utólsó levelemben jövendőmről való aggodalmamat. Én mindenre kész vagyok, ha látom, hogy hív szolgálatim méltó tekéntetbe vevődnek." ${ }^{627} \mathrm{~A}$ kapcsolat azonban megszakad, Festetics a nevelés tárgyában kötött Contractust ${ }^{628}$ kéri számon Takátson, Takáts pedig a saját igazát bizonygatja. Takáts még arra kéri a grófot, hogy a Magyar Minervát „oly hamar kihalni ne engedje”. Festetics megígéri, ha úgy alakulnak a dolgok, segíteni fogja. Erre azonban már nem került sor.

Péteri Takáts mindenképpen folytatni akarván a sorozatot saját maga kezdett támogatók gyüjtésébe. A szomorú tényről Földi Jánoshoz írt levelét Takáts Sándor az alábbiak szerint közli ${ }^{629}$ :

„Nagyérdemü tudós hazafi! A váratlan viszonttagságok okozák, hogy kedves úrnak igen becses levelére oly nagyon elkésett köteles válaszom; mindegyre reménylettem a jobbra fordulást, de haszontalanul. Most tehát már kifejtem az egész dolgot. Tudni való több ujságokból, hogy M. F. Gy. úr esztendőnkint 1000 forintot igért a magyar literatura

\footnotetext{
${ }^{627}$ Péteri Takáts József levele Festetics Györgynek, Bécs, 1799. január 14. MOL Fest. Lvt. P 27915 cs. 1799:81. Közli: Stohl, 2009. 302.

${ }^{628}$ MOL. Fest. Lvt. P 246. 5 cs. 9. ; Contractus. Péteri Takáts József szerződése. Keszthely, 1791. június 24.

${ }^{629}$ Takáts, 1890. 106-107. ; A levelet, mint érdekességet, ritkaságot és amely rávilágít Földi kötetének kálváriájára, Szilágyi Ferenc is közölte Mesterek és a tanitvány (Kazinczy, Földi és Csokonai) címü dolgozatában. (Szilágyi, 1998. 100-101.)
} 
gyarapodására; de a Minervának még második kötetje sem látott napvilágot, midőn egyszerre tudósít, hogy szándékát megváltoztatja és a meghatározott summát inkább másra fordítja. Ennek okát fel nem érhetvén, több ízben egész illendőséggel és fontossággal kértem, hogy ezen hazafiui hasznos igyekezetet ne hagyja kihalni. De semmire nem mehettem. Fájt szívemnek ezen álhatatlanság, annyival is inkább, mert a reám bízott hivatal szerint több tudósokat buzdítottam munkáiknak beküldésére. Ilyen környülállásokban lévén, közlöttem a dolgot Görög Demeter kedves barátommal - szíveinkben hordozván a tudományokat és a hazai nyelvet - arra határoztuk magunkat, hogy a Minervát továbbra is akarjuk folytatni, legalább is két kötetet adván ki esztendőnként (...) A harmadik kötet Virág Benedek költeményes munkáit fogja tenni, mivel örömest a folyó beszédủ munkát a kötöttel váltanánk fel. A negyedik kötet, édes úr Természeti históriájának első darabjából állhatna, szavunkat adván, hogy a folytatást is ily renddel, a kivánt különböző betűkkel kinyomattatnánk”.

Amint Péteri Takáts írja, Festetics ösztönzésére, számos helyen megígérte, hogy a Minerva folyamatosan közli a munkákat. Éppen ezért kellemetlen számára a pénzforrás elapadása. Aranka Györgynek írt levele részletes beszámoló az eseményekről és leendő terveiröl, pontos leírást adva a honi állapotokról. E levél a XIX. század végén a Kolozsvári líceum Levéltárában volt található. Először és valószínűleg utoljára Takáts Sándor közölte 1890-ben kiadott, idézett müvében. Az ő munkája alapján idézzük:

„Méltóságos Úr,

Bécsben, ápr. 29-én, 1799.

Drága Jóakaró Uram!

Magam is sokalom, hogy Nagyságodnak febr. 8-án írt úri levelére oly igen elkésett a válasz. Fájdalommal mondom, hogy Nagyságodnak isméretes buzgóságú hazafi szívét akartam megkímélleni - azért nem írtam. De már kifakasztom; mivel eltünik minden reménységem, hogy, bátor eleget iparkodtam, jobbra változzanak a szomorú környülállások. Ugy tetszik, mintha átok feküdnék a legszebb igyekezeteken hazánkban. Alig kezd a jó remény csillámlani; mindjárt megint komor fellegek borítják a tiszta eget. - Íme Minervánk is közelít a sírhoz! Midőn én tehetségem szerint dolgozom gyarapodásán, egyszersmind oly értelmü levelet veszek Keszthelyről, hogy Maecenasunk Lipszky hadnagy magyarországi mappáira 2000 forintot szánván, nem segítheti a M. Minerva folytatását. Szörnyü csapás volt ez az én jó szándékomnak; annyival is inkább, hogy én általam estek meg az igéretek néhány munkás férfiaknak irásaik kinyomatása iránt. Mely hirtelen, mely csúfos változások ezek! Oda néki. Én ugyan még minden erőmet megvetem, hogy fordulást tegyek a rossz dolgon; 
nem kímélem a szép, a nyomos kérést; de ha ez nem használna is, mégsem hagyom oly hamar kihalni a Minervát. Reá szánom időmet, fáradságomat, csekély mindenemet, a míg csak győzöm. Ha kevesebbet is, de csak fog esztendőnként valamit látni édes hazám. Bécsben kivánván tölteni életem napjait, eshetik módom, hogy pártfogókat szerezhetek a jámbor és hasznos igyekezetnek. Lehetetlen, hogy az olyan munkálkodásnak ellenségi támadjanak, a melyhez, igérem, soha még csak a gyanú sem fog férhetni. A mi a 2. kötetböl bejövend, nekem méltóztatott ajándékozni a mélt. gróf. Ezt én a III. kötet, Virág Benedek felséges költeményei kiadására fordítom; és így teszek a többi részekkel is. Mely könnyü dolog volna minden akadályokon győzedelmeskedni, ha a köny(v)béli kereskedés jobb lábon állana hazánkban. Mind tiszta, de szomorú igazság, a mit ezen tárgyról méltóztatott utolsó levelében írni Nagyságod. Vajha foganatos eszköz volna a fogyatkozás megjavítására a könyvárusokkal való szövetség! De tapasztalásból szóló, így sem orvosolhatjuk meg a nyavalyát. Ezen zsugori emberek sokkal drágábban árulják a könyveket, hogysem keletök lehetne; vagy, ha van, részint megcsalódik s így elkedvetlenedik az olvasó fél; részint nem adnak annak idejében számot, föl nem küldik a bévett pénzt, epesztő bizonytalanságban hagyják, számtalan levelire is, a kiadót. Veber (sic!), pozsonyi könyvnyomtatónak, még tavaliban 50 exemplárokat küldöttem Ányosból az eladás végett és még csak két hét előtt tudhattam meg gyakori értekezéseim után tőle, hogy csak egyetlen-egyet sem adott el belőle. Még eddig csak jó barátim segítségével kelt el Minervából, a mi elkelt. Reménylem, hogy a gr. Teleki Domokoshoz küldött 100 nyomtatványokból is megtér nemsokára valamelyes. Azt tudom, hogy 25 exemplárok T. Benke tudós professor úrnál tevődtek el belölök N.-Enyeden; a ki is hazafiu buzgóságához képest igérte továbbra is kész szolgálatját. Nem kétlem, hogy T. Antal érdemes professor úr sem fogja tiltani szíves fáradságát a literatúra virágzása kedvéért. Kérem alázatosan Nagyságodat, méltóztassék ezen drága urat tisztelni nevemben, ismeretlen létemre is. Ha valamiben viszontagolhatom szívességét, én is édes-örömest megteszem részemről. A II. kötetből is bátorkodtam 24 exemplárokat utasítani hozzája. Valamint ebből, úgy az első részből is méltóztassék számára, vagy exemplárt, vagy ha tetszik, pénzt is megtartani. Csak arra bátorkodom kérdeni, hogy ne terheltessék tudósítani az elkelt könyvek számáról és a bevett pénz általküldhetése módjáról; hogy tudjam magamat mihez tartani. A mélt. gr. Festetits még nem nyilatkoztatta ki parancsolatját az Erdélyi Nyelv-mívelő Társaságnak küldendő csínyosabb exemplár iránt. Én tehát ezuttal csak Nagyságodnak kedveskedem munkámmal. - Szerencsésnek állítanám magamat, ha megérdemelhetném vele Nagyságod helybenhagyását. 
Hát a Társaság munkáinak II. drbja elhagyta-e már a sajtót? Igen óhajtva várom. Mint folynak a dolgok? Talán ott is dér érte az igyekezetet? ${ }^{630}$ - Az ifjú grófom tiszteletét izeni; én a legigazabb tisztelettel szünet nélkül vagyok

Nagyságodnak alázatos szolgája

Takáts József m. p., ${ }^{, 631}$

Péteri Takáts egyedül maradt a Magyar Minerva minden nyügével és bajával. A remélt támogatók sem voltak bőkezủek, így csupán kilenc év múlva jelenhetett meg a Magyar Minerva sorozat negyedik kötete, nem amint Földinek Péteri Takáts megígérte a Természeti história első darabja, hanem Pápay Sámuel munkája:

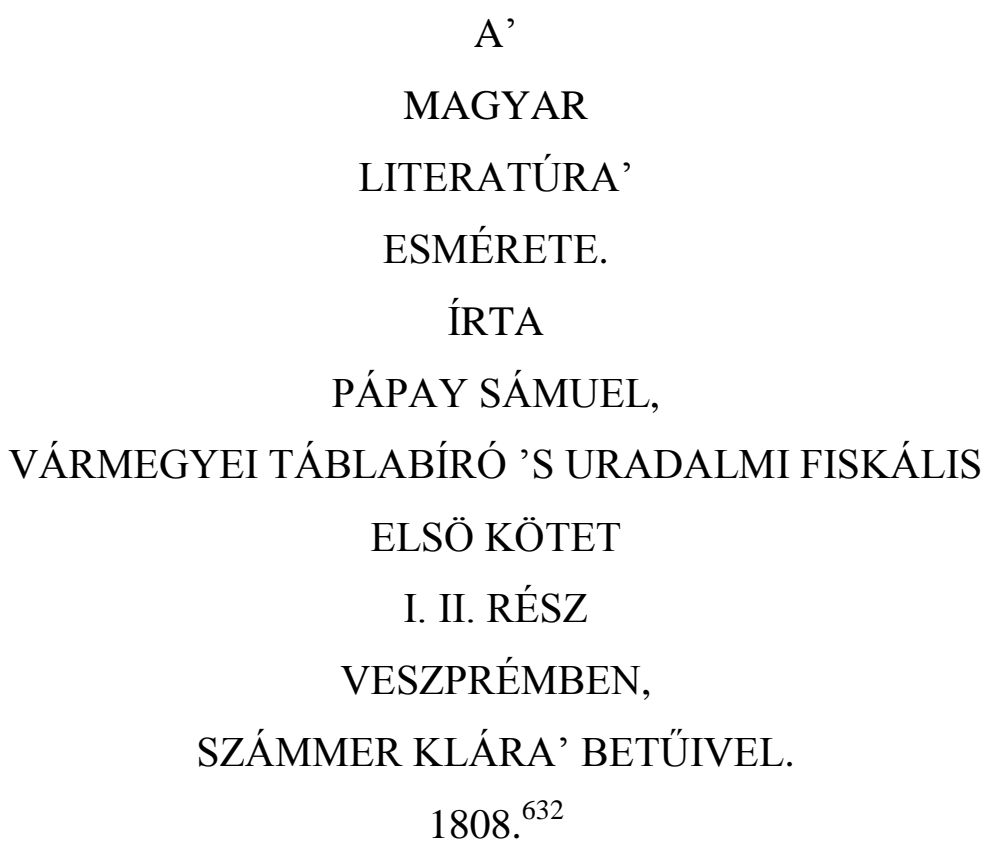

„Munkám első a’ maga nemében” - írja a kötet előszavában Pápay Sámuel, majd így folytatja: „Ezután annál könnyebb lesz azt tökélletesíteni, kivált azoknak, a’ kiknek mind idejek több van rá, mind hivatallyok' minémüsége azt hozza magával, hogy a' Hazai Literatúrát ne tsak pengessék szájakonn, hanem, munkás kézzel gyarapíttsák is. Benyújtom azért munkámat a’ Magyar Minerva’ oltárára azzal a’ belső szent érzelemmel, hogy áldozat

\footnotetext{
${ }^{630}$ A Társaság fennállása alatt csak egy kötetet jelentetett meg: A Magyar Nyelvmívelő Társaság munkáinak első darabja. Szeben, 1796. Döbrentei Gábor 1818-ban még megpróbált életet lehellni a Társaságba, de mindhiába. ${ }^{631}$ Takáts, 1890. 108-110. (Takáts szerint 1890-ben e levél a Kolozsvári Líceum Levéltárában volt található.)

${ }^{632}$ Fest. K. Hel. Knyvt., Lit. hung. 127/4
} 
tételeben hazafiúi kötelességemet olly híven tellyesítettem, a’ mint gyenge tehetségemtől kitehessen.",633

A felsőőrsi születésű irodalomtörténész, Segesvári István kísérlete, valamint Révai Miklós félbe maradt munkája után, valóban az első, és a korra jellemző irodalomtörténetet, nyelvtörténeti áttekintést, nyelvi összehasonlítást írt. ${ }^{634}$ Művében irodalmi szövegek illusztrációjával mutatja be irodalmunk fejlődését a saját koráig, négyszáznyolcvanhat oldal terjedelemben. Ez annál inkább fontos könyvnek minősült, mert Zala megye a vármegyék között elsőként (1805) kapta meg a királytól azt a jogot, hogy a megyegyüléseken magyarul szólhassanak. A magyar, mint hivatalos nyelv csak jóval később, 1844-ben lett elismerve. ${ }^{635}$ Takáts Sándor idézi Pápayt aki Kazinczynak írt levelében világossá teszi, hogy a Magyar Minerva terhe „egyedül Takáts erszényét nyomja”. 636

Ismét több évet kellett várni, hogy a Magyar Minerva következö, ötödik, egyben utolsó kötete is napvilágot lásson. Ennek a könyvnek a kiadását Dréta Antal ${ }^{637}$ támogatta.

A

FILOZÓFIÁNAK

ELÖLJÁRÓ

ÉRTEKEZÉSEI.

ÍRTA

RUSZEK JÓZSEF

A WESZPRÉMI NEVENDÉK PAPSÁG EGYGYIK'

S ÖREGEBBIK TANÍTTÓJA

WESZPRÉMBEN,

SZÁMMER KLÁRA BETÜIVEL.

$1812 .^{638}$

A Magyar Minerva sorozat megszünésének hírére többen keresték meg Festeticset levélben, másítsa meg döntését. Baróti Szabó Dávid 1799. Szent György havának 12-dik napján, tollat ragadott: „Méltóságos Gróf. Nemzetünk’ fénnye! Meg-szomorodván értettem a’

\footnotetext{
${ }^{633}$ Pápay Sámuel: A magyar literatúra esmérete. Veszprém, 1808. XII-XIII.

${ }^{634}$ MIT III., 1965. 201.

635 Harmath, 1985. 459.

636 Takáts, 1980. 111.

${ }^{637}$ Dréta (János) Antal (1762-1823) szerzetes, plébános, a zirci apátság házgondnoka, Zirc első magyar apátja. 1813-ban átvette a székesfehérvári és a pécsi jezsuita gimnáziumokat, megalapozta hazánkban a ciszterciek tanítói renddé válását.

${ }^{638}$ A Magyar Minerva ötödik kötete, Ruszek József munkája a Helikon Könyvtár állományában nem található.
} 
M. Minervának meg-szünését. Alig kezde a' Magyarok' tapsolásai köztt nap-világra jőni 's már-is a’ sírba fekszik - ! „, Majd így folytatja „Most már Bétsből az oda küldött munkáimat minden nap' várom vissza. Velem együtt ezek - is el-enyésznek." ${ }^{639}$ Mindamellett a leveléhez csatolta Festeticset dicsőítő versét az „Érdem-oszlop”-ot.

Stohl Róbert a Petrik Géza szerkesztette Magyar Könyvészet 1712-1920 alapján meghatározta azokat a könyveket, amelyek nem fértek bele a sorozatba, de később bizonyosan megjelentek:

- Baróti Szabó Dávidnak meg-jobbított, s bövitett költeményes munkáji (Komárom, özv. Weinmüller Klára, 1802),

- Földi János: Magyar természeti historia, első kötet (Pozsony, Wéber Simon Péter, 1801),

- Gvadányi József: Verses levelezés, a mellyet folytatott - nemes Fábián Juliannával...(Pozsony, Wéber Simon Péter, 1798),

- Mészáros József: Egyházi beszéd a papi rendről. Mondotta Rédén pünkösd utánn X. vasárnap egy új misének szolgáltatásakor (Veszprém, Szammer Mihály, 1801),

- Q. Horatius F. Poeticája Virág Benedek által (Pest, Trattner Mátyás, 1801),

- Az idösb Kátó vagy M. T. Cicerónak beszélgetése az öregségröl. Magyarázta Virág Benedek (Pest, Trattner J. Tamás, 1803).

Sajnos a Magyar Minervára vonatkozó levelek, más levelekkel együtt, melyeket Péteri Takáts saját levéltárában őrzött, úgy tünik, megsemmisültek. Stohl mutat rá, hogy Péteri Takáts hagyatéka egyetlen fia Sándor (nem azonos az életrajzíróval) 1873-ban bekövetkezett halála után szétszóródott, megsemmisült, avagy a mai napig lappang. Brocskó Lajos árvaházi igazgató jóvoltából megvásárolt pár darab, a Magyar Tudományos Akadémia Kézirattárába került. $^{640}$

A Minerva megszünésével egy időben Festetics úgy gondolta, hogy támogatni kívánja Lipszky János által készítendő Magyarország térkép kinyomtatását. ${ }^{641}$ Mezei Márta a keszthelyi Helikoni Ünnepségekről írt tanulmányban kifejti, hogy Festetics megvonta a pénzt a Magyar Minerva könyvsorozattól, hogy „egy kétes értékủ térkép kiadására” fordítsa azt. ${ }^{642}$ Reisz T. Csaba Lipszky müködésének kutatója azonban ellentétes véleményt fogalmaz meg a térképet és Lipszky müködését összegezve: „A magyarországi kartográfia-történetben a határkövek nem évszámokban és térképmüvekhez, hanem személyekhez és tevékenységükhöz

\footnotetext{
${ }^{639}$ Baróti Szabó Dávid Festetics Györgynek, 1799. április 12. ; MOL Fest. Lvt. P 279 1799:483.

${ }^{640}$ Stohl, 2005. 235.

${ }^{641}$ Lipszky János (1766. április 10. - 1826. május 2.) katona, geográfus, térképkészítő. Többet: Reisz T., 2002. ; Reisz T., 1997. 203-241.

${ }^{642}$ Mezei, 1997. 171.
} 
köthetők. A különféle szakmunkák és népszerüsítő feldolgozások Lázárt (a korábbi szakirodalomban még deákot, ma inkább secretariust), Mikoviny Sámuelt, Lipszky Jánost, Tóth Ágostont és Kogutowitz Manót tekintik olyan fordulópontoknak, amelyekhez a hazai kartográfia fejlődésének eredményeit viszonyítják. "643 Mindez természetesen nem menti fel a grófot ígérete megmásításának következményei alól. Lipszky támogatási kérelmének eredményességét Festeticsnél annak is köszönhette, hogy nem volt ismeretlen Festetics előtt. Ö is a Graeven huszárezred tagja volt és 1790-ben Festetics György alezredes parancsnoksága alatt, őt is Budára vezényelték az országgyülésre. Kapcsolatukra utal a Festetics Levéltárban talált német nyelvű levél is, amelyet Lipszky írt 1784. december 15-én Pozsonyból Festeticsnek. ${ }^{644}$ Bár nem írta alá, de jó okunk van feltételezni, hogy ő is részese volt annak a feliratnak, amit az országgyülés elé terjesztettek a Graeven ezred magyar tisztjei és amely miatt Festeticset is meghurcolták. (A magyar katonai egységek ügye.) Festetics nemcsak anyagilag, azaz 2000 forinttal támogatta Lipszky kezdeményezését, de Széchényi Ferenc térképgyüjteményébe is bejárást szerzett egykori tiszttársának. Lipszky Festetics és Széchenyi segítségével terjesztette be elképzelését József nádornak, 1798. szeptember 9-én. ${ }^{645} \mathrm{Ez}$ az időpont kísértetiesen egybeesik a Magyar Minerva indulásának dátumával. Lipszky János legnevezetesebb három térképe:

Mappa generalis Regni Hungariae (Pest, 1806. 12 lap),

Tabella generalis Regni Hungariae (Pest, 1810. 1 lap),

Plan der Beyden königl. freyen Haupstädte Ungarns Ofen-Pesth (Bécs és Pest, 1810. 4 lap).

Festetics valószínüleg az első térkép megvalósítását támogatta anyagilag. Ráadásul nem ez volt az első alkalom, hogy földabroszok kiadásához anyagilag is hozzájárult. 1798. március 8-án Péteri Takáts Józsefnek írt levelében maga határozza meg, hogy az eddig támogatott kilenc Görög-féle térkép anyagi támogatását további három szponzorálásával toldja meg. ${ }^{646}$

\footnotetext{
${ }^{643}$ Reisz T., 1998.

${ }^{644}$ MOL Fest. Lvt. P 2461 cs. B. IV. 2. Lipszky János Festetics Györgynek, Pozsony, 1784. december 15.

${ }^{645}$ Reisz T., 1998.

${ }^{646}$ „Soprony, Vass, Zala, Baranya, Fejér, Moson, Pest, Heves, Maramaros” vármegyék térképéről van szó. (Festetics György levele Péteri Takáts Józsefhez. Keszthely, 1798. március 8. MOL Fest. Lvt. P 279 Directoriatus regestruma 259. köt. 1798:121. Közli: Stohl, 2009. 248.)
} 
Hász-Fehér Katalin tanulmányában a Helikon és a Parnasszus hegyének ókori motívumtörténetét vizsgálva a két földrajzi, mitológiai egység megjelenésével foglalkozik európai és hazai kultúránkban. ${ }^{647}$ Összeveti Johanna Schmidt, valamint Elizabeth Schröter ebben a témában írt véleményét, ${ }^{648}$ és idézi Schrötert, miszerint a Parnasszust a görög irodalom nem sorolja a Múzsák tartózkodási helyei közé, a költői eredetmítoszokban a müvészi beavatás szent helyének a Helikon hegye számított. Wanda Markowska szerint a múzsák Apollón kedvelt tartózkodási helyén a boiótiai Helikon hegyen illetve a Parnasszuson laktak. ${ }^{649}$ Hasonlóan vélekedik az 1988-ban kiadott Mitológiai Enciklopédia amikor mindkét hegyet, mint a Múzsák tartózkodási helyét jelöli. Ám Markowskától némileg eltérően azt írja, hogy a Múzsák a Parnasszuson éltek Apollón körében. Itt eredt a Kasztalia forrás és aki ivott vizéből költői tehetséget nyert. A Helikon hegyén pedig a Pegazus patája által kivágott föld helyén a Hippokréné forrás eredt. ${ }^{650}$ Ugyancsak így vélekedik Csiky Gergely, aki könyvében leírja, hogy a Múzsák olimposzi lakhelyükről költöztek át a Helikonra és a Parnasszusra. ${ }^{651}$ A mi esetünkben a Helikon hegyét fogadhatjuk el, mint a múzsák tartózkodási helyét, hisz részben ennek tudatában nevezték így a keszthelyi ünnepeket megálmodóik. Mert a Helikon csúcsán a múzsáknak táncterük és palotájuk is volt, ahol táncoltak és himnuszaikat „visszhangozták a bércek”. ${ }^{652}$ A keszthelyi Helikon megrendezésével ünnepi hagyomány született és kultuszhellyé vált az addig poros városka.

Mindezen túl a Helikonok a felvilágosodás korának tipikus összejövetelei voltak. A felvilágosodás eszméit oly nagyon magáénak valló Festetics, Bessenyei György véleményével értett egyet és ezt példázzák lépései is. Az olvasás, a tanulás, a tudás - vallja Bessenyei és Festetics is - az embert jobbá formálhatja, tökéletesítheti. ${ }^{653}$ Bessenyei 1777 második felében elkezdett programírásaiban azt fejtegeti, hogy a hiba mindig kerül felszínre, ha a hatalom és

\footnotetext{
${ }^{647}$ Hász-Fehér, 2000. 173-187.

${ }^{648}$ Parnassos címszó szerzője Johanna Schmidt = Realenzyklopädie der klassischen Altertumwissenschaft. Hrsg. von A. Pauly. Neue bearbeitung von G. Wissowa und W. Kloll. Stutgart, 1894, 1949. ; Elisabeth Schröter: Die Ikonografie des Themas Parnass vor Raffael. Die Schrift- und Bildtraditionen von der Spätantike bis zum 15. Jahrhundert. Hildesheim-Nem York, 1977. (Studien zur Kunstgeschichte, Band 6.)

${ }^{649}$ Markowska, 1953. 48.

${ }^{503}$ MIT. E. I., 1988. 679. 736. ; Szabó, 1973. 140. 189. 274.

${ }^{651}$ Csiky, 1911. 52-54.; Kilenc múzsa lakott Helikon hegyén: Klio, a történetírás, Melpomene a tragédia, Thalia a komédia, Kalliope a hősköltemény, Urania, a csillagászat, Euterpe a lantos költészet és zene, Polyhymnia az ének, Erato, a szerelmi dalok, Terpsichore a tánc múzsája.

${ }^{652}$ Kerényi, 1977. 73.

${ }^{653}$ Bíró, 1994. 87.
} 
az alattvalók nem találnak egymásra. Vajon a kard vagy a penna, avagy mindkettő megléte a fontos? Ez több korabeli írónál, költőnél felmerül, de ,igazi jelentőségre a nemzet felemelkedésének alternatíváiként tesznek szert". ${ }^{654}$ Bessenyeinél és Batsányinál is hasonlót tapasztalhatunk. Batsányi a Magyar Museumban írja: ,az Országok nemtsak karddal 's fegyveres erővel, hanem egyszer- 's mind pennával 's ésszel szereztetnek, kormányoztatnak, és tartatnak fenn." ${ }^{\circ 55}$ Hász-Fehér Katalin egyik tanulmányában azt boncolgatja hogy az udvar, az arisztokrácia és a köznemesség milyen szerepet játszott a kultúratervezetekben. ${ }^{656}$ Ez fontos és lényeges kérdés a mi esetünkben is. Vajon mennyire fontos a magyar nyelv ismerete, mennyire hat az etnikai közösség életére? Bessenyei a magyar nyelv latinhoz, vagy bármelyik más nyelvhez hasonló szintre fejlesztését sürgette, nem javasolva más idegen nyelvek tiltását. ${ }^{657}$ Festetics a „többnyelvü” modellt részesítette előnybe, hisz a Helikonon latin, német és magyar nyelven adhatták elő munkáikat a résztvevők. Választását az is befolyásolhatta, hogy a Georgikon tankönyvei németek nyelvüek voltak s a többi iskolában meghatározó volt a németen kívül a latin is. Azonban ne hagyjuk figyelmen kívül, hogy az első Helikoni Ünnepségen elhangzott versek közül kizárólagosan a magyar nyelvűeket jelentette meg nyomtatásban. Talán ismerte Batsányi Magyar Museumhoz írt bevezetőjét, ahol keserüen fakadt ki, miszerint nem volt olyan időszak, ahol a királyi udvar becsben tartotta volna a magyar nyelvet. ${ }^{658}$ Festetics azt gondolhatta, hogy ő lesz, kinek udvarában „Nyelvünk bötse” megmutatkozik és példát adhat másoknak is. Új kihívásokhoz, új gondolatoknak kell társulniuk. S míg egymásnak feszül az új és a régi, a későbbiekben rájöhetünk, hogy mindez nem öncélú és szükségtelen, hanem a fejlödés, a váltások szükségszerü velejárói.

\section{6. 1. A kezdetek}

A keszthelyi iskolák által 1804-től kezdődően elindított nyári ünnepélyek, ahol zene, tánc, szavalat, felolvasás volt müsoron - méltán nevezhetők a Helikoni Ünnepségek elődjének. Itt a Georgikon hallgatói, a líceum és a gimnázium diákjai vettek részt. ${ }^{659}$ Mivel ezek a rendezvények jobbára csak diákköri előadásokként, illetve vizsgákként értékelhetők

\footnotetext{
${ }^{654}$ Debreczeni, 2009. 206.

${ }^{655}$ Erröl részletesen: Debreczeni, 2009. 205-208. ; Lásd még: Egyed, 1998.

${ }^{656}$ Hász-Fehér, 2006. 279.

${ }^{657}$ Hász-Fehér, 2006. 282-283

${ }^{658}$ Erről lásd: Hász-Fehér, 2006. 290; Vélelmezhetjük, hogy ismerte Festetics Batsányi állásfoglalását annak ellenére, hogy a Festetics Könyvtárban nem találhatóak meg a Magyar Museum példányai.

${ }^{659}$ Cséby, 1998. 15.
} 
jelen munkában ezekkel nem kívánunk foglalkozni. ${ }^{660}$ Figyelmünket arra az öt összejövetelre összpontosítottuk, melyek 1817. február 12 és 1819. február 16-a között zajlottak, minden év februárjában a császár születésnapjához és májusban a georgikoni vizsgákhoz kapcsolódva.

Berzsenyi Dániel 1816. november 15-én egy levél kíséretében elküldte verseinek második kiadását Festeticsnek. Az egyiket a hercegnének, Festetics György menyének, Hohenzolern-Hechingen Josefának ajánlotta, „mert kevélykedve hallom beszélni sok hazafiaktól, hogy ő Hercegsége magyarul tanul, a másikat a kis Taszilónak, mert reménylem, hogy az is magyar Tasziló fog lenni”. ${ }^{661}$ Ugyanezen levél következő bekezdésében döbbenettel és fájdalmasan panaszolja a grófnak: „Rumi ${ }^{662}$ megajándékoza engem a Georgikonnak legújabb nyomtatványival. Elhültem - elhaltam, látván, hogy azok mind németek! - Én Keszthelyben egy magyar Weimárt óhajtok látni! A nemzetiség minden, s nincs enélkül semmi boldogság. Minek töltjük csüreinket, ha azokat oltalmazni nem tudjuk, nem tudjuk pedig, ha nemzetiségünket elvesztjük. - De engedjen meg Excellentiád ezen hazafiúi gyengeségemnek! mert valóban gyengeség ily semminek, mint én, a nemzetről aggódni; Excelentiád gondja az, mert oly dicső épületnek rakta le talpköveit, melyet csak a haza omladéka temethet el". 663

Berzsenyi Festetics nagyságában elsősorban azt látta, hogy a magyar nyelv ügyét felkarolta; tehát felesége, gyermeke is tanul magyarul, abban az országban, ,,ahol a nagyok az anyanyelvet cigány nyelvnek nevezik" ${ }^{\text {664 }}$ Bánthatta, hogy Magyarországon közel sem olyan a helyzet, mint Erdélyben. Döbrenteinek írt egyik levelében megjegyzi: „S az az Erdély hát még magyar világ a föbbrendủek körében is?"665 Másutt ugyancsak Döbrenteinek a következőket írja: „Örülök, hogy Erdély, valamint mindenkor, úgy mast is magyarabb, mint mi, örülök a theatrumnak is, és olyast Kolozsvárról álmodni sem tudtam”, 666

\footnotetext{
${ }^{660}$ Meg kell jegyezni, hogy Festetics már 1814-ben személyesen hívta meg a georgikoni vizsgákra Berzsenyit, de ő kitért a meghívás elől. Kazinczynak 1814. december 15-én le is írja ennek okát: „...ez a jó gróf minden emberséget mutatott hozzám. Kertjének legritkább oltványival megajándékozott, s megparancsolta kertészének, hogy valamit kívánok, mindent adjon. Igen szívesen invitált magához, és különösen a georgikoni exámenre megkért, hogy elmenjek. De minthogy azt veté hozzá, hogy akkor nekem valami jó svájcer tehenekkel is fog udvarolni, én nehezen fogok neki udvarolni. Kevély nem vagyok ugyan, de a szemtelenségtöl superstitiose irtózom. Már mast pedig vagy gorombának kell lennem vagy szemtelennek." (Berzsenyi Dániel Kazinczy Ferencnek, Mikla, 1814. december 15. ; KazLev. XII. 260.)

${ }^{661}$ Berzsenyi Dániel Festetics Györgynek, Nikla, 1816. november 15. ; Berzsenyi, 1978. 481.

${ }^{662}$ Rumi Károly György (1780-1847) szakíró, pedagógus. Mint középiskolai tanár 1813-ban a Georgikonban gazdászatot és természettudományt tanított. Sokoldalú írói tevékenysége elsősorban természettudományokra és gyakorlati ismeretekre irányult; egy elégiagyüjteményt és több irodalomelméleti tanulmányt írt.

${ }^{663}$ Berzsenyi Dániel Festetics Györgynek, 1816. november 15. ; Berzsenyi, 1978. 481-482.

${ }^{664}$ Berzsenyi Dániel Kazinczy Ferencnek, 1817. február 27. ; Berzsenyi, 1978. 427.

${ }^{665}$ Berzsenyi Dániel Döbrentei Gábornak, 1812. július 30.; Berzsenyi, 1978. 449.

${ }^{666}$ Berzsenyi Dániel Döbrentei Gábornak, 1814. január 5.; Berzsenyi, 1978. 455. ; Itt arról a kolozsvári színházról van szó, amit Festetics is támogatott.
} 
Berzsenyi tehát felvetette a magyar Weimar eszméjét. Festetics már minden bizonnyal érlelhette magában a gondolatot - ebben segítői is voltak, elsősorban Asbóth János és Ruszek József -; megszervezni birtokán a költők, írók, tudósok, a honorácior értelmiség összejövetelét. Ezt a feltevésünket támasztja alá, hogy Berzsenyi levelére két hónap múlva válasz érkezett, melyben a gróf meghívja egy solemnitásra, azaz a Helikonra. Berzsenyi ismerte Kazinczy véleményét Festeticsről, ezért 1817. január 12-én kelt levelét semmitmondóan kezdte, arról írt, hogy semmi érdemleges nem történt vele. „Nincs mit írjak” - tájékoztatja a Széphalmi Mestert.. Hogy mégis legyen veleje a levélnek, mintegy mellékesen megemlíti Festeticstől kapott meghívóját. Ez azonban csak álca. Annyira fontosnak tartotta a meghívót, hogy teljes egészében bemásolja Kazinczynak írt levelébe, közben mentegetőzik a címzésen (Tekintetes Táblabíró Úr!) és megnyugtatja Kazinczyt: „gr. Festeticsnek minden köpenyeges ember Tekintetes Úr, a gazdag nemesek pedig Nagyságosak és Méltóságosak”. Festetics levele Berzsenyi számára, igaz csak a gróf részéről, elismerést hoz. Ugyanakkor csupán annyit tud, hogy a gróf „valami tudós solemnitásra invitál”-ja. Festetics barátságos levele fontos adalékokkal szolgál a Helikon történetéhez, így lényeges ide idézése:

„Tekintetes Táblabíró Úr, nékem Nagy jó Uram!

Nagyon köszönöm, hogy rólam és fiamról megemlékezni méltóztatott, és híres, nemes Munkáinak második kiadását velem közölte. Ezen alkalmatossággal, midőn a könyvet felnyitnám, éppen szemembe ötlött azon Aoni lelkeknek tulajdonos jövendölése, hogy a keszthelyi zöld parton emelkedik a csendes Helikon. Azért, hogy beteljesedjen a Niklai Bölcsnek, akinek dicshírét a halandóság köde el nem éri, előre való mondása: íme, itten, Keszthelyen Böjt-elő havának, azaz febr. 12-én akarván Felséges Urunknak születése napját ülleni, az ifjúságot Helikonra vezetni kívánjuk, hogy az úgynevezett declamatio által a magyar, német és deák írásszerzésben jó ízlésre kapjon. De a Helikonra vezető Kalauz nekünk szükséges. Bátorkodunk tehát a somogyi Kazinczyra vetni szemeinket, és azon napra való maga-megalázására kérni. Lesznek talán több pártfogóink is, akik hívásunkat meg nem vetik, hogy összevetett vállakkal ezen töretlen ösvényen tanácsot adjanak és vezéreljenek, oktatván, mint kell az idővel élni s bölcsen örülni. Evvel magamat a Tekintetes Úrnak tapasztalt favoritba ajánlván, örökös tisztelettel maradok stb." ${ }^{\text {,67 }}$ Berzsenyi nem felejti el megjegyezni

${ }^{667}$ Berzsenyi Dániel Kazinczy Ferencnek, Mikla, 1817. január 12. ; Berzsenyi, 1978. 424-425. 
Kazinczynak, hogy „az elhúzott sorok verseimből vagynak szedve”. Arra gondol, hogy az ünnepséget azért rendezi Festetics, mert „azt mondatik, hogy herceggé lett”, s szarkasztikusan tovább füzi a gondolatát: „,de nem gondolhatom, minek kellenének ide a poéták”. Berzsenyi titokban lelkes, ám Kazinczynak szeme megakad Festetics egyik kifejezésén, nevezetesen azon, hogy Berzsenyit „somogyi Kazinczynak” nevezi. Hász-Fehér Katalin véleménye, hogy Festetics ezen kijelentése Kazinczyt szíven ütötte, mert azt képzelhette, hogy Széphalom irodalmi központját lokális keretek közé szeretnék visszaszorítani. ${ }^{668}$ Mezei Márta úgy gondolja Festetics vezekelni akart, hisz korábban megvonta támogatását a Magyar Minerva könyvsorozattól, többször szűkmarkúan támogatta a politikailag „kormossá” váltakat, így Kazinczyt is. ${ }^{669}$ Nem kerülhetjük meg azon véleményeket sem, amelyek konkrét publikációkban nem jelentek meg a maguk markáns valóságában, de Festetics György megítélésének vitáiban olykor szóban megismétlődtek. Ezek szerint Festetics Helikoni fellángolása csupán a gróf szeszélyeinek egyike volt. Mintául Esterházy (Fényes) Miklós fertődi vígasságai szolgáltak, ezeket óhajtotta volna utánozni Festetics, de szükmarkúsága miatt, csupán pár szegény magyar poétára, s a keszthelyi zeneiskola tanárára futotta. Ezzel a vélekedéssel nem érthetünk egyet. Festetics szerepe a magyar oktatásügyben elévülhetetlen. Nagyon sok mindent ennek érdekében cselekedett. A Helikonok részben a georgikoni megmérettetések ünnepélyesebbé tételéhez voltak hivatva hozzájárulni. Ezért szerepeltek valamennyi ünnepségen iskoláinak nagyobb diákjai is, akik találkozhattak a Dunántúl jeles irodalmáraival, országos tudósokkal. Az Helikoni összejövetelek tehát irodalmi, tudományos és nevelési funkciókkal bírtak. Ennek gyümölcseit arathatták le nemcsak a résztvevők, de ezek a „szellemi műhelyek” hozzájárultak Festetics gazdaságának korszerüsítéséhez is.

Nemcsak Berzsenyinek írt Helikoni meghívót Festetics. Kevésbé ismert a Sümegen élő Kisfaludy Sándornak szóló, nagyon személyes hangot megütő invitáló levele. A Magyar Tudományos Akadémia Kézirattárában fellelhető négy oldalas meghívó szerves része egy több helyen javított vers. Úgy véljük, hogy a javításokat a későbbiekben eszközölték.

„Tekéntetes Tábla Biró Úr, nékem drága nagy Jó Uram!

Somlyó Regéje’ fel-porozott Prometheusi tüzének szikrája lángot vetett szivünkben, Böjt' elő-havának $12^{\text {dikén }}$ Felséges Királyunknak Születése' napját magyarossan ünnepelni készülvén. Az itten tanuló ifjuságnak a’ Kasztáli forrásnak csermelyét fel-nyittni kivánnyuk,

\footnotetext{
${ }^{668}$ Hász-Fehér, 2000. 183.

${ }^{669}$ Mezei, 1997. 171.
} 
és az úgy-nevezett declamatió által magyar, német és deák költeményes munkákkal érzéseit nemesitteni igyekezünk, Ki volna tehát az köz’tunk, a’ ki illyen alkalmatossággal ama hires Himfit tisztelni nem kévánná, és őtet a’ borostyánnak osztogatásában, mint birót, el-nemfogadná? A' Vértse lakta Tátika' Váráról zengnek immár a' Bakonyban Sümegh felé ezen esdeklések, 's meg-hivó szózatok:

Te Keszthelyi Helikonnak

Légy jó szives munkása,

Véled Vállusi Kasztálnak

Ditsekedjen forrásai;

Mert te igaz Árpád fajja!

Bár fegyvert jó forgattál,

Minket többre versed bájja

Által el-magasztaltál.

Barátunk, ki által kedves

Lett nékünk a Helikon,

Kérünk, hogy te is részt vehess

E' munkában, és buzgón:

Kinek lelke fellengezvén

Lelkünket is felkapád,

Vagy jó szíved ömledezvén

Szivünket is el-rántád,

Király napját ünnepelni

Midőn itten készülünk,

Regék’ iróját tisztelni

Volna mi ditsőségünk.

Ne vess'd meg e' kérésünket

Magyar Muzsák' kedvese!

Vidámítsad érzésünket

Lantosoknak ékese!

Azért bátorkodván ezen közönséges kivánságnak tolmátsa és ki-fejezője lenni, kérem tisztelettel a' Tekéntetes Urat, hogy bennünket meg ne vessen, hanem tanátsaival 
gyámolítson; hogy ugy ezen csiráján bimbózó ibolyából hazai nyelvünknek díszére valaha terebélyes tölgy-lomb nőjjön fel és a’ Keszthelyi Helikonnak bibora a Tekéntetes Urnak ápolgatásával díszeskedjen. - A’ Méltóságos Aszszonyt, kinek kezeit csókolom, el-ne-felejtse akkorra magával el-hozni, és véle szegény házomnál meg-szállni.

Ezzel magamat szives indulatiba és Uri jóvoltiba ajánlom, állandó tisztelettel maradván

\section{A’ Tekéntetes Urnak}

Keszthelyen Karátson havának

$$
19^{\text {dik }} \text { napján } 1816^{\text {kban }}
$$

alázatos szolgája

Gr. Festetits György"

Nem megállapítható, hogy a levél elküldése elött történtek-e javítások a versen, vagy egy későbbi alkalommal történtek a változtatások. A javításon túl jegyzettel is ellátták a verset. Nem gondolhatjuk, hogy Festetics aláírta volna az alaposan „összefirkált” levelet, lehet, hogy a Magyar Tudományos Akadémia Könyvtárában található levél csak a piszkozat. Ugyanakkor kinek készülhettek a javítás mellé írt jegyzetek? A javítást tevő, véleményünk szerint a keszthelyi születésű poéta, Szép János volt. ${ }^{671}$ A javítások a következők:

\section{Eredeti szöveg}

5. sor Mert te igaz Árpád' fajja!

6. sor Bár fegyvert jól forgattál,

7. sor Minket többre versed' bájja

8. sor Által el-magasztaltál.

11. sor Kérünk, hogy te is részt vehess

21. sor Ne vess'd meg e' kérésünket
Javított szöveg

Mert te nem tsak Árpád' fajja!

Bár fegyvert is jól forgattál,

Hanem mindent versed' bájja

Által magadhoz vontál.

Hivunk, részt hogy te is vehess

Fogadd esedezésünket

Szép fontosnak tartotta a javításon túl, hogy jegyzettel is ellássa, mintegy magyarázva a vers természetleírását: „Vállus egy a’ Rezi Várnak dülékeny tsørba falai napkeleti vidékjén

\footnotetext{
${ }^{670}$ MTA. Kézirattár Magyar Irod. Levelezés 4 r. 121. Festetics György Kisfaludy Sándornak, Keszthely, 1816. december 19.

${ }^{671}$ Szép János (Keszthely, 1774. január 23. - Jászberény, 1834. augusztus 30.) tanár, író költő, műfordító. 1794 1810-ig Szombathelyen, majd Kassán, végül Jászberényben tanított a Gimnáziumban. Magyar és latin nyelvü alkalmi verseket írt. Jelentősebb alkotása a „Keszthely városának Párnásszus hegyéről való szemlélése s leírása. Budán, Landerer Katalin Betűivel, 1790.” Szép e versének egyetlen nyomtatott példánya az OSZK-ban található egy kolligátum 14. darabjaként a 403.413 számon. A ritka nyomtatványt faximilében, magyarázatokkal ellátva az Irodalomismeret közölte. (Sajtó alá rendezte és jegyzetekkel ellátta: Dala Sára, Földváry Kinga, Klaáb Adrienn, Kovács Edit Alexandra. = Irodalomismeret, 1996. 1-2 szám)
} 
levő Helysége Grófomnak. A' faluhøz és az emlétett vár' omladéki köz’tt vagyon egy Vadászi lakás, mellyhez ragasztott, 's a' és az ahøz a' hol egy a közellévö bérczek alljáig kinyúló kis vadas kertnek ernyős völgyéből, egy’ tsőnek üregéből egy gyönyörüséges egy igen kellemetes csermely folydogál le a' kies réteken által, és több patakokkal egyesűlve a Balatonba omlik. Szép ${ }^{\text {,672 }}$

Festetics a levelekben a címzett erényeit ecseteli, arra kéri a „somogyi Kazinczyt” és „Himfyt”, segítsenek abban, hogy a keszthelyi Helikon terebélyes, erős tölgyfává cseperedjék. Festetics mindkét elöbb idézett leveléböl világosan kiderül, hogy nagyon fontosnak tartotta a költők részvételét Helikonján, mivel ez rangot és elismerést ad a rendezvénynek. Tudta, hogy az 1804-től folyamatosan megtartott iskolai ünnepélyeket - híres emberek hiányában - csak önképzőköri találkozóként, legföljebb iskolai vizsgákként lehetett értékelni. Míg Berzsenyi a Somogyi Kazinczy a Helikonra vezérlő kalauz, addig Kisfaludy, Himfy, a borostyán osztogatásnak bírája a Festetics által megálmodott solemnitáson. Ugyancsak érdekes megjegyezni, míg Berzsenyi feleségét Dukai Takács Zsuzsannát nem, addig Kisfaludyné Szegedy Rózát invitálja a Helikonra. Feltételezhetjük, hogy Festetics tisztában volt a feleségek irodalomhoz füződő kapcsolatával, (nem is beszélve Kisfaludyné esetében a rokoni kötelékekről) ezért történhetett a különbségtétel. Ezt támasztja alá Berzsenyi jellemzése feleségéről, amikor Kazinczynak a következőket írja: „Ami a feleségemet illeti, középszerü mindenben; tizennégy éves korában vettem el, együgyüségben találtam és abból fel nem szabadítottam, mert e részben egy kevéssé napkeletiesen gondolkoztam, vagy igazábban szólván, ezen kis barbaries familiai nyavalám; testvérei kastélyokban és festett szobákban laknak, de ő énvelem két kis szobában megelégedik. Ha módi ruhák helyett jószágot szerzek, nem zúgolódik, hanem a gyertyavesztegetésért és firkálásért néha nagy panasza van ellenem, de én azt Socratesként csak úgy hallom, mint a kocsizörgést ablakom alatt”. ${ }^{673}$

A Helikoni Ünnepségek nevének megválasztásában egyrészt a múzsák lakhelye, másrészt Festetics György szabadkőműves neve (Helikon testvér) volt a meghatározó, amelyről korábban már írtunk. Kornis Gyula 1927-ben arra hívta fel a figyelmet, hogy a kor elsősorban külsőségekben - antikizáló hatásának köszönhető a név megválasztása: „Ha görög szavakat használnak, már azt hiszik, hogy szellemük minden ízében görög. Még családi

\footnotetext{
${ }^{672}$ A jegyzet eredeti, áthúzott javított részeit jelen dolgozatban hasonló módon jeleztük. A jegyzeteket kézjegyével látta el írója: „Szép”

${ }^{673}$ Berzsenyi, 1978. 378-379. Berzsenyi Dániel Kazinczy Ferencnek, Mikla, 1809. március 12.
} 
életüket is külsőleg klasszicizálják, amikor gyermekeiket antik névre keresztelik: Kazinczy leányainak neve Iphigenia, Anna Sophronia Thalia Theresia, fiáé Antoninus Sophron; gr. Dessewffy József elsőszülött fiáé Marcus Aurelius; Ráth Mátyás Sokrates nevet adja fiának, Németh László Aristipposét. A folyóiratokat is antik névre keresztelik: Orpheus, Uránia, Aspasia, Klio, Musarion, Minerva, Athenaeum, Hebe. A keszthelyi költői ünnepeket alig merné gr. Festetich másként elnevezni, mint Helikónnak". ${ }^{674}$ Minden bizonnyal volt a fentieknek is meghatározó szerepük a név megválasztásában, mi azonban fontosabbak tartjuk az előzőekben megállapítottak névválasztásra gyakorolt hatását. A meghívottak jórészt szabadkőmüvesek voltak (gr. Festetics György, Horváth Ádám, b. Pászthory Sándor, Nagyváthy János, Fáy Barnabás, stb.) Tehát, ha Helikon testvér Helikoni Ünnepségre hívja vendégeit, akkor mindenki, aki a rend egyik nagymesterét tisztelte a vendéglátóban, tisztában volt azzal, hogy milyen szellem fogja vezérelni az ünnepet. Az ünnepségek deklarált célját az első ünnepségek szervezői Asbóth János, Ruszek József és Petróczy Béla leírták a „Helikon I.” kötet bevezetőjébe. Ezek szerint a serdülő ifjúság nevelése minden nemzet fejlődésének záloga és érdem a hazában. Az emberi elme, szépérzék, erkölcs kifejlődésének eszközeit kell felsorakoztatni, melyek közül a poézis az első, mert a poézis volt, amelyik az embert vadságából kivetkőztette. Ugyanakkor fontos a retorika, amit Cicero a következőképpen jellemez: „Ezen tanulmányok az ifjúságot táplálják, az öregséget mulatják, a’ szerentsének diszt, a' balsorsnak menedéket, 's vigasztalást nyújtanak, gyönyörködtetnek itthon, nem

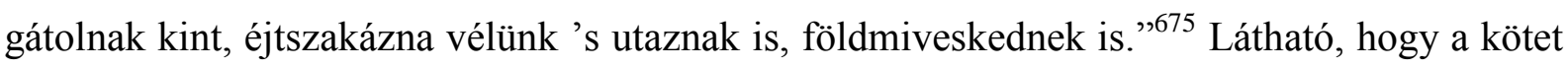
bevezetője mintegy megelőlegezi Széchenyi István kimüvelt emberfőkről való mondását és elsősorban az ifjúságot jelöli meg ennek letéteményeseként, ugyanakkor az ifjak figyelmébe ajánljál az idősebb, tudós generáció ösztönző példáit:

„Illy szent czélra, és nemes vígbül állott fel 1817 Esztendőben a’ Keszthelyi Helikon is, mellyben három Felvigyázók, és annyi Segédek ügyellése alatt, mind a' Georgikoni, mind a' Lyceumi Ifjak 's Humanisták, s magokat az ékes előadásnak mindegygyik nemében, deákul, magyarul, 's németül holnaponként gyakorolhatják, szabad kénnyökre hagyván a' fel adott tárgyakon kívül, mást is ha tetszik, tsak szerelmes, vagy illetlen dolog ne legyen, válosztani; melly folyó, és kötött beszédbéli kidolgozásokbul azután a’ jobbak, kivált a’ husz rendes Stipendiátusok, nyilván való próbákat is tartoznak kétszer esztendőnként adni; egyszer

\footnotetext{
${ }^{674}$ Kornis II., 1927. 263-264.

${ }^{675}$ Helikon I., 1818. V.
} 
Február 12-dikén mint Felséges Urunk' ditső születése napján, másodszor a' gazdasági látogatás alkalmatosságával Majusnak a’ végén.

Hogy pedig annál nagyobb kiterjedésű ösztönnel, haszannal, és sikerrel birna e' serdülő Intézet; meg voltak itt egy napi járó földre körül belül minden jelesebb Irók 's Tudósok híva és kérve, valamint ezennel meg kérünk, és hívunk minden egyéb hazai Irót is, hogy ha valaki az előadandó darabok meg itélésére, és az ünnep fényesbítésére személyesen meg nem jelenik is; leg alább akkora bé küldött apróbb dolgozásai által az Ifjuságnak ösztönző példát, az egybe gyült Tudósoknak pedig tetemes gyönyörködést szerezni ne terheltessék." 676

Érdemes megfigyelni, hogy a bevezető külön szól a Stipendiátusokhoz, azaz a Festetics által ösztöndíjban részesülőkhöz, kiket szigorúbban itél meg. Elvárás, sőt kötelező volt a két Helikonon való részvétel, az azon való szereplés. Az írók esetében elsősorban a környékbeliekre gondoltak, akik „egy napi járóföldre” esnek Keszthelytől, de nem zárkóztak el a távolabb élők elől sem. A fent említett és idézett bevezető egy évvel az első Helikon után került ki a nyomdából. Rendelkezésünkre áll ugyanakkor az a tervezet, amit a Helikonok megálmodója és Festeticsnél kijárója papírra vetett. A tervezet latin nyelvü és címe: „Projectum de Heliconis' Keszthelyensis institutione”. ${ }^{677}$ A tervezetet 1816. december 30-i keltezéssel írták, de Festetics csak az első Helikon után, némi bővítménnyel megtoldva, látta el kézjegyével. A Directoriatus jegyzőkönyvébe bejegyezték, hogy az a projectum helybe hagyatott és a „Georgiconnak megküldeni rendeltetett”. ${ }^{678}$ A tervezet magyar fordítását, mint az egyedüli eredeti dokumentumot az alábbiakban közöljük: ${ }^{679}$

„A keszthelyi irodalom és müvészetekkel foglalatoskodó szorgos ifjúságnak a Keszthelyi Helikon intézményében nyilik lehetőség arra, hogy bővebb gyakorlatot szerezzenek és összemérjék tudásukat a latin, a nemzeti magyar és német ékesszólásban, legyen az kötött, vagy szabad beszéd, mutassák meg mit tudnak, mit tanultak a dispozicióban, digestioban, esztétikában, kifejezés- és előadásmódban, amit a Moderátor segitségével, és korrekciójával adnak elő a legjobbak. Ennek végén pedig a Gróf Ö Excellentiája az ifjúság és az irodalom bőkezű gondoskodója a legjobbaknak jutalmat fog osztani.

\footnotetext{
${ }^{676}$ Helikon I., VI-VII.

${ }^{677}$ MOL Fest. Lvt. P 2461 cs. 226-227

${ }^{678}$ MOL Fest Lvt. P 279284 k. Ternio II.

${ }^{679}$ Köszönettel tartozom Csiky Gergőnek a latin szöveg magyarításáért. ; A szöveg rezüméjét Négyesy László is feljegyezte. Kéziratos vázlata a MTA Kézirattárában található. (MTA Kézirattár MS 712/8)
} 
1. A stílusgyakorlatokon, amelyek a Keszthelyi Helikon név alatt nyújtatnak be részt vehessenek a gimnázium mindkét humán tagozatának diákjai, a liceumi auditorok úgy a logikai, mint a természettani fakultásból, végül a Georgikoni praktikánsok.

2. Bár a nevezett tanulmányoktól senki távol nem tartatik, mégis a nagyobb vetélkedésröl gondoskodva és elkülönítve azokat akik gyakorlataikkal kiemelkednek a többiek közül, tétessék különbség a Helikon rendes tagjai között, akiknek Ö Excellentiája bőkezüsége révén ajándék van kitüzve, s a nem rendes tagok között; azok a scandensek, emezek az aspiránsok.

3. A scandensek száma húsz lehet, bármely bölcsész osztályból három-három, azaz hat, a filozófiai líceum osztályaiból négy-négy, azaz nyolc, a georgiconi praktikánsok közül hat. Az aspiránsok száma nincs meghatározva, mivelhogy azok is beletartoznak, akik a Helikon ügyivel foglalkoznak. A scandensek jutalma havi 2 forintban állapíttatik meg. A scandensek minden december hónap végén neveztessenek meg a tanév első szemeszterére, másodikra pedig április havában, de olyan módon, hogy ha valaki az aspiránsok közül jobban kimagaslik, a következő félévben a scandensekhez lehessen állíttani.

4. A professzorok közül három legyen, aki a stílus felülvizsgálatát és korrekcióját magára vállalja. Az e célra keresettek és a munkának szívesen eleget tevők: latinból a kiváló Harm Gábor rektor, magyarból a kiváló Drinóczy György rektor, németből Liebbald Gyula rektor. Ezen professzoroknak a magukra vállalt fáradozásaik miatt száz forint évi honorárium juttassék.

5. A stílusgyakorlatok havonta olyan napokon tartassanak, amikor hivatalos teendök nincsenek. Ez alkalomból a scandensek kötelezve vannak minden hónapban - ha többet nem is - egy dolgozatot készíteni, az aspiránsok ugyanezt kedvük szerint teszik. A rektor urak az egyes nyelveken, amelyeken a vetélkedés folyik, gondoskodjanak a feladatokról és arról, hogy a legjobb dolgozatok felolvastassanak.

6. Évente kétszer tudniillik február 12-én a császár születésnapján illetve májusban bemutattassanak a helikoni produkciók. Mindkét ünnepen, akiknek dolgozatai előadásra méltónak ítéltetnek, minden munkáért öt forintot kapnak, akik viszont kiemelkedő, több nyelven elkészített munkákat adnak be az öt forint jutalmon túl annak felét is, tudniillik két és fél forintot megkapnak, együtt hét és fél forintot.

7. Ezen ünnepek alkalmával zenei összejövetelek is vannak, amelyekért, ha a zeneiskola kiemelkedően teljesít a tanárnak nyolcvan forint, ha jól, de nem kiemelkedően teljesít hatvan forint ajándékoztatik. A zeneiskolai diákok pedig, és mások is akik az éneket segítették, első alkalommal negyven, a továbbiakban harminc forintot kapjanak, 
8. Az ünnepekre, melyeken a produkciók tartatnak, meg kell hívni más müvelt férfiakat és nőket Keszthelyről és a közelben élők közül is, elsősorban olyanokat, akik költői és előadói munkáikkal ismertségre tettek szert, s akik jelenlétükkel emelik a Helikont, valamint munkáikkal az ifjú lelkeket serkentik. Ök a Helikon támogatói névvel ruháztatnak fel.

9. A Helikon költői müvei elbíráltatnak, hogy méltó-e a nyilvánosságra s ezek után különböző nyelvek szerint csoportosítva nyomdába küldenek. De vigyázni kell, hogy a gyönyörüség közepette erotikus vers, se mü ne legyen s minél jobban kell törekedni arra, a versek az uralkodó és haza iránti hüséget, dícséretet árasszák, jó emlékezetre méltó férfiakról szóljanak, erényekről, erkölcsről, hőstettekről.

10. A professzorok segítségére három felügyelő is meghatároztatik, az első a magyar stílust felügyelő, tiszteletreméltó Ruszek József apát, a második a latint felügyelő, kitünő Petróczy Béla a helyi gimnázium igazgatója, a harmadik pedig a germán stílus felügyelője az alulírott prefektus, akik a saját munkájuk és vizsgálódások révén megkönnyítik a rektorok dolgát, rézben az ifjúság által létrehozott gyakorlatok megvizsgálásában, másrészt a Helikon nyomdába küldendő müveinek átnézésében.

Keszthely, 1816. december 30.

Asbóth János professzor”

E tervezet azzal a rendelkezéssel hagyatik jóvá, hogy a rendes együttmüködők, avagy az ajándékot kapók a Laureatus „Babérkoszorús” névvel jelöltessenek, a rendkívüliek Apollóiaknak neveztessenek; a felügyelők az átvizsgált művekért évente százötven forint honoráriumot kapjanak ezen iskolaév kezdetétől, azaz 1816. november 1-jétől, s ezek a Georgikon iskolai kasszájába berovattassanak.

Keszthely, 1817. március 6.

Gróf Festetics György m. p.”

A tervezet, amely döntő részben meg is valósult rávilágít arra, hogy az évente megrendezett két Helikon tulajdonképpen vizsgája volt a diákoknak, amire tanáraik felügyeletével készültek. A februári az uralkodó születésnapjához kapcsolódott, a májusi az ókori Ceres ünnepeire emlékeztetett. Asbóth János a segítő tanárok nevét is meghatározta, gondoskodott a felkészítők és felkészülők anyagi juttatásáról is, azaz a honoráriumról, illetve az ajándékokról, amit jelen esetben pénznek kell értenünk. A Helikonok tervezetében nagy teret kap az elkészített munka minősége is, hisz a jobbak több pénzt kaphattak a gróftól. Asbóth meghatározta azt is, hogy az elhangzott legjobb müvek kinyomtatásra kerülhessenek. Ö még úgy tervezte; a magyaron túl a latin és a német nyelven elhangzott művek is nyomdába 
kerüljenek. Nem rajta múlott, hogy végül is csak egy kötet, a magyar nyelvü munkákat tartalmazó kerülhetett ki Perger keszthelyi mühelyéből. A tervezet ismeretében az sem véletlen, hogy a Helikon I. kötet már említett bevezetőjét Ruszek, Petróczy és Asbóth neve fémjelezte. Érdekes megfigyelni, Asbóth milyen módon akarta a közönséges iskolai vizsgák napját emelkedett ünneppé tenni. Tervezet 8. pontjában kitért azokra a Keszthelyen és a környéken lakó nevezetes emberekre, akik emelhetik a Helikon fényét. Tudta, csak neves emberek tehetik elismertté a Helikon intézményét. Erre mutat rá az első Helikonra meghívottak névsora is.

A Festetics Directio iratai között is megtaláljuk a helikoni elképzeléseket és a Helikonra szóló meghívásokat tartalmazó levelek másolatait, melyeket Szigethy László csurgói professzornak, Horváth Ádámnak, Potyondy Ferenc ügyvédnek, táblabírónak írtak. A csurgói professzornak írt levélből kiderül, hogy a Helikonra nemcsak a keszthelyi diákokat várták el, de a csurgóiakat is. ${ }^{680}$ Festetics a lehető legkörültekintőbben akart eljárni. Ezt hivatott igazolni, többek közt a Directorátus 1817-es Repertoriuma, ahol a következőket olvashatjuk: „Stipendiátusok is mindenkor Membrumai legyenek a' Heliconnak - Profact. Ruszek Apát és Petroczy Director Urak Concentráljanak miképp lehetne a' Heliconi tagokat meg jutalmazni mindenmunkáért, hogyan kellene a' nevezetesseb munkákat ki nyomtatni, és azok jövedelmiböl Remuneratiokat (renumeratio!) vagy jutalom kérdéseket határozni”. ${ }^{681}$

Festetics György Asbóth Jánoson keresztül tehát számos helyre elküldte meghívóit. A meghívók az írók körében nem arattak maradéktalan sikert. Kezdetben visszamondta Horváth Ádám és Berzsenyi is a megtiszteltetést s csak Asbóth rábeszélésére jöttek el Keszthelyre. Horváth megköszönve Asbóthnak az első meghívó levelet, sajnálattal közölte, hogy éppen ez idő tájt a Külső Somogyhoz tartozó Centrális iskola megtekintését kellett beütemeznie, de a májusi Helikonra már minden bizonnyal elmegy. ${ }^{62}$ Asbóthnak is feltünhetett a mondvacsinált kifogás, így a rábeszéléshez volt kénytelen folyamodni. Három levélben is kérlelte. Horváthnak ezen túl is voltak aggályai; a meghívás kizárólagosan a dunántúli íróknak szólt, s Széphalom kimaradt a meghívandók köréből. Rosszul esett neki, mert a széphalmi mesterrel ő is és Berzsenyi is jó barátságot ápoltak. Zavarta a nyelvújítás körüli meg nem értés. ${ }^{683}$ Úgy tünik, Horváth még bízott, azt írta Kazinczynak, hogy „én pedig elébb

\footnotetext{
${ }^{680}$ MOL Fest. Lvt. P 279288 k. Ternio Secundus Protocollum Determinationum. 1817. A Conceptusnak Copiája és a' Subscribensek Nevei. 1817. január 12.

${ }^{681}$ MOL Fest. Lvt. P 291 k. Repertorium 1817. Magyar nyelvű szakmutató. Eő Excellentiája Gazdaságbéli foglalatosságai. $1960 \mathrm{sz.}$

${ }^{682}$ Horvát Ádám Kazinczy Ferencnek, 1817. ; KazLev. XV. 49.

${ }^{683}$ A nagy viták Csokonai értékelése körül bontakoztak ki 1805-ben. 1811-ben Kazinczy Ferenc Tövisek és virágok (Széphalom, 1811) címen epigramma gyüjteményt jelentetett meg, mellyel megindult a nyilt nyelvújítási
} 
már úgy hallottam, hogy Téged is meg hívnak, és igérkeztél is (...) némelly fiatal barátim azt hitték 's most is hiszik hogy Te is ott leszel, és kérték, hogy veled őket ismertessem meg."684 Ugyanakkor magyarázkodik is, a Helikonon való részvételét egyrészt azzal magyarázva, hogy reményli, találkozhat Kazinczyval, másrészt, ha mégsem lesz ott Kazinczy, akkor pedig megvédi őt a dunántúliakkal szemben. Különben is úgy hallotta, hogy sem Berzsenyi, sem Kisfaludy nem jönnek és így a gróf „buzgósága meg bántatódik”. Kazinczyt azonban nem hívták meg az első keszthelyi Helikonra. Nem tudni mennyi köze volt ebben személyesen Festeticsnek, mennyi a Helikon szervezőinek, de tény, hogy a gróf nem értett egyet a nyelvújítás Kazinczy-féle irányzatával, ezt több ízben ki is fejtette. Talán arra is ügyeltek, hogy a gróf körül semmiképpen ne csaphassanak fel irodalmi köntösbe bújtatott politikai hullámok. Festetics részéről, még az ily körültekintően megszervezett ünnepek is magukban hordozták a botrányok lehetőségét.

Fontos tudni, hogy a keszthelyi Helikonra érkezők a nyelvújítási vitában elfoglalt véleményük szerint két csoportra az ortológusokra és neológusokra voltak oszthatók. A helyzetet bonyolította számos pletyka, amely nem volt igaz, de megkeserítette sokaknak szája ízét. Többen úgy gondolták - rossz információk alapján - Festetics támogatásával jelenhetett meg a Mondolat. Erre semmiféle hitelt érdemlő bizonyíték nincs. Kazinczy nagyon megbántott, nagyon gyanakvó és bizalmatlan volt, ebből kifolyólag sokszor összekuszálta a szálakat. Még 1817. június 14-én is a következőt írta Kölcsey Ferencnek: „Rumi is vendége vala Festeticsnek azon asztalánál, mellynél Ruszek a’ maga Philos. Munkájit és a’ Mondolatot kiosztogattatá, ’s R(umi) kérdést teve, mit osztanak? Azt felelte az osztó, hogy Apát Úrnak két Munkáját (és így a’ Mondolat nem magáé Somogyié, a’ mit én mindég mondottam.) Egy idő mulva Ruszek és Rumi egymás mellett ülnek az asztalnál, 's Ruszek deklarátiót tesz Ruminak, hogy mennyire sajnálja, hogy én reá neheztelek etc. Rumi ezt nekem megírja. Én pecsét nélkül küldék Ruminak eggy levelet, Ruszekhez szólót, mellyben ezen szavainál fogva

harc, összecsapás. E kis kötetben leginkább Kisfaludy Sándort sérti meg a Himfy című epigrammával: „DAYKA. Tüzbe felét! HIMFY. Vetem. D. / Újra felét! H. Ím. D. Harmadikát még / Lángol az is. D. Jer most; vár az / Olympuszi kar.” De Kazinczy első német nyelvű recenziója a Himfy szerelmeiről még 1809-ben jelent meg az osztrák Annalen der Literatur und Kunst in dem oesterreichischen Kaiserthume folyóiratban. A kritika azért érte váratlanul Kisfaludyt is, mert annak előtte Kazinczy dicsérte mind a két versciklust. (Hász-Fehér, 1999. 801-814) ; Ugyancsak 1811-ben jelent meg Kazinczy tollából „Poétai episztola Vitkovics Mihály barátomhoz”, melyre a Szatmár megyeiek Mátészalkai Hőgyész Máté álnéven válaszoltak. Kazinczy a nyelvújítási programját „Báróczy minden munkáji” és „,Ujhelyi Dayka Gábor versei” előszavában fogalmazta meg 1813-ban. A nyelvújítási harc az 1819-ben Kazinczy által írt „,Ortológusok és neológusok nálunk és más nemzeteknél” (Tudományos Gyüjtemény, 1819) címmel megjelent munkájáig tartott. Ebben elismeri Kazinczy saját túlkapásait, de lándzsát tör a nyelvújítás fontossága mellet.

${ }^{684}$ Horváth Ádám Kazinczy Ferencnek, 1817. január 12. ; KazLev.XV. 55-56. 
jobbomat nyujtom neki; Ruszek elpirul, barátsággal felel de nem egészen hive, fogadja, hogy tisztelőm, barátom 's azzal végzi, hogy Kisfaludi engesztelő szavamra csak nevete". ${ }^{65}$

A Mondolat 1813-ban jelent meg Veszprémben. ${ }^{686}$ Írója Szentgyörgyi József, Kazinczy barátja volt, aki bár nem Kazinczy ellenes éllel fogalmazott, e nyelvújításával nem értett egyet. A végleges szöveget Somogyi Gedeon készítette el, a mérsékelt nyelvújítás híve. Bizonyos „typographiai” korrekciót Ruszek József is végzett a művön; a Mondolat negyedik ívének kefelevonatát javította. ${ }^{67}$ Ezért tartotta fontosnak Hász-Fehér Katalin megjegyezni dolgozatában, hogy Kazinczy utalásainak fényében a Helikon „,erkölcstelen állammá vált, mert Ruszek ahelyett, hogy papi hivatásához méltó módon elsimította volna az ellenségeskedést, Kisfaludy (Kazinczy-ellenes) leveleit széles körben terjesztette, s ezzel a viszályt szította közöttük". ${ }^{688}$ Kazinczy azt hitte először, hogy Somogyi Gedeon csak eszköz volt Ruszek, Kisfaludy és Péteri Takáts József kezében. Péteri Takáts később maga is megvallja Kazinczynak, hogy az igazi szerző Somogyi. Somogyi kérte fel Péteri Takátsot az előszó megírására, amit ő nem vállalt el. ${ }^{689}$ A névtelenül kiadott munka vérig sértette Kazinczyt, hisz a címképmetszeten saját magát volt kénytelen látni, amint tülköt fújva, szamárháton üget a Parnasszusra. A kötetet Zafyr Czenczinek kedves Cousinémnek, miveltt lelkü Onkelem’ jó Leányának hálás buzgalommal tulajdonolja a’ Kiadó ajánlották, azaz magának Kazinczy Ferencnek. Ezután következik a Czenczihez intézett bővebb ajánlás, melynek már néhány bekezdő mondata is teljes világosságot vet a gúnyirat stílusára: „Édes Angyalném! Mondolatomat, mellyet a' Közönyújjságok oly magosra dítsértek fel 's a' miről köztünk is volt már a' beszélgetés' beszédje, a' minapság eligért szóm szerént imé Szépnéségednek felajánlom; külmiképségét olly idomra szabván, hogy dolgozáserszénykédbe is belé illjen. Kellemid, mellyeket kikészítésül kaptál, hiszelékennyé tesznek, hogy előtted koránt sem úgy nézek ki, mint ha feltétemnek személlytzim, vagy sajátkeresés lett volna rugástolla. Óh nem! Nem vagyok olly pulyátska - nem akarok nyelvemmel tő’sérkedni. Önn’ ékeidnek, ritka kecseidnek emléke ez; Cyane' szinét fellyülhaladt szép szemeid' kegyeletjének - 's ha szabadna neveznem (de megengedj, ha ojkor-ojkor nem birok Fantáziám' fogja lenni) Madonnámnak szentelve.” A Mondolat a nyelvújítók új szavainak és erőltetett kifejezéseinek egybegyűjtésével akarta bionyítani, mennyire túlzó a nyelvújítás. A Mondolatot Szentmártoni Radó Sándor küldte meg Kazinczynak. A széphalmi mester köré

\footnotetext{
${ }^{685}$ Kazinczy Ferenc Kölcsey Ferencnek, 1817. június 14. ; KazLev. XV.

${ }^{686}$ Mondolat. Sok bővitményekkel, és egy kiegészitett újj-szótárral együtt. Angyalbőrbe kötve, egy Tünet-forint. Dicshalom, 1813.

${ }^{687}$ Kazinczy Ferenc Horváth Istvánnak, 1817. január 3. ; KazLev. XV. 15.

${ }^{688}$ Hász-Fehér Katalin, 2000. 184.

${ }^{689}$ Váczy János, 1905. 194.
} 
gyülekezők közül Kölcsey Ferenc és Szemere Pál válaszoltak a sértésre, „Felelet a Mondolatra" című munkájukban. ${ }^{60}$ Gorombán vágtak végig a Mondolat szerzőin és terjesztőin. Kazinczy személyesen nem akart válaszolni, végül mégis írt ellenfeleinek a Tudományos Gyüjtemény 1818-as évfolyamában. Ekkor már barátai is - többek közt Kölcsey - intették túlzásaira, s a Festetics köré tömörülők jó része viseltetnek ellenségesen vele szemben. ${ }^{691}$

Ilyen előzmények után került sor az első Helikonra.

\section{6. 2. Az első Helikoni Ünnep: 1817. február 12.}

1817. január 4-én azok a keszthelyi diákok, akik a Helikonon szerepelni akartak, feljegyzésbe kerültek a „Prefectus és az Archon Urak által”. ${ }^{692}$ Az elökészületek az ünnep kezdetéig folyamatosan történtek.

Horváth Ádám egy nappal előbb érkezett a grófi udvarba, hogy még az utolsó simításoknál segédkezhessen. „Estve meg érkezvén Börzsönyi (sic!) betegen, Kis-Faludi (sic!) egésségesen" - írta később Kazinczynak. ${ }^{693}$ Ezt követően megérkezett Dukai Takács Judit, Fáy Barnabás királyi udvari tanácsos, Zala vármegye referendáriusa, Szegedy Ferenc császári és királyi kamarás, Zala megye első alispánja. ${ }^{694}$ A nyelvújítás körül kibontakozó vita éreztette a keszthelyi Helikonon is hatását. Berzsenyi és Horváth megpróbálta védeni Kazinczyt Festetics előtt, aki nagy embernek tartotta a széphalmi mestert, különben nem írta volna Berzsenyinek, hogy egy somogyi Kazinczyt lát benne. Ezt támasztja alá Kazinczy Döbrenteinek írt levelének egyik mondata: „B(erzsenyi) írja, hogy Festetics felőlem sok jót monda de nem szereti Németizmusaimat; az ellen harcolni kell”. ${ }^{695}$ Később Kazinczy, bár nem Festetics ellenében, így magyarázza álláspontját Berzsenyinek: „Ezek az Urak most a’ Nationalismust pengetik. Szent szó: de szent szó e, ha ez alatt olly Nationalismust értenek, melly irtózzék az idegentől ha az szép is?" ${ }^{966}$ Pedig sok támadás érte Kazinczyt az első

\footnotetext{
${ }^{690}$ Felelet a' Mondolatra néhai Bohógyi Gedeon úrnak. Mondolat. Sok Bővítményekkel és egy kiegészített új Szótárral együtt. Dicshalom (azaz Weszprém) 1813. czímű Pasquilusára. Pesten, Trattner Ján. Tam. Betüivel 1815.

${ }^{691}$ Kazinczy Ferenc Szentgyörgyi Józsefnek, 1818. március 29. ; KazLev. XV. 541.. ; Kazinczy Ferenc Döbrentei Gábornak, 1818. május 21. ; KazLev. XVI. 41.

${ }^{692}$ MOL Fest. Lvt. P 279288 k. Ternio Secundus Protocollum Determinationum. 1817. 18/36

${ }^{693}$ Horváth Ádám Kazinczy Ferencnek,, 1817. március 2. ; KazLev. XV. p. 56.

${ }^{694}$ Kisfaludy, 1817. 84.

${ }^{695}$ Kazinczy Ferenc Döbrentei Gábornak, 1817. március 13.; KazLev. XV. 114.

${ }^{696}$ Kazinczy Ferenc Berzsenyi Dánielnek, 1817. március 13.; KazLev. XV. 116.
} 
Helikonon, főleg Kisfaludy Sándor részéről, ő vérig sértődött a széphalmi mester Himfy kritikájától. „Kisfaludy gyülöl és mocskol - tájékoztatja az ünnepség után Kazinczyt Berzsenyi, majd folytatja -, s nem a recensióért (úgy mondja), hanem azokért amiket $\mathrm{s}$ amazoknak firkálsz. Én kérleltem s oltalmaztalak, de egyebet nem nyertem, hanem hogy énreám is megharagudott, úgyhogy búcsúzatlan hagyott el, pedig egy házban voltam vele szállva. Vedd kedvesen barátodtól ezen kis áldozatot. Kisfaludy virgonc, kevély, minden filozófia, szelídség és szívesség nélkül." ${ }^{297}$ Kisfaludy még egy általa Kazinczynak írt levelet is át akart adni Berzsenyinek, aki azt, a levél tartalmára és barátjára való tekintettel, nem fogadta el. Horváth Ádám is írt Kazinczynak, de addig, míg Keszthelyen Kazinczyt védte, Kazinczyval szemben a grófot védelmezi: „...a’ Gróff felüled egészen rosszul van elhitetve”, s mikor Horváth ecsetelte Festeticsnek Kazinczy érdemeit és pozitívumait, a gróf „úgy tetszik, hogy látszott térni”. ${ }^{698}$ Nehezebb helyzetben volt Horváth Kisfaludyval szemben, ő is megpróbál közvetíteni, ám nem ér el többet, mint azt, hogy Kisfaludy „nem haragszik, de barátságot nem ígér”. ${ }^{69}$ Kisfaludy epésen megjegyzi még a vita során, hogy nem akar úgy járni, mint Verseghy, kivel Kazinczy együtt raboskodott, mégis megtámadta az ypszilon-háború során. ${ }^{700}$ Fenyő István Kisfaludyról írt tanulmányában az ellenségeskedésről írja, hogy Kisfaludy, Ruszek és Festetics ismételten hevesen támadták Kazinczyt, föleg a recenzió miatt. ${ }^{701}$ Kisfaludy valóban hevesen támadta, Ruszek sem volt visszafogott, de Festeticsről mindez nem mondható el. Emlékezzünk Berzsenyi levelére, aki azt írta, hogy a gróf csupán Kazinczy németizmusait nem szereti. Nem találunk „terhelő adatot” Horváth leveleiben sem, pedig ha vannak, minden bizonnyal papírra vetette volna azokat.

Az események lefolyásáról a korabeli újságok, elsősorban a Magyar Kurír és a Hazai 's Külföldi Tudósítások számoltak be, de emberi közelségbe mégis azok a levelek hozzák, melyeket Berzsenyi és Horváth Ádám Kazinczyval váltottak. Ugyanakkor sokat megtudunk

\footnotetext{
${ }^{697}$ Berzsenyi Dániel Kazinczy Ferencnek, 1817. február 27. ; Berzsenyi, 1978. 426-427.

${ }^{698}$ Horváth Ádám Kazinczy Ferencnek, 1817. március 2. ; KazLev. XV. 83-84.

${ }^{699}$ Horváth Ádám Kazinczy Ferencnek, 1817. március 2.; KazLev. XV. 83.; ,...jobb te veled távolyrul békélni; mert szemben szorosabb kötelességü barátoddal 's valaha rab társaddal is, Versegivel (sic!), igen gorombán bántál. Ő nála hát nem erőlködtem többet...” - tájékoztatja a levélben Horváth Kazinczyt.

${ }^{700}$ Verseghy Ferenc és Révai Miklós nyelvi és helyesírási vitája ypszilon-háború néven vált ismertté irodalomtörténetünkben. Révai 1803-ban jelentette meg „Antiquitates Litreraturae Hungaricae” címü művét, amelyben a „Halotti Beszéd” szövegét közölte magyarázatokkal. Ugyanebben az évben jelent meg összefoglaló magyar nyelvtana latin nyelven: Elaboratior Grammatica Hungarica. Kora európai nyelvtudósait is megelőzve az élőbeszéd grammatikáját a nyelv történeti előzményeiböl magyarázta. Régi nyelvemlékek tanúságából kiindulva próbálta a nyelvi és helyesírási egységet megteremteni. Verseghy előbb német nyelvü grammatikájában (Neueverfasste Ungarische Sprachlehre, 1803), majd „A tiszta magyarság, avagy a csinos magyar beszédre és helyes írásra vezérlö értekezések, 1805." címü vitairatában támadta Révait. Verseghy szerint mivel a nyelv folyton tökéletesedik, helytelen a korábbi, fejletlenebb állapot alapján ítélni a helyes nyelvi formákról, az élő nyelvet szabad csak alapul venni. (Lásd: Pennaháborúk. Nyelvi és irodalmi viták 1781-1826. Összeállította: Szalai Anna. Szépirodalmi, Budapest, 1980)

${ }^{701}$ Fenyö, 1961. 297.
} 
azokból a levelekből is, amelyeket Kazinczy ír barátainak, elsősorban Kazinczy véleményét a helikoni eseményekröl. Ezek a vélemények a Helikonok három éves története során változtak, a teljes elutasítástól a dícséretig.

Egy alkalommal a gróf által rendezett ebéden, vagy vacsorán Festetics György kínálta az összejövetel fiatal, kedves és bájos költőnőjét Dukai Takács Juditot, Dudit, aki attól a boldogságtól, hogy dukai magányából kiszakadva ,igazi” költők között, fơúri vendéglátásban lehet része, valószínüleg az evés helyett, környezetére figyelt. A további történetet Berzsenyi így írja le Kazinczynak: „Kisasszony, úgymond Kisfaludyné, már mast nem módi ám a konyhán jóllakni, hanem itt benn kell enni. A gróf mosolygott, s kérte Dudit, hogy senki kedvéért a gyomrát el ne rontsa. Hogy ezt jól megértsd, még hozzá kell tennem, hogy Dudi a legvirgoncabb, leglelkesebb társalkodó mindazon asszonyok között, melyeket én valaha esmértem."702 Berzsenyi szavait Kazinczy, nem kis kárörömmel azonnal „világgá repítette”. Berzsenyi felháborodása Szegedy Róza minden kétséget kizáróan epés megjegyzésére érthető, ráadásul, ha figyelembe vesszük, hogy a költő feleségével rokonságban lévő Takács Judit fiatal lénye, beragyogta az idősödő Berzsenyi szívét. Nehéz ma már megfejteni, mi okozta a betegeskedő Kisfaludyné kifakadását. Elképzelhető, hogy a vallásos, istenfélő családi ház légköre, a zárdai nevelés annyira zárkózottá tette az akkor még csak negyvenkét éves, de beteges asszonyt, hogy idegesítően zavarhatta a huszonkét éves fiatal lány virgonc, kedélyes, férfiakat bámulatba ejtő lénye. ${ }^{703}$ Kisfaludyné Szegedy Róza, aki „atyafiságban” volt Festeticcsel úgy gondolhatta, rokonként többet is megengedhet magának. ${ }^{704}$

A helikoni eseményekről a Magyar $\operatorname{Kurir}^{705}$ számolt be toldalékában, de a legrészletesebb beszámolót a Tudományos Gyüjtemény közölte „egy jelen volt vendég”, azaz Kisfaludy Sándor tollából. ${ }^{706}$

A Helikon előestéjén A gimnázium nagytermében a tanulóifjúság bemutatta a „pozsonyi nevendék papság” által írt, „A nevelők” című vígjátékot. ${ }^{707}$ Kisfaludy cikkében

\footnotetext{
${ }^{702}$ Berzsenyi, 1978. p. 427. Berzsenyi Dániel Kazinczy Ferencnek, 1817. február 27.

${ }^{703}$ Kisfaludyné Szegedy Róza életéről Jakab Ferenc írt rövid, 52 oldalas, ma már mindenképpen feülvizsgálatra szoruló életrajzot. (Jakab, 1936.); Kisfaludy Sándor és Szegedy Róza életéről forrásanyag-értékü szépirodalmi müvet Darnay Kálmán írt. (Darnay Kálmán: Elkésett csók. Pantheon, h. n., é. n.) Darnay elkötelezett kutatója volt Kisfaludy Sándor munkásságának, múzeumában számos Kisfaludy relikviát gyüjtött össze. A költő életéről írt müve: Testőrszerelmek. Regényes korrajz Kisfaludy Sándor életéből. Pantheon, h. n., é. n.

${ }^{704}$ Kisfaludy Sándor felesége révén volt rokonságban Festeticcsel. Azonban tudta, hogy a Kisfaludy és Festetics családnak is régi kapcsolata van. Ugyanis Kisfaludy Sándor őse, Kisfaludy László $(+1684)$ „,keze alatt nevelődött katonává” Festetics György dédapja Festetics Pál (1639-1720), Kristóf apja. (Vö.: Kisfaludy L., 2004.)

${ }^{705}$ MK., Hazai Dolgok és egyéb Toldalék 1817.I. 19 sz. (március 17.) 144-145.

706 TGY. 1817. III. 76-85.

${ }^{707}$ Másutt a darab címe: A két nevelő. Valószínűleg Fejér György színpadi művéről van szó, amelynek eredeti címe: A nevelök. (Szinnyei III., 1894. 258.) ; A pozsonyi növendék papság (Fejér ott tanult theológiát) másutt is elöjön munkáiban: „Lantos versek, mellyekel A Hadi-Történetek által a’ Hazáról nagy Érdemet nyert Görög
} 
megjegyzi az előadás kapcsán, hogy „a’ magyar színjátszásnak ezen igen csekély zsengéjét látni, és arról meggyőződni, hogy a’ Magyar és az ő nyelve mindenre alkalmatos a’ Világon; úgy más részről fájdalmas, éles, bosszús érzemény lehet minden ott lévő hazafinak azt tudni, hogy a' Magyar Theatrom, ez a' Nemzeti 's nyelvbéli Cultúrának, csinosodásának, hazafiságnak legerősebb munkáló és emelő eszköze, ez a' gyönyörködtetve oktató, taníttó, a' gonoszat megutáltató, a' Virtust követésre ragadó Intézet Hazánkban lábra nem kaphat." ${ }^{, 708} \mathrm{~A}$ cikk természetesen nincs a legjobb véleménnyel sem a müről, sem az előadásról, de alkalma nyílik megemlíteni a magyar nyelvü színjátszás szükségszerüségét. Ez különösen érzékenyen érintette Kisfaludyt, s nem véletlen, hogy a balatonfüredi magyar színház alapításának gondolata is tőle származik. ${ }^{709}$ A keszthelyi előadásban elhangzott az „Isten tartsd meg királyunkat!" címü ének, amelyet minden tudósítás is közölt. Este a premontreiek zárdáját a nagy ünnepre való tekintettel kivilágították.

Február 12-én reggel a királyért ünnepi szentmisét celebrált Ruszek József apátplébános, ahol Festetics György és vendégei, a tanulók és a helybéli lakosok is megjelentek. Ezt követően vonult a közönség a Georgikon épületébe, ahol a keszthelyi iskolák tantestülete és a diákok ünnepélyesen fogadták a grófot és a vendégeket. Ebben az épületben (és valószínüleg legnagyob termében) zajlottak a tulajdonképpeni felolvasások. „A Helikon épülete theatrum-forma. - tudjuk meg Berzsenyi Kazinczynak küldött leveléből - Az emelet közepén áll az asztal és szék, melyen a munkák olvastatnak s declamáltatnak, körülötte pedig mindennémű muzsikusok, akik minden olvasásra harsognak. A kárpitot borostyánkoszorú övezi. A nézők előtt ismét egy asztal, melyre a béküldött írások rakatnak". ${ }^{710}$ Tehát a Helikonon részt vettek a Zeneiskola diákjai is, minden bizonnyal tanáruk, Stärk Péter vezetésével. A beküldött írások azokra a munkákra is vonatkoznak,

Demeter Úrnak Neve Napjára áldoz a' Pozsoni Nevendékség. Saffo' rende szerint." Pedig itt is eredeti Fejér György müröl van szó. (Fejér, 1994. 25.)

${ }^{708}$ TGy. 1817. III.

${ }^{709}$ Felépült 1836-ra, oszlopait gróf Festetics László adományozta az építtetőknek. Mára csupán az oszlopok, s az épület frízének egy része maradt meg. Ez látható ma Balatonfüreden. A színház több festő, grafikus megrajzolta (Raimann Rudolf ?-?, Zombory Gusztáv 1835-1872), de legismertebb Libay Károly Lajos (1816-1888) körajza. ; Az oszlopok történetéröl Rédey Tivadar a következőket írja: „Kevéssel a háború előtt (I. világháború Cs. G.) a lebontott tóparti Kisfaludy-vendéglő falai tövéből kiásták a Festetics-féle szép és nemes oszlopok néhány darabját. Azután abbamaradt a keresés, pedig föltehető, hogy a többi is napvilágra kerül még. (...) Ha meglesz a füredi játékszín minden oszlopa, emeljünk belölök a szép balatonfüredi park valamely alkalmas pontján kupolás, klasszikus stílusú kis gloriettet..." (Rédey,1921. 109) ; 1935-ben megtalálták a többi oszlopot is. Többszöri áthelyezést követően 1958-ban került mai helyére a Kiserdőbe. (Tóth-Bence, 2011. 102, 106, 110, 124.)

${ }^{710}$ Berzsenyi Dániel Kazinczy Ferencnek, 1817. február 27. ; Berzsenyi, 1978. 426. 
amelyeknek szerzői nem jelentek meg az ünnepségen. Kazinczy Dessewffy grófnak írt levelében is leírja, hogy „Gr. Festetics György egy Helikon nevü kerek Palotát építete”. 711

A rendezvényt Liebbald Gyula ${ }^{712}$ georgikoni archon, professzor ékes (Kisfaludy szerint cicerói magaslatokba emelkedett) latin nyelvü beszéde nyitotta meg. Ebben az igazgató részletesen kifejtette a Helikon célját, programját a király születésnapjához való kapcsolódását. „Beszédjének tárgya olly jeles, szempontjai, oly igazak és nyomósak, magyarázattyai oly valóságos feselő virágok voltanak, hogy a’ még csak támadni vélt Helikon az ő támadásának szép és nagy okaival együtt csakhamar egész szépében, és reményekkel biztató virittásában állott előttünk.” - lelkendezett cikkében a ,jelenvolt” Kisfaludy. ${ }^{713}$

Öt Jánossy József ${ }^{714}$ matematika professzor követte, aki a király tiszteletére mondott latin nyelvü beszédet az uralkodó „ritka erköltseiről, 's ditsőséges tetteiről, és az alattvalóknak eránta való kötelességeiröl", 715

Ezt követően a diákok léptek fel az emelvényre és mondták el részben versben, másrészt prózában megírt munkáikat. Elsőként Konyáry Mihály a pristaldeum ösztöndíjasa lépett az emelvényre és magyar nyelven verset mondott „Felséges királyunk Születése napjának megtiszteltetése" ${ }^{\text {716 }}$ címmel. A poéta és a múzsa szólal meg ebben a szépen formált versben, amint Kisfaludy Sándor írja már idézett írásában, ${ }^{717}$ megmutatkozik, hogy a magyar nyelv mennyire alkalmas a görög versmértékre. Azonban kritikája végén nem mulasztja el, hogy nyelvújítási álláspontját ne bökné oda a szerzőnek: „Szépet reményelhetünk Tőle, kivált ha némelly még polgárságot nem nyertt új szavakkal nagyobb válogatással és mértékletességgel él”. A vers tartalma természetesen nem tér el a szokásos dicsőítő versektől. Van benne „Párduczos Árpád”, „Héroszi dicső Császár”, „virtusos élet”, „nagy Diadal, Érdem”. Befejezésként a császár halál utáni életéről gondolkodik, nem kis pátosszal adva a Múzsa szájába a következőket: „Hogy később, majd ha elalszik / Ott, akkor köz’ttünk éllyen

\footnotetext{
${ }^{711}$ Kazinczy Ferenc Dessewffy Józsefnek, 1817. március 16.; KazLev. XV. 117.. ; A Helikonra építtetett kerek palotára való hivatkozás véleményünk szerint túlzó megállapításnak tủnik.

${ }_{712}$ Liebbald Gyula Tamás $(+1846)$ orvos és bölcsészdoktor, a tudományos akadémiának tagja. Liebbald mint prosector, állatorvos és tanárhelyettes 1806 október hóban jött a Georgikonba, de már két évre rá a természettan és állatgyógyászat rendes tanára, a lovásziskola inspektora és ugyanott a lóisme elöadója volt. Tizennyolc évi tanároskodása alatt kilenc éven át volt archon. (Csanády, 1897. 33.)

${ }^{713}$ TGy. 1817. III.

${ }^{714}$ Jánossy József Alajos (?-?) bölcsésztudor, 1812. november 1-jétől tizenkét éven át a mennyiségtan, épitészet, számvitel és ajz tanára volt. Georgikoni mérnök. 1813 és 1815 között archon. Egyidejüleg a lyceumban is tanított, 1824-ben, minta annak igazgatója. (Csanády, 1897. 30)

${ }_{715}^{715}$ Magyar Kurír 1817. I. 19 sz. (március 17.) 144

${ }^{716}$ Helikon I. 44-49.

${ }^{717}$ TGy. 1817. III.
} 
mint Isten örökké.” A verset a Poéta kurta kérdéssel fejezi be: „Igy hát én Múzám! Mit tudgyak Néki kivánni?"

A következő diák Németh Péter volt, ,„phisikus”, aki latin nyelven mondta el a király tiszteletére megfogalmazott versét. A vers úgy tünik nem nyerhette meg a hallgatóság tetszését, mert az ünnepségről szóló írások nem szólnak róla részletesebben, s a „,Helikon I.” kötetbe sem került beválogatásra. Ezt követően a „két árva” közül gróf Festetics Ernő szavalt „Egy Attya’ halálát kesergő Fiúnak Elégiája”-t. Kisfaludy is megjegyzi, hogy az ifjú gróf verse annál inkább meghatotta a hallgatóságot, mert „csak a’ múltt esztendőkben vesztette el ő is itt az egész vidéken becsültt édes attyát, és annyát”. ${ }^{718}$

Tischler Antal „logikus” latin nyelven tartotta meg a királyt üdvözlő beszédjét. Gertinger Adolf georgikoni praktikáns hasonló tartalmú német versét olvasta fel. Vadnay Lajos gimnáziumi tanuló latin verse, melyet Kisfaludy szerint, „különös bátorsággal” adott elő szintén a királyt dicsérte.

A másik ,árva”, gróf Festetics Leó szintén az uralkodót dicsőítő saját német nyelvü verseket adott elő. Ezt követően hallhatta a közönség szintén az ifjú gróf előadásában Theodor Körner ${ }^{719}$ Hoch lebe Österreich címü hadi éneket. Kisfaludy a Tudományos Gyüjteményben megjelent, már említett tudósításában ${ }^{720}$ nem felejti el megjegyezni az előadásról és Körnerről a következőket: „,...az ifjú Gróf által olly tüzzel declamálva (ti.: Körner verse), valamint az a' szerzőnek tűzlelke, és hazafisága általérezve és gondolva vala. Ezen declamatio azon okból is nagyobb részvételre bírta, és mondhattyuk, ragadta a' hallgatókat, mint hogy az a' boldogúltt Körnernek, ezen szintén olly lelkes Poétának mint bajnoknak, az egész világ előtt esméretes hazafiúi vitéz halálára emlékeztetett bennünket. ${ }^{721}$ Körner nagy tisztelője volt a' Magyaroknak; bizonysága ennek Zrínyi Drámája; 's ha a' kora halál őtet el nem ragadgya vala, tehát a' Magyarnak még több oka lett volna őtet barátságával, és szeretetével ölelni:

\footnotetext{
${ }^{718}$ TGy. 1817. III.

719 Theodor Körner (Drezda, 1791. szepember 23. - Gade busch, Mecklenburg, 1813. augusztus 13.), német költő, drámaíró. Apja magas rangú bíró volt, akinek vendégszerető házában a kor számos ismert irodalmi és zenei kiválósága megfordult, s aki szoros barátságot tartott fenn Schillerrel. Bányászatot, jogot, történelmet, irodalomtörténetet, filozófiát tanult Freibergben, Lipcsében és Berlinben. W. v. Humboldttal, F. Schegellel és Eichendorffal barátkozott, császári színpadi költőnek nevezték ki. 1813-ban önkéntes Lützow ezredes szabadcsapatában. Németország egységéért, Napóleon ellen harcolt. Hazája szabadságáért esett el a gadebuschi csatában. Verseit apja 1814-ben adatta ki Leier und Schwer (Lant és kard) címmel. Gondolati töltés híjával lévő, művészileg is kiforratlan, bár ügyesen megírt vígjátékai és tragédiái közül megemlítendő a Zrinyi, amely a szigetvári hős halálát viszi színpadra, hatásos csatajelenetekben, poetikus monológokkal, heroikus, csillogó romantikával. (Bródy Miklós = VIL. 6., 1997. 585.)

${ }^{720}$ TGy. 1817. III.

721 Festetics Leó (1800-1884) ifjúkorban már tapasztalható volt a színészettel, a színházzal való kezdeti elkötelezettség. Nem véletlen tehát, hogy a helikoni versmondók közül egyedül az ő produkciója érdemelt kitüntetett elismerést. Amint már jeleztük, Festetics Leó később a Nemzeti Színház, majd a Színitanoda igazgatója lett.
} 
mert ő néki az volt a' feltétele, hogy minden Dramájinak tárgyát, és vitézeit a' magyar históriából vegye. Kisfaludy Sándor már kezdett is néki Programmákat ezen czélra dolgozgatni, noha csak a’ hazafiú Gróf Eszterházy Mihály által, de személyesen még nem esmerték egymást. Az 1813-ki háború és Körnernek ebben történtt halála semmivé tette ezt a' szép reményekkel biztató feltételt”.

Festetics Leó után Nagy József ${ }^{722}$ „Directionalis Cancellista és georgikoni praktikáns” lépett az emelvényre és elkezdte magyar nyelvű ünnepi beszédjét: Nagy méltóságú gróf, császári és királyi kamarás és valóságos belső titkos tanácsos úr, kegyelmes urunk! S minden renden lévő nagy fényességű gyülekezet! A megszólítást követően elmondta, mily nagy nap ez, az uralkodó születésnapja, amikor minden magyar hazafiúi, buzgó elragadtatást érez. A közhelyektől hemzsegő beszédnek egyetlen helyi vonatkozása volt, hacsak érintőlegesen is: „Engedje a’ Nagy Isten az egész Fejedelmi Ház’ nagy lelkü Tagjának, mint a’ Mezei Gazdaság' előmozdítani törekedő buzgó Mentorinak számtalanboldog napokat tölteni”. ${ }^{723}$

A versek és felolvasások között olykor megszólaltak a zeneiskola diákjai is, magyar és német nyelven énekeltek. A magyar nyelvü daloknak Ruszek József, a németeknek Asbóth János volt a szerzőjük. A magyar nyelvű ének egyikét a „Helikon I.” kötet is közli, szerző megjelölése nélkül. Valószínűleg Ruszek az írója, Stärk a zeneszerzője, címe pedig: „,Helikon örvendezö éneke. Muzsikára téve a' Kar által énekeltetett Februárius 12-kén 1817."724 Az ének mindenkinek megparancsolja, hogy örüljön a császár születésnapján, s aki nem ezt teszi azt megfenyegeti: „Ki ma nem vigad jaj, jaj, jaj, jaj, / Ki ma nem vigad jaj annak.-,, A bárgyú szöveget mennyiben „erősítette” a dallam, ma már nem állapítható meg.

A tanulók után a „felnőttek” következtek. Festetics György maga kérte fel Dukai Takács Juditot, hogy szavalja el versét, aki azt meg is tette. A hosszú költemény, „Örvendező versek, Felséges I-sö Ferencz' Ausztriai Császár' 's fel kent Magyar Koronás Királyunk'

\footnotetext{
${ }^{722}$ A fellépő diákok pár adata. Konyáry Mihály: 1796-ban született a Szabolcs megyei Acsádon. 1816-ban iratkozott be a Georgikonba. (Csanády, 1897. 61.); Nevét a Magyar Kurir 1817. I. március 17.-i és a Pester Zeitung 1817. február 27.-i számában helytelenül Komjáthynak írják. Németh Péter: 1797-ben született Zala megyében, Pacsán. 1817-nem iratkozott be a Georgikonba. (Csanády, 1897. 69.) gróf Festetics Ernö: 18001857. Az árvák egyike. Édesapja 1815-ben halt meg. Szülei halála után gróf Festetics György lett a gyámja. 1817-ben iratkozott be a Georgikonba. Tischler Antal: (másutt Ignácz) 1798-ban született Tatán, Komárom megyében. 1817-ben irtakozott be a Georgikonba. (Csanády, 1897. 79.) Gertinger Adolf: 1799-ben született a Sáros megyei Eperjesen. A Georgikonba 1815-ben iratkozott be. (Csanády, 1897. 53.) Vadnay Lajos: valószínüleg Vadnay Károly hírlapíró, szerkesztő apja, liberális politikus, Miskolc képviselője, ítélőszéki bíró, irodalombarát. Vadnay Lajos édesapja Festetics György jogügyi igazgatója volt. (Szinnyei XIV. 731-732.) gróf Festetics Leó: Pécs, 1800 - Budapest, 1884. Az árvák egyike. Szülei halála után gróf Festetics György lett a gyámja. 1817-ben iratkozott be a Georgikonba. 1850-52-ben a Nemzeti Színház igazgatója, 1886-tól a Színitanoda igazgatója. (ÚMÉL II., 2001. 667.) Nagy József: 1796-ban született a Bihar megyei Patsain. 1815ben iratkozott be a Georgikonba. (Csanády, 1897. 68.)

${ }^{723}$ Helikon I., 1818. 88.

${ }^{724}$ Helikon I., 1818. 90-91.
} 
születése' Napjára" címet viselte s ha tartalmában nem is, de formáját tekintve mindenképpen kiemelkedett az eddig elhangzottak közül. Nemcsak az uralkodót dícsérte, de az elmúlt időszak történéseit is felvillantja a hosszú vers:

A' Francz' békétlen lelke, 's dőlfös vádgya

Vélte, hogy egy világ retteg hatalmától,

A’ Magyarnak végső romlására vágya

Meg fosztni a' Nemest szép szabadságától

'S ősi Törvénnyétől.

Csalóka szin alatt mellye boszszút fedett,

Hangoztatta, hogy ő majd Rákosra megyen,

Ott oszt igazságot minden Népek felett,

Óh nem azért! Hanem hogy rab igát tegyen

Nemzetem te reád. ${ }^{725}$

Nem csoda hát, hogy a korabeli tudósító arról számolt be, a költőnő nagy tapsot kapott. Ez elsősorban bájos személyének szólhatott. Dukai Takács Juditot Asbóth János követte, aki a tragikusan, fiatalon elhunyt Zichy Károlyné ${ }^{726}$ haláláról írt magyar nyelvü versét olvasta fel „Keszthelynek keservei. Néhai Nagy Méltóságú Gróf Zichy Károlyné született Tolnai Grófné Festeits Juliánna' halálán” címmel. ${ }^{727}$ A vers nem kimondottan a Helikonra készült, már egyszer elmondták, a grófné temetésén 1816. december 12-én. Érdemes megemlíteni, hogy a Magyar Kurir 1817. március 17-i és a Pester Zeitung 1817. február 27-i száma tévesen a vers írójának és elmondójának Horváth Ádámot jelöli meg. Minden bizonnyal ugyanabból a rossz forrásból dolgoztak. Az ünnepélyen Festetics felkérte Horváth Ádámot is, hogy egyik művét adja elő, de ő betegségére hivatkozva csak székében ülve mondott pár részletet eklogájából „A' földmívelö Varró”-ból. ${ }^{728}$ Maga a rendkívül hosszú vers, „pásztori beszélgetés” komplikált mitológiai elemekből építkező, eléggé zavaros színpadi dialógusok sora, így elképzelhető, hogy a közönség csak nyert Horváth gyengélkedése miatt.

\footnotetext{
${ }^{725}$ Helikon I., 1818. 53-58.

${ }^{726}$ Gróf Zichy Károlyné, Festetics Julianna Keszthelyen született 1789. november 6-án. Festetics György leánya volt, aki 1816. november 18-án, Bécsben, 27 éve korában halt meg.

${ }^{727}$ Helikon I., 1818. 119-120.

${ }^{728}$ Helikon I., 1818. 1-33.
} 
Ezután „némely távollévők munkái olvastattak fel”. Horváth Ádám szerint ezt a munkát Ruszek József apát vállalta magára. ${ }^{729}$ Az 1818-ban megjelent „Helikon I.” kötetből tudhatjuk meg, kik voltak azok, kiknek magyar nyelvű munkái felolvasást nyertek:

Kazinczy Klára: Göcseji Nimfa,

Matskási József: Mennyegzöi Dal, Felséges Urunknak Carolina Augusta

Bavariai Herczegnével lett egybekelésére,

Szigethi Péter: Idvezlő versek Ő Felségének Mennyegzőjére,

Kiss Bálint: E napnak hármas öröme,

Horváth Ádám: Uránia. ${ }^{730}$

Kazinczy Klára, Horváth Ádám gyámleányának, későbbi feleségének fénye legjobban a keszthelyi Helikoni Ünnepségeken világított - írja Péterffy Ida. ${ }^{731}$ A Tudományos Gyüjtemény és a Hasznos Mulatságok is kiemelték írásaikban egyrészt Kaziczy Klára, másrészt Dukai Takács Judit tálentumát. ${ }^{732}$ A Göcseji Nimfa című vers könnyed köszöntése a Helikonnak, a vendégeknek és a mecénásnak. Keszthelyen, hol „ma Helikont építenek” mindenki boldog és éljenzésre hivatott. ${ }^{733}$ Kisfaludy Sándor elhozta az ünnepre „Óda Tolnai Gróf Festetics Györgyhez” címü hosszú, huszonnyolc versszakos munkáját. Az ódát Festetics nem engedte felolvasni, s a „Helikon I.” kötetbe sem kerültbe, mert „,a grófot igen dicsérte, a többi nagyjainkat pedig igen alázta” - tudjuk meg Berzsenyi Kazinczynak írt leveléből. ${ }^{734}$ Kazinczy, mint minden értesülést, így a helikonit is megírja barátainak. Így ő is értesültek Kisfaludy ódájának történetéről. Aztán Dessewffynek megjegyezte, hogy Berzsenyi nem vitt verset - ezt tettem volna én is - írta, és a végén megerősítette: „Olympiában Herodot is olvasta Munkájit. De én Keszthelyen nem fognék. Horátz is irtózott ettől, hihető, mert a' Római hallgatók ollyanok voltak mint a' Keszthelyiek, nem mint az Olympiaiak". ${ }^{355}$ Ami az igazsághoz tartozik az, hogy Berzsenyi valóban nem hozott, így fel sem olvasott verset, de utólag elküldte Festeticsnek a „Hymnus Keszthely Isteneihez” művét, amit majd a második Helikonon, 1817 májusában olvasnak fel - sajnos Berzsenyi távollétében. Kazinczy nagyon

\footnotetext{
${ }^{729}$ Horváth Ádám Kazinczy Ferencnek, 1817. március 2. ; KazLev. XV. 97.

${ }^{730}$ Kazinczy Klára, Matskási József, Szigethi Péter csurgói professzor, Kiss Bálint „Csurgói négy hónapos Poéta Deák" és Horváth Ádám verse eltérő poétai tehetséget mutatnak, de arra mindegyik megfelelőnek bizonyult, hogy nyomtatásban megjelenjen. (Helikon I., 1818.)

${ }^{731}$ Péterffy, 1973. 125..

732 TGy., 1818. VII. p. 133 ; Haszn. Mul., 1818. 47. sz. p. 375

${ }^{733}$ Helikon I., 1919. 38-39.

${ }^{734}$ Berzsenyi Dániel Kazinczy Ferencnek, Mikla, 1817. február 27. ; Berzsenyi, 1978. 426.

${ }^{735}$ Kazinczy Ferenc Dessewffy Józsefnek, 1817. március 16. ; KazLev. XV. 117-118.
} 
magasra értékelte Berzsenyi ezen munkáját, ezt meg is írta Niklára, egyben válaszolva a költő levelére is: „Hat napi vajúdás után Múzád nem azt a’ Chimaerát szülte, mellynek feje Schiller, közepe Berzsenyi, hátulja Horátz, hanem olly nagy tüzű Ódát, a' mellyet csak tőled halla még a’ Haza. Melly erő! Melly képek! Melly nyelv!",736 Szentmiklóssy Alajos is dícséri az ódát: „,...Te uj nimbuszokkal növelted dicsőségedet. Olvastam Keszthely Isteneihez írtódádat, s ez nyilván bizonyítja, hogy költői ered még mindig igen bő folyamattal bír."737 Csak megjegyezni kívánjuk, hogy Festetics véleménye Berzsenyi ódájáról nem ismeretes, de bizonyára nagyon tetszett. Ezt bizonyítja a Berzsenyinek odaítélt többszöri jutalom, valamint a későbbi, versírásra történő felkérések is (Felséges Királyunknak Keszthelye váratásakor, 1817, Felírás. A' királynak Keszthelyre váratására).

Négyesy rámutat, hogy Kisfaludy Festeticsnek írt ódájában a nála ritkán alkalmazott klasszikus versalakot használta, az alkaius strófát de pátosza inkább szónoki, mint költői érzés, s a költemény nagy része inkább okoskodás a XVIII. századi felvilágosodás és az 1790es évek magyar társadalmi és politikai irodalma szellemében. ${ }^{738}$ Érdemes azonban mind e vádakat, illetve megállapításokat jobban szemügyre venni. Kisfaludy Ódájá-nak első negyedében arról ír, hogy minden ember sorsát, életét származása határozza meg - elméjétől, tisztességétől, tudásától függetlenül - azaz, hogy szalmafedél alatt, vagy tornyos kastélyban látta-e meg a napvilágot. A szembekötött hamis szerencse játszik mindenkivel.

Ott egy szegény Pár, rongy atya, rongy anya,

Egy gyermeket szül szalmafedél alatt;

Az elme és szív benne szép 's nagy;

Más születés, nevelés mi ritka

Felséges embert, nagy hazafit, jeles

Vitézt teendő volna belőle; de

Pór sorsa őtet porba nyomván, Él, szaporitt, 's kihal a' baromként. -

Ott a' hegyen keltt, 's tornyaival kevély,

'S a' merre a' szem lát, maga birtokát

\footnotetext{
${ }^{736}$ Kazinczy Ferenc Berzsenyi Dánielnek, 1817. március 23. ; KazLev. XV. 135.

${ }^{737}$ MTA M. Irod. Lev. 4-r 120. Idézi: Berzsenyi ÖM., 1979. 787.

${ }^{738}$ Négyesy, 1925. 179.
} 
Látó, ezer jobbágy uraltta

Vár is az új uri rajnak örvend.

Az Urfi, ámbár emberi érdeme

Silány is, Úr lesz; éspedig ollyan Úr,

Ki kénnyeként majd sorsot oszt: mert

Bár esze nincs, van arannya, módgya.

Kisfaludy versének egészéből nem annyira a megvetés, mint inkább az állapotokkal való egyet nem értés kritikai megfogalmazása olvasható ki. Arról ír, hogy vannak akik tenni tudnának, de nincs erre lehetőségük és vannak olyanok, kik tehetnének, van erre módjuk, de nem tesznek semmit. Az óda valóban kritikával illeti azokat az arisztokratákat, kik a haza szeretete helyett az önszeretetet helyezik elötérbe. Ezt követően még inkább felértékelödik a versben Festetics dicsérete:

Sok gazdag embert, dúzs Urat esmerek

Én itt közöttünk a' magyar ég alatt,

A' kit megáldott a' szerencse

Sok Fejedelmi javakkal. Ám de

Ezek közül hány érdemelé meg e'

Bangó szerentsét! - Fáj! Mikor illy bitang,

Söt átok a' föld' kincse sok száz

Emberi, nemzeti jót nem érző

Duzmadtt Kevélynek vesztegető keze

Köztt. Átkozott légy önszeretet! te vagy,

Valál, 's leszel minden gonosznak

Kútfeje a' nap alatt örökké. -

Kiválsz Te a' megvesztegetett Sereg

Közül, Hazámnak nagy Fija Festetics!

Kivál utánnad - csak kevés még; 
Ám de csak a’ Te neved világitt. ${ }^{739}$

Festetics úgy gondolhatta, hogy Kisfaludy túloz, bár költeménye nem sokban ütött el a kor alkalmi verseitől. A gróf kényelmetlennek érezte volna, ha jelenlétében hangzik el a mü. Óvatos maradt, mert tudta, hogy a Helikoni események híre bejárja az országot, őmaga nem akart semmiféle konfliktust élezni arisztokrata társaival. Tehát nem engedte felolvasni a verset a Helikonon, amely később a Tudományos Gyüjteményben jelent meg. A megjelenést követően kortársai keményen kritizálták a müvet: a ráspoly, a mügond ne látszik, sok a pongyola szólás és technikai hanyagság - vélekedett Batsányi. ${ }^{740}$ Bár ebben a költeményben is „lélek van”, mégsem hasonlítható Berzsenyi verseihez. Valóban, Berzsenyi írta a legtöbb és legszebb verset - minden kényszeredettség nélkül - Festetics György grófhoz.

A beküldött versek közül sem mindegyik került felolvasásra. Ezek közül sajnos csak a magyar nyelvü művek maradtak fenn, éppen a már többször említett „,Helikon I. ” kötetben, a német és latin nyelvüek nem. A magyar nyelven írt müvek, melyek nem kerültek felolvasásra, a következők voltak:

Bárány Boldizsár Kis Gombáról hozta $\mathrm{s}$ mutatta be versét, „A Helikon Innepe” címmel. A vers első részében Ferenc császár győzelméről írt, majd Festetics és a Helikon dicséretéről. A versben Széchényit is megemlíti, egyenrangú félként Festeticcsel:

Most is Festeticsek 's Széchéniek viszik

A’ lángban haladó Nap' szekerét egünk'

Térén; a' jelesebb pálya futónak ád

Pálmát Festetics, a’ Magyar.

Ö lett a' mi időnk' kincse, Pericleszünk,

A’ Nemzet nevelö, a' köz ügy' oszlopa,

Ö a’ szörnyet üző harczok után az $U^{\prime} j$

Század' ritka nagy embere. ${ }^{741}$

A versben Festetics Ceresnek remek templomot épített (Georgikon), Themis is iskolát kapott (pristaldeum), Flaccus lantja pedig magyar fogást (Helikon). Az Olympias megnyílik,

\footnotetext{
${ }^{739}$ A verset közli: Berzsenyi ÖM, 1979. 792-795.

${ }^{740}$ Négyesy, 1925. 182.

${ }^{741}$ Helikon I., 1818. 40-43.
} 
megjönnek a pindari nagy napok, új fény lepi be a Balaton körét, lelkes grófja varázsvesszeje szétűzi az utolsó fellegeket, ,s így nyer e Helikon hazát”. ${ }^{4}$

Szilágyi József georgikoni külső praktikáns „Hálaadó éneke a magyaroknak Ő Felségéhez” címmel adott be verset. Az önképzőköri színvonalú vers az uralkodót, mint a nemzet reménységét emlegeti szokványos, más diák-költők verseihez hasonlóan. ${ }^{743}$

Döbrentey László georgikoni praktikáns verse „A' békeség 's helyre-állitójának Dicsérete”. A békesség helyreállítója természetesen nem más, mint a magyar király, aki békét és nyugodalmat hozott népének, a parasztnak, a tudós világnak, így érdemeiben él örökké. 744

Papp József Zalaszántóról hozott verset „Örömének Királyunk születése napjára” címmel. A zalaszántói káplán verse sem emelkedik ki az alkalmi alkotások közül, gyengécske alkotás. Csak reménykedhetünk, hogy nem váltotta be a vers befejező sorait:

Én is tehát kézbe veszem

Szegén függő lantomat,

Addig többé le sem teszem

Míglen kivánságomat

Bé nem töltöm, 's nem éneklem

Együgyü vig nótámat,

Királyomnak nem szentelem

Hívségemet, 's magamat. ${ }^{745}$

Németh Antal a „Philosophiának halgatója” „A' jámborság becse” versét küldte be a Helikonra. A vers önképzőköri szintű, a jámborság dicsérete, aki a jámborság kincseivel él, nem irigy, s a jószívüség minden kincsnél többet ér. ${ }^{746}$

Nagy Ignác ${ }^{747}$ georgikoni praktikáns „,Keszthely "748 című versével szerepelt a Helikonon. A keszthelyi születésű fiatalember leíró verse párrímes alexandrinokban olyan -

\footnotetext{
${ }^{742}$ Helikon I., 1818. 40-43.

${ }^{743}$ Helikon I., 1818. 71-74.

${ }^{744}$ Helikon I., 1818. 75-78.

${ }^{745}$ Helikon I., 1818. 79-81.

${ }^{746}$ Helikon I., 1818. 121-123.

747 A szerzők adatai. Bárány Boldizsár ügyvéd, a Somogy megyei Gombán született, Több színművet írt és fordított. Szilágyi József: 1795-ben született Pápán. 1816-tól a Georgikon hallgatója. (Csiky, 1897. 77.) Döbrentey László: 1791-ben született a Vas megyei Hőgyészen. 1815-.től hallgatója a Georgikonnak. (Csiky, 1897. 50.) Nagy Ignác: 1796-ban született Keszthelyen. 1815-től a Georgikon hallgatója. (Csiky, 1897. 68.) Nagy Ignác georgikoni hallgató nem tévesztendő össze az ugyancsak Keszthelyen született Nagy Ignáccal (1810-1854), a modern, magyar újságírás megteremtőjével, a „,Tisztújítás” színpadi mű szerzőjével.
} 
írja Négyesy -, mint egy Gvadányi tanítványé, nem éppen költői, de nem is nagyon száraz, nincs elmésségek és ügyes kifejezések híján. ${ }^{749}$ Ami számunkra érdekes, az inkább helytörténeti vonatkozása a versnek, amelyben a város szinte minden nevezetességét leírja természetesen azért, mert mindez a Festetics család mecénási magatartását hivatott alátámasztani. Elvitathatatlan, hogy a település városias arculatát és az ezzel járó intézményeket valójában a Festeticseknek köszönheti. Leírja Keszthely környékét, a mezőket, a szarvasokkal, őzekkel és madarakkal teli erdőket. Megemlíti Keszthely környékének szőlőhegyeit, apró településeit: Vonyarcz, Diás, Gyenes, Cserszeg Palotával. ${ }^{750}$ Megjeleníti az állattartással foglalkozó földművest. Szól Hévízről, a tavat a Balatonnal összekötő csatornákról, amelyeknek soha be nem fagyó vize abban az időben számos malmot hajtott és szól az egykori római erődről, a mai Fenékpusztáról ${ }^{751}$ :

Napnyúgotról híres hév viznek fördeje,

Sok betegségben gyógyító ereje,

Híres rajta forgó malmoknak kereke,

A’ molnárnak hasznos sok lisztes pitlije.

Hallottad e' hirét erős Fenék-várnak,

Hogy leomlott fala azt tartjuk nagy kárnak...

Nagy Ignác is tengernek, méghozzá a magyarok tengerének nevezi a Balatont, amelyben számos hal él, megélhetést nyújtva a környék halászainak. A környék leírása után a szerző Keszthelyre invitálja a nézőt, akár egy korabeli útleírásban. Elsőként a grófi kastélyt és a könyvtárat említi, majd a Festeticsek által alapított patikát. ${ }^{752}$ A továbbiakban sorba vesz minden érdekességet.

Lassanként ballagj már Keszthelynek, halmára,

Tekénts Méltóságos Grófunk’ Kastéljára,

Hozzá ragasztott Bibliothékára,

\footnotetext{
${ }^{748}$ Helikon I., 1818. 115-118.

${ }^{749}$ Négyesy, 1925. 201.

${ }^{750}$ Vonyarcz = ma Vonyarcvashegy, Gyenes és Diás = ma Gyenesdiás, Cserszeg Palotával = ma Cserszegtomaj része.

${ }^{751}$ A Keszthelytől 6 kilométerre fekvő Fenékpusztát előbb a római Mogentianeval, majd később Valcummal azonosították. A mai régészeti leletek alapján megállapították, hogy a két római település egyike sem azonos a mai Fenékpusztával.

${ }^{752}$ A keszthelyi gyógyszertár valószínűleg szerzetesi alapítású volt, s a nagykanizsai után a második patika Zala megyében. 1748-ban alapították, 1790-től uradalmi tulajdonú volt. (Blázy, 1974.)
} 
'S általa állított szép Apothékára.

Ezek után nézd meg Uradalom’ kertét,

A' hol Pomona ráz kosárba cseresnyét,

Flóra Nimfáival kötözi Szegfüvét,

Méltóságos Grófnak hogy keressék kedvét.

Díszeskedik Város szép épületekkel,

Ceresnek, Mózáknak Szentelt lakhelyekkel,

Háborúkban forgott bátor vitézekkel,

Boltos Kalmárokkal, kézi-mívesekkel.

Bőlcs Minerva benne rendelte lakását,

A’ Tudományoknak megnyitá forrását,

Tanulók’ fejére árasztja folyását,

Benn' helyeztetvén sokféle tanítását.

Deák tanulásra vezet Gymnasium,

Bölcsességnek útját mutatja Lyceum,

Gazdaságra oktat hires Georgicum,

Kisdedet tanítja nemzeti Studium.

Sólon magyarázza Törvények’ folyását,

Aeteon vezeti vadaknak fogását,

Apolló itt hagyá tanító hárfássát,

Kiki tanulhatja házok’ rajzolását.

S mindez Györgynek és Lászlónak köszönhető, akik „Magyar Országunknak most fő Oszlopai”. S a végén Nagy Ignác azt kéri, hirdessék, dicsérjék a két Festetics munkáját.

Dukai Takács Judit több verset hozott magával. A felolvasotton kívül a költőnő még két verssel kedveskedett a Helikonnak: „Epistola, Nagy Méltóságu Tolnai Gróf Festetics Györgyhez” és „A Halál hatalma. Nagy Méltóságú Vásonkői Ifjabb Gróf Zichy Károly Hites Társának Született Tolnai Grófné Festetics Juliánna árnyékához”. Mindkét vers megjelent a „Helikon I.” kötetben, s mindkettőnek mottója Berzsenyitől származik. ${ }^{753}$ A Festeticset laudáló mű befejező három sora mintegy összefoglalója a költőnő mondanivalójának. Rövid, sallangmentes, lényegretörő és éppen ezért hangsúlyos sorok:

${ }^{753}$ Helikon I.,1818. 92-97., 111-114. 
Hazánk boldogullyon!

Keszthelyi Helikonnak virágozzék’

Festetitsünk éljen!!

A fiatalon, huszonhét évesen meghalt és hat gyermeket maga után hagyó Zichy Károlyné emlékezetét már Asbóth megénelte, s most hosszabb versben Dukai Takács Judit teszi meg ugyanezt. A versben a szokásos fordulatokon túl természetesen túlzásokat is találhatunk, miszerint Festetics Julianna halálán még „koronás királyunk is könnyekre olvada". A vers lábjegyzetében Dukai Takács Judit megerősíti a király látványos bánatát: „Igen bizonyos hír volt, hogy midőn az udvarhoz ért a szomorú hír, Ö felsége könnyezve mondott nyugalmat a grófné hamvaira". ${ }^{754}$

Itt kell megjegyeznünk, hogy bizonyíthatóan olyanok is küldtek verseket, akik valamely oknál fogva nem akarták inkognitójukat felfedni. A Directorátus dokumentumai között a következő bejegyzés olvasható: „Egy nevezetlen a’ Helikonra verseket küld Szombathelyröl"' 755

A felolvasások után Festetics György 4500 forintot osztott ki, 2000 forintot a magyar invalidus katonák részére, 2000 forintot a háziszegényeknek és 500 forintot azon georgikoni és gimnáziumi tanulók részére, akik aktívan vettek részt a délelőtt folyamán zajló ünnepélyben és verssel, prózával készültek a Helikonra. ${ }^{756} \mathrm{Az}$ ünnepség legvégén elénekelték magyarul az Isten tartsd meg Királyunkat kezdetü dalt. ${ }^{757}$

Az ebéd a grófi kastélyban volt. Valószínüleg itt történt meg Szegedy Róza és Dukai Takács Judit közötti affér. Nincs meg az ebéd menüje, de tudjuk, hogy a desszert a Helikoni torta volt. A Helikon hegyét idéző cukrászremeken még a csörgedező Hippocrene is helyet kapott. ${ }^{758} \mathrm{Az}$ uralkodóért emelték poharaikat a vendégek ,és az örvendező hangoktól zengett a palota" - írta Kisfaludy tudósításában.

Az ebédet követően a vendégek a Georgikoni Fás Kertbe mentek, ahol a zöld növényzet között egy „,amphitheatrum-forma” domb emelkedett, ott hirtelen 12 legény valószínűleg georgikoni diákok - hangos dudaszóra pásztortáncot jártak. „Ez az egész jelenés játszi volt, de nékem mégis igen érzékeny" - számol be erröl Berzsenyi Kazinczynak, már többször idézett levelében, de táncokra utalást találunk Kisfaludy cikkében is. A tánc után a

\footnotetext{
${ }^{754}$ Vadász, 1909. 141.

755 MOL Fest. Lvt. P 291 k. Repertorium 1817. Magyar nyelvű szakmutató II. Tertiobéli Külsőkkel való Levelezések 99/299

${ }^{756}$ TGy. 1817. III. 85.

${ }^{757}$ MK. 1817. I. 19 sz. (március 17.) 145.

${ }^{758}$ Berzsenyi Dániel Kazinczy Ferencnek, 1817. február 27. ; Berzsenyi, 1978. 426.
} 
fás kertben Kisfaludy Sándor, Horváth Ádám és Dukai Takács Judit madárberkenyét ültettek Gyöngyösi István emlékére, majd egy-egy fát saját emlékezetükre is. Felkoszorúzott ásó, öntöző és csemeték várták a faültetőket. Horváth Ádám azt írta Kazinczy Ferencnek, hogy nem értett egyet az ott lévő négy költő fájának elültetésével, de ,az én ellenemre, a’ Groff akaratjára” mégis megtörtént. ${ }^{759}$ A Magyar Kurir a madárberkenyén túl „két délszaki ritka fá”-ról ír, de erre sehol sem találtam megerősítő adatot. ${ }^{760}$ A levelezésekben, így Berzsenyi leveleiben is kizárólagosan madárberkenyéről, Sorbus aucupariáról van szó. ${ }^{761}$ Igaz Sámuel pár évvel később, a keszthelyi Helikonokról írt cikkében, javaslatot tett a fa nevének megváltoztatására: „...Ö Excellentiája e' végre a' Keszthely körűl ritkább 's ákácz vagy inkább rhus formájú, levelei 's veres bogyóji által tetsző Sorbus aucupariát (madár-berkenyét) választotta. Ezt a' fát a' Gróf’ emlékezetére méltó volna Festetics-berkenyének (Sorbus Festeticsia) neveznünk". ${ }^{762}$ A faültetés ünnepélyén Horváth Ádám felolvasta A' földmívelő Varró címet viselő pásztori beszélgetését. Az ódában szereplő visszhang eljátszására Dukai Takács Judit vállalkozott úgy, hogy Horváth szavaira egy bokorban, elbújva válaszolt. Segítségükre a zeneiskola diákjai voltak. Berzsenyi megírta Kazinczynak, hogy Horváth énekelt is. Kazinczy Döbrenteinek írt két levelében is kitért az eseményre: „Horváth Ádám még énekelt is az ültetés alatt, a' megszakadt (herniás) és ezért beszélni is alig tudó ember". 763 Majd három nappal később megismétli: „Horvát Ádám nem csak verset vitt, hanem énekelt is, noha tökös (herniás) lévén, szólani is bajosan tud", 764

Este a gimnázium épületében a diákok és tanárok koncertet adtak, ahol ismét elénekelték, de most németül, az Isten tartsd meg Királyunkat, című éneket. ${ }^{765}$ A Magyar Kurir a koncerten fellépők nevét is ismertette: „Mezner és Stansits Normális Iskolai Tanítók, Obermayer az "Erdőszséget Tanitó" és Lucam Gazdaságbeli Practicans". 766

A koncertet követően vacsora volt és bál. Így ért véget az első Helikoni Ünnep.

Hazaérve Berzsenyi is, Horváth Ádám is megírja barátainak, elsősorban Kazinczynak az ünnepség lefolyását. Berzsenyi Wesselényi Miklós bárónak is ír és rá akarja beszélni - a Helikonok történetét ismerve eredménytelenül -, hogy a következő ünnepen jöjjön el

\footnotetext{
${ }^{759}$ Horváth Ádám Kazinczy Ferencnek, 1817. március 2. ; KazLev. XV. 98.

${ }^{760}$ Magyar Kurír 1817. I. 19 sz. (március 17.) 145.

${ }^{761}$ Berzsenyi Dániel Kazinczy Ferencnek, 1817. február 27. ; Berzsenyi, 1978. 426.

${ }^{762}$ Igaz, 1823. 245.

${ }^{763}$ Kazinczy Ferenc Döbrentei Gábornak, 1817. március 13. ; KazLev. XV. 114.

${ }^{764}$ Kazinczy Ferenc Döbrentei Gábornak, 1817. március 16. ; KazLev. XV. 117.

${ }^{765}$ Isten tartsd meg... / = Gott erhalte... Haydn zenéjére az osztrák császári himnusz. Felhasználta a „KaiserQuarten" lassú op. 76. tételéhez is. (Szabolcsi, 1965. 65.)

${ }^{766}$ MK. 1817. I. 19 sz. (március 17.) p. 145
} 
Keszthelyre: „, Mely nagy jutalom s mely hatalmas ösztönzés lenne a nemes szívü Grófra nézve a Te megjelenésed, s mely szép napokat élhetnél Keszthelyen és Füreden!"767

Az ünnepet követően jelent meg a Tudományos Gyüjteményben a már többször idézett beszámoló „egy jelen volt vendég”, azaz Kisfaludy Sándor tollából, „A Keszthelyi Helikon” címmel. Erre a tudósításra gúnyosan és lenézően, ám felettébb gyanús szemmel írt visszhangot a bécsi Vaterlandische Blatter für Össterreich címü lap: ${ }^{768}$ „Keszthelyer Helikon. Beschreibung der Feyer des Gebursfestes seiner Majestät des Kaisers und Ihrer Majestat der Kaiserin. - So was gehört eigentlich in politische Flugblatter: wir sehen an Mittags - und Abendschmausen und an Tanzen nicht Wissenshaftliches.” (Keszthelyi Helikon. Öfelsége a császár és őfelsége a császárné születésnapja alkalmából rendezett ünnepélyek leírása $\mathrm{Az}$ ilyesmi voltaképpen politikai röpiratokba való. Mi nem látunk semmi tudományos szempontból jelentőset az ilyen ebédekben és vacsorákban...) Vagyis - írja Merényi Oszkár a bécsi újság szemében az a keszthelyi Helikon-ünnepély, amely költőnk számára egy új magyar világ kezdetét jelentette, csupán egy gyanús politikai lakmározás volt, amire a célzatos tudósítás mintegy a rendőrség figyelmét is felhívta a biztonság kedvéért. ${ }^{769} \mathrm{~A}$ Tudományos Gyüjtemény visszautasította a bécsi újság támadását, kiemelve a Helikonnak a király születésnapjához való kötődését. „Sok rossz akarat, irigység, vagy gonosz lélek kell ahhoz" - írja, hogy politikai lakmározásnak nevezzék az ünnepet. ${ }^{770}$

Amint látjuk, nem volt zökkenőmentes a még ennyire körültekintően megrendezett ünnepély megítélése sem. Ennek további bizonyítékaként megemlítjük Kazinczy maliciózus megjegyzését egyik Berzsenyinek írt levelében: „Horváth Ádám megküldé nekem Keszthelyen elmondott Eclogáját. A' levelet egy becsületes ember feltörte a' postán, 's ismét lepecsételte. Hah czimbora!"771 Bármit is gondolhatunk, de ebben az esetben a pecsétfeltörést más egészen prózai dolog okozta. Erről tájékoztatta is Horváth Kazinczyt, megjegyezve azonban, hogy „les céljából” bizony gyakran feltöretnek a levelek. ${ }^{772}$ Ez a szituáció kitűnően mutatja a kor bizalmatlan, mindenben rebelliót kereső, és olykor találó, a császári udvarból kisugárzó légkörét. Ha Festeticset, a Helikont megítéljük, ezt is figyelembe kell venni.

Kazinczyt, ha esetenként úgy is tünt, hogy hidegen hagyta a helyi jelentőségünek vélt keszthelyi összejövetel, igazán nagyon is izgatta. Ugyan 1817. június 11-én is azt írja Kölcseynek, hogy „ez a kedves barátom (ti.: Horváth Ádám Cs. G.) nagyon örvend a'

\footnotetext{
${ }^{767}$ Berzsenyi Dániel Wesselényi Miklósnak, 1817. február 20. ; Berzsenyi, 1978. 484.

768 1817. évfolyam 5. szám

${ }^{769}$ Berzsenyi ÖM, 1979. 791.

${ }^{770}$ TGy. 1818. III. 113-114.

${ }^{771}$ Kazinczy Ferenc Berzsenyi Dánielnek, 1817. március 23. ; KazLev. XV. 138.

${ }^{772}$ Horváth Ádám Kazinczy Ferencnek, 1817. május 24. ; KazLev. XV. 199.
} 
Keszthelyi bohóságnak”"773, a Helikoni Ünnepség napján mégis azt közli Berzsenyivel: „Te tehát ma Keszthelytt vagy az istenek asztalánál, quos inter recembeus purpureo bibis ore nectar. Élj szerencséddel kedves barátom! én oda nem mehetek, nem csak mert meg nem hivattatám, hanem azért is, mert oda nem illek. Köszönöm a’ levél közlését. Már hallottam valamit a' Helikonról, de ennyit felöle nem tudtam". ${ }^{774}$ Ez a levél világosan bizonyítja, Kazinczyt nagyon is érzékenyen érintette a „nem meghívás” és szívesen ott lett volna a helikoni társaságban. Nem véletlen tehát, hogy a Helikon napján, február 12-én ül le az asztalhoz és írja meg hosszú levelét Berzsenyinek, akinek helikoni jelenlétét szerencsének titulálja, bár nem hagyja ki, hogy lekicsinylően meg ne jegyezze: ma Berzsenyi „az istenek asztalánál” van. Márciusban már elismeri, hogy amit Festetics cselekedett, az nem csak szép, hanem nagy is és idővel nagy hasznot hajthat. Sajnálja, hogy ezen a napon nem lehetett velük együtt Keszthelyen. Megdicséri Berzsenyit, hogy nem olvasott fel, mert ha ő, mármint Kazinczy, ott van, hasonlóan cselekedett volna. ${ }^{775}$ Ebben a levelében nem felejti el megjegyezni, hogy míg Berzsenyi nem olvasott fel semmit, Horváth Ádám, aki minden lehetőséget megragad a szereplésre, még énekelt is. Berzsenyinek kedveskedve írja, hogy még jobban megszerette Dukai Takács Juditot: „szeretném azt a’ szép barnahajú leányt öszve meg öszve csókolni”. (...) De valamint ezt leveled megszerettette velem, úgy Kisfaludynét a' Dudihoz tett szava velem nagyon útáltatja”. Valószínűleg Berzsenyi, a levél ezen mondatát túl erősnek találva, kitörölte az olvashatatlanságig. ${ }^{776}$

Berzsenyi vigasztalni próbálja Kazinczyt reményét fejezve ki, hogy a májusi ünnepen már részt vesz s, hogy örülne ennek Dukai Takács Judit is. Később megvallja nem érezte magát jól Keszthelyen. A légkör, a vita a vagdalkozás nem volt számára kedves, de a jót, mármint Festetics mecénásságát, tiszteli és szereti. Mint minden Berzsenyi levél, ez is felfedi a költő véleményét az őt körülvevő világról, eseményekről amely Nikla határain túl már sok esetben nehezen értelmezhető számára. Kicsit szomorúan jegyzi meg: „Nem illesz Keszthelyre. Én sem. De én annyira tisztelem a' jót, akármi színben legyen az öltöztetve, hogy én Néked is alig merém ezt kimondani. Midőn egy oly ember, akinek jövedelme három milliom körül van, egy ily innepre 30 ezret költ, semmi; de nem semmi az, midőn az ősz Festetics a' szegény Ber'senyinek az utcára kalap nélkül elejbe szalad. Minden cselekedet becsének az idő és hely az igazi mértéke. Egy oly népnél, ahol a’ nagyok az anyanyelvet cigánynyelvnek nevezik, 's a' magyar írónak nem is köszönnek, 's a' legjobb poétát

\footnotetext{
${ }^{773}$ Kazinczy Ferenc Kölcsey Ferencnek, 1817. június 11. ; KazLev. XV. 231.

${ }^{774}$ Kazinczy-Berzsenyi, 1860. 202.

775 Kazinczy Ferenc Berzsenyi Dánielnek, 1817. március 13. ; KazLev. XV. 115.

${ }^{776}$ Váczy János lábjegyzete. ; KazLev. XV. 115.
} 
legfeljebb is joculatornak nézik, Festetics nagy ember, vagy ami még több, jó ember, s akármint veszem a dolgot, igen illene néked Keszthelyt megtekinteni. Tán ezen intézetnek oly igazítást is adhatnál, mely nélkül meglehet, hogy a' célt egészen eltéveszti”, ${ }^{777}$ Berzsenyi jól sejti, hogy irodalmi vezér kellene Keszthelyre. Magát nem gondolja, Kisfaludy már a régi izlés képviselője így számára Kazinczy a megfelelő személy. Berzsenyi sem vette észre, hogy Kisfaludy Károllyal az élen Pesten, már megjelentek az új irodalmi izlés fiatal képviselői. Bizonyos vélemények szerint, Kisfaludyt Kazinczy-ellenes indulata vitte Keszthelyre. Azon munkálkodott - nem sok eredménnyel -, hogy Festetics körül kiépüljön egy Széphalomellenes dunántúli ortológus-centrum. ${ }^{778}$ Erre sem ideje, sem kedve nem volt Festeticsnek. Talán ezt is felismerve, nem látta értelmét Kisfaludy, hogy később ismét Keszthelyre jöjjön.

1983-ban került kezünkbe a keszthelyi Balatoni Múzeum irattárában három, pár lapból álló, kékes, illetve zöldes cérnával összefüzött aranymetszéssel ékített és kézzel merített papírból álló füzetecske. A három füzet Dukai Takács Judit, minden bizonnyal saját kezével, a keszthelyi Helikonra írt verseit tartalmazza. ${ }^{779}$ A kéziratok, amelyek a tulajdonosi bélyegző tanúsága szerint Jánossy Auréltól származnak, feltalálásukkor nem kis meglepetéssel, sőt irodalmi csemegével szolgáltak. Az 1817 februári füzet címlapja hiányzik, így csupán a versek alapján lehet azonosítani melyik ünnepségről van szó. A füzetben a versek sorrendje a következö:

(Örvendezö versek) Felséges I. Ferenc Ausztriai Császár s felkent Magyar Koronás Királyunk születése Napjára,

A Halálról. Nagy Méltóságú Vázsonköi Iffjabb Gróff Zichi (sic!) Károly Cs. Kir. Kamarás és belső Titkos Tanácsos Úr Ö Excellentiája Hites Társának Született Nagy Méltóságú Tolnai Gróff Festetics Juliánna árnyékához,

Epistola Nagy Méltóságú Tolnai Gróff Festetics Györgyhez Cs. Kir. Kamarás és belsö Titkos Tanácsos Úr Ö Excellentiájához 12 dik Februariusban 1817.

A füzet érdekessége még két bejegyzés az utolsó vers címét tartalmazó oldalon. A szépen kalligrafált írástól elütő, korabeli, férfias írás mintegy jegyzetként tájékoztat bennünket az oldal közepén: „Irta 's magával hozta Dukai Takáts Judith 12 feb 1817.” Ugyanezen oldal jobb alsó sarkában szálkás huszadik századi, a fenti mondatra utaló jegyzet:

\footnotetext{
${ }^{777}$ Berzsenyi Dániel Kazinczy Ferencnek, 1817. február 27. ; Berzsenyi, 1978. 427.

${ }^{778}$ MIT III., 1965. 331-332.

${ }^{779}$ Erről részletesen: Cséby, 1990. 97-119.
} 
„Berzsenyi sajátkezü írása. Dr. Perényi J., ${ }^{780}$ A füzet versei megtalálhatók Dukai Takács Judit mindezidáig az egyetlen, munkáit összegyüjtő kötetben. ${ }^{781}$ A költőnő több példányban készítette el kis füzetecskéit. Az 1817. februári Helikoni versek füzetének másik példánya a Pannonhalmi Főapátság Könyvtárának tulajdonában van. ${ }^{782} \mathrm{~A}$ harmadik másolat a Magyar Tudományos Akadémia Kézirattárában a Döbrentei hagyatékban található. A füzet nagysága azonos, s a három vers is ugyanaz. Felvetődhet a kérdés, hogyan kerülhetett Döbrenteihez a kézirat? Valószínüleg a Döbrenteivel rendszeres levélváltásban lévő Dukai Takács Judit küldte el levelezőpartnerének. ${ }^{783}$ Ugyanis az ifjú, nyílt szívü költőnőt, a tíz évvel idősebb Döbrenteihez, első találkozásuk óta (1814) szívélyes és meleg barátság füzte, amely levelezésükből is kiolvasható. Álljon itt példának egy személyes vallomás a házasságról, amelyet Dukai Takács Judit még 1815-ben vagy 1816-ban küldött Döbrenteinek, s amelyből a levélíró véleménye és álláspontja is kicsendül: „El hidd Kedves Barátom hogy ’a mi tájunkon olly sok rossz Házasságok vagynak, hogy 'a Házasságra lépő személlyek mind 'a két részröl méltán retteghetnek pedig egy sem Poeta sem nem Poetria, én csak ugy gondolom hogy azok 'a szomorú példák 'a rossz erkölcstelen neveléstől vagynak, mert Berzsenyiként 'a miveletlen föld csak gazt terem". 784

3. 6. 3. A második Helikoni Ünnep: 1817. május 20-21.

Az 1817 májusi ünnepély a georgikoni vizsgákhoz volt kötve. Elsősorban a georgikoni hallgatók tudása mérettetett meg, a mezőgazdasággal kapcsolatos dolgozatok felolvasására, beadására, az újítások bemutatása került sor. A Hazai 's Külföldi Tudósítások lelkesen számolt be a vizsgákról, amely kapcsán „minden hazafi méltán örvendhet”. Leírja ennek lényegét is, miszerint a Georgikon „Május 20-kán a’ kitanult Practicansokkal esztendőnként

\footnotetext{
${ }^{780}$ Cséby, 1990. 103. ; Németh József a kor jeles zalaegerszegi kutatója szíves szóbeli közlése szerint Perényi József tévedett és az írás Horváth Ádámé.

${ }^{781}$ Vadász, 1909.

782 Jelzete: 10 a. E. 7/2 ; Néhai Szabó Flóris pannonhalmi főkönyvtáros 1989-ben, a kéziratok sorsára vonatkozóan kérdésünkre, a következö levelet küldte. „Idekerülésükröl sajnos nincs semmi adatunk, valószínűleg, hogy valamelyik irodalmár bencés (Guzmics Izidor?) hagyatékából, avagy ajándékából került könyvtrunkba. Csak az a 33 oldal van, amit a kiállításra adtunk..."

${ }^{783}$ 1814-ben az Itáliából hazatérő ifjú Wesselényi Miklós báró, Pataky Mózes, a báró nevelöje és Döbrentei Gábor meglátogatták ismerőseiket; Niklán Berzsenyit, Keszthelyen Festeticset, kinek Georgikon emlékkönyvébe még emléksorokat is írtak. Ezt követően utaztak Dukára a Dukai Takács familiához. A vizit jól sikerült, a fiatal költőnő versei tetszettek, föleg Döbrentei vette pártfogásba. E látogatáskor tőlük kapta a Malvina nevet. (Cséby, 1990. 99.)

${ }^{784}$ MTA Kézirattár Magyar Irod. Levelezés 4 r. 207. Dukai Takács Judit Döbrentei Gábornak 1815 (16?) (töredék)
} 
szoros Exament tartat, 's ezen alkalmat egyszer 's mind arra fordítja, hogy a' meghívott Vendégekkel, vagy önként érkezett Látogatókkal előmeneteleit közölje, és viszont azoknak a' gazdaságbeli tárgyakról való itéleteiket meghallgassa". ${ }^{785}$ Az irodalom a májusi ünnepeken kissé háttérbe szorult. A német nyelvü Vereinigte Ofner Pester Zeitung lelkesen tudósított a vizsgákról és a Georgikont az egész osztrák birodalom egyedülálló kultúrintézményének tartotta, amely az új magyar kultúrtörténet csillogó fénypontja. ${ }^{786}$ Horváth Ádám, Dukai Takács Judit és Kazinczy Klára vettek részt az ünnepen. Sem Kisfaludyt, sem Berzsenyit nem láthatták. Berzsenyi ekkor már valójában beteg, amit hypohondriája nagyít, nehezen mozdul, csalódások érték. A Vereinigte Ofner Pester Zeitung szerint megjelent többek közt, Pászthory (Menyhárd) báró a Mária Terézia rend lovagja, Sopron vármegye első alispánja, Szabó Ignác Sopron vármegye főjegyzője, Nitzky Kristóf. Kazinczy ekkor sem volt Keszthelyen. Még márciusban megírta Berzsenyinek: „Óhajtom látni Keszthelyt miattad és Dudi miatt is, Kisfaludi(!) miatt is; de Májusban abból semmi sem lehet; erszényem sem engedi most tennem azt az útat."

Az ünnep vendégei és szereplöi a Georgikoni szálában gyülekeztek. Itt Liebbald Gyula archon köszöntötte a vendégeket, majd „De Dualismo Agricolarum inter Productionem et Consumptionem "788 (Mitsoda befolyása légyen a' bővebb termesztésnek a' nem termesztő munkás népre, és viszontag az illyen készből élőknek a’ gazdák termesztésére?) címmel latin nyelven tartotta meg nyitóelőadását. A téma minden kétséget kizáróan érdekelhette a hallgatóságot, de a vita, a fogadtatás részleteiről sem a korabeli sajtó, sem a Helikonon megjelent költők levelei nem árulkodnak. Az archon előadását követően három georgikoni növendék következett, ök adtak számot tudásukról: Márton Ferenc, Nagy József és Nagy Zsigmond. ${ }^{789}$ A három növendéket szigorú vizsgálat alá vonták, de mindnyájan kitünően megfeleltek a követelményeknek. A szóbeli vizsga után gyakorlatit is tenniök kellett „a mezőgazdaság különböző munkálatainak és eszközeinek tárgyában”. ${ }^{790}$ Horváth Ádám megírja Kazinczynak, hogy Festetics arra kérte tegyen fel pár kérdést a diákoknak. Horváth

\footnotetext{
${ }^{785}$ HKT. 1817. 51. sz. (június 25) 405.

${ }^{786}$ Pest. Zeit., 1817. június 8.

${ }^{787}$ Kazinczy Ferenc Berzsenyi Dánielnek, 1817. március 13. ; KazLev. XV. 116-117.

${ }^{788}$ NG., 1817. XXVI. 401-404.

${ }^{789}$ A fellépő diákok pár adata. Márton Ferenc: 1796-ban született a Jász megyei Kis-Éren. 1815-ben iratkozott be a Georgikonba (Csiky, 1897. 66) ; Nagy József: 1796-ban született a Zala megyei Pacsán, 1815-től hallgatója a Georgikonnak. (Georgikon 200. II. 30. ; Csanády, 1897. 68.) ; Nagy Zsigmond: 1790-ben született a Nógrád megyei Herencsényben. 1815-től hallgatója a Georgikonnak. (Csiky, 1897. 68.)

${ }^{790}$ Pest. Zeit., 1817. június 8. ; Hasonlóan dicséri a diákok teljesítését a HKT. 1817. évf. 51. sz.
} 
büszkén írja: „a Physicabúl kemény kérdést tettem, mellyet a’ Professorok akartak meg fejteni, de vékony sikerrel: 's egy kis azt követett nehezteléssel", 791

A vizsga után tudományos felolvasások következtek. ${ }^{792}$ Elsőként báró Pászthory „Miképp lehetne a' gazdaságbeli isméreteket a' Parasztságra is általvinni” címü értekezését hallgatták meg, majd Dr. Ries, egy a Palatinus óhajára már kipróbált eljárási módot ismertetett a közönséggel: „Mitsoda haszonnal lehetne a' kukoricza szárból czukrot késziteni?”. Asbót János prefektus, a Georgikon igazgatója „Miképpen lehessen a' Birkások' fizetéseiket úgy intézni, hogy az a' Birtokosnak hasznával arányosan nevekedjék, vagy alább száljon?” címü előadását olvasta fel. Végezetül Kehrn Vilmos ${ }^{793}$ főmérnök ismertette „A birkaaklok célszerü épitése és berendezése" című dolgozatát, sok példával illusztrálva. ${ }^{794}$

Ezt követően pár beküldött munkát olvastak fel - közölte a Hazai 's Külföldi Tudósítások már idézett lapszáma. Ismertették Rumy Károly György „Karlovitzi Director” munkáját „A köz legelöknek hasznos felosztásáról”795 címmel. Brüszle Jakab, Esterházy gróf „Dárdai Actuariusának” írását olvasták fel „Csaplovics Ur kettős köpüinek jobbittásairól” címmel, majd Pertivall (Perivall) József Fridrik késmárki professzor írása került ismertetésre „az által feltalált, vagy megjobbíttatott Tséplő-Mángoló-Hányó-Seprő Masinákról”. A Vereinigte Ofner Pester Zeitung azt is tudni véli, hogy Petrivall beszélt egy szövő-és kelmefestő gépröl is. ${ }^{796}$

A beküldött munkák felolvasása után magyarázattal egybekötött bemutatók következtek. Annyit mindenképpen meg kell említeni, hogy a Helikonokon bemutatott makettek a Georgikon múzeumába kerültek, amit a georgikoni diákok munkájával egyetemben Festetics szívesen mutatott meg vendégeinek. A bemutató sorát Szluha György apát, szekszárdi plébános kezdte, aki a földi bodzából (Sambucus ebullus) készített kék festékjét ismertette, ,amellyel festetett különbféle gyoltsok is előmutattattak, mellyek fokonként szebb szebb színt mutattak, a’ mint vagy tsupán Főldi-Bodzával, vagy 1/8, 1/6, 1/4 rész Indigóval keverve lett a festés. Különössége az, hogy a’ szín a’ napon sem halaványodik meg, és az 1/4 Indigóval készült festés gyönyörü szép, és így azon drága festékből legalább is

\footnotetext{
${ }^{791}$ Horváth Ádám Kazinczy Ferencnek, 1817. május 24. ; KazLev. XV. 200.

${ }^{792}$ Az előadások címét a HKT. 1817. 51. sz. (június 25) 405-406. közli.

793 Kehrn Vilmos. 1790-ben született Sopronban. A Georgikon hallgatója 1809/10-ben. 1811-1812 közt a mennyiségtan tanára az intézetben, 1819-től uradalmi fömérnök. A Georgikon igazgatójának is megválasztották. Később, 1828-tól tizennégy éven át hol a mennyiségtan, hol az építészet, hol a gyakorlati mértan tanára. Mint az uradalmi igazgatóság tanügyi referense is szerepel. (Csiky, 1897. 31.)

${ }^{794}$ Ezt az előadást nem közli a HKT., adatot a Pest. Zeit. 1817. június 8-i számában találtunk.

795 A NG. 1817. XXVI. 401-404 szerint Rumy a közbirtokok felosztásáról tartotta meg előadását.

${ }^{796}$ Pest. Zeit., 1817. június 8.
} 
3/4 részt meg lehetne kémélleni a" Földi-Bodza által". ${ }^{797}$ A második előadó Müller Nepomuk János „a schönaui árendás”, azaz a Schönaui és Theresienfeldi Uradalmak bérlöje egy nyíróollót mutatott be. Az olló nem volt hazai találmány - vélekedett a már idézett lapszám mert eredetijét János föherceg hozta be Angliából. Ezt a mintadarabot viszont az angliai olló alapján, az előadó piestingi vashámorban készítették, amely a bécsi Neustadt mellett működött. ${ }^{798}$ A harmadik előadó dr. Jánossy József georgikoni matematika professzor volt. Bemutatta saját maga által készített kettős ekéjét, amelyet egy embernek kell vezetnie, két barázdát szánt, mégsem igényel több vonóeröt. Bemutatta ezen kívül azoknak a gépeknek a rajzait, amelyek a Georgikonban eredeti nagyságban, illetve modellekben megtalálhatóak voltak. ${ }^{799}$ A Vereinigte Ofner Pester Zeitung szerint még többen is bemutatták munkáikat, nevezetesen Paletta György ${ }^{800}$, aki „, A Georgikonban nyomásváltó gazdálkodás hatása három egymást követö évben” címmel bemutatással egybekötve olvasta fel dolgozatát. Nagy József $^{801}$ végzős hallgató, akit már a februári és a mostani Helikonról is ismerhetünk, „, $A$ krumplitermesztés monográfiája” címü értekezését mondta el. Végezetül ismét Asbóth János emelkedett szólásra és befejezésként felolvasta „A Georgikon és az ezzel összekötött intézet leírása a mai állapotban" címü ismertetőjét. Az előadások és bemutatókat követően Putz Lőrinc soproni állattenyésztő a Georgikon múzeumának részére átadta az általa módosított fünyíró gép modelljét, amely azonban eredeti nagyságban is megtalálható volt az intézményben. ${ }^{802}$ A Nemzeti Gazda már idézett cikke szerint: Putz „Sopronyi fojómértékbéjjegző s helybenhagyó” elkészített „egy mérséklett Szénamérő Kismást, melljet a Georgiconban nagyban is felállítanak".

Az első nap rendezvénysorozata azzal fejeződött be, hogy Festetics György gróf „hazai és külföldi személlyeknek” georgikoni assesorságot (tiszteletbeli tag, ülnök) osztott. A megtisztelő címet a következők kapták:

báró Pászthory Menyhárd,

báró Wenckheim József,

Altmann Arlinget,

\footnotetext{
797 HKT. 1817. 51. sz. (június 25) 406. ; Verbói Szluha György Demeter (1747-1820) apát-plébános, táblabíró.1764-ben lépett be a remete Szent Pál rendbe, Pécsett teológiát tanult. Nagyszombatban szentelték pappá, 1792. november 19.-től szekszárdi plébános, később madocsai apát.

${ }^{798}$ NG. 1817. XXVI. 401-404.

799 „Theatrum Machinarum Georgici” (Pest. Zeit., 1817. június 8.)

${ }^{800}$ Paletta (Paleta) György ,grófi igazgató” Keszthelyen. A Georgikonba 1808-ban iratkozott be. (Csiky, 1897. 70.)

${ }^{801}$ Nagy József: 1796-ban született a Zala megyei Pacsán, 1815-től hallgatója a Georgikonnak. (Georgikon 200. II. 30. ; Csanády, 1897. 68.)

${ }^{802}$ Pest. Zeit., 1817. június 8 .
} 
Leopold Trautmann,

Carl Andre

Tessedik Sámuel,

Rösler Kristóf,

Ottrokóczy József,

Rumy Károly György,

Asbóth János,

Kelemen Imre,

Kövy Sándor. ${ }^{803}$

Asbóth János ezen felül megkapta a Georgikoni láncot a Numisma oeconomicum éremmel, a Haza 's Külföldi Tudósítások szerint „mentekötőn függő Georgikoni Emlékpénzzel tiszteltetett meg". ${ }^{804}$ Tessedik Sámuel német nyelvü önéletrajzában az eseményt a következőképpen idézi fel: „A keszthelyi Georgicon mellett ülnökké és munkatárssá való megválasztásom. 1817. máj. 20. és 21.-kén tartott nyilvános keszthelyi gazdászati vizsgán engem vallottak Magyarországon a legelső gazdászati iskola alapítójául, s mint ilyet, tizenegy más tudós férfiúval együtt megválasztottak ülnökké. A megválasztási oklevelet 1817. dec. 9-kén nyújtották kezembe az óhajtással, hogy a keszthelyi intézetet a gazdászati tudományok és kísérletek mezején tanácsaimmal és útmutatásommal segítsem”. 805 Úgy látszik Festetics gróf Tessediknek a Georgikon alapítása körüli munkáit - többek közt - e babérággal köszönte meg.

Az ülés befejeztével ebédre került sor. Ebéd után a Georgikoni gyakorlati tangazdaságba vonultak a vendégek, a tanulók és a tanárok, ahol megtekintették a délelőtt elhangzott vetésforgó gyakorlati alkalmazását. Fellenberg és Axter vetőgépeit használat közben láthatták. Úgy tünik János főherceg nemcsak nyíróollót, hanem más angliai „mintákat” is hozott magával. Nevezetesen angliai mintára egy Burg nevezetü gépész szénaforgató gépet készített, amelynek gyakorlati alkalmazását megtekinthették az érdeklődők. A szénaforgató az újság szerint jól működött. ${ }^{806}$

\footnotetext{
${ }^{803}$ Báró Wenckheim József cs. és kir. kamarás, ezredes. A békés megyei mocsarak lecsapolásában, a lótenyésztés előmozdításában játszott kimagasló szerepet. Részt vett a magyar gazdasági egyesület megalapításában. Altmann Arlinger osztrák prelátus, gottweichi apát. Leopold Trautmann a cs. és kir. bécsi egyetem mezögazdaságtudományi professzora. Carl Andre mezögazdasági tanácsos. Rösler Kristóf a Vereinigte Ofner Pester Zeitung szerkesztöje. Nem véletlen tehát, hogy az újság nagyobb cikkben számolt be az eseményekröl. Ottrokóczy József a Károlyi uradalom könyvelöje. Kelemen Imre teologiai és jogi doktor. Székesfehérváron, Győrben, majd Pécsett tanított. Ezt követően Pestre költözik, ahol háromszor dékán, kétszer rektor lett. Kövy Sándor ev. ref. föiskolai jogtanár. Sárospataki professzor. Előadásait latinul tartotta, ellensége volt a nyelvújításnak.

${ }^{804}$ HKT. 1817. 51 sz. 406.

${ }^{805}$ Tessedik, 1873. 89-90. ; A szarvasi Tessedik-féle gazdasági iskoláról van szó.

${ }^{806}$ HKT. 1817. 51. sz. 406. és Pest. Zeit. 1817. június 8.
} 
Másnap, május 21-én délelőtt a Georgikoni Declamatóriumban gyülekeztek az ünnepség résztvevői. Először a „Philosophiát és szép Tudományokat tanuló ifjak és a Georgikoni Praktikánsok" mondták el latin, magyar és német nyelven írt verseiket, írásaikat. Latinul adott elő Malotsay Ferenc georgikoni, Németh Antal líceumi, Vadnay Lajos gimnáziumi és Bertalan Lajos szintén gimnáziumi tanuló. ${ }^{807}$ Ezt követően gróf Festetics Ernő gazdasági gyakornok és Németh György georgikoni praktikáns magyar nyelven ismertették műveiket. ${ }^{808}$ Szilágyi József georgikoni külső praktikáns „,Vers Oszlop, Nagy Méltóságú Tolnai Gróf Festetics Györgynek tiszteletére” címmel szavalta el magyar nyelvü versét, amelyben sok jót kíván, de akár a többi vers zömmel általános szólamokat, közhelyeket sorjáz. Öt a „Buzditás” című, szintén magyar nyelvű verssel Konyáry Mihály követte. ${ }^{809}$ Sajnos a versekben sok a „személyi kultusz”- ahogy Négyesy írja - annál kevesebb az eszme, az igazi költői érzés. ${ }^{810}$ Gróf Festetics Leó és Gertinger Adolf gazdasági gyakornokok, valamint Jendrasik Antal a filozófiai líceum hallgatója német nyelven adtak elő. ${ }^{811}$

A diákok után a költők, írók müvei következtek. Berzsenyi Dániel nem jelent meg, de elküldte a „Hymnus Keszthely Isteneihez” címü versét, amelyet Festetics elsőként olvastatott fel. Berzsenyi Festeticshez írt költeményeinek egyik legszebbikéről van szó. Merényi rámutat, hogy a vers keletkezése hosszú, bonyolult alkotási folyamat eredménye és alapeszméje hosszú időn keresztül érlelődött Berzsenyiben. A költő egész versciklust írt a Festeticsekhez, Györgyhöz és fiához Lászlóhoz akit arra buzdít, folytassa apja munkáját. Felvetődhet a kérdés, miért éppen Festeticsek voltak a kitüntetettek? Merényi Oszkár mutat rá, hogy a kultúra és a (kulturális) haladás eszméinek világánál a korszerű hős típus keresése közben bukkant fel Berzsenyi költészetében Festetics György alakja. ${ }^{812}$ Ő megfelelt annak az ideának, amit a költő keresett. Berzsenyi kiválóan tudta, hogy Festetics Györgyöt és Széchényi Ferencet méltán állíthatja a magyar arisztokrácia elé példaképnek, ezzel mutatva be az áldozatkész, eszményi föúr „modelljét”. ${ }^{813}$ Két verset is ír „,Gróf Festetics Györgyhez” címmel, az egyiket 1797 után, a másikat 1802 körül. Az előbbi vers a kiválasztott, gazdag Festeticsről szól, akinek van anyagi lehetősége a mecenaturára, és él is ezzel a lehetőségével:

\footnotetext{
${ }^{807}$ Malotsay Ferenc 1797-ben született a Bars megyei Komjáton. 1816-ban iratkozott be a Georgikonba. (Csiky, 1897. 65.)

808 Németh György 1797-ben született a Zala megyei Szántón (Ma Zalaszántó) 1817-ben iratkozott be a Georgikonba. (Csiky, 1897. 69.)

${ }^{809}$ Szilágyi József és Konyáry Mihály mindketten aktív szereplői az ünnepeknek.

${ }^{810}$ Négyesy, 1925. 202.

${ }^{811}$ Gróf Festetics Leó és Gertinger Adolf is rendszeres szereplők.

812 Merényi, 1966. 108.

${ }^{813}$ Berzsenyi ÖM., 1979. 776.
} 
Festetics! boldog, kit az ég kegyelme

Anyja méhéből kijegyez magának,

S a szerencsének ragyogó ölében

Rengeti a sors.

S aki jóltévő kezeit kinyújtván,

Mint egy istenség, valamerre fordul,

Hinti áldását, $\mathrm{s}$ kebelében érzi

Tettei bérét. ${ }^{814}$

Azt is feltételezhetjük, hogy Berzsenyi elfogult a gróffal szemben, ezt próbálja Kazinczy Ferenc leveleiben ellensúlyozni mindaddig, amíg ő is nem kap meghívást a Helikonra. Berzsenyi minden találkozásuk alkalmával meggyőződhetett Festetics jobbító, tudatos törekvéseivel és mecénási bőkezüségével. A februári ünnepet követően Berzsenyi egy levél kíséretében küldte el a verset Festeticsnek. „Ime én ismét jövendölö lettem; alig tellyesedett bé a’ Helikon már Weimárt álmodok. Mosolyogjon Excellentiád! Nem tehetek róla. Én Excellentiádnak falukat nem jövendölök, mert elég van, hanem dicsőséget, nagyságot, mellyek nélkül a' faluk nem sokat érnek. Dicsőséget is eleget szerzett mát ugyan Excellentiád, mert a' legszebb, hazafi polgári virtusokban minden egy korúit fel multa. De itt még nincs határ: haladja meg Excellentiád a' maradékot is, mert mi fény azok között tündökleni, kik az anyai nyelvet czigány nyelvnek nevezik, és a’ poetát Joculatornak nézik? Jön mi utánnunk egy szebb világ melly Excellentiád érdemeit csudálni s áldani fogja, de ez még nem elég: Festetics lelkének élni, munkálni, alkotni kell még vég nélkül azon szebb világban is. Melly csak ugy legyen, ha Excellentiád intézeteit tartósakká, örökösökké teszi, mert ha azok Excellentiád becses életével el enyésznek, ugy azok csak gyenge virágok, melylyek már Excellentiád koporsóján el hervadnak s azzal együtt szemeink előtt el tünnek. A mi életünk az örökkévalóságban tsak egy pillanat; mi nagyot teszünk ha virtusainknak illy szük határt szabunk?"815 Berzsenyi nem túloz, azt írja, amit gondol. Nincs szüksége föurak kegyeit keresni, ő jól érzi magát Niklán, s talán csak akkor érezné magát még jobban, ha felesége, Dukai Takács Zsuzsanna, a gazdaságon túl affinitást mutatna - ha morzsányit is - a költészet, és így az ő költészete iránt. Nem véletlen tehát, amikor mintegy megjegyzi csupán

\footnotetext{
${ }^{814}$ Berzsenyi ÖM., 1978. 24-25.

${ }^{815}$ Berzsenyi Dániel Festetics Györgynek, 1817. március 16. ; Berzsenyi ÖM., 1978. 485.
} 
későbbi levele végén: „Éljen szerencsésen Excellentiád! Ez az én szívemnek mindennapi ódája". 816

A vers tehát elhangzott és elhangzott a tizenhatodik versszak kívánsága is, amire Berzsenyi Festeticsnek írt levelében céloz is:

Hogy vérrel ázott századaink’ nyomán

A' szent pálma' arany bimbaji nyiljanak,

'S e' kis magyar Weimár' öléből

Lássa hazám kiderülni napját. ${ }^{817}$

A vers természetesen bekerült a „Heikon I." kiadványba is. Érdemes összevetni a Merényi Oszkár szerkesztette Berzsenyi összes mủvei első kötetében közölt egyes versszakok változatát és az 1818-ban kiadott kötetben lévő változat eltéréseit.

A ,Helikon I. ” kötetben megjelent változat:

Vidám avénám titeket énekel.

A' szebb emberiség bennetek él 's tenyész

15

Ti adtok annak testi lelki

Jobb eledelt 's magas égi éltet.

$(\ldots)$

Főbb létre lobbant lelke fel oldozá

A' Szép', Jó', 's az Igaz' mennyei csirjait;

Zengtél!' 's körülte új világ nyilt

40

'S Elyzion szomorú vadonján;

$(\ldots)$

Kronos' szülötje! 's Delphi nagy Istene!

Ti munkátok azon titkos örök kötél,

Melly a' halandó port 's az Istent

${ }_{817}^{816}$ Berzsenyi Dániel Festetics Györgynek, 1817. szeptember 15. ; Berzsenyi ÖM., 1978. 486.

${ }^{817}$ Berzsenyi ÖM., 1979. 130-132. 
Egy csuda mívbe csatolva tartja:

$(\ldots)$

Hogy vérrel ázott századaink’ nyomán

A’ szent pálma' arany bimbaji nyiljanak

'S e' kies magyar Veimár' öléből

Lássa hazánk ki derülni napját.

$(\ldots)$

Le rakja 's áldoz, 's mint mikor a' Bakonyt

70 Meszszünnen riadó menykövek és szélek

Csattogva rázzák, zeng 's fölötte

Tegzed' arany nyila és az Aegis. - ${ }^{818}$

Az 1979-ben kiadott Berzseny összes műveiben található változat:

Vidám avénám titeket énekel.

A' szebb emberiség bennetek él 's tenyész

16

Ti adtok annak földi, leki

Jobb eledelt 's magas égi éltet.

$(\ldots)$

Főbb létre lobbant lelke feloldozá

A' szép', jó', 's az igaz' mennyei csírjait;

Zengtél! 's körülte új világ és

41

Elyzion nyilt bús vadonján.

${ }^{818}$ Helikon I., 1818. 34-37. 
$(\ldots)$

Kronos' leánya! 's Delphi’ nagy istene!

Tí munkátok azon titkos örök kötél, Melly a' halandó port 's az Istent

Egy csuda mívbe csatolva tartja.<smiles>[CH]1[CH]C=C1</smiles>

Hogy vérrel ázott századaink’ nyomán A’ szent pálma' arany bimbaji nyiljanak 'S e' kis magyar Weimár' öléből Lássa hazám kiderülni napját.<smiles>[TeH]</smiles>

Lerakja 's áldoz, 's mint mikor a' Bakonyt

70 Messzünnen riadó mennykövek és szelek

Csattogva rázzák, zeng fölötte

Tegzed' arany nyila és az Aegis. - ${ }^{819}$

A két változatra két magyarázat is található. Egyrészt elképzelhető, hogy a keszthelyi szerkesztők változtattak a müvön, föleg a kis és kies magyar Weimár esetében - egyszerüen fennköltebbnek gondolták a kies szót. Másrészt elképzelhető, hogy Berzsenyi kéziratát ilyen szöveggel juttatta el Keszthelyre, s tudjuk, hogy a Merényi által szerkesztett kötet az 1936-os kiadás alapján közöli a verset. Az 1936-os kiadás alapjául pedig egy, a második világháborúban megsemmisült kézirat szolgált, melyet Berzsenyi hagyatékában őriztek. ${ }^{820}$

Berzsenyi versének elmondása után Dukai Takács Judit szavalta el „Hazafiúi Szóztat Felséges Ferdinand Károly Ausztria Császári Királyi Fö Herczeg, 's a’ Magyar Szent Korona dicső Örököséhez "821 címmel megírt versét. Öt Kazinczy Klára követte az „Isishez ének”

\footnotetext{
${ }^{819}$ Berzsenyi ÖM., 1979. 130-132.

${ }^{820}$ Berzsenyi ÖM., 1979. 776.

${ }^{821}$ Helikon I., 1818. 59-64.
} 
verssel. ${ }^{822}$ Horváth Ádám új művét hozta el és adta elő az ünnepen. "Az én Melodrámám, Hyperborei Zsenge, rekesztette be a' dél előtti oskolát"- tudatja Kazinczyval. ${ }^{823}$

A Vereinigte Ofner Pester Zeitung és a Hazai 's Külföldi Tudósítások még két verselőt említenek meg, akik Horváth Ádám után elmondták verseiket: Simon György latin költeményt, Schildbach János Gottlieb ${ }^{824}$ valószínüleg német nyelvű költeményt szavalt, esetleg a ,Das Frühlingfest in Keszthely”-t. ${ }^{825}$

Ezen a Helikonon is voltak olyan versek, melyeket a szerzők elhoztak magukkal, de nem kerültek felolvasásra. Ilyen munkának kell számítanunk Dukai Takács Judit versét a „Pásztori Áldozat, Horváth Ádám Tábla Bíró Ur' Hazánk’ Orpheusának születése napján Május 11-iken „826 címüt. Ugyanakkor Péterffy Ida szerint népes közönség előtt adták elő a művet Keszthelyen 1817. május 21-én, szereposztással, szóló énekkel, pásztori karral. A grácia öltözetében Dukai Takács Judit is megjelent és a szavalás mellett énekelt is. ${ }^{827}$ Sajnos ezt megerősítő forrásra nem találtam; sem a Haza 's Külföldi Tudósítások, sem a Vereinigte Ofner Pester Zeitung már többször idézett cikkeinek írója nem szól az előadásról és nem szól a versről sem. Ugyancsak nem említi meg az előadást, vagy felolvasást Horváth Ádám Kazinczynak írt, szintén már idézett, május 24-i levelében. A „Helikon I.” kötet közli a verset, de megjegyzésként annyit ír: „Magával hozta 's bémutatta Dukai Takáts Judit Kis Asszony Majus 21-ikén 1817”.

Este a premontrei kolostorban zeneestet szerveztek. Gróf Festetics Ernő klavíron játszott, Rusitzka (Ruzitska) Ignác veszprémi zeneszerző hegedűn, Lehrman József a Georgikon kertészeti tanára flótán. ${ }^{828}$

Dukai Takács Judit erre az ünnepre is saját maga által készített füzetében hozta el verseit. A füzet címlapján a következő felírás: „Keszthelyi Heliconra készült munkáji Takács

\footnotetext{
${ }^{822}$ A vers megtalálható: Péterffy, 1973. 130-140.

${ }^{823}$ Horváth Ádám levele Kazinczynak, 1817. május 24. ; KazLev. XV. 200. ; A levél mellékleteként megküldte a Hyperborei Zsenge kéziratát is.

${ }^{824}$ Simoga György ügyvéd. Veszprém és Somogy megye táblabírája. Több munkája jelent meg. ; Schildbach János Gottlieb pozsonyi polgár. Több munkája ismeretes, melyek közül bennünket leginkább a következö érdekel: DAS FRÜHLIGFEST IN KESZTHELY Leierakkorde SE. EXC. dem hochgebornen Herrn GEORG GRAF FESTETITS von TOLNA k. k. Geheimer Rath \& c. \& c. ZUR HOHEN NAMENSFEIER angestimmt und in tiefster Verehrung dargebracht. v. Ioh. Gottl. Schildbach. am. 24 April 1818. (Fest. K. Hel. Knyvt. Lit. hung. 539/29)

${ }^{825}$ HKT. 1817. 51. és Pest. Zeit. 1817. június 8. ; A két lap tévesen Schildbach János Gottlieb helyett Józsefet ír.

${ }^{826}$ Helikon I., 1818. 103-113.

${ }^{827}$ Péterffy, 1973. 107.

${ }^{828}$ Rusitzka (helyesen: Ruzitska) Ignác. (1777-1833) zeneszerző, karmester. 1800-tól a veszprémi káptalan zenekarának első hegedűse, majd a székesegyház karnagya. Az 1790-es évektől kezdve a verbunkos mestereinek jóvoltából indult fejlődésnek Magyarországon a hegedűművészet. Ennek az irányzatnak legjelesebb képviselői: Bihari János, Lavotta János, Csermák Antal, Rózsavölgyi Márk és Ruzitska Ignác. Lehrmann József 1825-től fogva 20 éven át tanított a Georgikonban, a növénytan, technológia, borászat, szőlömüvelés és kertészet tanára volt. A Pester Zeitung Lehrmannt tévesen a Georgikon kertészének nevezi. (1817. június 8.)
} 
Judithnak. Május 21 dikére 1817 ’ ${ }^{829}$ A címlap belső oldalán pár átlós vonallal áthúzott sor. Az áthúzás oka csak sejthető, ideje ismeretlen, ám a vers magáért beszél, s némi adalékul szolgál az oly sokszor rosszul, vagy tévesen megítélt keszthelyi Helikoni Ünnepek elkötelezettségéröl:

Szép Magyarnak lenni! ’s hát? Magyar Királynak Kiböl hiv Népei kész Atyát csinálnak

Szép Magyarnak lenni! ’s hát Magyar Királynak?

Kit Királynak termett Jobbágyok szolgálnak.

Budán $2^{\text {dik }}$ Júni $1792 . \quad$ Horváth Ádám

A verset Horváth Ádám négy nappal I. Ferenc Budán magyar királlyá való koronázása előtt írta. Semmiféleképpen el nem hallgatható a vers politikai éle és éppen ezért szerfeletti veszélyessége írójára, terjesztőjére és hallgatójára nézve. A füzetben a következő versek szerepelnek:

Felséges Ferdinánd Károly Austriai Fö Herczeg és a’ Magyar Szent Korona örököséhez, ${ }^{830}$

Feld Blumen. Gewidmet Am Geburst Tage der Josephiene gebohren Fürstin von Hohenzollern von Hechingen, vermahlter Gräfin Festetics von Tolna. 14 ${ }^{\text {sten }}$ May 1817,

Pásztori Áldozat. Tekéntetes Horváth Ádám Tábla Biró Urnak, Hazánk Orpheusának születése napjára $11^{\text {dik }}$ Maj 1817. ${ }^{831}$

A versek a Feld Blumen kivételével megtalálhatóak Vadász Norbert idézett müvében. A vers és fordítása megtalálható a már korábban idézett dolgozatban. ${ }^{832}$

\footnotetext{
${ }^{829}$ Ebböl a füzetből is két példány ismert az egyik a keszthelyi Balatoni Múzeum tulajdonában, a másik a Pannonhalmi Főapátság Könyvtárának tulajdonában található (10 a. E. 7/2) A két kézirat teljes egészében megegyezik, kivételt képez, hogy a pannonhalmi kéziratban Horváth Ádám verse nincs áthúzva.

${ }^{830}$ Vadász, 1909 és a Helikon I. kötetekben a vers címe: Hazafiúi szózat Felséges Ferdinánd Károly... stb.

${ }^{831}$ Cséby, 1990. 103-104.

${ }^{832}$ Cséby, 1990. 109-113.
} 
3. 6. 4. A harmadik Helikoni Ünnep: 1818. február 12.

Az ünnepség leírása előtt kell megemlíteni, hogy Berzsenyi Dániel 1817. szeptember 8-án olvasta Kölcsey Ferenc bírálatát verseiröl. Berzsenyit szíven ütötte az ingerült bírálat, amely az utókor szerint sem volt teljesen meggyőző és igazságos. Kölcsey ugyanis egy eltérő költői eszmény alapján, merev klasszicista platformról bírálta a romantika irányába induló Berzsenyi költészetét. Kritizálta a költő provincializmusát, nyelvét és naturalizmusát. Ha Kazinczy nyíltan nem is, de hallgatólagosan egyetértett Kölcseyvel. ${ }^{833}$ Többen, így Döbrentei is túlzónak tartotta Kölcsey ítéletét $\mathrm{s}$ megpróbált közvetíteni a két ember között mindhiába. ${ }^{834}$ Berzsenyi jóval később is fájdalmasan emlékezik vissza a recenzióra. ${ }^{835}$ Mégis elküldi Festeticsnek a gróf által megrendelt ódát, a „Felséges Királyunknak Keszthelyre váratásakor 1817." címüt, amely a királyt volt hivatva dicsérni egy tervezett keszthelyi látogatás alkalmából. ${ }^{836} \mathrm{Az}$ ódából a titkos nemzeti remény sugárzik - mutat rá Merényi -, hogy a királyt is át kell hatnia a „szent honszeretet” hevének, amely jellemző a nagy fejedelmekre. Miképpen a ,jobbágyi tisztelet” is az ily fejedelmeknek jár: hisz a két virtus együtt tesz fejedelmeket és nagy embert. ${ }^{837}$ Berzsenyi a verset levél kíséretében küldte meg Festeticsnek: „, Parancsolatjára Excellentiádnak küldöm az ódát; csekély, de úgy vélem, az okosoknak elég, a nem okosoknak pedig a sok is kevés. Nehéz az illy esetben a középutat eltalálni, s tán mindenkor jobb a kevés, mint a sok. Ha megtudhatom mikor lesz a solemnitás, elmegyek, mert én Excellentiád geniális lelkének munkáiban nagy gyönyörüséget találok, s mert igen óhajtom hazámnak atyját hazámnak legnemesebb fiával együtt látni. - „ ${ }^{838} \mathrm{De}$ Berzsenyi soha többé nem utazott el a Helikonra és az ifjú László gróf sem folytatta az apja által megkezdett találkozók megszervezését. Berzsenyi távolmaradását betegségének, hypohondriájának erősödésével magyarázhatjuk. Pedig ha a király eljön a Helikonra és

\footnotetext{
833 Merényi, 1966. 308-311.

${ }^{834}$ Berzsenyi ÖM., 1979. 836.

${ }^{835}$ Berzsenyi Költsey címü verse.

Költsey meg mérted lattal, póznaval itzével

Lelkemet és keskeny ürbe, időbe dugád.

Ah, de segélj rajtam, katrotzban kotlani készül!

„, Tollat az orrába!' Zapokat adjon ugy e?

(Nikla, 1827) (Berzsenyi ÖM., 1979. 144.)

${ }^{836}$ Berzsenyi ÖM., 1979. 133. Majdnem egy év után Berzsenyi elküldte Festeticsnek a Felírás (A’ királynak Keszthelyre váratására) címü rövid epigrammaszerü versét is, amely 1956-ban került elő a Festetics Levéltárból. ${ }^{837}$ Berzsenyi ÖM., 1979. 796.

${ }^{838}$ Berzsenyi Dániel Festetics Györgynek, 1817. szept. 15. ; Berzsenyi ÖM., 1978. 486.
} 
Berzsenyi felolvashatja versét, fontos üzenetet közvetített volna az uralkodónak: a királynak szeretnie kell a nemzetet, legyen ö is jó hazafi!

A harmadik Helikoni Ünnepség csupán egy napig tartott, tudjuk meg a korabeli sajtó tudósításaiból, amelyik lelkendezik: „Keszthely, hol a’ hasznost a’ széppel olly ízléssel öszve tudják párositani, hol a’ Nemzet’ boldogsága és ditsősége alá egyformán szántanak, és a' hol soha a’ Felséges Uralkodó Ház eránt tartozó tiszteletnek kimutatására elő adódott alkallmatosság használatlan maradni nem szokott, most is úgy inneplette Felséges urunk születése napját, hogy effélét nem minden helyekről olvashatunk" ${ }^{839}$ Akármennyire is lelkes a tudósító, számunkra mégis egy, a cikkíró által ugyan megemlített, de nem hangsúlyozott esemény a fontos. Az irodalom és művelődéstörténet szempontjából legnagyobb jelentőségü eseményre ugyanis itt került sor. A „Túladunaiak” Kazinczy Ferenc tiszteletére fát ültettek. Az ünnep rövidségének okára Horváth Ádám világított rá Kazinczy Ferencnek írt levelében: „Gr. Festetics ámbár beteg vólt, 12-a Febr. meg-tartatott a’ Helicon most is, de tsak Ruszek Apát és Takáts Judit voltak a munkás tagok." ${ }^{\text {,40 }}$

Az ünnep nagymisével kezdődött, de az ,ájtatos buzgó tzeremonika kívül, tudományos innep tartatott a' Georgikonban" - írja a Magyar Kurír. ${ }^{841}$ A felolvasások tehát a szokott helyen voltak, a Georgikon nagytermében. Először Phaler Károly a „Magyar Törvény Doktora”, a Georgikon archonja, a császár „fejedelmi virtusairól” szólt latinul, különösen kiemelve a császár és a császárné legutóbbi utazásait a birodalomban, amit „a’ Kormánya alatt lévő legtávulabb Tartományaiba legnagyobb maga el szánásával tenni méltóztatott”. ${ }^{842}$ Ezután Dukai Takács Judit magyar nyelven olvasta fel elégiáját „József Cs. Kir. Fő Herczeg, Magyarország' Nádor Ispánja Hitvesének, Hermina Herczeg Asszonynak halálára” címmel. Ezután a helybeli diákok, hallgatók magyar, latin és német nyelven prózát, verset mondtak. Legelébb Festetics Ernő és Leó grófok léptek az emelvényre, majd a pristaldeum diákjai következtek. Gosztonyi Sándor magyar nyelven mondta el „Felséges Nádor Ispány Urunk István Cs. Kir. Herczeg fiának születésére" címü müvét, amely a Hazai 's Külföldi Tudósítások cikkírójának a legjobban tetszett az összes felolvasott mü közül. Öt Szigethy József követte. ${ }^{843}$ A gazdaságbeli praktikansok közül Magger János, Gertinger Adolf,

\footnotetext{
839 Lásd: MK. 1818. I. 18. sz. 155. ; HKT. 1818. I. 16. sz. 121-122.

${ }^{840}$ Horváth Ádám Kazinczy Ferencnek, 1818. február 26. ; KazLev. XV. 489.

${ }^{841}$ Magyar Kurír, 1818. I. 18. sz.

${ }^{842}$ HKT. 1818. I. 16. sz. 121.

${ }^{843}$ Gosztonyi Sándor, 1796-ban született a Zemplén megyei Hrabóczon. A Georgikonba 1817-ben iratkozott be. Jogi tanulmányokat Kassán végzett, az 1817/18-as tanévben pristaldus volt, ezt követően a keszthelyi uradalomban prisdaldus curialis. 1824/25-ös tanévben a Georgikon jogtanára. (Csiky, 1897. 54.), Szigethy József 1796-ban született a Sopron megyei Ladonyban. A Georgikonba 1817-ben iratkozott be. (Csiky, 1897. 77.)
} 
Fleischer Sámuel, Németh Péter, Fábriczy László, a gimnázium humán osztályából Vadnay Lajos és Simon Mihály szerepeltek. ${ }^{844}$

A felolvasások után Festetics jutalmakat osztott ki 800 forint összegben. A Magyar Kurír és a Hazai 's Külföldi Tudósítások négy ,jelesebb férfit” tud, aki a tudományok művelése terén különösen ismertté váltak. Vadászt Norbert Dukai Takács Juditról írt művében tételesen közli az összegeket, valamint a neveket is. ${ }^{845}$ Ebből értesülhetünk, hogy Berzsenyi Dániel 200 forintot, Virág Benedek 200 forintot, Fejér György 300 forintot, míg Dukai Takács Judit „úgynevezett gombostüre”846 100 forintot kapott a gróftól. Így annak ellenére, hogy Dukai Takács Judit kivételével egyik kitüntetett sem jelent meg, a mecénás gróf szép summákat osztogatott. ${ }^{847}$ Döbrentei Gábor úgy tudta, hogy Rőtth fiscalis elárulta Fejér Györgynek, aki akkor a pesti egyetem professzora volt, hogy a gróf ezen túl minden évben nyolcszáz forintot oszt írói honoráriumokra. ${ }^{848}$

Ezt követően a gróf vendégeit meghívta ebédre. Ebéd után került sor a Georgikoni Fás Kertben a faültetésre. Festetics gesztust gyakorolva és bizonyítva, hogy elöítéletei nincsenek: Kazinczy Ferenc és Csokonai Vitéz Mihály tiszteletére, emlékére ültettek fát a jelenlévők. Nem akarunk túlzott jelentőséget tulajdonítani a faültetésnek, de bátorkodjunk feltételezni azt, hogy hozzájárult az ortológusok és neológusok közti, még egy darabig ugyan

\footnotetext{
${ }^{844}$ Magger (Mager) János, 1796-ban született Szepes megyében, Ruszquinotzon. 1817-ben lett a Georgikon hallgatója. (Csiky, 1897. 65.) A HKT. 1818. I. 16. sz. helytelenül Jánosnak nevezi. Fleischer Sámuel, 1797-ben született Szepes megyében. 1817-től a Georgikon hallgatója. (Csiky, 1897. 52.) Fábriczy László, KisHartyánban, Pest megyében született 1797-ben. 1817-ben iratkozott be a Georgikonba. (Csiky, 1897. 51.) Simon Mihályról közelebbi adatot nem sikerült megtudnunk.

${ }^{845}$ Vadász, 1909. 33.

${ }^{846}$ Dukai Takács Juditnak több alkalommal kedveskedett Festetics egy-egy szép ajándékkal. A legismertebb az a porceláncsésze, amelyre a költőnő miniatür portréját festette a gróf. Annak ellenére, hogy számos helyen ezt a portrét közlik, az eredeti lelöhely, azaz a csésze számunkra ismeretlen helyen van. Az ajándékok között kell megemlíteni azt a karneolköves, gyémántokkal díszített arany pecsétgyürüt is, amely szintén Festetics ajándéka volt. (Vö.: Vadász,1909. 33.)

${ }^{847}$ A Festetics által kiosztott összegek nagyságát csak abban az esetben lehet megérteni, ha tudjuk vásárlóerejüket. Ebben az időben a zalai árak a következök voltak: Egy rövid férjfiu Mentének, Bárány bőrbül való bélésétül és vörös róka nyakkal való prémezésétül: $9 \mathrm{Ft}$. Egy legnagyobb és legjobb tiszta fejér hosszú Szür helyesen elkészítve: 4,30 Ft. Egy közönséges puska ágyával és hozzá tartozándó minden szerszámmal együtt: 6 Ft. Kaszás vagy kazal rakó napi bére 20 Krajtzár, tartás nélkül. Petrencehordó és baglázó napi bére 15 Krajtzár, tartás nélkül. Szőlőszedő napi bére 6 Krajtzár, tartás nélkül. Szőlőkapás napi bére 20 Krajtzár, tartás nélkül. De a cselédek évi bére is 14-26 Ft.-ig terjed, de ehhez hozzá kellett számítani a természetbeni juttatásokat. A legnagyobb bért a legjobb szakácsné kapta aki hideg és meleg ételeket és süteményeket is tud készíteni, évi bére 35 Ft. (Vö.: A' mester emberek kézi mivek, és egyéb szerek árának nem különben a 'tselédek bérének Tekéntetes nemes Zala Vármegyében az 1813-dik Esztendöben Böjt-elö Havának 8-dik napján Zala Egerszegi MezöVárosban folytatva tartott köz Gyúlése alkalmatosságával megállapétott limitátiója. Győrben, özv. Streibig Józsefné betüivel.) Lelöhely: Fest. K. Hel. Knyvt. Miscell. Nova Tom. 5. Acta varia Zaladiensis.

Összehasonlításként közöljük az ipari munkák 1813 évi árszabását Győr vármegyében: Egy pár legnagyobb Kordován, vagy hal zsirral készített Borju bör Zsozma selyem Sinorral: 4,40 Ft. Egy pár Szolgáknak való legnagyobb Tehén bör Tsizma: 3 Ft. Egy selyem Posztó mentének két felül gombkötő munkára nyári bélléssel a' varrástul 1,40 Ft. Búza virág szinre föstött vászonnak réfétül 15 Krajtzár, Jó föstékkel föstött gyapjunak fontjátul 30 Krajtzár. (Száva, 1896. 247-251.)

${ }^{848}$ Berzsenyi ÖM., 1842. 93.
} 
fennálló, feszült viszony oldásához. Kazinczy véleménye Festeticsről ekkorra már teljesen megváltozott. Meghatódva köszöni meg a grófnak iránta való jóindulatát:

„Nagy Méltóságú Gróf!

Kegyelmes Uram!

Az-a’ figyelem, mellyet erántam ezidei innepén Keszthely mutatott, engem egészen váratlanúl ére: nem hittem, hogy akár a’ Balatoni Helikon, akár annak nagylelkü Alkotója méltónak ítélhessen e’ megtiszteltetésre, mely az ott meg nem jelent Írók köztt nekem jutott legelébb. Melly kész voltam volna én megosztani az új Olympia' pályaágát két barátommal, kiket szívem forrón szeret - Virággal és Kissel! De tisztelem Excellentiádnak okait, ha nem értem is, 's köszönöm a' legforróbb hála' köszönetével megbecsülhetetlen kegyességét. Méltóztassék elhinni Excellentiád, hogy annak a’ nagyragyogású polgárnak javalása, kit annyi érdemek tevének halhatatlanná közöttünk és az egész Európa előtt, nekem kedvesebb minden bérnél, mellyet a' szerencse ollykor ingyen ád, ollykor gondatlanúl még hullogat is. Bár maradékink, kik érdemeinket igazábban fogják megszabni mint a’ jelen kor, javalhassák e’ tettet! bár későbbi dolgozásaim méltónak kiálthassanak e’ szerencsére, mellyet most egyedül az Excellentiád' jóságának köszönhetek!

Keszthelyhez csatolva e' kegyesség által, igyekezni fogok e' nyáron megjelenhetni Excellentiád előtt, hogy végre ne legyen okom pirulni, hogy soha nem láttam azt a' nagy férjfit, a' kinek emlékezete örök áldásban lesz a' Nemzet előtt, 's annak mások által is irígylett alkotását. Hat testben és lélekben ép gyermek' atyja lévén, 's elfogva ezeknek nevelési gondjaik által, e' szerencse még eddig nem lehete enyém; illő, hogy azt magamévá tegyem, 's Kisfaludit, és az én Berzsenyimet 's a' szeretetre-méltó Malvínát, meglássam; meglássam Szigethet és Csáktornyát, hol a’ két Zrínyi a’ Dicsőségnek élt. Az illyenek’ látása alatt emelkedik a' szív, 's ez az érzés az enyémből által fog menni a’ másokéba.

Maradok a' leghívebb tisztelettel

Excellentiádnak

alázatos szolgája

Széphalom, Martzius 25d. 1818.

Kazinczy Ferenc" ${ }^{849}$

\footnotetext{
${ }^{849}$ Kazinczy Festeticshez írt levelének szövegét Kis Jánosnak címzett leveléböl vettük. Ott így ír Kazinczy: „Kedves Barátom! Én tehát Keszthelyi ember vagyok! - Óhajtottam volna látni képedet, mit mondál erre, midőn a' hírt legelébb meghallottad! - az az mit gondoltál, mit mondottam én erre, midőn a' hírt meghallám. - Én úgy hiszem, hogy te engem eléggé ismersz. Halld feleletemet, minden változtatás, minden kihagyás nélkül" (Kazinczy Ferenc Kis Jánosnak, Széphalom, 1818. március 29. Közli: KazLev. XV. 538-539)
} 
A levél nagy jelentőségü és Festetics éleslátását dicséri. Tudjuk, hogy a faültetés nem jelentette az ortológusok és neológusok közötti azonnali egyetértést, hisz még ezt követően is azt írja Kazinczy Döbrenteinek, hogy „rettenetes az a’ düh, a mellyel erántam Tuladuna viseltetni meg nem szün". ${ }^{850}$ Nem tudni milyen forrás alapján, de Váczy János 1886-ban megjelent dolgozatában azt fejtegeti, hogy ,a gróf akarata ellenére, az 1818 februári ünnepélyen már az ő (ti.: Kazinczy) emlékére is ültettek egy szál csemetét”. ${ }^{851}$ Nem érthetünk egyet ezzel a megállapítással, s csak megmosolyogni való az a feltételezés, hogy Festetics birtokain a gróf akarata ellenére bármi is történhetett volna.

Kazinczy azonban boldog és elégedett, Festeticsnek írt levelét másolatban elküldte Kis Jánosnak és Döbrentei Gábornak is. ${ }^{852}$ Kisnek írt levelét a következő felkiáltással kezdi: „Én tehát Keszthelyi ember vagyok! - Óhajtottam volna látni képedet, mit mondál erre, midőn a' hirt legelébb meghallottad!” Döbrenteinek a grófot dícséri: „Festetics érdemli azért a' magasztalást, a' miért magasztaltatik.” Ez a véleménye Festetics halálát követően sem változott, hisz azt írta Buczy Emilnek: „,...ki ne örvendjen az ollyan ember’ kegyességének, a' kivel a' Haza kevélykedhetik?" 853 Ám az egész faültetés ceremóniáját nem ismerve gyanakszik a keszthelyi faültetés kapcsán: „Még nem tudom, az én fám nem bodza e. Sem Horváth Ádám, sem az Ujságok, sem a’ Tud. Gyüjt. Martziusi darabja nem szól róla, nem nevezi-meg." - írja Döbrentei Gábornak. Azért mégiscsak boldog és örömmel újságolja a hírt Szentgyörgyi Józsefnek is: „'S nekem Keszthely fát ültete! - Épem ez órában köszöném-meg Gr. Festeticsnek, 's kimondám világosan, hogy ezt nem vártam. Tavaly négy jelen volt Iró koronáztatott-meg; 's ha akkor mások is jelen voltak volna, azok is ültettek volna fát magoknak: én a' meg nem jelentek köztt első kapám e’ megtiszteltetést. Miért én? kit Tuladuna nem szeret." ${ }^{\text {854 }}$ Számos levelében mégis kitér a keszthelyi ünnepekre és Festeticsre, mindenkivel hasonlót közöl, Festeticset tiszteli és nem csak az udvariasság kedvéért. Egy ismeretlennek a következőket írja: „Én Gróf Festeticset olly szentül tisztelem a’ mint festem. Ki nagy közöttünk, 's ki volt nagy közöttünk, ha ő nem az? Illy férjfi kegyessége' jelét venni, bizonyosan igen nagy szerencse; én csak azt is sajnálom sőt szégyenlem hogy őtet soha nem láttam". ${ }^{855}$ Elő - előjön Kazinczy gondolataiban a fa neme, mert nem mindegy, hogy milyen fát kap a koszorús költő, a mester: nemes, avagy nemtelen növényt? Szentmiklóssyval

\footnotetext{
${ }^{850}$ Kazinczy Ferenc Döbrentei Gábornak, 1818. május 21. ; KazLev. XVI. 41.

${ }^{851}$ Váczy, 1886. 530.

852 Kazinczy Ferenc Kis Jánosnak, 1818. március 29. ; KazLev. XV. 538-539.; Kazinczy Ferenc Döbrentei Gábornak, 1818. március 29. ; KazLev. XV. 542-543.

${ }^{853}$ Kazinczy Ferenc Buczy Emilnek, 1819. március 18. ; KazLev. XVI. 334.

${ }^{854}$ Kazinczy Ferenc Szentgyörgyi Józsefnek, 1818. március 29. ; KazLev. XV. 541.

${ }^{855}$ Kazinczy Ferenc ismeretlennek, 1819. március 6. ; KazLev. XXIII. 269.
} 
tépelődve közli: „,mely nemü fát ültettek nekem, nem tudom, ’s bár Malvina ültette volna! Ha valaha meglátom Keszthelyt; 's azt találják kivánni, hogy ültessek valamit, én Báróczinak ákátzot, Daykának egy Lonicera tartaricát ültetek, nem magamnak semmit. Festeticsnek meg fogom köszönni hajlandóságának ezt a jelét” ${ }^{856}$ Majd azzal ostromolja Horvát Ádámot, „nem írhatnád-meg nekem, melly nemü fát vagy bokrot ültet - nekem is Csokonainak is Keszthely Ura? Mi is sorbus aucupariát kapánk-e? mint ti. De ha erre felelsz, tudast velem kételkedést nem szenvedő bizonysággal". ${ }^{857}$ Horváth betegsége miatt nem ment ki, a kastélytól viszonylag messze lévő, faültetés színhelyére, így ő is csak Dukai Takács Judittól értesülhetett - később - az eseményekről. De Horváth válaszát sürgetve Kazinczy újból ír neki: „Festetics gyönyörü fényben ragyog már is. Ki tett ennyit a Nemzet fényéért? A’ ki így fénylik, az nem bánom, sőt akarom hogy teljes fényében ragyogjon. Csak azt nem szeretem, ha hamis fénnyel ragyog valaki, mert a hamis fény árt. Miattam ugyan akár igaz fényben, akár hamisban ragyoghat valaki, mert nekem vele - sem az eggyikkel, sem a' másikkal - nem árt, sőt az elsővel használ is - az igazzal. Nagyon sajnálom, hogy az idén meg nem láthatom Keszthelyt. Bár megláthassam valaha! S inkább óhajtom magát látni azt a valóban nagy embert, mint az a' nagy helyet. Bár trónusra is ültették volna a' Végzések! Hol volnánk ugy! Most már meg fogod nekem irhatni, melly nemü csemete van nékem ültetve a' Keszthely ligetei között, 's erre nagyon kérlek. Nem hiúságból kérdem ezt, hanem azért, mert hálátlan volnék, ha ez nem interesszálna". 858

Horváth most már gyorsan válaszolt: „Azért késtem levelemmel ekkoráig, hogy a’ Keszthelyi fa felül tett kérdésedre bizonyosabbat felelhessek: Nem láthattam én azt magam, mert a' társaság ebéd után gyalog ment a' kertbe; én pedig fiatalabb ideimben, mikor még a' lábammal kerestem mind a' mindennapi, mint /!/ a' jövendőre való kenyeremet, úgy legyalogoltam magamat, hogy kétszáz lépés is sok kivált étel után”. A levél további részében megnyugtatja, hogy ő is madárberkenyét (Sorbus aucuparia) kapott, és ennek megírja okát is: „Februáriusban nem minden fát lehet bizonyos reménységre ültetni, a’ mint hogy Gyöngyösié ki is száradt; de mást tettek helyébe, ugy hogy az idei Innepen ismét élt". ${ }^{859}$ Horváth a levélben még megírja, hogy „Keszthelyen nagyon vártt vendég voltál: leveledet a’ Groff nagy örömmel vette 's velem közleni akarta, de reá nem akadott. Gondosan tudakolta tölem birtokaidat 's jövedelmedet; mert úgy voltál előtte festve, mint szegény; én mindenik

\footnotetext{
${ }^{856}$ Kazinczy Ferenc Szentmiklóssy Alajosnak, 1818. március 28. ; KazLev. XXIII. 264.

${ }^{857}$ Kazinczy Ferenc Horváth Ádámnak, 1818. május 31.; KazLev. XVI. 52.

${ }^{858}$ Kazinczy Ferenc Horváth Ádámnak, 1818. július 2.; KazLev. XVI. 105.

${ }^{859}$ Horváth Ádám Kazinczy Ferencnek, 1818. július 7. ; KazLev. XVI. 106-107.; Gyöngyösi fáját az első Helikonon ültették, 1817. február 12-én.
} 
extremumot tagadtam, de bizonyost mondani nem tudtam". ${ }^{860}$ Ha Horváth jobban tájékozott, Festetics pénzt küldött volna Kazinczynak az útra, aki ebben az időben valóban anyagi gondokkal küzdött. Így azonban elmaradt a grófi támogatás. Kazinczy lelkében végképp megnyugodott és önmagában is megfogalmazta, hogy mindenképpen ellátogat a keszthelyi Helikonra.

A harmadik Helikon 1818. február 12-én este zeneesttel zárult, amelyet valószínüleg a premontreiek kolostorában tartottak. A korabeli tudósító külön kiemeli Festetics Ernő gróf klavír-müvészetét.

Nem találtuk meg Dukai Takács Juditnak a harmadik Heikonra írt versfüzetét. Talán nem készített, amint azt megtette 1817 februárjában és májusában, vagy 1818 májusában. (1819-es füzetet sem találtunk.) Sem a Balatoni Múzeum, sem a Pannonhalmi Főapátság nem tud róla. Esetleg lappang a kézirat. Éppen ezért csupán következtetésekre hagyatkozhatunk Dukai Takács Judit „Serkentés a Magyar Muzsákhoz „861 című versével kapcsolatban. Addig amíg Vadász Norbert kötetében minden dátumot híven közöl, annál a versnél csupán a következöket írja: „Mondatott a halhatatlan Festetics György keszthelyi Helikonjában”. A vers nem található az ismert kéziratos füzetekben, viszont utalás van benne az első 1817 februári Helikonra:

Nézzetek túl az ég kárpitjain Helikoni társim! - ott az érdem bére

Kisfaludy dicsőségkarjain Halhatatlanság szállt Berzsenyi nevére.

Lelkesedés égi etherében

Köztük lebeg Horváth, magyar Orfeusunk,

Mosolyogjon Írigyink szemébe, Egy alakban őriz három geniuszunk.

Négyesy már többször idézett tanulmányában sem írja meg a költemény elhangzásának idejét. Egyetlen korabeli újság nem számol be előadásáról. Gyakorlatilag a vers tartalma sem ad konkrét eligazítást. 1819-ben férjes asszonyként, talán emlékeivel küszködve írta meg a verset, vagy még a friss élmény alapján 1817-ben, s az 1818-as

\footnotetext{
${ }^{860}$ Horváth Ádám Kazinczy Ferencnek, 1818. július 7. ; KazLev. XVI. 110.

${ }^{861}$ Vadász, 1909. 151-153.
} 
Helikonra küldte be, vagy vitte el? Megoldást az jelentene, ha megtalálnánk az 1818. februári füzetet, addig azonban csak feltevésekre alapozhatunk. Mindkét változat elképzelhető. A nem szerelmi házasságot kötött asszony búcsúját a Helikontól, vagy az ünnepelt Malvina Helikon fölötti örömét olvashatjuk a versben? Mindkettőre találhatunk példát. Úgy gondoljuk azonban, hogy a vers keletkezésének története mellett éppoly fontos az, hogy a Helikoni irodalom egyik kiemelkedően szép verséröl van szó, amelyet mind a mai napig elszavalnak az újkori Helikoni Ünnepségek nyitórendezvényein.

3. 6. 5. A negyedik Helikon Ünnep: 1818. május 20.

A májusi ünnepre Festetics egészségi állapota romlott. „Ö most is beteg, a Drávai Győzedelmi kapunál sem jelenhetett meg, hanem fiját küldötte...”- írta Horváth Ádám Kazinczynak. ${ }^{862}$

A Hazai 's Külföldi Tudósítások három részben közölte az ünnepek lefolyását. ${ }^{863} \mathrm{~A}$ szerző, Kutsár István, számos vendéggel együtt már május 19-én Keszthelyre érkezett. Elsősorban Somogy, Zala, Vas és Veszprém vármegyékből érkeztek a gróf meghívására, aki gondoskodott a megérkezők elszállásolásáról is. Kultsár egy mondattal a várost is jellemzi: „A’ Kastélytól délre nyúlik a’ város, és virágzásra emelkedő nagy lépésekkel szépül. Lakosi munkás Mesteremberek, Szőllőmívesek és Szántóvetők". ${ }^{864}$ A Helikon műsorának leírását, amennyiben más forrás nincs megjelölve, a Hazai 's Külföldi Tudósítások alapján tesszük meg.

Május 20-án reggel nyolc órakor Festetics György László fiával egyetemben a Georgikon nagytermébe ment vendégeivel együtt, ahol a pódium és a nézőtér már feldíszítve várta az ünnepre érkezőket. Először Phaler Károly a Georgikon jogi professzora emelkedett szólásra és orációjában a „Földmívelés eredetéről, jelesb előmeneteleiről és a’ régi, ’s ujabb nevezetes Földmívelőkről” szólt. A nyitóelőadást követően a vizsgákra került sor. A georgikoni praktikánsok közük Guttmann András és Gertinger Adolf tettek évzáró, illetve tanulmányaikat záró vizsgát. A vizsgabizottság Petrovits János „oeconomia” professzorból,

\footnotetext{
${ }^{862}$ Horváth Ádám Kazinczy Ferencnek, 1818. július 7. ; KazLev. XVI. 110.; Arról van szó, hogy Ferdinánd kir. Főherceg, Magyarország hadi fökormányzója feleségével egyetemben olaszországi útjáról Klagenfurton keresztül Bécsbe, majd Sopronba érkezett. 1818. július 2 -án fogadták a föhercegi párt a győzelmi kapunál világi és egyházi méltóságok, közöttük gróf Festetics László, aki betegeskedő apját képviselte.

${ }^{863}$ HKT. 1818. I. 44. száma, 48. száma, és az 51. száma.

${ }^{864}$ HKT, 1818. I. 44 sz. 346.
} 
Jánossy József „,mathesos” professzorból, Dr. Gerhard Pál ${ }^{865}$ „veterinariae” professzorból és Asbóth János igazgatóból állt. A vizsgáztató tanárok kérdéseire a diákok „,egész készséggel helyesen megfeleltek" - tudósít Kultsár István. A praktikánsok után a jogászok vizsgája következett ahol is Sényi László (Gábor?) ${ }^{866}$ prisztaldeumi vizsgát abszolvált. A vizsgáztatók Phaler Károly professzor és Matkovits (Markovits) „fiscalis” voltak. ${ }^{867}$

Asbóth János a Georgikon igazgatója két előadást tartott. Az egyiknek címe: „,Mi módon lehessen gyarapitani a' Magyar Országi Mezei Gazdaságot”. A másiké: „,A' Krumpli

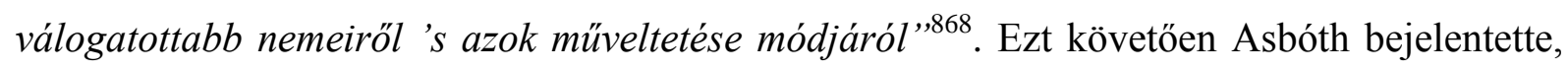
hogy a „Bátsi Canalis Administratiójához hívták meg eggyik igazgató assessornak” és elbúcsúzott a jelenlévőktől. A közel húsz éven keresztül hatalmas szervező, pedagógiai és tudományos munkát végző Asbóth távozása érzékenyen hatott a Festetics uradalom direkciójára. Kultsár idézett cikkében meleg szavakkal búcsúztatja a Helikon agilis szervezőjét, az ünnepek lelkét: „,...Ásbóth Director Úr számot adott a' gyülekezetnek, 's mind Ö Excellentiájától, az Intézet Elöljáróitól, és a' Vendégektől bútsút vett (...) Az egész gyülekezet érzékeny tisztelettel vette ezen érdemes Hazafinak kijelentését, 's annál nagyobb indulattal betsülte, mivel a'Georgikoni Intézetben 17 esztendők óta tett érdemei mindnyájoknál fris emlékezetben vannak 's ő távúl létében is a'hoz való hajlandó indúlatját, 's kész szogálatját szívesen megigérte". ${ }^{869}$

Ezután a Helikonra, illetve a Georgikoni vizsgára meghirdetett pályázat beérkezett munkáinak felolvasása következett. A pályázat címe: „Miböl áll a Georgyikonnak (sic!) munkás ereje”. ${ }^{870}$ Saját munkáját Palleta György „inspector”, Petrovits János „gazdaságbéli professor” és Sövegjártó Kristóf „Szetgyörgyi Preceptor” ismertette. A pályázatok

\footnotetext{
${ }^{865}$ A vizsgáztatók: Petrovits János 1791-ben született a Nyitra megyei Holicson. A jogot Pozsonyban végezte. 1813-1814 között a Georgikon hallgatója. 1816-ban itt tanársegéd. 1817-től a mezőgazdaság és technológia tanára, majd a rákövetkező évben a természetrajzot is átvette. 1819-ig tanított Keszthelyen. Dr. Gerhard Pál orvostudor az 1817/18-as tanévben az állatgyógyászat helyettes tanára. A rákövetkezö évben az élettan és a vegytan rendes tanára. (Csiky, 1897. 29.)

${ }^{866}$ A vizsgázók: Guttmann (Gutman) András 1792-ben született Magyaróváron, Moson megyében. 1815-ben iratkozott be a Georgikonba. (Csiky, 1897. 54.) ; Sényi László. A HKT 1818. I. 44. száma a 347. oldalon Séllyey-t ír, majd ezt elírásnak tünteti fel ugyanezen évfolyam 48. számában (378. oldal) és a helyes Sényi nevet írja. A Magyar Kurír 1818. I. 47. száma Széllyey-t ír és megjegyzi „a’ Budai Ujság szerint Sényi László Úr”. A Csiky 1897-es Emlékkönyvben Séllyey, vagy Széllyey névvel nem találkoztunk. Találtunk egy Sényit, de nem Lászlót, hanem Gábort. E szerint Sényi Gábor zalaegerszegi születésű fiatalemberről, aki 1815-ben irtakozott be a Georgikonba. Mivel az évszám egyezö, valószínüleg róla van szó. (Csiky, 1897. 74.) Ezt az adatot veszi át: Georgikon 200. II. 35.

${ }^{867}$ Tévesen szedte a HKT nyomdásza és nem Matkovics, hanem Markovits Sándor „Dirigens Fiscalis”-ról van szó. Lásd: MOL Fest. Lvt. P.279 287 k. Ternio Primus Protocollum Determinationum. 1817. 319/1164

${ }^{868}$ Az Asbóth által aláírt tervezet ezt a címet a következöképpen rögzíti: , A Kolompér nevezetesebb nemeiröl és miveléséröl valóértekezés". (1818 ${ }^{\mathrm{ik}}$ esztendei Május hó $20^{\mathrm{kán}}$ a' Georgikonban tartott Mezei látogatás alkalmatosságával előadott különbféle értekezéseknek lajstroma.) MOL. Fest.Lvt. P 274. 18 cs. 257.

${ }^{869}$ HKT. 1818. I. 44. sz. 347.

${ }^{870}$ HKT. 1818. I. 38. sz.
} 
elhangzását követően a többi tudományos dolgozat ismertetésére nyílt lehetőség. Leibitzer János csurgói számtartó „A gazdaságbeli különbféle Arányosságról; a' lehetséges Kéméllésekröl, és a' Jutalomadásokról” tartotta meg értekezését. Kehrn Vilmos (Wilhelm) „Fő Inzsellér és a' Georgyikonnak jövendőbeli Directora” az „Épitésre való útmutatás” címü munkáját olvasta fel. Rumy Károly György „Karloviczi Director” „A’ Szeremi Szöllök különbféle fajtáiról”, Schubert József „Kapniki Bányász Actuarius” pedig „Az Oláh istállókról” és „Miként kellenék a' terh hordó szekereket legjobb móddal alkotni?” címmel tartott előadást. Utoljára Bene Gergely ismertette dolgozatát „Leírás a’ Franczia Országi nevezetesebb kertekről" címmel. ${ }^{871} \mathrm{Az}$ újság nem írta, de az értekezések lajstromában szerepel még egy Madas János nevü miskolci postamester, aki „Egy orvos kovátsról” számolt be. $^{872}$

Az ismertetett dolgozatokon kívül más írások is beérkeztek, amelyeket azonban az idő rövidsége, valamint a másnapi Úrnapi ünnepre való készülődés miatt nem ismertettek, annál is inkább, mert hátra volt még a assessori címek kiosztása. 1818 májusában a Haza 's Külföldi Tudósítások ${ }^{873}$ cikke szerint a következőket tisztelték meg:

Gróf Salm Hugó,

Báró Duka, hadi tárnokmester,

Báró Stift, státus tanácsos,

Fejér György, a Győri Tud. Ker. fő directora,

Wittmann Mihály, Albert kir. hg. uradalmainak regense,

Ruszek József, apátplébános,

Villax Ferdinánd, cisztercita szerzetes, polányi adminisztrátor,

Hadaly Károly, kir. tanácsos, a pesti egyetem mathesos professora,

Kultsár István, a Hazai ’s Külföldi Tudósítások szerkesztője,

Wango Kajetán, báró Mandel titoknokja,

Brunkala Roman, a pesti egyetem állatorvoslástan professzora,

Nagyváthy János,

\footnotetext{
${ }^{871}$ Bene Gergely a HKT. 1818. I. 48. sz. szerint Georgikonban végzett. Erre vonatkozó adatot a Csiky-féle Emlékkönyvben nem találtam. Az újság szerint ausztriai, franciaországi és németországi tanulmányúton járt a Georgikont befejezve és ,jelenleg Harlemben, Hollandiában van”. A Directorátus feljegyzéséből azonban tudjuk, hogy „Bene Gergely Kertész Legény” 1817-ben Ludwigsburgban volt és onnan kérelmezte, hogy a gróf párizsi útját finanszírozza. A kérelem mellett Asbóth megjegyzését találjuk, neveztessen azt, hogy Benét eddig is a gróf segítette, s most ,,igyekezzen önnön érdeme által szerentséjének ki-menetelét eszközölni. (MOL Fest. Lvt. P 279288 k. Ternio Secundus Protocollum Determinationum. 1817. 32/81. 32/32) Végül - úgy tủnik Bene mégiscsak kiment Franciaországba.

${ }^{872}$ MOL Fest. Lvt. P 27418 cs. 257.

${ }^{873}$ HKT. 1818. I. 51. 402.
} 
Szajdenschwarz Jánosa mérnök,

Szlemenics Pál, a pozsonyi egyetem jogtanára,

Pfahler Károly.

Az adományozások után Asbóth János bejelentette, hogy Festetics két személy részére 200 - 200 forintos jutalmat ad át. Nagyváthy Jánosnak „,A’ szorgalmatos mezei gazda a' Magyarországban gyakoroltatni szokott gazdaságnak rendjén keresztül” (I.-II. kötet. Pest, 1791) címü alapmunkájáért, Kultsár István szerkesztőnek pedig azért, mert Pethe Ferenc „Nemzeti Gazda”-jának megindulásáig (1816), „Gazdaságbéli Gyüjtemény” név alatt kiadott Toldalékban gazdasági jellegü cikkeket publikált, és azóta is folyamatosan közli azokat. Ezután báró Pászthory Menyhárdnak nyújtották át a Georgikoni láncot, amit a báró magyar nyelvű értekezésével köszönt meg. Az előadás címe: „Miképpen kell viselnie magát a' Magyar Gazdának, hogy napról napra inkább szükülő Pénz fogyatkozását ne érezze” ${ }^{\text {874 }}$. A tudósító szerint „Nagy figyelmetességgel halgatta ezt az egész Gyülekezet mind fontos tárgyára, mint lelkes előadására nézve. (...) Valamint ez méltó a kőz figyelmére, úgy az Országnak tellyes isméretéből merített észrevételei, minden jelenlévőknek tetszését annyira kifakasztották, hogy az előadást köztapsolás, és magasztalás követte" ${ }^{875}$ A tudományos értekezések és díjak átadása után a Zeneiskola növendékei adtak rövid koncertet, majd a versek és prózai müvek felolvasására került sor.

Kazinczy nem tudott eljönni, bár kapott meghívót. Úgy tünik keszthelyi útjait fátumszerüen kísérték balszerencsék. Most jég verte el vetését, lovai megbetegedtek olyannyira, hogy sorra kellett őket lövetni. Erre a sorsra jutott Wesselényi bárótól kapott kedvenc lova is. ${ }^{876}$

A költők közül Dukai Takács Judit lépett először a pódiumra és két versét szavalta el. Az első „A Keszthely Vidék”,877, a másik a „Búcsúzás Tekintetes Ásbóth János Prefectus Urtól ${ }^{, 878}$. Az előbbi vers a természetleírás jó példája. Keszthelyt a „,szent természet remek csodájá"-nak nevezi. Megénekli a Balatont, Tihany szikláit, melyeket Délosz szigetének lát, ahonnan szirének köszöntik „Somogy géniuszát”, azaz Berzsenyi Dánielt. A „györki” (balatongyöröki) partot, a Szent Mihály kápolnával, a Kisfaludy által is versbe foglalt Szigligetet. S e vidék, e tájak „Ezek fogják körül Keszthely palotáját”, - írja a költemény utolsó versszakában, majd így folytatja:

\footnotetext{
${ }^{874}$ Az előadás szövege nyomtatásban is megjelent „A' napról napra kevesedö pénz miatt miként segithet magán a' Magyar mezei gazda" címmel. (TGy. 1819. I. 56.)

${ }^{875}$ HKT. 1818. I. 44. sz. 347.

${ }^{876}$ Váczy, 1905.

${ }^{877}$ Vadász-féle kötetben a vers címe: „Keszthely vidék leirása”. Megtalálható: Vadász, 1909. 148-151.

${ }^{878}$ HKT. 1818. I. 51. sz. 403.
} 
Mecénás lakik itt: gróf Festetics - a Nagy,

S dicső földi Isten!...

A második vers nem található a Vadász-féle kötetben. A Balatoni Múzeumban fellelt Dukai Takács vers-füzetek egyikében azonban benne van. Ennek a füzetnek címe: A Keszthelyi $4^{\text {dik }}$ Heliconra készült munkái Takács Judithnak. 20 dik Maj: 1818. A füzet verseinek címe:

\section{A Keszthelyi Vidék,}

Bucsuzás Tekéntetes Ásbóth János Prefectus Urtól,

'A Muzsikához.

A Búcsúzás címü versen kívül 'A Muzsikához címü sem található meg Vadász által szerkesztett Dukai Takács kötetben. A verseket a már idézett tanulmányban közöltük. ${ }^{879}$

A következő szereplő Kazinczy Klára volt, aki a „Kerti Idyllium”-ját olvasta fel. A müben Jola a kertészlány beszélget a keszthelyi kertben a virágokkal, fákkal, külön a madárberkenyével, ahogy arra Kazinczy Ferenc figyelmét felhívja Horváth Ádám, közölve Kazinczy Klára versének részletét is:

Engem a’ Helikon első Innepébe’ Bele plántálának Apolló kertébe:

Gyöngyösibül akkor Berkenye fa lettem; 'S bár másod életem röviden élhettem;

De állati valóm, mellyben most is élek, Nálatok(nál) tudósabb jövendölő lélek:

Nem ád a' természet 's nem is rendelhetett A' Nagy Georgusnak olly rövid életet,

A' mint a' Helikon felett 's felettetek Minap a' nyavalyák fenyegetődzöttek:...

De ha majd későbben még is meg-kell lenni, A’ mi minden élőn meg szokott

történni,

Hogy ő mi elölünk szemre el-távozik; Akkor sem hal ő meg, nem, tsak el változik. $^{880}$

A vers szerint Festetics György betegségének hírére elsápadtak a virágok a Georgikon kertjében, mert „van bennek érzés”, „van lelkek nékik is”. A versben felsejlik a halál, egyértelmüen a „Nagy Georgus”-ra vonatkoztatva, mint olyan dolog ami „minden élőn meg

\footnotetext{
${ }^{879}$ Cséby, 1990. 115-118.

${ }^{880}$ Horváth Ádám Kazinczy Ferencnek, 1818. július 7. ; KazLev, XVI. 107.
} 
szokott történni”, de ő nem fog meghalni, csak eltávozik. A fenti rövid idézet Gyöngyösi kiszáradt madárberkenyéjéről is megemlékezik.

Kazinczy Klárát a már ismert Konyáry Mihály pristaldus követte, aki magyar nyelven mondott verset a nemzet feléledéséről. Gosztonyi Sándor pristaldus „Nemzet áldását a Fő Herczegi utazó Ikrekre”, Fleischer Sámuel praktikáns latinul a „Nagy Magyar Férfiak”-ról mondta el munkáját. Gróf Festetics Leó németül szavalta el az „Álom” címü költeményt. Szigethy József magyarul „Jelenés Sz. István születése napján ”881 , Géczy József ${ }^{882}$ latinul „Iső Ferencz király magasztalása”, gróf Festetics Ernő magyarul „Óhajtások a Fő Herczegi Magzatok el-utazásakkor" munkáját ismertette. Utánuk ismét gróf Festetics Leó következett, aki magyarul „egy bús éjszakának leírását” ismertette. Németh Péter külső praktikáns „, $A$, mezei életnek kellemetességei” címen adta elő munkáját. Kömíves Mihály ${ }^{883}$ „philosophus” a „Balaton leírása” müvével szerepelt, míg Simonyi (Simon) Mihály a gimnázium humanista

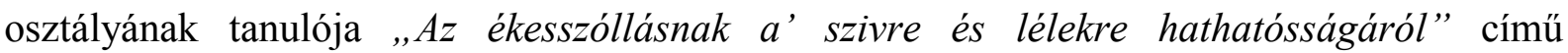
dolgozattal. Gosztonyi Sándor pristaldus ismét fellépett és elszavalta „I. Ferencz érdemei” című versét. $^{884} \mathrm{Az}$ Asbóth-féle helikoni előadások rendjéről szóló tervezet Vadnay Lajost is előadónak írja, aki latinul szólt volna az egybegyültekhez. ${ }^{885}$ Horváth Elek „Fiscalis Vas Vármegyéből” és Bárány Boldizsár Somogy vármegyei nótárius verseket küldött be, amelyek közül párat felolvastak. Horváth Ádám fejezte be a felolvasást, aki egy ott rögtönzött „elmés” epigrammáját mondta el. A délelőtt a Zeneiskola tanulóinak müsorával fejeződött be, miközben a vendégeknek ajándékokkal kedveskedett Festetics és Asbóth. Három nyomtatványról van szó. Az első a Georgikonnak tervei, melyet Asbóth János a német nyelvü „Georgikon leírása” címü, kiadásra kerülő müvéhez késztett. A második az „Aehrenlese des Georgikons”, amelyben dr. Liebbald Gyula a „Juh-Himlő Ojtásról” írt értekezését tartalmazta és végül harmadikként a „Helikon I.” kötetet, amelyben az 1817. februári és májusi Helikoni Ünnepek legjobb magyar nyelvü írásai szerepeltek. A vendégek tehát a tudomány és az irodalom üzenetét kapták kézhez, érdekes lenne tudni, melyiket forgatták nagyobb érdeklődéssel?

\footnotetext{
${ }^{881}$ Az Asbóth által aláírt 1818. május 20-i Helikoni előadások rendje szerint az előadás címe: „Látás István Magyar Herczeg születése napján”. (MOL. Fest.Lvt. P 27418 cs. 274.)

${ }^{882}$ Géczy (Gétzy) József, 1798-ban született Budán. 1817-ben iratkozott be a Georgikonba. (Csiky, 1897. 54.)

${ }^{883}$ Kömíves Mihály gimnáziumi tanuló. 1800-ban született Győrben. 1819-ben lépett be a Georgikonba. (Csiky, 1897. 62.)

${ }^{884}$ Az Asbóth által aláírt 1818. május 20-i Helikoni előadások rendje szerint az előadás címénél a következő beírást találjuk: „Eő Felségéhez Ferencz Austriai Császár és Magyar Királyhoz a Balaton felett Fenék omladékai”. (MOL. Fest. Lvt. P 27418 cs. 274.)

${ }^{885}$ MOL. Fest. Levt. P 27418 cs. 274
} 
A „Helikon I." kötetről a Hasznos Mulatságok írt recenziót. ${ }^{886}$ A kritika már az első mondatában a magyar olvasó figyelmébe ajánlja a könyvet. Dícséri Festetics mecénási tettét, hogy a költészetre, ékesszólásra serkenti, buzdítja az arra érdemeseket. „A' mi a’ könyvnek foglalatját illeti, - írja az ismeretlen szerző - áll az kisebb, 's nagyobb költői, 's ékesenszóllási ollyan darabokból, mellyeket különbféle alkalmakra vagy még most viruló Ifjak, vagy nevezetesebb Iróink készítettek, 's a' Georgicon ünnepein (mint hajdan Athénának Irói az Odeumban) részint el mondottak, mások által felolvastattak". A recenzió végén a szerző azon óhaját fejti ki, hogy a „Nemzeti Literatura” még több jeles munkával fog gazdagodni, ,a’ mit minden Hazafi szívesen óhajt”.

Ezt követően került sor az ebédre, ahol Festetics nyolcvan embert látott vendégül. Ebéd után Asbóth János és Ruszek József a beküldött, de fel nem olvasott munkákat ismertette. Ennek meghallgatása után a vendégek a Georgikon múzeumába látogattak, ahol megtekintették a gyüjteményt, az egyes gépmodelleket, a különös és ritka növényeket, úgy mint az óriási kendert, amely csaknem két ölnyi magas volt - a tudósító szerint - a különleges gabonafajtákat. Valószínűleg itt láthatták a svájci Schneeballen lisztes burgonyát, valamint az angol fajtát is, itt lehetett a báró Pászthory által megkedvelt kukoricagóré is, amelynek egy példányát a báró is felállíttatta somogyi birtokán. Itt látták a kapáló ekét (extirpator), melyet gróf Festetics László készíttetett, aki szívesen beszélt a gépekről, az intézményről a megjelent vendégeknek. Ezután a juhakolban megnézték a „valóban selyem nyájat”, majd a Geogikon majorjában „válogatott Helvécziai tehenek, és bikák az istállóban való táplálás szerént tartván, szépségökkel, és nagyságokkal bámulást gerjesztettek”. A tudósító nem felejti el leírni az al-praktikánsok pásztori táncát sem, amelyet Festetics minden alkalommal bemutatott vendégeinek. A fiatalok ködmönben, bőrnadrágban, birkabör süvegben, botokkal dudaszóra táncoltak a kert egyik tisztásán. Később „a’ ritka fák között felmenének a' Vendégek a' Keszthelyi Heliconra is, melly barlangot formáló kősziklák felett emelkedik” tudjuk meg Kultsártól, a cikk írójától. ${ }^{887}$ Meglátogatták a Georgikon Tangazdaságát is, ahol „minden növénynek külön kertje van”, amit a tanulók bármikor látogathatnak. E kertek

\footnotetext{
${ }^{886}$ Haszn. Mul. 1818. I. 47. 375-379.

${ }^{887}$ A georgikoni hallgatók oktatását segítendő a Georgikon területén két botanikus, fóleg dendrológiai kertet létesítettek. Az egyik a gyümölcsöstől délre haladó országút túloldalán feküdt, ez a benne álló mesterséges barlangról a „Grottás kert” nevet kapta. A másik nagyobb kertet ezzel szemközt, a gyümölcsös szomszédságában, egy korábbi temető helyén hozták létre, s ez itt gyertyánfákból ültetett sövényszínházról a „Theatromos kert” elnevezést nyerte. (Alföldy, 2001. 46. ; Csoma, 1997. 320.) ; Kultsár minden bizonnyal a Grottás kertben található mesterséges barlangról írt. A kastély épületéhez képest sem a barlang sem a színház nem volt túlzottan közel, így a vendégek hosszabb sétára voltak kényszerítve. Mivel az előző leírások (Bright, Kisfaludy S.) nem emlegetnek barlangot, megerősíthető az a feltevés, hogy korábban a szabadtéri színpadon, jelen esetben a mesterséges barlang feletti kis téren történt meg a tánc.
} 
végében van a „nyolc telekre fel szelt Váltó Gazdaság”. Itt kapáló-és töltőekék, szénaforgató,szántó-vető,- aratógépek bemutatója következett.

Este a „theatromban” a Zeneiskola részvételével búcsú koncertet adtak. Ma már nehéz eldönteni, hogy mi volt a tudósító által Theatromnak nevezett hely. Eddig a premontreiek kolostorában tartották a zeneesteket, amit nem lehet színháznak nevezni. Talán a Georgikon nagyterme adhatott helyet a koncertnek. Ha meleg májusi estét képzelünk el, akkor szóba jöhet, a Georgikoni Fás Kertben létesített szabadtéri színpad. Ha ezt a „theatrumot” vesszük figyelembe, talán akkor járunk legközelebb az igazsághoz.

3. 6. 6. Az ötödik Helikoni Ünnep: 1819. február 16.

Kazinczy Ferenc a faültetésre valamilyen választ óhajtott adni, mert nem akarta a grófot megsérteni hallgatagságával. 1819. január 3-án megírta Festeticshez intézett versét és egy levél kíséretében megküldte Keszthelyre.

Nagy ember, ki nekünk kedvező Istenek

Gyámolúl s ragyogó fényül engedtenek;

Zrínyieknek társa gazdag örökökben,

De még inkább társa magas erkölcsökben;

Te, kit a jók jónak s nemesnek ismernek,

László’ atyja, s ipa egy Hohenzolernek!

Melly ész, mely józanság vive arra téged,

Hogy jó s szép töttekben leld gyönyörüséged',

$\mathrm{S}$ midőn pillongásért epedeznek mások,

Téged nem szédítnek semmi csillámlások?

Büszke, de nem hisz, a csörgést megveted,

S nyugalmas nagyságban foly el szép életed.

Mint sok hős polgára a régi Rómának,

Természetnek híve, híve hazájának,

Honn ülsz, szántasz és vetsz, kazlakat állítasz,

Ugart törsz, árkot nyitsz, mocsárt s tót szárítasz,

Nemesíted almád', sajtólod szőlődet,

Ménes, gulyák nyájak lepik el meződet; 
S azért örülsz a nagy birtok’ nagy hasznának,

Hogy a sokból sokat adhass a hazának.

Földmívest neveltek legelébb gondjaid,

És ifjú katonát: most már oltárad

Gyujtják tömjéneket a lant' és az ének'

S a Virág' és a Kis' nyelve' Istenének.

Olympiánk nyilt meg; ím fut a délczeg nép;

Három pártás költőnk, s velek egy ifjú Szép,

Székedhez jutottak, s elveszik béredet;

Tapsol a sokaság, s harsogja nevedet.

Javaltatni kedves: de bérre szolga vágy;

Szabad megteszi a mit szent tiszte hágy,

$\mathrm{S}$ bár nincs, s soha nem lesz tanúja tettének,

Áldozatokat nyújt szeretett ügyének.

Néked dicső férjfi, maga a tett a bér;

Érted te az üres lárma s a hír mit ér,

$\mathrm{S}$ bírván megnyugtató intését keblednek,

Bátor léptekkel jársz útján érdemednek.

Tamás, a Nádasdi-háznak fényes ága,

Védistenink közzé az érzéssel hága,

Így Bethlen, Fejedelme a rokon hazának,

Kik dicsőségökből néznek volt honjokra,

$\mathrm{S}$ áldást kiáltanak arra s új társokra.

Menj, nagy férfi, s példád tanítson bennünket,

Magunknál még inkább szeretni ügyünket. ${ }^{888}$

\footnotetext{
${ }^{888}$ Kazinczy a következő megjegyzést füzi verséhez, már Festetics halálát követően: „Ez a’ nagy ember, felállítván Keszthelytt a' Georgicont, melly a' hazának földmivelöket adjon, 's a' Katonai Academiában nevelt Magyar Ifjak eránt is éreztetvén jóltevőségét, 1817. úgy rendelé, hogy a' Keszthelyi Helicon minden esztendőben innepelje az Első Ferencz' születése' napját, Február 12dikét, 's minden illy innepen, a' Helicon körül eggy és eggy megholt Irónak sorbus Festeticsia (aucuparia) ültettessék. Az első innepen Horváth Ádám, Kisfaludy Sándor, Berzsenyi Dániel, Dukai Takács Judith, elébb, együtt mindnyájan, Gyöngyösi Istvánnak ültetének eggyet, azután, külön mindenike, magának. - 1818. e' megtiszteltetésre Kazinczyt nevezé, és Csokonait, 's 1819. Superint. Kist, és Faludit. A' következő innepen a' kösznetképpen beküldött Munkának fel kelle olvastatni, 's illyen az, a' mi itt áll. Festetics ezen eszt. April. 2dikán megholt, 's több innep nem tartatott." (Kazinczy ÖK., 1998. 171-172. ; 408.) A versben Nádasdy Tamás (1498-1562) nádorról van szó, a müvészetpároló foúrról. Festeticset Nádasdy és Bethlennel emeli egy sorba. Kazinczy a gróf fiának Lászlónak
} 
A levél első mondatában, amit a vershez csatolt, elnézést kér a hosszú hallgatásért és magyarázza ennek okát. A továbbiakban dicsőiti a grófot és sajnálatát fejezi ki, hogy 1818ban nem mehetett Keszthelyre és nem vehetett részt az ünnepen.

\section{„Nagy Méltóságú Gróf, \\ Kegyelmes Uram,}

Hallgattam, mert azt akarám éreztetni, hogy tavalyi megtiszteltetésem a' Keszthely Heliconában engem reménységemen kívül ére: de hallgatásom hálátalannak mutatott Excellentiád eránt, 's ez megszólaltata. Fogadja Excellentiád kegyelemmel azt a' versezetet, mellyet itt leghívebb tisztelöje benyújt. Keszthely által megtiszteltetni nagy szerencse: de ennek(!) semmi sem kedvesebb, mint midőn annak a’ nagy férjfinak kegyeivel dicsekedhetik, kit még letében tisztel minden, holott az igen gyakran csak holta után szokta érni az érdemet.

Épen az az ok, melly hallgatásomból kilépni hagya, óhajtatja velem azt a’ szerencsét, hogy ez a’ vers a’ Keszthely’ Februáriusi innepén felolvastassék. Ha Excellentiád el nem tilt, azt az Újságlevelekben is ki fogom nyomtattatni.

Azon reménységem, hogy az elmúlt esztendőben meg fogom láthatni Keszthelyt, elenyészett, 's én Octób. 27d. beléptem életem 60dik esztendejébe. Bár annak addig nyujtanák fonalát a’ Párkák, míg legforróbb kívánságaimnak eggyike teljesedést láthat.

Maradok alázatos tisztelettel

Excellentiádnak

Széphalom Január $3^{\mathrm{d}}$. 1819.

alázatos szolgája

$$
\text { Kazinczy Ferencz"889 }
$$

A vers másolatát - január 3-i keltezéssel - levél kíséretében több ismerősének, barátjáénak is elküldte Kazinczy: Kis Jánosnak, gróf Dessewffy Józsefnek. ${ }^{890}$ Nem várta levelei szerint - a megtiszteltetést, de jól esett neki és nem akart a hálátlanság színében tünni azzal, hogy semminemü választ nem ad a faültetésre. Dessewffynek írt levelében kitér a

\footnotetext{
feleségének családját is megemlíti a versben, de nem gúnyosan, úgy, mint eddig barátainak írta leveleiben „Herczegi menyü Festetics” (KazLev. XV. 26. Kazinczy Ferenc Horváth Ádámnak, 1814. augusztus 14.), hanem dicsőségként, felkiáltójellel a mondat végén. Érdemes ide idézni, hogy Kazinczy, Virág és Kis neve mellett megemlíti Szép Jánosét is.

${ }^{889}$ Kazinczy Ferenc Festetics Györgynek, 1819. január 3. ; KazLev. XVI. 271-272.

${ }^{890}$ Kazinczy Ferenc Kis Jánosnak, Széphalom, 1819. január 3. ; 272.; Kazinczy Ferenc Dessewffy Józsefnek, Széphalom, 1819. január 3. ; KazLev. XVI. 275.
} 
berkenyefára is: „Itt küldöm azon Versemet is, mellyet Gróf Festeticsnek küldék köszönetül a' tavaly ültetett berkenyéért. A' berkenye engem pirít: de eggy olly érdemű polgár kegye, mint, mint Festetics, kevélysége lesz még gyermekeimnek is. Azért nem tettem szót a' versben a' berkenye felől”. ${ }^{891}$ Dessewffy nem késik a válasszal, bár nem szereti Festeticset, egyetért Kazinczyval: „Festetitsnek sok szépet mondtál; neked az esett legjobban, hogy nem kellett füllentened, néki pedig az, hogy te magasztaltad". ${ }^{892}$

Tehát Festeticsnek a berkenyéről nem ír semmit és verse is olyan, miről tudja, hogy a gróf inkább szereti. Horváth Ádámnak még panaszkodik is, hogy „olly schemát” választott, amelyben nem igazán szokott verselni. ${ }^{893}$ Festeticset is, Horváth Ádámot is kérte, hogy ha csak egy mód van rá, a versét olvassák fel a legközelebbi, tehát az 1819. februári Helikonon. A költemény nyomtatásban való megjelenése mintha a Helikonra lett volna időzítve; Kazinczy ugyanis elküldte a Magyar Kurírnak, ahol február 23-án megjelentették. ${ }^{894}$

Kazinczy Horváth Ádámot is értesíti a Festetics versről és megjegyzi, úgy látja hasonlóképpen lesz a keszthelyi Helikonon, amint a Francia Akadémiában szokott lenni, ahol a felvett személy beszéddel köszöni meg a megtiszteltetést. Kéri, a Helikont követően azonnal írja meg milyen volt az, és Festetics miként fogadta versét. Kazinczy tudja, illetve sejti, hogy sokan vannak Keszthelyen, a Tuladunaiak, kik nem fogják kellő megértéssel fogadni az episztolát, ezért is roppant kíváncsi a gróf véleményére. „Égek tudni - írja Kis Jánosnak mint vevé azt a' Gróf. Mert a' Keszthely emberei’ itéletét előre tudom”. ${ }^{895}$ Horváth a Helikont követően megírta, hogy a gróf kegyesen fogadta a verset és nem kellett arra ösztönözni, hogy olvastassa fel, mert elhatározta már annak elmondatását. Amikor Kazinczy erről értesülvén megírta Döbrenteinek, miszerint „nem nagyitás az, midőn én őtet Nádasdi Tamáshoz, Bethlen Gáborhoz s a két Cardinálishoz hasonlítottam..."896

Az ötödik és egyben az utolsó Helikonra nem 12-én, hanem 16-án került sor, ugyanis tizenkettedike péntekre esett és a gróf babonából nem akkor tartotta meg. Erről azonban Horváth Ádám nem tudott és sárban, hidegben utazva, már 12-én Keszthelyen volt. Láthatta az előkészületeket s megfogalmazódott benne, amit később Kazinczynak is megírt, hogy az ünnep nem úgy ment, amint azt a gróf korábban megígérte. Érzékelhető volt Asbóth János

\footnotetext{
${ }^{891}$ Kazinczy Ferenc Dessewffy Józsefnek, 1819. január 3. ; KazLev. XVI. 275.

${ }^{892}$ Dessewffy József Kazinczy Ferencnek, 1819. január 16. ; KazLev. XVI. 276.

${ }^{893}$ Kazinczy Ferenc Horváth Ádámnak, 1819. január 19. ; KazLev. XVI. 280.

${ }^{894}$ MK., 1819. I. 15. sz.

${ }^{895}$ Kazinczy Ferenc Kis Jánosnak, 1819. február 16. ; KazLev. XVI. 299.

${ }^{896}$ Kazinczy Ferenc Döbrentei Gábornak, 1819. március 17. ; KazLev. XVI. 317.
} 
hiánya és a gróf betegsége. ${ }^{897}$ A korabeli újság tudósítását a következő mondattal kezdi: „Az ide való Ifiuság bé vett szokása szerint, Heliconi Gyülekezetének fényes meg tartásával, ünnepelé az idén is Felséges Urunk' és Asszonyunk születése’ Napját, mellyet a' Georgiconi Szállában több érdemes Vendégek előtt Pfahler Károly Fiscalis, a törvényes Tudományok Doktora, és Tanitója, mint ez évi Archon, nyitá meg egy ékes, 's mai nap már többé már nem igen könnyen hallható classicus deákságú beszédjével, mellyben különösen Ő Felségének Humanitásságát fejtegette, és magasztalta szép szerrel". ${ }^{898}$ Az archon bevezető előadását a Zeneiskola három osztályának hangversenye követte, amelyben magyar és német énekeket énekeltek. Az egyes szavalatok, beszédek után ismét fel-felcsendült a muzsika. Az előadások sorrendjét két újság is közölte, az ő írásuk alapján tudtuk a müsort összeállítani. ${ }^{899}$

Bernáth György ${ }^{900}$ georgikoni praktikáns magyar nyelven „magyar vitézi versezetet” adott elő az „emberi élet céljáról”, ${ }^{901}$, gróf Festetics Leó németül mondta el a „Hasadó hajnal" című ódát, majd Ludovits István a gimnázium filozófiai osztályának tanulója latin beszédet mondott a Tudományok sokféle hasznáról, gróf Festetics Sándor ${ }^{902}$ pedig magyarul üdvözölte a királyt a magyar ifjúság nevében. Honetzy István georgikoni praktikáns latin hexameterekben mondta el a „Keszthely kies vidéke” címü költeményt, Hegedűs József pristaldus magyar nyelven szólt az ,időnek visszahozhatatlanságáról”, Jeszenszky Antal pristadus a nyelv pallérozottságáról tartott előadást német nyelven. Ballier József praktikáns magyar szavalata a „szerentse álhatatosságáról” szólt, Veber (Weber) József „rhetorikai hallgató” a „Békességnek méltó örömei” címen mondta el beszédjét, Jochmann Sámuel praktikáns németül arról beszélt, „,hogy kinek kinek okosan kellessék választani az élet nemét, és a’ választottnál állandóul megmaradni”. Ismét egy korábbi Helikonon is szerepelt tanuló, Kömüves Mihály a filozófiai liceum másod éves hallgatója lépett a pódiumra és magyar nyelven adott elő egy „magyar Saphionokban” megírt verset a „Scwartzenberg Familiának Hazánkban tett nagy érdemeiről”, majd Kováts Pál „logicus”-tól latin nyelvű elégiát olvasott fel a „mezei élet Boldogságáról”, Tornyos Pál gimnáziumi tanuló előadást tartott latin nyelven „Az Erköltsnek egyedül halhatatlanitó ereje” címmel, Sényi Gábor grófi titkár a király születése napját dicsőítve „szép deák vitézi verseket” szavalt, míg a már ismert

\footnotetext{
${ }^{897}$ Horváth Ádám Kazinczy Ferencnek, 1809. április 10. ; KazLev. XVI. 349.

${ }^{898}$ HKT. 1819. I. 18. sz. 138.

${ }^{899}$ HKT. 1819. I. 18. és MK., 1819. I. 19 sz.

${ }^{900}$ Bernáth György 1798-ban született a Pest megyei Tasson. 1818-ban iratkozott be a Georgikonban. (Csiky, 1897. 46.)

${ }^{901}$ Az elöadások sorrendjét és témáját a HKT. 1819. I. 18. 13-139. alapján közöljük.

902 Festetics Sándor gróf (1805-1877), Festetics Ernő gróf testvéröccse. Ekkor 14 éves, valószínűleg a gimnázium tanulója.
} 
Gosztonyi Sándor uradalmi pristaldus „egy fontos német Epistolát, ama régi hires Papiniánus Római Törvény-tudónak jeles tselekedeteiről” adott elő. ${ }^{903}$

Az előadások, szavalatok után a beküldött munkákat olvasták fel. Elsőként természetesen Kazinczy Ferenc „Gróf Festetics Györgyhöz” címü versét, s ezzel teljesült Kazinczy óhaja is. A hatvannégy éves beteg mecénás örült a versnek, s talán önmagában meg is fogalmazta, hogy akarattal, következetességgel sokat tett a nyelvújítási harcban, az ortológusok és neológusok közötti megbékélésben; hisz kertjében ott virít Kazinczy fája, s a helikoni amphitheatrumban felolvassák Kazinczy neki ajánlott költeményét.

Dukai Takács Judit sem volt ott a Helikonon. Az első ünnepen már ott tüsténkedett körülötte Geöndötz Ferenc, ${ }^{904}$ aki 1818. augusztus 9-én feleségül is vette a huszonhárom éves költőnőt. Festetics nászajándékba két gyönyörü lovat küldött a fiatal párnak. Nem volt szerelmi házasság, maga a férj nem volt érzékeny Helikon múzsáira. ${ }^{905}$ Nem költőnőt, hanem háziasszonyt akart házába. ${ }^{906}$ Ezzel kezdődött Dukai Takács Judit lassú költői haldoklása.

\footnotetext{
903 Az eddig még nem szerepeltek: Honetzy István, 1795-ben született a Kis-Hont megyei Fürészen. 1818-ban iratkozott be a Georgikonba. (Csiky, 1897. 56.), Hegedüs József, 1797-ben született Pesten. 1818-tól a Georgikon hallgatója. (Csiky, 1897. 56.), Jeszenszky Antal, 1795-ben született a Bars megyei Zsarnován. 1818ban iratkozott be a Georgikonba. (Csiky, 1897. 58.), Ballier (Balicz ?) József, 1795-ben született a Somogy megyei Szentkirályon. 1818-tól a Georgikon tanulója. (Csiky, 1897. 44.), Jochmann Sámuel, 1796-ban született a Sáros megyei Eperjesen. 1818-ban iratkozott be a Georgikonba. (Csiky, 1897. 58.) A Magyar Kurír a már idézett számában Jochmann helyett helytelenül Joachimot írt. A Pester Zeitung 1819 évi 18. száma (március 4.) latinul is közli Jochmann elöadásának címét: „Vitae genus prudenti deliberatione eligendum, electum constanter, temendum”. Kováts Pál valószínűleg a filozófiai líceum I. éves hallgatója (Vö.: Pest. Zeit., 1819./18. március 4.), Tornyos Pál valószínüleg a gimnázium humán osztályának II. éves hallgatója (Vö., Pest. Zeit., 1819./18. március 4.)

904 Geöndötz Ferenc földbirtokos 1792. március 3-án született Felsőbükön. 1817. október 27-én kéri Vas vármegyétől nemességének megerősítését. (Vadász, 1909, 39.)

905 Weöres Sándor a Három veréb hat szemmel című munkájában közli „Göndöcz (sic!) Ferenc, az illúziótlan férj” nyilatkozatát ,az impozáns grófi irodalmi ünnepélyröl”:

Ó, nagy Helikon,
}

Szarom neked a sikon. (Weöres, 1977. 463.)

Valószínűleg Laczkó András irodalomtörténész jöhetett rá, mi okozta Geöndöcz lesújtó véleményét. Geöndötz ugyanis költői babérokra vágyott, s dicsekedni is akart felesége előtt tehetségével, Kisfaludy Sándornak véleményezésre elküldte következő versét:

Az ösz

Fának nincs levele, minthogy lehullott már, Ebböl tudhatjuk, hogy az ösz itt van már, A piypalatty elment, cinege van s veréb, Ebböl láthatjuk, hogy az élet csak cserép.

Kisfaludy válasza nem késlekedett, ő is versben válaszolt: Ne ülj Pegazusra, kedves jó barátom, Ezt a mesterséget nem éted, azt látom. Hagyj békét az ösznek, verébnek, cserépnek, Mert mint a szajkó járt, téged is megtépnek. Aztán fejed is már ösz szálakkal tele. Hagyjad el ezt a munkát, megkopaszodsz bele. Hagyd a pitypalattyot, hadd röpüljön tova, A Te fáradt lábad úgysem érne oda. (Laczkó, 2006. 86.)

${ }^{906}$ Dukai Takács Judit életéről és munkásságáról lásd: R. Kocsis Rózsa: Dukai Takács Judit élete és költészete. Bölcsészdoktori értekezés. ELTE sokszorosító üzem, é. n. ; Vadász Norbert: Dukai Takács Judit élete és munkái, 
Nem jött, nem jöhetett el az utolsó Helikonra, azonban verseit elküldte. A korabeli sajtó nem közölte a vers címét, így a jelzett tartalom alapján lehet azonosítani, hogy „A Magyar Hon dicsősége” és a „Mársnak dicsőséges fiaihoz” címü művekről van szó. ${ }^{907}$ Ezen a Helikonon Horváth Ádám nevelt lányából feleséggé lett Kazinczy Klára ${ }^{908}$ is felolvasta versét „, $A z$ álhatatatos Thália, a' kinek képében Keszthelyi Helikon' ünnepit üli" címmel. ${ }^{909}$ A vers kezdetén Keszthelyt boldog, kies vidéknek írja:

Boldog vidék! Kies Keszthely! Czirha ditső halmai!

Szent Helikon! 'S Apollónak koszorúzott fijai!

Csupa dicséret, csupa felkiáltójel. Majd az újdonsült asszony versében kinyilatkoztatja, hogy nincs szándékban a „kedveltt kilencz Szüzek seregét” elhagyni, annak ellenére, hogy férjhez ment, azaz letette pártáját, a „hajadonok’ bélyegét”. Ö továbbra is meg pendíti húrját, „ha a Helikon társaságra méltóztatja” lantját. Mennyire más Horváth Ádám feleségének lenni, mint Geöndötz Ferencnének. Horváth segíti a versfaragó hölgyeket, nem véletlenül szervezi meg a Göcseji Helikont, melynek lokális jelentősége nagyobb volt, mint utóbb látszik, verses levelezést folytat a szárnya alá vett poetriákkal Kazinczy Klárával, Dótzi Terézzel, Tuboly Erzsébettel, Tuboly Rozáliával és Dukai Takács Judittal. ${ }^{910}$ Jobbára gyengécske versek születtek, kivéve talán Dukai Takács Juditot, aki idő előtt hallgatott el. Közel járunk az igazsághoz, ha azt állítjuk, hogy az irodalom, a magyar nyelv művelése terén szerepe volt a Göcseji Helikonnak is. Kazinczy Klára versét Festetics dicsőítésével fejezi be:

Méltó hogy kiáltsa minden Flóra kertje' munkássa:

Hogy éljen Groff Festetics György, a’ Musák Métzénássa!

\footnotetext{
Bp., 1909 ; Fenyő István: Költőnő a magyar klasszicizmus korában. Dukai Takách Judit. = Kardok és kulcsok (Jelenlét), Szombathely, 1990. ; Cséby Géza: Dukai Takács Judit a Balaton-vidék egyik korai tájleirója. Nők a Balatonért Egyesület Kiskönyvtára 3. Balatonfüred, 2002. ; Cséby Géza: Dukai Takács Judit kéziratos versfüzetei. $=$ Zalai Gyüjtemény 31. Müvelődéstörténeti tanulmányok. Zalaegerszeg, 1990. ; Schöpflin Aladár: Dukai Takács Judit = Nyugat, 1904. 4. szám.

${ }^{907}$ Vadász, 1909. 157-159. ; 127.

${ }^{908}$ Horváth 1806-ban fogadta örökbe leányának hitt Kazinczy Klárát. Kazinczy Klára anyja csak halálos ágyán , 1817-ben árulta el, hogy a lány nem Horváth gyermeke, így a nevelt lányból feleséggé léphetett elő. (Cséby, 2012. 39-44.)

909 Péterffy, 1973. 147-148. ; Horvát Ádám Kazinczy Ferencnek, 1818. november 9. ; KazLev. XVI. 222-227.

${ }^{910}$ Részletesen lásd: Péterffy, 1973. ; Művek és rövid életrajzok: Magyar költőnők antológiája. Összeállította: S. Sárdi Margit, Tóth László. Enciklopédia, Budapest, 1997. ; Összefoglaló mű: Fábri Anna: „A szép tiltott táj felé” A magyar írónők története két századforduló között (1795-1905) Kortárs, h. n. 1996., Fáylné Hentaller Mariska: A magyar írónőkről. Budapest, a szerző kiadása, 1889, A Göcseji Helikon költőnői. Sajtó alá rendezte: S. Sárdi Margit. Universitas, Budapest, 2002
} 
Horváth Ádám, bár tizenkettedikén érkezett, valószínű, hogy Keszthelyen maradt az ünnep végéig. Versét nem maga mondta el, hanem felolvasták. Minden jel arra mutat, hogy betegségének elhatalmasodása miatt már nehezen mozgott és minden kisebb erőfeszítés is hatalmas kínokkal járhatott. Horváth mintha megérezte volna, hogy ez az utolsó Helikon, versének címe: „Hattyúi Ének a' Keszthelyi Helikon' ünnepére. Febr. 12-dikén 1819. „911 A versben ő búcsúzik, öregségére, betegségére hivatkozva:

Már a' belső müszereknek van bizony hozzá köze

Mint midőn a' Mestereknek vásik éles eszköze. -

A’ miket tehát még tőlem élve várnál égi tüz!

Most mikor téged' belőlem a' ki fáradt müszer űz

Bízd ezentúl ollyanokra, hol az alkotási por

Még nem oszlik új porokra, 's még virít a' férjfi kor.

És mivel közelget a' sír, testi gyengeség tanit

'S int hogy a' lélek már nem bír annyi voltat 's mostanit.

Hát nehogy több földi gondok égtől elrekesszenek,

Régi munkámról lemondok, és ezentúl pihenek.

A versnek egyik érdekes szakasza a búcsú mellett, amikor felidézi az első Helikont és Keszthelyről való távozását. Délre indult el a ma közigazgatásilag Keszthelyhez tartozó Fenékpusztán hattyúkat látott a tóról felrebbenni:

\section{Éppen a’ szomorú bútsu-vétel vala gondja}

Bánatos elmémnek; sok régi valóra, sok édes

Kedvem' töltteire, 's közelebb a' Helikon' első

Ünnepjére való emlékezet, a’ le-hanyatlott,

'S illy hamar el-tikkadt kort, kétszeresen nyomorultnak

Képzeltette velem; 's illy andalgásba merülve

Járkálék a' kék Balaton' tava’ partja Fenéki

Görbületjénél, még fél-betegen; mikor imé

A' tsuhubúl tizen-egy hattyú szárnyalla-fel, és az

Ott, közel a’ parthoz nyugovó gályára repüle...

\footnotetext{
${ }^{911}$ Birtokunkban van egy minden impresszum nélküli 4 lapos ( 8 oldal) 12,5 x 20 centiméter nagyságú korabeli nyomtatvány Horváth e versével. Valószínűleg alkalmi, esetleg a Helikonra készült nyomtatványról van szó.
} 
Ha kizárólagosan a természeti jelenséget s a versben megjelenő történést vizsgáljuk feltételezhetnénk, hogy a sérvpanaszokkal hazainduló Horváth valóban a Keszthelyi-öböl déli részén a hajóépítő arzenáltól nem messze láthatta a Phoenixre szálló hattyúkat. A vers azonban egyértelműen szabadkőműves ihletésű $\mathrm{s}$ további részében maga Horváth látomásában hattyúvá válik és a „Ritka szömörczésen, 's a' vad Lyány lakta likon túl"912 önkéntelenül egy tágas üregbe repül, ahol két oszlop közt az ajtón belépve, szemben az oltár helyén tükröt lát, előtte arany ágú és aranycsillagú fát. A padló
Sinai szőnyeggel látszik be-padozva, ’s azon kék
Tábori köntösben öltözve Ferencz nagy Urunk áll, Szemköztt Varróval; jobb kézzel véle kezet fog, Baljával le-szakaszt egy tsillagot a' tsuda fárúl 'S azt a' búza kalászok alá Varróra ragasztja. - Harmadik oldalrúl a’ Kesztheli Helikon állott, ...

A látomásban koszorús lantosok, múzsák s a fényes fellegekbe repülő Delusi Angyal Apolló, kinek papja volt Horváth a Helikonon, tünnek fel. A vers-részlet utolsó soraiban Festeticset említi, akinek annyi minden köszönhető, s éppen ezért,

Szent fogadásom után, hogy az a’ jutalomra ki jegyzett

Mind három koszorú a’ Keszthelyi Grófnak örökje,

A’ kinek a' Hattyú hangokra szabott bútsúzó

Éneket is, mert azt a' rend kivánta, mutasd-be.

A vers szerteágazó szimbólumrendszerének vizsgálatára itt nincs mód kitérni. Azonban nem szabad figyelmen kívül hagyni, hogy a hattyú a magány, a bölcsesség, a jóstehetség, a tisztaság, a halál, az újjászületés és a költészet szimbóluma. A görögöknél Apollón kocsiját húzzák, s mint ilyenek a költészet erejét szimbolizálják. ${ }^{913}$ Ugyanakkor az alkímiában a szublimált lélek jele a sas mellett. A tizenegy „tsuhu”-ból felröppenő hattyú

\footnotetext{
${ }^{912}$ A cserszömörcével borított Keszthelyi-hegység leismertebb Vadlány-barlangja Gyenesdiáson található. A népiesen „Vadlánlik”-nak nevezett barlang keményebb-lazább dolomitbreccsába mélyül. Feltehető, hogy az idők folyamán emberi beavatkozással tágították. A környékbeli monda szerint egy megesett lány élt az aprócska barlangban, ám ez - ismerve a barlang méreteit - jószerével lehetetlen. Horváth hallhatott a barlangról.

${ }^{913}$ Hoppál-Jankovics-Nagy-Szemadám, 1997. 91.
} 
esetében a tizenegy a tökéletlenség megjelenítője, éppen ezért Horváth maga is hattyúvá lesz, hogy a szám tizenkettőre bővüljön, amely szám a teljességet, az egyetemességet és az összetartozást jelképezi. ${ }^{914}$ Végezetül, a „rend” kívánságára, a hattyúi ének bemutattatik.

A költők versei után Sümegi Mihály ,értekezése az igazi Hazai Szeretetről” szólt, őt Erdélyi Kontz Sámuel követte, akinek „három rendbéli verse” hangzott el, majd egy „Magyar Elégiát" olvasott fel Ovidiusból a premontrei Hatos László. ${ }^{915}$ Végezetül a már beteg Nagyváthy János ${ }^{916}$ munkájából a „Magyar Földes (Fewdes) és Zászlós Urak’ (sic!) eredetéről és mivoltáról" című munkából hallhattak részleteket. Ez az a munka, amelyet a cenzúra nem engedett kinyomatni. ${ }^{917}$ Csupán megjegyezni kívánjuk, hogy Zsivora György ügyvéd 1841 végén arról értesíti Nyikos Lászlót ${ }^{918}$, hogy Nagyváthy műveinek, a „Magyarország hazai gazdálkodása” és a „Magyar Földes és Zászlós Úr...” kiadása ügyében csak akkor tud eljárni, ha a kéziratokat megkapja. ${ }^{919}$ A dolgozat részletének felolvasása tehát bátorságot jelentett. De egyet kell értenünk Németh József szép megfogalmazásával: „...ha a bátorság gyülne is, az erő nem a régi. Nemcsak azért, mert Festetics, Horváth, Nagyváthy is öregek, betegek, a halálra készülnek. Azért sem, mert 1818-

\footnotetext{
${ }^{914}$ Szimbólumtár, 1997. 461.

${ }^{915}$ Hatos László a keszthelyi gimnázium tanára volt 1813 és 1820 között. (Győrffy, 1896. 206.)

${ }^{916}$ Festetics és Nagyváthy kapcsolatát többen többféleképpen magyarázták. Sági Károllyal kell egyetértenünk, aki a következőket írta: „Festetics György és Nagyváthy János kapcsolatában és viszonyában olyan, ami Festetics Györgyöt elmarasztalná, nem látunk. Nagyváthy halála után családja viselkedése sem tükrözi ezt.” (Sági, 1967. 337.) Láthatjuk azt is, hogy a Csurgóra költözött Nayváthyval mindvégig kapcsolatot tartott a gróf, sőt többször ki is tüntette. Itt kell megemlíteni, hogy Nagyváthy halálának dátumával kapcsolatban több helytelen adat jelent meg. Valószínűleg az alapot a Pallas Nagy Lexikona 12. kötet (Budapest, 1896. 969.) Nagyváthy címszó alatti rossz adat adta. Itt ugyanis Nagyváthy halálát 1819. február 13-ra teszik. A Pallas adataira hivatkozva közli Szinnyei (Magyar írók élete és munkái IX. Budapest, 1903. 793.) is tévesen a dátumot. Ezek után szinte természetes, hogy rossz a Magyar Irodalmi Lexikon 1-3. kötet (Akadémiai, Budapest, 19631965. 2. 336.) és a Magyar Életrajzi Lexikon 1-3 kötet (Akadémiai, Budapest, 1981-1982. 2. 282.) dátuma, ahol szintén február 13-át írnak. Ugyancsak hibásan közli halálának dátumát a Magyar Agrártörténeti Életrajzok 1-3. kötete (Magyar Mezőgazdasági Múzeum, Budapest, 1987-1989. 2. 619.). Nem jobb a helyzet az Új Magyar Irodalmi Lexikon 1-3 kötetének (Akadémiai, Budapest, 1994. 2. 1461.) valamint az Új Magyar Életrajzi Lexikon $I V$. kötetének (Magyar Könyvklub, Budapest, 2003. 100) esetében sem. A valós dátum: 1819. február 24. Ezzel kapcsolatosan idézzük Sági dolgozatát: „Nagyváthy 1819 elején meghalt. Veje Nyikos László írja: >E folyó $1819^{\text {ik }}$ esztendő Febr. Hónapnak 24-ik napján egy hétig tartó hideglelés után: ki mult e világbul.< A halál oka mai szóval tüdőgyulladás. Lovaczky Ferdinánd gyógyszerész 54 forint 14 krajcáros számlája 19-én, 20-án, 22-én és 24-én kiadott gyógyszerekröl szól, melynek zöme China Mixtum”. (Sági, 1967. 337.) Nagyváthy temetésén több verzió szerint Festetics is részt vett. A különösen hideg februári úton meghült, ami siettette halálát.

917 „A nagyméltóságú Magyar Királyi Helytartótanács az 1822. évi szeptember 10-én kelt 22346. számú legkegyelmesebb határozata értelmében a Magyar Fewdes és Zászlós Úr című kéziratos mű kinyomtatását megtiltja. Könyvrevizori Hivatal. Budán, 1822. október 4-én. Nagy Antal A nagyméltóságú Királyi Helytartótanács cenzora és revizora." A kézirat a Somogy vármegyei könyvtár birtokába került, majd a II. világháború alatt nyoma veszett. Csak 1955-ben került elö. Első kiadására Csurgón, 2009-ben került sor. (Nagyváthy, 2009. 3-5.Varga Róbert könyvtárigazgató előszava.)

${ }^{918}$ Nagyváthy Lidia férje, Nagyváthy János veje

${ }^{919}$ Balatoni Múzeum Adattára, 57. 1789. 13 ; A Balatoni Múzeum Adattárában található egy másik igazolás, amely 1819. június 7-i keltezéssel igazolja, hogy Trattner János Tamás „megnézettetés” céljából Nyikos Lászlótól, több Nagyváthy művet átvett, többek közt a Magyar Zászlós és Földes Urat is. (N. 59.100)
} 
ban (1819-ben !) a szabadkőmüvesség csak a férfikor szívben megőrzött szép emléke, a társadalom már a reformok új erőit érleli". 920

A felolvasások után a „Honnyi Horátz” Virág Benedek kapott kétszáz forint jutalmat Festeticstől.

Az ünnepséget követően a Georgikoni kertben két emlékfát ültettek. Az emlékfával megtiszteltek neve körül némi zavar van, ugyanis a tudósítások megoszlanak e tekintetben. A Hazai 's Külföldi Tudósítások, a Magyar Kurír és a Pester Zeitung ${ }^{921}$ egyértelmủen Faludi Ferencet és Kis Jánost említik. Kazinczy azonban azt írja február 26-án Horváthnak, hogy kimondhatatlanul örült levelének, amelyben arról tudósította, hogy Zrínyi és Kis fognak „ez évben” fát kapni. Majd sajnálkozva folytatja a levelet: „Mikor láthatom-meg Keszthelyt, nem tudom. Az sokba kerül, 's bezzeg hozott esztendőket ránk nem mondom az Isten, mert az Istennek csak a' jót kell tulajdonítani, hanem eggy rossz démon". ${ }^{922}$ Döbrenteinek megerősíti március 7-én: „Horváth Ádám írja, hogy a’ Gróf ez idén Faludi és Ányosnak akart ültetni berkenyét: de Zrínyi és Superint. /Kis/ nyerék-el azt (ha t. i. azután meg nem változott a' tervezet) Ezen kimondhatatlanúl örvendek. Még nincs róla tudósításom".923

Tehát Kazinczy is csak Horváth előzetes, és nem az ünnep utáni tudósításaiból értesült a faültetésről. Váczy János is Zrínyi és Kis fáinak elültetését igenli. ${ }^{924}$

Délután a diákok magyar nyelven előadták a „Themistocles” címü „heroikus szinjátékot”, és ezzel fejeződött be az 1819 februári, egyben az utolsó Helikon. „Véget ért a szakmai, politikai demonstráció-sorozat; az írók pedig szegényebbek lettek egy illúzióval, s megfosztattak az oly nagyon hiányzó összejöveteltől, az elismeréstől, az értékeléstől, s halhatatlanságra jelölésük egy szép gesztusától." - írja dolgozatának befejező részében Mezei Márta. $^{925} \mathrm{~S}$ valóban, nemcsak egy illúzióval lettek szegényebbek, de a Helikonok megszüntével szegényebb lett mindaz, amit magyar irodalomnak, magyar nyelvnek nevezünk.

Megjegyezzük, hogy az 1818 -és az 1819-es Helikonok esetében a gimnáziumi tanárok közül Petróczy Béla igazgató, Drinóczy György és Harm Gábor segédkeztek. A Helikoni ephorusok" e munkájukért fejenként százötven forint tiszteletdíjat kaptak. ${ }^{926}$

\footnotetext{
${ }^{920}$ Németh, 1988. 23.

${ }^{921}$ HKT. 1819. I. 18. szám ; MK., 1819 I. 19. szám ; Pest. Zeit. 1819. 18. szám (március 4)

${ }^{922}$ Kazinczy Ferenc Horváth Ádámnak, 1819. február 26. ; KazLev. XVI. 309.

${ }^{923}$ Kazinczy Ferenc Döbrentei Gábornak, 1819. március 7. ; KazLev. XVI. 317.

${ }^{924}$ Váczy, 1905.

${ }^{925}$ Mezei, 1997. 180.

${ }^{926}$ Győrffy, 1896. 243.
} 


\section{7. Festetics György gróf halála}

Már a Helikoni Ünnepségek részvevőinek leveleiből értesülhettek a címzettek, hogy Festetics beteg. A Hazai 's Külföldi Tudósítások 1819. március 10-én közölték olvasóikkal, „Keszthelyről vett tudósítások szerént Nagy Mélt. Gróf Festetics György Ö Exc.-ja Feb. utolsó hetében alsó részeinek a’ gutaütés által tellyes elgyengülése miatt ágyba fekvő beteg lett. Febr. 27-én életéhez kevés reménység volt. - Azonban ujabb tudósítások szerént reménylenünk lehet, hogy a' Hazának e' nagy oszlopát köz örömünkre a' Gondviselés fentartani fogja". ${ }^{927}$ A tudósítás szerint Festeticset csak február végén ütötte meg a szél, azaz kapott agyvérzést, holott tudjuk, hogy már a február tizenhatodiki Helikonon is beteg volt, illetve egy évvel korábban sem volt egészségileg rendben. Több kortársa szerint is, betegségét lelki megnyugvással, olykor humorral fogadta. Erről számos anekdota, feljegyzés és történet tanúskodik, melyek azonban nem többek a helyi legendárium szüleményeinél. ${ }^{928} \mathrm{Az}$ események lefolyását a kortárs Horváth Ádám levele talán közelebb hozza az olvasóhoz, éppen ezért Festetics utolsó napjainak krónikáját az ő tollából is idézzük: „Ö, magamként igen vidám beteg vót, 's mennél inkább közelített halála, annál játszibb, sőt valóban enyelgő, mint rólam mondta néha napján $\mathrm{Sp} / \mathrm{issich} / \mathrm{J} / \mathrm{ános} /$, hogy borjazik az eszem. Szél ütése után rossz vólt a' gyomra; lágy vagy kemény, a' mint az orvos szerek izgatták: egyszer midőn le vették a' székrül; azt mondta: valaha mikor a' kis groff a’ bugyogójába sz...t, meg paskólták a' s...it; most pedig örülnek az Orvosok, ha ö Excellentiája egy keveset sz...hatik. - Az ifju Groff Lászlót egy alkalmatlan Creditorja Bétsbül Keszthelyig kísérte, hogy vagy meg fizettessen vele, vagy kezessé tehesse; sokáig kellett tartózkodnia, mivel az Öreg Groff elnehezedett, 's a' szégyen miatt az Ifju Groff is meg betegedett: mellyet meg értvén az Öreg, öregbedett betegsége a' fia nyavalyája miatt, mert azt ő, mint mások is testi nyavalyának vélték. - Valaki nagy sokára bejelentette a' Creditort az Öregnek: ő mindjárt be kérte az adós levelet, 's reá irta ezt: Cavet Georgius Festetits; - a' Német el-ment: 's ezt meg értvén az ágyba fekvő Ifju Groff; meg gyógyúlt és fel kelt; Hirül viszik ezt az Öregnek:'s azt felelte, hogy az Ö Orvossai nem tudnak annyit mint Ö, mert ő három szóval meggyógyitotta a' beteget. A' medicum Consilium, biztatásképen azt vallotta, hogy még négy öt esztendeig el élhet; ő pedig érzette hogy nem: (érezhette is, mert még életében három vagy négy nap halott szaga vólt): 'S kérte a' Consiliumot, hogy miatta ne zsenirozza magát: hanem bizvást mondja meg a' mit érez; 's hallotta is suttogva, hogy kevés napot szántak neki: akkor hát hivatta a

\footnotetext{
${ }^{927}$ Hasonló tudósítást közölt a MK. 1819. március 16-i száma is.

${ }^{928}$ Bisztray, 1968. 92-93.
} 
Fiscalist, és diktált neki egy Instantiát, és egyszersmind apellatát, hogy ő a' Tettes medicum consilium végzését apellálja a' Bétsi és Parisi Medica facultas elejbe; de kéri is Orvossait, hogy nyujtsák meg életét négy vagy öt esztendővel. E' tréfa után czifra kotsit küldött Ruszek Apaturért, hogy jöjjön minden czókostul mókustúl, és készítse el őtet az Örök utra: Az Apatur el ment, meg halgatta gyónását, ki tárván minden ajtajit a’ szobának; az absolutio után el akart menni az Apatur; de a' beteg, hát u. m. az utolsó kenet? azt felel az Apatur, nem szoktuk adni, még halálnak nem válik a’ beteg; de ezt kivánta, hogy essünk által azon is; akkor, no ugymond, már most hát semmi hijjunk sints: el eresztem Fő Tisztelendő Urat, ugy hogy ezentúl kétszáz ölnyire a' kastélyhoz ne közelittsen; azomban valamint a" Testi Doctornak, azon utolsó napokban 100 forintot rendelt naponként, ugyan annyit adjanak a' haláláig a' Lelki Doctornak is; 's ezt a' mondást, tilalmat és rendelést kevés ember, vagy senki sem értette. Az Ifju Groff László haza sijetett Bétsbül a' halálos hirre; annak azt mondotta talán a' Successiót által venni sijetett; hiszen nem viszem el a’ hátamon. - A’ Muraközi Perceptorja pénzt hozott, 's ezt tudtára adván neki, be hivatta és azt mondta neki: Az Úr jó ember, nekem pénzt hozott, tsak hogy már én nem soká veszem hasznát, azonban lesz gondom az Urra, mindjárt meg-parantsolom, hogy jól tartsák az Urat. - A' testamentomára kívül reá irta; hogy ha a’ Directio és Groff László ennél okosabbat tudnak gondolni, ám tselekedjék, de ha nem; fogadják meg a' mi bele van irva. - Temetésérül, és az ahoz tartozandókrúl maga gondoskodott és rendeléseket tett: régen Varga László jó Barátomnak beszéd közben egy kettős ekét igért; az is eszébe jutott, és halála előtt való nap meg-küldötte."929 Horváth levelében beismeri, hogy amit írt azt másoktól hallotta és úgy gondolja, hogy hallanak még számos anekdotát Festetics utolsó napjairól és haláláról. Horváth János veszprémi kanonok Festetics halálának évében megjelent nyomtatványában hasonlóan ír. A leírás sok pontban megegyezik Horváth Ádám levelével. Van azonban egy különbség, míg Horváth Ádám nem egyházi szempontokat vesz elsősorban figyelembe, névrokona azt bizonygatja, hogy a nyugodt halál egyetlen lehetősége az, ha a vallásba, az egyházba, a hitbe, azaz a „Relígyióba” veti a haldokló bizalmát. Horváth János így írja le az utolsó napokat: „A’ nagy Férjfiú egyedül maga nézte háborodás nélkül a' közelgő halált, ’s annyi tárgyakkal körülvéve, mellyek vagy az élni kívánást, vagy az érzékenységet felébreszteni termettek, még csak bánatos szemet sem vet vissza az életre. Szerelmesi zokogásinak, hűvei siránkozásának közepette, a’ Religyió karja köztt keresi nyugalmát. Tudgya, hogy eljött az órája, hogy már nincs segítség, és mégis legkevésbé sem csükkenik az ő vidámsága; azzal a' gondossággal, 's

\footnotetext{
${ }^{929}$ Horváth Ádám Kazinczy Ferencnek, 1819. április 10. ; KazLev. XVI. 348-349.
} 
nyugodtsággal teszi rendeléseit, mintha most kezdené el igazgatni a’ maga dolgait; töredelmes szívvel megvallya még eggyszer vétkeit, 's feloldoztatásért könyörög az Isten szolgájának; az örök élet kenyerét mély alázatossággal veszi az utra magához, 's felkészettetni kivánkozik a' végső tusakodásra; az üres napok, 's a' bajos éjtszakák hosszabbra nyullanak; de ő rettenthetetlensége erősödik, vastagodik a' test romladéki között; végpontyára érvén azonban kiszabott pállyájának, elaludt. Illy naggyá teszi embert a' halálban az isteni malaszt, ha nyugvó pontyát a' Relígyióban keresi ügyekezetinek". ${ }^{930}$ Mindkét leírásban valószínűleg van túlzás, van némi elfogódottság és anekdotikus jelleg. Horváth János „szerelmesinek zokogásá"-ról ír, holott tudjuk, hogy fia Bécsben tartózkodott és csak az utolsó órákra érkezett Keszthelyre, felesége is régen elköltözött a keszthelyi kastélyból, ő sem volt jelen az utolsó percekben, bár korábban betegágyánál meglátogatta. „Hüvei siránkozásá”-t is fenntartással kell fogadnunk. Erre utal Kövér János vörsi plébános feljegyzése, aki az utolsó napokat, órákat máshogyan látta: „Az 'igen is’ szó, tsaknem minden harmadik szavánn szokása volt a Grófnak: mikor halálos ágyában feküdt, mindenek el hagyták, hanem egy öreg asszonyt fogadtak melléje, ki az emésztetjébül tisztogatta és imádkozott: mikor hát a Miatyánkban ezen szókra jött az asszony: Mi kenyerünket adgyad nékünk, és botsásd meg nékünk a mi vétkeinket, az Öreg Gróf akkor is tsak untalan ezt felelte: 'igen is'."931 Kövér János is az írta feljegyzéseiben, hogy a beteg grófot Ruszek József apát gyóntatta és áldoztatta meg betegágyában. A három „beszámoló” nem egyezik meg mindenben, ugyanakkor azt is feltételezhetjük, hogy Horváth Ádám és Horváth János a betegség korábbi szakaszáról, míg Kövér János a halál előtti órákról beszél. Az ellentéteket így lehet feloldani. Ha hihetünk a Kövér-féle feljegyzésnek - s miért ne tennénk? - a legtragikusabb az a mondat, amelyben a hatalmas Festetics birtok ura, a történelmünkben meghatározó szerepet játszó gróf, az agyvérzéstől elborult elmével, egy a szolgálataira megfogadott öregasszony társaságában várja életének utolsó percét. Sic transit gloria mundi? - tehetjük fel magunkban a kérdést, de a válasz mindenképpen - legalább is Festetics György gróf esetében - nemleges. ${ }^{932}$

\footnotetext{
${ }^{930}$ TISZTELET OSZLOPA, MELLYET NÉHAI NAGY MÉLTÓSÁGÚ TOLNAI GRÓF FESTETICS GYÖRGY ÚR Ö EXCELLENTIÁJÁNAK A' CS. KIR. APOST. FELSÉG KAMARÁSSÁNAK, VALÓSÁGOS BELSÖ TITKOS TANÁCSOSSÁNAK, Aprilis 15-kén 1818- eszt. EMELT HORVÁTH JÁNOS RUDINAI APÁT, 'S WESZPRÉMI KANONOK. - WESZPRÉMBEN, NYOMTATTATTOTT SZÁMMER KLÁRA BETÜIVEL, 1819. (Fest. K. Hel. Knyvt. Lit. hung. 1061/2. p. 18)

931 Kövér kézirat, 1834. 21.

${ }^{932}$ Festetics halálának irodalmi feldolgozására Dr. Csák Árpád vállalkozott a „Festetics György gróf” címü elbeszélésében. = A szép Balaton mellöl. Beszélyek, rajzok. Keszthely, 1906. 39-50.
} 
A gróf halálát követően kiadott gyászjelentésekből ${ }^{933}$, ha a halál közvetlen körülményit nem is, de pár lényeges adatot pontosíthatunk. Megtudjuk, hogy „1819-ik Esztendei Böjtelőhavának 19-kén a' Szél által megüttetvén, hat egész hetekig tartó betegségből, minden Szentségek áhitatos felvétele után, Keszthelyen folyó Sz. György Havának 2-kán Regveli 9, és 10 óra között, betses életének 65-dik Esztendejében e' Múlandóságból az Örökkévalóságba által lépett." ${ }^{934}$ Felesége Sallér Judit külön értesítést nyomatott, amelyben Festetics valamennyi címét felsorolta: „Nagy Méltóságú Gróf Tolnai Festetics György Császári 's Királyi Kamarás és Valóságos Belső Titkos Tanátsos Úr Ö Excellentiája, Rezi, Tádika, Kemend, Vasvár és Csáktornya Várának, úgy Keszthely, Rezi, Tádika, Kemend, Vasvár, Csurgó, Sz. Miklós, Balaton Keresztur, Ságh, Muraköz, Csáktornya és Szalk Szent Márton Uradalmak’ örökös Ura, Légrád' Fő Kapitánya.” A nyomtatvány a gyászoló családtagokat név szerint említeti. A házasságuk harminchetedik évében meghalt férjet „Felséges Urunk hüséges Jobbágyának, Nagy Hazafinak, a’ Tudományok’ Előmozdítójának, a’ Nemzeti Tsinosodásban az Ifjúi kor' Felsegítőjének, jó Férjnek és legjobb Atyának” nevezi. A szokványosnak mondható értesítést a következőkkel zárja: „A’ Boldogúltnak hideg teteme, Keszthelyen a’ Parochialis Templomnál lévő Sirboltba ezen Hónapnak 14-dikén fog addig is illendő tisztességgel letétetni; míg egy Kápolnát, és ahoz Sirboltot, ugyan Keszthelyen a' Fiam Gróf László épittetvén, az örök nyugodalomra oda fogja általtemettetni. ${ }^{935}$ Exsequiái Keszthelyen, és az Elhúnytnak minden Uradalmiban ezen Sz. György Havának 15-dikén fognak tartatni."936

Festetics haláláról a legnagyobb magyarországi sajtóorgánumok beszámoltak. ${ }^{937} \mathrm{~A}$ temetés részletes leírását a Hazai 's Külföldi Tudósításokból ismerhetjük. ${ }^{938}$ A Magyar Országos Levéltárban található „Gyászos Rendelések és Levelezések Protocoilluma” "939 tételesen leírja gróf Festetics László rendkívül részletes utasításait a temetésre vonatozóan.

1819. április 14-én gróf Festetics György temetésén Zala, Vas, Veszprém és Somogy megye nobilitásai, vezetői képviseltették magukat. Az Országosa Levéltár Festetics

\footnotetext{
${ }^{933}$ A gyászjelentéseket Perger Ferenc keszthelyi nyomdász nyomtatta ki. Erről tanúskodik az 1819. április 17 -én benyújtott 165 forint értékủ szálája. (MOL Fest. Lvt. P 246 B IV. 110. 67.)

${ }_{934}$ Particédula. Balatoni Múzeum, 2178. 2006/169. ; MOL Fest. Lvt. P 246 B IV. 110. 2.

${ }^{935}$ Erre sohasem került sor. Festetics György hamvai mind a mai napig eredeti helyükön, a keszthelyi Fő téri Plébániatemplom kriptájában nyugszanak. A Festetics család önálló mauzóleumot csak 1925-ben épített a keszthelyi Szent Miklós temetőben, ahol az első elhelyezett koporsó Lady Mary Douglas Hamilton (1850-1922) herceg Festetics Tasziló feleségének hamvait tartalmazta.

${ }^{936}$ Balatoni Múzeum, 2178. 2006/169. ; MOL Fest. Lvt. P 246B IV. 110. 2.

${ }^{937}$ TGy. 1819. IV. köt. 127. ; MK. 1819. április 13. 233. ; HKT. 1819. I. 28. 218-219. ; Haszn. Mul. 1819. 33. 249.

${ }^{938}$ HKT. I. 33. $257-260$

${ }^{939}$ MOL. Fest. Lvt. P 246. B. IV. 110. 70-78.
} 
Levéltárában megtalálható az a kartonált mappa, amelynek borítóján a következő cím olvasható: „Nagy Mságú Tolnai Gróff Festetits György Úr Eö Exja halotti temetésére és Exequiájára megjelent mindennémü Vendégek fel-jegyzése. diebus 13. 14. Apr. 819".940 A szerintünk nem kellő pontossággal vezetett ${ }^{941}$ - füzet huszonkét nevet sorol fel, köztük Forintos Györgyöt, gróf Festetics Imrét, Kisfaludy Sándort, Mezőszegedy Szegedy Ferencet, Bezerédy Györgyöt. ${ }^{942}$ A névsor mellett a vendégek szálláshelye is szerepel. Gróf Festetics Imre, Mezőszegedy Szegedy Ferenc és Kisfaludy Sándor a kastélyban kaptak szállást. Bezerédy György szállása nincs jelölve. A többiek a város különböző helyein lévő szállásokban tölthették az éjszakát. A vendégek túlnyomó része a keszthelyi Darú Vendégfogadóban ebédelt és vacsorázott április 13-án, 14-én és 15-én. ${ }^{943}$ A Hazai 's Külföldi Tudósítások szerint, nemcsak a förendek, de a köznép is jelen volt. Az újság szerint a gyászolók között ott láthatták Festetics Imre grófot, György öccsét, a híres mezőgazdát, vejeit; Zichy Károly és Almássy Illés grófokat. Betegségre hivatkozva nem jelent meg a temetésen Sallér Judit, az özvegy, valamint László felesége, herceg Hohenzollern Hechingen Jozefina. Két püspök, négy apát és hatvan közrendü pap vett részt a temetési szertartáson, amely reggel kilenc órakor kezdődött. Festetics bebalzsamozott, de a belső részektől meg nem szabadított holttestét hármas koporsóba tették. Az első puhafából, a középső keményfából, végül a külső koporsó rézből készült. A kastélykápolnában felravatalozott koporsót halottaskocsira tették, amelyet fekete szalagokkal és kárpittal díszítettek. A kocsi elé hat fekete sallangokkal feldíszített lovat fogtak A halottas menet résztvevőinek kezébe viaszgyertyát adtak. Miután a szertartást végző papok a plébániatemplomból ${ }^{944}$ megérkeztek a kastélyhoz, elkezdődött maga a szertartás. A temetési gyászszertartást Somogyi Leopold szombathelyi püspök és Horváth János kanonok és Ruszek József keszthelyi apát celebrálták.

\footnotetext{
${ }^{940}$ MOL. Fest. Lvt. P 246. B IV. 110. ; Horváth Ádám neve nem szerepel a listán, holott saját kezű feljegyzése szerint a temetésen szétosztotta Festetics halálára írt versét.

${ }^{941}$ Annak ellenére, hogy külön íródeákot is fogadta, Kvatsák István uradalmi íródeák személyében, kinek 3,51 forint útiköltséget kifizettek. (MOL. Fest. Lvt. P 246. B IV. 61.)

${ }_{942}$ A felsorolás sorrendje: „Forintos György Mihályfáról, Sényi Gener. Perceptor, Csernák Fiscalis, Novák Stridói Pléb., Vachtarits Szoboticai Pléb., Ollári és Csurgói Fiscalisok, Horváth Fer. (?) Notar., Jagasits Director, gróf Festetits Imre, Safranits Káplán, Perlaky Káplán, Krajner Fiscalis, Csondor János, Palini Inkey János két fiával és Professorral, Dr. (? olvashatatlan), D Oroszi (?), D Kazai Gener. Professor, D Fábián VDM, M. Szegedy Kamarás Úr, Ttes Kisfaludy Sándor, Bezerédy György, B. Foky Obester" (Mol Fest. Lvt. P 246 B IV. 110.)

${ }^{943}$ A Darú Vendégfogadó számlája szerint a vendégek étkezéséért 426 forint 30 krajcárt fizetett a Festeticsudvar. (MOL Fest. Lvt. P 246 B IV. 110. 49.). Festetics László utasításainak megfelelően 6-7 fogásos ebédet szolgáltak fel a vendégek számára. (MOL Fest. Lvt. P 246 B IV. 110. 75.). Az ekkor már emeletes, ma is álló, egykori Darú uradalmi vendégfogadó későbbi nevei: Amazon Szálló, Szabadság Szálloda. Ma (2013) használaton kívül van. Ez az a fogadó, ahol Csokonai is megszállt. (lásd: 493. lábjegyzet)

${ }^{944}$ Ez ma a keszthelyi Magyarok Nagyasszonya gótikus plébánia templommal azonos (Fő tér).
} 
Az egyházi énekek, valamint az alkalomra írt magyar nyelvű búcsúztató ének elhangzása után megindult a gyászmenet. A tudósító a sorrendet is leközli: „Elöl a’ keresztnél vezérül ment egy uraság Tisztje, hármad magával gyászban; azután a' Polgárság, kiket követték a' Zsidóknak Vénei, a' Czéhek, a’ Deákság, ’s ezek után a' Muzsikusok fekete köpönyegekben a’ szomorú Marsot fujdolgálván”. Ezután következett a papság, élén Somogyi Leopold püspökkel, majd a házi cselédek, az udvari és a directio tisztjei. Öket a lovászmester követte lóháton, mellette pedig szintén lóháton, két lovász lovagolt. A halottaskocsi elé fogott hat ló mindegyikét egy-egy ,istálló-béli tseléd” fogta a zablájánál. A koporsónál a család címerei kerültek elhelyezésre, s a kocsi két oldalán tizenkét georgikoni praktikáns vonult fáklyákkal és címerekkel. A halottaskocsit Festetics László követte, majd a rokonság, a förendek, köznemesek, asszonyok vonultak.

A Festetics Levéltárban fennmaradt számlák alapján tudjuk, hogy Magyar Ferenc és Szily János huszárok gyászegyenruháit Varga János keszthelyi szabómester készítette. Ugyancsak ő, Vlasits István szabómesterrel egyetemben tisztította ki a templomban és ,az Kastélyban eltsunétot és motskolt posztókat." ${ }^{945}$ Fliszár Mihály szabómesternek szintén van számlája az iratok között. ${ }^{946}$ Dobosi József keszthelyi gombkötő zsinórokat, rojtokat, öveket készített a gyászszertartáshoz. ${ }^{947}$ Ebből kitűnik, hogy elsősorban keszthelyi iparosok szolgáltatásait vették igénybe, ekkor már szinte minden mesterség képviselve volt a településen.

A hosszú gyászmenet végül elért a plébániatemplomhoz, ahol a templom kriptájának egyik fülkéjébe elhelyezték Festetics György koporsóját, majd a nyílást egyszerü, vésett csigavonallal keretezett, felül ívelt kőlappal lefedték. A kőlapon hibásan írták fel születési évét, egy évvel öregítve Festeticset. A meg nem bolygatva, sír és a kőlap, mind a mai napig eredeti állapotban található meg a templom kriptájában:

\section{G. GEORGIUS FESTETICS \\ DE TOLNA \\ SCR. A. M. CAM. ET. ACT. \\ INT. STAT. CONSILIARIUS}

NATUS DIE 1. J JAN. 1755.

\footnotetext{
${ }^{945}$ MOL Fest. Lvt. P 246 B IV. 110. 13. ; A szabómesterek 1819. április 16-án kelt számlájának végösszege 58 forint $20 \mathrm{kr}$., kerekítve 59 forint. A számlán lévő átvételi elismervény azonban csak 50 forintról szól.

${ }^{946}$ MOL Fest. Lvt. P 246 B IV. 110. 16. 1819. április 16-án kelt számlájának összege 45 forint 30 kr., de csak 30 forintot vett fel.

${ }^{947}$ MOL Fest. Lvt. P 246 B IV. 110. 30. ; A gombkötő számláján az összege 320 forint, kifizetésre 310 forint került.
} 
OBIIT DIE 2. ${ }^{\mathrm{a}}$ APRILIS 1819

A helikoni költők közül Kisfaludyn, Pálóczi Horváthon kívül talán csak Berzsenyi Dániel vett részt a temetésen. Erre is csupán következtetni tudunk, elsősorban Berzsenyi „Elégia Gróf Festetics György hamvaira” címü versének első soraiból (Keszthelyi partnak evez ladikom...), amint azt Négyesy is megteszi. ${ }^{948}$ Az ellenév azonban eléggé nyomós, mert tudjuk, hogy Berzsenyi 1819 elején még súlyosan beteg volt, s így kétséges lehetett utazása a keszthelyi gróf temetésére. ${ }^{949}$

A temetés után a förangú vendégek visszatértek a kastélyba, ahol Mezőszegedy Szegedy Ferenc császári és királyi kamarás, Zala vármegye első alispánja felbontotta és ismertette Festetics György végrendeletét, amely a vármegyénél volt letétbe helyezve. ${ }^{950} \mathrm{~A}$ végrendelet szerint Festetics György teljes örökösének fiát Lászlót nevezte meg, de kikötötte azt is, hogy a rokonok mit kapjanak. Festetics György ugyanis azt szerette volna, ha a Festetics Kristóf-féle birtok, amelyért annyit küzdött, egyben marad. ${ }^{951}$

Az Országos Levéltárban fennmaradt dokumentumok, számlák alapján következtetni tudunk a temetés utáni torra is. Öt szakács tevékenykedett, munkabérük kifizetésének jegyzékén a következők állnak: „Zalabéri szakács 30 forint, Szentgróti szakács 30 forint, Ötvösi szakács 30 forint, Dvornokovitsné szakács 15 forint, Novota György szakács 30 forint". A tor alapanyagainak egy kisebb részét helyben vásárolták meg, így Mázsa Mihálytól és Kováts Ferenctől 1400 rákot vettek összesen 24 forintért. ${ }^{952}$ Az élelmiszer alapanyagokat elsősorban Bécsből szerezték be. Két számlát is találtunk a bécsi „der Cioccolate Fabrique des Stephan Rinaldi in der Nagler Gasse No. 330" fejléccel, ahonnét csokoládékat és rumot vásároltak. ${ }^{953} \mathrm{~A}$ híres, szintén bécsi Casali cégtől, melyet akkor már az alapító fia Julian Casali vezetett különféle likőröket vásároltak: vanílialikőrt, maraschinot, kávélikőrt. ananászlikőrt és pezsgőtt. ${ }^{954}$ A rendelkezésre álló számlaösszesítő negyvennyolc tételből áll, és a Bécsben vásárolt, a halotti torhoz szükséges különféle termékeket sorolja fel. Élelmiszereken, gyümölcsökön kívül konyhai eszközök és egyebek vásárlására is sor került. Izelítőül pár tétel: sziták rezes rostával, konyhakés, keményítő, cinóberfesték, festőecset,

\footnotetext{
948 Négyesy, 1925. 208-209.

949 Berzsenyi ÖM., 1979. 806. ; Berzsenyi temetésen való részvételéről irodalmi alkotás is született: Laczkó András: Hogyan üljünk a pegazuson? Pro Pannónia, Pécs, 1997. 64-65.

${ }^{950}$ Festetics végrendeletének több változata ismert, a magyar nyelvủ változata 1817. január 17-én íródott, német nyelvü 1819. február 25-én. (MOL Fest. Lvt. 1 cs. 14-26)

${ }^{951}$ Szabó, 1928. 304.

${ }^{952}$ MOL Fest. Lvt. P 246 B IV. 110. 61.

${ }^{953}$ MOL Fest. Lvt. P 246 B IV. 110. 32-33.

${ }^{954}$ MOL Fest. Lvt. P 246 B IV. 110. 35.
} 
gumiarábikum, arany füst, ezüst füst, cukorsütemény, angolna hal, holland héring, parmesan sajt, lüneburgi sajt, édes mandula, sago, narancs, vanília, szekfüszeg, szerecsendió, szerecsendióvirág, vizahólyag, pisztácia, kávé, spanyol aszúszőlő. ${ }^{955}$

Sajnos a tor lefolyásáról nincs hitelt érdemlő adatunk. Tudjuk viszont, hogy a temetésre jövő jobbágyok között ezer darab másfél fontos kenyeret és tizenöt akó 1818-as évjáratú bort osztottak ki. A grófi udvar utasítása szerint mindezeket úgy kellett szétosztania a felsőmajori ispánnak, két vincellér és két gazdaságbeli hajdú segítségével, hogy a temetésen résztvevő mindegyik jobágynak jusson. ${ }^{956}$

Másnap a keszthelyi gyászmisét reggel kilenckor, Kurbélyi György veszprémi püspök mutatta be, segédkeztek Ruszek József apát és Küllei János kanonok. A plébániatemplom fekete posztóval volt bevonva, a katafalk a templom közepén állott a Festetics címerekkel, körben számtalan gyertya égett. A már idézett Hazai 's Külföldi Tudósítások szerint a „Requiem végével a’ Liberea, és Absolutiok az egyházi szertartás szerént tartattak”. Ezt követően Horváth János apát, veszprémi kanonok prédikált és a Királyok könyvéböl a következőket citálta: „Nem tudjátok e’, hogy egy Fejedelem, a’ legnagyobbik, esett el ma Israelben".

A prédikációt a „Ditsőitő Mise” a Sacrum gloriosum követte, amelyet Somogyi Leopold püspök és Küllei János kanonok, valamint Ruszek József apátplébános celebráltak. A vendégek közül a förendek a kastélyban, a papság a premonteri kolostorban, illetve a plébánián, a köznemesek és polgárok a vendégfogadóban, illetve az uraság tisztjeinél laktak. Megjegyzi befejezésül az újság, hogy ,a’ Szegényebbeknek pedig Bor, kenyér, és pénz bőven osztogattatott”.

Több egyesület, társaság is megemlékezett a gróf haláláról, elsősorban azok, akiket anyagilag támogatott. Ilyen terve volt a Soproni Magyar Társaságnak is, akiknek tagjai 1819ben elhalasztották az úgynevezett örömünnepet, mert Festetics Györgynek, aki a „Társaságnak nagy Gyám Atyja volt, tehát illő volna a’ Magyar Nemzet részére gyászos halálán minekünk is egy Innepet szentelni, ’s abban érdemeit 's halálán epekedő szívünk jajjait szájolni". ${ }^{957}$ Ebben az esetben azonban nem történt meg a tervezett Festetics emlékünnep, ugyanis addig-addig halasztották a dolgot, mígnem 1820. május 17-én örömünnepüket rendezték meg emlékünnepély gyanánt.

\footnotetext{
${ }^{955}$ MOL Fest. Lvt. P 246 B IV. 110. 31.

${ }^{956}$ MOL Fest. Lvt. P 246 B IV. 110. 78.

${ }^{957}$ Bodolay, 1963. 156. (A kötet részletesen foglalkozik a Soproni Magyar Társasággal)
} 
A temetést követően Festetics György halálán kesergő versek sora született: Berzsenyi Dániel, Virág Benedek, Kisfaludy Sándor, Horváth Ádám, Kazinczy Klára, Dessewffy József emlékezett meg a grófról. Berzsenyi megírja szép versét az „Elégia Gróf Festetics György hamvaira" "958, amely egy idilli képpel nyit, de ím felsejlik a való:

Keszthelyi partnak evez ladikom, mosolyognak elömbe

A szeretett tájék öblei s árbócai.

Nyugszik az ég, lebegő zephyrek ringatva vezetnek,

Csak keblem zajlik, hányja halála jegét:...

Virág Benedek epigrammája plasztikus és lényegében tárja fel Festetics nagyságát:

György! te nem énekléd (mint a nagy Római Költő Hagyta magáról) ezt: ,pascua, rura, boves.”

Formáltad, nagy okosságú! e szép haza földét,

És annak, mit amaz verseze, lelket adtál. ${ }^{959}$

Kisfaludy Sándor „, Gr. Festetics György árnyékához,960 című huszonnégy versszakos ódája mondandójában hasonló az előző Festetics vershez. Az óda első két verse szól csupán Festeticsröl:

„Nem élsz te, Árpád nagy fiam Festetics,

S azolta már nem füstölög áldozat

Oltárain hazánknak; azt mind

Önszeretet nyeli és emészti.

$\mathrm{Az}$, a ki mindent, a miket általad

Cselekve látott, tenne, szegény; s kiket

A sors megáldott bő vagyonnal,

Átkai többnyire a magyarnak.

\footnotetext{
${ }^{958}$ Berzsenyi, 1978. 131-132.

959 „Tolnai Gróf Festetics Györgynek emlékezete” (Virág, 1980. 131.)

${ }^{960}$ Kisfaludy, 1871. 201-205.
} 
Az óda további részében, akár csak az első Festetics versében kemény hangon ostorozza, az önzö és hazafiatlan főurakat, és különös eréllyel tör felettük lándzsát. Kisfaludy nem válogat a keményebbnél keményebb szavak közt, amikor az általa fontosnak tartott nemzeti kérdések megbicsaklanak az önérdek, a hazafiatlanság, a nemtörődömség, a lustaság béklyóiban. Aki tenni tud: tegyen! Megvetendő, ki tenni képes lenne, de nem tesz.

\author{
Az ott - temérdek földjei, erdei, \\ S jobbágyi zsírját egy fene vérszopó \\ Nadály szerint magába szíván, \\ Háta megé veti szép hazáját, \\ És mind azon szent kötelékeket, \\ Mellyekkel emberléte kötözve van, \\ Természet és polgárszövetség \\ Által (az erdei vad koránt sem
}

Felejti honját s társait ily vadúl),

$\mathrm{S}$ a nemzet ügyét messze tekergi el.

S hivalkodásra vesztegetve

Költi el itt kizsarolt vagyonját.

Váteszként dörgi a vers utolsó szakaszában a végső órának nagy kérdését, amely eldönti minden ember örök jutalmát itt a földön és a másvilágon, azaz neve és tetteinek emléke megmarad-e az örökkévalóságnak, avagy a megvetés a feledés szakadékába zuhan?

De eljövend még egykor az óra, mely

Kérdést teszen majd: „Életed a haza

Javára, vagy vesztére volt-e?”

Mint kereséd, legyen úgy jutalmad! 
Horváth Ádám, már a Hattyúi énekkel is búcsúzott, de április 13-án megírta és a temetésen szétosztotta a szabadkőműves szimbólumokat is felsorakoztató, „,Gróf Festetits György halálára" című versét. ${ }^{961}$

A’ midőn Gróf Festetics György Életének vége lett,

Pörbe szállt a' Föld az Éggel a' dicső halott felett:

Miért irigyled monda, nékem halhatatlan Egyemet?

'S tiltod, hogy tovább is élve diszesitsen engemet!

Hogy világoljon sokaknak, hogy tanítson százakat,

Hogy hogy éljenek haszonra 's boldogítsák honjokat!

Mellyre mond az Ég: enyim Ö, égi volt és égi lesz,

Eddig engedtem Te Néked 's hát ezentul mit keressz?

Nem becsülték őt eléggé, míg vezér csillag vala,

Ködbe vonta fényét a’ Gög és irigység angyala;

Most midőn az égi tüz-szesz, tüz helyébe vissza tért,

El tünésével tanuld meg, míg jelen volt, mennyit ért?

A’ Dicsőség Templomából egy nagy Angyal közbe szállt:

Halhatatlant semmiségbe nem rekeszt bé semmi bólt,

'S bár ha földbe megy, porrá lesz teste, minthogy föld neme,

Számos századon keresztül fog ragyogni Érdeme!

A’ Dicső Lélek tekintvén ez feleselésre le,

Ugy szóllt gyámolítottihoz, mint az Angyal felele:

Által estem a' halálon, de nem gyáva lelkekén,

Itt ezer Nagyok sorában, ott fiamban élek én!

Dessewffy József 1819. május 13-án keltezett versben búcsúzik a gróftól, aki a legelönek szánt cserjésben, mint a villámtól lesújtott öreg tölgy zuhant le, de új ágat, tövet nevelt László személyében. A veszteség azonban így is óriási: ${ }^{962}$

\footnotetext{
${ }^{961}$ MOL Fest. Lvt. P 2461 cs B. IV. 2. ; A vers megjelent: Haszn. Mul. 1819/ 33. 249. ; Lásd még: Jászberényi, 2003. 92-93.

962 „Gróf Festetics György’ halálakor Gróf László fiához” ; KazLev. XVI. 388-389.
} 
Dülnek az oszlopok, roskad az épület.

Festetits elhuntál hazád' omladékin,...

De amit György vetett aratni kell, s Lászlót dicséri majd ezután az ének, ha igyekszik a mag érlelésére. Szinte az egész versben az ifjú László grófhoz intézi szózatát, hogy apja alkotásait vigye tovább, ne a nemzet, az ország hanyatlását, de felemelkedését tűzze ki célul. Érdekes a tizenegyedik versszak első sorának intelme, mintha Arany János „,Toldi estéjé”-ben”963 olvasnánk, a magyarságot megóvni akaró figyelmeztetést:

Gyomlálgasd nemzetünk’, de Magyar maradjon,

Ám hiába volt a sok jó tanács, Festetics László nem tartotta magára nézve kötelezőnek apja elgondolásainak továbbvitelét. Bár sokat áldozott kulturális célokra, amint arra korábban már rámutattunk, a balatonfüredi magyar színház oszlopait ő faragtatta, ${ }^{964}$ megyei könyvtárak felállítását szorgalmazta, ${ }^{965}$ de a Helikon eszméje nem érdekelte, így az ünnepek megszüntek. ${ }^{966}$

A Magyar Tudományos Akadémián Kis János tartott emlékbeszédet gróf Festetics György fölött.

Széchenyi István gróf „Nemzetünk nagyjainak megbecsülése” címü írásában a következőket írja: „Nincs szükség drága és költséges emlékoszlopokra. Egyszerü márványkövek, tán éppen oly egyszerü vaskerítéssel környezve, meg néhány anyagi gonddal táplált ültetvény - köréjük helyezve s itt-ott előtűnő ily nevek, mint Berzsenyi, Kölcsey, Kazinczy, Festetics György, Virág Benedek, Dömötöri Németh János, Kisfaludy Károly, Deák Antal..."967

\footnotetext{
963 „Szeresd a magyart, de ne faragd le - szóla, Erejét, formáját, durva kérgét róla..."

Arany János: Toldi estéje = Arany János munkái III. köt. Franklin, Budapest, é. n. 108.

${ }^{964}$ Eszes László: A balatonfüredi színház oszlopai - Kézirat. -

${ }^{965}$ Fülöp, 1978. 167.

${ }^{966}$ Talán nem is egyedül Festetics Lászlónak róható fel a Helikon megszünése. Ebben az időben az irodalmi (kulturális) élet már inkább Pestre koncentrálódott. 1821-től beindult a Kisfaludy Károly szerkesztette Auróra. Minden vidéki irodalmi központ, még Széphalom, Debrecen is provinciálissá vált. Méginkább ez a sors várt volna Keszthelyre. Kizárólag Darnay Kálmán színes tollának köszönhetjük azt a feltételezést, hogy Festetics a következő Helikonra meg óhajtotta hívni Kisfaludy Károlyt és előadatni „A kérők” címü darabját, csupán halála akadályozta meg ebben. ( Darnay, é. n. II. 132.)

${ }^{967}$ Fekete-Várady, é. n. 416-417.
} 
Számos ismeretlen szerző is elsiratta a grófot, sokan verssel fejezték ki megdöbbenésüket, fájdalmukat. Ilyen Cseresnyés Sándor „Nevendék Orvos”, aki saját költségén adta ki Bécsben, 1819. május 10-én „A'Nagy Festetits Árnyékához” címü versezetét: ${ }^{968}$

Hol jársz istenesült Festetitsünk Neve?

Pannonból szomorúan néztelek a’ minap

Céresz karjai közt égbe tolongani; -

'S ismét e' zokogás lakta fedél alatt

Unszolsz, mennyei fény! könnyeket ejteni?

${ }^{968}$ Fest. K. Hel. Knyvt. Lit. hung. 653/5 


\section{FESTETICS GYÖRGY AZ UTÓKOR TUDATÁBAN, HELYE A MAGYAR MÜVELÖDÉSTÖRTÉNETBEN}

Az eddigiekböl kiderült, hogy Festetics György megítélésében a kortársak sem vélekedtek egyöntetűen. Másként látta, másként ítélte meg a kastélyban vendégeskedő, másként a munkatárs, beosztott, alárendelt. Másként ítélte meg az udvar és teljesen másként azok, akik csak alkotásait vették számba, vagy személyes ellenszenvüket vetették papírra. Kurucz György írja, hogy a kortársak gyakran értetlenül álltak Festetics György tetteivel szemben, hiszen az értők számára egyértelmű volt, hogy a magyar nyelvű újságok támogatása, iskolák, alapítványok létrehozása, az „elárvult haza” szolgálatát jelentik. Negyven írónak volt nemcsak barátja, de jórészt pártfogója is - idézi Merényi Oszkárt Fülöp Géza már többször említett művében. ${ }^{969}$ Ugyanmakkor, midőn a jakobinusok börtönei megnyíltak, legtöbbször elhatárolódott a politikailag besározódott emberektől ${ }^{970}$ Ezt többen föleg Kazinczy Ferenc - vetették szemére. Ma már joggal feltételezhetjük, hogy alkotásainak védelmében volt határozottan körültekintő és óvatos. A kortársak ugyancsak negatívumként említették, azt a tényt, miszerint minden alkotását, elképzelését saját maga igyekezett irányítani, következetesen ellenőrizni. (A korabeli elbeszélések szerint hajnalban gyakorta meglátogatta a tehenészetet, arra volt kíváncsi, hogy utasításainak megfelelően látják-e el a jószágot. Máskor személyesen vizsgáztatott hallgatókat a Georgikonban, s rossz feleletek esetében retorziót alkalmazott.) A folyamatos jelenlétet a munkatársak, beosztottak a bizalmatlanság jelének is vehették. Pethe Ferenc ,tudálékos cenzornak” nevezi s az volt a vélekedése, hogy Asbóth Jánoson kívül senki nem tudott kijönni a gróffal. Kazinczy „Füttyös Gyurinak" aposztrofálta egyik levelében, szerinte cselédei így hívják a grófot, mert mikor „melancholisal, vagy haragszik, a’ legpajkosabb vagy verbunkos magyarokat fütyöli.,"971

Jelen dolgozat keretein belül megpróbáltuk valamennyi vélekedést összegezni, amelyek reményeink szerint elősegíti Festetics György - sokszor ellentmondásos, de mindenképpen célratörő, a haza üdvét kereső - alakjának jobb megismerését.

\footnotetext{
${ }^{969}$ Fülöp, 2010. 91.

${ }^{970}$ Kurucz, 1996. 74.

${ }^{971}$ Kurucz, 1996. 75.
} 
Az utókor sem egyértelmüen foglalt állást Festetics György személyének megítélésében. Halála utáni évek nem tették lehetővé tevékenységnek, személyének pártatlan megítélését. A politikai mozgalmak álltak a közérdek előterében, új írói nemzedék jött, kiknek közvetlen benyomása már nem volt Festeticsről. A felvilágosodás eszméit a reformkor eszméi váltották fel, a klasszicizáló irodalom a múlté lett, hogy helyet adjon a romantikának. Festetics László nem vitte töretlenül tovább mindazon alkotásokat, amelyek apja számára fontosak voltak. Az irodalom kevésbé érdekelte, az iskolák még tovább müködtek, $\mathrm{s}$ Lászlónak köszönhető a Georgikon magyar nyelvü tankönyvekkel való maradéktalan ellátása. A Magyar Minerva könyvsorozatról alig hallunk, a Helikoni Ünnepségek megítélése is sokszínű. Pedig Peretseni (Perecsényi) Nagy László ${ }^{972}$ „A híres keszthelyi gazdaság ügyelő oskoláról" írt versében felsorolva a gróf érdemeit, megjósolja Festetics György halhatatlanságát (részlet):

Lám, Keszthelyen nyert Uranus életet,

Nézd, bére mellett orvos, ügyész tanul:

Ím, a tudákosság beszélget,

S Pithagorás szabadon felelget!

Gróf Festeticsnek gongyja, - Georgikon

S könyvtárja - ösztönt nyújt ezekre.

Már folyamatban vagyon divattya.

Miképp oroszlányt nem nevel menyét,

Nem sast nem éleszt a nyomorult galamb,

Ugy Festeticsnek nagyra termett

Tettei, nagy nemeit mutattyák.

Elébb kiszikkadt tér Balaton vize,

Vagy Mátra bércén úszni fog hajó,

Mint Festetics szívét hazája

Oszlopos érdemiben ne, áldaná! ${ }^{973}$

Negyven évvel az utolsó Helikoni ünnep után Toldy Ferenc úgy jelentette meg „, $A$ magyar nemzeti irodalom történetét”, hogy abban egy szót sem ejtett a Helikoni ünnepekről -

\footnotetext{
${ }^{972}$ Peretseni (Perecsényi) Nagy László (1771-1827) író, költő, Arad vármegyei szolgabíró. Versei, írásai a Magyar Kurírban, a Hazai 's Külföldi Tudósításokban, a Tudományos Gyüjteményben jelentek meg. Több kötete ismert. (Szinnyei, 1903. 690-700.)

${ }^{973}$ Megjelent: ,,Helikon 1992 Keszthely” Castellum, Keszthely, 1992. 13.
} 
panaszolja Chalupka Rezső 1922-ben kiadott könyvében, ahol így ír: „...pedig a széphalmi neológiai szertelenkedéseit éppen a keszthelyi Helikon mérsékelte le és segítette a középútra, a nyelv természetes pszichéjének megfelelő mederbe! De nem ismeri a keszthelyi Helikon egyetlen egy más érdemét sem". ${ }^{974}$ Chalupka természetesen elfogult, ahogy más irányban

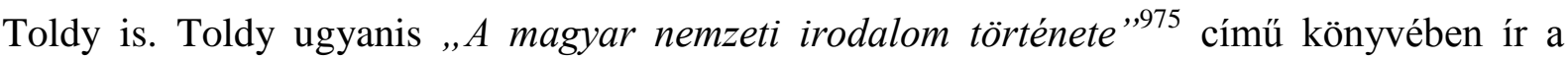
Helikonról, azonban nem veszi észre annak a magyar nyelvre és a irodalomra gyakorolt hatását. Csupán a nyelvújítás ellenzőinek maradi csoportját látja benne: „A társas téren, gyüléseken, a sajtóban kongattatott vészharang, s annál zajosabban, mert az ósdiak tiszta, de korlátolt meggyőződéséhez járultak a személyes rokon- és ellenszenvek is. Különösen a keszthelyi kör, gróf Festetics György vezérlete alatt, megtagadva mástól azon szabadságot, melyet maga elég bátran gyakorlott, tömött ellenzékként lépett utjokba a lelkes igyekvéseknek..."976 Toldy nem hatol mélyre elemzésében, csak a felszínt látja s szerinte maga az öt helikoni alkalom sem lett volna elég ahhoz, hogy „tömött ellenzékként” meghatározó hatást gyakoroljon Kazinczyra a nyelvújítás ellenében. Erre Négyesy is felhívja a figyelmet, amikor Toldy a Festetics ,,augusztussága” alatt létrejött keszthelyi kör tagjaként Kisfaludyn és Ruszeken kívül Takáts Józsefet, Pápay Sámuelt, Pázmándy Horváth Endrét, Dömét, Sághyt, Verseghyt, Somogyit, Fejér Györgyöt, Szabó Dávidot is említi, holott e költők, író jó része meg sem fordult Keszthelyen. Toldy tehát itt is téved és jóval nagyobbnak látja Festetics szerepét a Kazinczy elleni dunántúli csatározásokban, mint amilyen az valójában volt. ${ }^{977}$ Talán megengedhetjük magunknak azt a feltételezést, hogy Festetics jóval megengedőbb és békülékenyebb volt, mint a Helikonra érkező ortológus írók. Toldy más vonatkozásban elismeri Festetics nagyságát, amikor leszögezi, hogy hazafiságához a kétkedés leghalkabb lehelete sem fért. ${ }^{978}$ Gyulai Pál a keszthelyi ünnepeket negatívan értékelte: „minden olyan magasabb cél nélkül folytak le, melyek irodalmunknak használtak volna”.979 Ugyancsak Gyulai veti szemére Festeticsnek, hogy végletekbe tévedő magatartása miatt sem az irodalomban, sem a politikában, sem a társadalomban nem találta meg helyét. Gyulai ezen vélekedésének egyik alappillére lehet Festetics egynémely kortársának hasonló vélekedése. Az ünnepekre fordított pénzt gyümölcsözőbben is fel lehetett volna használni, írja Gyulai. ${ }^{980}$ Bizonyára, de ez a megállapítás a Helikonok érdemeit nem csorbítja, mivel független tőle.

\footnotetext{
${ }^{974}$ Chalupka, 1922. 9-9. ; Chalupka Rezső m. kir. tanfelügyelö, a székesfehérvári Vörösmarty Kör keszthelyi helikoni küdöttségének tagja 1921-ben.

${ }^{975}$ Toldy MNIT , 1987.

976 Toldy MNIT, 1987. 198.

977 Négyesy, 1925. 113.

978 Toldy-Kazinczy, 1987. 65.

${ }^{979}$ Négyesy, 1925. 215.

${ }^{980}$ Hasonló véleményen van a Beöthy Zsolt-féle magyar irodalomtörténet is. (Beöthy, 1906. 860.)
} 
Váczy János hasonló szellemben ítéli meg a Helikont a Vasárnapi Újságban megjelent tanulmányában. ${ }^{981}$ Váczy korabeli levelekből idéz, de tetszőlegesen válogat és ezzel támasztja alá mondandóját. Szerinte a Helikonok kevés és felületes ízlésről tanúskodnak, rávilágítanak Festetics csekély jártasságára az irodalomban. Másutt azt veti a szervezők szemére, hogy a sok felolvasás „szó szoros értelemben kifárasztotta a jelen voltak figyelmét”. ${ }^{982}$ Váczy ebben a dolgozatában tovább megy és legnagyobb alkotását a Georgikont is megkérdőjelezi: „Valóban arról lehet vitatkozni, hogy Festetich intézetei elérték-e ama célt, mellyet annyi áldozattal csakugyan el kell vala érniök, vagy téves irányba csaptak: de annyit el kell ismernünk, hogy szándéka csakugyan tiszta és önzetlen volt”. ${ }^{983}$ Váczy másik tanulmánya Budapesti Szemlében jelent meg, 1905-ben. ${ }^{984}$ Ez a tizenkilenc év után megjelent tanulmány más sokkal árnyaltabban fogalmaz, mélyebb merítéssel dolgozza fel a témát, bár a Helikoni Ünnepségek Váczy szerint „önmagukban véve csak lidércfényei voltak az irodalmi életnek”. Szerinte irodalomtörténetünkben egy feladatot teljesített: „kibékítő” volt a neológusok és ortológusok között. Váczy e dolgozatában, felülbírálva korábbi állításait is, Gyulainál reálisabban ítéli meg a Helikont. Ifjú Szinnyei József szerint a Helikon „hatalmas rugóul szolgált, hogy nemzeti művelődésünk első szikráinak fárasztó ápolásában és terjesztésében a nagy közönség közönyössége miatt el ne lankadjanak". ${ }^{985}$ Takáts Sándor és Nagyváthy Kálmán ${ }^{986}$ rokonukról írt életrajzi tanulmányukban burkoltan, vagy nyíltabban Festeticset teszik meg bűnbaknak azért, hogy Péteri Takáts Józsefnek, illetve Nagyváthy Jánosnak el kellett hagynia a keszthelyi udvart. Takáts Sándor szeszélyesnek ítéli meg a grófot, de elismeri, hogy nagy olvasottságú ember volt, takarékos is, de sokat áldozott az irodalomra. Nagyváthy Kálmán szintén szeszélyesnek, kapkodónak, a politikai pályán salto mortalékat tévőnek és a mezőgazdasághoz alig értőnek mutatja Festeticset. Ebből kifolyólag hibásak ítéletei, írja Nagyváthy, s nem kis rosszindulattal idézi Rumy könyvének történetét, Pethe Ferenc Keszthelyre jöttének rövid históriáját: „Átolvassa (ti. Festetics) Rumi Lehrbuch der Oeconomie címü könyvét s 600 forintot küld csodálata jeléül az írónak; pedig az egész könyv praktikus zseni nélküli compiláció, mint Korizmics mondja. - Olvassa a gróf az inpraktikus Pethének dagályosan, minden eredeti felfogás nélkül szerkesztett bécsi lapját s meghívja

\footnotetext{
${ }^{981}$ Gróf Festetich György és a magyar Helikoni ünnepélyek (Váczy, 1886.)

982 Váczy, 1886. 529.

${ }^{983}$ Váczy, 1886. 495.

${ }^{984}$ A Keszthelyi Helikon (Váczy, 1905.)

${ }^{985}$ Ifj. Szinnyei József: A keszthelyi Helikon 1817-1819= Közérdek, 1875/16

986 Takáts, 1890. ; Nagyváthy K., é. n.
} 
Keszthelyre tanárnak". ${ }^{987}$ Pedig nem volt másról szó - mutat rá Vörös Károly -, mint arról, hogy más, modernebb gazdákodási formára akart Festetics áttérni, s így a Nagyváthy-féle „practicus” gazda helyett a Pethe-féle ,theoretico-practicus” szakemberre volt szüksége. ${ }^{988}$ Nagyváthy Kálmán ezen írásának részei világosan elárulják, hogy számos dolgozatot - így ezt is - csak nagy fenntartással lehet kezelni. Nagyváthy ítéleteinek tarthatatlanságára legelébb Ballagi Géza mutatott rá az Irodalomtörténeti Közlemények 1891-es évfolyamában, ${ }^{989}$ megvilágítva Festetics sokoldalú szakértelmét. Ezzel ellentétes Schöpflin Aladár maliciózus írása 1910-ben, melynek gondolatai ma már elfogadhatatlanok: „...Festetics György, akit kora úgy körülhizegett, hogy még most is alig tudjuk tisztán meglátni derék, jószándékú, de szük látókörü, mindenben csak a dilettantizmusig jutó alakját." ${ }^{990}$ Fülöp Géza világosan mutat rá a két „rivális” a mezőgazdasági tudományokban elfoglalt helyére, Festetics okos döntésére, amikor annak a véleményének ad hangot, hogy a Georgikonban tanító Nagyváthy és Pethe az akkori Magyarország legjobb mezőgazdasági könyveit adták ki. ${ }^{991}$

Vas Gereben több regényében foglalkozik Festeticcsel, a Helikonnal, de munkáit csak mint szépirodalmi mủveket vehetjük figyelembe, mert a korabeli dokumentumokat a regénynek megfelelően kiszínezte. ${ }^{992}$ A Magyar Tudományos Akadémia 1900 évi Teleki pályázatán, a száz arannyal kitüntetett legjobb pályamü, Prém József „,Helikoni ünnep ” címü darabja volt. ${ }^{993}$ Négyesy szerint a darab történelmileg nem hü, szétszórt és olykor unalmas. ${ }^{994}$ A Helikon száz éves fordulójának tiszteletére 1921-ben, Herczeg Ferenc megírta „A holicsi Cupido" című vígjátékot. ${ }^{995}$ Ugyancsak erre az alkalomra, Négyesy László elkészítette az eddigi leginkább elemző és mélyreható irodalomtörténeti munkát „,Gróf Festetics György a magyar irodalomban" címmel. ${ }^{996}$ Végső következtetésével egyet lehet értenünk, s ezzel Festetics munkájának fontosságára is rávilágíthatunk. Ezek szerint, ha Festetics tovább él

\footnotetext{
${ }^{987}$ Nagyváthy K., é. n., 25-26. ; Helyesen: Rumy Károly György: Populäres Lehrbuch der Oeconomie. I.-II. Bécs, 1808. ; Pethe vonatkozásában a Bécsben megjelenő Magyar Újságról, illetve a szintén bécsi kiadású Vi’sgálódó Magyar Gazda című lapról van szó. A Magyar Újság első számában - valószínűleg Pethe tollából az alábbiakat olvashatjuk: „mostantól fogva még csak egy birtokosok se találtassék Magyar- és Erdélyországban, aki a német nyelv mellett magyarul is ne beszéljen...”. (Süle, 1964. 62.)

${ }^{988}$ Vörös, 1962/4. 393.

${ }^{989}$ ItK., 1891. 1. évf. 2. füzet 209-215

${ }^{990}$ Schöpflin, 1910.

${ }^{991}$ Fülöp, 2010. 86.

${ }^{992}$ Vas Gereben: A régi jó idök (1855), Régi képek I.-II.(1856), Nagy idök, nagy emberek (1856), A nemzet napszámosai (1857), stb.

${ }^{993}$ Prém József (1850-1910) író, mủvészettörténész. A darabot a Nemzeti Színház is bemutatta, 1904. december 16-án.

${ }^{994}$ Négyesy, 1925. 230-232.

${ }^{995}$ Bemutatták 1921. július 2-án Keszthelyen, a Helikoni emlékünnepségen. Főszerplők: Ódry Árpád, Bajor Gizi, Cs. Aczél Ilona. ; A darabot leközölte: Keszthelyi Helikon. Szerkesztette: Dr. Lakatos Vince. Keszthely, 1925. 359-394.

${ }^{996}$ Lásd: Négyesy, 1925.
} 
„talán vendégül láthatja Helikonján a magyar irodalom igazi központi alakját a széphalmi mestert, Kazinczyt. De még ez évben (1819) feltünik Pesten egy új csillag, Kisfaludy Károly, akinek müködése Pestet emeli irodalmi központtá, úgyhogy se Keszthely, se Széphalom nem tarthatja meg vezérszerepét". 997 Chalupka Rezső már idézett müvében száll síkra a Helikoni Ünnepségek mellett. A szerző elfogultsága hamar kitünik mondanivalójából, így fenntartással kell fogadni az ő véleményét és állásfoglalásait is. Túloz, és addig, amíg többen negligálják a Helikon szerepét, ő sosemvolt magaslatokra emeli. „A keszthelyi kör volt tulajdonképpen megmentője és megtermékenyítője annak a talajnak - írja - melyen Kisfaludy Károly és az Auróra kör nemzeties romanticizmusa később a Kazinczy szertelen, szinte erőszakolt, idegenszerű irányával és neologizmusával szemben - oly gyorsan és biztosan lombba borulhatott". 998 Szerb Antal irodalomtörténetében foglalkozik a Helikonnal és szerinte az ott megjelenő dunántúliak „barokkos és preromantikus módon szövetkeznek a magyar nyelv müvelésére és fákat ültetnek a kiválóak tiszteletére. (...) Az írói öntudat fokozásához ezek a több éven át megismétlődő ünnepélyek nagyban hozzájárultak". 999 Horváth János a természetleírás fejlődésének állomását látja a Helikoni ünnepekben, amikor így ír: „Egyes magyar tájak ekkor kezdenek a többiek felett nagyobb nevezetességre szert tenni. Legalább úgy látszik - a Balaton válik, mint magyar tájspecialitás, bizonyos kegyeletes érzések tárgyává. Kisfaludy Sándor Regéi, Berzsenyi költeménye (A Balaton), a Helikoni ünnepségek már kiemelték a puszta természeti szépség kategóriájából s bearanyozták a nemzeti emlékek varázsával.". 1000

A második világháborút követően hosszú időnek kellett eltelnie, hogy Festetics György hazai kultúrtörténetben elfoglalt helyéröl még csak érintőlegesen is, a realitásokat figyelembe véve, beszélni lehessen. Ez sem volt teljesen zökkenőmentes, s a császár születésnapjának megünneplését nemcsak a kortársak némelyike (Dessewffy József) fogadta viszolyogva. A születésnap még hosszú ideig szálka volt az ítészek szemében. Mezei Márta érdekes dologra hívja fel ezzel kapcsolatban a figyelmünket. Elgondolkodtató - írja, hogy 1817-re mennyire megszépült Ferenc uralkodása. Minden bizonnyal annak köszönhetően, hogy a francia forradalom és a napóleoni háborúk után megnőtt a rend és a béke értéke, $\mathrm{s}$ ennek az uralkodó volt biztosítéka. ${ }^{1001}$ Mindazonáltal úgy véljük, hogy Festetics gondolataiban és tetteiben sokszor a jezsuiták diplomata művésze lép előtérbe, tudja meddig

\footnotetext{
${ }^{997}$ Négyesy, 1925. 74.

${ }^{998}$ Chalupka, 1922. 9-10.

${ }^{999}$ Szerb, 1978. 282.

${ }^{1000}$ Horváth, 1978. 239.

${ }^{1001}$ Mezei, 1997. 174.
} 
és ne tovább. A lehetőségeket viszont a végletekig kihasználja. Egyetérthetünk Keresztury Dezső szavaival, aki az Irodalomtörténeti Társaság Keszthelyi Vándorgyülésének nyitó előadásában a következőket mondotta: „A Keszthelyi Helikon hatása kisebb volt (a Georgikonénál Cs. G.); főképp azért, mert mielőtt intézményessé tehette volna, Festetics György 1819-ben meghalt. De ha alaposan megnézzük, kik vettek részt munkájában, milyen célokat tüzött maga elé s milyen magvakat hintett ki a jövőbe: látni fogjuk, hogy jelentősége komoly volt, s hatása is méltó azokhoz, akik létrehívták. Újjászülető irodalmunk bölcsőjénél ott állnak a Keszthelyi Helikon géniuszai is". ${ }^{1002}$

Négyesy László találóan jellemzi Festeticset már többször idézett munkájában: „Az aulikus foúr és a kuruc hajlamú magyar nemes, mintha viaskodnának lelkében az elsőségért. Rengeteg vagyonánál fogva konzervatív arisztokrata, de a XVIII. század felvilágosodásával megfuttatva. Olvasmányaiból, társalgásból nem is meretlenek előtte Voltaire eszméi. Érzi és magáévá teszi a XVIII. század társadalmi bölcselőinek azt az elvét, hogy a nagy vagyonnak a köz iránt nagy kötelezettségei vannak, s hogy jog csak ott van, ahol előbb kötelesség is van. Aprólékos takarékosság és grandiózus áldozatkészség nagylelkűség és kicsinyesség, szívós, lelkes munkásság és állhatatlanság, nagyszabású conceptiók és töredékesség, bátor szókimondás és opportunizmus, saját személyére nézve az életmódban igénytelenség, de a család nimbuszáért fejedelmi pompa kifejtése, s az uralkodóházzal való összeköttetés ápolása, nála kisebb rangú jóravaló emberek iránt úri figyelem és barátság, de némelyekkel szemben némelykor önkény és szeszély is; dicsvágy és szerénység; mindez sajátságos keverékben jelentkezik egyéniségében és pályájában." ${ }^{1003}$ Négyesy pályamunkáját az 1921-es Helikoni Ünnepségre írta, melynek egyik támogatója Festetics Tasziló herceg volt. Úgy vélhetjük, hogy Festetics György dicsérete, erkölcseinek és mecenatúrájának felemlegetése az idős hercegnek szánt üzenet is volt. Ha egyáltalán elolvasta a dolgozatot.

Nem könnyű megrajzolni Festetics György jellemrajzát, még akkor sem, ha meggyőződésünk, hogy Keszthelyre költözését követően iskoláinak megtartása, továbbfejlesztése volt egyik legfontosabb életcélja. Ehhez kapcsolódtak a felvilágosodás eszméiből eredeztetett feladatok, úgy, mint a magyar nyelv, az irodalom, a magyar színház, a magyar könyvkiadás felkarolása, támogatása. Festetics valójában a felvilágosodás embere volt, tevékenységére, magaviseletére, a köz iránti érzékenyégére ezek az eszmék nagymértékben hatottak. Szabadkőmüves volta mindezt elősegítette. Azonban nem lehetünk kétségesek afelől, hogy mindvégig - még akkor is, midőn erre ellenkező példát vélhetünk

\footnotetext{
${ }^{1002}$ Keresztury, 1963. 563.

${ }^{1003}$ Négyesy, 1925. 45-46.
} 
látni - megmaradt aulikus fóúrnak, aki nemzete felemelkedéséért hajlandó volt nagy terveket kigondolni és megvalósítani.

Érdekes, hogy e nagy terveket szövő és megvalósító ember ugyanakkor - kortársai szerint - hajlamos volt a melankóliára, a hirtelen haragra, olykor a bizalmatlanságra. Filantróp volt és egyszerre racionalista. Nyájas és szeszélyes. Nagyvonalú és kicsinyes. Bátor és egyben óvatos. Családjával, feleségével és fiával való kapcsolatát éppen szeszélyei és túlzott racionalizmusa és sokszor túlzott szigora mérgezte meg. Ezért annyira különböző a kortársak véleménye Festeticsről. Kazinczy Ferenc észrevétele szerint Festeticcsel hosszú időn át csak egy Asbóth János tudott kijönni. ${ }^{1004}$ (kiemelés tőlem Cs.G.) Bright szerint ,a gróf a megtestesült udvariasság volt”. ${ }^{1005}$ Amikor Kovács Lajos, gróf Széchenyi István személyes ismerőse, ragaszkodó híve Széchenyiről írt könyvében a gróf „kedélyvilágát” veszi górcső alá, részben Festetics György jellemére is utal: „,...ama korban legkiválóbb ész-ember a rideg, minden érzést kigúnyoló Fesztetics (sic!) György." ${ }^{1006}$ Kovács a Festeticsnél jóval fiatalabb, de mégiscsak kortárs Deák Ferenc véleményét is idézi Festeticsre vonatkozóan: „Rendkívüli értelemmel és tevékenységgel bírt, de mély megvetéssel az érzelmek gyarlóságai iránt, és minden kigúnyoló hajlamának nem bírt ellenállni még legmagasabb személyekkel szemben sem. E hajlamának kielégítésénél nem vette számba az áldozatot mibe néha kerültek. Az ész rideg embere volt, ki a szív gerjedelmeire szánalmas megvetéssel tekintett."1007

Kövér János vörsi plébános feljegyzésében így jellemzi a grófot: „Tudott ő minden tudhatórul beszéllni óra számra; és (mivel nagyonn is pénz-bőves időben élt) ajándékozott minden kéméllés nélkül."1008 Ítéletünket azonban nem szabad elhamarkodnunk. Személyes élete nem volt felhőtlen. Nagyapja fantasztának tartotta, apja mindenáron a jogi pályára szánta, holott - talán az első nagy ellenállás eredményeképpen - ő a katonai pályát választotta. A felvilágosult eszmékkel egyetértő gróf, mihelyt a mindennapokban szerette volna megvalósítani elgondolásait, a császári udvar azonnal lefogta kezét. A kötelesség, a morális elvek játszottak annak idején szerepet Sallér Judittal kötött házasságában, amely azonban megromlott olyannyira, hogy felesége 1801-ben elköltözött Keszthelyről. Fiában nem láthatta meg a hatalmas szívósságával megszilárdított Festetics birtok leendö jó „gazdáját”. Számos korabeli és későbbi történetírója szemére vetette, hogy Festetics az úrbéri terhek súlyát növelte és könyörtelenül behajtotta a neki járó adókat, szolgáltatásokat.

\footnotetext{
${ }^{1004}$ Négyesy, 1921. 63.

1005 Bright, 1935. 11.

${ }^{1006}$ Kovács, 1889. 242.

${ }^{1007}$ Kovács, 1889. 242.

${ }^{1008}$ Kövér kézirat, 1834. 21.
} 
Keszthely polgárai örökös perben álltak a Festetics birtok urával, még a megyéhez is jogorvoslatért folyamodtak. Az egyik korabeli anekdota egyértelmủen világít rá a helyzetre: Keszthely Főutcáján égett a földesúr kocsmája, amit a keszthelyiek ölbe tett kézzel álltak körbe. Az odaszaladó uradalmi tiszt felszólította őket a tüz oltására, amire a keszthelyiek azt válaszolták, hogy fizetünk elég füstpénzt a Festeticsnek, oltsa ő. De azt is látnunk kell, hogy a hatalmas birtok kényes pénzügyi egyensúlyának fenntartása - amint arra Kurucz György is rámutatott - nem volt egyszerű feladat. ${ }^{1009}$ Festetics kiválóan tudta, hogy birtokainak fenntartása csakis egy megújuló termelési struktúrával lehetséges. Könyvtárában, számos modern angol gazdasági és közgazdasági szakkönyvet tartott, s amint azt Richardt Bright keszthelyi utazása során meg is jegyezte, jobban volt értesülve a szigetország dolgairól, mint az angol Bright. ${ }^{1010}$ Tisztában volt a robotmunka és a bérmunka közötti különbséggel, de a még meglévő feudális viszonyok megkötötték a kezét. Rájött, hogy a haladás, a fejlődés egyetlen záloga a kimüvelt emberfők sokasága, amint azt később unokaöccse, Széchenyi István papírra is veti. Ezért alapított iskolát, ezért támogatta a könyvkiadást, az irodalmi életet, a magyar nyelvü folyóiratokat, amelyhez részben a tanárok, tudósokat, másrészt az írókat igyekezett megnyerni. Diákként és katonaként majd fél Európát bejárta és megismerkedve a szabadkőművesség és a felvilágosodás eszméivel magáévá tette azokat. Nem tagadhatjuk, hogy életműve vitathatatlanul hozzájárult a modern nemzetté válás folyamatának szellemi előkészítéséhez. Alkotásival nagy lépést tett a nemzettudat megalapozása területén. Végiglapozva az 1800-ban felfektetett „Georgikon emlékkönyv”-et azt láthatjuk több helyen, hogy míg az apa németül köszöni meg a látogatást és kíván további eredményeket, addig a Georgikonban tanuló fiú magyarul. ${ }^{1011}$

Festetics György helyét és szerepét a magyar müvelődéstörténetben az eddig említett tevékenységei határozzák meg. Ez a hely, amely kiemelkedik az egészből, elvitathatatlan. S

\footnotetext{
${ }^{1009}$ Kurucz, 1996. 76.

${ }^{1010}$ Bright, 1935. 65.

1011 „Örök emlékezet 1800” A Georgikon emlékkönyve. Található: Keszthelyi Könyvtár Kézirattára, kiállított anyag (2008).; A bejegyzések közül párat ide idézünk: Tu nihil invita dices, faciesque Minerva. 1801. Fr. Pethe. ; Georgikon szépítted már Keszthelyed telekjeid / Lesz idő s felkészítted Hunnia vidékjeit. Horváth.; A' ki a' haza-szeretet szent oltárán áldozik fenn marad annak neve 's a' késő maradék áldani fogja. Keszthely, $15^{\text {dik }}$ Sept. 1814. B. Wesselényi Miklós.; Luarere non minor est virtus, quam parta tueri. Die $3^{\mathrm{a}}$ Nov. 1802. Stephanus Kultsár.; Boldog a' kit hív keblébe zárván / A’ Magyar Tenger gyönyörü vidéke, / Láttya Jószágát gyarapodva hozni / Ritka gyümöltsit. Keszthely, Julius $4^{\text {dikén }}$ 1808. Takáts József Dir.; Ki nagy szivvel, nagy lélekkel / Csak a' Közjót tárgyazod, / 'S a' mit tudsz, birsz bő kezeddel / A' Hazának áldozod, / Nagy Hazafi! olly kész, olly gyors / Megosztozni a jóban, / Te azt a' mit Rád mért a' Sors, / Megérdemled valóban. / Jeles vagy Te a' nemzetben, / Ki, jó tétre nyugszik 's kél; - / Élsz míg csak egy Magyar él. Keszthelyen Máj. 10kén 1811. Kisfaludy Sándor.; A' Honny javáért gyúladozó fiú / Elmegy majd porodhoz Ó Nemes! / És felemelkedett lélekkel / fogja áldani tettidet. Keszthely die 15. Augusti 814 D. G. (azaz Döbrentei Gábor); végül egy kilenc éves látogató beírása: Egész Életemben leg kedvesebb lesz elöttem azon idö pontja, a' méllyben Szerentsém volt Kedves Uram Bátyámot Mtgos Gróf Festetits György Ö Nagyságát Kestelyen (!) d'Este Professor Úr ÚtiTársammal leg elöszszer meg-látogatni. Kesztely 26 September 1806. Gróf György Andrássy.
} 
mindezt abban a korban, amikor a magyar társadalom - a müvelődési állapota szempontjából - nagyjából az ország helyzetének megfelelő helyet foglalt el Európában. Elmaradt NyugatEurópához, de az örökös tartományokhoz képest is. ${ }^{1012}$ Festetics György nemcsak a patrióta nemesség egyik kiemelkedő alakja, de a hazai kultúra, művelődés tántoríthatatlan tevőleges munkása is volt. Anyagi támogatását nem nélkülözhették az általa arra érdemesnek tartottak, s ez az összeg nem volt kevesebb, mint amit anyagilag megengedhetett magának. Az anyagi megbecsülésen túl sokkal nagyobb kulturális szerepe volt az irodalmi összejöveteleknek. Erre Bécsy Ágnes is rámutat, aki Berzsenyiről írt dolgozatában, tulajdonképpen valamennyi megjelent költőre, íróra vonatkoztatva bizonyítja, hogy milyen szubjektív jelentőséggel is bírt, milyen természetü ihlető hatást tett rájuk az akkor valóban szokatlan, újfajta demokratikus szellemü ünnepség a Helikon. Többen, de különösen Berzsenyi az ünnep szellemi, érzéki szépségét ragadja meg és gyönyörködtetik a poétai események. ${ }^{1013}$ A felvilágosodás eszméinek megfelelően Festetics a magyar müvelődés szinte valamennyi területén megpróbált maradandót alkotni. Ez csak részben sikerült, de az eredmények mind a mai napig meghatározóak hazánk müvelödéstörténetében. Keszthely mai kulturális központ szerepének megalapozását a XVIII. század végére és a XIX. század első felére datálhatjuk, kizárólagosan Festetics György szerepének köszönhetően. Iskolákat alapított és tartott fenn akkor, amikor a tanköteleseknek csak 30-40 \%-a járt iskolába. Ekkor vált iskolavárossá, a zene, az irodalom fontosságát valló településsé a Balaton-parti település. Ekkor alakult ki a település épített környezetének meghatározó arculata. Ekkor alapozta meg a meglévő föúri könyvtáron túl a város két meghatározó könyvtárát, a Georgikonét és a gimnáziumét. Megépíttette Somogy vármegye első gimnáziumát, hogy pallérozott embereket neveljen az alma máter. A magyar nyelv érdekében kifejtett erőfeszítései tették lehetővé, hogy a latin és német nyelv mellett a magyar is „polgárjogot” nyerjen a tudomány, az irodalom, a főurak egymás közti kommunikációjában. Festetics megítélését kizárólagosan a saját korának társadalmát, rendjét figyelembe véve lehet megtenni. Talán nem tủnik túlzásnak, ha azt tartjuk, hogy Festetics ugyan publicisztikai minőségben nem vetekedhetett Széchenyi Istvánnal, de mint a fejlődés, a kultúra, a művelődés fontosságának felismerője és támogatója mindenképpen elődjének számít.

\footnotetext{
${ }^{1012}$ Mo. tört., 2005. 155.

1013 Bécsy, 1998. 165.
} 


\section{Rövidítések}

ABAFI, 1993 = Abafi Lajos: A szabadkőművesség története Magyarországon.

Reprint. Akadémiai, Budapest, 1993.

ALAPI, 2001. = Alapi Gyula: Kultsár István. = Tudós, könyvtáralapító, kultúraközvetítő Kultsár István. Tatabánya, 2001.

ALFÖLDI, 2001. = Alföldy Gábor: A keszthelyi Festetics-kastélypark rövid története $=$ Királyi és hercegi kertek Magyarországon. Eszterháza, Gödöllö, Keszthely, Visegrád. Szerk.: Alföldy Gábor. Szent István Egyetem Kertmüvészeti Tanszék - Mágus Kiadó. Budapest, 2001.

BAL.SZ., 1943. = Balatoni Szemle 1943. évfolyam

BÁLINT, 1977. = Bálint Sándor: Ünnepi kalendárium. Szent István Társulat, Budapest, 1977.

BARÓTI SZABÓ, 1802. = Baróti Szabó Dávidnak meg-jobbíttott, 's bővíttett költeményes munkáji I-II. köt. Komárom, 1802.

BÁRTFAI SZABÓ, 1912. = Bártfai Szabó László: A sárvár-felsővidéki gróf Széchényi család története II. Budapest, 1912.

BATSÁNYI ÖM. I., 1953. = Batsányi János összes művei I. Versek. Sajtó alá rendezte: Keresztury Dezső, Tarnai Andor. Kritikai kiadás. Akadémiai, Budapest, 1953.

BATSÁNYI, 1980. = Batsányi János poétai munkái. Kézirat a Magyar Tudományos Akadémia Kézirattárában. Facsimile. Keresztury Dezső Batsányi János költői munkáinak kiadástörténete című tanulmányával együtt kiadta az Akadémiai - Magyar Helikon, Budapest, 1980.

BAUSZ, 2001.= Bausz Teodorik: Kultsár István élete és müködése $=$ Tudós, könyvtáralapító, kultúraközvetítő Kultsár István. Castrum könyvek 8 ., Tatabánya, 2001.

BÉCSY, 1998. = Bécsy Ágnes: „Halljuk, miket mond a lekötött kalóz”. Berzsenyi versek elemzése. Korona Nova, Budapest, 1998. 
BÉL, 1943. = Bél Mátyás: Notitia Comitátuum Vesprimiensis, Simighiensis Szaladiensis (kézirat) fordítása és ismertetése = Lukács Károly: A Balaton-vidék földrajza kétszáz év előtt. A Magyar Biológiai Kutatóintézet Munkái XV. Tihany, 1943.

BENDA, 1978. = Benda Kálmán: Emberbarát vagy hazafi? Tanulmányok a felvilágosodás korának magyarországi történetéböl. Budapest, Gondolat, 1978.

BENDA, 1982. = Magyarország történeti kronológiája II. köt. Szerk: Benda Kálmán Akadémiai, Budapest, 1982.

BENDA I. 1957. = A magyar jakobinus mozgalom iratai. I. kötet. Sajtó alá rendezte: Benda Kálmán Akadémiai, Budapest, 1957.

BÉNYEI, 1998. = Bényei Miklós: A nemzeti és polgári kultúra felé. Csokonai Históriai Könyvek. Csokonai, Debrecen, 1998.

BEÖTHY, 1906. = Beöthy Zsolt: A magyar irodalom története. I. Szerk.: Badics Ferenc. Athenaeum, Budapest, 1906.

BERTÓK, 1973. = Bertók László: Így élt Csokonai Vitéz Mihály. Móra, Budapest, 1973.

BERZSENYI ÖM, 1842. = Berzsenyi Dániel' összes művei. Költelem 's folyóbeszéd. Közrebocsátá meghagyása szerint Döbrentei Gábor. Harmadik kiadás. Kéziratban maradott még nem ismertekkel. Budán, Magyar Királyi Egyetem Sajtóval, 1842.

BERZSENYI ÖM, 1978. = Berzsenyi Dániel összes müvei. Szerk.: Merényi Oszkár. Szépirodalmi, Budapest, 1978.

BERZSENYI ÖM. 1979. = Berzsenyi Dániel költői müvei. Berzsenyi Dániel összes müvei I. Sajtó alá rendezte: Merényi Oszkár. Akadémiai, Budapest, 1979.

BÍRÓ, 1994. = Bíró Ferenc: A felvilágosodás korának magyar irodalma. Balassi, Budapest, 1994.

BÍRÓ, 2005. = Bíró Ferenc: Bevezetés. $=$ Tanulmányok a magyar nyelv ügyének 18. századi történéböl. Szerkesztette: Bíró Ferenc. Argumentum, Budapest, 2005.

BISZTRAY, 1968. = Bisztray Gyula: Jókedvü magyar irodalom. Budapest, 1968.

BLÁZY, 1974. = Blázy Árpád: A gyógyszerészet megjelenése és fejlődése Zala megyében 1711-1847. Zalai Gyüjtemény 1. Zalaegerszeg, 1974. 
BODOLAY, 1963. = Bodolay Géza: Irodalmi diáktársaságok 1785-1848. Akadémiai, Budapest, 1963.

BONTZ, 1896. = Bontz József: Keszthely város monográfiája. Keszthely, 1896.

BRIGHT, 1935. = Bright, Richard: Angol szemmel Keszthelyen százhúsz évvel ezelőtt. Szemelvények Richard Bright m. d. 1815 évi útleírásából. Angol eredetiből fordította: Dr. Szerecz Imre. Sujánszky, Keszthely, 1935.

CHALUPKA, 1922. = Chalupka Rezső: A Keszthelyi Helikon 1921-ben. Székesfehérvár, 1922.

ČREP, 2010.= Črep Josip: Feštetići posljednji grofovi Međimurja 1791-1923. Čakovec, 2010.

CZOMA, 2003. = Czoma László: „A Keszthely ’s Czenk istenülő Grófjai...” A Széchényiés a Festetics-család. = Kastélykonferenciák II. Keszthely, 2003.

CSANÁDY, 1897. = Emlékkönyv a Georgikon alapításának 100-ik évfordulójára. Szerk.: Csanády Gusztáv. Keszthely, 1897.

CSÁNYI, 1962. = Csányi László: Első könyvkiadói vállalkozásunk a Magyar Minerva. = Új Helikon, Veszprém, 1962.

CSÁSZÁR, 1910. = Császár Elemér: Kisfaludy Sándor. Franklin, Budapest, 1910.

CSÉBY, 1990. = Cséby Géza: Dukai Takács Judit kéziratos vers-füzetei. = Zalai Gyüjtemény 31. Müvelődéstörténeti tanulmányok. Zalaegerszeg, 1990.

CSÉBY, 1992. = Cséby Géza: Adalékok Festetics György irodalompártoló tevékenységének összegzéséhez. In: Hévízi Almanach. A Csokonai Asztaltársaság találkozói 1. Hévíz, 1992.

CSÉBY, 1993. = Cséby Géza: Hévíz első ismertetője. = Hévíz. Kulturális folyóirat. 1993. I./1.

CSÉBY, 1996. = Cséby Géza: A porából megelevenedett Phoenix. $=$ Somogy 1996/3. 249252.

CSÉBY, 1998. = Cséby Géza: A Keszthelyi Helikoni Ünnepségek rövid története 1817-1819. = Szabolcs András: Az ifjúság Helikon Ünnepségei Keszthelyen. Nagykanizsa, 1998. 
CSÉBY, 2000. = Cséby Géza: Csokonai Vitéz Mihály és Keszthely. = Tóparti üzenet.

Szerk.: Bakonyiné Ligeti Mária. Hévíz-Keszthely, 2000.

CSÉBY, 2001. = Cséby Géza: A Balaton képe a Tudományos Gyüjtemény évfolyamaiban I.

$=$ Új Balaton. Társadalmi és müvészeti folyóirat. 2001 december.

CSÉBY, 2004. = Cséby Géza: „...négy Szobák Ajtó-ragasztói kőbül készüljenek...” A keszthelyi Festetics kastély és parkjának története. = Bakony-Balaton Kalendárium 2005. Veszprém, 2004.

CSÉBY, 2012. = Cséby Géza: Nők Keszthely irodalmi életében $=$ Szendrey Júlia emlékkönyv. Georgikon kiskönyvtár 25. Keszthely, 2012.

CSÉBY-SÁGI, KÉZIRAT = Cséby Géza - Sági Károly: Adalékok a Széchenyi és Festetics család kapcsolataihoz. Kézirat.

CSEML., 1960. = Csokonai emlékek. Összeállította és a jegyzeteket írta Vargha Balázs. Akadémiai, Budapest, 1960.

CSIKI, 1972. = Csiki László: A keszthelyi Georgikon története. $=$ Georgikon 175. Szerk.: Sági Károly. Mezőgazdasági, Budapest, 1972.

CSIKI, 1993. = Csiki László: A keszthelyi agrárfelsőoktatás története. Georgikon kiskönyvtár 1. Keszthely, 1993.

CSIKY, 1911. = Görög-római mythologia. Összeállította: Csiky Gergely. Franklin, Budapest, 1911.

CSOKONAI LEV, 1999. = Csokonai Vitéz Mihály összes művei. Levelezés. Sajtó alá rendezte: Debreczeni Attila. Akadémiai, Budapest, 1999.

CSOKONAI ÖM, 1994. = Csokonai Vitéz Mihály összes művei. Költemények 4. Sajtó alá rendezte, jegyzeteket írta: Szilágyi Ferenc. Akadémiai Kiadó, Budapest, 1994.

CSOKONAI ÖM, 2002. = Csokonai Vitéz Mihály összes művei. Költemények 5. Sajtó alá rendezte, jegyzeteket írta: Szilágyi Ferenc. Akadémiai Kiadó, Budapest, 2002.

CSOMA, 1997. = Csoma Zsigmond: Kertészet és polgárosodás. (Az európai szőlészetiborászati-kertészeti ismeretek oktatása, szaktanácsadása a Georgikonban és a Keszthelyi Uradalomban, a 18. sz. végétől a 19. sz. közepéig) Centrál Európa Alapítvány, Budapest, 1997.

DARNAY, é.n.. = Darnay Kálmán: Kaszínózó tálabírák I.-II. kötet. Athenaeum, Budapest, é.n. 
DEBRECZENI, 2009. = Debreczeni Attila: Tudós hazafiak és érzékeny emberek. Integrációs és elkülönülés a XVIII. század végének magyar irodalmában. Universitas, Budapest, 2009.

EGYED, 1998. = Egyed Emese: Kard és penna. Tanulmányok a felvilágosodás magyar irodalmáról. Budapest, 1998.

ESZES, 1980. = Eszes László: A keszthelyi kőfaragó műhely emlékei a Balaton vidékén (1750-1850). = Müemlékvédelem, 1980. XXIV/2.

ESZES, 1985. = Eszes László: Feledésbe ment utcanevek Keszthelyen. Keszthely, 1985.

FEHÉR, 1999. = Fehér Katalin: A felvilágosodás pedagógiai eszméi Magyarországon. Eötvös József Kiadó, Budapest, 1999.

FEHÉR, 2001. = Fehér Katalin: Kerekes Ferenc. Országos Pedagógiai Könyvtár és Múzeum, Budapest, 2001.

FEHÉR-KÓKAY, 1990. = „Tekintetes Szerkesztő úr!” Levelek a magyar sajtóról 17901848. Magyar Levelestár. Válogatta, gondozta, jegyzetekkel ellátta: Fehér Katalin és Kókay György. Szépirodalmi, Budapest, 1990.

FEJÉR, 1994. = Fejér György versek. A bevezető tanulmányt írta: Kovács Sándor Iván. Keszthely, 1994.

FEKETE-VÁRADY é. n. = Fekete József-Váradi Antal: Széchenyi vallomásai és tanításai. Budapest, é.n.

FENYÖ, 1961. = Fenyő István: Kisfaludy Sándor. Irodalomtörténeti Könyvtár 9. Akadémiai, Budapest, 1961.

FERENCZY, 1984. = Ferenczy Miklós: Csokonai Lillája Második bővített és javított kiadás. Almásneszmély, 1984.

FEST. K. HEL. KNYVT. = Festetics Kastély Helikon Könyvtára

FRAKNÓI, 2002. = Fraknói Vilmos: Gróf Széchényi Ferenc (1754-1820) Osiris, Bubapest, 2002.

FRIEDELL, 1998. = Egon Friedell: Az újkori kultúra története II. Holnap Kiadó, Budapest, 1998. 
FÜLÖP, 1978. = Fülöp Géza: A magyar olvasóközönség a felvilágosodás idején és a reformkorban. Akadémiai, Budapest, 1978.

FÜLÖP, 2010. = Fülöp Géza: Olvasási kultúra és könyvkiadás Magyarországon a felvilágosodás idején és a reformkorban (1772-1848) Hatágú Síp Alapítvány, Budapest, 2010.

GEORGIKON 200 II. = Georgikon 200. II. Adattár 1797-2000. Emlékkönyv a Georgikon alapításának 200. évfordulójára. Keszthely, 2001.

GONDA-NIEDERHAUSER, 1977. = Gonda Imre - Niederhauser Emil: A Habsburgok. Gondolat, Budapest, 1977.

GÖRGÉNYI-PÉCZELY-SÁGI, 1957. = Görgényi Géza - Péczeli Piroska - Sági Károly: Adatok Hévízfürdő történetéhez. = Az Országos Orvostörténeti Könyvtár Közleményei 5. Budapest, 1957.

GYÖRFFI, 1896. = Győrffi Endre: A keszthelyi Kath. Főgymnasium története. (A keszthelyi Kath. Főgymnasium Értesítője az 1895-1896 évről. Közzéteszi: Dr. Burány Gergely igazgató) Keszthely, 1896.

HADI ÉS MÁS, 1790 = Hadi és Más Nevezetes Történetek. Második szakasz. 1790.

HARMATH, 1985. = Harmath István: A Magyar Minerva könyvsorozat és társadalmi indítékai. $=$ A Veszprém megyei Múzeumok Közleményei 17. 1984. Szerk.: Törőcsik Zoltán-Uzsoki András. Veszprém, 1985.

HARMATH-KATSÁNYI, 1984. = Harmath István - Katsányi Sándor: Veszprém megye irodalmi hagyományai. Veszprém, 1984.

HÁSZ-FEHÉR, 1999. = Hász-Fehér Katalin: „Kinek vagyon jussa...” A felvilágosodás kori folyóirat-kritika etikai kérdései. = Híd (Újvidék) 1999/11.

HÁSZ-FEHÉR, 2000. = Hász-Fehér Katalin: A keszthelyi Helikon-ünnepség a XIX. század elején. $=$ Az irodalom ünnepei. Kultusztörténeti tanulmányok. Petőfi Irodalmi Múzeum Könyvei 9. Budapest, 2000.

HÁSZ-FEHÉR, 2004. = Hász-Fehér Katalin: A „,nemzeti szentimentalizmus” programjának egyik forrása: az osszianizmus. = Tanulmányok Fried István 70. születésnapjára. Szerk.: Ármeán Otília, Kürtösi Katalin, Odorics Ferenc és Szörényi László. Pompeji Alapítvány, Szeged, 2004. 
HÁSZ-FEHÉR, 2006. = Hász-Fehér Katalin: A magyar nyelvüség programjai a XVIII-XIX. század fordulóján. = Historia litteraria a XVIII. században. Szerk.: Csörsz Rumen István, Hegedűs Béla, Tüskés Gábor. Universitas Kiadó, Budapest, 2006.

HASZN. MUL. $=$ Hasznos Mulatságok

HELIKON I., 1818. = Helikon I. Keszthely, 1818.

HIRMANN, 2004. = Hirmann László: Fekete János gróf. = Újpesti Helytörténeti Értesítő, 2004. december XI./4.

HK. $=$ Festetics Kastély Helikon Könyvtára (Keszthely)

HK. MISC. $=$ Festetics Kastély Helikon Könyvtár, Miscellanea (Keszthely)

HKT.$=$ Hazai s Külföldi Tudósítások

HOPP, 2001. = Hopp Lajos: A kézirat első kiadásáról. = A tudós, könyvtáralapító kultúraközvetítő Kultsár István. Tatabánya, 2001.

HOPPÁL-JANKOVICS-NAGY-SZEMADÁM, 1997. = Hoppál Mihály - Jankovics Marcell - Nagy András - Szemadám György: Jelképtár. Helikon, Budapest, 1997.

HORVÁTH, 1978. = Horváth János: A magyar irodalmi népiesség Faluditól Petőfiig. III. kiadás. Akadémiai, Budapest, 1978.

HORVÁTH, 1992. = Horváth József: A csurgói Csokonai Vitéz Mihály Gimnázium és Óvónői Szakközépiskola. Tankönyvkiadó, Budapest, 1992.

HORVÁTH, 2009. = Horváth József: Csurgó monográfiája. Csurgó, 2009.

HT. = Hazai Tudósítások

IGAZ, 1823. = Igaz Sámuel: Keszthelynek Poétai innepe. In: Hébe zsebkönyv MDCCCXXIII. Pest.

ItK. = Irodalomtörténeti Közlemények

IVÁNYI, 1947. = Dr. Iványi Béla: A Festetics család keszthelyi levéltára. Különlenyomat a Levéltári Közlemények 1946. évi huszonnnegyedik évfolyamából. Bp., 1947

JAKAB, 1936. = Jakab Ferenc: Kisfaludy Sándorné Szegedy Róza élete. Győr, 1936. 
JANCSÓ, 1936. = Dr. Jancsó Elemér: A magyar szabadkőművesség irodalmi és müvelődéstörténeti szerepe a XVIII-ik században. Irodalomtörténeti tanulmány. Ady Endre Társaság, Cluj, 1936.

JÁSZBERÉNYI, 1996. = Jászberényi József: A felvilágosodás korának magyar irodalma és a szabadkőmüvesség. = Hitel, 1996/12.

JÁSZBERÉNYI, 2000. = Jászberényi József: „A Sz: SOPHIA’ Templomában látom én felszentelve NAGYSÁDAT...” Csokonai Vitéz Mihály és a szabadkőmüvesség kapcsolatáról. = Irodalomtörténet, 2000/2.

JÁSZBERÉNYI, 2003. = Jászberényi József: „A Sz: Sophia’ templomában látom én felszentelve Nagysádat" A felvilágosodás korának magyar irodalma és a szabadkőmüvesség. Irodalomtörténeti füzetek. Argumentum, Budapest, 2003.

JÁSZBERÉNYI, 2005. = Jászberényi József: A magyarországi szabadkőművesség története. PrintXBudavár, Budapest, 2005.

JÁSZBERÉNYI, 2006. = Jászberényi József: „A kőmüves az emberiséget szolgálja” Festetich György és a szabadkőművesség. = Kelet, XLIX. évf. 2006/1-2.

JUHÁSZ, 1963. = Juhász Géza: Csokonai a kicsapatás után. Egy ismeretlen dokumentum felbukkanása alkalmával. $=$ Alföld, 1963/7.

JUHÁSZ, 1997. = Juhász Géza: Csokonai tanulmányok. Akadémiai, Budapest, 1977.

JULOW, 1975. = Julow Viktor: Csokonai Vitéz Mihály. Gondolat, Budapest, 1975.

KA = Kriegsarchiv Wien, Akten des Wiener Hofkriegsraten - Bécsi Hadi Levértár, Haditanács iratai

KÁLLAY, 1980. = Kállay István: A magyarországi nagybirtok kormányzata 1711-1848. Akadémiai, Budapest, 1980.

KAZINCZY ÖK., 1998 = Kazinczy Ferenc összes költeményei. Sajtó alá rendezte Gergye László. Balassi, Budapest, 1998.

KAZINCZY, 1979. = Kazinczy Ferenc: Pályám emlékezete. = Kazinczy Ferenc Versek, müfordítások, széppróza, tanulmányok. Válogatás, szöveggondozás, jegyzetek: Szauder Mária. Szépirodalmi, Budapest, 1979.

KAZINCZY-BERZSENYI, 1860 = Kazinczy levelezése Berzsenyi Dániellel 1808-1831. Kiadta: Kazinczy Gábor. Heckenast, Pest, 1860. 
KAZLEV XXIII. = Kazinczy Ferenc levelezése XXIII. 1927 óta elökerült és kötetbe nem foglalt levelek gyüjteménye. Közzéteszi: Berlász Jenő, Busa Margit, Cs. Gárdonyi Klára, Fülöp Géza. Akadémiai, Budapest, 1960.

KAZLEV. = Kazinczy Ferenc levelezése. Közzéteszi Dr. Váczy János. I.-XXI. köt. MTA. Budapest, 1890-1911.

KERÉNYI, 1977. = Kerényi Károly: Görög mitológia. Gondolat, Budapest, 1977.

KERÉNYI, 1987. = A vándorszínészettől a Nemzeti Színházig. Magyar Levelestár. Szöveget gondozta: Kerényi Ferenc. Szépirodalmi, Budapest, 1987.

KERÉNYI, 1990. = Magyar színháztörténet 1790-1873 Szerk.: Kerényi Ferenc. Akadémiai, Budapest, 1990.

KERESZTURY, 1963. = Keresztury Dezső: Festetics György és a magyar irodalom. = Irodalomtörténeti Közlemények 1963/5.

KERESZTURY, 1982. = Keresztury Dezső: Híres magyar könyvtárak. Budapest, 1982.

KISFALUDY L., 2004. = Kisfaludy László: A kisfaludi Kisfaludy család története. Debrecen, 2004.

KISFALUDY, 1817. = Egy jelen volt vendég (Kisfaludy Sándor): A keszthelyi Helikon = Tudományos Gyüjtemény 1817. III. köt.

KISFALUDY, 1871. = Kisfaludy Sándor hátrahagyott munkái II. Elegyes versei s egy kiadatlan vígjátéka némely zsengéivel együtt. Kiadta: Toldy Ferenc. Heckenast, Pest, 1871.

KLEMPA, 1938. = Klempa Károly: A keszthelyi Festetics-féle Zeneiskola. Győr, 1938.

KLEMPA, 1943. = Dr. Klempa Károly: Az első keszthelyi nyomda. Pannónia Könyvtár 73. Pécs, 1943.

KLEMPA KFK, é. n. = Klempa Károly: A keszthelyi Festetics könyvtár. Mérei, Keszthely, é.n.

KLEMPA, é.n. = Klempa Károly: II. József látogatása Keszthelyen, Sujánszky, Keszthely, é.n.

KLEMPA, F.GY., é.n. = Klempa Károly: Fejér György keszthelyi diákévei. Keszthely, é.n.

KOCISZEWSKI, 1982. = Aleksander Kociszewski: Pieśnią i szablą. Rzecz o twórcy hymnu narodowego. Iskry, Warszawa, 1982. 
KÓKAY, 1979. = A magyar sajtó története I. 1705-1848. Szerk.: Kókay György. Akadémiai, Budapest. 1979.

KÓKAY, 1983. = Kókay György: Könyv, sajtó és irodalom a felvilágosodás korában. Akadémiai, Budapest, 1983.

KÓKAY, 2000. = Kókay György: Felvilágosodás, kereszténység, nemzeti kultúra. Universitas, Budapest, 2000.

KOPPÁNY, 1993. = Koppány Tibor: A Balaton környékének müemlékei. OMH. Budapest, 1993.

KOPPÁNY-PÉCZELI-SÁGI, 1962. = Koppány Tibor - Péczely Piroska - Sági Károly: Keszthely. Képzőművészeti Alap Kiadóvállalat, Budapest, 1962.

KORNIS I., é. n. = Kornis Gyula: A magyar művelődés eszményei 1777-1848. I. Királyi Magyar Egyetemi nyomda é.n. I. köt.

KORNIS II., 1927. = Kornis Gyula: A magyar müvelődés eszményei 1777-1848. II. köt. Királyi Magyar Egyetemi Nyomda, Budapest, 1927.

KOSÁRY, 1983. = Kosáry Domokos: Művelődés a XVIII. századi Magyarországon. Budapest, Akadémiai, 1983.

KOSTYÁL, 1960. = Kostyál István: Kultsár István levele Festetics Györgyhöz. = Irodalomtörténeti Közlemények 64. 1960.

KOVACSICS, 1991. = Kovacsics József: Zala megye helytörténeti lexikona. Keszthely és könyéke. Statiqum, Budapest, 1991.

KOVÁCS, 1889. = Kovács Lajos: Gróf Széchenyi István közéletének három utolsó éve 18461848. I. köt. Franklin, Pest, 1889.

KÖVÉR KÉZIRAT, 1834 = Kövér János: A Vörsi Plébániának Története. Összve írtam Kövér János Vörsi Plébános, 1834. Kézirat. Feldolgozta: Tóth Dénes

KULCSÁR, 2004. = Kulcsár Krisztina: II. József utazásai Magyarországon, Erdélyben, Szlavóniában és a Temesi Bánságban 1768-1773. Gondolat - MOL, Budapest, 2004. 
KURUCZ, 1996. = Kurucz György: A Georgikon alapításától 1848-ig. = Georgikon 200. Szerk.: Fülöp Éva Mária. Keszthely, 1996.

KURUCZ, 1999. = Kurucz György: Festetics György gróf. = Zalai Múzeum, Zalaegerszeg, 1999.

KURUCZ, 2006. = Kurucz György: Kényszer és szolgálat. Portrévázlatok Festetics Györgyről = Századok 2006/6.

KURUCZ, FEST. KNYVT., 2006. = Kurucz György: Könyv és főnemesi müveltség: Festetics György magánkönyvtára katonai pályára lépésének kezdetén. = Aetas, 21. évf. 2006/2-3.

KURUCZ, FEST. PÜ., 2006. = Kurucz György: Festetics György pénzügyi helyzete 1782 és 1818 között. $=$ Századok 2006/3.

KURUCZ, IROD., 2006. = Kurucz György: Irodalmunk ,jó embere”. Festetics György és a magyar felvilágosodás. In: Magyar Napló XVIII./5. 2006. május

LACZKÓ, 1981. = Laczkó András: Diákszínjátszás Somogyban. Somogy Megyei Levéltár, Kaposvár, 1981.

LACZKÓ, 1991. = Laczkó András: Keserédes történetek. Kaposvár, 1991.

LACZKÓ, 2006. = Tanulmány Dukai Takács Juiditról. = Hévíz. Művészeti és müvelődési folyóirat. 2006. XIV./2-3.

LADÓ, 1982. = Ladó János: Magyar utónévkönyv. Akadémiai, Budapest, 1982.

M.H. = Magyar Hírmondó

MAGYAR LEVELESK. = Magyar Leveleskönyv I. - II. Szerkesztette: Balogh József és Tóth László. Kiadja H. Balázs Éva. Corvina, Budapest, 2001.

MAGYAR, 2006. = Magyar Eszter: Tűzifa, épületfa, faszén. = História, 2006/5.

MAGYARORSZÁG HADTÖRT., 1984. = Magyarország hadtörténete I.-II. kötet. Főszerkesztő: Liptai Ervin. Budapest, Zrinyi, 1984.

MAGYARORSZÁG TÖRT.,1980 = .Magyarország története 1790-1848. 5/1 köt. Főszerkesztő: Mérei Gyula. Akadémiai, Budapest, 1980. 
MARCZALI, 1884. = Marczali Henrik: Magyarország története II. József korában I. Budapest, 1884.

MARCZALI, 1898. = Marczali Henrik: Magyarország története III. Károlytól a Bécsi Congressusig. = A Magyar nemzet története. Szerk.: Szilágyi Sándor. Athenaeum, Budapest, 1898.

MARGÓCSY, 2005. = Margócsy István: A magyar nyelv jelenléte a 18. századi iskoláztatásban. = Tanulmányok a magyar nyelv ügyének 18. századi történetéböl. Szerkesztette: Bíró Ferenc. Argumentum, Budapest, 2005.

MARKOS, 2001. = Markos János: Kultsár István. = A tudós, könyvtáralapító, kultúraközvetítő Kultsár István. Tatabánya, 2001.

MARKOWSKA, 1953. = Markowska, Wanda: Mity greckie. Iskry, Warszawa, 1953.

MERÉNYI, 1996. = Merényi Oszkár: Berzsenyi Dániel. Irodalomtörténeti Könyvtár 19. Akadémiai, Budapest, 1966.

MÉSZÁROS, 1980. = Tanulmányok a magyar nevelésügy XVII-XX. századi történetéből. Szerkesztette: Mészáros István. Akadémiai, Budapest, 1980.

MEZEI, 1997. = Mezei Márta: A keszthelyi Helikon-ünnepek - és ahogy az írók látták. = Kegyelet és irodalom. Kultusztörténeti tanulmányok. A Petőfi Irodalmi Múzeum Könyvei 7. Budapest, 1997.

MIT III., 1965. = A magyar irodalom története III. 1772-től 1849-ig. Szerk.: Pándi Pál. Akadémiai, Budapest, 1965.

MIT. E. I., 1988. = Mitológiai Enciklopédia I. Főszerkesztő: Sz. A. Tokarev. Gondolat, Budapest, 1988.

MK. $=$ Magyar Kurír

MO. TÖRT., 2005. = Magyarország története a 19. században. Szerk.: Gergely András. Osiris, Budapest, 2005.

MOL RÉTHEI RÖTTH LVT. = Magyar Országos Levéltár réthei Rötth család Levéltára MOL SZÉCHÉNYI LVT. = Magyar Országos Levéltár Széchényi Levéltár MOL. FEST. LVT. = Magyar Országos Levéltár Festetics Levéltár MORVAY, 1903. = Morvay Győző: Galánthai gróf Fekete János 1741-1803. Magyar 
történelmi életrajzok. Budapest, Magyar Történelmi Társulat, 1903.

MTA Kézirattár = Magyar Tudományos Akadémia Kézirattár

MÜLLER, 1996. = Müller Róbert: A Phoenix gálya. = Pannon Tükör 1996/3. V.-VIII.

NAGY I., 1858. = Nagy Iván: Magyarország családai czímerekkel és nemzékrendi táblákkal. Negyedik kötet. Pest, Ráth Mór, 1858.

NAGY I., 1863. = Nagy Iván: Magyarország családai czímerekkel és nemzékrendi táblákkal. Tizedik kötet. Pest, Ráth Mór, 1863.

NAGYVÁTHY K., é. n. = Nagyváthy Kálmán: Nagyváthy János élete. Pozsony, é. n.

NAGYVÁTHY, 1821. = Nagyváthy János: Magyar practicus termesztő. Pest, 1821.

NAGYVÁTHY, 2009. = N. Nagyváthy János: A Magyar Fewdes és Zászlós Úr. Csurgó, 2009.

NÉGYESY, 1925. = Négyesy László: Gróf Festetics György a magyar irodalomban. = Keszthelyei Helikon. Szerk.: dr. Lakatos Vince. Keszthely, 1925.

NÉMETH, 1804. = Németh Ladislaus: Über das Georgikon in Keszthely. $=$ Patriotisches Wochenblatt für Ungern. 1804. április 4.

NÉMETH, 1988. = Németh József: Horváth Ádám és a szabadkőművesség = Pálóczi Horváth Ádám: Felfedezett titok. Szépirodalmi, Budapest, 1988.

NG. $=$ Nemzeti Gazda

PANDULA, 1986. $=$ Pandula Attila: Insigniológia $=$ A történelem segédtudományai. Szerk.: Kállay István. Második, bővített kiadás. ELTE. BTK., Budapest, 1986.

PÁLFY, 2005. = Pálfy Ágnes: A felvilágosodás korának kettős arculata a francia és magyar szabadkőmüvesség tükrében = Neveléstörténet, Székesfehérvár, 2005/1-2.

PÉCZELY, 1958. = Péczely Piroska: A keszthelyi Festetics kastély és belső berendezése. Múzeumok Központi Propaganda Irodája, Budapest, 1958.

PÉCZELY, 1963 = Péczely Piroska: Soproni vonatkozású diákversek a keszthelyi Helikon könyvtárban $=$ Soproni Szemle, XVII. évf. 3. sz. (1963)

PÉCZELY-SÁGI-SZUTRÉLY, é. n. = Péczely Piroska - Sági Károly - Szutrély Antal: A 200 éves keszthelyi kórház története. h. n., é. n. (Keszthely, 1959 ?) 
PEST. ZEIT. = Vereinigte Ofner Pester Zeitung

PÉTERFFY, 1973. = Péterffy Ida: Horváth Ádám levelezése ,„poétriáival”. Zala megye irodalmi hagyományai 1. Göcseji Helikon 7. Zalaegerszeg, 1973.

PÉTERI TAKÁTS, 1799 = Erköltsi oktatások, melyeket tolnai gróf Festetics László, kedves tanítványa szívére kötött Péteri Takáts József Bétsben, özvegy Alberti Ignátzné betüjével, 1799

PINTÉR, 1942. = Pintér Jenő: A magyar irodalom története I. kötet. Második kiadás. Bibliotheca, Budapest, 1942.

POLGÁR, 1997. = Polgár Marianna: Katolikus fớr protestáns egyetemen. Festetics Pál lipcsei tanulmányai 1741-43. = Iskola és társadalom. Zalai Gyüjtemény 41. Zalaegerszeg, 1997.

RÉDEY, 1921. = Rédey Tivadar: A füredi magyar játékszín = Balatoni évkönyv 1921. Bp. A Balatoni Társaság kiadása, 1921.

REISZ T., 1997. = Reisz T. Csaba: Lipszky János térképészti „hagyatéka”. = Fons IV. $1997 / 2$.

REISZ T., 1998. = Reisz T. Csaba: A központi kormányszervek és a vármegyék szerepe a Lipszky-térkép elkészítésében. Elhangzott: Lipszky emlékülés, OSZK, Budapest, 1998. dec. 14. ( Lelöhely [2012]: http:/lazarus.elte.hu/hun/tantort/1998/reisz.htm)

REISZ, T., 2002.. = Reisz T. Csaba: Magyarország általános térképének elkészítése a 19. század első évtizedében. Lipszky János és segítői térképészeti vállalkozásának jellemzése. Cartofil, Budapest, 2002.

SÁGI J., 1909. = Sági János: Magyar színház a szabad természetben. = Vasárnapi Újság, 1909. február. 7. 6. sz.

SÁGI, 1967. = Sági Károly: Adatok Festetics György és munkássága értékeléséhez. = A Veszprém megyei Múzeumok Közleményei 6. Szerk.: Éri István. Veszprém, 1967.

SÁGI, 1972. = Sági Károly: Festetics György élete, kulturális és politikai törekvései. = Georgikon 175. Szerk.: Sági Károly. Mezőgazdasági, Budapest, 1972.

SÁGI, 1974. = Sági Károly: A Balaton és az irodalom. = Balaton monográfia. Szerk.: Dr. Tóth Kálmán. Panoráma, Budapest, 1974.

SÁGI, 1983. = Sági Károly: Egy régi iskolai büntetés és egy farsangi népszokásunk kapcsolata $=$ A Veszprém megyei Múzeumok Közleményei 16. Szerk.: Törőcsik 
Zoltán, Uzsoki András. Veszprém, 1983.

SÁGI, 1987. = Sági Károly: Antonio Borri - Bori Antal = A Veszprém megyei Múzeumok Közleménye 18. Szerk.: Törőcsik Zoltán, Uzsoki András. Veszprém, 1987.

SÁNDOR LIPÓT, 1926. = Sándor Lipót Főherceg nádor iratai 1790-1795. Kiadta: Mályusz Elemér. Magyar Történelmi Társulat, Budapest, 1926.

SCHÖPFLIN, 1910. = Schöpflin Aladár: Dukai Takács Judit = Nyugat, 1910. 4. szám

SIMON, 1982. = Simon István: Gyönyörü terhem. Szépirodalmi, Budapest, 1982.

SISA, 2005. = Sisa József: A dégi Festetics-kastély. Műemlékek Állami Gondnoksága, Budapest, 2005.

SOÓS, 2005. = Soós István: II. József német nyelvrendelete és a „hivatalos” Magyarország. = Tanulmányok a magyar nyelv ügyének 18. századi történetéből. Szerk.: Bíró Ferenc. Argumentum, Budapest, 2005.

STOHL, 2005. = Stohl Róbert: Péteri Takáts József irodalmi kapcsolathálója a Magyar Minerva körül. $=$ Kutatások az Eötvös József Főiskolán. Szerk.: Steinerné Molnár Judit. Budapest, 2005.

STOHL, 2009. = Stohl Róbert: Fragmenta Takatsiana. Források és kiegészítések péteri és téti Takáts József (1767-1821) életrajzához. Doktori (Ph.D.) értekezés. Szeged, 2009.

SÜLE, 1964. = Süle Sándor: Kisszántói Pethe Ferenc 1763-1832 Akadémiai, Budapest, 1964.

SÜLE, 1967. = Süle Sándor: A keszthelyi Georgikon. 1797-1848. Akadémiai, Budapest, 1967.

SZABÓ, 1928. = Szabó Dezső: A herceg Festetics-család története. Franklin, Budapest, 1928.

SZABÓ, 1973. = Szabó György: Mediterrán mítoszok és mondák. Kriterion, Bukarest, 1973.

SZABÓ, 1983. = Szabó Sándor: Péteri és Téti Takáts József író és költő mint irodalomszervező. = Zalai Gyüjtemény 18. Zalaegerszeg, 1983.

SZABOLCS, 1998. = Szabolcs András: Az ifjúság Helikoni ünnepségei Keszthelyen. Nagykanizsa, 1998.

SZABOLCSI, 1965. = Szabolcsi Bence-Tóth Aladár: Zenei lexikon 2. köt. Budapest, 1965.

SZAJBÉLY, 2001. = Szajbély Mihály: Exkurzus „régiek” és „újak” a 18. század második 
felének magyar irodalmában = Szajbély Mihály: „Idzadnak a’ Magyar tollak” Irodalomszemlélet a magyar irodalmi felvilágosodás korában, a 18. század közepétől Csokonai haláláig. Akadémiai - Universitas, Budapest, 2001.

SZÁNTÓ, 1977-1980. = Szántó Imre: Hévíz története 1-2. Szeged, 1977-1980.

SZÁNTÓ, 1984 = Szántó Imre: Keszthely úrbéri viszonyai a Festeticsek földesurasága idején 1739-1848. Acta Universitas Szegediensis de Attila József Nominate Acta Historica Tom. LXXVIII. Szeged, 1984.

SZARKA, 1990. = Szarka Lajos: Thália papjai Keszthelyen az első világháborúig. = Zalai Gyüjtemény 31. Zalaegerszeg, 1990.

SZÁVA, 1896. = Száva Gyula: Győr. Monográfia a város jelenkoráról a történelmi idők érintésével. Győr, 1896.

SZÉCHÉNYI ÉS CSEHO., 2003. = Széchényi Ferenc és Csehország. Levelestár. Válogatta és a bevezető tanulmányt írta: Richard Pražák, Sajtó alá rendezte: Deák Eszter és Erdélyi Lujza. OSZK.- Gondolat, Budapest, 2003.

SZÉCHENYI, 1978. = Széchenyi István: Napló. Gondolat, Budapest, 1978.

SZÉCHENYI-WESSELÉNYI, 1986. = Széchenyi István - Wesselényi Miklós. Feleselő naplók. Szerk.: Maller Sándor. Budapest, 1986.

SZERB, 1978. = Szerb Antal: Magyar irodalomtörténet. III. kiadás Magvető, Budapest, 1978.

SZILÁGYI, 1981. = Szilágyi Ferenc: Csokonai művei nyomában. Tanulmányok. Akadémiai, Budapest, 1981.

SZILÁGYI, 1998. = Szilágyi Ferenc: „Az ész világa mellett...” Mundus, Budapest, 1998

SZILÁGYI M., 1993. = Szilágyi Márton: Adalék Péteri Takáts József irodalmi kapcsolataihoz. $=$ Irodalomtöréneti Közlemények, 1993.

SZILÁGYI M., 1998. = Szilágyi Márton: Kármán József és Pajor Gáspár Urániája. Csokonai Könyvtár. Kossuth Egyetemi Kiadó, Debrecen, 1998.

SZILÁGYI M., 2002. = Szilágyi Márton: Kegyelem és erőszak. Fazekas Mihály Lúdas Matyija. Alföld. 2002. július 53/7. 41-57. ; Az Alföld internetes oldalán: http://epa.oszk.hu/00000/00002/00075/szilagyi.html (2007) 
SZIMBÓLUMTÁR, 1997. = Szimbólumtár. Szerk.: Pál József, Újvári Edit. Balassi, Budapest, 1997.

SZINNYEI III., 1894. = Szinnyei József: Magyar írók élete és munkái. III. köt. Budapest, 1894.

SZINNYEI IX., 1903. = Szinnyei József: Magyar írók élete és munkái. IX. köt. Budapest, 1903.

SZINNYEI XIII., 1909. = Szinnyei József: Magyar írók élete és munkái. XIII. köt. Budapest, 1909.

SZINNYEI XIV., 1914. = Szinnyei József: Magyar írók élete és munkái XIV. köt.

Budapest, 1914.

TAKÁTS, 1890. = Takáts Sándor: Péteri Takáts József. Hunyadi Mátyás Intézet, Budapest, 1890.

TESSEDIK, 1873. = Theschedik Sámuel önéletírása. Eredeti német kéziratból fordította és kiadta Zsilinszky Mihály. Pest, 1873.

TGY. = Tudományos Gyüjtemény

THIELE, 1833. = Thiele, J. C. v.: Das Königreich Ungarn. Ein topographisch-historischstatistisches Rindgemälde, das Ganze dieses Landes in mehr 12400 Artikeln umfassend. I.-VI. Kaschau, 1833.

TOLDY-KAZINCZY, 1987. = Toldy Ferenc: Kazinczy Ferenc és kora. Életrajzi emlék. 1859-1860. Gondozta: Szalai Anna. Szépirodalmi, Budapest, 1987.

TOLDY MNIT, 1987. = Toldy Ferenc: A magyar nemzeti irodalom története. A legrégibb időktől a jelen korig. Rövid előadásban. 1864-1865. Gondozta: Szalai Anna. Szépirodalmi, Budapest, 1987.

TÓTH, 1965. = Tóth Lajos: 200 éves a fenékpusztai hajóarzenál. $=$ Hajózástudományi Együttmüködési Bizottság Müszaki történelmi sorozata 4. Gépipari Tudományos Egyesület, Budapest, 1965.

TÓTH, 1980. = Tóth István: A keszthelyi Helikon nevének eredete. = Múzeumi Kurír IV./3. Debrecen, 1980. 
TÓTH, 1980. = Tóth Lajos: Tessedik Sámuel kapcsolatai a jakobinus mozgalom vezetőivel. Tanulmányok a magyar nevelésügy XVII-XX. századi törtnetéből. Szerkesztette: Mészáros István. Akadémiai, Budapest, 1980.

TÓTH-BENCE, 2011. = Tóth-Bence Tamás: Balatonfüred az évszámok tükrében. Balatonfüred Városért Közalapítvány kiadványai, 60. Balatonfüred, 2011

ÚMÉL II., 2001. = Új magyar életajzi lexikon II. Magyar Könyvklub, Budapest, 2001. ÚMÉL V., 2004. = Új magyar életajzi lexikon V. Magyar Könyvklub, Budapest, 2004.

URÁNIA I. = Uránia. Első Esztendő (1794) I. kötet Be-vezetés.

VÁCZY JÁNOS, 1905. = Váczy János: Horváth Endre és a nyelvújítás. = Magyar Nyelv. 1905. V. I. köt./5.

VÁCZY, 1886. = Dr. Váczy János: Gróf Festetics György és a magyar Helikoni ünnepélyek. = Vasárnapi Újság 1886. évf.

VÁCZY, 1905. = Váczy János: A keszthelyi Helikon. In: Budapesti Szemle. Szerk.: Gyulai Pál. CCCXLV. 1905.

VADÁSZ, 1909. = Vadász Norbert: Dukai Takách Judit élete és munkái. Franklin, Budapest, 1909.

VARGA, 2010. = Varga Kálmán: Egy szabadkőműves „,fészek”. A dégi kastély. = Rubicon, 2010./2.

VARGHA, 1984. = Vargha Balázs: Jelek, jelképek, jellemek. Irodalmi és nyelvészeti tanulmányok. Magvető, Budapest, 1984.

VAS, 1856. = Vas Gereben: Régi képek. Jellemvonások nevezetesebb férfiak életéből. Pesten, 1856.

VAS, é. n. = Vas Gereben: Nagy idők, nagy emberek. Magyar korrajz. Vas Gereben munkáinak együttes képes kiadása II. kötet. Méhner, Budapest. é. n.

VAY, 1986. = Vay Sarolta: József nádor Keszthelyen. = Vay Sarolta: Régi magyar társasélet. Magyar Hírmondó. Magvető, Budapest, 1986.

VERMES, 2011. = Vermes Gábor: Kulturális változások sodrában. Magyarország 1711 és 1848 között. Balassi, Budapest, 2011.

VIL. 6., 1997. = Világirodalmi Lexikon 6. Akadémiai, Budapest, 1997. 
VIRÁG, 1980. = Virág Benedek válogatott müvei. Szépirodalmi, Budapest, 1980.

VÖRÖS, 1961. = Vörös Károly: Fejezetek Nagyváthy János életéből I.-II. = Agrártörténeti Szemle 1961/3-4.

VU. = Vasárnapi Újság

WALLESHAUSEN, 2008. = Walleshausen Gyula: Denis professzor és tanítványa, Festetics György. = Könyvtári Figyelő 2008./1.

WEÖRES, 1977. = Weöres Sándor: Három veréb hat szemmel. Szépirodalmi, Budapest, 1977.

ZÁKONYI, 1974. = Zákonyi Ferenc: Hévíz múltja és fejlődése 1820-ig. Hévíz, 1974. 


\section{Irodalom}

Abafi Lajos: A szabadkőmüvesség története Magyarországon. Reprint. Akadémiai, Budapest, 1993.

Alapi Gyula: Kultsár István. = Tudós, könyvtáralapító, kultúraközvetítő Kultsár István. Tatabánya, 2001.

A Festetics családi levéltár. Repertórium. Összeállította: Kállay István. Kézirat. MOL, Budapest, 1978.

A magyar irodalom története. Első kötet. Megindította és vezeti: Beöthy Zsolt. Szerk.: Badics Ferenc. Athenaeum, Budapest, 1906.

A magyar irodalom története III. 1772-től 1849-ig. Szerk.: Pándi Pál. A magyar irodalom története III. Főszerk.: Sőtér István. Akadémiai, Budapest, 1965.

A magyar jakobinus mozgalom iratai. I.-III. köt. Sajtó alá rendezte: Benda Kálmán Akadémiai, Budapest, 1952-1957.

A magyar jakobinusok elleni felségsértési és hütlenségi per iratai 1794-1795. Szerk.: Benda Kálmán. Akadémiai, Budapest, 1952.

A magyar sajtó története I.-II. köt. Akadémiai, Budapest, 1979-1985

Ányos Pál Munkáji. Magyar Minerva, Bécs, 1798.

Arany János munkái III. köt. Franklin, Budapest, é. n.

A vándorszínészettől a Nemzeti Színházig. Magyar Levelestár. Szöveget gondozta: Kerényi Ferenc Szépirodalmi, Budapest, 1987.

Az Iparmúvészeti Múzeum gyüjteményei. Összeállította: Miklós Pál. Magyar Helikon/Corvina, Budapest, 1979.

Balatoni Múzeum Adattára

Balatoni Szemle 1943. évfolyam

Bálint Sándor: Ünnepi kalendárium. Sz. István Társulat, Budapest, 1977.

Ballagi Aladár: Elfelejtett írók. Péczeli és Péteri Takáts = Irodalomtörténeti Közlemények, 1891. 1. évfolyam 4. füzet

Baróti Szabó Dávidnak meg-jobbított, ’s bővített költeményes munkáji I.-II. köt. Komárom, 1802. 
Bártfai Szabó László: A sárvár-felsővidéki gróf Széchényi család története II. Budapest, 1912.

Batsányi János összes múvei I. Versek. Sajtó alá rendezte: Keresztury Dezső, Tarnai Antal. Akadémiai, Budapest, 1953.

Batsányi János poétai munkái. Kézirat a MTA Kézirattárában. Facsimile. Hozzá tartozik Keresztury Dezső tanulmánya. Akadémiai - Magyar Helikon, Budapest, 1980.

Bausz Teodorik: Kultsár István élete és müködése. = Tudós, könyvtáralapító, kultúraközvetítő Kultsár István. Tatabánya, 2001.

Bécsy Ágnes: „Halljuk, miket mond a lekötött kalóz”. Berzsenyi versek elemzése. Korona Nova, Budapest, 1998.

Bél Mátyás: Notitia Comitátuum Vesprimiensis, Simighiensis Szaladiensis (kézirat) fordítása és ismertetése $=$ Lukács Károly: A Balaton-vidék földrajza kétszáz év előtt. A Magyar Biológiai Kutatóintézet Munkái XV. Tihany, 1943.

Benda Kálmán: Emberbarát vagy hazafi. Tanulmányok a felvilágosodás korának magyarországi történetéből. Gondolat, Budapest, 1978

Bényei Miklós: A nemzeti és polgári kultúra felé. Csokonai Históriai Könyvek. Csokonai, Debrecen, 1998.

Berzsenyi Dániel összes múvei. Költői művei. Sajtó alá rendezte és szerkesztette: Merényi Oszkár. Akadémiai, Budapest, 1879.

Berzsenyi Dániel összes múvei. Szerk.: Merényi Oszkár. Szépirodalmi, Budapest, 1978.

Berzsenyi Dániel' összes múvei. Költelem 's folyóbeszéd. Közrebocsátá: Döbrentei Gábor. III. kiad. Buda, 1842.

Bertók László: Így élt Csokonai Vitéz Mihály. Móra, Budapest, 1973

Bíró Ferenc: A felvilágosodás korának magyar irodalma. Balassi, Budapest, 1994

Bisztray Gyula: Jókedvü magyar irodalom. Budapest, 1968

Blázy Árpád: A gyógyszerészet megjelenése és fejlődése Zala megyében 1711-1847. Zalai Gyüjtemény 1. Zalaegerszeg, 1974

Bodolay Géza: Irodalmi diáktársaságok 1785-1848. Akadémiai, Budapest, 1963.

Bontz József: Keszthely város monográfiája. Keszthely, 1896.

Bright, Richard: Angol szemmel Keszthelyen százhúsz évvel ezelőtt. Ford.: Dr. Szerecz Imre. Sujánszky, Keszthely, 1935.

Chalupka Rezső: A Keszthelyi Helikon 1921-ben. Székesfehérvár, 1922. 
Črep Josip: Feštetići posljednji grofovi Međimurja 1791-1923. Čakovec, 2010.

Csák Ấrpád: A szép Balaton mellől. Beszélyek, rajzok. Keszthely, 1906

Csányi László: Első könyvkiadói vállalkozásunk a Magyar Minerva. = Új Helikon, Veszprém, 1962

Császár Elemér: Kisfaludy Sándor. Franklin, Budapest, 1910

Cséby Géza: „...négy Szobák Ajtó-ragasztói kőbül készüljenek...” A keszthelyi Festetics kastély és parkjának története. = Bakony-Balaton Kalendárium 2005. Veszprém, 2004.

Cséby Géza - Sági Károly: Adalékok a Széchenyi és Festetics család kapcsolataihoz. Kézirat.

Cséby Géza: A porából megelevenedett Phoenix. = Somogy 1996/3.

Cséby Géza: Hévíz első ismertetője. = Hévíz. Kulturális folyóirat. 1993. I. évf. 1 sz.

Cséby Géza: Adalékok Festetics György irodalompártoló tevékenységének összegzéséhez. = Hévízi Almanach. Hévíz, 1992.

Cséby Géza: A Balaton képe a Tudományos Gyưjtemény évfolyamaiban I. = Új Balaton. Társadalmi és müvészeti folyóirat. 2001. december.

Cséby Géza: Csokonai Vitéz Mihály és Keszthely. = Tóparti üzenet. Hévíz-Keszthely, 2000 .

Cséby Géza: A Keszthelyi Helikoni Ünnepségek rövid története 1817-1819. = Szabolcs András: Az ifjúság Helikoni Ünnepségei Keszthelyen. Nagykanizsa, 1998.

Cséby Géza: Dukai Takács Judit kéziratos vers-füzetei. = Zalai Gyüjtemény 31. Zalaegerszeg, 1990.

Cséby Géza: Nők Keszthely irodalmi életében = Szendrey Júlia emlékkönyv. Georgikon kiskönyvtár 25. Keszthely, 2012.

Csiki László: A keszthelyi agrárfelsőoktatás története. Georgikon kiskönyvtár 1. Keszthely, 1993.

Csiki László: A keszthelyi Georgikon története. = Georgikon 175. Mezőgazdasági, Budapest, 1972.

Csokonai Vitéz Mihály összes múvei. Költemények 4. Sajtó alá rendezte: Szilágyi Ferenc Akadémiai, Budapest, 1994.

Csokonai Vitéz Mihály összes müvei. Költemények 5. Sajtó alá rendezte: Szilágyi Ferenc Akadémiai, Budapest, 2002. 
Csokonai Vitéz Mihály összes múvei. Levelezés. Sajtó alá rendezte: Debreczeni Attila. Akadémiai, Budapest, 1999.

Csokonai Mihály minden munkái. Kiadja: Schedel (Toldy) Ferenc, Pest, 1844.

Csokonai emlékek. Összeállította és a jegyzeteket írta: Vargha Balázs. Akadémiai, Budapest, 1960.

Csoma Zsigmond: Kertészet és polgárosodás. CE Alapítvány, Budapest, 1997.

Czoma László: „A Keszthely 's Czenk istenülő Grófjai...” A Széchényi- és a Festeticscsalád. = Kastélykonferenciák II. Keszthely, 2003.

Darnay Kálmán: Kaszinózó táblabírák I.-II. köt. Athenaeum, Budapest, é. n.

Debreczeni Attila: Tudós hazafiak és érzékeny emberek. Integrációs és elkülönülés a XVIII. század végének magyar irodalmában. Universitas, Budapest, 2009.

Dornyay Béla: Emlékeztető jegyzetek Keszthelyről az 1710-1831-dik évekből. Keszthely, é. n.

Egyed Emese: Kard és penna. Tanulmányok a felvilágosodás magyar irodalmáról. Budapest, 1998.

Emlékkönyv a Georgikon alapításának 100-ik évfordulójára. Szerk.: Csanády Gusztáv. Keszthely, 1897

Eszes László: Feledésbe ment utcanevek Keszthelyen. Keszthely, 1985.

Eszes László: A keszthelyi kőfaragó mühely emlékei a Balaton vidékén 1750-1850. = Müemlékvédelem, 1980./2.

Eszes László: A balatonfüredi színház oszlopai. Kézirat.

Fehér Katalin: A felvilágosodás pedagógiai eszméi Magyarországon. Budapest, 1999.

Fehér Katalin: Festetics György oktatásügyi tevékenysége a korabeli sajtó tükrében. = Magyar Pedagógia 97/1.

Fehér Katalin: Kerekes Ferenc. Országos Pedagógiai Könyvtár és Múzeum, Budapest, 2001.

Fejér György versek. A bevezető tanulmányt írta: Kovács Sándor Iván. Keszthely, 1994.

Fekete József-Váradi Antal: Széchenyi vallomásai és tanításai. Budapest, é.n.

Felelet a Mondolatra néhai Bohógyi Gedeon úrnak. Pest, 1815.

Fenyő István: Kisfaludy Sándor. Irodalomtörténeti Könyvtár 9. Akadémiai, Budapest, 1961. 
Ferenczy Miklós: Csokonai Lillája. Második bővített és javított kiadás. Almásneszmély, 1984.

Festetics Kastély Helikon Könyvtára

Fraknói Vilmos: Gróf Széchényi Ferenc (1754-1820) Osiris, Budapest, 2002.

Friedell Egon: Az újkori kultúra története II. Holnap Kiadó, Budapest, 1998.

Fülöp Géza: A magyar olvasóközönség a felvilágosodás idején és a reformkorban. Akadémiai, Budapest, 1978.

Fülöp Géza: Olvasási kultúra és könyvkiadás Magyarországon a felvilágosodás idején és a reformkorban (1772-1848) Hatágú Síp Alapítvány, Budapest, 2010.

Georgikon 200. II. Adattár 1797-2000. Emlékkönyv a Georgikon alapításának 200. évfordulójára. Keszthely, 2001.

Gonda Imre - Niederhauser Emil: A Habsburgok. Gondolat, Budapest, 1977.

Görgényi Géza - Péczely Piroska - Sági Károly: Adatok Hévízfürdő történetéhez. = Az Országos Orvostörténeti Könyvtár Közleményei 5. Budapest, 1957.

Görög-római mythologia. Összeállította: Csiky Gergely. Franklin, Budapest, 1911.

Győrffi Endre: A keszthelyi Kath. Főgymnasium története. Gimnáziumi értesítő, 1895/96. Keszthely, 1896.

Hadi és Más Nevezetes Történetek. Második szakasz. 1790.

Harmath István: A Magyar Minerva könyvsorozat és társadalmi indítékai. = A Veszprém megyei Múzeumok Közleményei 17. Veszprém, 1895.

Harmath István - Katsányi Sándor: Veszprém megye irodalmi hagyományai. Veszprém, 1984.

Hász-Fehér Katalin: A keszthelyi Helikon-ünnepség a XIX. század elején. = Az irodalom ünnepei. Kultusztörténeti tanulmányok. PIM Könyvei 9. Budapest, 2000.

Hász-Fehér Katalin: A „nemzeti szentimentalizmus” programjának egyik forrása: az osszianizmus. = Serta Pacifica. Tamulmányok Fried István 70. születésnapjára. Szerk.: Ármeán Otília, Kürtösi Katalin, Odorics Ferenc és Szörényi László. Pompeji Alapítvány, Szeged, 2004.

Hász-Fehér Katalin: „Kinek vagyon jussa...” A felvilágosodás kori folyóirat-kritika etikai kérdései. = Híd (Újvidék) 1999/11.

Hász-Fehér Katalin: A magyar nyelvüség programjai a XVIII-XIX. század fordulóján. = Historia litteraria a XVIII. században. Szerk.: Csörsz Rumen István, Hegedűs Béla, Tüskés Gábor. Universitas Kiadó, Budapest, 2006. 
Hasznos Mulatságok vonatkozó számai

Hazai ’s Külföldi Tudósítások vonatkozó évfolyamai

Hazai Tudósítások 1806 évf.

Helikon I. Keszthely, 1818.

Helikon 1992 Keszthely. Castellum, Keszthely, 1992

Hirmann László: Fekete János gróf. = Újpesti Helytörténeti Értesítő, 2004. (december) XI./4

Hopp Lajos: A kézirat első kiadásáról. = Tudós, könyvtáralapító, kultúraközvetítő Kultsár István. Tatabánya, 2001.

Hoppál Mihály - Jankovics Marcell - Nagy András -Szemadám György: Jelképtár. Helikon, Budapest, 1997.

Horváth József: A csurgói Csokonai Vitéz Mihály Gimnázium és Óvónői Szakközépiskola. Tankönyvkiadó, Budapest, 1992.

Horváth József: Csurgó monográfiája. Csurgó, 2009.

Horváth János: A magyar irodalmi népiesség Faluditól Petőfiig. III. kiad. Akadémiai, Budapest, 1978.

Huttkay Lipót dr.: Mikes Kelemen Törökországi Levelei. Az Egri Érsekmegyei Könyvtár eredeti kézirati kincseiből. Egri érseki liceumi sajtó, Eger, 1905.

Igaz Sámuel: Keszthelynek Poétai innepe. = Hébe zsebkönyv MDCCCXXIII. Pest.

Irodalomtörténeti Közlemények

Iványi Béla dr.: A Festetics család keszthelyi levéltára. Különlenyomat a Levéltári Közlemények 1946. évi huszuonnegyedik évfolyamából. Bp., 1947

Jakab Ferenc: Kisfaludy Sándorné Szegedy Róza élete. Győr, 1936.

Dr. Jancsó Elemér: A magyar szabadkőmúvesség irodalmi és múvelődéstörténeti szerepe a XVIII-ik században. Irodalomtörténeti tanulmány. Ady Endre Társaság, Cluj, 1936.

Jászberényi József: A magyarországi szabadkőmúvesség története. PrintXBudavár, Budapest, 2005.

Jászberényi József: „A Sz: Sophia' templomában látom én felszentelve Nagysádat” A felvilágosodás korának magyar irodalma és a szabadkőmüvesség. Irodalomtörténeti füzetek. Argumentum, Budapest, 2003. 
Jászberényi József: „A Sz: SOPHIA' Templomában látom én felszentelve NAGYSÁDAT..." Csokonai Vitéz Mihály és a szabadkőmüvesség kapcsolatairól. = Irodalomtörténet, 2000/2.

Jászberényi József: „A kőmüves az emberiséget szolgálja.” Festetich György és a szabadkőművesség. = Kelet, XLIX. évf. 2006/1-2.

Jászberényi József: A felvilágosodás korának magyar irodalma és a szabadkőművesség. In: Hitel, 1998/12

Juhász Géza: Csokonai a kicsapatás után. Egy ismeretlen dokumentum felbukkanása alkalmával. $=$ Alföld, 1963/7.

Juhász Géza: Csokonai tanulmányok. Akadémiai, Budapest, 1977.

Julow Viktor: Csokonai Vitéz Mihály. Gondolat, Budapest, 1975.

Kállay István: A magyarországi nagybirtok kormányzata 1711-1848. Akadémiai, Budapest, 1980.

Kazinczy levelezése Berzsenyi Dániellel 1808-1831. Kiadta Kazinczy Gábor. Heckenast, Pest, 1860.

Kazinczy Ferenc: Versek, múfordítások, széppróza, tanulmányok. Szépirodalmi, Budapest, 1979.

(Kazinczy Ferenc) Tövisek és virágok. Széphalom, MDCCCXI.

Kazinczy Ferenc levelezése. Közzéteszi: Dr. Váczy János. I.-XXI.köt. MTA Budapest, 18901911.

Kazinczy Ferenc levelezése. XXIII. köt. Közzéteszi: Berlász Jenő, et... Akadémiai, Budapest, 1960.

Kazinczy Ferenc összes költeményei. Sajtó alá rendezte: Gergye László. Balassi, Budapest, 1998.

Kerényi Károly: Görög Mitológia. Gondolat, Budapest, 1977.

Keresztury Dezső: Híres magyar könyvtárak. Budapest, 1982.

Keresztury Dezső: Festetics György és a magyar irodalom. = Irodalomtörténeti Közlemények 1963/5.

Királyi és hercegi kertek Magyarországon. Eszterháza, Gödöllő, Keszthely, Visegrád. Szerk.: Alföldy Gábor. Szent István Egyetem Kertmüvészeti Tanszék - Mágus Kiadó, Budapest, 2001.

Kisfaludy László: A kisfaludi Kisfaludy család története. Debrecen, 2004. 
Kisfaludy Sándor hátrahagyott munkái II. Elegyes versei s egy kiadatlan vígjátéka némely zsengéivel együtt. Kiadta: Toldy Ferenc. Heckenast, Pest, 1871

(Kisfaludy Sándor) A keszthelyi Helikon. In: Tudományos Gyüjtemény 1817. III. köt.

Klempa Károly: A keszthelyi Festetics-könyvtár 1500-ig terjedő ősnyomtatványai. Sujánszky, Keszthely, é. n.

Klempa Károly: II. József látogatása Keszthelyen. Sujánszky, Keszthely, é. n.

Klempa Károly: A keszthelyi Festetics könyvtár. Mérei, Keszthely, é. n.

Klempa Károly: Az első keszthelyi nyomda. Pannónia Könyvtár. Pécs, 1943.

Klempa Károly: Fejér György keszthelyi diákévei. Keszthely, é. n.

Klempa Károly: A keszthelyi Festetics-féle Zeneiskola. Győr, 1938.

Kociszewski, Aleksander: Pieśnią i szablą. Rzecz o twórcy hymnu narodowego. Iskry, Warszawa, 1982.

Kókay György: Felvilágosodás, kereszténység, nemzeti kultúra. Universitas, Budapest, 2000.

Kókay György: Könyv, sajtó és irodalom a felvilágosodás korában. Akadémiai, Budapest, 1983.

Koppány Tibor: A Balaton környékének müemlékei. OMH. Budapest, 1993.

Koppány Tibor - Péczely Piroska - Sági Károly: Keszthely. Képzőműv. Alap Kiadóváll., Budapest, 1962.

Kornis Gyula: A magyar múvelődés eszményei 1777-1848. I.-II. köt. Királyi Magyar Egyetemi Nyomda, Budapest, é. n. ill. II. köt.1927.

Kosáry Domokos: Múvelődés a XVIII. századi Magyarországon. Akadémiai, Budapest, 1983.

Kostyál István: Kultsár István levele Festetics Györgyhöz. = Irodalomtörténeti Közlemények 64. 1960.

Kovacsics József: Zala megye helytörténeti lexikona. Keszthely és környéke. Statiqum, Budapest, 1991.

Kovács Lajos: Gróf Széchenyi István közéletének három utolsó éve 1846-1848. I. köt. Franklin, Pest, 1889.

Kövér János: A vörsi plébánia Historia Domusa. Tóth Dénes feldolgozásában. Kézirat. 
Kulcsár Krisztina: II. József utazásai Magyarországon, Erdélyben, Szlavóniában és a Temesi Bánságban 1768-1773. Gondolat - MOL, Budapest, 2004.

Kurucz György: Kényszer és szolgálat. Portrévázlatok Festetics Györgyről. = Századok 2006. 140/6.

Kurucz György: Könyv és fónemesi müveltség: Festetics György magánkönyvtára katonai pályára lépésének kezdetén. = Aetas, 21 év. 2006/2-3.

Kurucz György: Festetics György gróf. = Zalai Múzeum, Zalaegerszeg, 1999.

Kurucz György: Festetics György pénzügyi helyzete 1782 és 1818 között. = Századok 2006/3.

Kurucz György: Irodalmunk ,jó embere”. Festetics György és a magyar felvilágosodás. = Magyar Napló XVIII/5. 2006.

Kurucz György: A Georgikon alapításától 1848-ig. = Georgikon 200. Keszthely, 1996

Laczkó András: Diákszínjátszás Somogyban. Somogy Megyei Levéltár, Kaposvár, 1981.

Laczkó András: Keserédes történetek. Kaposvár, 1991.

Laczkó András: Tanulmányok Dukai Takács Juditról. = Hévíz. Művészeti és művelődési folyóirat. 2006. XIV./2-3.

Ladó János: Magyar utónévkönyv. Akadémiai, Budapest, 1982.

Lúdas Matyi egy Eredeti Magyar Rege Négy Levonásban Bétsben 1815.

Magyar Eszter: Túzifa, épületfa, faszén. = História, 2006/5.

Magyar Hirmondó évfolyamai

Magyar Kurír évfolyamai

Magyar Leveleskönyv I.-II. Szerk.: Balogh József és Tóth László. Kiadja H. Balázs Éva. Corvina, Budapest, 2001.

Magyar Merkurius 1797. július 17.

Magyar múvelődéstörténet. Szerk.: Kósa László. Osiris, Budapest, 1998.

Magyar Múvelődéstörténeti Lexikon - középkor és korai újkor - X. Balassi, Budapest, 2010 .

Magyar színháztörténet 1790-1873. Szerk.: Kerényi Ferenc. Akadémiai, Budapest, 1990.

Magyarország hadtörténete I.-II. köt. Főszerk.: Liptai Ervin. Zrínyi, Budapest, 1984. 
Magyarország története 1790-1848. 5/1. köt. Főszerkesztő: Mérei Gyula. Akadémiai, Budapest, 1980.

Magyarország történeti kronológiája II. köt. Szerk.: Benda Kálmán. Akadémiai, Budapest, 1982.

Magyarország története a 19. században. Szerk.: Gergely András. Osiris, Budapest, 2005

Magyar Országos Levéltár Festetics Levéltár

Magyar Országos Levéltár Széchényi Levéltár

Magyar Országos Levéltár Réthei Rötth család Levéltár

Magyar Tudományos Akadémia Kézirattára

Marczali Henrik: Magyarország története II. József korában I. kötet. Budapest, 1884.

Marczali Henrik: Magyarország története III. Károlytól a Bécsi Congressusig. = A Magyar nemzet története. Szerk.: Szilágyi Sándor. Athenaeum, Budapest, 1898.

Margócsy István: A magyar nyelv jelenléte a 18. századi iskoláztatásban. = Tanulmányok a magyar nyelv ügyének 18. századi történetéből. Szerkesztette: Bíró Ferenc. Argumentum, Budapest, 2005.

Markos János: Kultsár István. = A tudós könyvtáralapító, kultúraközvetítő Kultsár István. Tatabánya, 2001.

Markowska, Wanda: Mity greckie. Iskry, Warszawa, 1953

Merényi Oszkár: Berzsenyi Dániel. Irodalomtörténeti Könyvtár 19. Akadémiai, Budapest, 1966.

Mezei Márta: A keszthelyi Helikon-ünnepek - és ahogy az írók látták. = Kegyelet és irodalom. Kultusztörténeti tanulmányok. A PIM Könyvei 7. Budapest, 1997.

Mikes Kelemen: Törökországi levelek és misszilis levelek. Sajtó alá rendezte: Hopp Lajos. Budapest, 1966.

Mitológiai Enciklopédia I. Fősz.: Tokarev. Gondolat, Budapest, 1988.

Mondolat. Sok bővitményekkel, és egy kiegészített újj-szótárral együtt, Angyalbőrbe kötve. Dicshalom, 1813.

Morvay Győző: Galánthai gróf Fekete János 1741-1803. Magyar történelmi életrajzok. Magyar Történelmi Társaság, Budapest, 1903.

Morvay Győző: Galánthai gróf Fekete János. Második közlemény. = Irodalomtörténeti Közlemények, 1911. 11 évfolyam 2. szám 
Müller Róbert: A Phoenix gálya. = Pannon Tükör 1996/3.

Müvek és életrajzok. Magyar költőnők antológiája. Összeállította: S. Sárdi Margit, Tóth László. Enciklopédia, Budapest, 1997.

Nagy Iván: Magyarország családai czímerekkel és nemzékrendi táblákkal. Első tizenkettedik + pótlékkötetek. Pest, 1857-1868

Nagy képes világtörténet XI. Szerk.: Marczali Henrik Franklin, Budapest, é. n.

N. Nagyváthy János: A Magyar Fewdes és Zászlós Úr. Csurgó, 2009.

Nagyváthy János: Magyar practicus termesztő. Pest, 1821.

Nagyváthy Kálmán: Nagyváthy János élete. Pozsony, é. n.

Németh Ladislaus: Über das Georgikon in Keszthely. = Patriotisches Wochenblatt für Ungern. 1804. április 4.

Négyesy László: Gróf Festetics György a magyar irodalomban. = Keszthelyi Helikon. Szerk: dr. Lakatos Vince. Keszthely, 1925.

Németh József: Horváth Ádám és a szabadkőmüvesség. = Pálóczi Horváth Ádám: Felfedezett titok. Szépirodalmi, Budapest, 1988.

Nemzeti Gazda, 1817. / XXVI.

Neveléstörténet, 2005. / 1-2.

Netjogtár

Örök emlékezet 1800. A Georgikon emlékkönyve. Festetics Kastély Helikon Könyvtára, Kézirattár.

Pandula Attila: Insigniológia. = A történelem segédtudományai. Szerk.: Kállay István. Második, bővített kiadás. ELTE. BTK., Budapest, 1986.

Pápay Sámuel: A magyar literatúra esmérete. Magyar Minerva, Veszprém, 1808.

Péczely Piroska: Soproni vonatkozású diákversek a keszthelyi Helikon könyvtárban = Soproni Szemle, XVII. évf. 3. sz. (1963)

Péczely Piroska: A keszthelyi Festetics kastély és belső berendezése. Budapest, 1958.

Péczely Piroska - Sági Károly - Szutrély Antal: A 200 éves keszthelyi kórház története. h. n. é. n.

Pennaháborúk. Nyelvi és irodalmi viták 1781-1826. Összeállította: Szalai Anna. Szépirodalmi, Budapest, 1980. 
Péterffy Ida: Horváth Ádám levelezése „poétriáival”. Zala megye irodalmi hagyományai. Zalaegerszeg, 1973

Péteri Takáts József: Erköltsi oktatások, melyeket tolnai gróf Festetics László, kedves tanítványa szívére kötött Péteri Takáts József Bétsben, özvegy Alberti Ignátzné betűjével, 1799

Pintér Jenő: A magyar irodalom története I. Második kiadás. Bibliotheca, Budapest, 1942.

Polgár Marianna: Katolikus fốr protestáns egyetemen. Festetics Pál lipcsei tanulmányai 1741-43. = Iskola és társadalom. Zalai Gyüjtemény 41. Zalaegerszeg, 1997.

Rédey Tivadar: A füredi magyar játékszín = Balatoni évkönyv 1921. Bp. A Balatoni Társaság kiadása, 1921.

Reisz T. Csaba: Magyarország általános térképének elkészítése a 19. század első évtizedében. Lipszky János és segítői térképészeti vállalkozásának jellemzése. Cartofil, Budapest, 2002.

Reisz T. Csaba: Lipszky János térképészeti hagyatéka. = Fons IV. 1997/2.

Reisz T. Csaba: A központi kormányszervek és a vármegyék szerepe a Lipszky-térkép elkészítésében. (Lelőhely [2012]: http://lazarus.elte.hu/hun/tantort/1998/reisz.htm)

Sági János: Magyar színház a szabad természetben. = Vasárnapi Újság. 1909./6.

Sági Károly: Adatok Festetics György és munkássága értékeléséhez. = Veszprém megyei Múzeumok Közleményei 6. Veszprém, 1967.

Sági Károly: Festetics György élete, kulturális és politikai törekvései. = Gergikon 175. Szerk.: Sági Károly. Mezőgazdasági, Budapest, 1972.

Sági Károly: Antonio Borri - Bori Antal. = Veszprém megyei Múzeumok Közleménye 18. Veszprém, 1987.

Sági Károly: A Balaton és az irodalom. = Balaton monográfia. Panoráma, Budapest, 1974.

Sági Károly: Egy régi iskolai büntetés és egy farsangi népszokásunk kapcsolata. = Veszprém megyei Múzeumok Közleményei 16. Veszprém, 1983.

Sándor Lipót Főherceg nádor iratai 1790-1795. Kiadta: Mályusz Elemér. Magyar Történelmi Társulat, Budapest, 1926.

Schöpflin Aladár: Dukai Takács Judit = Nyugat, 1910. 4. szám

Simon István: Gyönyörü terhem. Szépirodalmi, Budapest, 1982.

Sisa József: A dégi Festetics-kastély. Épített örökségünk. Müemlékek Állami Gondnoksága, Budapest, 2005. 
Soós István: II. József német nyelvrendelete és a „hivatalos" Magyarország. = Tanulmányok a magyar nyelv ügyének 18. századi történetéből. Szerk.: Bíró Ferenc. Argumentum, Budapest, 2005.

Süle Sándor: A keszthelyi Georgikon. 1797-1848. Akadémiai, Budapest, 1967.

Süle Sándor: Kisszántói Pethe Ferenc. Akadémiai, Budapest, 1964.

Stohl Róbert: Adatok Péteri Takáts József nevelői tevékenységéhez. = Könyv és Nevelés, $2005 / 4$.

Stohl Róbert: Péteri Takáts József irodalmi kapcsolathálója a Magyar Minerva körül. = Kutatások az Eötvös József Főiskolán. Budapest, 2005.

Stohl Róbert: Fragmenta Takatsiana. Források és kiegészítések péteri és téti Takáts József (1767-1821) életrajzához. Doktori (Ph.D.) értekezés. Szeged, 2009.

Szabad Polgár 1873. évfolyam

Szabó Dezső: A herceg Festetics-család története. Franklin, Budapest, 1928.

Szabó György: Mediterrán mítoszok és mondák. Kriterion, Bukarest, 1973.

Szabolcs András: Az ifjúság Helikoni ünnepségei Keszthelyen. Nagykanizsa, 1998.

Szabó Sándor: Péteri és Téti Takáts József író és költő mint irodalomszervező. = Zalai Gyüjtemény 18. Zalaegerszeg, 1983.

Szabolcsi Bence - Tóth Aladár: Zenei lexikon 2. köt. Zeneműkiadó, Budapest, 1965.

Szajbély Mihály: „Idzadnak a' Magyar tollak” Irodalomszemlélet a magyar irodalmi felvilágosodás korában, a 18. század közepétől Csokonai haláláig. Akadémiai - Universitas, Budapest, 2001.

Szántó Imre: Keszthely úrbéri viszonyai a Festeticsek földesurasága idején 1739-1848. Acta Universitas Szegediensis de Attila József Nominate Acta Historica Tom. LXXVIII. Szeged, 1984.

Szántó Imre: Hévíz története I.-II. Hévíz, 1977-1981.

Szarka Lajos: Thália papjai Keszthelyen az első világháborúig. = Zalai Gyüjtemény 31 . Zalaegerszeg, 1990.

Száva Gyula: Győr. Monográfia. Győr, 1896.

Széchenyi István: Napló. Gondolat, Budapest, 1978.

Széchenyi István - Wesselényi Miklós. Feleselő naplók. Szerk. Maller Sándor. Budapest, 1986. 
Széchényi Ferenc és Csehország. Levelestár. Válogatta és a bevezető tanulmányt írta: Richard Pražák, Sajtó alá rendezte: Deák Eszter és Erdélyi Lujza. OSZK.-Gondolat, Budapest, 2003.

Szép János: Keszthely városának Párnásszus hegyéről való szemlélése $s$ leírása. = Irodalomismeret, 1966/1-2. Sajtó alá rendezte, jegyzetekkel ellátta: Dala Sára, Földváry Kinga, Klaáb Adrienn, Kovács Edit Alexandra)

Szerb Antal: Magyar irodalomtörténet. III. kiad. Magvető, Budapest, 1978

Szilágyi Ferenc: Csokonai müvei nyomában. Akadémiai, Budapest, 1981

Szilágyi Ferenc: „Az ész világa mellett..” Mundus, Budapest, 1998.

Szilágyi Márton: Adalék Péteri Takáts József irodalmi kapcsolataihoz. = Irodalomtörténeti Közlemények 1993.

Szilágyi Márton: Kármán József és Pajor Gáspár Urániája. Csokonai Könyvtár. Kossuth Egy. Kiadó, Debrecen, 1998.

Szilágyi Márton: Kegyelem és erőszak. Fazekas Mihály Lúdas Matyija. = Alföld. 2002/7. Interneten: (http://epa.oszk.hu/00000/00002/00075/szilagyi.html)

Szimbólumtár. Szerk.: Pál József, Újvári Edit. Balassa, Budapest, 1997.

Szinnyei József: Magyar írók élete és munkái. III., IX., XIII., XIV. köt. Budapest, 18941914.

Szinnyei József ifj.: A keszthelyi Helikon 1817-1819. = Közérdek, 1875/16.

Takáts Sándor: Péteri Takáts József. Hunyadi Mátyás Intézet, Budapest, 1890.

Tanulmányok a magyar nevelésügy XVII-XX. századi történetéből. Szerk.: Mészáros István. Akadémiai, Budapest, 1980.

Tanulmányok a magyar nyelv ügyének 18. századi történetéből. Szerkesztette: Bíró Ferenc. Argumentum, Budapest, 2005.

„Tekintetes Szerkesztő úr!” Levelek a magyar sajtóról 1790-1848. Magyar Levelestár. Gondozza: Fehér Katalin, Kókay György. Szépirodalmi, Budapest, 1990.

Theschedik Sámuel önéletírása. Eredeti németből ford. és kiadta: Zsilinszky Mihály, Pest, 1873.

Thiele, J. C. v.: Das Königreich Ungarn. Ein topographisch-historisch-statistisches Rindgemälde, das Ganze dieses Landes in mehr 12400 Artikeln umfassend. I.-VI. Kaschau, 1833.

Tóth-Bence Tamás: Balatonfüred az évszámok tükrében. Balatonfüred Városért Közalapítvány kiadványai, 60. Balatonfüred, 2011 
Toldy Ferenc: A magyar nemzeti irodalom története. A legrégibb időktől a jelen korig. 1864-1865. Gondozta: Szalai Anna. Szépirodalmi, Budapest, 1987.

Toldy Ferenc: Kazinczy Ferenc és kora. Életrajzi emlék. 1859-1860. Gondozta: Szalai Anna. Szépirodalmi, Budapest, 1987.

Tóth István: A keszthelyi Helikon nevének eredete. = Múzeumi Kurír IV/3. Debrecen, 1980.

Tóth Lajos: 200 éves a fenékpusztai hajóarzenál. HEB Müszaki Történelmi sorozat 4. Gépipari Tud. Egy., Budapest, 1965.

Tóth Lajos: Tessedik Sámuel kapcsolatai a jakobinus mozgalom vezetőivel. Tanulmányok a magyar nevelésügy XVII-XX. századi történetéből. Szerkesztette: Mészáros István. Akadémiai, Budapest, 1980.

Tudományos Gyüjtemény vonatkozó évfolyamai

Uránia 1794. évfolyam

Új magyar életrajzi lexikon I.-VI. Magyar Könyvklub, Budapest, 2001-2007

Váczy János: Gróf Festetics György és a magyar Helikoni ünnepélyek. = Vasárnapi Újság 1886. évf.

Váczy János: A keszthelyi Helikon. = Budapesti Szemle. CCCXLV. 1905. évf.

Váczy János: Horváth Endre és a nyelvújítás. = Magyar Nyelv, 1905. V. I. köt./5.

Vadász Norbert: Dukai Takách Judit élete és munkái. Franklin, Budapest, 1909.

Varga Kálmán: Egy szabadkőműves „fészek”. A dégi kastély. = Rubicon, 2010./2.

Vargha Balázs: Jelek, jelképek, jellemek. Irodalmi és nyelvészeti tanulmányok. Magvető, Budapest, 1984.

Vasárnapi Újság vonatkozó számai

Vas Gereben: Régi képek. Pesten, 1856

Vas Gereben: Nagy idők, nagy emberek. Budapest, é. n.

Vay Sarolta: József nádor Keszthelyen. = Régi magyar társasélet. Magyar Hírmondó. Magvető, Budapest, 1986.

Vereinigte Ofner Pester Zeitung vonatkozó évfolyamai

Vermes Gábor: Kulturális változások sodrában. Magyarország 1711 és 1848 között. Balassi, Budapest, 2011. 
Világirodalmi lexikon 6. Akadémiai, Budapest 1997.

Virág Benedek válogatott müvei. Szépirodalmi, Budapest, 1980.

Walleshausen Gyula: Denis professzor és tanítványa, Festetics György. = Könyvtári Figyelö, 2008/1.

Weöres Sándor: Három veréb hat szemmel. Szépirodalmi, Budapest 1977.

Vörös Károly: Fejezetek Nagyváthy János életéből. = Agrártörténeti Szemle, 1961/3-4.

www.neumann-haz.hu

Zákonyi Ferenc: Hévíz múltja és fejlődése 1820-ig. Hévíz, 1974. 
MELLÉKLETEK 


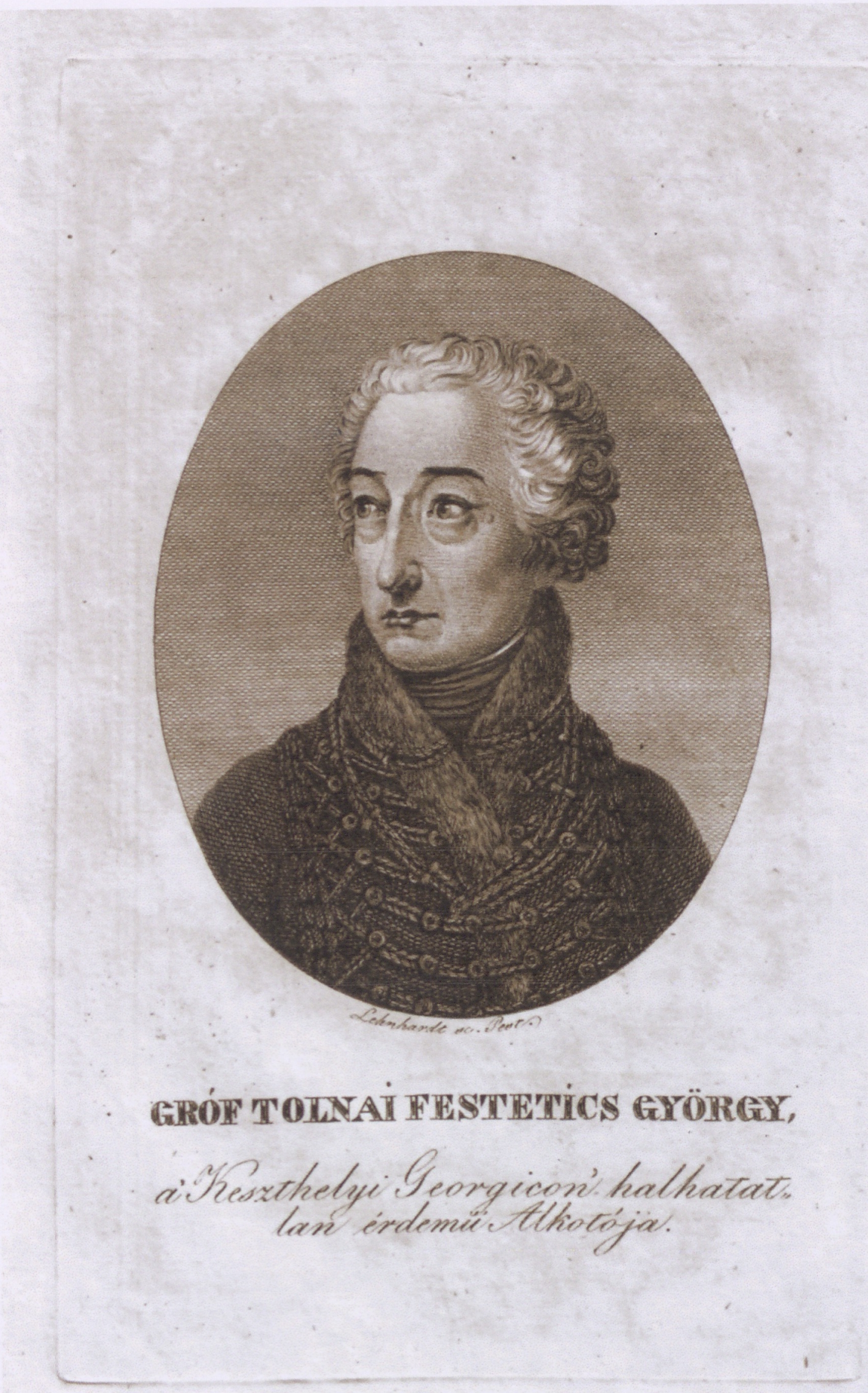




\section{TÖRÖK ORSZÁGI}

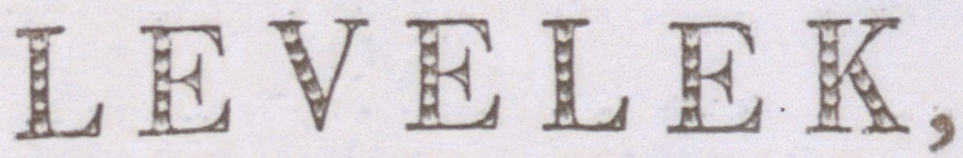

mellyekben

\section{A Ildik RÁKÓTZI FERENTZ}

Fejedelemmel Bújdosó Magyarok' Történeteí más egyébb emlékezetes dolgokkal eggyütt barátságoflan eléadatnak.

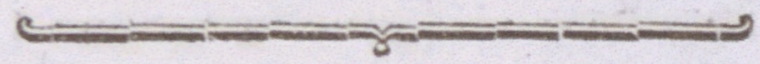

$$
\text { Irta }
$$

MIKES IK ELEMEN

Az emlétett Fejedelemnek néhai Kamaráfla. Moft pedig

Az eredetképpen való Magyar Kézíráfokból kiadta

KULTSÁR ISTVÁN

Az Ékesfzólląsnak Tanitója.

$$
\text { SZOMBATHEL YEN, }
$$

Nyomtatta Siess ANTAL Jósef:

$$
8794 \text { i }
$$


Qtm

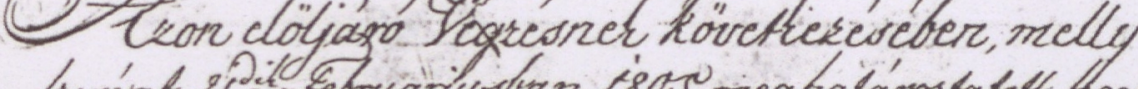

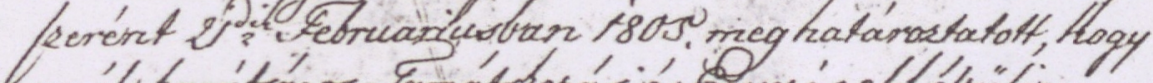

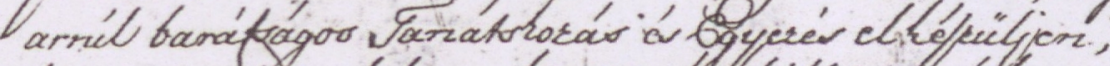

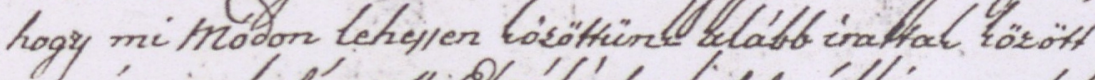

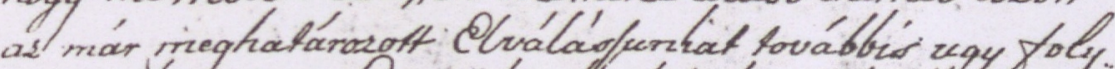

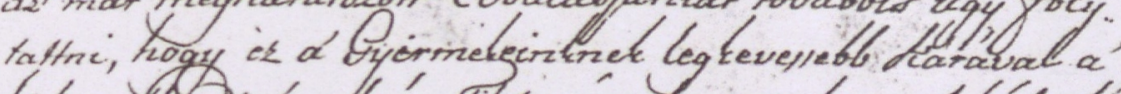

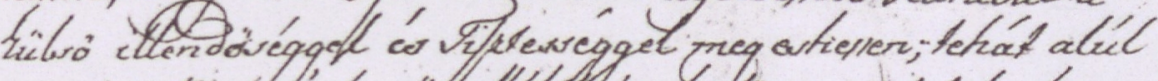

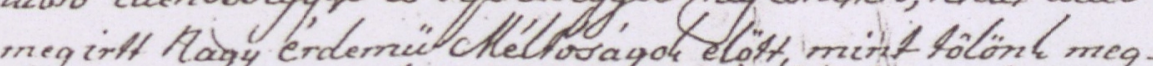

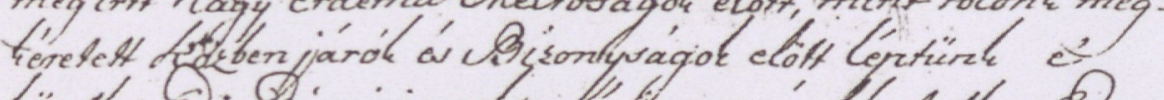

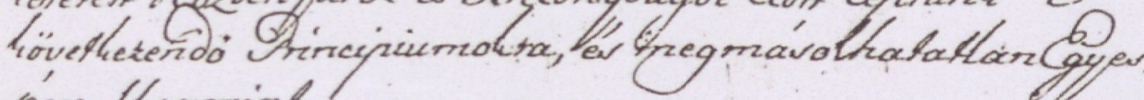
végre. Ulaypring Olofer. hogy a' Querme 1

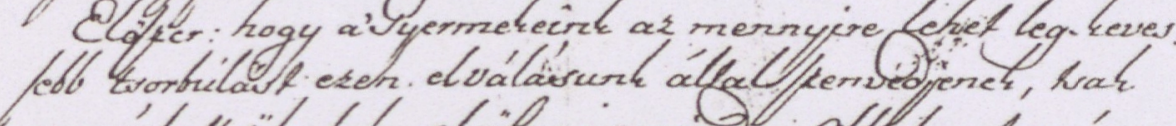

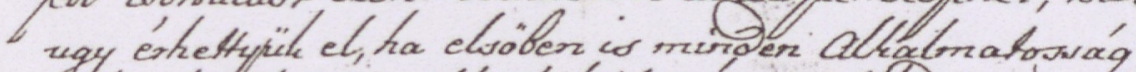

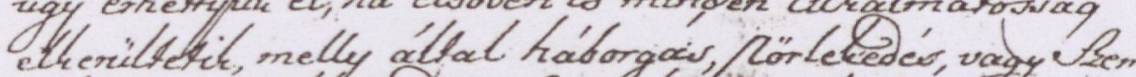

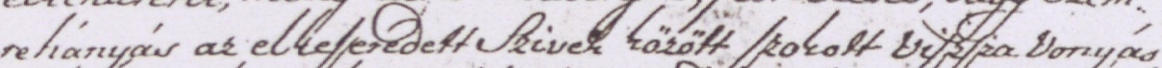

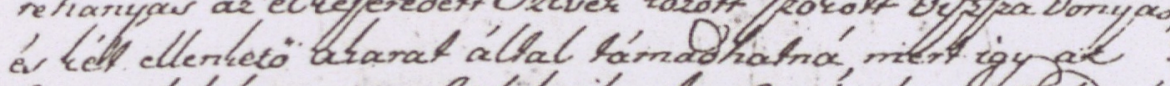

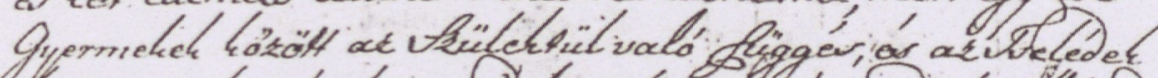

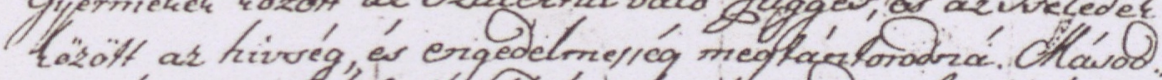

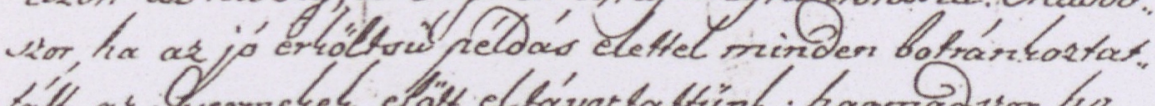

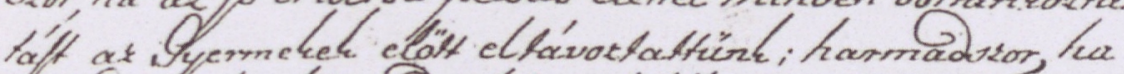

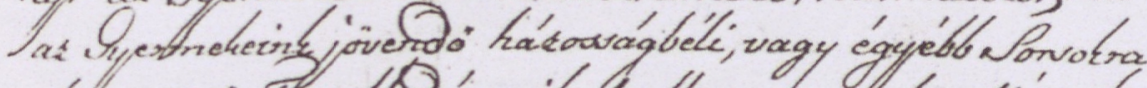

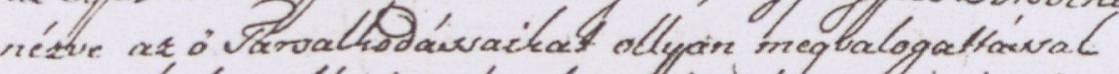

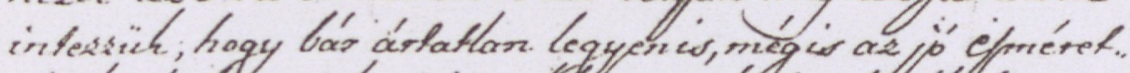

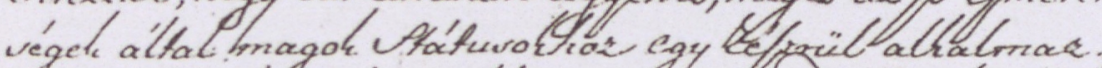

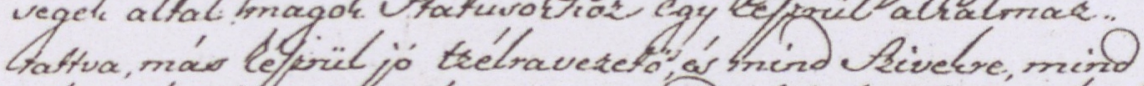

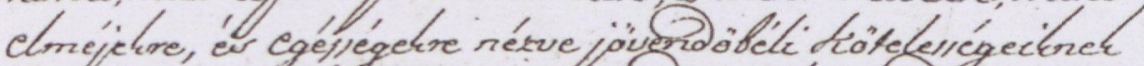

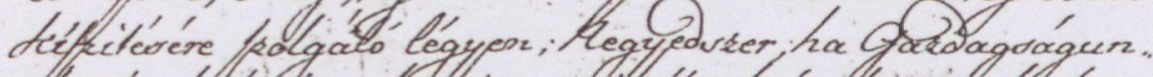

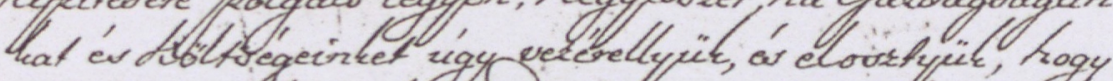

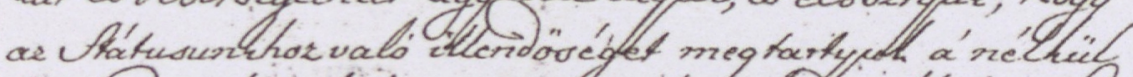

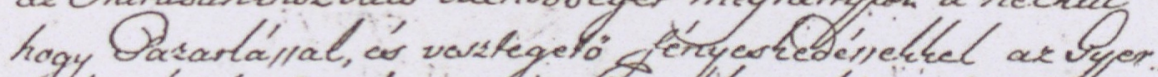

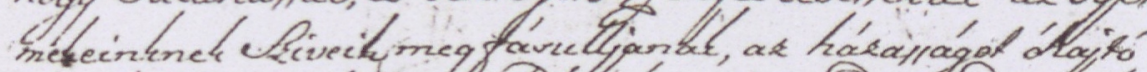

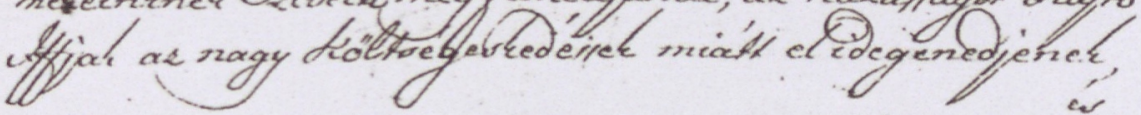

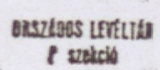

Gróf Festetics György és Sallér Judit válásával kapcsolatos szerződés első oldala. Kelt Bécsben, április 15-én.

(MOL Fest. Lvt. P 2471 cs. B. V. 1.) 


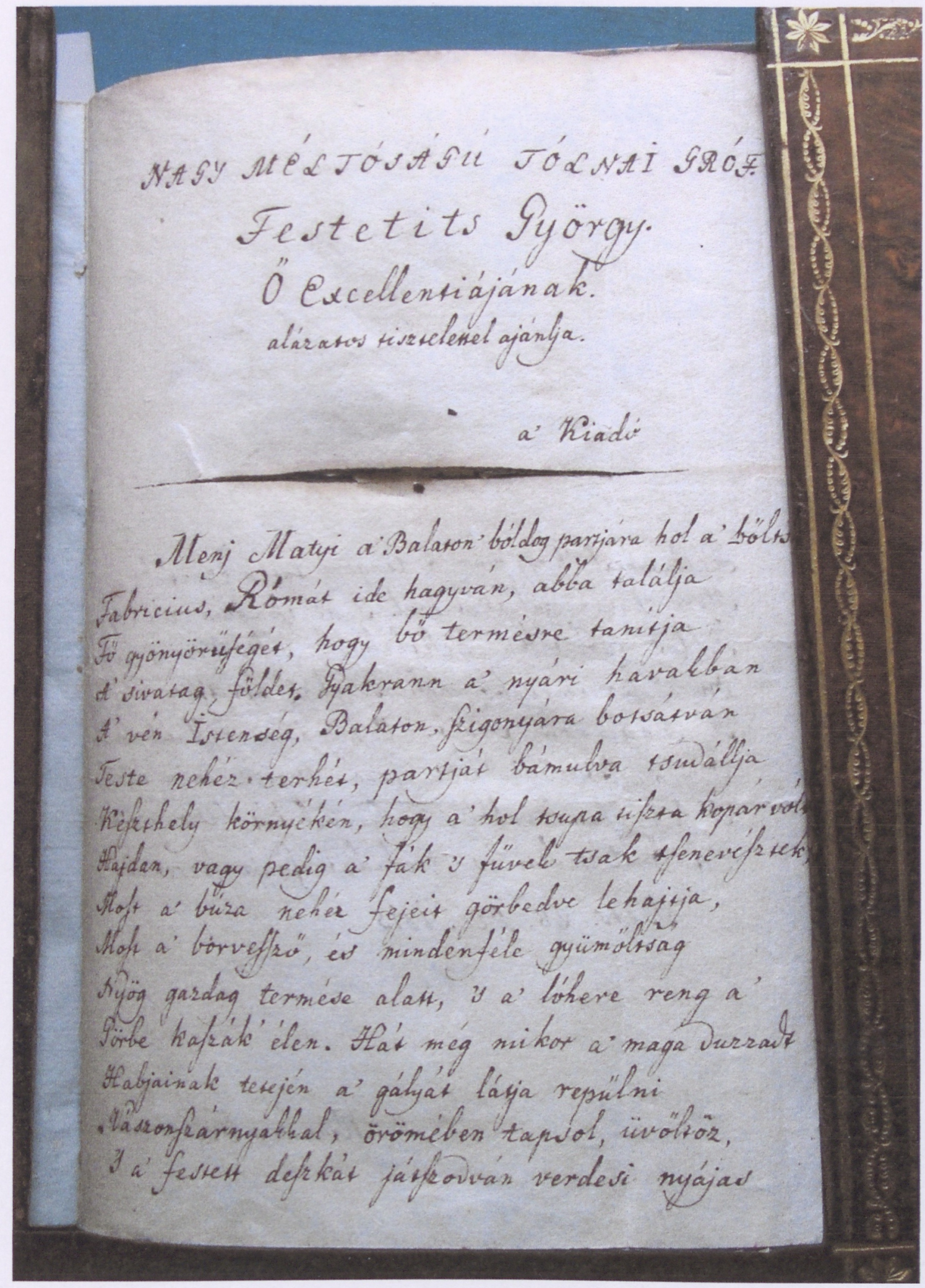

Kerekes Ferenc gróf Festetics György számára irt dedikációjának első oldala a Lúdas Matyi első kiadásában

(Festetics Kastély Helikon Könyvtára, Keszthely) 


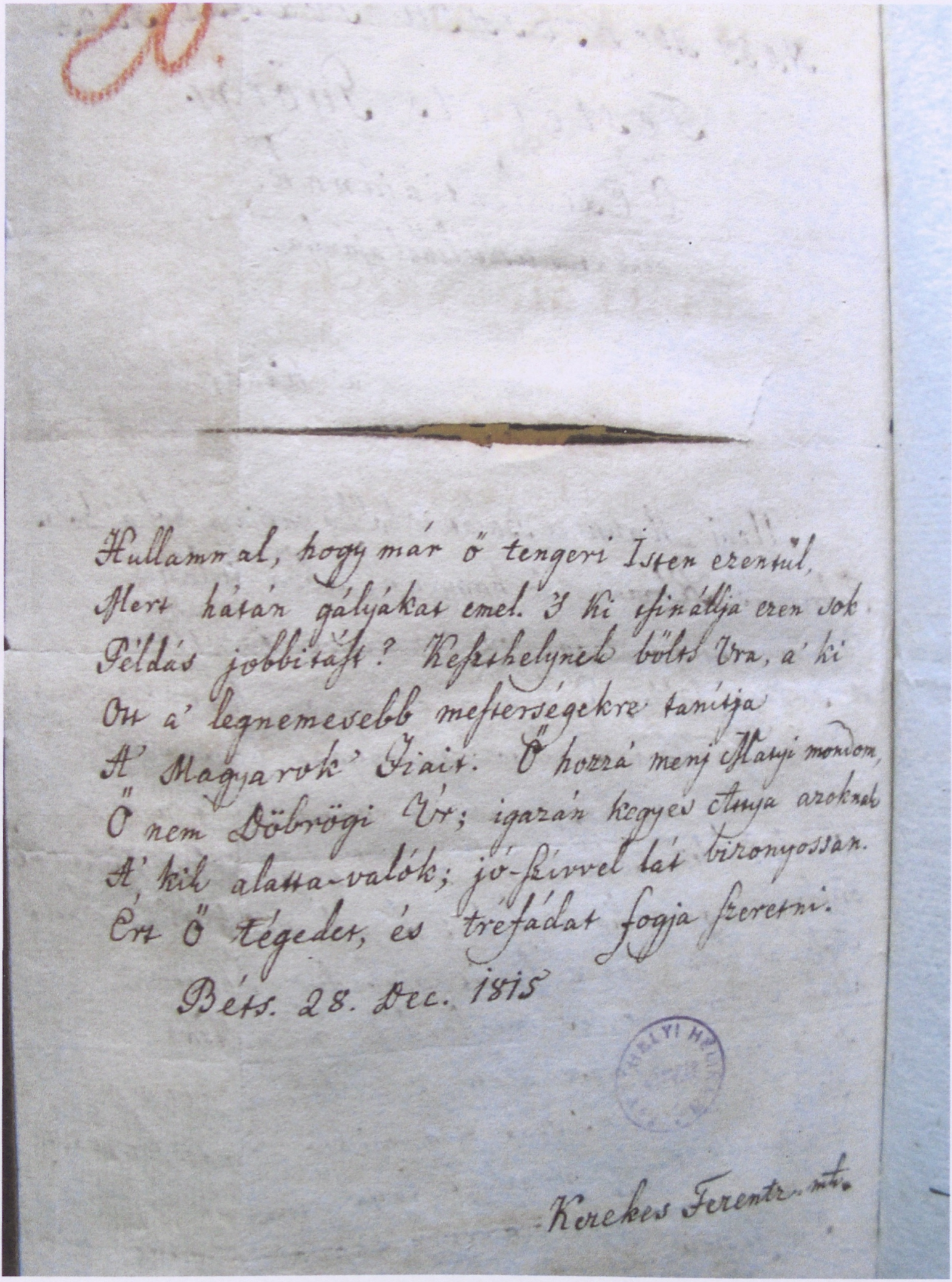

Kerekes Ferenc gróf Festetics György számára írt dedikációjának második oldala a Lúdas Matyi első kiadásában

(Festetics Kastély Helikon Könyvtára, Keszthely) 
$1 / 5086 / 47$

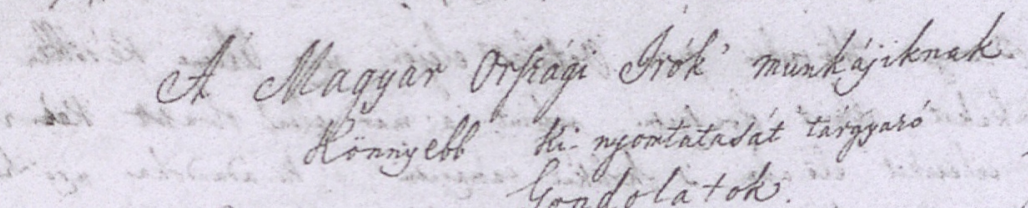

$$
\text { (1) Londolator. }
$$

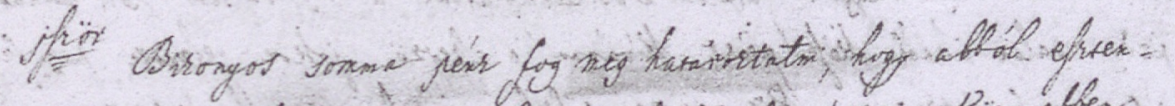

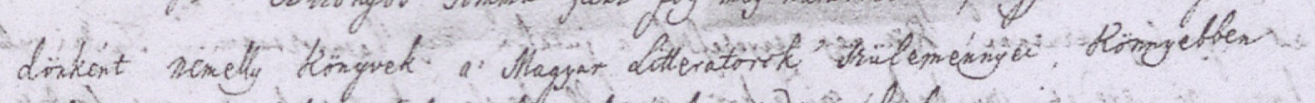

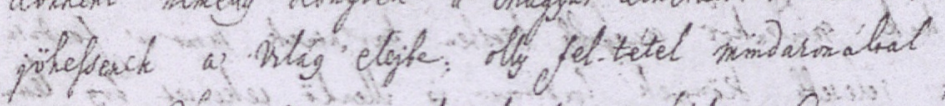

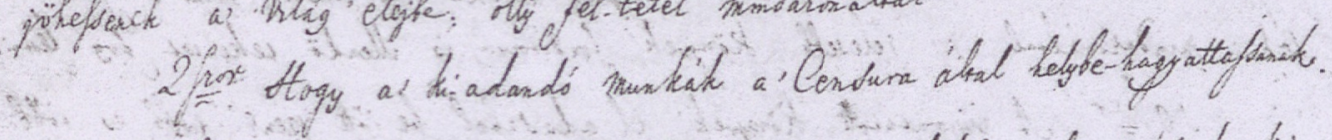

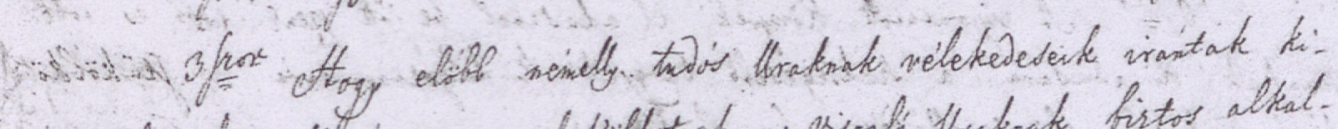

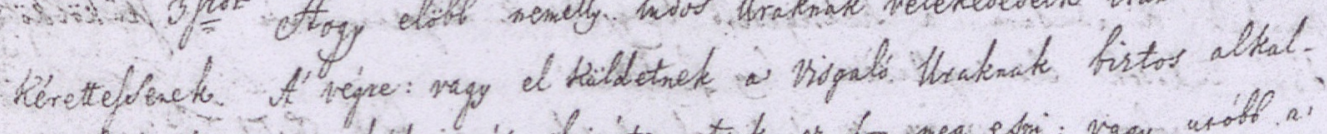

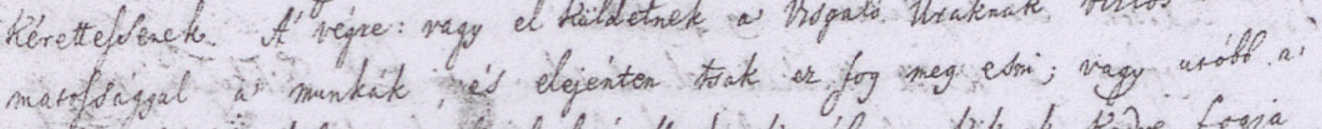

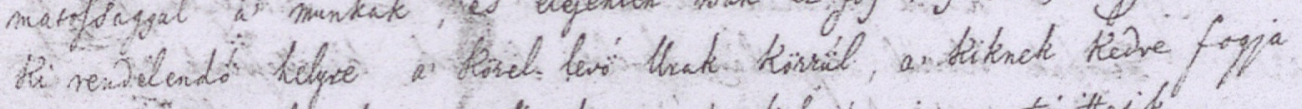

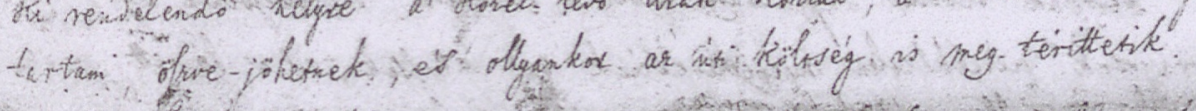

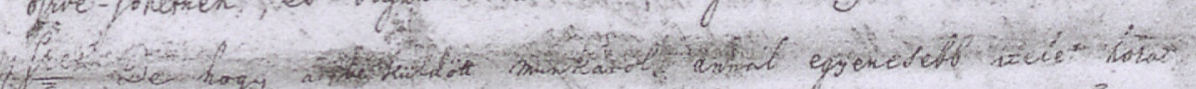

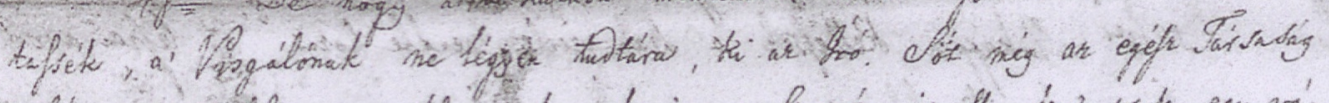

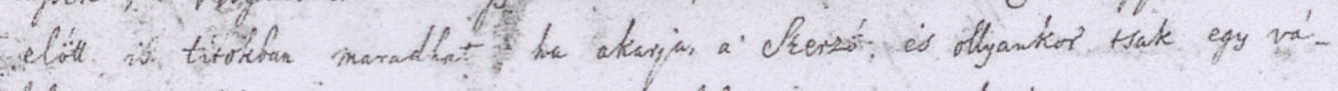

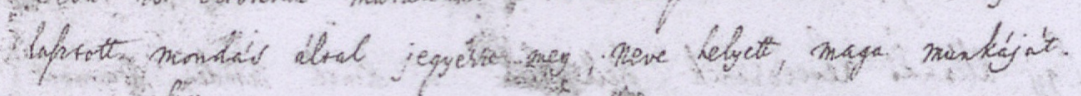

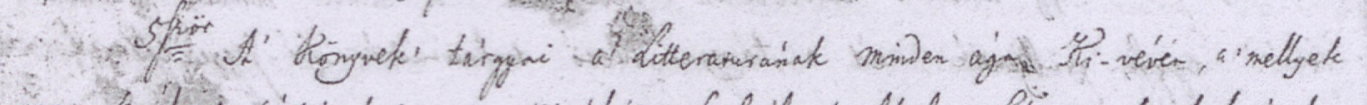
migoklitit.

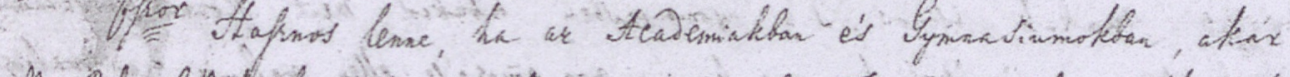

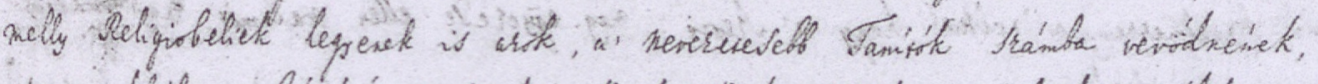

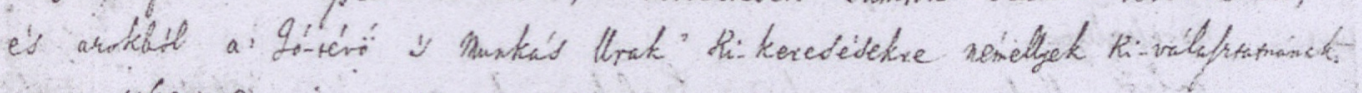

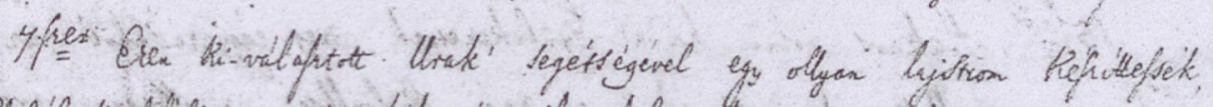

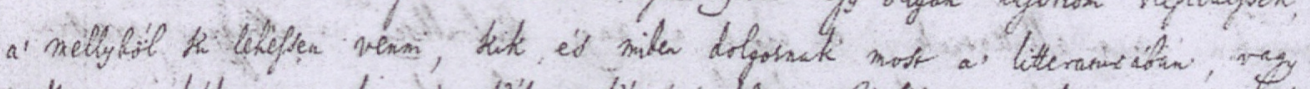

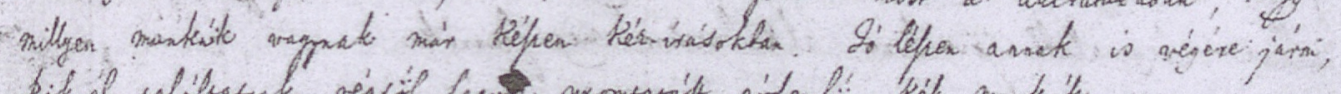

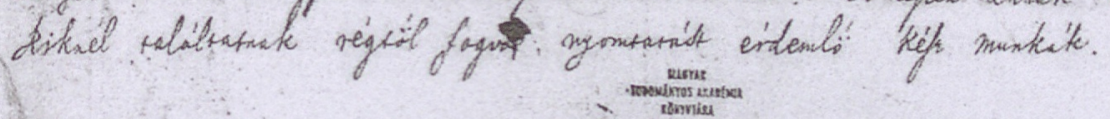

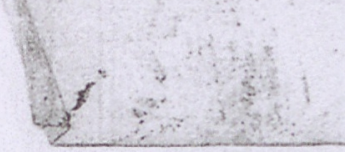




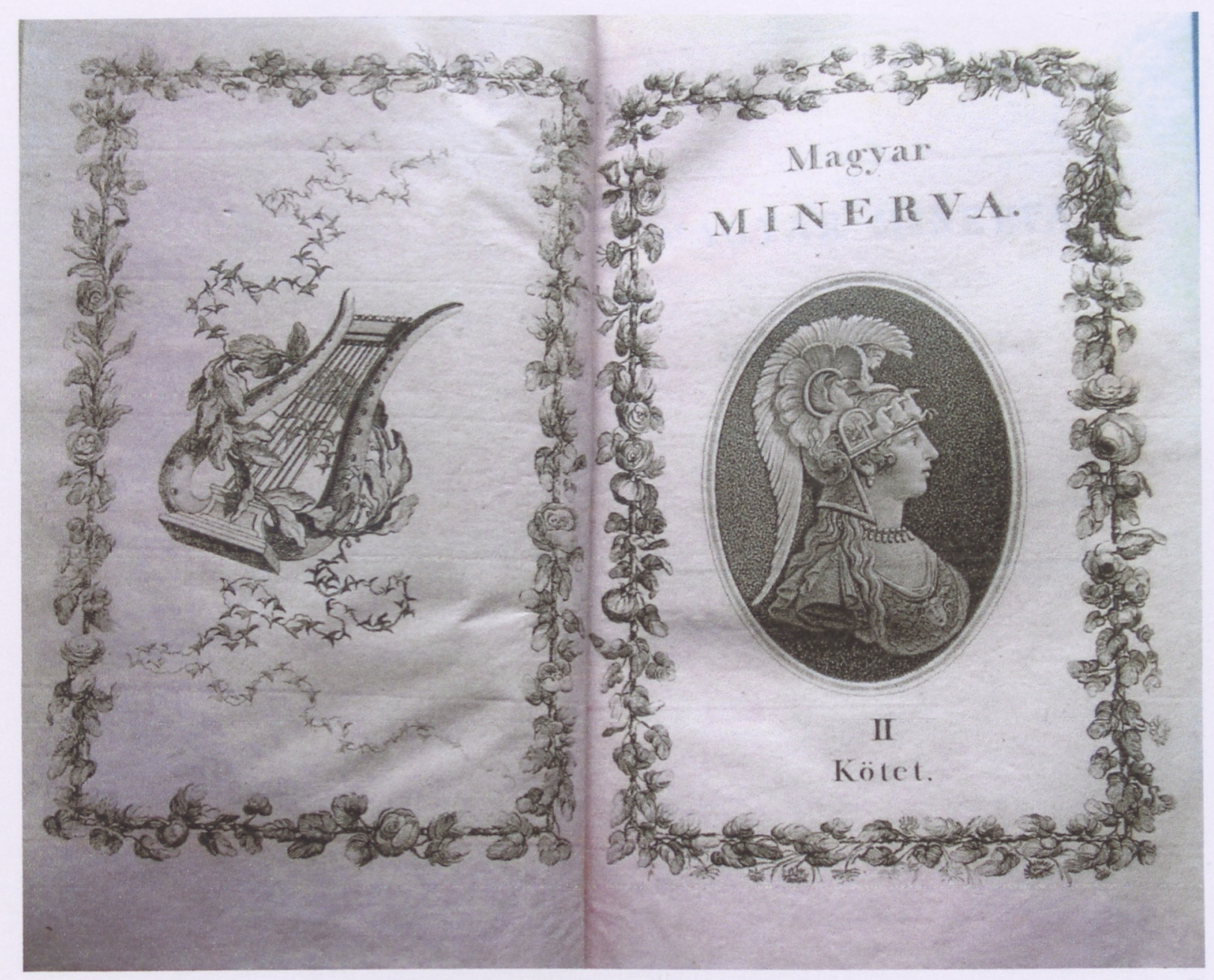

A Magyar Minerva második kötetének borítója

(Festetics Kastély Helikon Könyvtára, Keszthely) 


\section{E R K Ö L T S I \\ OKTATÁSOK,}

MELLYEKET

$\begin{array}{lllllll}\text { T } & \mathrm{O} & \mathbf{L} & \mathrm{N} & \mathrm{A} & \text { I }\end{array}$

GRÓF FESTETITS LÁSZLÓ, KEDVES TANÍTVÁNNYÁNAK, SZIV́́RB KÖTÖTT

PÉTERI TAKÁTS JÓZSEF.

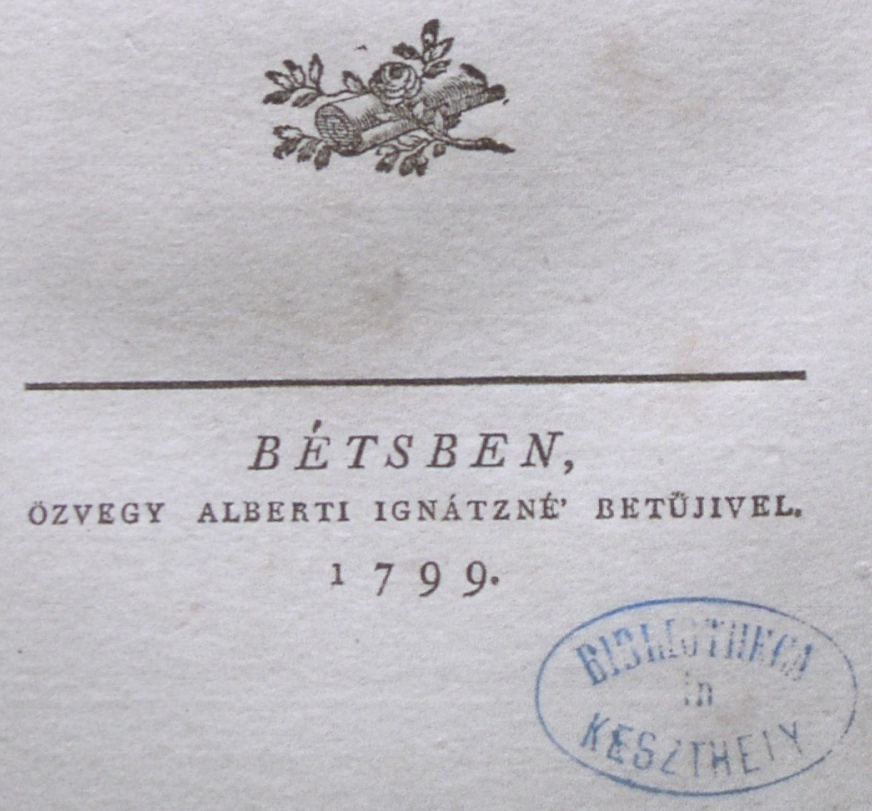




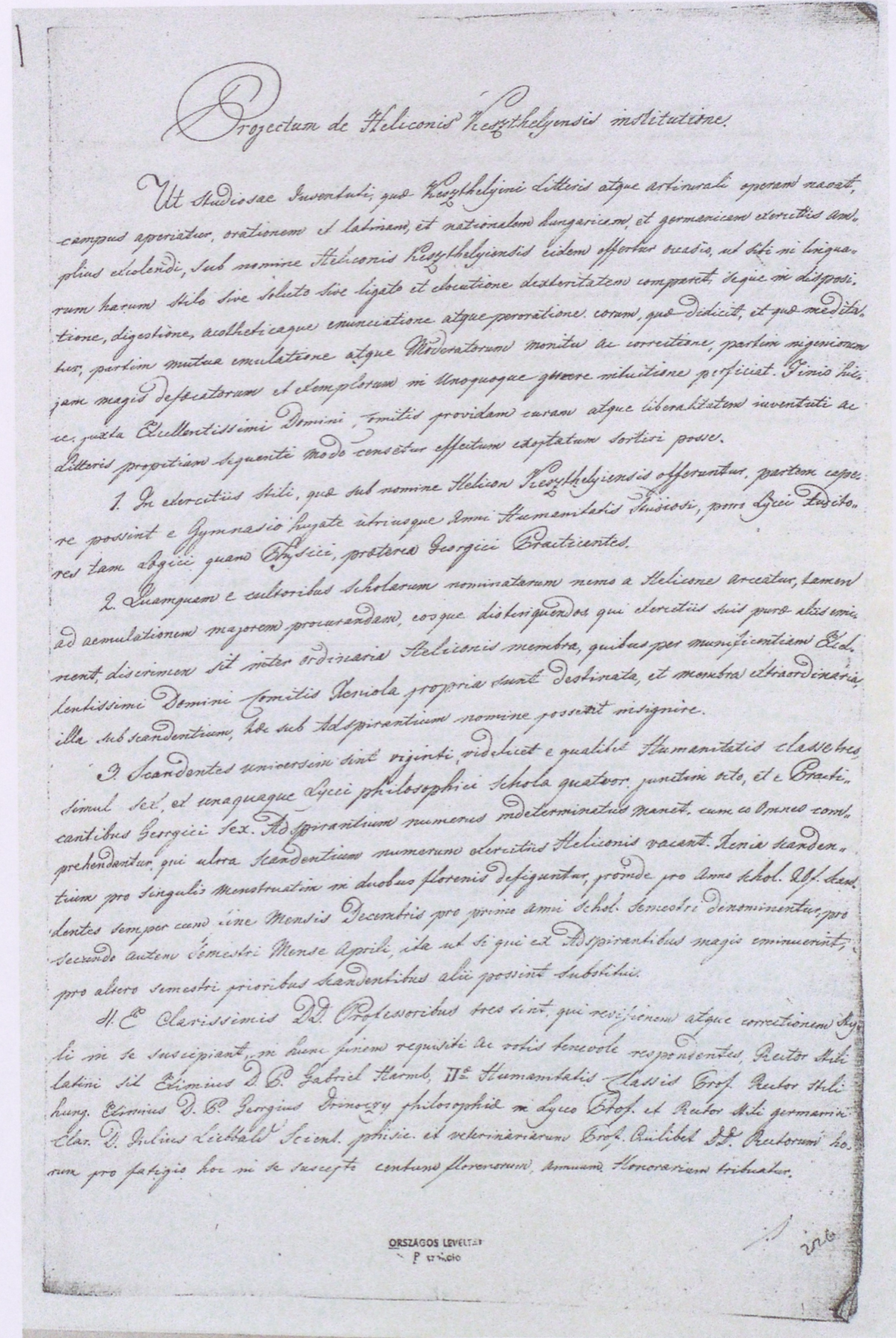

A Helikoni Ünnepségek tervezetnek első oldala, kelt 1817. március 6-án (MOL Fest. Lvt. P 2461 cs.) 


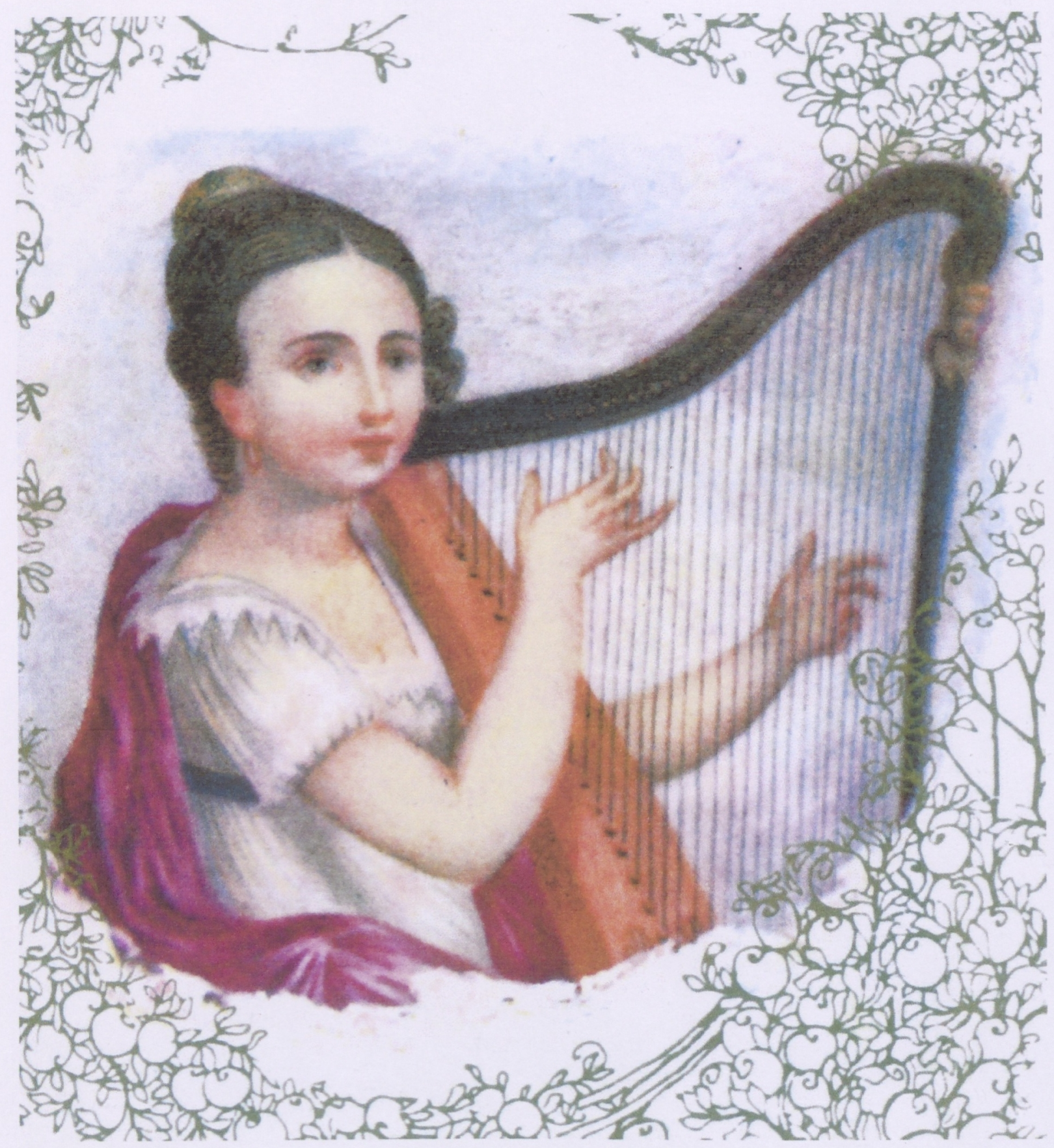

Dukai Takács Judit portréja a Festetics György által neki ajándékozott csészén

(Vadász Norbert: Dukai Takách Judit élete és munkái című kötetből) 


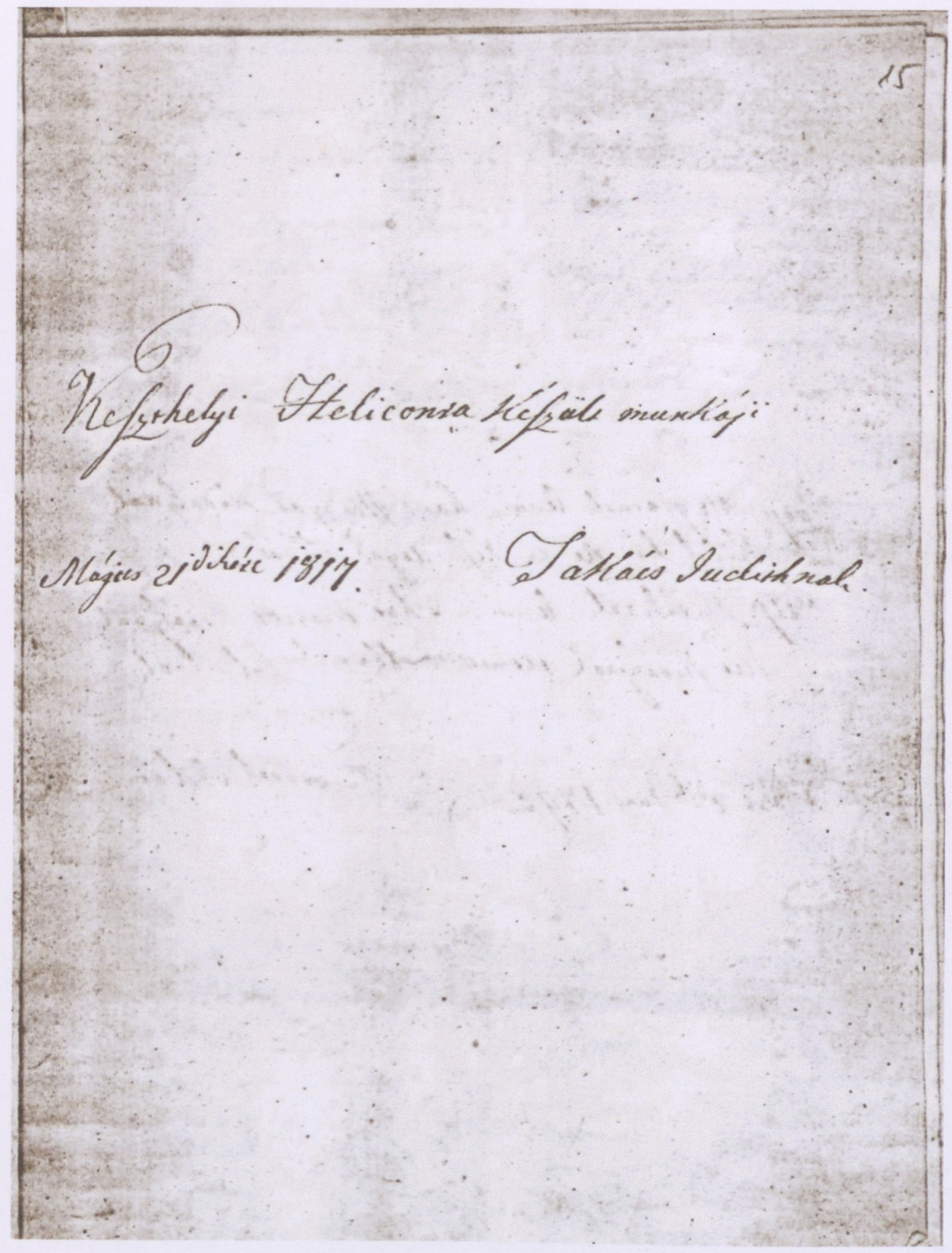

Dukai Takács Judit kéziratos vers-füzete az 1817 májusi Helikonra (A Pannonhalmi Főapátsági Könyvtár tulajdona) 


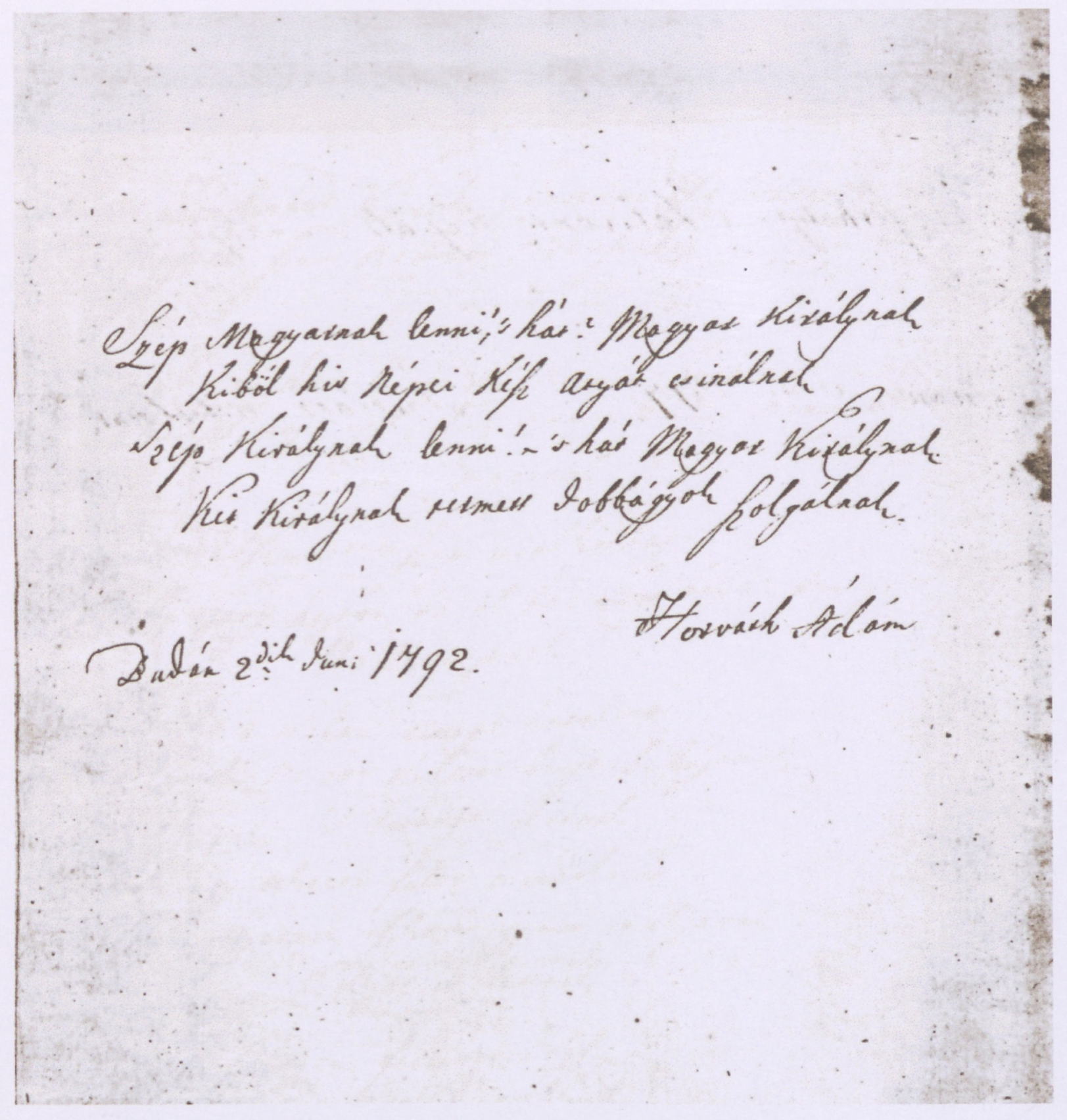

Dukai Takács Judit kézírásos vers-füzetének belső lapja, Horváth Ádám versével 1817 májusa

(A Pannonhalmi Főapátság Könyvtárának tulajdona) 


\section{HILI KO N}

\section{I.}

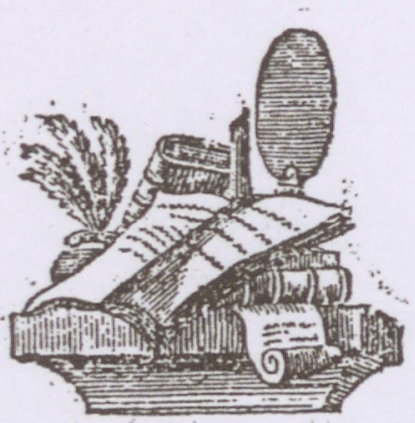

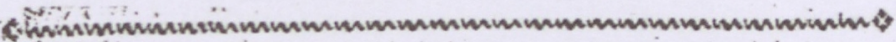

$$
\begin{gathered}
\text { hes } z \text { the ly } \\
1818 .
\end{gathered}
$$




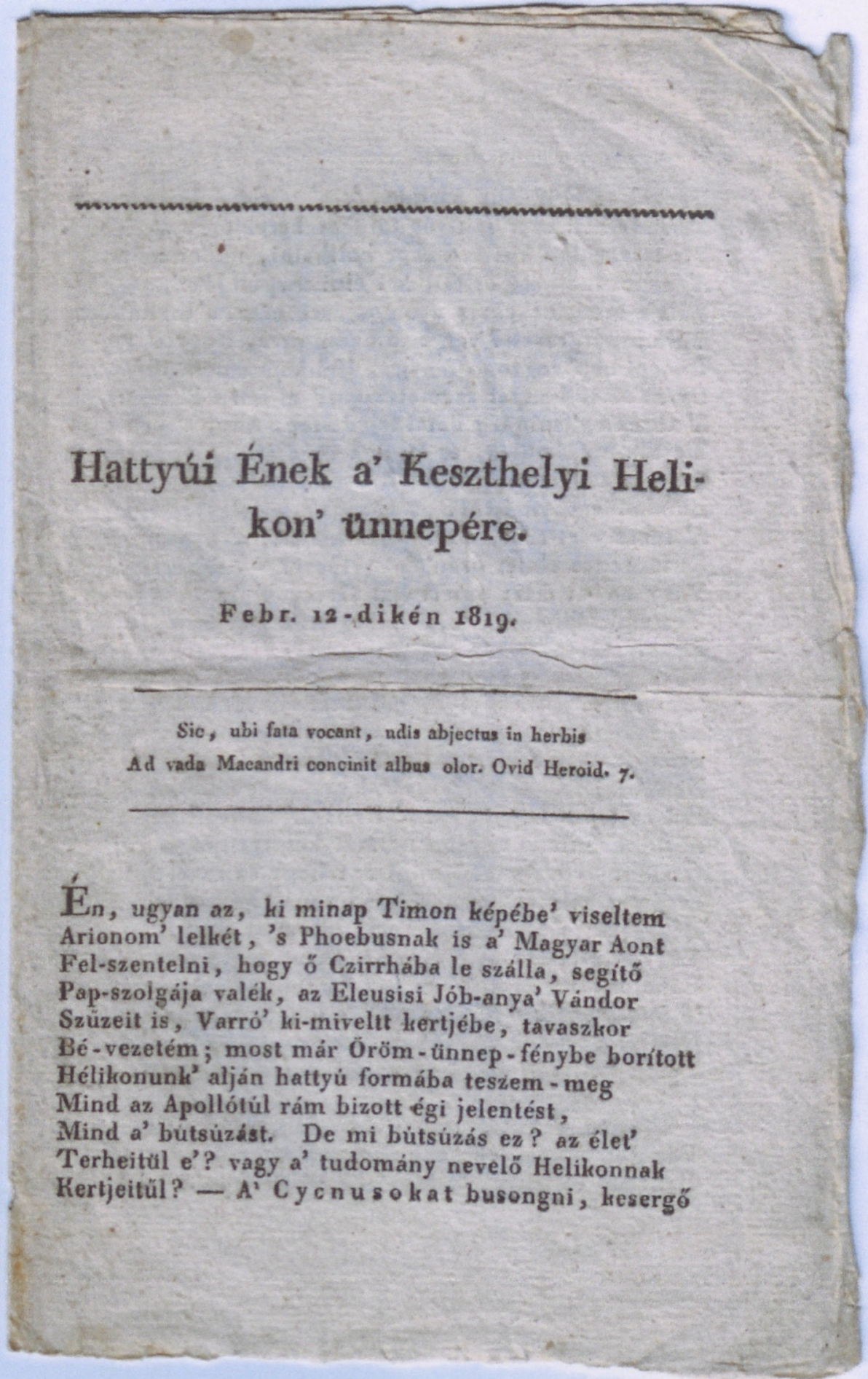

Horváth Ádám kinyomtatott versének első oldala

(Cs. G. tulajdona) 


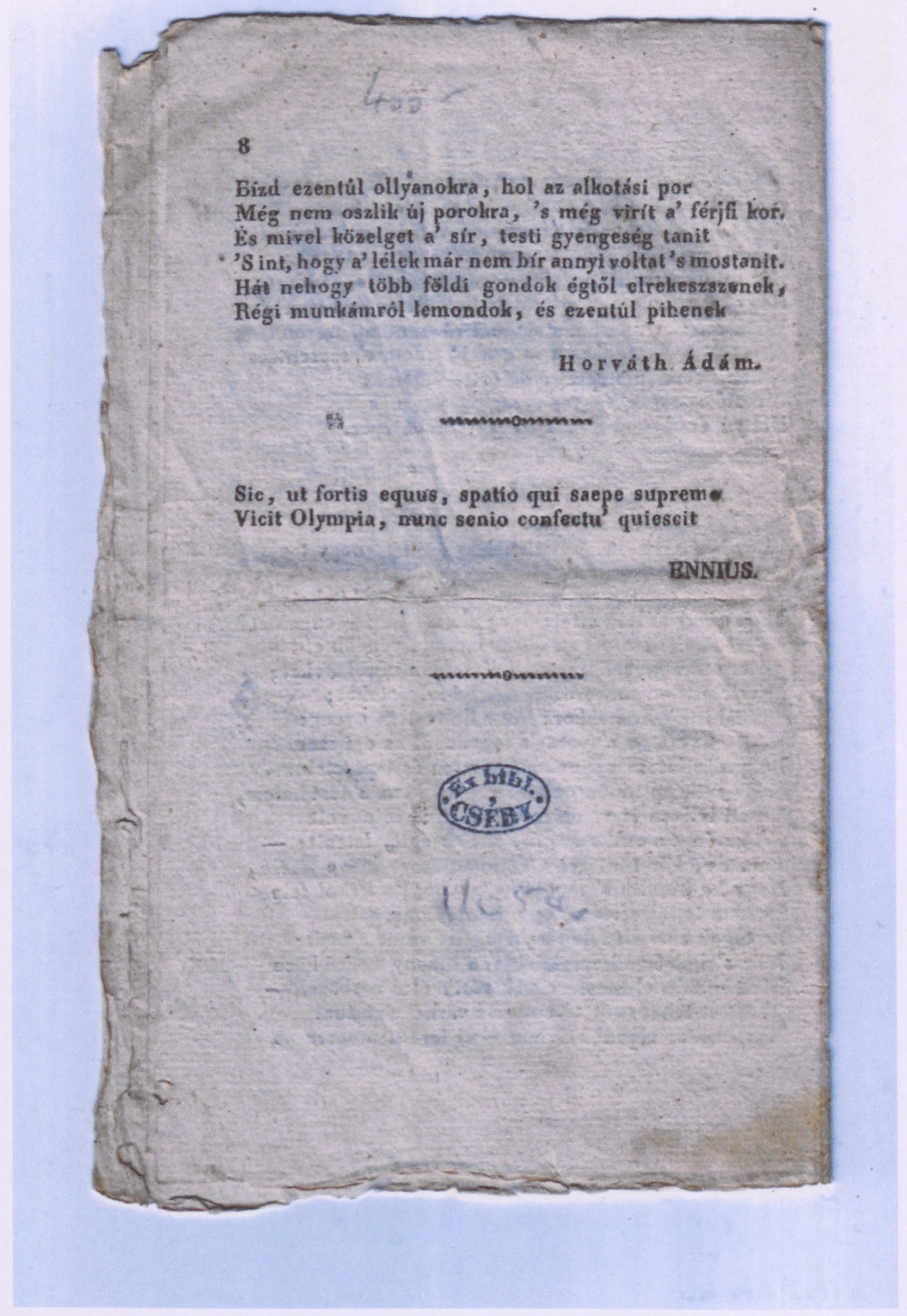

Horváth Ádám kinyomtatott versének utolsó oldala (Cs. G. tulajdona) 


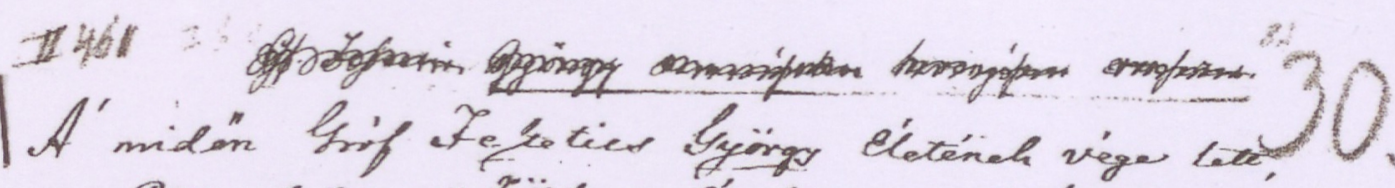

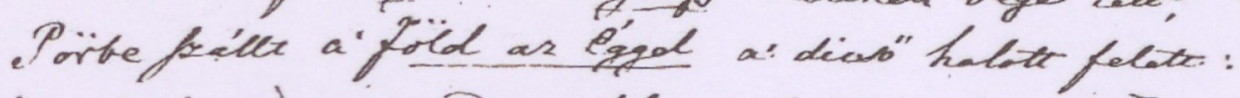

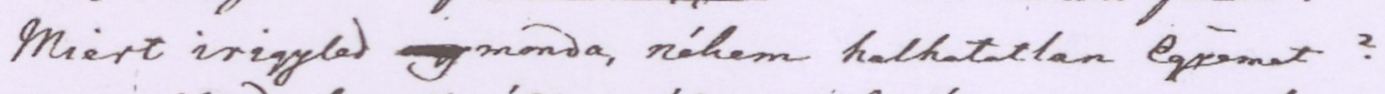

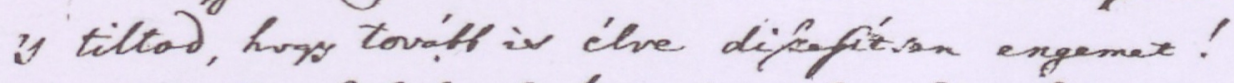

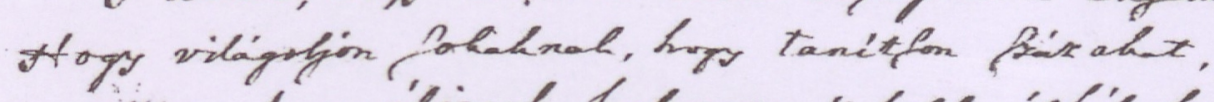

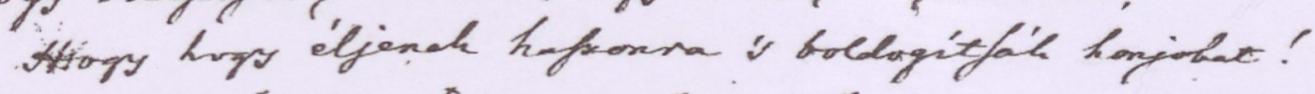

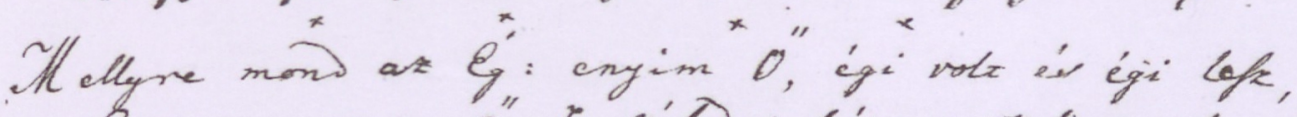
Eddig engedtem " Je keher," hat exentul mix hoxefor = Nem becuiltele o"t eleggé, míg vexér evilly vala, Kodbe vonta féngé a' log e's irigyrég angyala.

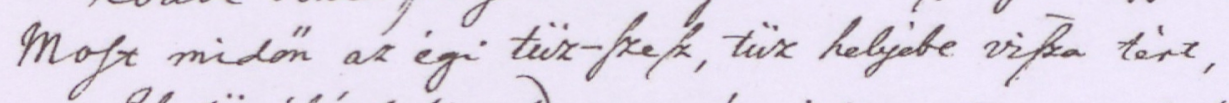
El tienefeivel tanuld meg, múg jelen vole, manmit' ere?

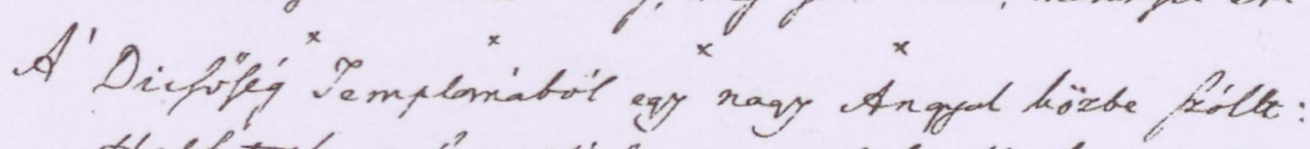

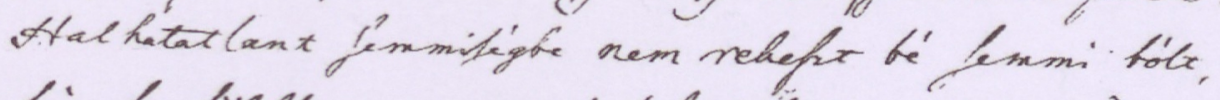

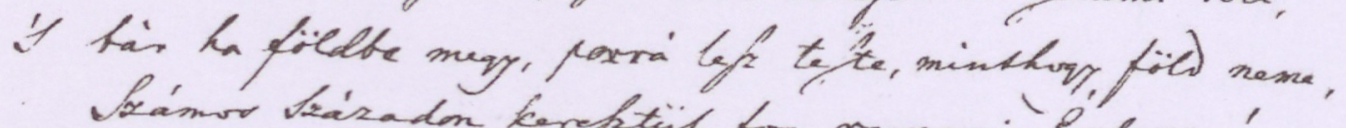

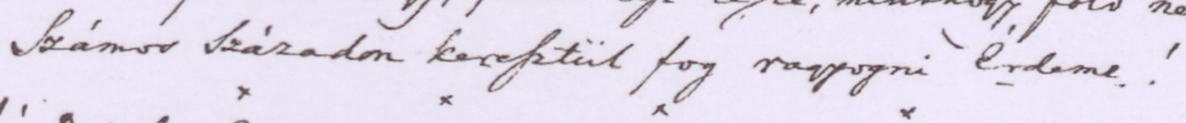

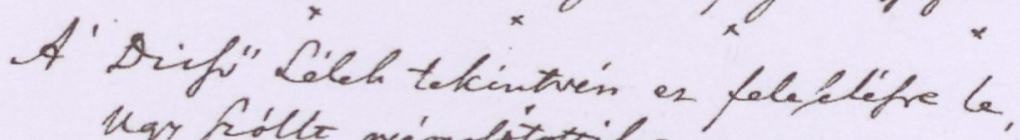
ugy follt gyamolitotihos, mint as ingyal felele:

Altal eftem a haliton, de nem quira bltekin.

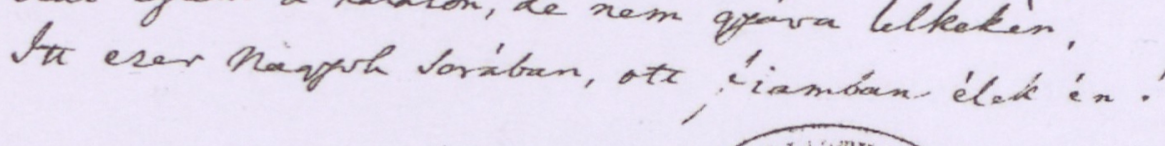

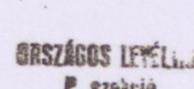

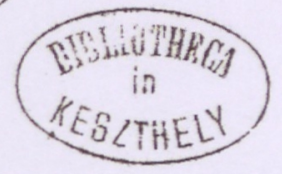

Egy példánya azon versnek, melyet Horváth Ádám gróf Festetics György temetésén osztogatott

(MOL Fest. Lvt. P 2461 cs. B. IV. 2.) 


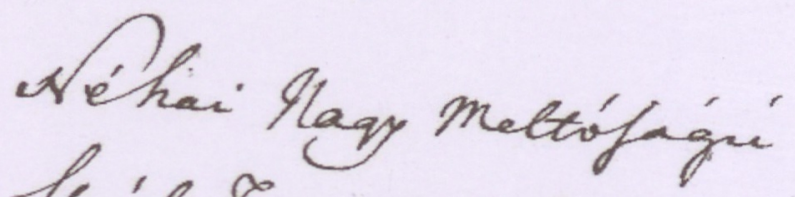

Srifiestetior byoiry temetifer isig ki Aprithis isatie nayjain Aorviath Adim, uny tethic,

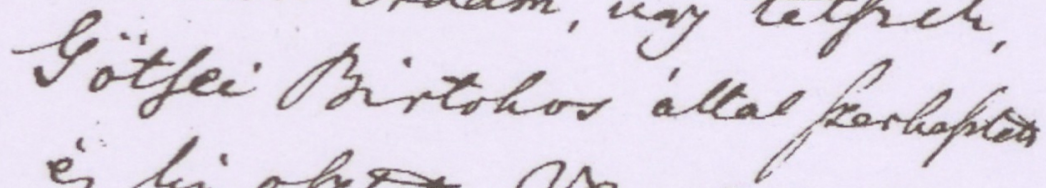
is hiofisa vervext.

Horváth Ádám gróf Festetics György temetésén osztogatott versének hátlapjára írt tanúsítvány. A tanúsítványt író vagy tévedett a dátumot illetően, vagy Horváth Ádám valójában egy nappal a temetés előtt osztotta szét versét.

(MOL Fest. Lvt. P 2461 cs. B. IV. 2.) 